\title{
THROUGH SIBERIA
}

\section{THE LAND OF THE FU'TURE}
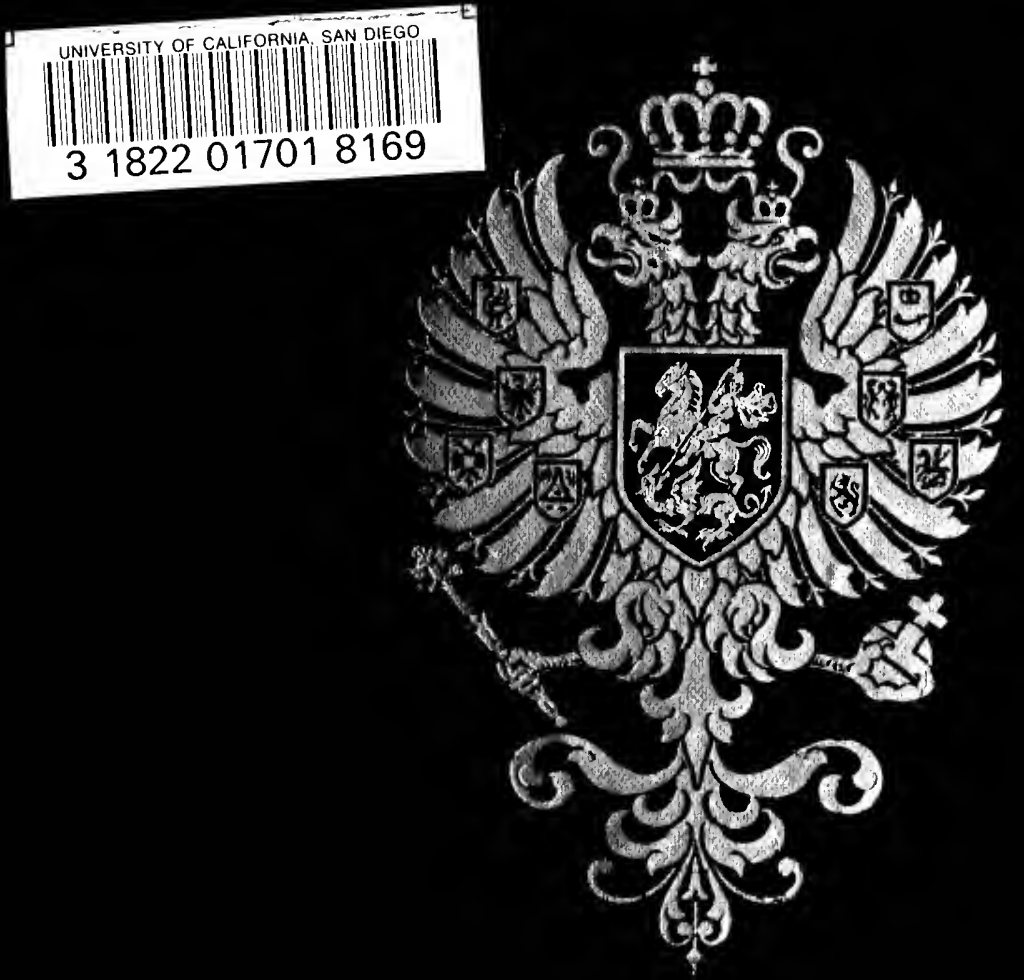

ylifornia

gional

cility

MIDTJOF NANSEN 


\section{Central University Library}

University of California, San Diego

Please Note: This item is subject to recall.

\section{Date Due}

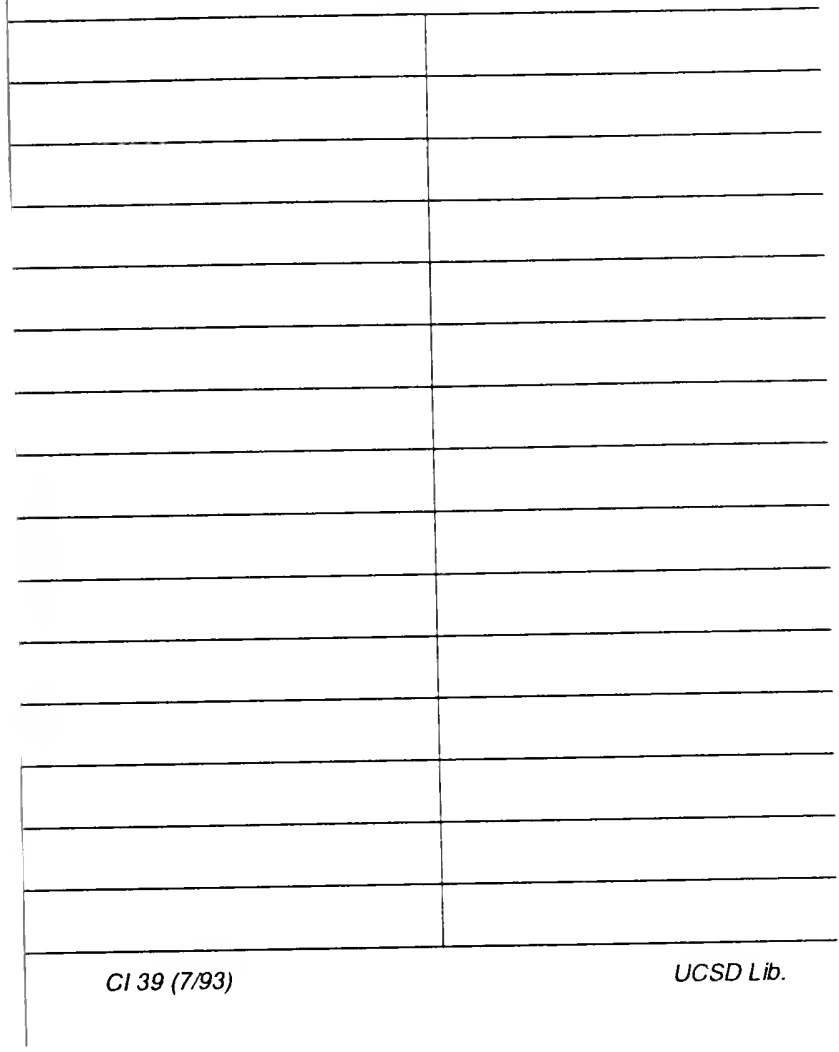




\section{THROUGH SIBERIA THE LAND OF THE FUTURE}




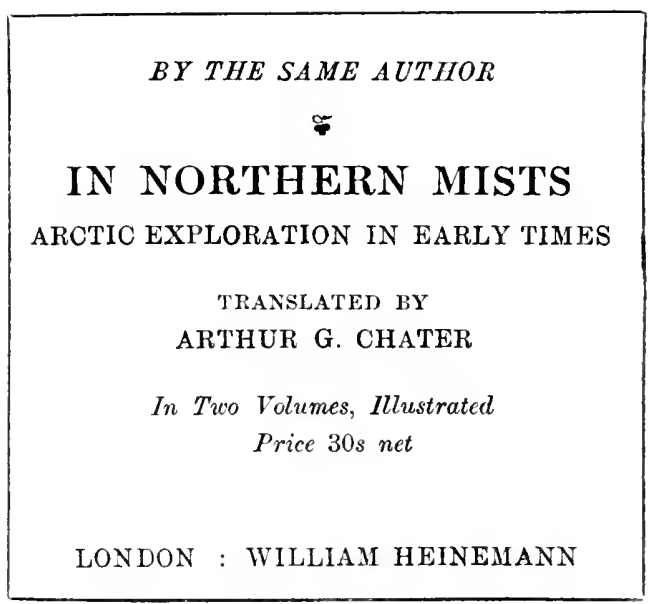





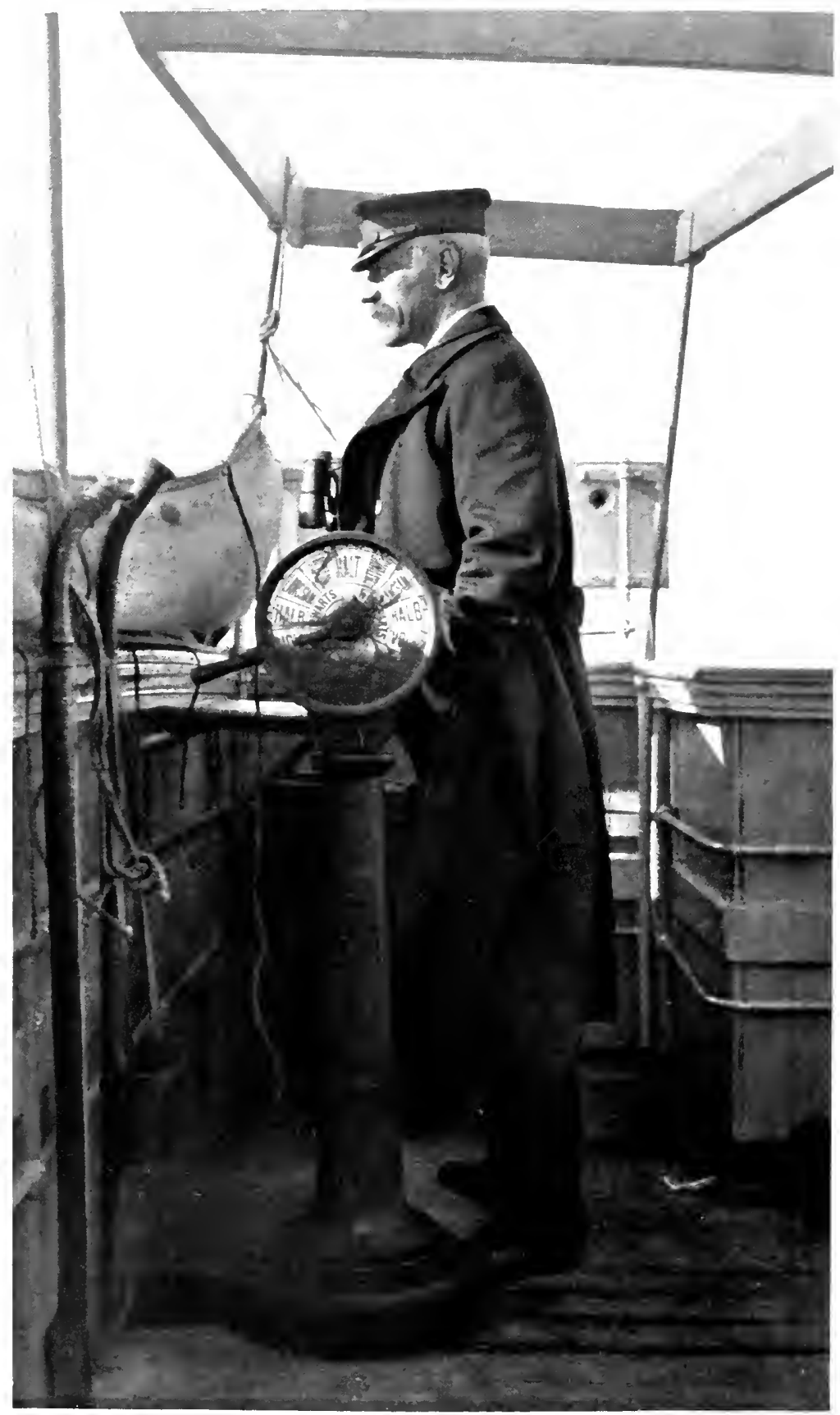

THE AUTHOR ON THE BRIDGE 


\section{THROUGH SIBERIA}

\section{THE LAND OF THE FUTURE}

\section{BY FRIDTJOF NANSEN}

G.C.V.O. D.Sc. D.C.L. Ph.D. PROFESSOR OF OCEANOGRAPHY IN THE UNIVERSITY OF CHRISTIANIA ETC TRANSLATED BY ARTHUR G. CHATER

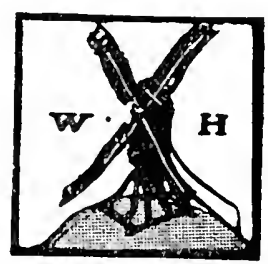

LONDON: WILLIAM HEINEMANN MCMXIV 
PRINTED AT

THE BALLANTYNE PRESS

LONDON 


\section{PUBLISHER'S NOTE}

A $\mathrm{T}$ the present time, when the thoughts of all are centred on the early and critical phases of the European struggle, it may seem a hazardous enterprise to claim attention for a subject which appears at first sight to have only a remote connexion with that struggle; but as Dr. Nansen's narrative gives the most recent account of the vast Asiatic resources of our Ally, and of the attempt, by opening up the Kara Sea route, to make those resources available for the benefit of Western Europe, it will be seen that the questions of which he treats may before long become of direct interest to ourselves and our Allies nearer home.

At a moment when the possibility of transporting troops from the White Sea to the Western theatre of war has been widely discussed, the whole question of opening up the North of Russia and Siberia to European trade, is of more than academic importance. The country traversed by the Yenisei and its tributaries is a very fertile region, including wheat-lands far greater in extent than the combined territory of France and Germany. If these wheat-lands can be made to yield their produce to Europe, they may even prove a vital factor in the decision of the struggle which is now absorbing the attention of the world. For this reason, Dr. Nansen's journey is of paramount interest, not only as revealing the future possibilities 


\section{PUBLISHER'S NOTE}

of Siberia, but because it shows a possible way of increasing in the present emergency the resources of the enemies of Germany. The railway route from that country westward to the Baltic and eastward to the Pacific is so long as to render the freight prohibitive, even if the overland route were not anyhow hopelessly congested in war time.

It may be hoped, therefore, that efforts will be made next season to take advantage of the experience of Dr. Nansen and his companions and to establish regular communication between the Kara Sea and Western Europe, during the months in which that sea is available to navigation.

While everything that leads to a better knowledge and understanding of our Russian Allies and their country cannot fail to interest us, it is in particular the practical consideration referred to-namely, the possibility of increasing our food-supply by a new route-that has led the publisher to issue this book at the present juncture. 


\section{CONTENTS}

CHAP.

I. FROM NORWAY TO THE KARA SEA

Departure : Object of the Voyage : Shipmates : At Tromsö : Captain Ritscher and the unfortunate expedition to Spitsbergen : Captain Samuelsen and the Correct : Johansen, the ice-pilot : Leaving Norway : The Barents Sea, a sunken continent : Our prospects : The wireless : no connexion : Through the Kara Strait in fog, ugly shoals and rapid current : The Kara Sea open : In and along the ice : Yamal

II. VISITS FROM SAMOYEDES

A Samoyede boat arrives : Samoyedes on board: Life of the YamalSamoyedes : Northward through the ice : Packed ice : Another Samoyede boat comes : Eating raw fish : The mate sculling : Yet another Samoyede boat

III. THROUGH THE ICE NORTHWARD ALONG YAMAL

Ice and lifeless waters : Our life on board : Big floes of thin ice : Ground-ice : A dangerous block: Fog and ice : Unbroken ice : The dirty ice of the Arctic : Walrus : Ice closing in : The wind breaks up the ice: A land channel : Out of the ice

IV. OPEN SEA, EASTWARD TO THE YENISEI

Open sea north of the Gulf of Obi : Stopped by ice west of Sibiriakov Island : Aground : Landing on Dickson Island : Brusilov's and Rusanov's expeditions : Unsuccessful reindeer-stalking : The coastal platform : Southward to the mouth of the Yenisei : The Yenisei and its course : Movement of the river towards the right : Political exiles; a hermit : Difficult navigation, we run aground : Meeting with the tug and lighters from the south : Prospects of delay

V. NOSÓNOVSKI PESOK AND THE SAMOYEDES

Native tribes along the Yenisei : The Samoyedes and their history : Visit to Yenisei-Samoyedes : Position of women : Christianity and idol-worship : How to clean a tent : Appearance of natives : A drunken prince : Honesty : A "convent" with monks and nuns : Yenisei fisheries : Fish, their migrations and growth : Fishing tackle and the condition of the fishermen 


\section{CONTENTS}

CHAP.

VI. WAITING TO GO ON

Unsuccessful sport in swamps : An unpleasant winter, and a spring flood : Disappointed traders : A frozen mammoth : How were the mammoths frozen ? : Visit to Lebiashiy Ostrov : Strong mirage : Yenisei-Samoyedes and Yuraks : The Yurak chief and his two wives : The Yuraks' taxes : Dolgans and Tunguses : Sledge-dogs : The Omul arrives : Russian steamboats arrive

VII. UP THE YENISEI

The deepest channel : A place feared by skippers : Motor trouble : Pimen's Grave and its legend : Karaulnoye : Yurak camp : Kasanskoye, a brownie : Lukováya Protóka : The river bank and the excavating power of the stream : The first trees : Sturgeon soup : Ananyino and the steamer Lena: Siberian peasant types resembling Norwegian : In search of an expedition : Steamboats and lighters on the Yenisei and the ice-drift : Autumn fishing : A YeniseiOstiak and a civilized Samoyede

VIII. DUDINKA TO THE KUREIKA

Dudinka : Political exiles : Caucasia : A discoverer and his strange tales : Thin forest : Coal measures : Movement of rivers to the right : Large rocks carried by the river ice : Forest, taiga and tundra : Hay in stacks : Still flat forest land : The first beds of rock : Sushkóv : Epidemic among hares and squirrels : Want of medical aid and epidemics : The forest often burnt : Thin forest and frozen soil : Hardiness and utility of Siberian timber : Origin of the Arctic drift-wood : The Yenisei-Ostiaks and their origin : The Kureika: In the forest : Graphite : Outside the world : Fog : The first bill

IX. TROITSKIY MONASTIR, AND ON TO THE SOUTH

Troitskiy Monastir and Turukhansk : Decline : The pristav : The guarded treasure : A plundering raid : The monastery church : Legend of a saint : A travelling priest : Tea with the pristav : The school : The town : A political exile : Convicts in caves : YeniseiOstiaks' tents : Canoes : Miroyédikha and beds of rock : Political exiles travelling : Villages : Moonlight : More luxuriant forest : Onr pilot: The Yenisei-Ostiaks, their poverty-stricken life

\section{VERKHNE-IMBÁTSKOYE TO SUMARÓKOVA}

A boat drawn by dogs : Verkhne-Imbátskoye : The church : Moonlight : At the priest's : River transport with dogs : Snaring capercailzie : Mirnaya by moonlight : Ridges : Thicker forest, including fir : Sumarókova : A drunken gathering : A pleasant trader : The Yenisei-Ostiaks, their life and their destiny : We visit them on the beach : A shaman : Old religion : Caucasian political exiles 


\section{CONTENTS}

CHAP,

Ridges along the river: The goldfield : Monastirskiy island : Osinovski rapids : Winter fishing for sturgeon in the rapids : Work on the river-bottom in frost: Vórogovo, the first telegraph station : Manure of no value in Siberia : Can only telegraph in Russian characters : A Tungus : A pleasant trader and an unpleasant one : Romance of the forest : Agriculture and cattle-raising : Continued difference between the west and east banks : The village system and freehold farming : Manuring and rotation of crops : Timber sawn by hand : Nasimovo telegraph station, but still only for Russian characters : Unsuccessful bread-hunt : Aground : Kholmogórovo : Sturgeon : Rotten fish : Arrival at Yeniseisk

\section{YENISEISK TO KRASNOYARSK AND BEYOND}

Letters and telegrams : Siberian hospitality : Yeniseisk : The population : At the boy's school : A Georgian exile : The municipal lunch : The Museum : At the girls' school: A late lunch : Overland to Krasnoyarsk : Wild driving with tarantass and troika : Broad roads : Unsafe conditions, thieves : Arrival at Krasnoyarsk : Hospitable reception : The town and neighbourhood : An easy method of ferrying : No Ice-Age : A game of football and the Sokol movement : The Museum : Meeting of the Geographical Society and big dinner : Farewell at the railway station : Kansk : Discussion of the sea-route to the Yenisei : Reconstruction of the railway-line : The express train

\section{THE COLONIZATION AND DEVELOPMENT OF SIBERIA}

The population of Siberia : Russia's steady expansion : Former views on Siberia : Emigration to America : Improvements in recent times : Immigration to Siberia : Siberia's internal politics : Wealth of Siberia : Loans and aid to colonists : Extent of the partition of land : Economic position of the settlers : Profits of agriculture : Room for many : Colonization has two sides for a nation

\section{IRKUTSK TO VLADIVOSTOK}

Irkutsk : Baikál : The line to the south of Baikál : The mountains : No Ice Age : The nature and fauna of Lake Baikál : Transbaikalia, its formation and climate : Petróvsk iron-works and political exiles : Over the Yáblonovi Mountains, the watershed between the Arctic and Pacific Oceans : Chitá : Mr. Wourtzel at work : In the Celestial Empire : The Khulunbuir plateau : Great Khingán : Chinese : Barim : Along the northern border of Eastern Gobi : Russian hospitality : Over the East Manchurian mountains : Chinese settlements : Forest fires : Illicit opium growing : The Khunkhus robber bands : A train of returning colonists 


\section{CONTENTS}

CBAP.

XV. THE USSÚRI REGION, VLADIVOSTÓK AND KHABARÓVSK

The Maritime Province, area and population : Natural features, climate : Natives : History : Vladivostók : The Ussúri line : Seeing Vladivostók : The Ussúri country : Cultivation : Khabaróvsk : Bridge over the Amúr : Difficulties of the work : The exhibition : A valuable stag : The museum, native sledges : Golds

XVI. RUSSIA IN THE EAST. THE YELLOW QUESTION

Russia's great task in the East : Altered situation in recent years : Seriousness and significance of the situation : Position of the Russian domination in the East : Her long line of communications : Colonization : Immigration and population : Difficulties : Immigration of the yellow race : Koreans, Chinese (Manses), Japanese : The yellow peril : Indispensability of the yellow race : Hostile feeling among the Chinese : Serious outlook

XVII. THE AMÚR DISTRICT AND THE AMÚR RAILWAY

Extent and natural features : Climate : Gold: Natives : Population : Access and railway projects : The new line : Labourers : Length and cost : Sections and engineers : Hygiene and schools : The Central Amúr plain : Drainage and arable land : Difficulties of the work : Fertility : Good farm land : By trolley and motor-car : The Little Khingán : A park of oalss : Birá : Forest country and game : Tunnels and frozen soil : Fertile land:The longest tunnel: Two motor-cars disabled: Liquor smugglers and brigandage : Deposits in an ancient lake

XVIII. FROM THE BURÉYA TO TRANSBAIKALIA

The Buréza-Séya Plain : On the Buréya : Abrupt variations in the water-level : Naming a station : Fertile soil but unpractical working: Curious effect of frost : On the Séya : A new town. Alexéyevsk: Hill country from the Séya to Transbaikalia : Gradual ascent : The forest : No sign of an Ice Age : We run over a man : Gondatti Station : Men's changing destinies : A dreary country : Storms and forest fires : Taldan : A spring and frozen soil : Origin of layers of ice in the soil : Prisons in the forest : A dismal country, but gold everywhere : The Nuksha : Agriculture and cattle : Storms and forest fires : A wrecked train : Across the border to Transbaikalia : The Amasár : Convict labour and prisons : The highest point of the Amúr Railway : Rich gold-mines : Chinese allowed here : The Black and the White Uryúm

XIX. HOMEWARD THROUGH SIBERIA

Along the Shílka : Climatic variations : Chitá : Along the Selengá : Baikál : Tulún : Krasnoyarsk : The country to the east of Krasnoyarsk : Rodichev : a politician's views of Siberia : Novo Nikoláyevsk: The flat steppes : The Urál and winter : Yekaterinenburg : Back to Europe : Perm and Viatka : Farewell to Siberia

APPENDIX: THE NAVIGATION OF THE KARA SEA 


\section{LIST OF ILLUSTRATIONS}

The Author ox the Bridge

$$
\begin{array}{r}
\text { To face } \\
\text { page } \\
\text { Frontispiece }
\end{array}
$$

(1) Captain Samuelsen ; (2) J. Loris-Melikov ; (3) J. Lied ; (4) S. V. Vostrotin; (5) The Adthor

Mr. Jonas Lied, Director of the Siberian Company 8

Captain Hans Johansen, the Ice-Pilot

The "Correct" in the ICE

The Bow of the "Correct," Showing Ice-Skin vear the Water 9

A Samoyede Boat dnder Way 26

$\begin{array}{ll}\text { Yamal-SaMoyede aNd Syryentax } & 27\end{array}$

YAMAL-SAMOYEDE $\quad 27$

A Happy Samoyede Chief 36

Samoyedes in their Boats. Those to the Right are eating Raw Fish 36

Samoyedes in their Boats at the Side of the ShIP 37

The "Correct" made Fast to a large piece of Grodnd-ICe 40

IN THE ICE

Mr. Lied ON THE UNBRokeN ICE-FIELd 41

The "Correct" at the Edge of the ICE-Field

Hoisting otr Catch on Board 46

A Lady Walrus 46

Tundra Scene, Dickson Island-The Author, Sajruelsex, Lied, LORIS-MeLIKOV

The Home of a Poutrical Exile at Sopochnaya Karga 60

Camels on the Deck of the Lighter 61

The Landing of Mr. Vostrotiy: his Reception by the Natives ox $\begin{array}{ll}\text { THE BEACH } & 61\end{array}$

A Samoyede Spring-cleaning $\quad 88$

Women and Children of the Yentser Sajoyedes in the Doorway of their TeNt $\quad 88$

Women of the Yenisei Samoyedes in the Doorway of their Tent 89

$\begin{array}{ll}\text { A Drunken Prince } & 94\end{array}$

An Admring SUbJect $\quad 94$

Novices and Nuns in the "Convent" 95

$\mathrm{xi}$ 


\section{LIST OF ILLUSTRATIONS}

Scale of a Nyelma (Stenodus nelma) from the Yeniser. 1.08 metres LONG (EIGHTEEN YEARS OF AGE) 95

Alexei, the Cook, with a Nyelma (Stenodus nelma) 100

A Boy with some Muksuns (Coregonus Muksun) 100

Alexet, the Cook, with a Sturgeon (Acipenser Baerii) 100

Over the Marshy Land of Nosonovski Ostrov 101

$\begin{array}{ll}\text { YeNiSEI SAMOYEDE } & 116\end{array}$

$\begin{array}{lr}\text { Yenisei Samoyede Talking } & 116\end{array}$

$\begin{array}{ll}\text { YURAK } & 117\end{array}$

$\begin{array}{ll}\text { Old Woman of the Yenisei Samoyedes } & 117\end{array}$

Men and Women of the Yuraks and Yenisei Samoyedes 120

Wonen of the Yenisei Samoyedes at Work in the Tent 121

Prince Yabtung Alyo with his Old Wife and his Young Wife with $\begin{array}{ll}\mathrm{BABY} & 126\end{array}$

$\begin{array}{ll}\text { Samoyede Tent on the TUNdra } & 127\end{array}$

A Good-homoured Dolgan Woman 132

The "Omdl." Our Departure from the "Correct" (Photographed BY Mr. LIED) 133

The Land on the Eastern Shore of the Yenisei 133

At Karadlioye: the Northernmost Cow 144

Yorak Sledges left on the Tundra at Karadlnoye

$\begin{array}{ll}\text { Ananyino } & 145\end{array}$

$\begin{array}{ll}\text { Russian Types at Ananyino } & 148\end{array}$

Kasanskoye. The Little Man and Mr. Vostrotin 149

At Levinski Pesok. A Civilized Yenisei-Samoyede and a YeniseiOstiak 149

Larches (Larix sibirica) at Dudinka. The Northernmost Trees 150

The Bank of the Yenisei, with Forest of Larch and Spruce. The High-Water Line IS DISTINCTLY SEEN $\quad 150$

The Forest at Kureika. Spruce, Birch, and Siberian Cedar (Pinus cembra) 151

Old Native Graves in the Forest at Kureika

$\begin{array}{ll}\text { Troitskiy Monastir } & 157\end{array}$

The Church of the Troitskiy Monastery 157

$\begin{array}{ll}\text { Cossack GUarding the Government's Money } & 178\end{array}$

$\begin{array}{lr}\text { Lunch with the Pristav aNd his Wife } & 179\end{array}$

$\begin{array}{lr}\text { IN The Street of Troltskiy Monastir } & 179\end{array}$

Released Convict in his "Cave" dug out of the Sandhill. The Pristay on Right of Pictore 184

Birch-bark Tents of the Yenisei-Ostiaks, with the Huts of the $\begin{array}{ll}\text { Convicts in the Sandhill above } & 184\end{array}$ xii 


\section{LIST OF ILLUSTRATIONS}

Sandy Foreshore on the Western Side of the Yenisei, with Birch-

bark Tents (September 10) 185

$\begin{array}{ll}\text { MIROYEDIKHA. ROCKY BANK } & 185\end{array}$

Women of the Yenisei-Ostiaks outside their Tent at Syrianski

$\begin{array}{ll}\text { PESOK } & 190\end{array}$

Children of the Yenisei-Ostiaks at Syrianski Pesor 191

On the Yentsei. The Captain and Exgineer on the Deck of the

"Oу⿰Lе " 196

The Church at Verkune, Imbatskoye, by Moonlight 197

Birch-bark Tent of Yenisei-Ostiak on the Sandy Foreshore on the

West Bank of the Yenisei (September 14) with Hodseboat LYING OUTSIDE

204

Group of Yenisei Samoyedes at Sumarokova

204

Grodp of Yenisei-Ostiaks. Russians standing to the Right and in the Backgrodnd (Sumarokova, September 16)

Men and Children of the Yenisei-Ostiaks (Sumarokova,

SEPTEMBER 16)

Yenisei-Ostiak (Sumarokova, SePtember 16) 221

Yenisei-Ostiak Womax (Sumarokova, September 16)

221

Yenisei-Ostiaks, Women and Children (Sumarokova, September 16)

Yenisei-Ostiak (Sumarokova, September 16)

Yenisei-Ostiak Bay (Sumarokova, September 16)

Shaman of the Yenisei-Ostiaks (Sumarokova, September 16)

The House-boats of the Yenisei-Ostiaks at Sumarogova (September 16)

Boats of the Yeniser-Ostiaks preparing to start from SUMarokova

(SEPTEMBer 16)

At the Rapids near Monastirsky (September 16)

Vorogovo. Entrance to the Village dP a Hill of Cow-dong

(September 17)

Dronken Tujges at Vorogovo (September 17)

The Captain of the "Omul" eativg the Raw Spinal Cord of the StURgeon (SEPTEMBer 20)

The Yenisei looking South, showing difference between High

Eastern and Low Westerx Banks of the River (September 19) 248

A Siberian Gateway

YeNisersK

Drove of Mongolian Cattle, with Mounted Herdsman roling a

Cigarette (September 24) 


\section{LIST OF ILLUSTRATIONS}

A Siberian High Road. In the Background is the Spot where the

MaIl-Driver was Kulled (September 25) 252

The Yard of a Posting-station 253

The Cathedral of Krasnoyarsk (September 26) 253

$\begin{array}{ll}\text { KRASNOYARSK } & \mathbf{2 5 8}\end{array}$

Krasnoyarsk from the Western Hill. Mr. Gadalov on Horseback (SEPTEMBER 26)

259

The Ferry across the Yenisei at Krasnoyarsk 262

On the Ferry across the Yentsei (September 27) 263

$\begin{array}{ll}\text { Mr. Wourtzel aNd the Author } & 266\end{array}$

The Mountains on the South-eastern side of Lake Batkal (SEPtember 30) $\quad 267$

Chinese at odr First Station in Manchuria (October 2) 267

Manchoria, near the River Khailar. Note Hills bare of Trees, and only a few Birches along the Streams (October 2) 267

Manchuria, House vear Railway Station, with Huts for Chinese Labourers at the Side (October 2) 267

Bukhedu Railivay-station in Maxchuria (October 2) 314

Projecting Ridge of Granite at Barim Railway Station, East of Great Khingan (October 2) 314

Manchuria : Typical Formation of the Hills (October 2) 314

Valley on the Western Slope of Kentei-Alin (October 3) 314

Chinaman at a Railway Station (October 3) 315

Chinese at a Railway Station (October 3) 324

Pogranichnoye Railway Station, on the Frontier of Mianchuria and the Ussuri Province (October 3) 324

VLADIVOSTOK

The Auúr year the Bridge. Forest Fire in the Distance (October 6) 334

Temporary Railway Bridge 334

The Quay at Kihabarovsk, with Russian Gunboat (October 6) 334

Gilyaks with their Boats at Khaparovsk 334

Chinese Gold-miners at a Transbatkal Railway Station (October

17) 335

Chinese Labourers at a Transbaikal Railway-station 350

Boggy Ground in the AMúr Country 351

The Yard of a Prison in the Amúr Country for Convicts working ON THE RaILWAY $\quad 376$

Children of the Russian Labodrers on the Amúr Railway 377

The Excavator at Work, digging a Channel for Drainage (OCTOBER 7) 380

Korean and Russiax Labourers at Work (October 7) 380 xiv 


\section{LIST OF ILLUSTRATIONS}

By Trolley across the Marshy Plains (October 8)

BeAr of the AMúr Country, Ursus torquatus (October 6)

OAK aNd Birch in the Forest Near Bira (October 9)

RoAd-bridge over a siall River (OCtOber 9)

View of the Kamenushka River and the Taiga (October 9) 389

Burnt Forest near the Kamenushka (October 9)

392

An Armed Russian Peasant looking for his stolex Horse throcgh the Amúr Country (October 10)

392

Black and White Birches (October 11)

393

Basalt Hill on the Bureya Plain, east of the River Arhhara

(OCtober 11)

393

CuffF ox the Bureya River where the Gold-miners Died

400

Nansen Station on the Amúr Railway. A Row of Telegas with

Labourers Returning Home passing the Station (October 12)

401

Telegas returntatg after taking Labourers Home (Horses shying at our Motor-car) (OCTOBER 12)

401

The Railway Bridge across the Seya, at Alexeyevsk (October 13) 404

Ferry across the Seya driven by Horse-capstay (October 13) 404

Forest Fire iN the AMúr Country

405

Trees felled by Stori in the Amúr Country 405

Ice formed over a Spring in Forest in the Amúr Coustry 408

Mode of Transporting a Corpse throcgh the Taiga in the Amúr COUNTRY

A Frozen Tunvel on the Amúr Railway

The Wrecked Train at the Bridge over the Chitkax (October 15)

The Prisons with Church at Rasdolni (October 17)

On the Watershed betweex the Amasar and the Black Uryua (October 17)

Near the Black Uryum (October 17)

Gold-washiyg Station on the Black Uryem (October 17)

The Church at the Station of Ksenyevshi (October 17)

Mr. Wourtzel axd his Section Exgineers Boris Seest and Evgene Podrutsky (Left to Right) in the Saloon Carriage (October 18) 423

Along the River Selenga (October 19) 423

Lake Baikal at Taxkhoi (October 19) 428

Street in a Siberiay Village (October 19) 428

Street in the Village of Tankhor, on the Shore of Lake Baikal

(OCtober 19)

Street IN TUlUN (October 20)

Well at Khodoyelayskaya Station (October 20) 


\section{LIST OF ILLUSTRATIONS}

Steamboats at Novo Nikolayevsk, takex from the Bridge over the Obi (October 22)

Rallway Passengers fetching Hot Water for Tea at a Siberian Station (October 23)

A View on the Steppes (Остоber 23)

Palace built by a Gold-yinne Proprietor in Yekaterinenburg, now a Printing Office (October. 24)

A Village in the Government of Viatka (October 25)

\section{LIST OF MAPS}

Map of the Kara Sea and adjoining Territories; Showing the Track OF THE "CORRECT" AND THE ICE CONDITIONS

Map of Eastern Siberia : Showing Dr. Nansen's Routes

Map of Siberia: Showing Dr. Nansen's Routes, Outward and HomeWARD 


\section{CHAPTER I}

FROM NORWAY TO THE KARA SEA

Departure : Object of the Voyage : Shipmates : At Tromsö : Captain Ritscher and the unfortunate expedition to Spitsbergen : Captain Samuelsen and the Correct : Johansen, the ice-pilot : Leaving Norway : The Barents Sea, a sunken continent : Our prospects : The wireless; no connexion : Through the Kara Strait in fog, ugly shoals and rapid current : The Kara Sea open : In and along the ice : Yamal

TT was already 3.20 on August 2, 1913 ; the train was 1 due to start at $\mathbf{3 . 2 5}$ from the Eastern Station in Christiania, and still there was no sign of the others. I can't deny that I was beginning to get rather impatient.

At last a man appeared, carefully prepared for travelling, accompanied by a servant carrying various traps. He introduced himself as Loris-Melikov, Secretary of the Russian Legation, and my shipmate on the trip. He had seen nothing of the others either.

Now there were only a few minutes left. Then Mr. Lied came up and said he did not think we could start to-day, as Vostrotin's things were still lying at the Grand Hotel; by some mistake they had not been brought down. He was going to look for Vostrotin, and would see whether the station-master could keep the train a few minutes. Then he disappeared.

As I stood there, uncertain whether to wait till next day or to start at once, Vostrotin arrived, out of breath, hot and flustered, and got into the train. He said he 


\section{THROUGH SIBERIA}

was going on ; his luggage would have to be sent after him; he had not seen Lied at the station-and with that he went off to find a seat.

Consul-General Lorentzen and Mr. Whist, both directors of the Siberian Company, came to say goodbye to us. Whist declared he had faith in my lucky star, and his insurance company had therefore underwritten the ship. At that moment the whistle sounded, and with a jerk the train began to move. Was the luggage on board? And Lied? Nobody knew. But there he was, calmly walking up and shouting that he was going to wait till next day and would bring Vostrotin's things with him. Then we might just as well have waited too, and there were several things I wanted to clear up before starting. But there we were, and we should have to put in a day at Trondhjem for nothing.

At Eidsvold I had a telegram from $\mathrm{Mr}$. Whist, saying they were sending Lied and the luggage after us by special train to Hamar. And by the time we had had a good dinner there, Lied rolled into the station, calm as usual, with his special train and the luggage.

Then everything was in order, and all four of us were able to go on happily together to Trondhjem, and from there by the steamer northward to Tromsö along the coast of Nordland, whose wonderful beauty we had to imagine behind the drizzling rain and grey weather at sea, and above the low bank of fog in which every blue peak and white glacier was hidden.

The object of the trip was nothing less than to make another serious attempt to open up a regular trade connexion with the interior of Siberia, via the Kara Sea and the mouth of the Yenisei. Mainly with this object in view the Siberian Company had been formed, through the enterprise of Mr. Jonas Lied and with him as manager.

2 


\section{FROM NORWAY TO THE KARA SEA}

The Company had already made an attempt the year before to reach the mouth of the Yenisei by the Kara Sea, and had chartered a Norwegian steamer, the Tulla, which was specially built for the ice and therefore seemed suitable. But the attempt proved a failure; the Tulla met with a great quantity of ice in the Kara Sea and came home disheartened as early as the beginning of September.

Lied himself had voyaged down the Yenisei from Krasnoyarsk to its mouth with some laden lighters, to meet the ship and provide her with a cargo, never doubting that she would come through. In fact, he went as far as Dickson Harbour, north of the estuary, in a little steamboat, to look out for the ship that was coming.

A custom-house officer and two custom-house soldiers had come all the way from Irkutsk to the mouth of the Yenisei to examine the Tulla's cargo-a journey of $\mathbf{1 8 0 0}$ miles, or as far as from Rome to Lofoten. And, no doubt, a lot of police and gendarmes had also arrived, including the Chief of Police himself.

Men and lighters had lain there waiting till far on in September, but then they were obliged to go up the Yenisei again in order to reach Krasnoyarsk before the river was frozen over.

This year a more serious attempt was to be made; the steamer Correct had been chartered and lay waiting for us at Tromsö; this time Lied was going to make the voyage from Norway. The boat was laden chiefly with cement from Stettin, which was to be delivered to the Siberian Railway.

The question now was, whether we should get through or not. If the attempt failed again this year, it was thought that the Company would have to give up the idea of going on. If, on the other hand, it was 


\section{THROUGH SIBERIA}

successful, it would perhaps inaugurate a new line of annual sailings to the mouth of the Yenisei. Considerable interests were therefore involved in this trip.

In Siberia itself the development of this sea route has long been regarded as a vital question.

The future possibilities of Siberia may almost be called unlimited; but their development is attended with difficulties, which are mainly due to the great distances. In Central Siberia the railway routewhether westward to the Baltic or eastward to the Pacific-is so long as to render the freight on the chief products of the country, such as grain, timber, \&c., prohibitive, since the cost of carriage to the markets may easily equal the value of the goods.

But immense districts of this country, from Minusinsk, Northern Mongolia, eastward to beyond Lake Baikal, possess in the Yenisei and its tributaries the most excellent of waterways, which are available at comparatively small cost northward to the mouth of the Yenisei. 'These are fertile agricultural districts, far larger than France and Germany together. But unfortunately the Yenisei falls into the Arctic Ocean, where all navigation has the ice to reckon with.

If regular annual sailings could be established, in spite of the ice, between the Yenisei estuary and Europe, so that in future the immense quantities of produce could be sent by this cheaper route, it would naturally be of the greatest importance to the future development of the whole of Central Siberia. Therefore the people of that country are keenly interested in anything that may promote this affair. And without our being aware of it-speaking for myself, in any case -many eyes were doubtless fixed upon our voyage and what it might lead to.

As I have said, there were four of us who travelled 4 


\section{FROM NORWAY TO THE KARA SEA}

north together. First there was the Director of the Company, Jonas Lied, to whom this expedition was due. A man of a little over thirty, who had spent some years in Russia and Siberia and had studied their conditions with an eye to the vast possibilities of this great country of the future, he had succeeded in forming his company with Norwegian, English, Russian and Siberian capital. He had made himself thoroughly acquainted with everything bearing on the navigation of the Yenisei, and had planned and prepared this undertaking with great care and knowledge.

Then there were we three who had been invited to take part in the voyage as guests.

There was Stephan Vasilievitch Vostrotin, a goldmine proprietor from Yeniseisk, formerly mayor of that town and now member of the Duma for Yeniseisk province; he was the sole representative of a district of about a million inhabitants. An enviable country; just imagine if our Storthing could be constituted on the same scale, it would then contain two and a quarter nembers, who would certainly be a great deal easier to get on with than the 123 we now have.

A better companion for a voyage to Siberia it would be impossible to find. He had already sailed through the Kara Sea once, on his wedding trip in 1894, and he had been up and down the Yenisei several times. He knew his country and his million people inside and out, and was like a walking guide-book to everything one wanted to know about their life and work. But in addition to this he was himself for a long time partowner, in the nineties, of vessels trading in the Kara Sea and on the Yenisei ; he had himself bought steamers for this trade and lost a lot of money in it. So there again he could speak from great personal experience.

The second passenger was Joseph Gregorievitch 


\section{THROUGH SIBERIA}

Loris-Melikov, who for many years has been Secretary of the Russian Legation in Christiania. By birth he is an Armenian from the Caucasus; he was educated for some years in Germany, studied at a German university, and, besides Russian and German, speaks excellent Norwegian, French and English. And on this trip he had opportunities of picking up some words of Yurak, Samoyede and Yenisei-Ostiak. As a man whose business it is to look after Russo-Norwegian relations, he was naturally much interested in an undertaking which was to open up a new trade route from North Norway to the heart of the eastern division of the great Russian Empire, and thus we had the pleasure of his company on the trip. Always friendly and obliging, always the well-groomed and elegant diplomat, always an amiable and entertaining companion, he was just as ready to make as to appreciate a quiet joke, and always had the same immutable faith in the Russian system of government and its excellence.

Then there was myself. How and why I was of the party is still a riddle to me. I am very far from being a business man, and I have never had anything to do with Siberia beyond once sailing along its northern coast. But of course this does not prevent my having always taken a lively interest in that immense country and being very desirous of making its acquaintance. Nor do I know of any other qualification which would make it desirable to include me, except that I once sailed through the Kara Sea, and that I have had some little experience of going through the ice.

But however that may be, Lied had been to see me once or twice to hear what I thought of the possibilities of annual navigation through the Kara Sea. Thus he probably got the impression that I was interested in the question, and one fine day an invitation arrived 6 


\section{FROM NORWAY TO THE KARA SEA}

from the Company to take part as a guest in the voyage of the steamer Correct to the mouth of the Yenisei; and at the same time I received a very kind invitation from Mr. Wourtzel, the engineer at the head of all Imperial Russian railway construction, to go on with him up the Yenisei and by rail to Eastern Siberia and the Amur district, to see the new railway in course of construction there. And through him the Russian Traffic Minister sent a message that I should be welcome as the guest of Russia on this journey.

Why not? It was a temptingly easy way of making a trip through the Arctic Ocean to the Yenisei, and then seeing the whole of Siberia to the farthest east, without any trouble or preparation. I wanted a holiday; there could not be a better way of spending it, and I accepted with thanks.

Mr. Wourtzel was also to have been on the Correct as a guest of the Company; but as the wireless telegraph stations on the Kara Sea were not yet ready, he could not cut himself off from communication with the world and with his work for so long, and therefore had to give it up. But he sent a message through Lied that he would meet me at Krasnoyarsk and would wait for me there till September 25.

It was about midday on August 5 that we reached Tromsö in dull, drizzly weather. There the gallant captain of the Correct, Johan Samuelsen, gave us a friendly reception. All was ready on board, they were only waiting for us to weigh anchor. But reports from the east were not favourable; a few days before a steamer had arrived from the Pechora; she had found the sea full of ice between the Pechora estuary and Kolguev, had stuck fast, and had drifted for several days with the ice so far north that they had sighted Novaya Zemlya. This did not sound encouraging, he thought. 


\section{THROUGH SIBERIA}

In this, our last town, there were a good many things to be seen to. Telegrams and letters had to be sent off, and our outfit for the Polar Sea completed; mits, leather caps and mufflers bought-indeed, LorisMelikov bought a complete costume in elegant brown leather, like a chauffeur's, to make sure of being able to face the severity of the Arctic Ocean.

Then came a message that I must really come and see Captain Alfred Ritscher, who was lying in the Catholic hospital at Tromsö. He was the master of the ship on the unfortunate Schröder-Stranz expedition to Spitsbergen, which had gone north the summer before, and in aid of which I had assisted the German committee in sending a relief expedition under Captain Staxrud in the following spring.

I went to him, and found a pleasant, smart young German sailor lying in bed, who greeted me with a smile. Poor fellow, it was more than seven months since he had at last reached Advent Bay in Spitsbergen in an exhausted state after his adventurous journey. There he lay still in bed, with the loss of a foot.

He told me of all the difficulties they had met with, which, he said, were in great measure due to the fact that none of them had any previous experience of voyages of this kind. None of them had been in the Arctic or in the ice. He told me what outfit they had had, and then of his own terrible walk from Treurenberg Bay on the north-east side of Spitsbergen, where the ship was shut in the ice, down to Advent Bay in the Ice Fjord.

There were seven men with him to begin with on that walk, but two left them to go another way, and they were never heard of again. Two more were left lying in a hut, as one of them could go no farther. Finally three more stayed at a hut farther south, and 8 


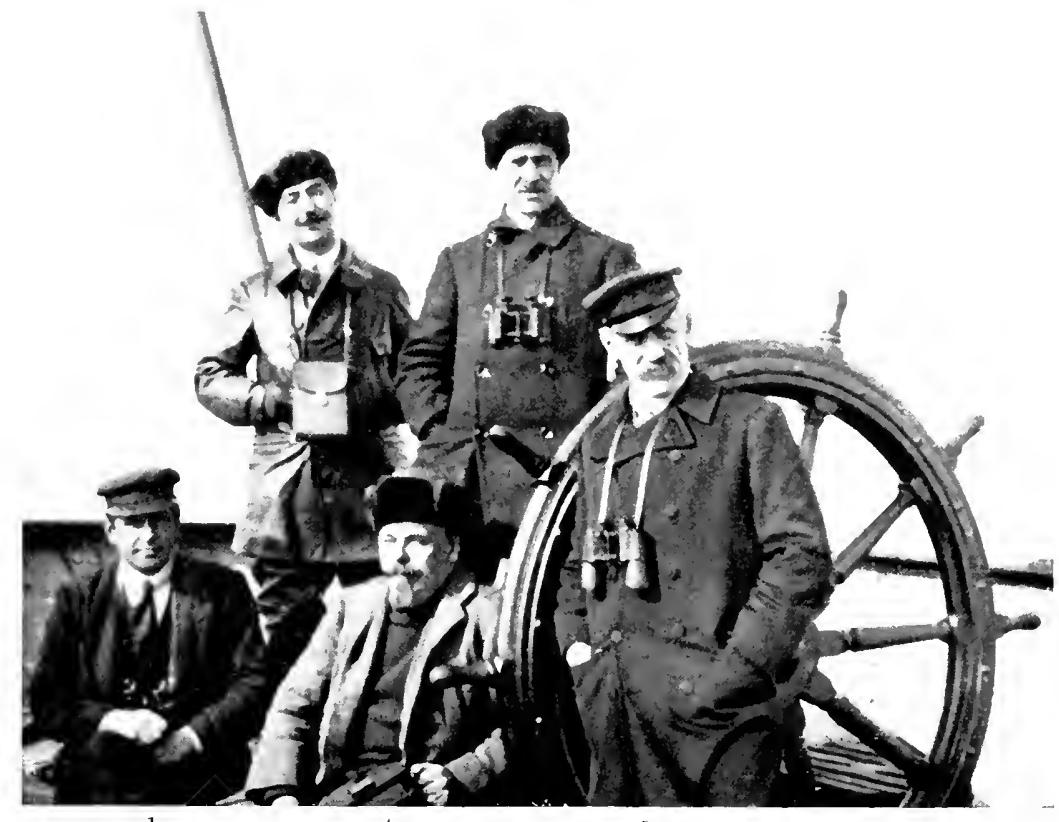

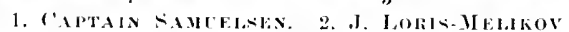

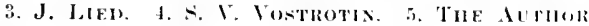

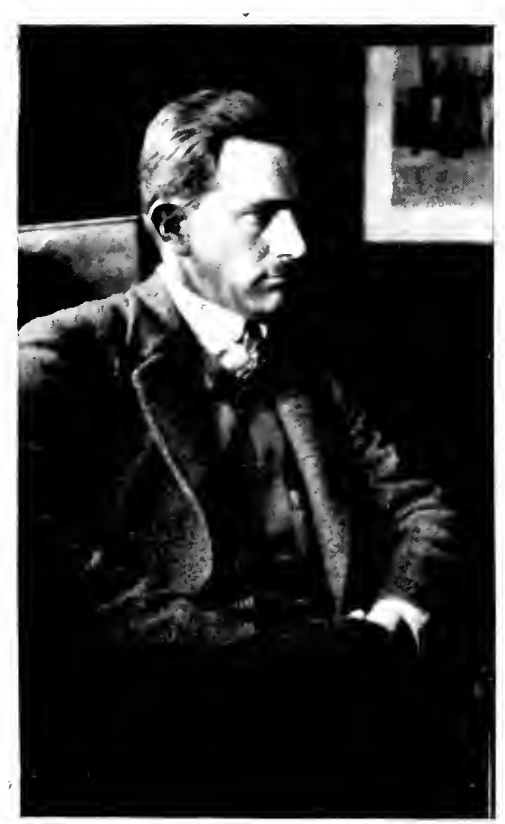

MII. JoNis LIED, DIRECTOR OF THE SIBEIRAN COMPANY

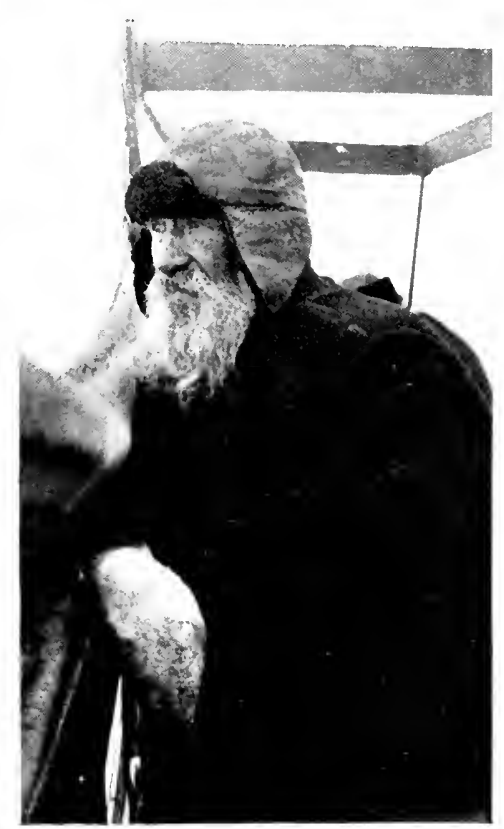

CAPTAN HAN JOUANSEN, THE ICE-PHLT 


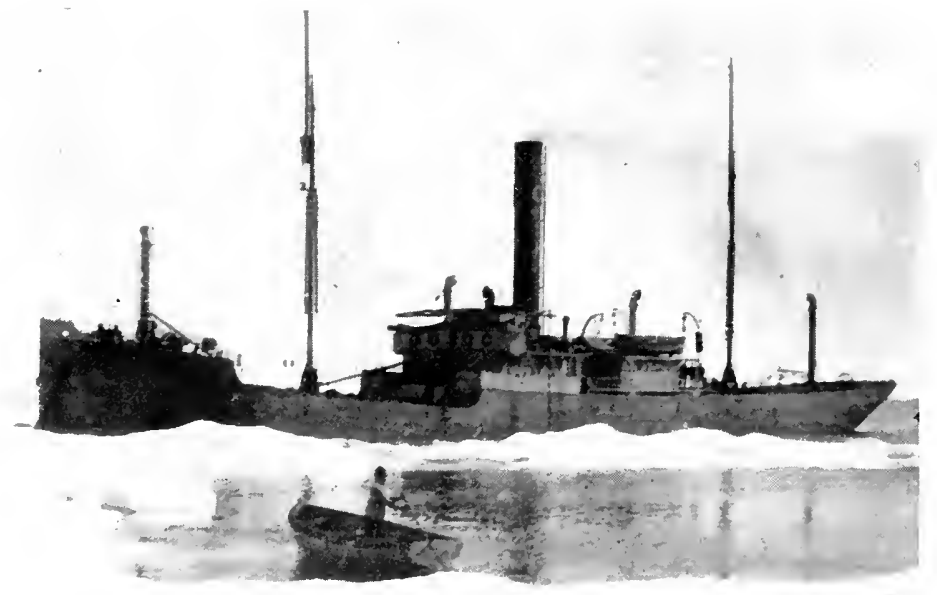

THe "Cornect" in the ICE

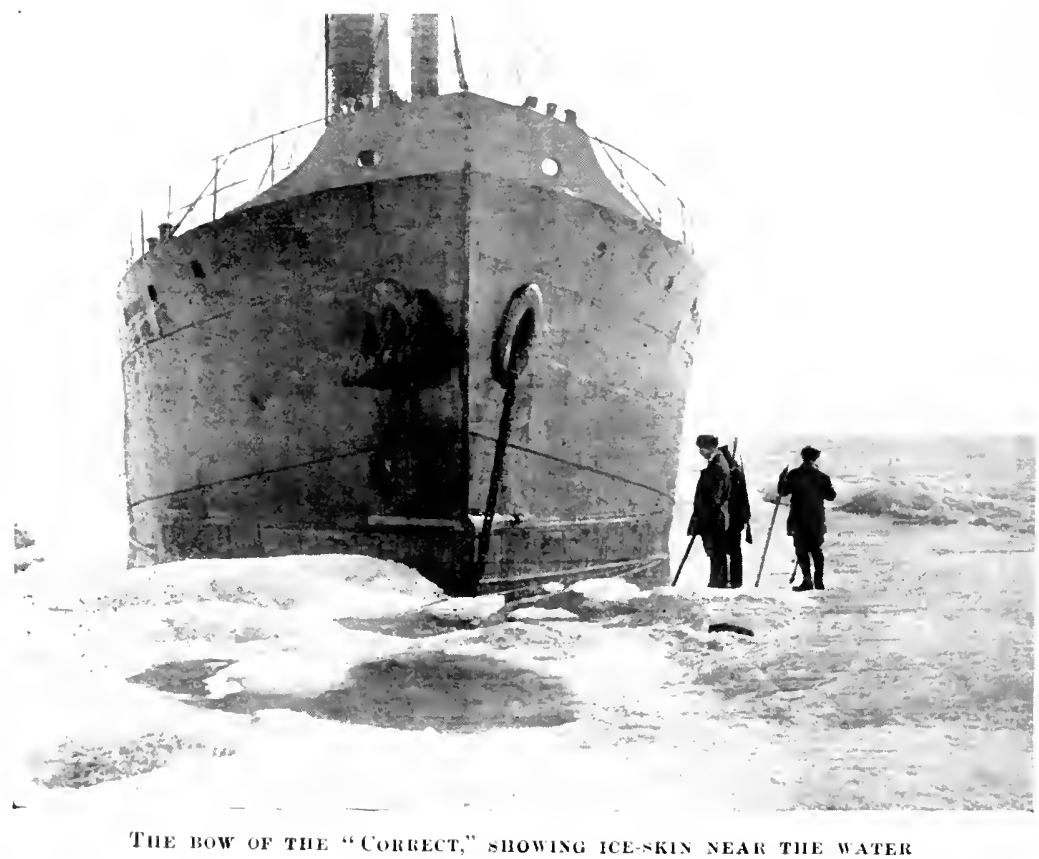




\section{FROM NORWAY TO THE KARA SEA}

then Ritscher went on alone in the middle of winter, with no sleeping-bag and with only a sack on his back, the whole long way over the mountain and across the Ice Fjord, where he fell through the new ice and was nearly drowned, and so reached Advent Bay at the last gasp, with one foot so badly frost-bitten that it had to be amputated. And he was not a practised ski-runner! One cannot help admiring the tenacity and strength of will that had kept him alive through all this. And he told his story with such engaging modesty.

Four of those who had been left behind during the march came back safely to the ship in Treurenberg Bay, while the fifth was lost on the way; one man had died of the three who had stayed on board the vessel, and Schröder-Stranz with his three companions, who had left the ship earlier, had also disappeared, and must have perished. A tragic expedition.

I asked him whether it was really possible, as I had read in the paper, that when Schröder-Stranz, the leader of the expedition, with three others left the ship in the ice to the north of North-East Land to make for that island, the arrangement was that the ship should wait for them at Spitsbergen till as late as December 15 ? I imagined it might be a misprint for September 15.

"No," he said ; " the arrangement was December 15." I then asked him if they did not see that this was an impossible date for returning from Spitsbergen, as the sea was covered with ice at that time, and besides it was dark winter with no daylight.

"Oh no," he said ; "it must seem strange to you, but none of us knew anything about it, for, you see, we had no experience; it is only now, when it is over, that I can see how foolish it all was."

He made a frank and winning impression, and seemed to be a keen and capable seaman. His one 


\section{THROUGH SIBERIA}

desire now was to get out of bed and go north again to Spitsbergen to fetch back his ship; for that was what he ought to do, there was no question about it, he said. I thought that might very well be left to others, and that he had better see about getting quite well first, as it was to be hoped he had a long life before him yet.

When I left him I thought of all the needless disasters and tragedies this unhappy hankering after the Arctic and the polar regions is responsible for. If these men had had a little experience of ice and snow, all this misery might easily have been avoided. Travels in these latitudes present difficulties enough, one would think, without their being increased by careless equipment and a superfluity of ignorance. How often I have said this to impatient young men in a hurry to start, but what is the use? And certainly nothing is gained by immature voyages of this kind.

But, to show how everything may depend on chance, it happened that in that very month of August 1912, I was up in those same waters to the north of Spitsbergen and Hinlopen Strait in my little boat, and there cannot have been very many miles between us. If we had happened to meet, who knows, perhaps a chance word or piece of advice might have averted the whole calamity, and they might all have been still alive and happy.

But such is the way of things. The weather was foggy just at that time, and we must have passed each other without knowing it.

At last we finished all we had to do at Tromsö. That is to say, Vostrotin still wanted a motor-boat, which he had been trying to buy to take us up the Yenisei. - But buying a motor-boat of that size in such a place was not to be done at a moment's notice Finally, in the course of the afternoon, we went on 10 


\section{FROM NORWAY TO THE KARA SEA}

board the Correct, which lay at anchor out in the sound. Dinner had been on the table waiting for us for three hours, to the steward's despair. But our hunger had not diminished on that account, and it was good to come into the warm cabin out of the damp, cold weather, and get something to eat and a glass of welcome and to be well looked after by our genial captain. Captain Samuelsen is a man of two or three and thirty, an officer in the Norwegian Naval Reserve. He has a share with his owners in this boat, which he has commanded for some years, chiefly in the Mediterranean fruit trade. He is a cheerful and capable sailor, with whom it was a pleasure to associate.

The first thing to be done was to settle ourselves on board the vessel, which was to be our home perhaps for some weeks. But it is not so easy to find room for four exacting guests on an ordinary cargo steamer which is not adapted for passengers.

Fortunately there was one guests' cabin with two berths, and there the two foreigners, Vostrotin and Loris-Melikov, were accommodated, though they were pretty cramped. Lied had to arrange with the chief engineer, who gave up his cabin to him and found room somewhere else. It was a more serious matter that, in order to make room for my humble self, the captain magnanimously gave up his own cabin, and had none for himself, but had to sleep in the saloon; for the chart-room, which he was to have had, was occupied by the wireless apparatus and its operator.

We all assembled for meals in the Correct's cosy saloon. There were generally six of us : the captain, Lied, we three guests and the ice-pilot. We were there a good deal at other times, too, and spent many a pleasant evening, reading, smoking and playing cards. Lied and Loris-Melikov were busy with chess, either 


\section{THROUGH SIBERIA}

there or on deck, whenever they had any spare time. Above all, we talked, discussing everything between heaven and earth, but chiefly the ice and the Arctic.

The Correct belongs to the ship-owning firm of Ivar A. Christensen of Haugesund, and was built in Holland in 1908-only for ordinary voyages, it is true ; but she is a good, strong vessel with thick steel plates, and she did very well on this trip. She is of 1550 tons dead weight. Her length over all is 225 feet, beam 33 feet, and when laden she drew about 17 feet. She has triple-expansion engines of 700 indicated horsepower, and ought to do about 10 knots in calm weather; but now she had a fairly heavy load, chiefly barrels of cement (over 1000 tons), so perhaps her speed was rather less.

In order to render the vessel better fitted for ice, the captain had had her bows sheathed with an ice-skin of oak planks. It extended from about two feet above the water-line to four feet below. As it was difficult to fix the planks in any other way, they were placed perpendicularly and held fast by two iron bands above and below. It would have been better if they could have been laid horizontally, but then it would not have been so easy to fasten them. As they were, they did good service and took many a shock that without them would have been very awkward, and on the whole they gave such protection to the bow that we were able without anxiety to force a way through the floes in narrow waters.

For this voyage the Correct had also been fitted with wireless telegraphy. The masts were raised, and antennæ rigged between them. The apparatus was installed in the chart-room, where the operator also had his quarters, as I said before. The idea was that we should be able to communicate with the wireless 12 


\section{FROM NORWAY TO THE KARA SEA}

stations on Vaigach and at Yugorsky Shar; and one was also to be established on Yamal. It is true they were not yet completed and open for traffic; but it was promised that they would be able to telegraph by the time we wanted them, and in any case ships fitted with wireless had gone there and would be able to give us information of the ice conditions.

But on the voyage east we could establish no connexion with them, and as far as they were concerned the wireless was of no use to us.

The crew of the Correct, as usual nowadays in Norwegian vessels, was a mixture of all nations. The mates and the engineer and two or three of the hands were Norwegians, but the rest were Englishmen, Scotchmen, Finns, Swedes and Danes.

As ice-pilot we took on board at Tromsö Captain Hans Christian Johansen, who knew these waters from many previous voyages. At the time of Nordenskiöld's expedition in the Vega, in 1878, he took the steamer Lena from Norway along the coast of Siberia to the mouth of the Lena. He then went up that river to Yakutsk, and for several years after that time he ran the steamer on the River Lena. In the years 1883 and 1884 he commanded Sibiriakov's steamer Nordenskiöld, and was to have taken her to the Yenisei estuary; but unfavourable ice conditions and other things prevented him. Afterwards he bought the sloop Gjöa, and used her for whaling in the Polar Sea for several years, until in 1901 he sold her to Roald Amundsen, who made his famous voyage through the North-West Passage in her. More recently Captain Johansen has commanded a small steamer, the Victoria, in the Polar Sea. With his long Arctic experience he was naturally a very valuable man on board, when it came to going through the ice. 


\section{THROUGH SIBERIA}

Tuesday, August 5. At last, on the evening of August 5, we were able to weigh anchor and steer to the north through Tromsö Sound, which in its grey and rainy mood did not smile its sweetest on our departure. A solitary motor-boat came bearing down on us and put about, steered by a lady, who stood up, tall and slender, and waved a farewell to us with her free hand.

Wednesday, August 6. To send off our last mail we went next day into Honnings-våg; and at ten o'clock at night we stood out to sea from there to the eastward. A course was made direct for Vaigach. Our idea was to attempt a passage through Yugor Strait or Yugorsky Shar.

The weather was overcast and there was a headwind, from the north-east and east, with a good deal of head sea, so that often enough the Correct took small breakers over her bow, but she worked her way to the eastward at about seven knots.

There are not many people about in that sea. The only vessel we saw was a four-masted White Sea trader the first day after leaving Honnings-våg.

After that the only living creatures to be seen above the billowy, leaden-grey surface were kittiwakes and fulmars, and now and then a dark skua darting down in its hawk-like flight upon a kittiwake that had just made a catch in the sea. The plaintive cry of the pursued bird rends the stillness of the sea. It heaves and plunges in a wildly rocking flight through the air ; and then it has to drop its catch. The skua darts down, lightly as a swallow, and snaps it up before it reaches the water-and then flies calmly on its way.

Friday, August 8. There were still many flights of kittiwakes to be seen on the second day out from Honnings-våg. This was in about latitude $70^{\circ} 45^{\prime} \mathrm{N}$, 14 


\section{FROM NORWAY TO THE KARA SEA}

in the sea approximately north of the entrance to the White Sea and Kanin Nos. It was a sign that there was food in the water, and probably also fish.

But this sea is a cold one, and the quantity of fish is variable and uncertain in consequence. It is true that a branch of the Atlantic current (the "Gulf Stream") runs in here to the eastward past the North Cape-the North Cape Current, as I have called it-and follows approximately the edge of the shallowest bank which extends northward from the continent, and over which we were sailing.

The whole of this sea is shallow. The depth varies from between 25 and 45 fathoms along the whole of this shelf to the north of the Russian coast, to between 150 and 180 fathoms in the deepest channel to the north of us. The current has no force in such shallow waters, with so uneven a bottom; it forms all kinds of whirlpools and eddies, and the shallow volume of water is sharply chilled in the course of the winter.

For all that, this warm Atlantic current influences the ice conditions in these regions; for, but for it, the water in this shallow sea would become colder; it would be cooled down to about the freezing-point of sea-water in winter, more and thicker ice would be formed over the whole sea, and there would be little open water for navigation in summer.

We took soundings on our way east, but the depth is very variable. At one time it may be over 100 fathoms, then 50 , then perhaps only 35 or 40 . There are many depressions, grooves and valleys down under the water.

In my opinion, the bottom of Barents Sea, to as far north as Spitsbergen and Franz Josef Land, is only to be considered as a part of the continent of Europe. It was once continuous dry land, intersected by mighty 


\section{THROUGH SIBERIA}

rivers, which dug out their long, wide valleys across the plains, with broad, low hills extending between the river valleys. Then, later on, these valleys were transformed by glaciers and by a great ice-sheath, and the whole country with its heights and valleys was depressed below the sea, or more correctly perhaps was inundated by it; and now the sea flows with its boundless surface over the forgotten lands.

We are excited about how we shall get on to the eastward, and at every meal, when we assemble in the saloon, our prospects are discussed: how we shall escape the ice, and how soon we can arrive at the mouth of the Yenisei. Wagering has begun; Lied has made a bet with Loris-Melikov that we shall be there by Thursday (August 14).

The ice-pilot, Johansen, firmly believes we shall get through. An old fortune-teller at Tromsö predicted it before he left; but there would be two difficulties to overcome on the way. And her prophecies generally come true, he declared. But then she had said that he was to earn a handsome gratuity on the trip, and he had no idea what that could mean. But when Lied, who was a mighty Nimrod and was burning to shoot a bear, promised fifty kroner to anybody who saw one, Johansen thought that would be the solution; for if we came into the ice, it was not unlikely that he would be able to find a bear with the glasses from the crow'snest.

We are still talking about the ice encountered by the steamer from the Pechora; but I do not think this can matter very much to us, as the ice in those waters has little to do with the ice conditions in the Kara Sea ; probably it was only ice from the sea to the west of Vaigach that had drifted northward.

Saturday, August 9. The wind is still fresh from 16 


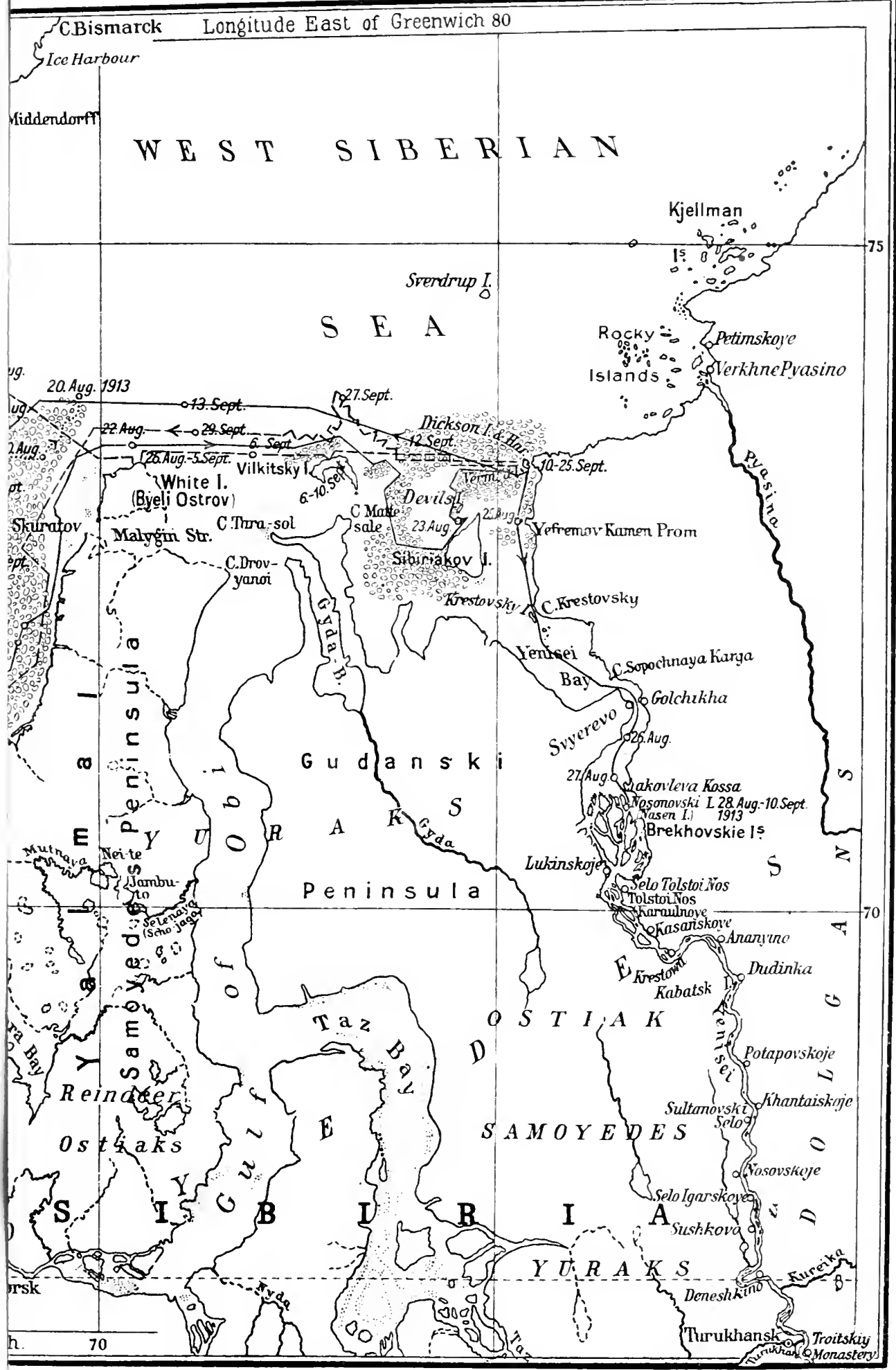

; THE TRACK OF THE "CORRECT" AND THE ICE CONDITIONS. 


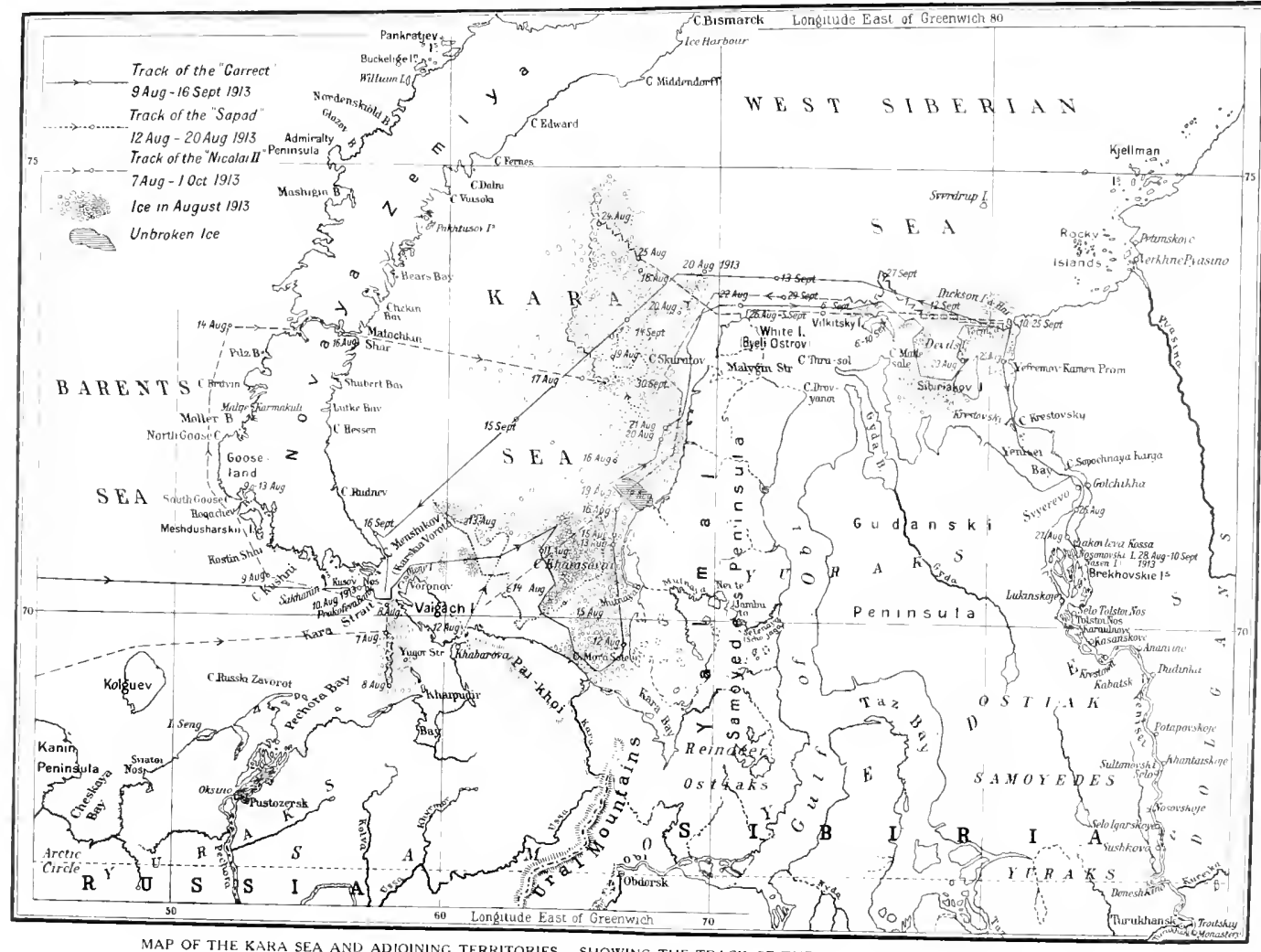

MAP OF THE KARA SEA AND ADJOINING TERRITORIES SHOWING THE TRACK OF THE "CORRECT" AND THE ICE CONDITIONS 


\section{FROM NORIVAY TO THE KARA SEA}

the eastward and there is more sea, so that it does not look as if there were ice to the east of us here.

At eleven in the evening of August 9 we had come far enough for the wireless operator to try to establish connexion with the station at Yugorsky Shar. The dynamo began its rising hum, and the wailing calls were sent out into the night-again and again, persistently. Then it stopped, and he listened. No answer. The dynamo hummed again; more plaintive calls. Then silence again-time after time, but no answer.

Evidently the station at Yugorsky Shar was not yet in working order after all; but what about the ships that were to be there with wireless?

An hour later we tried to get in touch with Ingö (Finmark), in spite of the long distance; but without success. Ingö was to send us telegrams, if there were any ; but there was nothing to be heard.

We were still well in touch with Ingö on the second evening out from Honnings-våg (August 7), although the distance was then 230 to 240 sea miles and our apparatus was only guaranteed for 150 miles at night. On the third evening (August 8) we could not get an answer, either from Ingö or Archangel.

On the afternoon and night of the 9th the weather was thick and at times foggy, so that we did not sight Novaya Zemlya, though we cannot have been far off. Dead reckoning and soundings agreed very well.

Sunday, August 10. At last, at 8 A.M. on the 10th, we definitely sighted land. This was Sakhanin island, which was then abeam, 3 miles off. The sounding gave 184 fathoms, said the mate. That seemed far too much and must have been a mistake, as it ought to have been about 90 fathoms; but it agrees at any rate with the fact that just here is the deep channel that 


\section{THROUGH SIBERIA}

extends along the south coast of Novaya Zemlya from Karskiya Vorota or the Kara Strait.

There is a heavy swell from the E.S.E., so that no ice can have come westward through the Kara Strait in spite of the constant easterly wind we have had; and we now begin to have hopes of getting through that way, although we thought we should have had to try Yugorsky Shar in order to reach the Kara Sea.

There is a thick fog, but soon we must be off the Kara Strait and shall be able to alter our course more to the east.

Still no sign of ice, but continued swell. It looks as if we should get through; this is beginning to be exciting. The soundings agree very well.

We try the wireless again, as there ought to be a ship with the apparatus here, in the vicinity of the station that is to be established on Vaigach. But there is no answer. Still thick fog.

Before twelve o'clock the lead had given 28, 26, 27 fathoms. At twelve we altered the course to the northeast to slip in through the Kara Strait. But when we had gone 3 miles on this course the lead gave, first 6 , then 4 fathoms. Stop! full speed astern! Then we bore away to the south-west.

Next sounding, 12 fathoms. Where are we ? The fog is as thick as a wall. Can it be Vaigach that we have approached too closely? No, we cannot possibly have come so far. It is more likely to be the Prokofeva Bank off Kusov Nos, on the north side of the entrance to the Kara Strait. The depth there ought only to be 2 fathoms.

Our course is made eastward again. The sounding gives 24 fathoms. That seems all right, we must be past. We are going at half-speed. Then the next 18 


\section{FROM NORWAY TO THE KARA SEA}

sounding gives 6 fathoms. Round again and southward. This is rather too exciting: we must be in among rocks.

The next sounding gives 30 fathoms, then $27-68-$ 100-108-105. We then turn to the south-east again and have 68 fathoms; after that more regular soundings, mostly between 20 and 30 fathoms. At 1.42 P.M. the course is made E., and at 2.5 P.M. N.E. by N.

In vain we gaze into the thick fog for some sign of islands or land. The soundings keep fairly regular, between 20 and 30 fathoms as a rule; sometimes they go up to over 40. We now think we shall go through the Kara Strait without sighting land.

At last, at 4.20 P.M., the fog lifts a little and we see an island ahead, a little on the starboard bow. That fits in; it must be Oleniy Island (i.e. Reindeer Island), and we steer accordingly, making the course half a point more northerly to clear the land. The only strange thing is that we do not see Chirachi holm, which ought not to be far away.

But then we have a holm ahead and have to bear still more to the north. This puts us out of our reckoning. We get into an ugly race; the current runs like a river, with white breakers and big eddies. It looks dangerous, and the vessel is turned to one side. We heave the lead, but it is over 30 fathoms.

Farther on, past the holm, were two small islands. These must have been the Yanova Islands and the holm was Chirachi. So that the first island we sighted was not Oleniy Island, but evidently Voronov Nos, and now we could see the island off this long promontory.

It was all clear in a moment. The current had set us over 13 miles to the south-east (true), and was still so strong against us that we had to bear up to the 


\section{THROUGH SIBERIA}

north to get round the land. We went through one race after another.

At last, after some hours, the current seemed to have turned and ran strongly with us. It was still a race, but the current must run to the eastward, as it banks up the seas, which were now coming from the north-east. To our great disappointment the wind had begun to blow from that quarter. It had been southerly in the morning, and we were glad of it, as it set the ice to the northward. Then it became westerly, and that was not so good; but this stiff north-east wind was the worst we could have, as it would drive the ice to the south-west and west in the Kara Sea.

In spite of that, we still saw no ice ahead; on the other hand, there was a good deal of slack and scattered ice away towards the land; but the weather was never clear, so we could not see far, and now it grew thick again, hiding the land. Once more we saw nothing but the fog around and above us, and the sea below us; but now we could make a course for Yamal, about E. by $\mathrm{N}$. true.

So we sailed out of the Kara Strait, as we had entered it, in fog; and the Kara Sea rolled in front of us with a swell from the north; it seemed to be quite open.

Then there was rejoicing on board. Johansen came to the conclusion that this was the first of the two difficulties that the fortune-teller at Tromsö had predicted we should have to overcome on this trip.

We were already thinking we had open sea before us as far as the Yenisei, when a few hours later (8.30 P.M.) we caught sight of ice on the starboard bow. It stretched farther and farther ahead, and about 20 miles from the Kara Strait we were in among blocks of ice and the Correct had her first experience of the floes. 20 


\section{FROM NORWAY TO THE KARA SEA}

But they were only small scattered blocks of worn and dirty ice in process of melting. The sky did not look particularly light in any quarter. It was brightest in the south, so there was perhaps some ice in that direction.

It was only a narrow, broken strip that we met with here; it seemed to be a little more packed to the southward. Judging from the light in the sky, there was also some ice on the north.

After getting a few bumps and testing the Captain's pride, the ice-skin on the bow, which stood them well, the Correct glided out into open water again. The sky was dark ahead, and again there was some swell from the north. It seemed as if we had open sea before us.

About midnight ice was again reported everywhere ahead. This was about $\mathbf{4 0}$ miles from the Kara Strait. But this, too, was only a strip of small ice, and after going slow for a full hour on a straight course we were through it and in wide, open sea again with no ice to be seen in any quarter.

There was a light sky ahead. This might be ice, but it was more likely to be clear sky beyond the clouds to the eastward. Johansen, the ice-pilot, was much offended on the bridge, beeause I did not consider it impossible that there could be any ice-blink near the horizon. It grew brighter the farther east we came. It must have been the light of the clear sky that we were sailing into.

Monday, August 11th. A fine night, blue sky, open sea and hardly any wind. The sun was beginning to gild the northern sky; soon it would rise above the sea horizon in full splendour.

At 3 A.m. the sea was so blue and we saw so far ahead that we altered our course to nearly N.N.E. 


\section{THROUGH SIBERIA}

in the hope of being able to go straight on, to the north of White Island (Beli Ostrov), and in that firm belief I turned in.

At about six I was awakened by the engines slowing down, so there was more ice. They had seen ice to the north for a long time, but now it was ahead as well. They thought it was only a line of broken ice and kept on through it. There was a little fog.

We went farther and farther in. When $I$ went up on the bridge at nine o'clock there was scattered jee on all sides, but it was markedly worn and for the most part small shreds of ice which would be entirely thawed away before many days were past.

On the east and north it was thicker, and it did not seem advisable to go in that direction any longer; it would no doubt be safer to come back into the open sea again. The sky ccrtainly looked as if there must be some open water in the ice to the eastward, as the air was bluish and not white in that direction; but there was no open water to be scen from the crow'snest, and it looked fairly close far to the eastward. It was therefore difficult to say how much open water there might have been, and whether there was enough for the Correct to get through. But we were still far from the coast of Yamal, and if there were ice the whole way, we should run the risk of being stuck fast and drifting in it for a considerable time. If only we had had an aeroplane to send to the eastward, then we might have found out for certain whether there was a passage and perhaps saved several days.

But we steered to the south-west at full steam between the floes so as to get out, and then southward along the edge in the hope of finding a way to the south of the ice and into Yamal. 


\section{FROM NORWAY TO THE KARA SEA}

In sailing through ice-filled waters like these, one may get on faster by hugging the coast, for, as soon as the least wind blows from landward, it sets the ice off the coast and forms an open lane.

On the other hand, if one tries to force a way through the masses of ice out at sea, one may be stuck fast, and no wind will have any special power of opening the ice. On the contrary, the winds will often pack it closer to windward, while scattering it somewhat to leeward.

The noon altitude gave latitude $70^{\circ} 51^{\prime} \mathrm{N}$., which was rather more southerly than we expected, and according to dead reckoning the longitude ought to have been about $63^{\circ} \mathrm{E}$.

Farther south along its edge the ice was more open, and we again steered to the east through the floes, hoping to find a passage. But after a while they became closer again. We now saw to the south-east of us a broad patch of clear water, which extended far in a north-easterly direction to nearly due north-east of us, but there was no way of getting through to it, and we had to steam for several hours to get round to the south of the tongue of ice.

We did not reach the point till about eight in the evening, and were able to stand to the eastward to the south of it. We reached the broad stretch of clear water on the inside, which extended to the north-east, as far as we could see from the crow's-nest, and there was scarcely an ice-floe in it. But on the eastern side of this clear water we could see ice, and this made it doubtful whether the open stretch reached as far as the land.

We decided not to try it, but rather to bear across this open bay to the ice on the other side, in a southeasterly direction, approximately. Here the water was 


\section{THROUGH SIBERIA}

quite deep; at eleven o'clock the sounding gave 105 fathoms, but then it became shallower again.

Tuesday, August 12. It took us several hours to reach the edge of the ice, which we did in the early morning. Again we had to stand to the south along it, and sometimes to go through the ice.

Our course took us farther and farther 'south. Meanwhile we had sighted the land on the south side of the Kara Sca, and in the morning we were scarcely more than 6 or 8 miles from it, the Captain thought.

Finally he found there was nothing for it but to try to go through the ice to the eastward, as it extended right up to the land on the south. After they had forced a narrow way among some big floes, the ice began to be slacker. And when I came out, at about nine in the morning, we were in fairly open water and could bear to the north-east. The weather had become overcast and thick, with fog now and again. We had come into shallow water; the lead only gave 11 fathoms.

At last, in the formoon, at about eleven, we could see low land through the mist to the east. 'This was Yamal, the same low sandy country that I had seen for the first time through the same mist twenty years before. It somewhat resembles Jxderen or Lister in Norway, though the shore is a good deal higher, perhaps more like the west coast of Jutland.

The whole of Yamal is a single great plain, made up of sand, clay, gravel and pebbles. Along the shore it falls in a steep slope, that may be 60 to 90 feet high, but inland it is one low, undulating plain, covered with grass and moss, with osier thickets here and there, and with a multitude of lakes great and small, and shallow rivers and brooks. There is excellent pasture for reindeer on these wide prairies, and the Samoyedes 24 


\section{FROM NORWAY TO THE KARA SEA}

travel all through the summer with their herds of reindeer over the whole country.

We now stood to the northward along this coast and soon caught sight of a lofty beacon raised on a promontory to the north of us. It must have been that which is marked on the Russian chart at the mouth of the river Mora Yaga, just north of the promontory of Mora Salé. But the country is uniformly flat the whole way, so that it is difficult to know one part from another.

Here there was rather less open water to the northward, and as the wind was still westerly, it seemed doubtful whether we ought to go on to the north through the channel along the shore, for if the ice closed in, it would be awkward for us on this open, shallow coast. We stopped to see how things were going and let the vessel drift. Meanwhile the Captain was able at last to have an undisturbed and wellcarned sleep; he had not been out of his clothes since we left Norway. 


\section{CHAPTER II \\ VISITS FROM SAMOYEDES}

A Samoyede boat arrives : Samoyedes on board : Life of the Yamal-Samoyedes : Northward through the ice : Packed ice : Another Samoyede boat comes : Eating raw fish : The mate sculling : Yet another Samoyede boat

TVHE westerly wind on our beam drove us slowly 1 in towards the land. As we came nearer we could make out people moving on shore by the beacon; they seemed to be standing up there on the level ground and gazing at us. Were they Samoyedes? Or were they perhaps Russians, who had just come here to set up the wireless station? We could not tell.

Soon after, in the inlet north of the beacon, we saw a boat with a mast. This made it seem probable that they were really Russians who had come here, and as it was important to hear something about the ice conditions, we decided to have a run ashore while the Captain was asleep. But first we had to have dinner.

When this was disposed of and we were all ready to row off, Johansen sang out from the crow's-nest that a boat was putting out from land. There was great excitement on board. Were they Samoyedes or Russians?

Then we could see the men in the boat with our glasses across the scattered floes. At any rate they wore Samoyede reindeer tunics with hoods over their heads ; and, as Loris-Melikov said, they looked more 26 


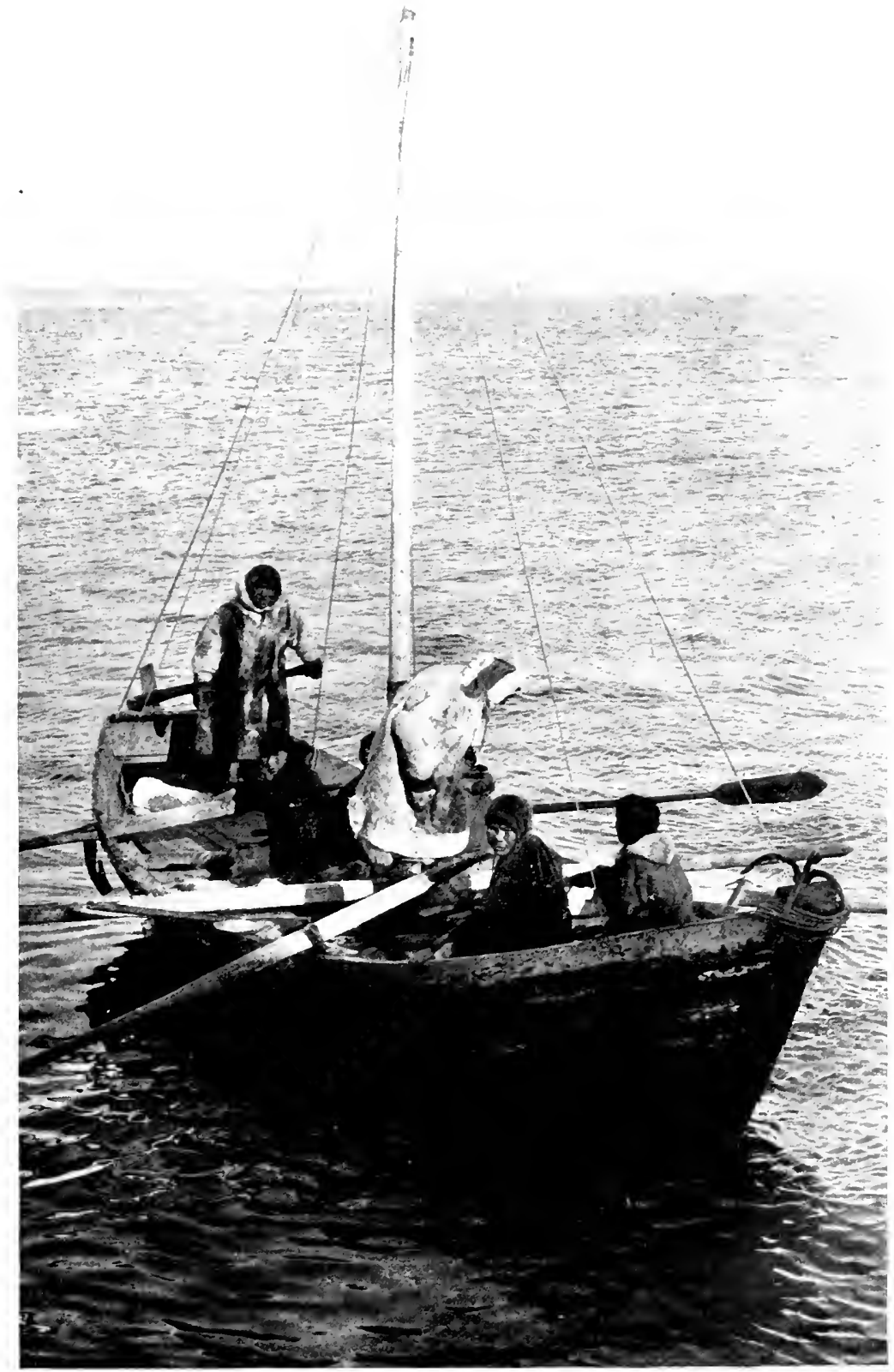

A SAMOYEDE BOAT UNDER WAY 

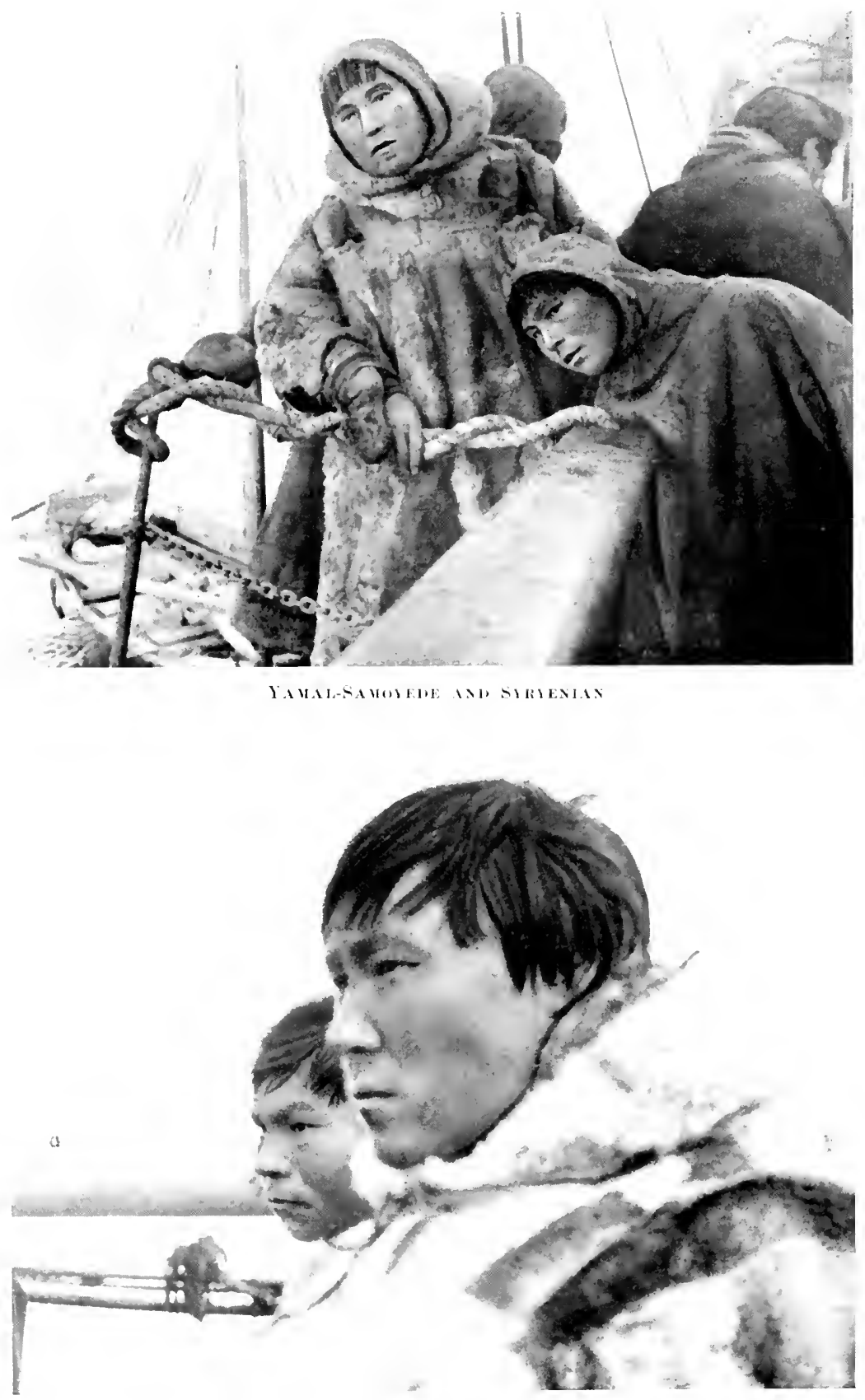

YAUAT-SAMOIEIE 


\section{VISITS FROM SAMOYEDES}

like monkeys than anything else. There were six of them in the boat, but it was not so easy to say which sex they belonged to.

Vostrotin shouted a greeting in Russian, but they only bowed in oriental fashion and waved their hands in return. Vostrotin called again. The old man who was steering and was evidently their chief, came forward to the middle thwart, bowed, but then stayed with his head bent and stared at us uncomprehendingly. They did not understand a word; they stopped rowing and hesitated, not knowing what to do.

Then we nodded in a friendly way and made signs to them to approach; and they rowed slowly and cautiously up to the gangway ladder, while Vostrotin continued speaking to them.

It then appeared that there was one who knew a little Russian. He came from the Pustozersk district and must have been a Syryenian. The Syryenians are the bloodsuckers of the Samoyedes, said Vostrotin. The rest were Samoyedes from the Obdorsk district.

The Syryenian explained that he was the old man's partner in fishing and hunting. He probably had some reindeer besides, and certainly carried on trade. He looked a crafty fellow, and was altogether different from the others. He told us, seemingly with a certain pride, that the scar on the right side of his lower lip was the result of a cut in a fight with knives. Vostrotin told me that the Syryenians were great fighters and fond of vodka, while the Samoyedes were peaceful, though they don't mind getting drunk either, when they have a chance.

The oldest of them, who still sat in the boat at the steering-oar, had a little grizzly beard and did not look like a pure Samoyede. But some of the younger ones had a very genuine appearance, especially one young man 


\section{THROUGH SIBERIA}

with a pleasing, almost handsome face. He might have been about twenty-five, and we were told that it was he who had built their boat. Then there was another who had evidently had smallpox. His whole face was red and scarred, and he looked ugly, and not very intelligent either.

We invited them on board and they came clambering up the ladder, really not unlike monkeys. They cautiously pattered about and stared at all the wonderful things on the big steamer. She must have been the biggest ship they had ever scen. All the costly iron that was everywhere about had to be carefully felt. The iron stays that held the big funnel had to be examined, and the rigging, which was also iron, and the masts and the hatches down into the ship. They looked down into the black depths of the engine-room and heard all the strange noises that eame from the stokers below, who were singing and elattering with their shovels. It must have seemed like a mysterious underworld.

Meanwhile Licd's business instinct was aroused; he began bartering with them and bought two knives with brass-mounted sheaths and belts, and brass chains. He showed them what he offered in exchange, and in particular a pocket electric lamp, which of course made a great impression. One of them could not resist that. He must have created a sensation when he got home to the camp with that piece of magic; but what sort of faces would they put on when the magic did not work any longer and there was no more light?

Then they came into the saloon and had a look round, and there they were given a performance of the gramophone, but it did not impress them very much. 'They had heard a better one in Obdorsk, they said, it made still more noise !

28 


\section{VISITS FROM SAMOYEDES}

But after that they were taken to the chart-room to hear the whining and humming of the wireless, while the operator worked his keys. They stared open-mouthed, one over the head of another, and their faces showed unconcealed astonishment and wonder. Whether they had any idea that all this extraordinary mechanism could send messages through the air to places far distant, is rather doubtful ; but at any rate they understood that they were here in the presence of a new and marvellous force.

Their clothes are for the most part nothing but reindeer skin, which they wear next their bodies, and if there was a hole anywhere, we saw their yellowishbrown skin through it. On the upper part of their bodies they all wear skin tunics (like a Lapp "pesk") with hoods, men and women alike, and it is not so easy for a stranger to see the difference between them. I now think they were six men who came aboard our ship, but several of the crew swore that two of them were women; indeed, the wireless operator afterwards declared he was certain one was a woman; he could tell by her hind quarters, he said.

Through Vostrotin as interpreter I found out that their boat was built by themselves, of planks they had brought with them all the way from Obdorsk, on three sledges fastened together lengthways and drawn by six reindeer oxen. One can understand from this that it is not so easy for them to procure boats, and there are only a few who possess them along this coast. Without them they can only hunt marine animals on the ice near land.

It is estimated that Yamal contains about 350 Samoyede men between the ages of fifteen and fifty or fifty-five, who are liable to pay yasak (tax) to the Russian Government. According to this, one might 


\section{THROUGH SIBERIA}

put the whole population of the peninsula at about 1000, including women and children. They belong to the branch of the Yurak-Samoycde race known as Kamen-Samoyedes (i.e. Ural-Samoyedes), which is somewhat mixed with Ostiak-Samoyedes. They are a branch of the Yuraks. A number of them inhabit the slopes of the Urals south of the borders of Yamal, and they are also estimated at about a thousand.

Samoyedes from the government of Archangel, west of the Urals, occasionally come to Yamal ; but apart from these almost all the Samoyedes there are from the Obdorsk district.

They make two great migrations in the course of the year. At the beginning of winter they trek with their reindeer to the forest districts near Nadim and Obdorsk, and spend the winter in the woods there, in the lower basin of the Obi.

At the winter fair of Obdorsk they sell their furs, walrus-tusks, reindeer-skins, reindeer-meat, \&c., and supply themselves with the necessary provisions, powder and shot, and anything else they require. The provisions consist chiefly of meal, white bread, butter, tea and tobacco, which is usually chewed, only a few take snuff or smoke; the wealthier among them also buy sugar and wheaten flour, and of course they all buy vodka according to their means, for they are very fond of it, and are apt to take it to excess if they only get a chance. At a pinch they will buy vodka from people who have a stock on the tundra, and then they may pay as much as a reindeer (i.e. 10 roubles) for a chetvert, which is about 3 litres.

In March and April they return to their pastures in Yamal.* The journey from Obdorsk to the central

* To save the reindeer from being too much tormented by mosquitoes and gadflies in summer, they have to take them either to the north, where it is colder, or up into the mountains.

30 


\section{VISITS FROM SAMOYEDES}

and northern parts of Yamal takes about two months, and the same time is occupied by the return journey in autumn. In this way the Samoyede with his tent is four months of the year on the march, northward and then southward again. The other eight months he spends comparatively quietly within his territory on the Yamal tundra, or in the forests on the Obi.

Thus from November to March Yamal is almost void of people; only a few Samoyedes stay behind on Malygin Strait, and on the coast of the Kara Sea, to hunt bears early in the spring. It sometimes happens, too, that Samoyedes stay the winter on the Gulf of Obi or on the great lakes, those who have too few reindeer to make the long journey to the south and are obliged to have recourse to fishing, and they may often settle there for years at a time.

There are ten different tribes in Yamal, each with its own section of the peninsula as a rule; and usually each tribe has fixed boundaries for its reindeer pastures, just as each chum (or tent) has, though they are not always kept very strictly. The chum keeps fairly quiet within these boundaries in summer; and only moves as far as may be necessary to secure fresh pasture for the reindeer.

Within his own territory the Samoyede fishes in the lakes and catches geese in the moulting season. He looks upon the lairs of the white and blue fox as his indisputable property, and sets his traps and snares round about them.

The Samoyedes live well in Yamal. It is a fertile country with broad pastures and with a wealth of furs, birds and fish. This accounts for the relatively large number of Samoyedes to be found there. The herd of a single owner may number as many as 5000 reindeer; Samoyedes who have only two or three hundred are not looked upon as well off. Those who are poor in 


\section{THROUGH SIBERIA}

reindeer fall back on fishing on the coast, especially the east side, near the Obi. In this they are somewhat like our Fishing Lapps, though the latter are much poorer. But the farther one goes into the tundra of Yamal, the richer the Samoyedes become.

A prosperous Samoyede has two or three, or even four chums (tents) with many sleeping-places (which are generally nothing but a few reindeer-skins), according to the size of his family. As a rule they only have one wife. Rich men, and lovers of the fair sexand there are not a few of them among the Samoyedes -have two or three, or as many as four wives, who occasionally have separate chums.

The price of a wife is from 30 to 100 reindeer, besides skins and various other things. The bride's father for his part gives the trousseau, clothes, outfit of furs, sometimes also jewels, and a showy reindeer for driving, which is considered as her private property. If they get tired of a wife who is lazy and will not work, they can send her back to her father, though without being able to claim the return of her price. The father is not always displeased with this arrangement, as he can sell her again and get paid afresh.

The Samoyedes are mentally well equipped, and are not considered below the average Russian peasant in intelligence. Their highest idea of civilization is of course Obdorsk, and they respect a civilization that can produce such results; but, at the same time, with the pride of the nomad, they esteem their own pretty highly, with their free life on the tundra, where neither Russian nor Syryenian is a match for them.

It struck me that these Samoyedes we met in Yamal were on the whole of good appearance, and they were bigger and stronger people than our Reindeer Lapps, though they could not be called tall ; they may probably 32 


\section{VISITS FROM SAMOYEDES}

best be described as of about the middle height, or a little under it.*

I cannot say that they presented any marked Asiatic or Mongolian features, such as prominent cheek-bones or very oblique eyes. They were for the most part almost beardless, and dark, with long black hair; some of their faces were quite handsome, even according to our taste. There is probably a considerable admixture of Russian blood in these people, and perhaps of other blood from the south as well. Shitkov says that he met in Yamal two men of the Okotetta and Lamdu tribes, who were tall and powerfully built, with sharp features and big, straight and even slightly aquiline noses. The same type is of frequent occurrence among the Samoyedes farther south, as his guide informed him. Shitkov says that such types are also to be found occasionally among the Voguls. They remind one of northern people of the so-called palæasiatic group, and both Samoyedes and Voguls may have received some admixture from people of that group, such as the Yenisei-Ostiaks.

The old man of the party we met here had, as I said, some hair on his chin, and looked as if he might have a good deal of Russian blood in him. On the fishingplaces along the Obi especially, where Russian workmen and Samoyedes live together, there must be considerable opportunity for this mixture of race.

While we were occupied with our visitors, it became clearer and we saw a broad channel to the north-

* Mr. Kai Donner informs me that according to measurements he has been able to take of various Samoyede tribes, the height of the Samoyedes varies between $5 \mathrm{ft} .3 \mathrm{in}$. and $5 \mathrm{ft} .5 \mathrm{in}$., while that of the Ugrian Ostiaks, for instance, often reaches $5 \mathrm{ft}$. $7 \mathrm{in}$. The cerebral index of the Samoyedes he found to average about 82 (they are thus not very brachycephalic, rather mesocephalic), while that of the Ostiaks was as much as 89 , which is unusually brachycephalic. 


\section{THROUGH SIBERIA}

ward. Just then the Captain came on deck after his nap and it was time to get away. When the Samoyedes saw that they had to go, they began to beg and beseech us to be allowed to buy vodka; but Vostrotin explained with a fatherly shake of the head that it would not do. And when at last they saw it was no use, they padded down the gangway-ladder again in deep disappointment and got into their boat.

As we steamed northward at full speed, we saw them hoist their little sail and steer in towards the point from which they had come. It is a strange thing that this was the very spot from which two Samoyedes came to visit the Fram, when we lay here on August 9, 1893, on the voyage eastward before forcing our way to the north. How time flies-is it really twenty years ago?

It was a little after six in the afternoon when we went forward through fairly slack ice, and not long after we were out in the open sea, with a good deal of swell. It seemed as if the sea must be free of ice for a long way to the west, the quarter from which the swell was coming, and in that case the ice along the edge of which we had steamed to the south must have been a pretty narrow belt which now lay to the west of us.

We went at full steam to the northward all night, and only encountered a floe here and there.

Wednesday, August 13. At 4.30 A.M. we again met with more ice, and soon after a fog came on and we had to slow down. We encountered huge flat floes, as much as half a mile in length, and several times we had to go astern. Finally the ice became closely packed ahead, and at seven o'clock we anchored in 10 fathoms of water. We lay at anchor the whole day. There was a north-westerly wind, but by degrees it fell light.

The fog lifted in the course of the forenoon and we 34 


\section{VISITS FROM SAMOYEDES}

had a clear horizon and sunshine. Viewed from the crow's-nest the ice lay white and closely packed as far as one could see to the north and north-west, and right up to the shore on the landward side; there was no sign of a lane in any direction. But the sky was fairly blue on the north, so that open water could not be very far away. Along the land to the northward the sky was whiter, so that the ice must have been closer there than it was at some distance from land. On the west it looked as if it could not be far to clear water, judging by the colour of the air. The noon altitude gave latitude $71^{\circ} 2^{\prime} \mathrm{N}$., and by our reckoning we were in longitude $66^{\circ} 27^{\prime} \mathrm{E}$.

In the afternoon a boat was reported in sight. This was unexpected here, right out in the ice and so far from land. It was another Samoyede boat with five men, rowing towards us. They hardly knew a word of Russian.

The coxswain lay reclining in the stern, looking like a pasha. He was no doubt the chief. $\mathrm{He}$ bore a remarkable resemblance to a Chinaman, as did a man who was rowing in the bow. In the middle of the boat sat a man with no nose and with a crooked hole where his mouth should have been. He looked like a leper, but was more probably a syphilitic; he was a terrible sight. The face of another man in the middle of the boat was swollen, red and scarred, most likely from smallpox, unless it was also syphilis in his case.

They were allowed to come on board and look round the deck. There was the same feeling and openmouthed staring at everything. But they gave us very little entertainment; their supply of Russian words was soon exhausted and conversation had to be carried on mainly by signs.

When they went back to their boat, the steward 


\section{THROUGH SIBERIA}

presented them with some bread, which was a great success. But the impression created by a bottle of whisky was a far greater one. The bottle quickly passed from mouth to mouth and after one round came back to the chief, who was not content with his first drink and whose face shone with the most heartfelt satisfaction as he held up the bottle in our faces and patted himself gleefully on the stomach.

They showed us various things, but none of special value. They brought some fish out of a box in their boat. They were of the salmon species; as far as I could see, they were "muksun," which is also found in the Yenisei ; a broad fish with large bright scales and a comparatively small head. The largest fish were quite a foot in length. They were badly salted and did not smell nice; some were a little fresher, and they gave us a few of these as a present, no doubt in return for what we had given them. We tried one of them for supper, but fresh it certainly was not. When we asked where these fish had been caught, they pointed to landward; but whether they meant on the coast or inland on Yalmal, I could not make out; I am inclined to think it was in the lakes of the interior.

Then they started scraping the scales off some of the raw fish and began to eat them. They cut them up lengthways, put the long strips into their mouths, and cut them off just in front of their lips, holding the end of the strip with the other hand. This is exactly the same way of eating as the Eskimo's, the only difference being that he brings his knife downwards to cut off the piece of meat or fish at his mouth, while these people cut upwards from below. Both are very expert and never cut off their noses or lips. It did not take them long to dispose of a big raw fish in this way. 

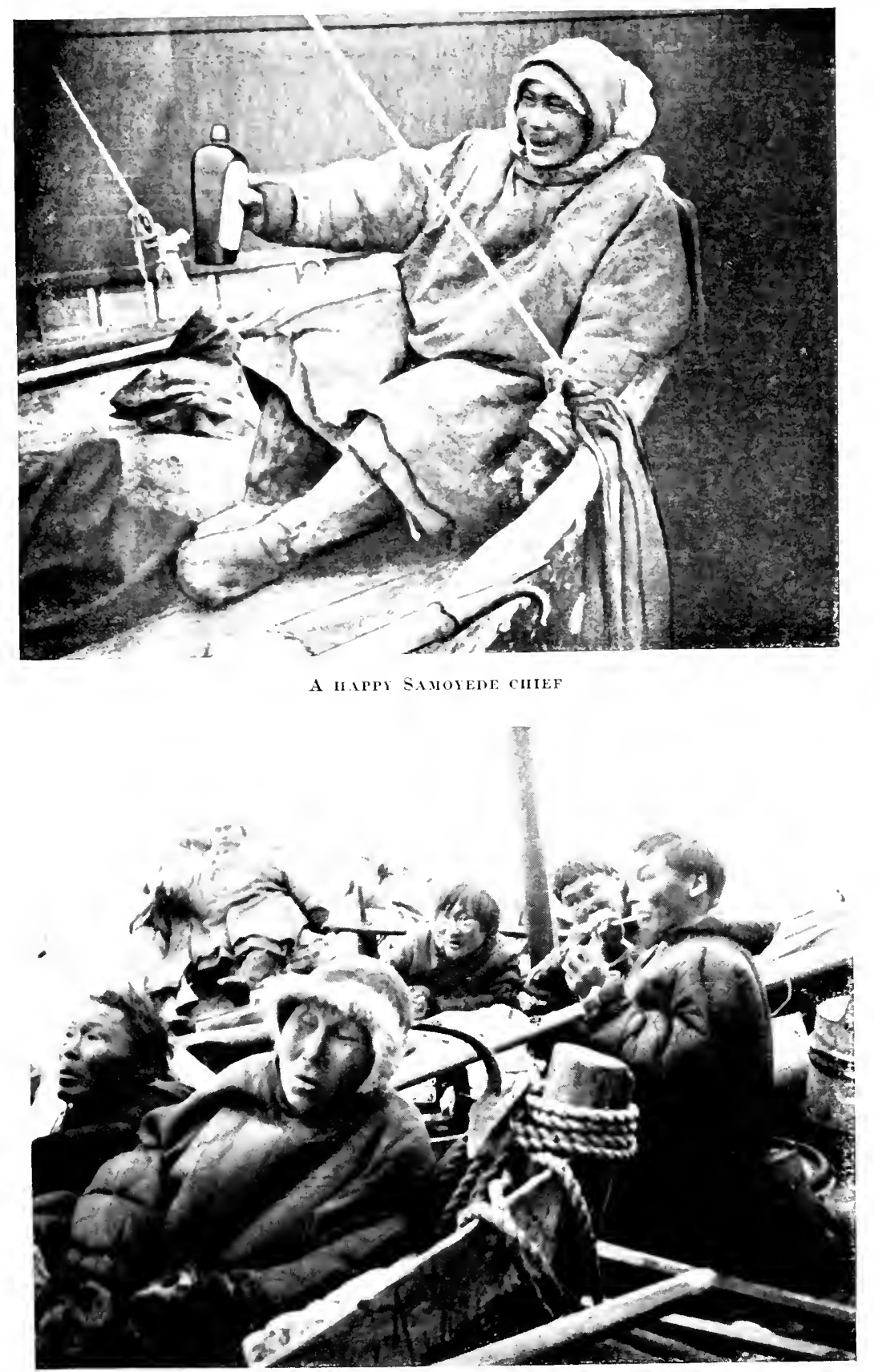

SAMOYEDES I N THEIR BOATS. THONE TO THE RIGHT ARE EATING RAW FISII 


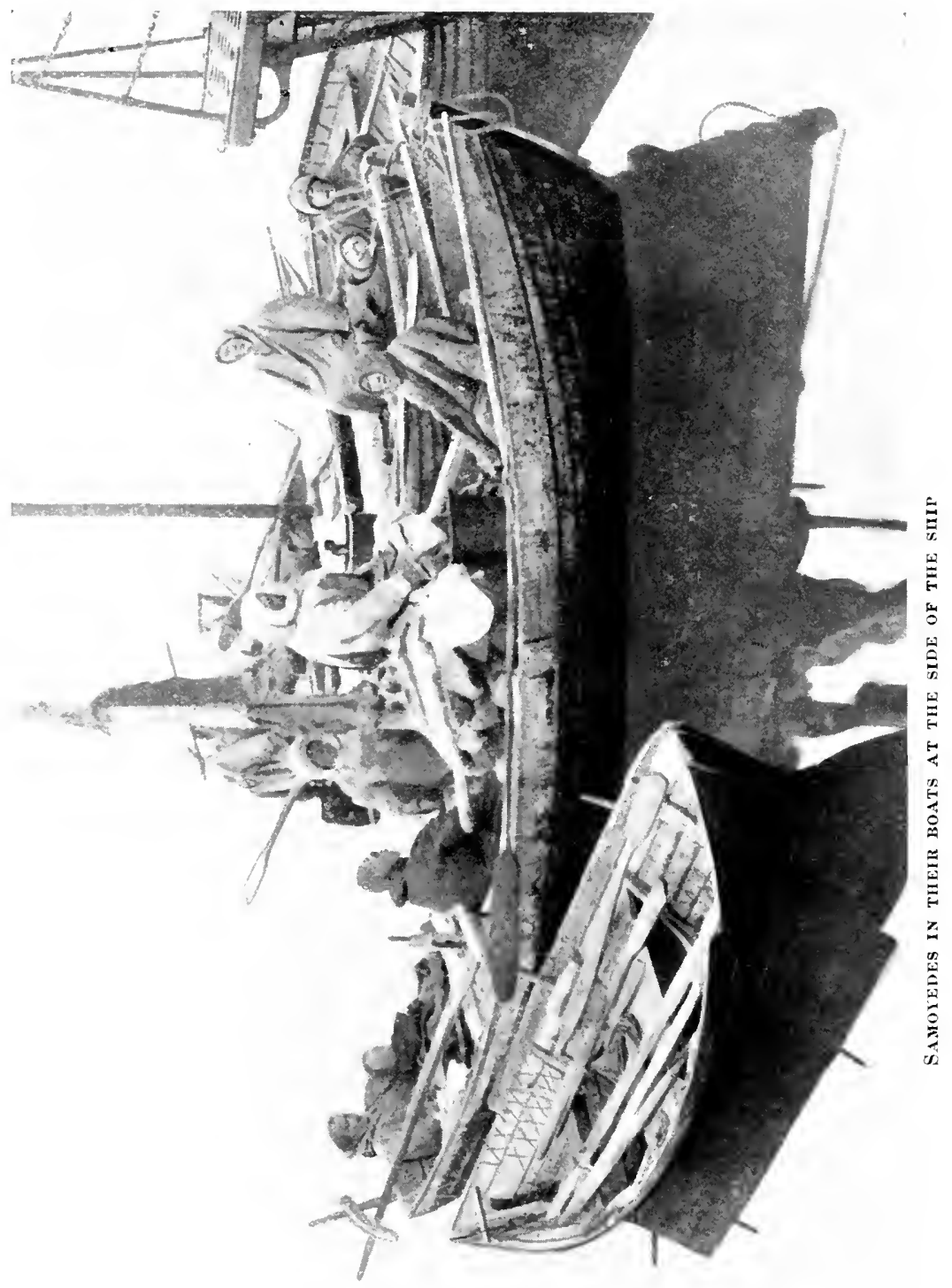




\section{VISITS FROM SAMOYEDES}

They also had a small ringed seal, phoca hispida, with them in the boat; it had just been shot. They had several guns and a Norwegian walrus-harpoon.

As they lay alongside a floe in front of the ship, a ringed seal came up; one of them fired at it with small shot, but it sank before he could reach it with the boat; he then threw the harpoon after it into the water, but did not get it. When the Samoyedes saw that the seal was hit, they all gave a yell and made a fearful noise all the time this was going on ; this gave me no very great idea of them as hunters, especially when I thought of the Eskimo and how quietly they set to work.

They had a small boat in tow, which might have been 12 feet long and was used, no doubt, for sealhunting, when they wanted to steal upon the animals; the big boat was for travelling and its length might have been 20 feet or more.

While we lay by a floe in the ship's boat, trying to talk to them and looking at their gear, they suddenly began to shout and yell to each other; the cause of their excitement was the mate, who was sculling the dinghy up to us; they pointed at him, roaring and shrieking with laughter. I believe that sight made more impression on them than anything else they had seen; a man propelling a boat simply by twisting one oar astern was something quite new and unknown to them; and when he made the boat go so fast as to raise foam round the bow, their joy reached its climax.

While they still lay alongside us, there was a cry that another boat was approaching, and soon it came up. In the stern sat the chief, an elderly man, with a few bristles on his chin, and a child of three or four who was no doubt the young prince, and whom his father exhibited with pride, making him nod to us. 


\section{THROUGH SIBERIA}

There were four other people in the boat. One of them was quite dark in the face, which was markedly prognathic and had a savage look. This one appeared to be a female.

These, like the others, only understood a few words of Russian and there was nothing to be got out of them.

No sooner had they come up alongside us, than the first boat's crew all began shouting to them, telling them how the mate had sculled the dinghy with one oar, and that seemed to amuse them all mightily.

The latest arrivals wanted to buy bread and tea; unfortunately we had none to sell, but they were given a few pieces of bread. Then we gave them walnuts and chocolate for the child, who was not at all impressed by it, but just stuffed it into his mouth and seemed to like it.

The second boat had also a small sealing-boat in tow, besides a little toy boat, a foot long, which the chief lifted out of the water and showed us, as soon as he saw we had noticed it ; it was the prince's toy. Both crews had evidently been out after seals in the ice, and on seeing the big black ship, had rowed towards us.

They talked incessantly and had a great deal to say to each other; but their language was entirely incomprehensible to us. They lay there staring, and showed no intention of going away again.

At half-past nine the sun went down in a red glow behind the ice in the calm night; the sea was as smooth as a mirror between the floes and there was not a breath of wind. On the south was a bank of fog, as blue as Danish porcelain. The ice was the same as before, but would now drift out slowly to sea, and we hoped for an easterly wind next day, to drive it away from the land.

38 


\section{VISITS FROM SAMOYEDES}

We went in and had supper. The Samoyedes still lay there ; but when we came out again, they had gone back to the ice.

Then there was nothing better for us to do than to have a smoke and a game of cards. It was chiefly boston we played. 


\section{CHAPTER III}

THROUGH THE ICE NORTHWARD ALONG YAMAL

Ice and lifeless waters : Our life on board : Big floes of thin ice : Ground-ice : A dangerous block : Fog and ice : Unbroken ice : The dirty ice of the Arctic: Walrus : Ice closing in : The wind breaks up the ice: A land channel: Out of the ice

THURSDAY, August 14. We lay at anchor all 1 night and the next day as well. There was remarkably little movement in the ice; we saw the same floe for a long time. But there was a good deal of tidal current setting southward along the land for a time, and then northward again. In the afternoon there was a little more movement in the ice, but nothing very great.

What deserted waters these are! A solitary ringed seal quietly puts its head up now and then and stares at us ; otherwise there is no life to be seen in the sea. The only birds we have seen are a few flights of longtailed ducks, but scarcely a gull here among the ice, and not a single guillemot. I have hardly ever seen so little life in the Arctic Ocean before.

Nor have I ever before lain at anchor in the ice. The usual plan, of course, is to make fast to a floe; but we have no ice-anchors, and this method seems to answer as well.

It is calm, with only a light breeze from the east or south-east. It keeps misty all day, and there is little to be scen around us. There seems to be a good 40 


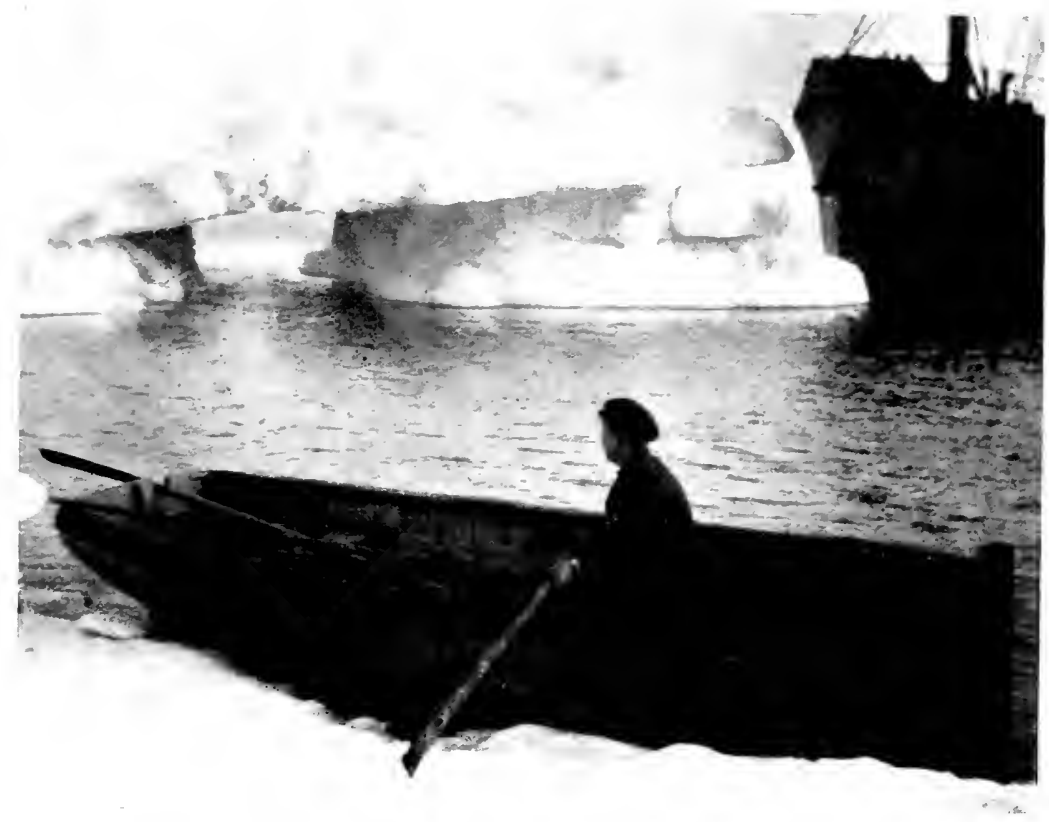

THE "CORRET" HALE FAST TU A MARE PIECE OF GROLYD-IL

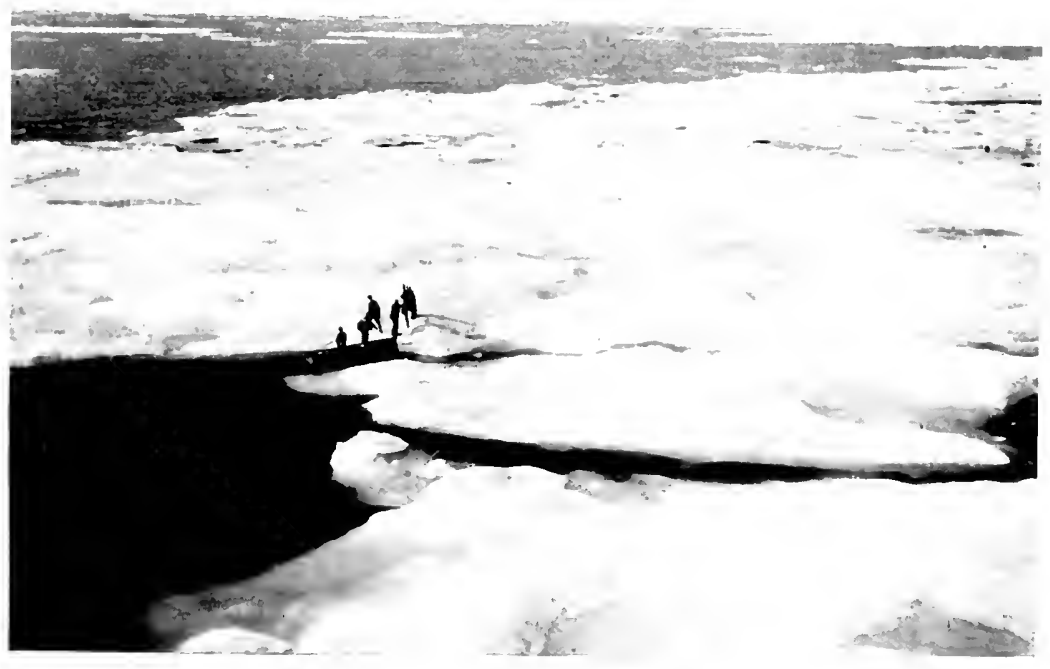

IX THE ICE 


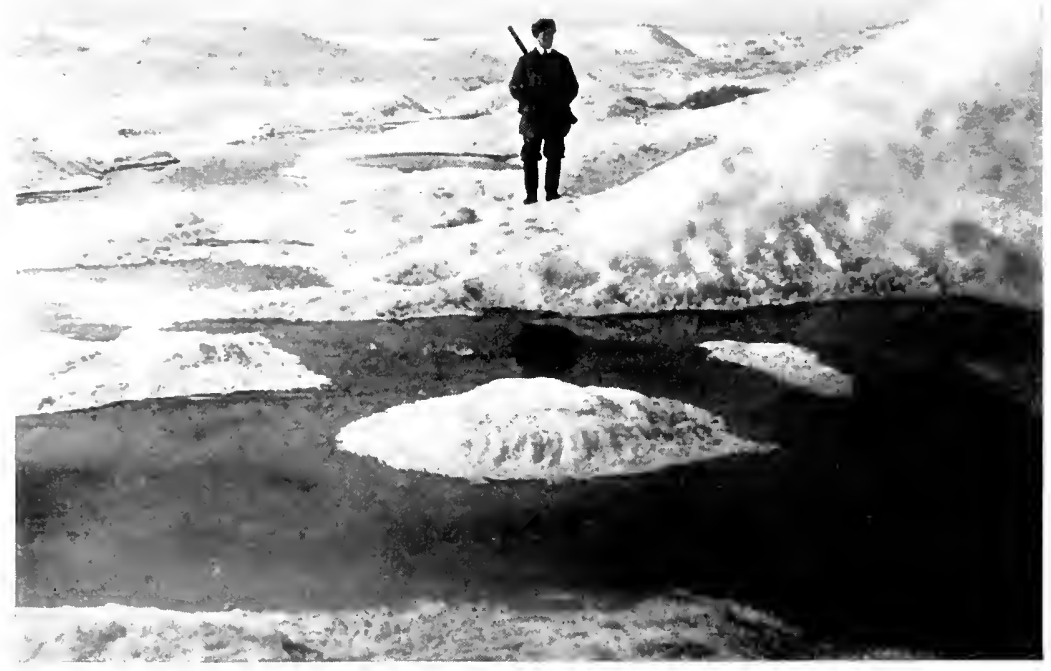

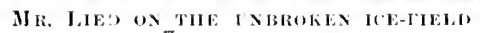

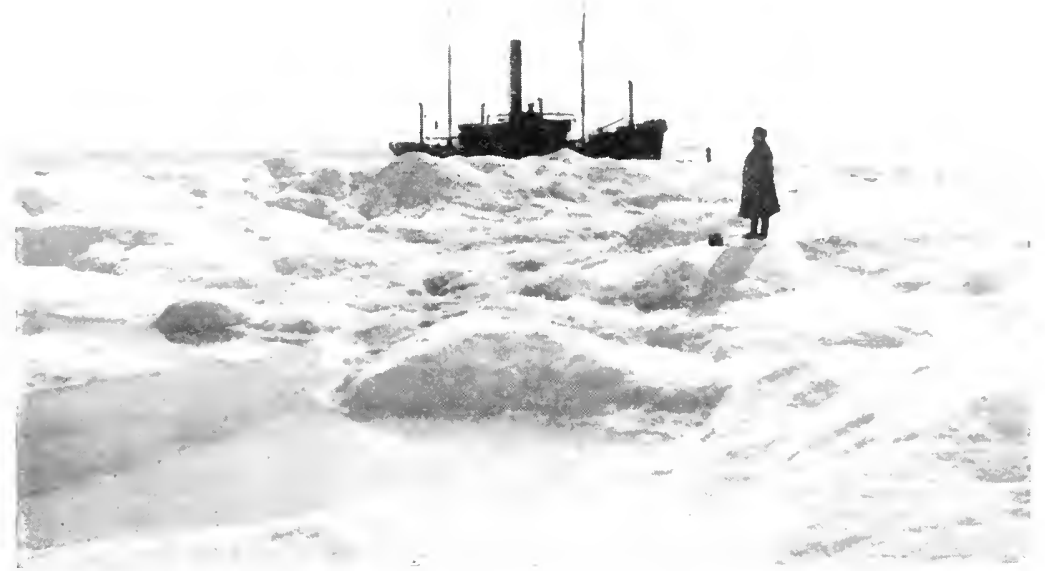

'HE "CORLCT" AT THE EDGE OF THE ICH-HELD 


\section{THROUGH THE ICE NORTHWARD}

deal of ice, and we can make no headway until it lifts. There is nothing to be done but to spend the time as pleasantly as one can indoors. Lied and Loris-Melikov play chess when they have nothing else to do. The Captain smokes a long pipe and looks on, or else makes himself comfortable with a book. Vostrotin and I take photographs and develop them. Now and then Lied and Loris-Melikov do the same, when they can spare time from their chess. They have converted the bathroom and the guests' cabin into dark rooms, and I have done the same with the captain's cabin, where I sleep. Johansen appears from time to time in the saloon and tells about his experiences in Siberia, or his voyages in this Kara Sea, or with Nordenskiöld, or in the Arctic.

The steward arrives with supper, and the chessplayers and photographers have to clear the table, so that he can lay it. Then we have a cosy meal and a long chat to follow. After supper there is a turn on deck, to see how everything is on board and outside, and then we go in again and the cards are brought out.

In the evening the ice began to drift more rapidly, and we had several bumps from passing floes. At about midnight, as we sat playing boston, a big floe came drifting on to the bows, so that we dragged our anchor. There was nothing to be done but to heave it up and go round the floe; but when we were once started, the Captain thought we might as well keep on as far to the northward as we could find open water in the fog.

There was nothing to be seen, but we kept going till five in the morning, when we had to anchor again after having progressed 11 miles. The depth had been pretty much the same all the time; here it was $9 \frac{1}{2}$ fathoms. 


\section{THROUGH SIBERIA}

Friday, August 15. Next forenoon the fog lifted a good deal and we could see a lot of open water to the northward from the crow's-nest. We also had a sight of the land inshore of us. It was the same low land, with a flat sandy beach and steep slopes above it, that is to be seen everywhere in Yamal.

We steamed northward, but the fog came on again and there was not much to be seen. We slowed down and went through the clear channel we had observed from the crow's-nest; but after about three hours the passage became closed, and we had to wait again.

The ice was much worn and everywhere thin. We saw floes that might have been a mile in length, but so worn that there were holes and cracks in them in every direction, and it was a marvel that they still held together. This shows how little movement there can have been in this ice, for the first strong wind must have broken up these floes into small pieces, and then they would soon have disappeared. They cannot have come from any distance and were most probably winter ice from somewhere in the neighbourhood.

The ice now lay pretty close to the north of us; but judging from the blue colour of the air, there must have been fairly open water not so very far in that direction, if only we could have got to it. The depth did not vary much. We were now lying at anchor in 9 fathoms of water. There was little current in the daytime; it seemed to change with the tide, as before; but after midnight, at about one o'clockwhich again found us at the card-table-it began to set the ice southward at about a mile an hour.

Saturday, August 16. Next morning the ice had slackened a good deal, and we could weigh anchor and steam to the north. The depth was still the same, 42 


\section{THROUGH THE ICE NORTHWARD}

about 9 fathoms; then it decreased somewhat, especially when we had to turn in a little towards the land.

To landward of us we saw several hummocks of ice lying aground. Suddenly we caught sight of a small block ahead which also looked as if it was stuck fast, as we could clearly see the race of the current around it. The lead gave 6 fathoms, then $5 \frac{1}{2}, 5,4 \frac{1}{2}, 4 \frac{1}{2}$ again, then $4 \frac{1}{4}, 4$. Then it kept about that, soon went down to $3_{4}^{3}$, and back to 4 . As the Correct drew 17 feet (nearly 3 fathoms), there was not much water under her keel; but as it was a sandy bottom here and not rock, and as the bottom was well scoured and levelled by the ice, no abrupt change of depth was to be looked for.

All the same, it was advisable to slacken speed and keep outside the block of ice, which could not be lying in deep water, as it was not a large piece. There was a strong current round it. When we were past it, the depth increased again to about 5 fathoms, and was then fairly regular.

There was a good deal of open water and we were able to go at full steam for some time and keep our course northward along the land, often through fog, but with pretty clear weather between whiles.

Later in the forenoon we could make no further headway and made fast to a large piece of ground-ice. This hummock was fairly high, over 20 feet, or about the height of the Correct's bows, and its sides were mostly perpendicular, so that by laying a ladder across from the forecastle, we were able to crawl on to the block of ice. The depth had increased to $11_{4}^{3}$ fathoms, strangely enough.

A tunnel ran right through the hummock, through which we were able to row with the boat, and we afterwards found that it divided the hummock into two separate 


\section{THROUGH SIBERIA}

pieces. The part to which we had made fast was rather narrow and high, and there was a danger of its capsizing as soon as the tide rose; it was thus rather precarious to be too near it, as we might get a harder knock than we cared for. We therefore cast off again and anchored a little farther away.

Old Johansen was the one who was particularly anxious to get away, and he was right. During the night the hummock actually did capsize, and he did not forget to pat himself on the back when he came on deck in the morning and saw it.

No doubt these hummocks are often very like small icebergs, but they must not be confused with them. Icebergs are glacier ice derived from land and are formed by the glacier running out into the sea and calving; but there are none of them to speak of in the Kara Sea. Some few small icebergs are formed on the coast of Novaya Zemlya, but they are of no great consequence. Small icebergs and lumps of calved ice are also found near Franz Josef Land and Spitsbergen, but these again do not travel far to sea before the majority of them melt away.

The hummocks in the Kara Sea and in the Arctic Ocean, as a whole, are formed by ice-pressure. They are floes that are squeezed edge to edge by severe pressure of wind and current, when they break up, are raised on end and pushed one above another, till they are piled up into hummocks 20 or 30 feet high above the water. When we remember that sea-ice, when afloat, has only about one-tenth of its bulk above water, we can understand that these hummocks have an immense mass of ice below them. The pieces that have been raised by pressure soon freeze together into a solid mass, which takes a long time to melt again, and when, in the course of the summer drift, the big ice-floes break 44 


\section{THROUGH THE ICE NORTHWARD}

up, these hummocks become separated from the flat floes and form greater or smaller blocks, which drift about in the sea or lie aground, and may last for more than a year before they melt away.

Sunday, August 17. In the morning there was fog again-the everlasting fog which is one of the greatest difficulties of navigation in the ice; for even if there is a little open water, one cannot see what one is doing or where one is going, and may easily sail into the closely packed ice and have great trouble in getting out again.

The ice was not particularly open, but was drifting from the south with the southerly wind, which freshened a little in the course of the forenoon.

We went northward in the fog for a while, but soon stopped again, as the weather remained thick, and the ice soon became denser except on the north-west; but that direction would have taken us too far out of our course, away from land. We preferred to keep nearer the shore, where there was more prospect of finding a clear channel to the north as soon as the wind backed a little. But unfortunately it became more southwesterly and likely to set the ice inshore, although the ice seemed to be drifting approximately northward along the land.

There is one thing necessary when you have to work your way through the ice, and that is patience, always patience. We have to wait and hope for better times.

So here we lie in the fog and ice-the same life that one knows too well-the same cold, dismal wastes.

At ten in the evening it cleared a little and looked like slack ice for some way to the north. The Captain got ready for a night on the bridge, and we made some headway through a good deal of open water. But after an hour we were stopped again. Ahead of us lay unbroken ice in every direction, the worst ice we 


\section{THROUGH SIBERIA}

had met so far. We had to anchor in an inlet on its edge.

I found it difficult to believe that so broad a piece of icc could remain in an unbroken surface. It was quite clear at midnight, but I could not see the end of that floe, either towards the land, which was still hidden by the fog, or seawards to the north-west. There certainly cannot have been much movement in the water here, or much wind either.

The depth was 15 fathoms and no deflection of the sounding-line was noticed, so there cannot have been any current to speak of.

The wind at midnight was quite light from the west-north-west. I heard a murmur coming from the westward. It sounded more like surf than anything else, but that must have been imagination, and it was probably nothing but the splash of water against the edge of the ice.

I was still wondering about this unbroken ice and could only imagine that it was partly aground with its blocks and hummocks, which I saw here and there on its surface, and perhaps it extended right up to the land. It must have lain there since the winter.

Monday, August 18. We lie at anchor all day by the edge of the same fixed floe. Beautiful sunshine at last with clear air for once. Light wind from the north-west. From the crow's-nest we can now see open water on the north side of this fixed ice, about 6 miles away. It extends seaward as far as to north-west by north.

On the north-west there is ice as far as we can see, and I should think for at least 10 miles in this direction; but the blue sky on the horizon tells of water beyond the ice there also.

On the west a lane can be seen extending northward 46 

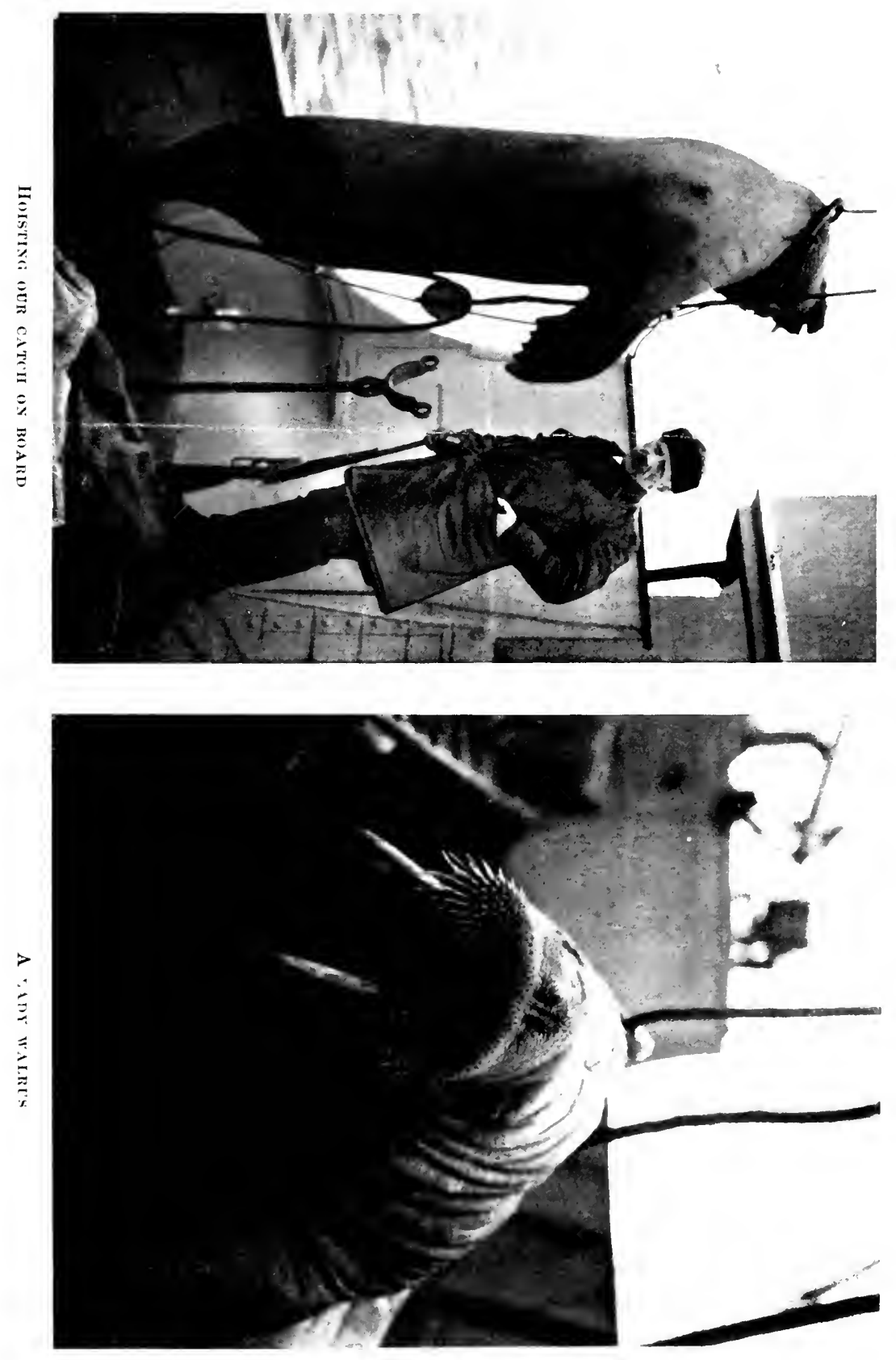


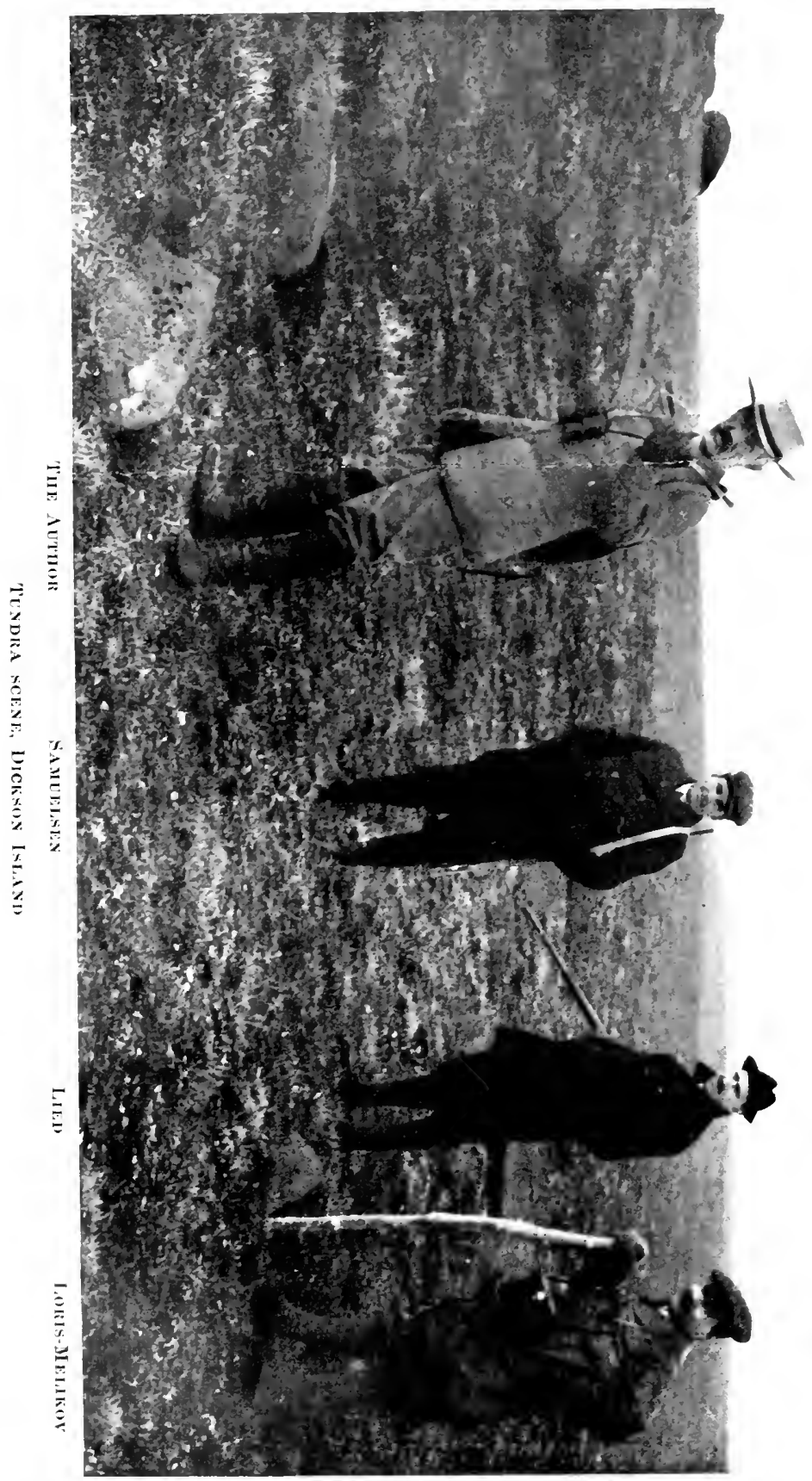




\section{THROUGH THE ICE NORTHWARD}

to about west-north-west; this must run along the edge of the fixed ice, and several lanes are to be seen in the loose ice outside in this direction; but there can hardly be a practicable passage at present. If only we could have a little easterly wind, there would soon be open sea round there, unless indeed this fixed ice should break off near the shore, but then, of course, we should have a channel on that side.

Strangely enough we cannot see land inshore of us, but only thick ice in that quarter. The land must be a good way off, and I come to the conclusion that this unbroken floe must be at least 20 or 25 miles long.

A good noon altitude gave latitude $71^{\circ} 29^{\prime} \mathrm{N}$.

We took a turn on the ice, and had our ski with us, but it was extraordinarily rough icc, nowhere level enough for us to use the ski for any distance; there were lumps big and small everywhere, with here and there great hummocks. It was exhausting to walk over.

It must consist of old, uneven, small floes and lumps of ice and hummocks from the year before, that were lying over this shallow bank last autumn, and that were then pressed into one mass and frozen together. For the most part this ice is very dirty, and all the hummocks and edges are much rounded, so that it seems most probable that a great deal of it is two summers old.

It is now so worn that great ponds and holes and lanes have formed in it in every direction. It seems as though the first high wind must break it up, and then all these lumps would float away from each other.

Some of the hummocks are so high that their foot may be supposed to touch the bottom, and thus it is, no doubt, that the floe is held fast; but quite fast it cannot be, as we can see by the chain-cable that 


\section{THROUGH SIBERIA}

the ice has moved the ship, which is lying at its edge, at any rate a few yards astern.

People who have no experience of the polar ice may wonder how this ice can get dirty. I have heard it asserted even by old hands in the Arctic that this dirty ice must come from the rivers or the land, where mud has been washed over it or dust blown upon it. It is not so.

All ice, wherever it is formed, even right up in the Polar Sea, will acquire in course of time, as it melts, a coat of drab-coloured dust or mud on its surface. All snow that falls, no matter where, brings with it a little fine dust from the air, and as the snow melts, this dust is left behind as a very fine grey coating on the surface. Therefore old, partly melted snow is hardly ever quite white.

But the dust collected in this way has less to do with the dirty colour of the ice than have the mud and the organisms suspended in the freezing sea-water. Immense quantities of small organisms often exist in the surface waters of the sea; these are enclosed in the ice when it freezes, and may sometimes colour it quite brown. An additional factor is that, especially in a sea like the Kara Sea, or still more to the north of the Obi and the Yenisei, the sea-water contains a quantity of floating mud brought down by the rivers. This also freezes into the ice.

Then, as the ice melts in summer, by direct radiation of heat from the air, as is usually the case all over the Arctic Ocean, one laycr after another is worn away, and, while the water runs off, the mud and the organisms are left lying on the surface of the ice, giving it a dirty appearance, which is increased in proportion to the thickness of ice that melts. It is thus easy to tell old ice from new. The old ice, which may have lasted 48 


\section{THROUGH THE ICE NORTHWARD}

several summers, is always dirtier and darker than the new.

It is easy to see that in this way there may be some difference between ice that is formed in one locality and in another. If we take, for instance, the ice that freezes to the north of the estuary of a river like the Obi, where the water is quite brown with river mud, it will be readily understood that not much melting need take place before this ice will be quite dirty on the surface; while ice from other regions, where the sea-water is comparatively clean, will have to melt a great deal before becoming noticeably dirty.

It is not uncommon for authors-like Nordenskiöld, for example - to imagine that dirty ice originates through muddy sea-water or river-water being washed on to the floes by the action of the waves, the water being then filtered through the snow, leaving its mud behind it. This is a misunderstanding. Of course, such a thing may happen, and does happen daily. But it is not the usual or the chief cause of dirty ice.

When the weather became quite clear, we still saw no land inshore of us on the east; on the other hand, we could see from the crow's-nest a point of land about south-east, or it might have been south-south-east, by compass.

The wind all day was a light breeze, first from the north-west, then more westerly, then north-west again; it freshened during the evening and the sky clouded over. Here again the current seemed to run mostly southward, but it was not slrong.

Tuesday, August 19. In the early morning it was calm and clear, and the unbroken ice, alongside which we lay at anchor, began all at once to drift northward, quite slowly, and great pieces of it broke off and drifted away. 


\section{THROUGH SIBERIA}

From nine in the morning we also noticed a marked slackening in the ice to seaward of us. We therefore weighed anchor in the forenoon and bore to the westward through fairly open channels, in order to go round to the west of the big floe, which we still saw stretching away unbroken to the north-west. There was a breeze from the south-south-west, which freshened a little, and the air was hazy.

There was some life to be seen here. On a little floe lay a big, old bull walrus. One of his tusks was entirely broken off, and of the other only a short piece was left. Imagine the strength required to break off such tusks!

There was excitement on board and the eyes of our longing sportsmen brightened when they saw so much live flesh on the ice. They stood ready with their rifles; but the ship was moving to windward, and as soon as the animal got our smoke, it dived into the water and made off.

We saw three or four bearded seals on the floes. Then suddenly Vostrotin, who was standing on the bridge, called out that there was a whole herd of bearded seals on the ice to the west of us. Seen through the glasses they became two walruses; a third was swimming in the water and tried several times to get up to the other two. A little ahead of us I saw the big heads of four or five more walruses rise and turn over in the sea.

Then things were lively on board. Lied and the Captain thought it would never do to leave such animals alone. The dinghy was got ready, for Lied was anxious to be off, and it ended in my going with him, as the Captain thought he could not leave the ship.

The walruses lay pretty quiet, and we came well up to them. I begged Lied to aim well for the back of the head, so that the animal might be killed on the 50 


\section{THROUGH THE ICE NOR'THIVARD}

spot; but after his first shot they plunged into the water in a shower of spray; the wounded walrus came up again and luckily clambered back on to the floe; the thing was to wait till we were quite close; and after a few more shots it turned over on its side and rolled into the water. We tried the harpoon in vain on its thick hide; it was too blunt, for the whole edge was broken off ; but then we managed to strike a hooked spike into the walrus, and after cutting a loop in its skin we made fast the harpoon-line and took the beast in tow.

It was pretty hard work in the little dinghy; the stern was mostly under water with the weight, and there was a good deal of wind and choppy sea besides. But at last we reached the ship; the walrus was hoisted on deck and photographed from every side by four enthusiastic photographers, who had been going up and down all day long like roaring lions, seeking what they might devour.

Meanwhile the weather had turned rainy and thick, but at last we came round the end of the big floe and were able to steer in towards land again to the northnorth-east and north-east.

The channel now looked fairly open, and most of the time we were able to go at full steam. But late in the afternoon there was more ice; we had to reduce. speed, especially as the weather was thick. The wind had freshened and changed to about south, sometimes east of south.

At about 8 P.M. the thick weather stopped us and we anchored in 16 fathoms of water. The wind increased nearly to a gale. There was a strong northward current and much ice.

Then at about eleven we weighed anchor, as we were lying in a nasty position between two big floes which 


\section{THROUGH SIBERIA}

might crush us. We went a little way at varying speed through the ice. But soon after midnight we stopped, as we could see nothing in the fog.

Wednesday, August 20. At 1 A.m. it lifted a little and we went ahead again at slow speed. There was a good deal of ice, but with patches of clear water among it. At 3 A.M. we anchored in $\mathbf{1 2}$ fathoms of water. It was thick weather-fresh wind with rain.

By eight in the morning the wind was light and southerly; thick fog. A number of big floes drifted past to the northward.

At noon we were still at anchor. The current was now setting strongly in a south-westerly direction. Weather calm and thick with rain.

Four P.M., light north-westerly wind, fog. As the ice threatened to break the rudder, two men were told off to shove it away; but that had little effect, and the engines were started ahead dead-slow, so that the wash of the propeller might keep the rudder clear, and that worked well. The ice lay pretty close as far as we could see, and some pressure was to be noticed.

At 4.30 P.M. the ice slackened somewhat round the ship, so that the engines could be stopped.

At 6.30 P.M. the fog lifted a little and the land lay quite near, between E.N.E. and E.S.E. (true), barely five miles away. From the crow's-nest I could see land all along to past N.N.E. (true); but the ice seemed to be packed right up to the shore, with only a little slacker ice here and there. On the south and west the sky was dark, which would be a sign of open water there ; but to the N. and N.N.W. (true) it was fairly light, and I thought there could not be very much open sea in that quarter; but a good deal of slack ice, perhaps.

The wind had now gone round to the north and north-east (N.N.E. and E.N.E. true), and the weather 52 


\section{THROUGH THE ICE NORTHWARD}

cleared. This was a land wind, and it looked more hopeful, as it might give us a lane along the shore.

At 8.15 P.M. we had to move, as some big floes were coming down on us, and we had a nasty position in between large and heavy pieces of ice with high hummocks on two sides of us. We anchored again at 9 P.M. (in 12 fathoms of water) to windward of the heavy ice.

The wind increased and came from the N.E. (true). This was from land, and now I had a good hope that the ice would slacken and move out to sea. We still had ice on all sides, but we could see slack and clear places among it.

Midnight. The wind from the north-east increased to a gale. The ice was setting to the westward; we could see it splitting up, and there were slack patches among it to landward. This looked well.

After midnight there was a whole gale from the north-east. The ice was slackening round us, but was still packed to the northward.

Thursday, August 21. By 8 A.m. the wind had unfortunately backed to N.N.E. (true), and a little later it went to $\mathbf{N}$. It no longer bears off the land, but is rather towards it, so that there is no longer the same prospect of its forming lanes along the shore; but as a rule I have found that the ice drifts a good deal to the right of the direction of the wind, on account of the earth's rotation, and so we may hope that after all it will move a little out from the land.

The wind is still fresh, with small snow showers. We are lying at anchor as before. There is some southerly drift in the ice, but not very marked. It is fairly clear. The ice seems still to be packed to landward, and the land is farther away than yesterday; we must have dragged our anchor a good deal, it only just catches the bottom. 


\section{THROUGH SIBERIA}

There is remarkably deep bluc sky over the land and northward as far as to the west of north. It looks just like the sky over open water. But perhaps it may only be darkened by the land; for both Johansen and the Captain declare that the ice is packed right up to the beach; they could see it with the glasses from the crow's-nest. I have not been up there myself today. It is strange, all the same; a sky darkened by the black land ought to be more of a greyish black, I should say; but this is such a deep blue, like a watersky.

Towards the north-west (N.N.W. true) the sky is light, and there must be lots of ice there. On the other hand, there is a good deal of open water and dark sky towards the S.W. (true), so we could certainly get out that way; but we have no business to be down there, although the icc-pilot is very anxious to go out to sea in that direction; he thinks we shall find open water and the whole Kara Sea ice-free to the north of us.

I have great doubts of it, and do not think that course would be a wise one. For we met the ice midway in the west of the Kara Sea, as we came from the Kara Strait, and we even found two strips of ice to the west of it; and all that ice is not likely to have got away with the south-west and north-west winds we have generally had.

Besides, if there is open sea on the west, we ought to have noticed some swell these last few days, while the wind was south-westerly; but there was not a sign of it.

And suppose now we came out into perfectly open water to the west of the ice we are now lying in, and that the edge of the ice extended northward, so that we could go forward in that direction, how are we to know that we shall be able to get through the ice to 54 


\section{THROUGH THE ICE NORTHWARD}

the eastward, when we reach the latitude of White Island (Beli Ostrov)? The ice-pilot thinks no doubt that we shall find open sea, but why?

I have therefore argued, and I still think, that it is wisest to keep as near the land as possible, so as to use the land channel, which-if it is not already there, as $I$ now suspect it to be-must in any case open out as soon as there is a calm or the slightest easterly wind, so that the ice will drift a little out to sea.

And it would be strange, by the way, if there were not some open water under the land with the northwesterly and westerly drift we have seen in the ice yesterday and last night.

Our latitude by a good noon altitude was $72^{\circ} 15^{\prime} \mathrm{N}$, which was 10 or 12 miles to the north of the dead reckoning. The longitude, judging by the soundings, should have been $68^{\circ} 20^{\prime} \mathrm{E}$., and by observation was $68^{\circ} 10^{\prime} \mathrm{E}$.

After sitting in the cabin developing photographs all day, I took a turn on deck and in the crow's-nest at about six in the afternoon, to stretch my legs a little, and also to have a look round; for it was tolerably clear.

But no sooner had I put the glass to my eyes than I saw open blue water in a north-easterly direction (E.N.E. true) in towards land. It might have been only about 6 miles away. This must be the broad, blue land channel, with only a few pieces of ice here and there. It extended northward along the shore. I could follow it a good way with the glass, but then it was lost behind the ice on the horizon. In an easterly and east-south-easterly direction (E.S.E. and S.E. true) I again saw open water under the land.

It was clear that there was a broad land channel all the way, just as might be expected, and I saw an 


\section{THROUGH SIBERIA}

easy passage into that channel through slack ice in a north-easterly direction. On the east it could also be done, more easily, in fact.

It may be guessed that I came down the rigging pretty quickly and in to the Captain, who was just taking a well-earned nap. The fires were stoked up at once; we weighed anchor and steered to the northeastward at 6.45 P.M. Soon we were in the land channel, which was fully a mile in width. It became a little narrower to the northward, but then widened out again. We steered northward along the land and sounded incessantly. The depth was steady at about 6 and $5 \frac{1}{2}$ fathoms.

There was still a fresh wind from the north-north-west, sometimes approaching a gale. The channel became wider as we went north. In some places there was a lot of ice outside us; but several times it looked as if there was fairly open water with much blue sky to the westward, although it was not so easy to see, as the sun was in that quarter.

When the ice-pilot came up from his after-dinner nap and heard us getting up the anchor to go in towards the land, he was not in a very good temper, and told the Captain on the bridge that this was not to his mind and he renounced all responsibility for keeping that course; the ice might easily drive us ashore, he thought.

But apart from him there were only cheerful faces to be seen on board, as soon as it got about that open water had been sighted under the land.

The spirits of the crew had not exactly been bright the last few days. They looked out and saw nothing but ice on every side. It seemed to be closing round us, and we were always meeting more instead of less. So it was not to be wondered at if they lost heart a 56 


\section{THROUGH THE ICE NORTHWARD}

little and began to doubt how things would turn out, and whether we should ever get out of this ice again with a whole skin. There were only two or three of them who had ever seen a bit of ice before. The engineer had been full of misgivings, but I don't think he was the only one on board who wished himself safely home out of the ice.

The fore-peak is leaking like a sieve-some of the plates in the bow must have been loosened-and bilgetank No. 2 has also begun to make a little water, but this cannot possibly be due to any direct blow of the ice; it is more likely to be a rivet that has given a little in the scraping we have had ; for it can't be denied that there has been some scraping and bumping now and then as we squeezed our way through the floes.

But now there is some life in the men and the work goes with a will; as we slipped past the last floes and into the channel, all hands stood along the bulwarks to look at the land and the promising blue surface, on which the little waves were dancing gaily past us. There was a new look in their eyes; now they believed we should reach the Yenisei after all. And from the crow's-nest Johansen reported open water to the northward as far as he could see.

It was no great delight to the eyes, though, this low-lying land-the same grey and drab sand-slopes that we had had farther south with a little thin grass up on the plateau.

At 11 P.M. we at last had the beacon on the northwest point of Yamal E. by S. (true) and about $3 \frac{1}{2}$ miles away. The lead gave 6 fathoms. Perfectly ice-free water to the northward; only a few hummocks of ice aground here and there. Now there was no doubt we should get round the north of White Island in open water. 


\section{THROUGH SIBERIA}

But we had to go forward rather cautiously, as the sea was not very deep. At 2 A.M., when we must have been about abeam of Malygin Strait and a little to the north of latitude $73^{\circ} \mathrm{N}$., we suddenly had 4 fathoms in two soundings, after having just had 8 and 10 fathoms. We had to stand farther out to sea for an hour or so (8 miles N.W. by W., half W., by compass), and then got 10 fathoms again and were able to steer more to the northward (N.N.W. by compass) again. Fresh wind, clear air. The depth kept steady at about ten fathoms. We saw some driftice to the north-westward ; but otherwise the sea was quite ice-free round us.

We had now said good-bye to the drift-ice, we thought. This was the second of the two difficulties predicted by the fortune-teller at Tromsö, Johansen concluded. 


\section{CHAPTER IV}

\section{OPEN SEA, EASTWARD TO THE YENISEI}

Open sea north of the Gulf of Obi : Stopped by ice west of Sibiriakov Island : Aground : Landing on Dickson Island : Brusilov's and Rusanov's expeditions : Unsuccessful reindeerstalking: The coastal platform : Southward to the mouth of the Yenisei : The Yenisei and its course : Movement of the river towards the right : Political exiles; a hermit : Difficult navigation, we run aground : Meeting with the tug and lighters from the south : Prospects of delay

TN the course of the morning of Friday, August 22, 1 we were at last north of White Island, and now had open, blue sea before us. There was a fresh breeze and sea from the north-north-west, enough to make some of us regret the ice and the calm water between the floes. White Island we did not see; it is quite low, and we were too far out.

It was a lovely sunny day in open sea off the mouth of the Obi, the finest day we had had since leaving Christiania. But there was not a little sea and a good deal of rolling, so that at dinner we had the fiddles on for the first-and last-time on the voyage to the Yenisei.

The water was remarkably brown and dirty, so that in the afternoon, when we passed one of the solitary drifting pieces of ice, it looked quite a dirty brown where it lay under water, or where the sea washed over it.

The temperature at noon was $51.8^{\circ} \mathrm{F}$. in the air, 


\section{THROUGH SIBERIA}

and $35.6^{\circ}$ in the water. The depth kept between 7 and 12 fathoms.

At 6.30 P.M. we saw some ice ahead, so the log had to be hauled in. The depth then decreased abruptly to 5 fathoms, and varied between 5 and 6 fathoms. Thus we found once more that the ice lay over shallow banks.

We kept going with constant soundings, and were soon north of Vilkitsky Island, which lies between the estuaries of the Obi and the Yenisei. We met a dense strip of ice, and had to steer farther north for an hour and a half, before we could again stand more to the eastward, and make a course straight for the northern point of the sandbank, to the north of Sibiriakov Island.

At midnight, when we had made about 22 miles on this course, we met another good-sized strip of ice, and had to steer more to the northward for an hour or so.

Saturday, August 23. At three in the morning we met large masses of ice, and as they looked like extending far to the north, we steered to the south and southwest in the hope of getting round to the southward of the ice, and then taking the channel on the west side of Sibiriakov Island into the Yenisei.

But there was a lot of ice, and various courses were steered southward among the floes, until the fairway west of Sibiriakov Island was found to be entirely closed. On the extreme west, near the land on the other side, there was perhaps some open water, but it would have been too shallow to go that way.

At seven in the morning they sighted Sibiriakov Island, and as the ice barred the way on the south-east, they had to hold on along the island to get round the north of it. But suddenly the water shallowed to 4 60 


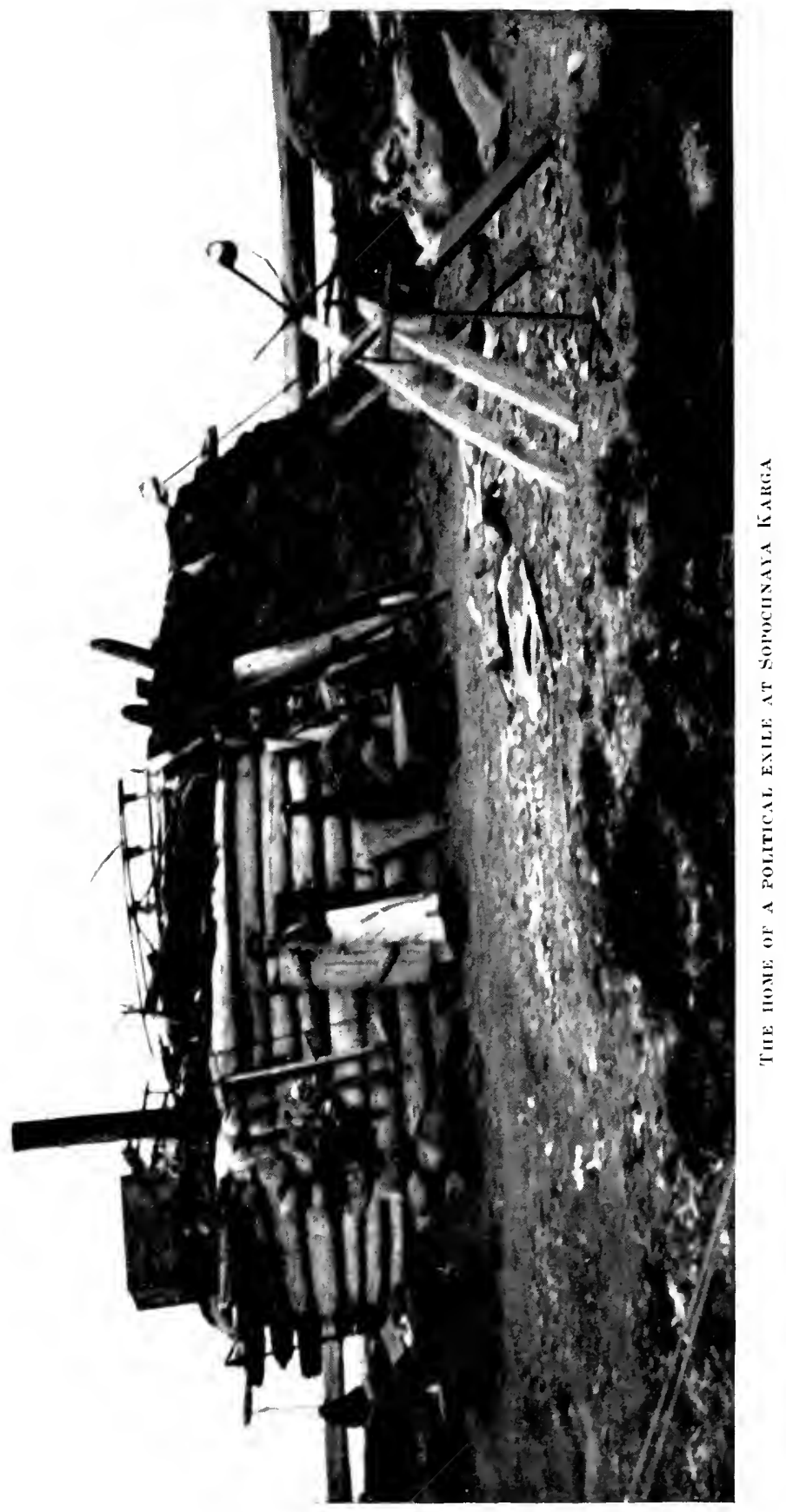




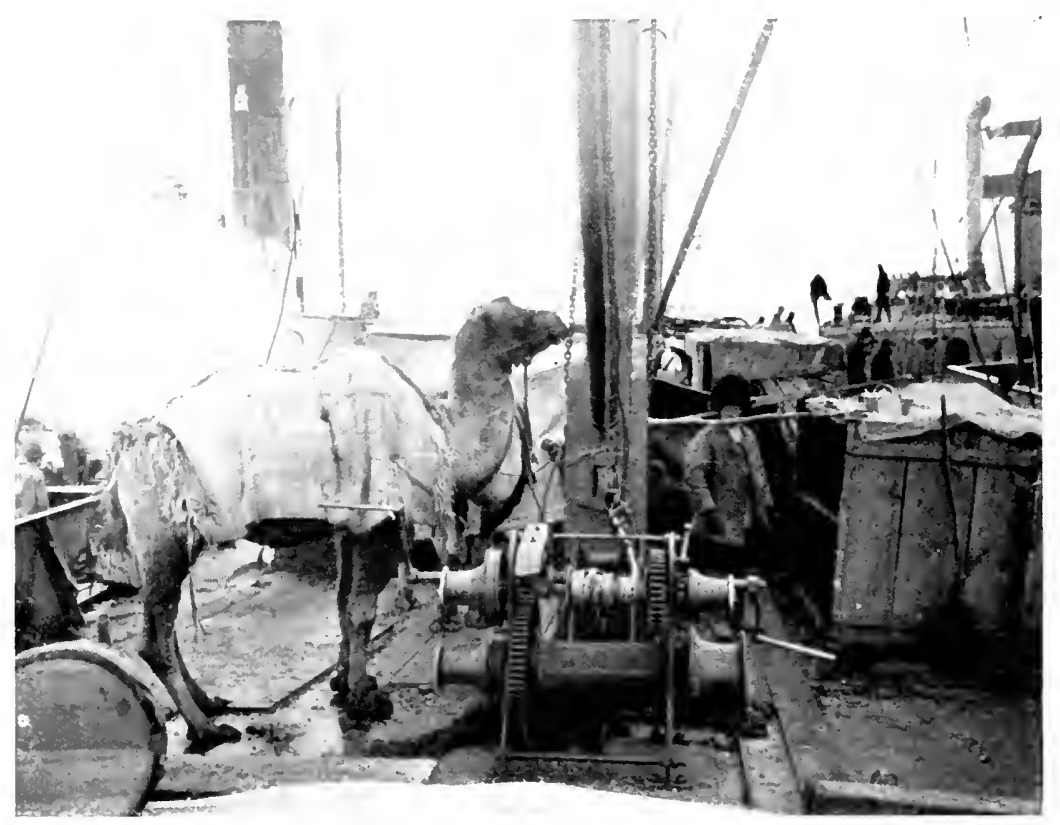

CAMELS OS THE DECK OF THE IOGITER

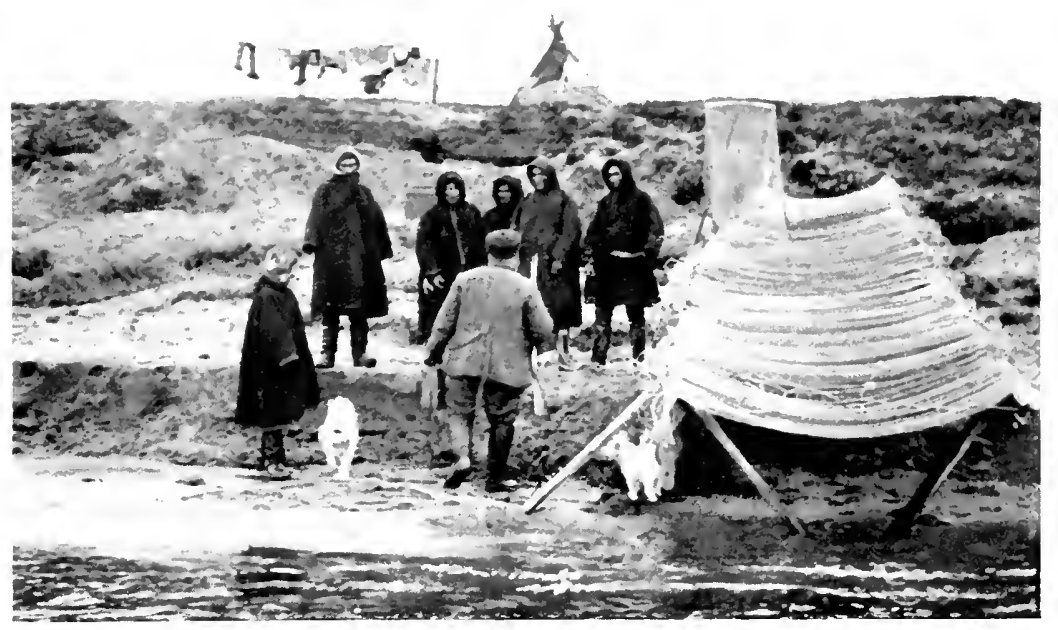

THE haNDING OF MR. VOSTROTIX: IIS RECEPTION BY THE NATIVE ON THE BEACH 


\section{OPEN SEA, EASTWARD TO THE YENISEI}

and 3 fathoms. We had got in among the sandbanks north of Sibiriakov Island, and again had to stand to the southward to come out to the south of the little island on the west side of these banks. Later on Johansen called it "Djævle-öia" (Devil's Island). They had not seen it before, as it was quite flat and low, and they had taken it for dirty ice.

All at once, as we were sitting at breakfast, the ship struck. The shock was not like that against ice. She heeled over a little to port, and then she bumped again; it felt as if she lay still! We looked out; there was no ice near, and she was not moving. The course had been taken too soon to the westward round the south of the island, and after the lead had given $7 \frac{1}{2}$ fathoms, we struck before the next sounding. It was clear that we were on a bank that extends southward from the island, for several ice-floes lay aground on it. Some scattered floes ahead seemed also to touch bottom, so there cannot have been many feet of water.

Luckily, as far as I could make out, it seemed to be low water on the floes that lay aground between us and the island, and there was thus a hope that the water would soon rise a little; but there could hardly be enough difference here between high and low water to float the vessel off. Soundings were made round the ship and showed $\mathbf{1} \frac{3}{4}$ fathom under the bow, which was raised several feet, 17 feet amidships, which was exactly what the vessel draws, and $\mathbf{3} \frac{\mathbf{3}}{\mathbf{4}}$ fathoms under the stern. Several attempts to go full speed astern were of no use ; she did not move from the spot, but the propeller stirred up the bottom and we had nothing but muddy water round us.

An attempt was then made to make a thick steel cable fast to the starboard anchor, lower it, and then 


\section{THROUGH SIBERIA}

heave on it with the big steam-winch aft. It was a slow business, and a great strain on the tackle; the whole vessel shook; when the anchor had come about 20 fathoms aft, the steel cable snapped with the violent heaving.

Then the after-tank was filled to lift the forepart, and after that we tried heaving on the anchor, while the engines went full speed astern. It was no use, we did not move. The port-anchor was also lowered, and all the chain cable was paid out to lighten the bows; but we lay just as fast as before. A kedge was rowed straight out from the port quarter, and heaved on to turn the vessel's stern to port, where the water was deepest. But the kedge did not hold.

We then got ready to shift the barrels of cement aft with the boats; but meanwhile the ship, which lay over to port, had righted a little; the tide must have risen. We decided to try once more with heaving on the starboard anchor, going full speed astern, and then heaving on to the kedge too, with what wire there was left. Meanwhile, I stood and kept an eye on the compass. The propeller spun round, the winches roared and worked so that the whole vessel shook. Suddenly I thought I felt a tiny jerk, and the compass-needle moved a quarter of a degree. Soon it was a little more, almost half a degree; then still more, and thenat last-the ship swung round, faster and faster. The compass moved a whole degree, 2 degrees, $3,5,10$, 15 degrees, and then she glided off, going slowly astern, and was afloat once more.

Great rejoicing. It cost some trouble to get in the port anchor, which still lay at the bottom with all its cable, and in heaving on it we pulled the ship back to the bank; but at last we got clear of that difficulty too.

We only had one mishap; as the ship glided stern 62 


\section{OPEN SEA, EASTWARD TO THE YENISEI}

first off the bank, the wire of the kedge fouled the propeller, broke, and the anchor was lost. When the vessel was docked after the trip, it was found that there were several turns of that wire round the shaft, and as we went astern we had struck against the kedge, so that one of the bottom plates had got a great dent. At last we were able to go on again, after having been delayed some hours in this way. On sounding the tanks everything proved to be as it was before we struck the ground.

We now steered well to the south of Devil's Island, and then northward on the west side of it, but had ice to the east of us and were obliged to follow its edge, first 8 miles to the north-west, and then 12 miles $\mathrm{N}$. by E., $\frac{1}{2}$ E. (by compass). Then we were able to stand more to the eastward, about true E. ; but we had ice both to the south and north of us.

In the evening, about seven o'clock, I got a sight of land ahead from the crow's-nest. This was Dickson Island. There was a great deal of ice on all sides; on the south it looked quite closed, and on the north as well; but under the land I could see open water, and found a passage, so that after some twisting about we reached it by eight o'clock.

There was broad open water here off Dickson Island. On the south the ice came in towards the land, and I could not be certain that I saw any lane there; but some slack ice I did see, and most probably there was enough open water to get through.

But as we were now so near Dickson Harbour, we thought we might as well put in there, and see if there was any news to be had of the Brusílov Expedition in the Sviataya Arna ("St. Anne "), which had set out the year before to make the North-East Passage, and to do some sealing on the way. 


\section{THROUGH SIBERIA}

The expedition was met in Yugor Strait on September 15, 1912, by the two ships Vasian and Nimrod, which were to bring materials to the wireless stations on Vaigach, at Yugor Strait and at Mora Salé. The next day, September 16, the Sviataya Anna proceeded on her voyage into the Kara Sea, and had not since been heard of.

It would also be a good thing to see whether Rusánov had been there; he had intended, in 1912, to go round the north of Novaya Zemlya in the motor-sloop Hercules, and had a theory, unfortunate in my opinion, that that would be a much easier way of reaching the Yenisei estuary than the more southerly routes, as the "Gulf Stream" was supposed to run there and keep the water open for him.

On our way to Dickson Harbour a dense fog came on, and there was little to be seen. We had to go carefully, and sound all the time; but by so doing we found our way between two islets, which lie south-west of the harbour; there was some ice there too. At midnight we anchored at the southern end of the strait, between Dickson Island and the mainland, in $7 \frac{1}{2}$ fathoms of water. The weather had now cleared, and it was a beautiful night with a flush of sunset over the islands and the land to the north.

Sunday, August 24. At 1 A.m. several of us went ashore in the bay at Dickson Harbour, where-in 1901, I think-a shed had been put up with a coal depot for Baron Toll's Expedition. But this coal was never called for, and it still lies there, together with a supply of matches. Brusilov, who had not much coal with him, intended to call here and use this supply, it was said.

As we approached the shed on the beach, a white fox darted out of the door, which stood open.

64 


\section{OPEN SEA, EASTWARD TO THE YENISEI}

We found no sign of any expedition having been here ; a tin containing letters from Lied, which he and his party had left behind when they were here in the previous year, lay outside the door; evidently it was the fox that had dragged it out. Lied and his men had nailed up the door, which they had found open. Possibly the wind had torn it open; or hunters from the south might have been here, though it seems unlikely.

As the Sviataya Anna was said to be short of coal, it is improbable that the expedition can have gone farther without calling here. We must, therefore, suppose that it did not get so far. Nor can the vessel still be lying in the ice in the Kara Sea; we saw nothing of her, and neither did the two ships which, as we have since heard, came through the same sea also in August. The natives along the coast of Yamal were also unable to give any news of the expedition, or of having seen any strangers.

Taken altogether, therefore, I am bound to say that things look badly. In all probability the ship must have been caught in the ice somewhere in the Kara Sea in September 1912. But she was an old ship. As far as I have been able to find out, she was the old British warship Newoport, bought years ago from the Admiralty by Sir Allen Young and renamed Pandora $I I$. Afterwards she belonged to Mr. Popham, and under the name of the Blencathra made several voyages to the Yenisei in the nineties. She could not be expected to be very strong in her old age, and evidently could not stand the pressure for long before going to the bottom.

If the crew succeeded in saving themselves and their food-supply on the ice, it was to be expected that they would be able to reach some part of the coast of the Kara 


\section{THROUGH SIBERIA}

Sea, as the distances are not very great; we should then have to suppose that they had managed to meet with human beings in the winter of 1912, or at the latest during the following spring or summer. But as nothing has been heard of them, it is to be feared that a disaster has occurred.

The only alternative would be that the expedition found open water, and so went on without calling for the coal at Dickson Harbour, which, of course, may have been closed by ice; but this does not seem very likely, and in any case they must have wintered somewhere before reaching Cape Chelyuskin, as otherwise they ought to have met the two ice-breakers, Taimyr and Vaigach, under Vilkitsky, which went along the coast westward from Bering Strait this year (1913). There is still a possibility that the Sviataya Anna may be drifting in the ice on the north in the Arctic Ocean, and that her crew may still be alive there, but there is no great chance of that either.

As regards Rusánov, it is less certain that he had any intention of making for Dickson Harbour in particular; but in any case he can hardly have reached the east side of the Kara Sea, as nothing has been heard of him in any quarter.

$\mathrm{He}$ is rather to be looked for on the coast of Novaya Zemlya. Not on any part of the west coast, however, since Sedóv's expedition does not seem to have come upon any trace of him. More probably, then, he wintered on the east coast, but in that case it is strange that we have not yet heard anything of him or his crew.

It seems to me, therefore, that things have an ugly look for this expedition as well as the other. Of course there is here again the possibility that the ship was shut in the ice, and has drifted north with it; and what may then have happened is not easy to say. It 66 


\section{OPEN SEA, EASTWARD TO THE YENISEI}

has been suggested in Russia that possibly he went through Matochkin Shar, and then tried along the east coast of Novaya Zemlya to reach Lonely Island (Ensomheten); but it does not appear that the ice conditions that year (1912) were favourable to sailing in that direction. And if he reached that little island, it is very doubtful whether he would find there any harbour for his vessel.

We took a turn inshore on the island to shoot, and found a herd of fourteen reindeer, but they were in such a position on a flat plain that it was impossible to get up to them. We had to wait for them to move. But that took time, and meanwhile a fog came on, as thick as a wall, and blotted out everything. I tried all the same to steal up to them, and got far enough to have a glimpse of some big deer ahead of me through the driving fog; but they saw me just as soon, and away they went before I got a shot. There I stood, and the other sportsmen were probably trying to stalk the same reindeer from their side. I thought it best to hail them, in case they might make a mistake and shoot me for a reindeer in the thick fog. You never know what may happen. I remember a mighty Norwegian Nimrod who got into the middle of a flock of sheep in a fog among the mountains, and shot fifteen sheep, thinking they were reindeer; not to mention the man who shot a cow for a duck.

At 9 A.M. we went aboard again. The weather was still foggy and thick, and it was not tempting to go to the southward. Another thing was that there was a continual strong current setting northward through the strait, which might be expected to bring the ice with it from the south, and soon give us an ice-free channel right into the mouth of the Yenisei. We therefore stayed where we were that day.

In the evening we took another turn ashore to look 


\section{THROUGH SIBERIA}

for the reindeer; but from time to time the fog came drifting over the flat land, and soon night came on and it was too dark. Of birds there were a few flocks of geese and also some long-tailed ducks to be seen.

This island is of much the same nature as the low, undulating tundra. It is mostly clay and gravel, and clay mixed with sand, covered over with thin grass and moss, which is fairly good pasture for the reindeer, though it could not be called very rich.

Here and there hard rocky knolls stick up over the plain. Most of the rock seems to be crystalline schists; but pieces of argillaceous shale are also to be found in the débris. These knolls are much worn and split, and big stones lie scattered all round them.

These islands, and a great part of the adjacent mainland, which also has a rocky substratum, seem to me as if they must be a typical Coastal Platform. By this I mean the low, level land with low islands outside along the coasts, which was formed in the first place by the rock in course of time being split into fragments and worn and scoured down to the sea-level by rain, and snow, and ice, and frost, and sun, and running water. Then the action of the sea and surf was added, planing out islands, islets and land into what geologists would call a plane of marine denudation.

We see this coastal platform clearly enough when we sail past the long coast of Norway, with the belt of skerries outside. It consists of the low skerries and islets that only rise a little above the water and often extend far out to sea, with an infinity of banks and sunken rocks and shallows outside them.

It was a beautiful calm night as we rowed back to the ship. Smooth water between skerries and islets, which emerged from the mist lying over the sea; high 68 


\section{OPEN SEA, EASTWARD TO THE YENISEI}

above, the clear blue vault of the sky, and the flush of sunset hovering in the misty vapours on the north. As mild and peaceful as such a night in the Arctic can be.

Monday, August 25. Next day the weather was clear, and at nine in the morning we weighed anchor and went southward. As we stood out past one of the little islets on the south side of Dickson Harbour, we saw two reindeer standing on its crest and staring at us. It would not have been difficult to shoot them on that little island; but we had no time, we were obliged to go on.

The water was quite open. The Captain had been quite right in waiting over the day before. The conditions had entirely changed since we entered Dickson Harbour; there was now no ice to be seen to the south, and on the west it was also far away. To the south of the promontory of Yefremov Kamen, which projects from the mainland, some ice lay on both sides of us, to westward and to landward; but there was an opening in the middle fully a mile broad. Then, some ten miles or more to the south of this, there was an end of the ice, and we had open sea before us.

We followed the land that extends southward from Dickson Island and forms the east side of the Yenisei estuary. The depth is fairly regular, between 9 and 11 fathoms. The land is quite flat the whole way, with a few beds of rock here and there on the shore. It slopes abruptly along the sea. Its height seems to be about the same here as on the north by Dickson Island, and it has the appearance of being the same typical coastal platform. These rocky knolls that stand up on the shore may some of them have been islands, holms and skerries, the space between them having since been filled up with river gravel, sand and clay. Then the sea has receded, 


\section{THROUGH SIBERIA}

and the whole coast has become the inconceivably vast flat land that we now see. The Krestovskiy Islands, and the other islands outside them, are also perfectly flat, without a mound.

We saw smoke on the shore, and there were huts with flat roofs. They looked rather like half-finished houses, with the roofs not yet put on. There were more and more of them as we went south. They belong to fishermen who come here in the summer, some of them Russians, others Samoyedes and Yuraks. We also saw many traps for foxes inland on the tundra. They were, of course, set by people who stay here during the winter to trap foxes; this may be a paying occupation now, as the price of white fox fur has risen so much.

We also saw boats along the shore and a few on the water a long way south among the islands. It was strange to come back to inhabited regions. The flag had to be hoisted.

The land on the west side of the river we could only just see, far away across the water. It might have been about 20 miles off. What a huge, broad mass of water flows out into the Arctic Ocean here; it makes a powerful impression. It gives one the feeling of being at the entrance to one of the great water-arteries of the world.

It is curious to think of the long journey that has been made by much of the water that runs out here; all the way from the mountains of Mongolia. The Yenisei, with the Angará and Selengá, is reckoned as the fifth longest river in the world, about $\mathbf{3 0 0 0}$ miles long.

With its great tributaries, the Angará, the Middle and Lower Tungúska and others, the Yenisei has a drainage-basin of 970,000 square miles, the seventh in size of the river basins of the world. Its tributary, 70 


\section{OPEN SEA, EASTWARD TO THE YENISEI}

the Angará, issues from the world's deepest lake, Baikál.

The sources of the Yenisei, the Bei-Kem, Khua-Kem and so on, rise in the mountains of north-western Mongolia, at a height of more than 5000 feet, in the neighbourhood of the sources of the Selengá and near to Lake Kossogol, from which a tributary runs out into the Selengá, which again falls into Lake Baikál, and through the Angará unites itself later with the Yenisei.

The Yenisei flows at a height of over 3000 feet through the plateau of Mongolia to the borders of Siberia. Here it forces its way through the Sayan Mountains and falls to the lowlands, until on passing Krasnoyarsk (558 feet) it flows out on to the immense plains of Siberia, over which it runs northward to the Arctic Ocean. At Yeniseisk it is $\mathbf{2 3 3}$ feet above sea-level.

All its greatest tributaries come from the east and are : the Kan, Angará, Podkámennaya Tungúska and Lower Tungúska, all mighty rivers with large basins in the Siberian plains. The Yenisei in the lower part of its course has a considerable width; to the north of Yeniseisk it is seldom less than a mile and a half in width and often much more. Out here near the mouth the width is something like $\mathbf{3 0}$ miles.

Every one going up the Yenisei must be struck with the remarkable difference between the east and west sides of the river. While the flat land on the east is comparatively high and falls abruptly with a steep bank to the river, a steeply sloping beach and relatively deep water outside, the land on the west is strikingly low. The steep river bank is not high, and the bare sandy beach slopes quite gently to the water, with a shelving bottom far beyond it, so that as a rule it is not easy to approach this shore in a ship or boat.

The deepest channel usually lies nearest the east 


\section{THROUGH SIBERIA}

side, and often quite close to it. The exceptions to this rule are places where the river makes a sudden bend. Where it turns sharply to the right, the stream, owing to the inertia, makes for the left bank, and has there dug the deepest channel. But one does not have to go far on to find the strongest current and deepest channel on the right again, that is, the east side.

There can be no doubt that this is an effect of the earth's rotation, which causes all water flowing in a horizontal direction to have a tendency to go to the right in the northern hemisphere, as mentioned before, and this tendency becomes stronger the farther north we go. This effect is particularly apparent in such broad rivers as the Yenisei, where the waters within its bed may flow at very different rates of rapidity. It must naturally lead to the river digging out its channel deeper on the right side of its bed, and also to its wearing away the right bank more than the left. In this way the whole river-bed has a tendency to move gradually to the right. Now it is clear that, when a great river flows through a flat country like northern Siberia, the effect of this must be that the river-bed is constantly on the move towards the right, until it comes upon obstacles which check this movement. The result must then be that in the course of ages the river leaves on its left side a flat country, where it formerly had its bed and where it has left its deposits, and on its right it will have higher land, into which it has not yet dug its way.

If we look at the Yenisei, we may thus expect that in remote times its bed lay far to the west of the present bed, and it will have left behind it a very low, flat plain. This is just what we find. But on the right of it, that is, the east, there should be higher land, which it has not yet reached, and from which most of its tributaries flow into it.

72 


\section{OPEN SEA, EASTWARD TO THE YENISEI}

Now perhaps geologists will object that the bed of the Yenisei is determined by a dislocation of the earth's crust, whereby the flat land on the west side of its lower course has sunk, while the land on the east side is what geologists call a "horst," which has remained standing at its original level. This may be so to some extent, but it does not exhaust the matter. The bed of the Yenisei may for all that have shifted in the course of ages from west to east, but have been partly checked in this eastward movement by coming upon this dislocation of the earth's crust, in places where the beds of rock were higher, and where it became more difficult for the river to excavate to the right.

Many things point to the river-bed having really undergone such a movement in the course of time. It is not only where we have rocks remaining from the dislocation that we find the right (east) bank considerably higher than the left (west), but also where the banks on both sides of the river consist of loose strata, and where no dislocation has taken place, there, too, the eastern bank is considerably higher than the western; and this applies to long reaches of the lower course of the river. It seems to me that the only explanation of this state of things is a movement of the river-bank towards the right.

It became noticeably darker here at night. We were now nearly in latitude $72^{\circ} \mathrm{N}$., and had come a good way south from Dickson Island, which lies in $73 \frac{1}{2}^{\circ}$.

At midnight, when I had just undressed to crawl into my bunk, the ship struck the bottom; once, and then a second time. They were heavy bumps, but she scraped over.

I went out on deck; others came running out too. 


\section{THROUGH SIBERIA}

The engines were stopped; but the lead showed no less than 4 fathoms, and we were afloat. It must have been quite a small sandbank sticking up.

Tuesday, August 26. Half an hour later we anchored in 8 fathoms of water to wait for daylight, for the channel was not so easy here. This was off Sopochnaya Karga, which lies on the west bank of the river. There were some bonfires burning on land, and some huts where Russian fishermen live in the summer.

I had not been in bed many minutes before the Captain came and warned me that we were going to have a visit from the shore, and there was nothing to be done but to turn out again. A boat came alongside in the darkness with seven or eight Russians. One of them was in Government employ, taking statistics of the fisheries here.

There were also two political exiles; one a factory hand from Kharkov in South Russia, and the other a Jew from Yekaterinoslav (South Russia), who had managed a little mill. They had both been exiled after the revolution, and must have come out to Siberia in 1906. We were invited to visit them ashore, and three of us went with them in the boat.

Three or four low timber huts stood on the shore, but it was so dark that we could hardly see them. In front of the huts the fire was burning, and food was being cooked. The shore was covered with barrels in which fish was being salted.

It was mostly "omul" (Coregonus autumnalis, Pall.), which is caught here in great quantities, and a smaller fish, "seld" (Coregonus merki, Günt.), which is salted and treated like herring. These are both fish of the salmon tribe, but with white flesh like the gwiniad. A higher price is obtained for a larger kind called "nyelma" (Stenodus nelma, Pall.), which is more like 74 


\section{OPEN SEA, EASTWARD TO THE YENISEI}

salmon, though it also has white flesh; but this is not so plentiful.

The exiled factory hand had also caught five belugas a short time before in a seine; they go up the rivers after omul. The skin is cut into long, broad strips lengthways of the animal; the strips are then salted in barrels and sold to the Samoyedes and Yuraks, who use them for reindeer harness and prize them greatly, as besides being strong they have the advantage of not getting stiff in cold weather. Here, too, we came upon the superstition that it is the whales that drive the fish in towards land; these people firmly believed that when fishing was bad, it was because there had been few whales or belugas out at sea.

It seems as though there must, formerly, have been far more whaling in these regions than there is now. In his book on "Northern Russiạ," Sidórov says that in 1859 there were caught in the Yenisei estuary 25 small whales, quantities of dolphins, and belugas which yielded 18 poods (650 lbs.) of blubber.

We went into the largest hut. Eight men lived in it, and a couple of women; one of them was the daughter of one of the men. They all had sleeping places on low plank beds on the floor. A table stood in the middle of the hut, and on it a stearine candle was burning. The men sat round about. One of the women stuck her head out of some bedclothes on the floor to look at the strangers.

I was anxious to try a photograph of this nocturnal scene, and they immediately offered to light more candles while I did so. But when we wanted to pay them, they handed back the money and would not take anything, saying it was a great honour to them to have us in their hut, and to be photographed and get into the papers. 


\section{THROUGH SIBERIA}

The Jew was the spokesman. He was not yet a free man. True, he had been released from prison, but he was not allowed to leave this part of Siberia, and even here he could go nowhere without permission. Why had he been exiled? It may have been sufficient that revolutionary documents were found in his house.

When Loris-Melikov asked him how it was that the Tsar's amnesty on the occasion of the Romanov Jubilee had not applied to him, he replied that it was not certain whether a man of principle would care to accept favours from the Government. This looked rather as if he was suspected of belonging to the anarchists. $\mathrm{He}$ was now overseer of the fisheries here for a trader in Krasnoyarsk.

As we went out of the hut, the other political exile came up and asked if we would not pay him a call too. His hut was quite small, with only room for himself and for a woman who kept house for him. As we came in she greeted us, sitting on a stool and filling up a lot of room.

She was uncommonly ugly, had seen her best days, and was anything but attractive; she must have been half-Samoyede, probably, but spoke perfect Russian and came from Golchíkha. She was so fat that she must at least have been pregnant, one would have thought, although she looked too old and ugly for that. Otherwise she must have had dropsy, for it was scarcely credible that it could all be natural fat; although I must say I have seen some amazingly fat women in this country, both Russians and natives.

A paraffin lamp was burning in the little room. And little it was, so low in the roof that we had to stoop; but it made a clean and tidy impression : a bed with curtains, a small table with ikons above it, a stove with 76 


\section{OPEN SEA, EASTWARD TO THE YENISEI}

a samovar in the corner behind the female, and various other little things.

He was a big fellow of over six feet, with a powerful face, a fair moustache, blue eyes capable of being either keen or gentle, either very much on the spot or dreamy and far away; a well-developed, powerful chin and a straight nose. He might have been about thirty. He seemed as if he filled the whole room, that fellow, and I could not take my eyes off him as he sat there on a stool talking to Loris-Melikov, with his features sharply outlined in the lamplight.

He had served his timc of exile, and had been free for the last three years; but he still lived on here alone, summer and winter. He had to get some money together before he went home, and he was doing this by fishing in summer and catching white fox and ermine in winter. The foxes he took, some with traps, some with snares and some with strychnine. Last winter he had got 26 white foxes and a couple of ermines. Blue fox is not much found in this quarter. That was not such a bad catch, when one remembers that each white fox's skin fetches 30 roubles.

When he spoke of Russia and of his native place, Kharkov, tears came into his eyes. His wife had died a year or two after he went to Siberia, and he had no children. When he did go back, he said, he would not have the heart to settle in the same part of the town as before and meet her people again. He would have to try some other quarter. He had not seen a newspaper for several years, and such things as the Balkan War were entirely new to him.

According to the hospitable Siberian custom, his woman offered tea in flowered glasses and bread, and we had to drink a couple of glasses.

Then we went out into the open air again. Day was 


\section{THROUGH SIBERIA}

dawning, and after we had bought a couple of poods of fresh fish, they put us aboard again.

The big man steered. Again I could not help looking at him, as he sat in the stern of the boat and managed the paddle with his superabundant strength and his calm eyes. What was it that made life worth living to him ? Could it be the solitude here, or was it rather something that his dreamy blue eyes saw far away in the future?

Then we said good-bye to them, weighed anchor and went on to the south. We had to take soundings incessantly; the depth varied from 12 fathoms to $5 \frac{1}{2}$ fathoms. At 8 o'clock the lead gave 5 fathoms. It varied between 5 and $6 \frac{1}{2}$, but then the ship took the ground and stuck fast. The shock was so slight that I lay in my bunk and knew nothing about it, until the steward came and announced that it was half-past eight and we were stuck again.

It was clear that we had come too close to the west bank for fear of the Yakovleva Kossá (i.e. Yakovleva sandbank) in the middle of the river. We were fast forward under the bow. After going ahead and astern with the engines, and thus working the ship backwards and forwards, we slipped off again at 11 o'clock.

We then steered more easterly at half-speed to find the deep channel; but a quarter of an hour later we struck again. It took us an hour to get off.

We were still scarcely more than a quarter of the river's width from the west bank-not much more than two miles from it-but the channel ought to lie nearer this side here, where the river has a bend to the right. Now we begin to miss the motor-boat Vostrotin wanted to buy; it might have gone on ahead and taken soundings. The mate was sent in the lifeboat to sound to the eastward, and soon found deeper water, 10 fathoms. That 78 


\section{OPEN SEA, EASTWARD TO THE YENISEI}

was evidently the channel, and the Correct was steered in that direction, and then on a south-easterly course at half-speed and with constant use of the lead.

The depth increased from 10 to 13 and 12 fathoms and remained at about that for a long time; but then it began to get shallower again, only 5 fathoms. The engines were stopped and went astern ; but immediately afterwards the vessel took the ground so gently that we scarcely noticed it and were not sure whether she was fast or not. We went full speed astern, but to no purpose. The lead gave $2 \frac{1}{4}$ fathoms forward, $2 \frac{1}{2}$ amidships, $3 \frac{1}{4}$ aft, and the ship was supposed to draw $2 \frac{3}{4}$ fathoms.

The starboard anchor was heaved aft with the steel cable, till the cable was taut, when there were 25 fathoms of chain out. Then the engines went full-speed astern, while we heaved on the anchor. But the ship lay just as fast in the soft clay bottom. There was a stiff breeze from the east-south-east with a strong tide running north and that was not exactly pleasant, as it was to be expected that the water would go down. There was some sea, and the ship rocked a good deal as she lay; but we did not get off for all that.

By midnight the water had sunk a foot; this was no doubt partly due to the south-easterly wind and partly to the tide.

It rained during the night, and that gave some hope that the water would rise as soon as the wind dropped or changed; but the stream was still setting northward at the rate of 4 miles. We lay aground that night.

Wednesday, August 27. The wind went round to the south-west, still with showers of rain, and now perhaps the water would rise. We were only waiting for high-water to make another attempt to get off. At 2.30 P.M. the water had risen sufficiently to make it 


\section{THROUGH SIBERIA}

seem worth while; and by heaving on the anchor and going full-speed astern, we at last glided gently and imperceptibly off. After that we cast anchor in 5 fathoms of water to have dinner. Loris-Melikov asked suddenly during the meal : "On what ground do we lie at anchor, here?" I replied: "To eat our dinner; isn't that a good enough ground?" He answered: "Yes, at any rate it's better than the one we were lying on just now."

The life-boat with the two mates then sailed first to the eastward to take soundings, and they found the channel a good way farther east. We went after them dead slow to the south-east, while they sailed ahead and sounded. It is evident that we must have struck on a bank that lies to the north of Nosónovski Island and is not charted.

At this spot the Yenisei is about 23 sea miles wide, and the land is low on both sides, but more so on the west. As the channel one has to follow lies near the east side, the west bank can scarcely be seen even from the crow'snest, and if the weather is thick one loses the east bank as well. In such conditions it is not easy to follow a narrow fairway out in the river, especially as it is not buoyed.

To the south of us, in the broad expanding part of the Yenisei, lie a number of large and small islands close together. They are quite flat and low, almost like somewhat high sand and mud banks, separated by shallow channels, which are mostly narrow. The whole group is like a low, flat delta, and it extends with wide sunken banks a long way to the north. The islands are known collectively by the name of Brekhovskie Ostrova.

Our destination was the most north-easterly of these islands, Nosónovski Ostrov (i.e. Nose Island), which, by the way, is divided into two islands by a strait. 80 


\section{OPEN SEA, EASTWARD TO THE YENISEI}

There was said to be a tolerably good anchorage thereabouts, where we could lie and discharge and load; and there it was that we were to meet the steamboat with the lighters, which were to come from the south just at this time; in fact, according to the arrangement they ought to have been there the day before, August 26.

But we could still see no land on the south, even from the crow's-nest, either ahead or to the south-west of us; it was no doubt quite low and flat and not to be seen at a distance.

But at last, at 6.45 P.M., I caught sight of the island from the crow's-nest, on our starboard bow, perfectly flat land, just above the horizon. The boat ahead of us was beginning to get into shoal water again; they found only 4 or 5 fathoms and less than that. So we anchored, while the boat sailed a little to the eastward of us; but there they had only $2 \frac{1}{2}$ or 2 fathoms; and then to the westward, but there it shoaled to 4 fathoms.

To the south-east of us I could see eddies over a bank. The Captain came up into the crow's-nest and saw them too. It all seemed difficult to understand. We might be about midway between the land on the east and the island on the west. It did not agree with the chart. It looked as if we had come into a channel that closed in ahead of us; but where was the main channel ?

At 10 P.M. we sent up three rockets and burned three blue lights from the crow's-nest as a signal to the steamboat and lighters, which according to arrangement ought to have arrived from the south at Nosônovski Island just at this time. It was said on board that, even if they were there, it was by no means certain that they kept a good enough look-out to see these signals ; 


\section{THROUGH SIBERIA}

and if they did see them, they would probably only take them for meteors or northern lights.

Thursday, August 28. At 5 A.M. we saw the smoke of a steamboat, and immediately afterwards we also caught sight of the masts of three lighters, which lay at anchor on the other side of the flat island ahead. Later in the morning we saw the steamer coming down towards us slowly and cautiously; she was sounding her way with a long pole. Finally she anchored a good way to the east of us. A boat put off and sounded ahead of the vessel ; it must have been shallow water. But then the boat came nearer, steering straight for us, and came alongside.

Two men in uniform and one civilian came aboard. The last was Lied's manager, Mr. Gunnar Christensen, an extremely agreeable young man, who had been some years in Russia and in Krasnoyarsk and spoke Russian to perfection. He had now come from the south with the goods which the Correct was to take back. One of the men in uniform was the captain of the steamboat Turukhansk, and the other was a Custom House official, who, with two of his soldiers, had made the long journey all the way from Irkutsk, simply to check our goods.

He and his men made the whole journey both ways at the expense of Lied's Company. The year before, as already mentioned, a Custom House officer and his soldiers had made the same journey, also at the Company's expense, and waited in vain, as the ship did not get through.

The Turukhansk with her lighters had arrived on the morning of the previous day at the anchorage on the south of the island, and we had come the same afternoon ; it must be said that we hit it off well, considering that they came about 1350 miles from the south, and 82 


\section{OPEN SEA, EASTWARD TO THE YENISEI}

we some 1800 miles from the west ; but I won't venture to assert that it was all due to careful calculation.

Yesterday evening the men of the Turukhansk had seen the last of our blue lights and, just as we had thought, had taken it for northern lights or something of the sort; but early this morning, as they were going on with one of the lighters to Golchíkha, they caught sight of our smoke as soon as they came clear of the point. They had to go back and leave the lighter, at the same time fetching Christensen, who had gone aboard one of the other lighters.

The captain of the Turukhansk told us that we were lying in a bend of the bank which extends westward from the island. We should have to go back to the northward, and then into the channel farther east, he said. He returned to the Turukhansk, which went ahead and took soundings, and we came through safely in her wake.

Meanwhile we had breakfast at last, and the Custom House man breakfasted with us. He looked weak and pulled down, and had been very ill. He was a goodnatured and agreeable man, and seemed to be touchingly fond of animals. At breakfast he told us about his tame deer and other animals that he kept at home in Irkutsk. They were evidently his hobby in life; and he might have had many a worse one.

At last we turned the point of the southern Nosonovski Island and approached the lighters, which lay at anchor there to the south of the shore, off Nosonovski Pesók (i.e. sand), where there were some houses and tents on land. Here we were well received with a salute of rifles from the lighters, and had to reply with our rifles and revolvers as well as we could.

The shore is so shelving here that we had to anchor a mile or more from land, and even then there were 


\section{THROUGH SIBERIA}

only two or three feet of water under the keel, so that when the tide went down a little later, the Correct lay aground. And that made the fifth time on this trip; and it was not to be the last time either, as on the homeward voyage she went aground twice in the Yenisei estuary.

The land about here was perfectly low; there was not a ridge or a mound to be seen anywhere. To the east of us, on the other side of the wide stretch of water, we could see the mainland on the right bank of the Yenisei. It was comparatively high, with steep slopes down to the river, but perfectly flat above. The boundless naked tundra extended inland from the bank. The island to the south of which we lay was quite low and flat, like all these Brekhovskie Islands. A large part of it is under water during the great floods of spring and early summer (June).

As soon as we had anchored, the Turukhansk brought up two of the lighters, one on each side of the Correct, so that the transhipment might begin.

On board one of the lighters were two camels from Mongolia, besides two bears from the Siberian forests (a third bear had been killed on the way by these two), a wolf (another one had hanged himself, and a third had escaped on the way north), and a roebuck. These animals were going to Europe to be sold. In addition to them, Christensen had a pointer bitch in pup tied up on deck, so there was a regular menagerie.

It was strange in this cold, naked, desolate land to come suddenly upon these camels standing there patiently, with their oriental phlegm, on the deck of the big iron lighter from Hamburg. The characteristic eternal smile on the mouths of these animals, so unlike everything around us, their humps of fat and the soft wool with its warm tawny colour were enough to make 84 


\section{OPEN SEA, EASTWARD TO THE YENISEI}

one feel, as it were, the heat of the desert sun on the arid sands of Gobi.

The deck of the other lighter was filled with great beams of Siberian cedar, deal and pine. In the hold they had bales of flax and hemp, hides, wool and hair. Then there were quantities of reindeer and elk horns, and about 30 tons of graphite, etc. It gave one a sense of standing at the gate of an immense country which contained everything, from the tundra and forests of the north to the deserts of Mongolia far to the south.

Among the other contents of these lighters should be mentioned a policeman and a fat gendarme, both in uniform ; they probably came to kecp us in order, and more especially to see that none of the exiles escaped on the Correct to Europe. This applied, of course, more particularly to the political exiles; if a criminal or two got away it would not matter so much.

So now we were at anchor at our destination in the Yenisei, and our voyage in the Correct was at an end for the time being. Discharging and loading were now the order of the day, and these are never very interesting proceedings in any part of the world.

There were three of us who were to continue the voyage up the Yenisei, and we were not a little impatient to get away. There were Vostrotin and Loris-Melikov, who were both bound for Yeniseisk and Krasnoyarsk, and from there back to Russia. But of the three I was probably most pressed for time, as I had to be at Krasnoyarsk by September 25, to make sure of meeting Mr. Wourtzel and going on with him to Eastern Siberia and the Amur country.

The plan was that we should continue the voyage up the river on the tug-boat that was to take the lighters up again as soon as the loading was finished. But for this work of transferring the Correct's cargo to the lighters 


\section{THROUGH SIBERIA}

and the lighters' cargo to the Correct, there were to begin with only eight men available, and the lighters had only hand-winches.

We had reckoned that a week at the most would be enough for this work; but with so few hands it looked as if it would take several weeks. If after that we were to go up the Yenisei in the tug, that would mean at least three weeks more to Yeniseisk with so many heavy lighters to tow against the strong stream. To reach Krasnoyarsk before September 25 in this way was an impossibility, and I might just as well give up at once all idea of meeting Wourtzel there.

The distance was pretty considerable : to Yeniseisk wc still had 1015 geographical miles to travel up the river, and from Yeniseisk to Krasnoyarsk is supposed to be 330 versts ( 217 English miles) by land, and 391 versts (259 miles) by the river. The whole journey was as long as a straight line from the North Cape to Berlin, and fully that. 


\section{CHAPTER V}

\section{NOSONOVSKI PESOK AND THE SAMOYEDES}

Native tribes along the Yenisei : The Samoyedes and their history : Visit to Yenisei-Samoyedes : Position of women : Christianity and idol-worship : How to clean a tent : Appearance of natives : A drunken prince : Honesty : A " convent" with monks and nuns : Yenisei fisheries : Fish, their migrations and growth : Fishing tackle and the condition of the fishermen

NE of the things that tempted me most on this trip was the opportunity I hoped it would afford of seeing some of the numerous primitive peoples of Siberia at close quarters. There is always something very attractive about primitive peoples, and the more primitive they are, the stronger the attraction; and in this extraordinary country there are numbers of them that are still comparatively little known, strange as it may seem.

Here, going up the Yenisei, before we come to Yeniseisk, we have races enough : first the so-called Yenisei-Samoyedes-then Yuraks, another branch of the Samoyedes-then, between the Yenisei and the Obi, Ostiak-Samoyedes-then, westward in the direction of the Obi, Ostiaks, who are a Finno-Ugrian stem-then, on the east side of the Yenisei, Dolgans-then that mysterious people, the Yenisei-Ostiaks, quite different from the others and probably a last remnant of a great and mighty people that once occupied vast tracts of Siberia-then the widely distributed Tunguses- 


\section{THROUGH SIBERIA}

and, finally, there may be here and there some Yakuts, besides the Russians.

On this stretch of country alone there was more than enough to occupy the philologist and anthropologist. Since the eminent Finnish philologist, Alexander Castrén, travelled here before the middle of last century, and the great Siberian authority, Middendorff, visited the region about the same time, these peoples and their languages have been little investigated.

Although the Samoyedes are not so very numerous, they nevertheless have an immensely wide distribution over the Siberian-European tundra and over the northern forest regions, from Khátanga Bay on the east side of the Taimyr peninsula on the east, as far as the shore of the White Sea on the west, a range of about 1800 miles. On the south, too, they must formerly have been widely diffused, and a small isolated tribe of Samoyedes, called Kamassintses or Kamassins, is still found on the rivers Kan and Mana, tributaries of the Yenisei, on the north side of the Sayan Mountains. They speak a Samoyede language.

As to where these widely spread Samoyedes originally came from, we know, to be candid, very little. Many hypotheses on the subject may be as probable as that of the learned monk, who gave Castrén a manuscript in which he had clearly proved that the Samoyedes were descended from the Israelites, because they knew the Ten Commandments. But the general supposition is that they were a people, divided into several tribes, who originally inhabited the Altai and Sayan Mountains. The Chinese historians mention in the seventh century a people called Dubo, living in the Altai, on the plateaux to the east of Lake Kossogol. They were neither a pastoral nor an agricultural people, but fishers and 88 


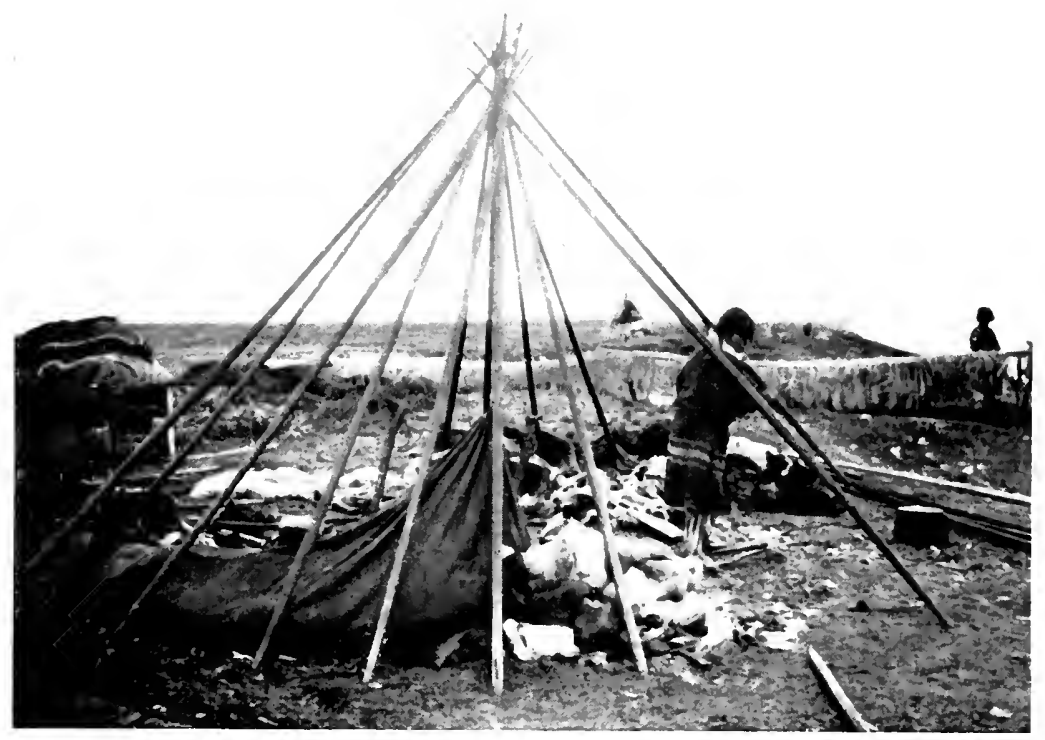

A SAMOIEDE SPRIXG CLEANIXG

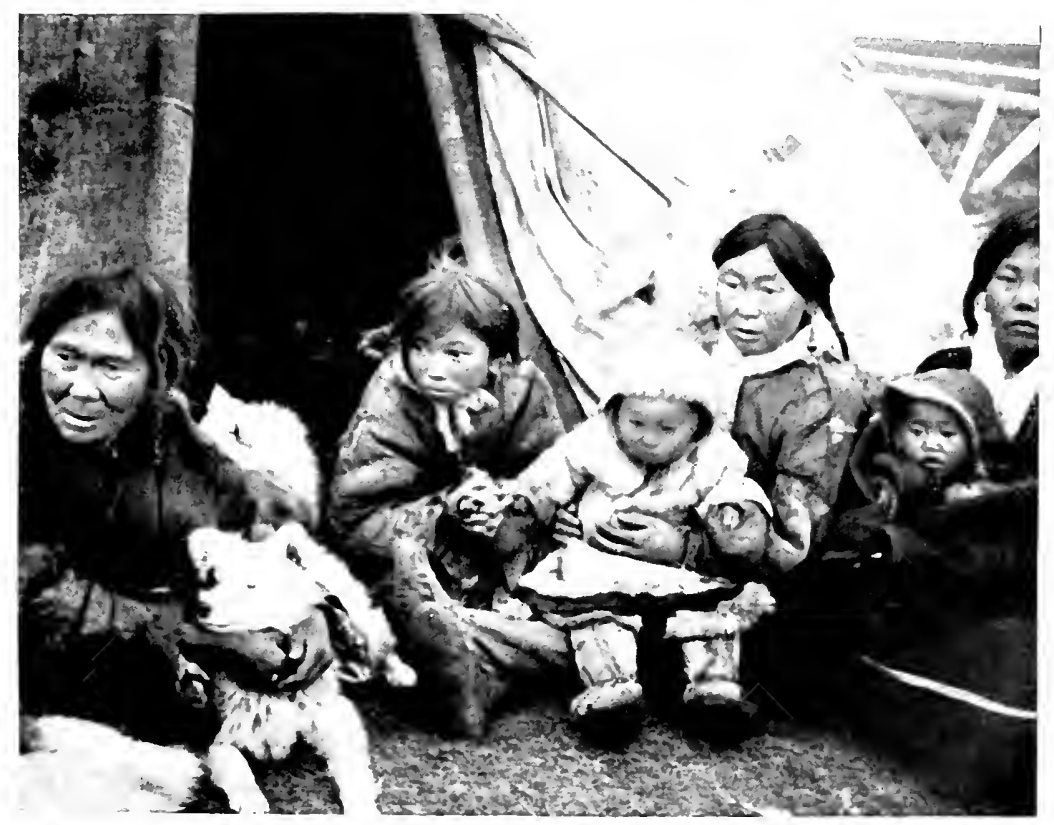

WOMEX AND CHLDREN OF TIE IENISEl SAMOYEDLA IS TUE DOORWAY OF THEIR TENT 


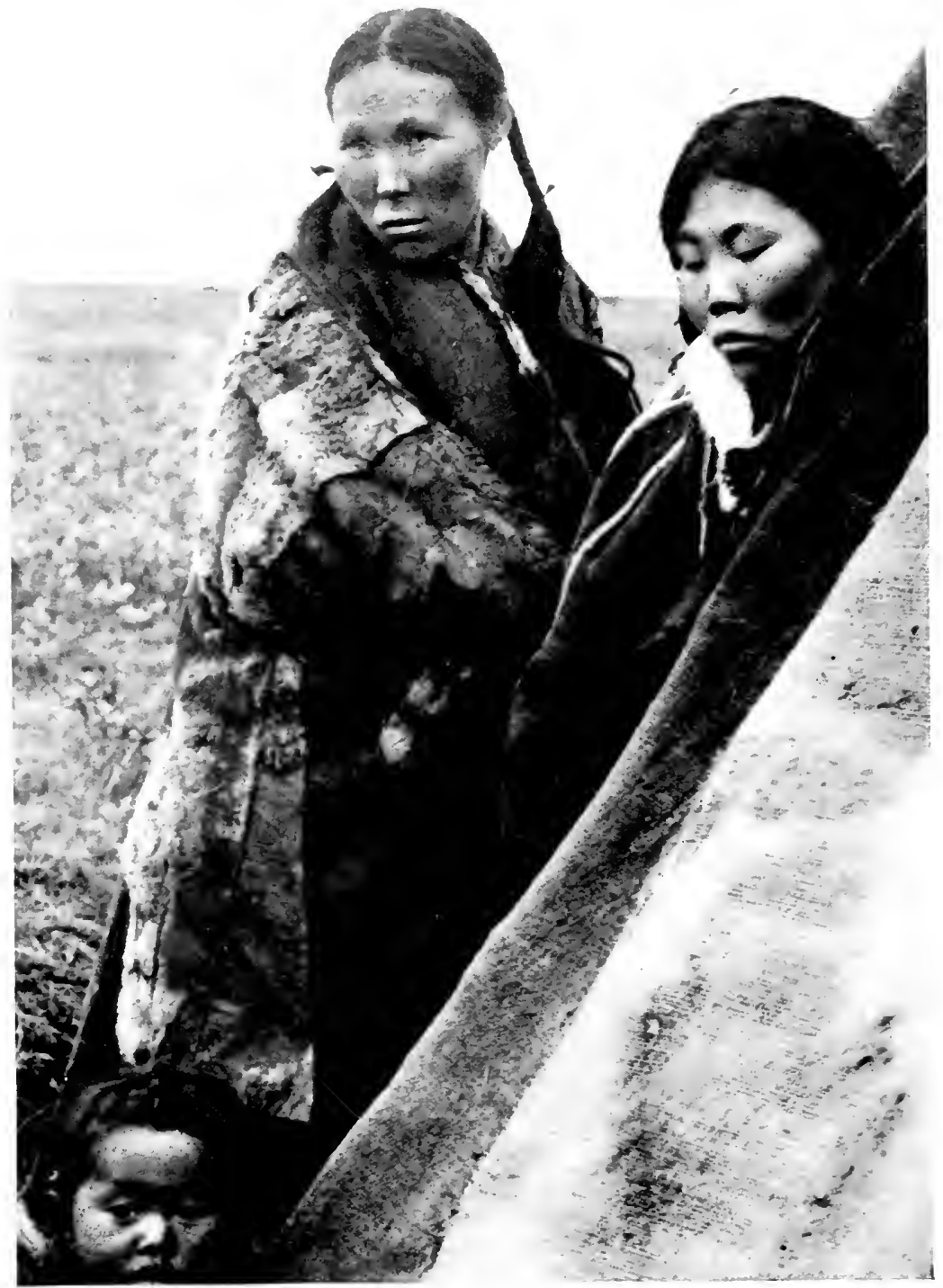

WOMEN OF THE YENINEI SAHOYEDES IN THE DOORWAY OF THEIR TENT 


\section{NOSONOVSKI PESOK AND THE SAMOYEDES}

hunters. Two other kindred tribes are also mentioned. They had wooden horses (i.e. ski) on their feet and props (ski-sticks) under their arms, and at every stride they went forward at least a hundred paces; at night they committed all kinds of thievery and pillage.

Dr. Wilhelm Radloff has maintained, rightly no doubt, that these Dubo people are the same as the Tubins, often mentioned in the history of Siberia during the seventeenth century, a very warlike race who, together with the kindred peoples, the Mators and Kamassins, long resisted the Russian domination, until at last, in the middle of the seventeenth century, they submitted and paid tribute (yasak). These three tribes must have been forest Samoyedes who lived chiefly by hunting, which made them unusually skilful with the bow. These tribes, with the exception of a few Kamassins, have now entirely disappeared and have become merged in the Turks and Tatars.

In the opinion of some, the Samoyedes migrated northward from this, their original native land, during the ceaseless unrest that resulted from the Hiong-nu and other Turkish tribes making themselves masters of the Altai country. Indeed, a writer like Middendorff goes so far as to suppose that they must have been driven in headlong flight from the Altai northward, and were not able to stay either in the Barabá steppes or in the primeval forests between the Yenisei and the Obi ; but only when they had left this broad belt of forest behind them did they find steppes where they could make their home, and settled on the tundra among Finnish tribes, chiefly Ostiaks, on the west, and Tunguses, who lived in the mountain districts on the south-east.

Such assumptions as these appear to me altogether impossible. The peculiar culture that characterizes a 


\section{THROUGH SIBERIA}

nomadic life on the tundra is not created in a day, nor in years, nor in centuries, but can only be the result of a slow development generation after generation through many centuries, not to say millenniums. A nation in flight northward from the Altai, reaching the tundra without any preparation, would necessarily perish by famine, unless they there found another people, which already possessed a culture adapted to the tundra, and were able to subdue this people and acquire its culture. To point only to one thing -in order to live as nomads on the tundra, they must have learnt to tame reindeer and to use them as domestic animals. This is not a thing that people can take to all at once; a long period of development must lie behind a special nomadic culture such as this.

In addition to this, we are told that the old Samoyede tribes of the Altai were not a pastoral people, but hunters and fishers, so that the whole nomadic culture with domesticated animals was foreign to them. For that matter we know even to-day of Samoyede peoples who live just in this way, by hunting and fishing, and do not keep reindeer; and many of the OstiakSamoyedes in the forests between the Obi and Yenisei live in this way and use dogs as draught animals.

I am inclined to think that these and many other theories of the sudden and long migrations of whole peoples have their origin to a great extent in the current view of the period of great migrations in Europe, as there is a tendency to move whole nations from east to west and from south to north, as one moves pieces on a chessboard. This may pass in the case of warrior hordes, who advance over peopled regions, ravaging as they go; but when it is a question of penetrating from the south to the north into the desolate tundra, where the newly arrived people must 90 


\section{NOSONOVSKI PESOK AND THE SAMOYEDES}

first provide themselves with a new culture in order to maintain themselves there, such migrations become an impossibility, even if a people of hunters had some qualifications for subsisting by fishing and hunting along great rivers like the Obi and Yenisei.

Nor can it be denied that there has been a strong tendency to derive most races from Central Asia and make them migrate from there fan-wise in all directions. Why precisely the middle of Asia should be the cradle of so many races is not quite clear to me. As to where the cradle of mankind stood, we know nothing at all. All we know is that the time when man appeared on the earth and spread over it and began to divide into different races lies so many hundreds of thousands of years behind us that it has no bearing on the questions of the origin and diffusion of races now living.

Then there is another thing which people are often apt to forget, and that is that the customary division of peoples into races such as Finno-Ugrians, Samoyedes, Turks and Tatars, Mongols, Tunguses and Manchus, and so on, rests entirely upon language, and can have little to do with the mutual kinships and origin of these peoples. A people, by becoming subject to, or coming into close contact with another, may easily adopt this people's language and culture, although there was originally no relationship at all between them.

Of this we have abundant examples. One near home is that of our own Reindeer Lapps. They speak a language which is nearly related to Finnish dialects, such as Finnish and Karelian, though in their origin they are certainly entirely different from these peoples. Another example is the Bulgarians, who were originally a Finnish people and spoke Finnish as late as the ninth century, but who, in the course of their migration 


\section{THROUGH SIBERIA}

through Russia, adopted the Slav speech and settled at the mouth of the Danube as Slavs.

When we find in the Altai small Samoyede-speaking tribes, or remains of earlier tribes, and are unable to suppose that they have immigrated recently to the places where we now find them, this seems to show in any case that at a remote period the Samoyede language was far more widely diffused to the south than it now is; and that Samoyede was spoken by various tribes all the way from the Altai to the tundra on the north, being perhaps specially diffused along the two great water-ways, the Obi and Irtish with their tributaries, and possibly the Yenisei and its tributaries. But that does not prove that the migration of the Samoyede-speaking peoples proceeded from the Altai towards the north-west and north; they are more likely to have spread in part in the opposite direction: from the great forests and rivers-where the conditions were favourable to fishers and hunters-south-eastward towards the Altai on the one side, and on the other northward to the tundra.*

Whether the various Samoyede-speaking tribes originally belonged to the same race is quite another

* Mr. Kai Donner, who has read the above, informs me that in his view the Samoyedes, at the time they spoke a common language, must have lived considerably farther west than their present haunts would lead us to suppose. The home of the primitive Finno-Ugrian people lay on the western side of the Ural Mountains, and this makes it seem probable that the original home of the Samoyedes was in the Ural distriets, and that they afterwards migrated from there in various directions. Only in the most recent times have they reached the Arctic Ocean-one indication of this being the fact that they have no word of their own for sea. According to this, then, their original home lay farther west than is assumed above; but it appears to me that the great rivers, like the $\mathrm{Obi}$, with their rich fisheries, must have offered specially favourable conditions for the maintenance of a people like this, as well as for their extension.

92 


\section{NOSONOVSKI PESOK AND THE SAMOYEDES}

question, which is by no means easy to decide. Many things may tend to show that the Samoyedes in our day are a fairly heterogeneous and mixed race. Thus while Middendorff speaks of the so-called Tavgy or Avam-Samoyedes as a small people, averaging only 4 feet 8 inches in height, with Finnish features, among whom a man of $\mathbf{5}$ feet had an imposing effect, there are other tribes, such as those we met in Yamal and some of those we find here on the Yenisei, who may often be a good deal taller and have a more "Mongolian" appearance.

But we must remember that no people here can be expected to be of pure race, as the various tribes live so close to each other and have so much intercourse. And there is the additional circumstance that among people such as these it is not even considered right to take a wife, or wives, from one's own tribe ; they have to be taken from a strange and preferably a hostile one, and formerly, of course, wives were often part of the spoils of war.

We must therefore expect in advance to find in all these tribes many different types mixed together. This is actually the case; and it is only reasonable that the most easterly Samoyedes, for instance, should show a great likeness to the Dolgans, Yakuts, and Tunguses, while, as Kai Donner informs me, not only the Kamassintses on the north side of the Sayan Mountains, but also the Ostiak-Samoyedes show evident traces of Tatar influence. It would not now be easy to separate the different races of Siberia purely by their appearance and anatomical structure; although, of course, there are certain features which pre-eminently distinguish one race from another, as, for instance, when we compare a good type of a north-westerly Samoyede tribe with a Tungus or with a Yenisei-Ostiak. 


\section{THROUGH SIBERIA}

One thing we may be sure of, and that is that the nomadic culture of the tundra, with the domestication of reindeer, is very ancient and has come down from a remote period. In North Norway we find the keeping of reindeer mentioned by Ottar in the ninth century, and it seems then to have been already well developed there. But it does not seem reasonable to suppose that this North-Norwegian culture should have arisen independently of the Asiatic reindeer culture, when we remember that the whole region from Finmark to Eastern Siberia is continuous and that nomads with reindeer are to be found all over it. It is therefore more reasonable to assume that there is a connection in this nomadic culture. Most probably it came from the eastward, from the great tundra of Siberia, where it must have developed long ages back. If it is not due to an unknown primitive people that preceded the Samoyedes, which is perhaps the most probable assumption, we must suppose that a Samoyede-speaking people of hunters that lived in the northern part of the forest region on the south, began little by little to tame reindeer and keep them as domestic animals, and from this the nomadic life of the tundra very slowly developed.*

Samoyede is the common name for all Samoyedespeaking tribes, but none of them calls itself so. The name Samoyede sounds entirely Russian, and one would

* Mr. Kai Donner expresses complete agreement with this view, and thinks that the reindeer culture "must be a very ancient Arctic hereditary culture, which later immigrants have acquired from the races, now perhaps vanished, that formerly inhabited the great tundras. This does not prevent the possibility of its having been far more widely spread in earlier times. In any case it is surprising that the terminology of reindeer-keeping shows so little linguistic agreement among the different peoples. We must no doubt interpret this to mean that the reindeer has been in use among them all for a very long time."

94 

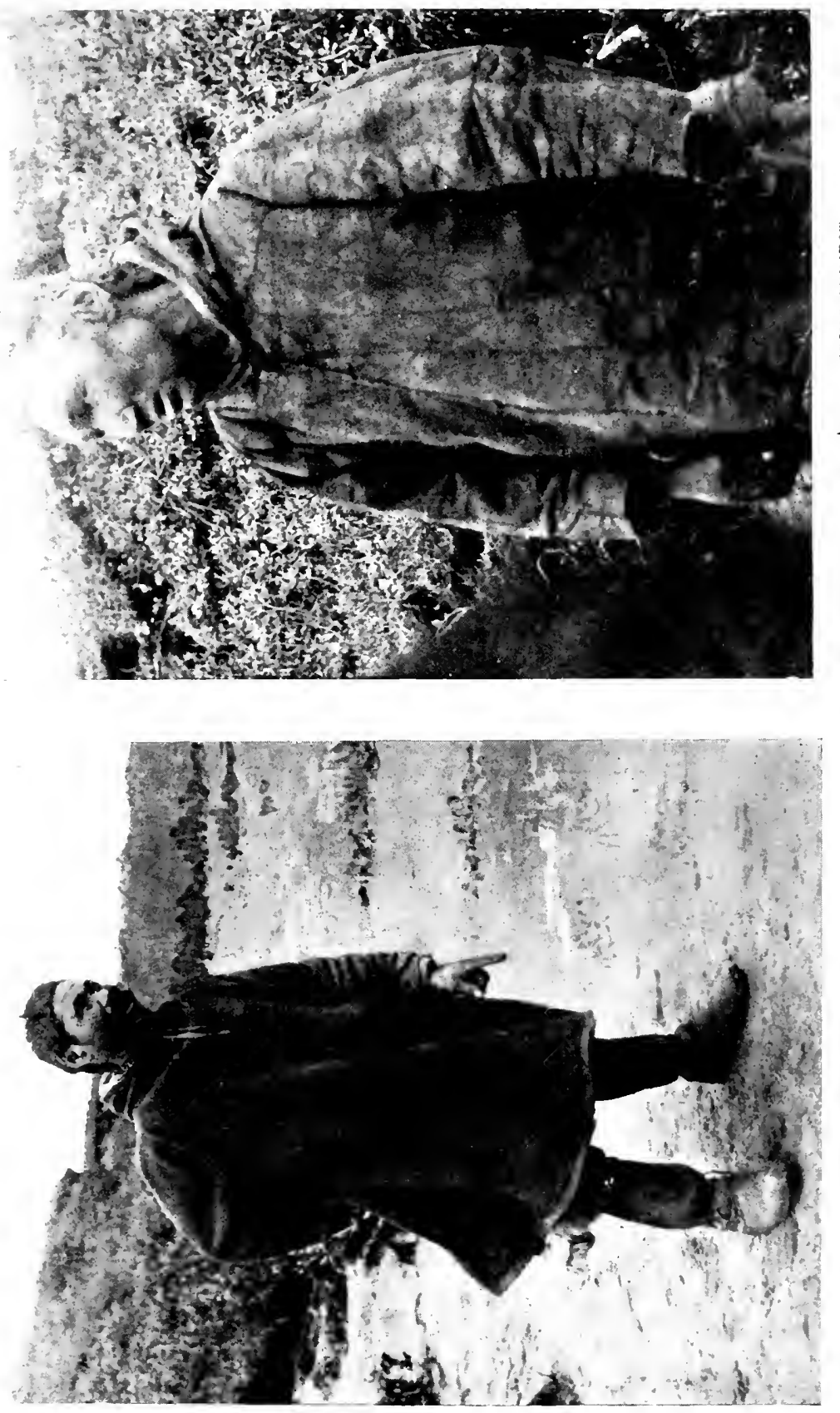


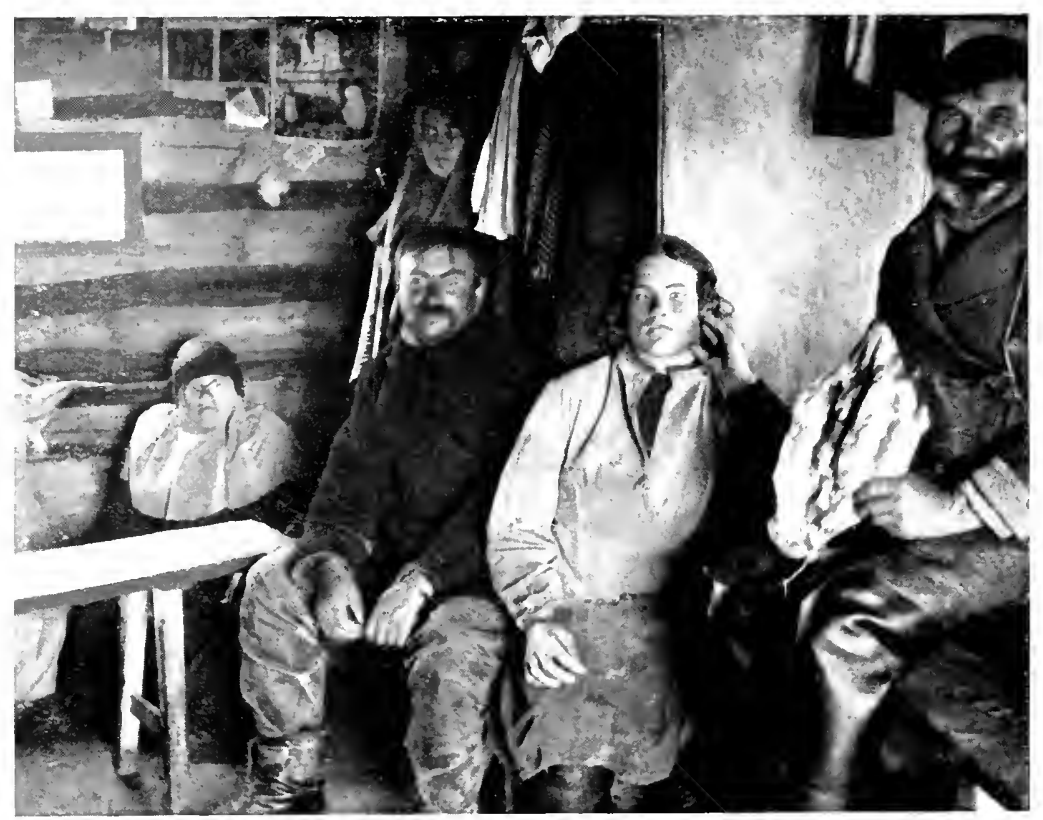

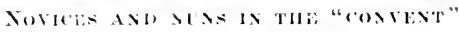

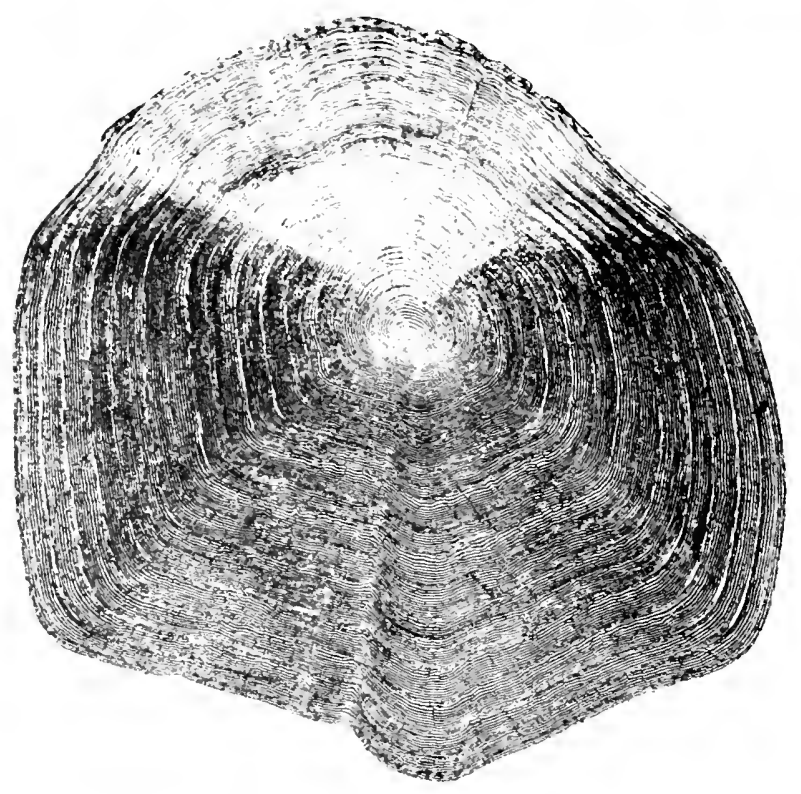

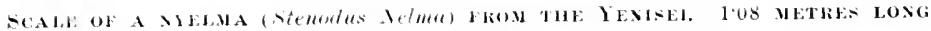
(IIUIITEEN ILARS OF AGE) 


\section{NOSONOVSKI PESOK AND THE SAMOYEDES}

be inclined to take it for a Slav word. In that case it means nothing but "self-eater," that is, one who eats himself or his kind, in other words a cannibal. It is not unlikely that the Russians may have applied such a name to the savage-looking natives whom they met with on the north-east; nor is it impossible that in time of famine these people may have eaten their dead, as has happened in so many other parts of the world. But it is nevertheless extremely doubtful whether this is the origin of the name. Others have tried to explain it by its resemblance to $S u o m i$, and held that it was of Finnish origin. In any case it seems most probable that it is derived from some misunderstood word or other that was foreign to the Russians, and that it was then turned into the Russian Samoyede according to the usual method of popular etymology.

The Samoyedes are usually divided into five main stems. These are (1) the Tavgy or, as we might call them, Taimyr-Samoyedes, who inhabit the Taimyr peninsula, eastward from the Yenisei to Khátanga Bay. They are reindeer nomads, and live on the tundra by their reindeer, though they may do some fishing in the rivers and lakes and hunt wild reindeer and furred animals besides. (2) The Yenisei-Samoyedes live along the Yenisei. They also keep reindeer, but on a smaller scale, and they live to a great extent by fishing in the river and by hunting. (3) The Yuraks extend from the Yenisei as far as the White Sea. They are mainly reindeer nomads, but do some hunting and fishing besides. (4) The OstiakSamoyedes live in the north of the forest belt, south of the tundra. Those farthest north keep some reindeer; but the more southerly ones are exclusively fishermen and hunters, and their only domestic animals 


\section{THROUGH SIBERIA}

are dogs, and sometimes also horses. (5) Finally there are the Kamassintses, who live on the northern slope of the Sayan Mountains as an isolated Samoyede tribe.

The languages of these main stems are different, and they are again divided into smaller tribes, which speak different dialects. The Samoyede languages are chiefly known through Castrén's pioneer work, but since his time little attention has been paid to them until within the last few years, when the young Finnish philologist, Kai Donner, has travelled in the districts adjoining the $\mathrm{Obi}$ and Yenisei, and has at present chiefly studied the language of the Ostiak-Samoyedes. He informs me that these Samoyedes, who may be about $\mathbf{3 0 0 0}$ in number, speak more than twenty different dialects. Since the various Samoyede tribes have lived scattered over such immense tracts of country, and since we may further reckon, as he says, that they must have separated from each other at least 2000 years ago, it is not to be wondered at that there should be a good deal of difference among them and their languages.

The reason for the Samoyede languages no longer having so great a diffusion on the south as they once had may be assumed to be that other cultures with other languages have forced their way in and superseded the earlier culture. Then the Samoyede-speaking peoples, have either been driven away, or rather, perhaps, have adopted by degrees the other culture and its language, in the same way as we know certain Samoyede tribes, such as the Tubins and Mators, to have taken to speaking Turkish or Tatar, with the result that they are now counted as Turks and Tatars.

The Samoyedes are, of course, among the primitive races who are not benefited by contact with European civilization, and who are therefore on the decline. It 96 


\section{NOSONOVSKI PESOK AND THE SAMOYEDES}

is true that many of the Samoyedes of the tundra have until now held their own fairly well, and rich people are still to be found among them who own their two or three thousand reindeer. But their whole life presupposes the culture which they themselves have developed and in which they have been trained. European civilization cannot give them much that is of use. On the other hand, it gives them new habits and new needs which are difficult to satisfy with their manner of life, and therefore many of those who have much intercourse with the Russians are sinking into deeper and deeper poverty. If, then, a bad year comes, it is easy to see that their condition may become critical. Middendorff tells us of years when famine carried away more than half a tribe, because their fishing and wild reindeer hunting had entirely failed. In other years there may be disease among the tame reindeer, so that a great part of them is lost; Samoyedes, formerly rich, may suddenly be impoverished in this way, it is not easy for them to recover themselves, and the trader with his tempting spirits and other things does not make it any easier. This decline of the nomads is all the more to be regretted, as they alone with their culture are able to turn to account the immense wastes of the tundra; the white race will never learn to do so.

On the above statements Kai Donner offers some observations of great interest. His experience is that the most distant natives, isolated in the north of the tundras, do not decrease in number except through the ravages of epidemics. Farther south it is quite another matter; there they are rapidly dying out; in certain districts the infant mortality amounts to 50 per cent. of the births. The cause of this is not want of care or illness brought on after birth, but, in Donner's opinion, the great debilitation of the parents ; 


\section{THROUGH SIBERIA}

and this is undoubtedly due to the sudden change of conditions which takes place when the nomad gives up his open-air life to take up his abode in a small hut. To this must be added liquor, syphilis, etc. Besides, the Russians take away their hunting grounds and fishing waters in the south, and make existence difficult for them. It is therefore not to be wondered at that in these districts they are rapidly and surely going to ruin.

On the land inside of us we saw a house and some mud huts, probably inhabited by Russians who stayed here to fish during the summer, but farther east were about five Samoyede tents. These tents and their inhabitants were now the special object of our longing.

During the afternoon some of us went ashore. The natives poured down to the river to meet us, but the bank is everywhere shelving here, and the boat grounded far out; it looked as if we could not possibly land without wading.

The people on the bank pointed to a place farther east, where one of their boats was tied. It was a little deeper there, and by crawling over their boat we came ashore tolerably dry. As a rule they keep their boats anchored at some distance from the bank and wade out to them, often up to their middles, but they wear leather trousers, which are sewed to their foot-gear (like Lapp komagers) in such a way as to keep out the water.

Vostrotin landed first, as became the parliamentary representative of this part of the world; for these people were citizens of the country that sends him to the Duma. Therefore we used to call him the King of the Samoyedes.

The natives proved to be Samoyedes from the east 98 


\section{NOSONOVSKI PESOK AND THE SAMOYEDES}

bank of the Yenisei, and not Yuraks, as we had thought on first seeing them. For they were dressed like Yuraks, in dark, tunic-shaped coats with hoods and red borders; but no doubt they had got these through being married to Yurak women.

Otherwise, judging from their appearance, the Yuraks of the district to the west of the Yenisei and the Yenisei-Samoyedes seem to be nearly related tribes ; their languages differ somewhat, but belong to the same linguistic stock.

On landing, we were, of course, stared at and closely inspected from every side, but what specially aroused the curiosity of these hunters was our guns; they lifted them as cautiously as though they had been precious gems, looked at them fore and aft and fingered them all over.

They lived in five tents which stood on the level ground above the steep slope to the beach; they were all reindeer Samoyedes, but they kept their reindeer 70 versts inland on the tundra on the opposite side of the Yenisei, while they themselves spent the summer here fishing. They had at the most 200 reindeer apiece, and could not be called rich. That was why they had to take to fishing; whereas the rich Samoyedes, who may have 1000 or 2000 reindeer, never think of degrading themselves by such a life, which they look down upon; they live all the year round with their reindeer in the interior of the tundra.

The man who lived in the first tent we came to pointed with pride to his womenfolk, and told us he had two wives. One of them we saw sitting crosslegged inside the tent, sewing skins. By her side was a child of three or four with long, light-brown curls, making one involuntarily look at the mother and her husband, who were both as dark as pitch. But the 


\section{THROUGH SIBERIA}

mother was an ugly, lame little creature, and it was difficult to understand that she could tempt anybody, whether Samoyede or Russian.

The other wife had an infant in a basket cradle, which hung under the sloping side of the tent; she herself was so well hidden behind the flap of the door that it was difficult to get a glimpse of her.

It is not to be wondered at that the children may be of somewhat mixed descent among a people like this, where wives are bought, often at a high price, and are treated as their husband's property, which he can hire out or dispose of as he thinks fit. From what Middendorff says, it was not an unusual thing for Cossacks, placer-miners, and others to borrow the wives of the natives for the summer, or sometimes for the winter, making a suitable payment in return. And if a man has two wives and does not want them both, he often hires out one of them; the advantage of this proceeding is that, while as owner he receives a share of the catch, by common custom another share falls to her.

In old times it was one of the duties of hospitality among these nomads that a host should honour his guest by placing his wife or daughter at his disposal ; indeed, Middendorff says this custom still prevailed among the Samoyedes in his time.

To what extent the wife is regarded as a piece of property is shown by the following story, which Castrén tells in 1846: A Samoyede nomad was arrested and sent to Turukhansk for having killed his wife and, as was reported, eaten her (?). When the judge, in the course of his examination, asked him how he could do such a thing, he coolly replied: "I bought my wife and paid a fair price for her, and I suppose I can do what I like with my own property." 100 

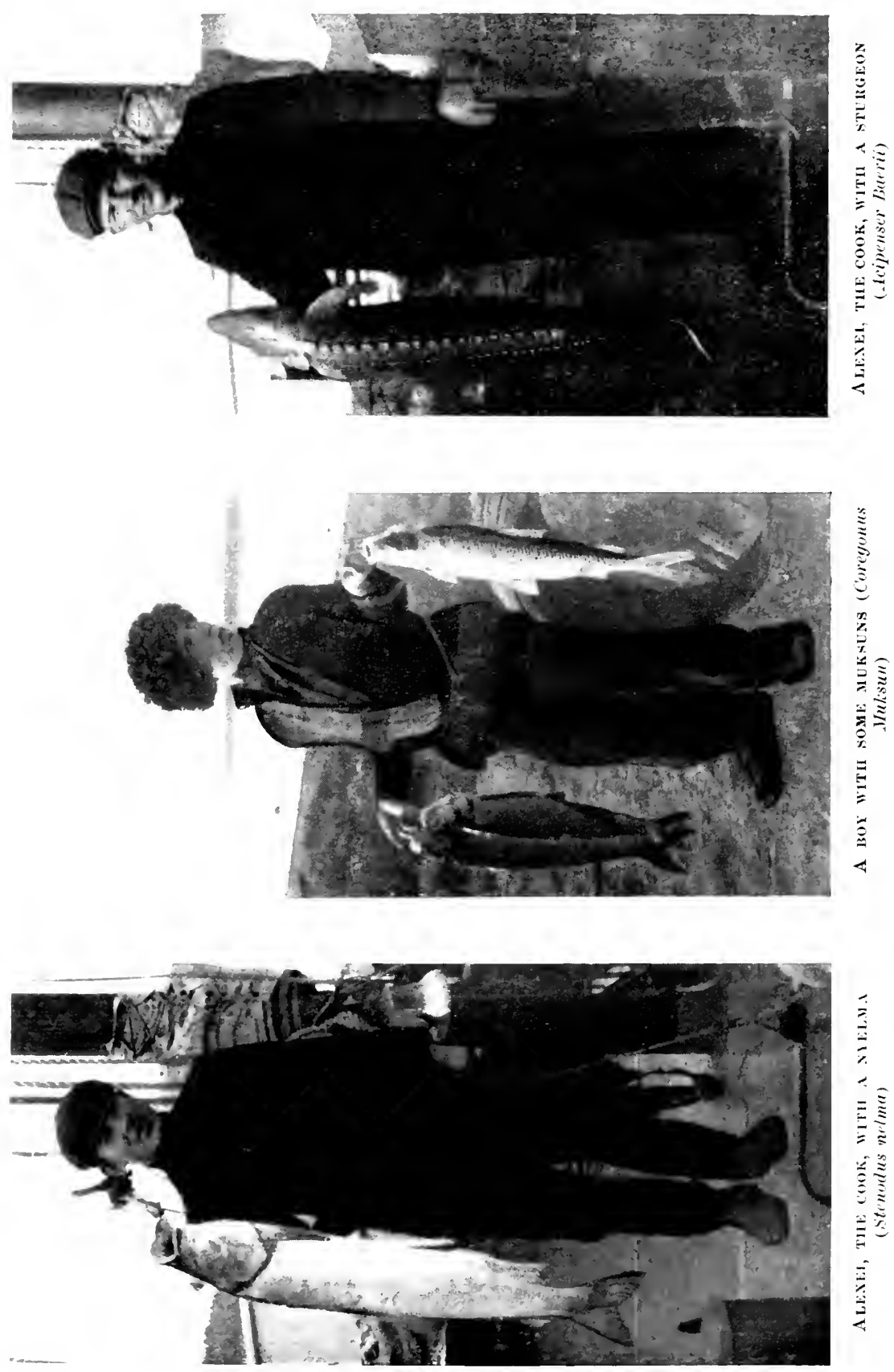


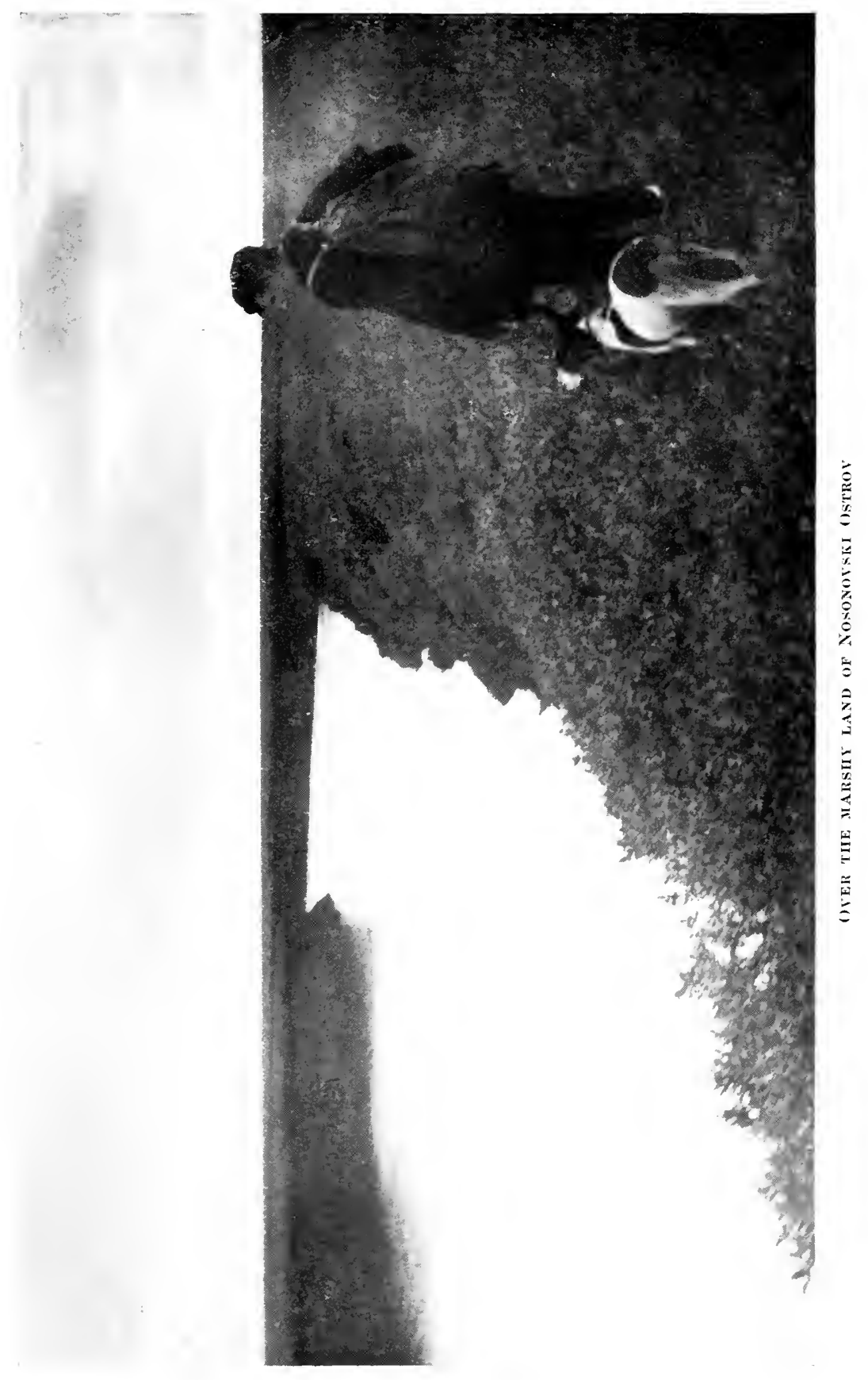




\section{NOSONOVSKI PESOK AND THE SAMOYEDES}

Woman is, of course, a lower creature, who exists to perform work for her husband, to give him pleasure, and to bear and look after his children. She is naturally altogether unclean, and must not on any account interfere in sacred or supernatural concerns. Thus in no circumstances may a woman cross the track of a caravan. Middendorff tells us that once, when making an observation, he set up his instrument on a sledge, to be able to read it more conveniently; but his Samoyede companion cried out in dismay: "A woman's sledge! You are offending your gods terribly." Middendorff was obliged to perform complicated ceremonies of expiation to reassure his Samoyede friend.

One soon notices, in mixing with these people, that a strict division of labour exists between men and women. The men have entire charge of the reindeer and of the driving with reindeer, and they also carry on fishing and hunting. But as soon as they come home to the tent, they do no work at all, except such things as mending their nets or other appliances. The women take charge of the catch, and do all the housekeeping, preparation of skins, sewing, and cooking. They set up the tent and keep it in order, take it down and move it when required, and then, of course, they have charge of the children.

Although woman thus occupies a subordinate position, one has the impression that she is in every way well treated; as a rule there can be no question of any oppression, and it is very rarely that she is spoken to harshly. She plays an important part in the household, and the husband consults his wife on all matters of consequence. Nor is there, I understand, any lack of wives who rule the roast, or henpecked husbands. When they are drunk it may somctimes happen that 


\section{THROUGH SIBERIA}

husband and wife come to blows, but otherwise the Samoyedes are peaceful people.

Their fecundity does not seem to be very great. Nowhere did I see many children. There might often be two or three, and sometimes more, in cases where there was more than one wife.

We also looked into the other tents. Outside one of them sat several women with their children. They ran into the tent and hid themselves as we came near. This display of bashfulness was a part of good manners, I suspect; for they had not the slightest objection to coming out again and being photographed, as soon as we asked them.

Under the tent-poles in some of the tents we saw little Russian ikons hanging, which they take about with them like other idols. They are supposed to be a sort of Christians, at any rate in name. How far down their faith goes is another matter; but they certainly keep up their old paganism side by side with it, as an alternative. It is always safest to have something else to fall back upon, in case the other should not work; and then there is the curious point about it, that the Christian God may be able to deal with men, but he does not know much about reindeer, as, of course, he cannot have picked that up in Europe ; for the reindeer they must have the old gods who are used to them.

Within the tundra they certainly have their sacrificial mounds here and there, with their rude idols made of blocks of wood, which they besmear with reindeer's blood as a sacrifice, and where they carry on their heathen ceremonies. They also undoubtedly have their shamáns or medicine-men, who conduct their relations with the supernatural powers and are able to conjure them in case of need.

102 


\section{NOSONOVSKI PESOK AND THE SAMOYEDES}

Several of the men were well-built and powerful; not so short as our Reindeer Lapps, but more like the Yamal Samoyedes in height, and rather like them in features. For the most part they were either beardless, or had a little thin hair on their upper lip ; only a few of them had any growth on their chins and cheeks. The women were for the most part noticeably shorter than the men, and usually had a more typically Asiatic look; they seemed to be of purer race.

Although it was one of the many holidays in Russia and Siberia and they were not working, only two or three of the women had put on any holiday finery; one was in a red cloak and another in a dark-blue one with a red border. The others had rather shabby leather dresses, sometimes torn; but then they are not well off, these fisher Samoyedes; they may best be compared with our Fishing Lapps.

They told us that their "prince," who lived in the most easterly of the tents, had gone down to the trader's on the beach to the west, and we should have to go there if we wanted to see him.

Every little tribe or "family" of Samoyedes is governed by a prince or chief, who is their leader and judge, and who has to collect the tax (yasak) for the Russian Government and pay it in.

While we stood there one of the women began to take off the covering of her tent, which was mostly ragged canvas, and then took down the poles. This was in order to pitch the tent again close by. That is how they do their spring cleaning; when the floor of the tent gets too dirty with all the things they throw away, they simply move on. An abandoned tent site is regarded as unclean, and they never pitch their tent 


\section{THROUGH SIBERIA}

there again. This accounts for the number of old tent-rings that are seen.

Then we went across to the trader's, and we were told there was a convent there, too. While still at a distance we heard loud yells, and saw two men lying on the shore. They were his highness the "prince" and his friend. They lay there dead drunk; that is to say, the "prince" was now half-sitting and roaring like a bull something that was meant to be a song, while the other lay with his face buried in the sand groaning like an animal.

When he saw us coming, the "prince" got on all fours, and then cautiously hoisted himself on to his feet, just like a child learning to walk; then he staggered towards us, with loud cries that he would have vodka, while between his shouts he repeated incessantly in Russian: "Tell me what's right, tell me what's wrong, what's right, what's wrong." Quite maudlin. It was difficult to get away from this drunken man, but soon his highness was sprawling on the beach again, and we went on.

What an extraordinary thing it is with these primitive peoples, worthy and honourable as they are, with such power of self-control that they hardly ever get excited or fly into a passion, that they are quite unable to resist spirits; and unfortunately there are people only too ready to take advantage of this weakness. But honest they are. I am reminded of what Middendorff tells us of his journey northward across the Taimyr tundra, that in spite of the perfectly bestial and unbridled desire the Samoyedes showed for his keg of spirits, he was able to leave that same keg and some bottles of spirits on the tundra without any protection or concealment, and they were never touched by the Samoyedes. He found a stranded 104 
boat, which might have lain a hundred years on the tundra; but not one iron nail was missing from it, for it was the property of the White Tsar-and at that time iron nails were worth more to the northern Samoyede than the purest gold.

How different people are! To men of our race it may be easier not to give way entirely to liquor, but perhaps it would be more difficult to leave it alone if they found it on the tundra and had a fancy for it, or still more difficult to deny themselves the iron nails, if they wanted them. But with contact with European civilization and its liquor, and too close an acquaintance with the extortions of traders and officials, honesty and morality decline even in a people like the Samoyedes.

We came now to two or three mud huts. They were inhabited by Russians, who fished here in summer and also bought fish from the natives.

Farthest west was a low timber house, which was the "convent" we had heard about. In it lived five or six monks, or rather novices, who were preparing to become monks. Together with them lived two nuns. They stayed here during the summer to fish for the monastery they came from.

They received us well and seemed to be decent, mannerly people. One of them had a long fair beard and resembled what I should call a good type of a Norwegian peasant, like so many men one finds in this part of Siberia. Another, who appeared to be their leading man, had long hair over his shoulders and a long beard, quite a Christ type, devout blue eyes, a very regular nose, and a well-shaped gentle mouth. To resemble the current representation of Christ in appearance and expression is the ideal sought after by all priests and monks in Russia and Siberia; therefore 


\section{THROUGH SIBERIA}

they wear their hair long, curly, if possible, and adopt the usual division of the beard into two. This man, whose age might have been about twenty-five, had succeeded so well in this respect that he will surely turn out a very useful monk.

Then there was a fat youth of extraordinary appearance, who looked exactly like a cherub, with long yellow locks, fair eyebrows, light sea-blue eyes, chubby round cheeks, and a little red mouth. The expression of his face was no more intelligent than that of an ordinary angel, and he looked equally indeterminable as to sex. He was dressed in a light linen blouse, with a belt round his waist, which also made him not unlike an angel, only he wanted wings. He did not often open his mouth, and when he did he spoke in jerks; but he stared most of the time and gave one rather the impression that he was imbecile, or at any rate so simple that he will certainly find no difficulties at the Gate of Heaven.

The elder nun was small and humpbacked, with a kind and clever face, and wore spectacles. The younger one looked like a cheerful Norwegian peasant girl, but she, too, had passed her first youth.

There was only one room in the "convent," where they all lived together. They slept on plank beds by one of the longer walls, and the nuns lay at the far end, separated from the others by a curtain.

They seemed to know all about fishing and how to treat the fish. Most of it was cleaned, washed, and salted in barrels; but a small quantity was dried, and their house was full of fish hanging from the roof to dry ; these would be tit-bits for the monks at home; with a drop of good spirits these fat dried fish are not bad and do very well for sakuska (hors-d'œuvre) in a convent. We bought some dried omul of them; it 106 


\section{NOSONOVSKI PESOK AND THE SAMOYEDES}

was all transparent fat, so that the grease ran out of it, and it tasted like something between dried halibut and smoked salmon. We also bought some fresh red caviar, which was a great success on the breakfasttable on board. This red caviar is chiefly the roe of the omul, but also of other fish of the salmon family that are caught here, and a good deal of it is salted.

\section{THE YENISEI FISHERIES}

A great and valuable fishery is carried on every summer in the lower part of the Yenisei, as in the other great Siberian rivers; and it has grown rapidly in recent years, since more regular steamboat communication has been established up and down the river. The fish most sought for are the valuable sturgeon (Acipenser Baeri, Brandt), and a number of species of the salmon family, mostly of the gwiniad kind, such as the great white salmon, nyelma (Stenodus nelma, Pall.), and the omul (Coregonus autumnalis, Pall.), the muksun (Coregonus muksun, Pall.), the little seldthe same word as the Norwegian sild (herring)-(Coregonus merki, Günt.), the chir (Coregonus nasus, Pall.), the sig (Coregonus pidschian, Gmel.), and others.

The sturgeon and the more important of the other fish, such as the nyelma, omul, muksun, and seld, make long migrations from the Arctic Ocean up and down the river every summer and autumn to spawn. Many sturgeon stay in the deep pools of the Yenisei at any rate for part of the winter, but they, too, migrate. A good deal of fish stays in the estuary of the Yenisei and in Yenisei Bay throughout the winter; at Svyerevo and Golchikha, on the estuary, in latitude $71^{\circ} 43^{\prime} \mathrm{N}$., and at Pustoy, higher up, in $71^{\circ} 11^{\prime}$ N., sturgeon, omul, and muksun are caught under the ice in winter. 


\section{THROUGH SIBERIA}

But there cannot be room for all the quantity of fish in this bay, and a great number of them must certainly migrate in the autumn farther out into the Arctic Ocean and spread along its coasts, which one is in the habit of regarding as somewhat empty of fish. The fishermen of Yenisei Bay distinguish, for instance, between the omul which keeps to the bay through the winter, and that which begins to come in from the sea about July 23. The sea omul is much fatter, and is lighter in colour and more silvery.

Many of the Yenisei fish attain a considerable size; sturgeon, for instance, may weigh as much as 200 to 220 lbs., but as a rule they are a good deal less; most of those I saw on the trip were scarcely above 50 or 60 lbs. The longest nyelma I saw was 3 feet $6 \frac{1}{2}$ inches in length.

Other kinds of fish, such as the elops, a small kind of sturgeon (Acipenser ruthenus, Lin.), the chir, and others seem to keep to the river all the year round, since, as a rule, they are not caught near its mouth.

Sturgeon and nyelma begin to go up the Yenisei as soon as the ice opens in the spring, at the end of May or beginning of June. Soon after the muksun and seld follow - they are expected to pass Golchikha about June 25 or 26 -and after them comes the omul about July 23; at the time we were at the Nosonovski Islands omul was the fish that was most caught. As the water of the Yenisei carries a quantity of plankton of different kinds in summer, the fish find food during their migration up the river, and thus they keep fat until, after spawning, they go out again.

During the voyage up the Yenisei I measured a number of fish of the various kinds, and collected their scales. It will be remembered that the scales 108 


\section{NOSONOVSKI PESOK AND THE SAMOYEDES}

grow every year, and the yearly rings thus shown are broad or narrow, according as the fish has grown much or little; it is therefore possible, by examining the scales, to determine the age of the fish and obtain information of its growth and conditions of life in the different years.

The scales I collected show that the fish of the Yenisei grow comparatively slowly, but reach a great age. This seems to confirm the general conclusion arrived at by Dr. Knut Dahl, * that freshwater fish living in northern Arctic conditions grow more slowly, but, on the other hand, live much longer than those whose habitat is farther south. A nyelma, 3 feet $6 \frac{1}{2}$ inches long, was eighteen winters old, while another, $20 \frac{3}{4}$ inches long, was nine winters old. $\dagger$ Muksun, $21 \frac{1}{2}$ inches, was sixteen winters old, and shorter ones were younger in proportion. Omul, 15 inches long, was ten winters old. The sig, which does not go out to sea,

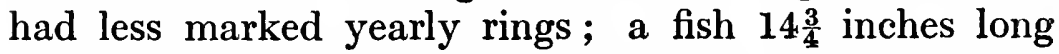
seemed to be about seventeen winters. The seld was younger; when $9 \frac{3}{4}$ inches it was six winters old, and the smaller ones were younger in proportion.

That fish grow slowly in a river is to be expected, as the running water cannot very well carry much food, although the turbid Yenisei is relatively favourable in this respect. All the fish there are very fat in spite of their slow growth. The great age of the fish seems to show that the fishing is not excessive in proportion to the quantity of fish that annually goes up the river, as otherwise the average age would soon be reduced;

* Dr. Knut Dahl has shown me the great kindness of photographing the scales for me; it may be hoped that he will also describe them elsewhere.

† According to V. Isachenko, its roe is not developed until it has reached a length of $19 \frac{1}{2}$ in. It may then be expected to be about seven years old. 


\section{THROUGH SIBERIA}

there may, in fact, be a possibility of still further developing the fishery.

Fishing is carried on for the most part with the seine, which is east out from the shelving sandy banks and drawn towards the shore, but the water is often so shallow that the fishermen have to wade out to get their nets in and bring the fish to land. At the best season great quantities of fish may be taken in a single cast. A great number of seines are in use : in 1907, in the lower Yenisei, there were 200 seines belonging to Russians and 550 belonging to the natives; in 1908, only on the Brekovskie Islands and lower down the Yenisei, there were about 150 Russian seines, while those of the natives did not exceed 250. The reduction in the number of native fishermen in that year was due to a great extent to a severe epidemic of smallpox. If we reckon five men to each net, there were about 2000 men fishing on the lowest part of the Yenisei in 1908. As to the numbers in later years, I have no information.

The catch for each net varies greatly, but on an average for the year it is put at about 250 poods (4 tons); what would be considered a good catch is about 400 poods ( $6 \frac{1}{2}$ tons) of fish to each net in a summer. The total quantity of fish caught has increased greatly of recent years. In 1846-1850 it was put at 3152 poods annually; in the sixties the first steamers came, and the export rose to 14,000 poods annually; at the close of the eighties it had risen to 32,000 poods; in 1902-1906 it is given as 84,000 poods. Then better and more regular steamboat traffic was established on the Yenisei, and with this the produce of the fisheries went up still more; in 1907 the total quantity may be put at about 188,000 poods, or, in round figures, 3000 tons of 110 


\section{NOSONOVSKI PESOK AND THE SAMOYEDES}

fish. I have no information of the quantities in more recent years.

The fishing is carried on partly by Russian boats' crews, partly by native Yenisei-Samoyedes and Yuraks. The latter sell their catch to the Russian buyers. As a rule they do not receive money for them, but goods, which they often get on credit, so that they get into debt to the traders, and thus fall into a position of dependence. They have to take the goods at the price fixed by the traders themselves, which is apt to be fairly high, and they are also obliged to sell their fish at the price fixed by the traders. It is easy to understand that the advantage of this arrangement is not on the side of the natives; many of them live in continual debt to the traders all their lives, and when they die the debt passes on to their family and children. A sad state of things, which we know well enough in connection with the fishing population of Norway in former times. The following prices of goods in Yeniseisk and at the fisheries give one some idea of the position of affairs :

Price in Yeniseisk.

1 pood of rye meal

1 brick of compressed tea

75 kopecks

80 kopecks

1 pood of sugar 1 rouble 30 to 50 kopecks

Price at the fisheries. 1 rouble 50 kopecks

1 rouble 40 to 60 kopecks

2 roubles 20 to 50 kopecks

And on the other side the prices of fish are illuminating :

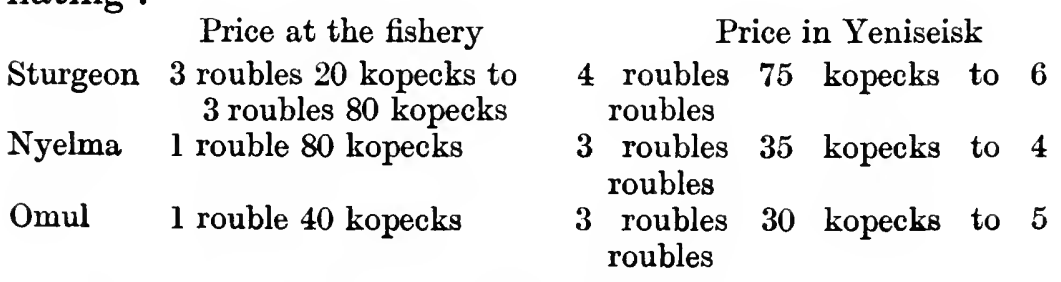

It appears from this that the traders on the Yenisei 


\section{THROUGH SIBERIA}

must make good profits when, for instance, in return for a pood of rye meal brought from Yeniseisk and bought for 75 kopecks, they can take back a pood of salted omul and sell it for between 3 roubles 30 kopecks and 5 roubles. Of course something has to be deducted for freight, barrels, \&c., but even then there is plenty left.*

* Most of the information about the fisheries is taken from Mr. V. Isachenko's official reports of his inquiries into the Yenisei fisheries, which contain much interesting matter. 


\section{CHAPTER VI}

\section{WAITING TO GO ON}

Unsuccessful sport in swamps : An unpleasant winter, and a spring flood : Disappointed traders : A frozen mammoth : How were the mammoths frozen? : Visit to Lebiashiy Ostrov : Strong mirage : Yenisei-Samoyedes and Yuraks : The Yurak chief and his two wives : The Yuraks' taxes : Dolgans and Tunguses : Sledge-dogs : The Omul arrives : Russian steamboats arrive

THE day after our arrival, Friday, August 29, I 1 took a longish walk over the flat, marshy island to look for ptarmigan and geese, and I had with me Christensen's pointer bitch, who was not much use. The Scotch cook's mate, Campbell, went with me to carry all the game I didn't get. The whole of this Nosónovski Island is nothing but a low, perfectly flat sand and mud bank, which does not rise many yards above the river. It is not easy to make one's way over these flat marshes, one sinks in up to the knees. Only along the shore and along an arm of the river which curved across the island, was there more or less dry going; for there the water could run away down the steep river bank.

Here and there inland were stretches with osier scrub, which might reach as high as one's chest. In some places there was also some alder. Between them were long flats with grass and swamp. One could manage in places to get on from tuft to tuft, but soon came to the soft bog, where one might sink in up to the 


\section{THROUGH SIBERIA}

armpits. It made one think of the souls on their way to heaven in the "Draumkvædi" :

"Heavy the way over Gangle bogs,

God keep him who has to tread it!"

I wonder if it can be heavier than this ? It is enough to wear a man out to walk here.

Nor was there much game to be seen; a few snipe here and there were too small to shoot, and then a lot of geese flew by and settled along a rushy brook with long pools. A few ptarmigan feathers lay about and the dog picked up a scent, which must have been ptarmigan; but she could not work it out.

A flock of geese lay cackling in a rushy pool. I tried to crawl and wade over the naked swamp, when the flock got up at long range and I only managed to shoot one goose, which fell into the pool ; but I could not get to it without swimming, and I didn't want to do that. There were geese of several kinds, big and small, out there among the reeds; but I had to give up that wildgoose chase and try where there were some osiers; even there the water was standing between the thickets.

How flat, how bare, how hopelessly impassable this country is, without cover, without a dry spot to be reached anywhere. But in the spring it is even worse ; then the greater part of these plains is under water. I could not help thinking of Nummelin and his men. It was here, on these very islands, that they spent the winter thirty-seven years ago (1876-1877). In their little ship, the Severnoe Sianie ("Northern Light"), they were stopped here by the ice and had to lay her up for the winter. While the captain and the rest of the crew returned to Yeniseisk, the mate, Nummelin, stayed on board with four criminal exiles. They lived in a wretched plank cabin on land during the winter. 114 


\section{WAITING TO GO ON}

It was cold, and they were badly equipped; three of the convicts died of scurvy during the winter, and the fourth was drowned in trying to cross the ice to Tolstoi Nos. Nummelin was now alone, but got two fresh men from Tolstoi Nos and from Golchíkha; and then, in the middle of May, three more men came from the south to help him. The first thing to be done was to dig the vessel out of the snow, which lay several yards deep on the river ice. When at last they had got her nearly free, she was buried again by a fresh blizzard.

But the worst came in the middle of June. The ice began to move and the river to rise. It rose higher and higher; there was a heavy flow of ice which carried all before it. The vessel was soon adrift, broke up and disappeared. The river rose to the hut, and the six men and two dogs had to take refuge on the roof, carrying with them some food and wood.

The whole country was now under water ; the other cabins and turf-huts in the neighbourhood were carried away by the water and ice, which also threatened the last one on which they sat. From their roof they could see nothing but endless wastes of eddying water and ice continually drifting past, with here and there the tops of some osier bushes that nodded in the stream as the floes scraped past them.

The river rose higher and higher; it had now risen 16 feet. They had to work day and night with poles to keep the floes off them. The roof was now only 10 inches above the water, and the whole hut trembled under the pressure of a heavy floe that had lodged round it and threatened to carry it away under them; then their last refuge would have been a little boat that they had made fast to the roof.

The great flood had come too suddenly even for the birds. For miles around there was not a single dry 


\section{THROUGH SIBERIA}

spot where they could rest, and tired-out ptarmigans settled among the men on the roof-one even sat on the head of a man, and some others settled on the dogs.

At last, after they had been a week on the roof, the water began to fall on June 23, and by the 25th it had sunk so much that they were able to move back into the hut. Soon the captain, Schwanenberg, arrived from the south; by chance they were able to buy another little vessel of 56 feet length, which had also been built on the Yenisei. She was given the hopeful name of Utrennaya Sarya, i.e., "The Dawn," and in that little craft they actually came safely through the Kara Sea and over to Norway.

What sufferings men can go through, to no purpose, and in such a country as this, too, which certainly would not tempt anybody-though who knows? perhaps Nummelin, if he is still alive, may sometimes think with melancholy longing of this watery land, of the river, of the shore in the spring sunshine, when patches were clear of snow and the birds came, and of the hut where they fought for their lives. We men are strange creatures: our longing often returns to places where we should least expect it, and where we have suffered the greatest hardships.

But this is not the place to fall into reveries. I must get on somehow across this watery island; surely to goodness it must be possible to find some sort of a bird at last; this wretched dog picks up their scent among the osiers everywhere. Poor Scotch boy! he comes striding behind through scrub and bog, wet as a crow.

At last a bird got up at long range, put up by the dog, which of course had got the scent. It was a young ptarmigan, upon my word! I fired, and it fell ; but, poor dog, she had had enough of it long ago, and could not be got to search among the tufts of long 116 


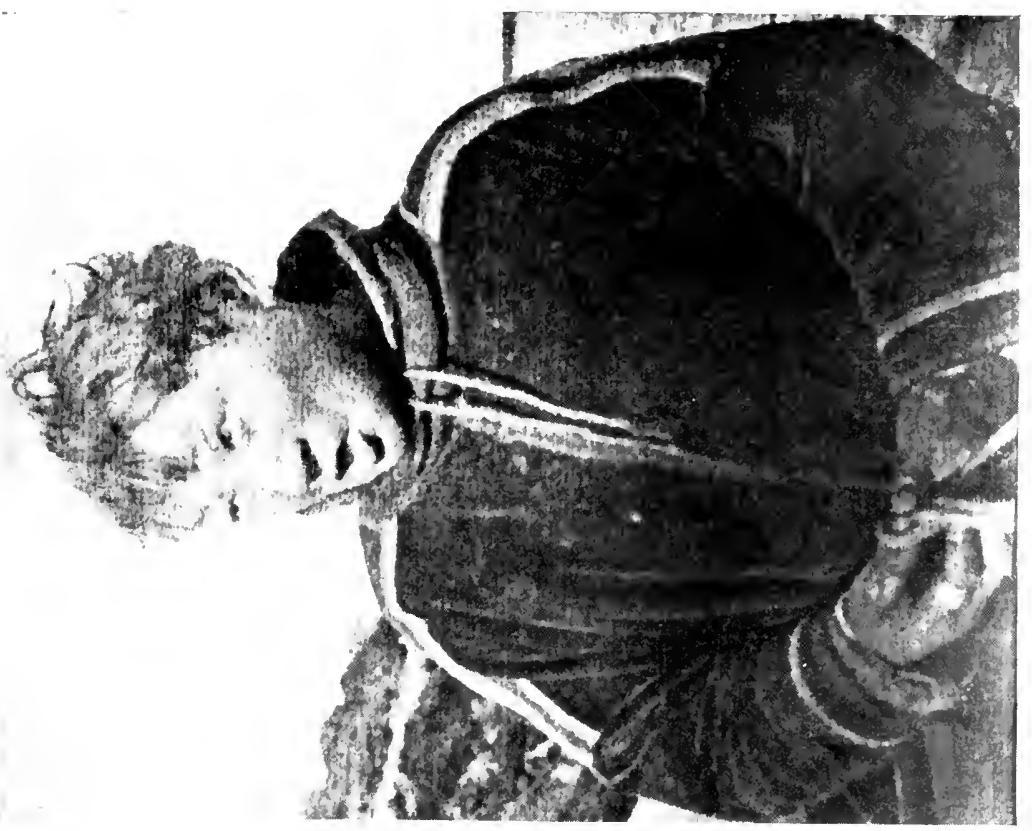

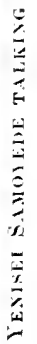

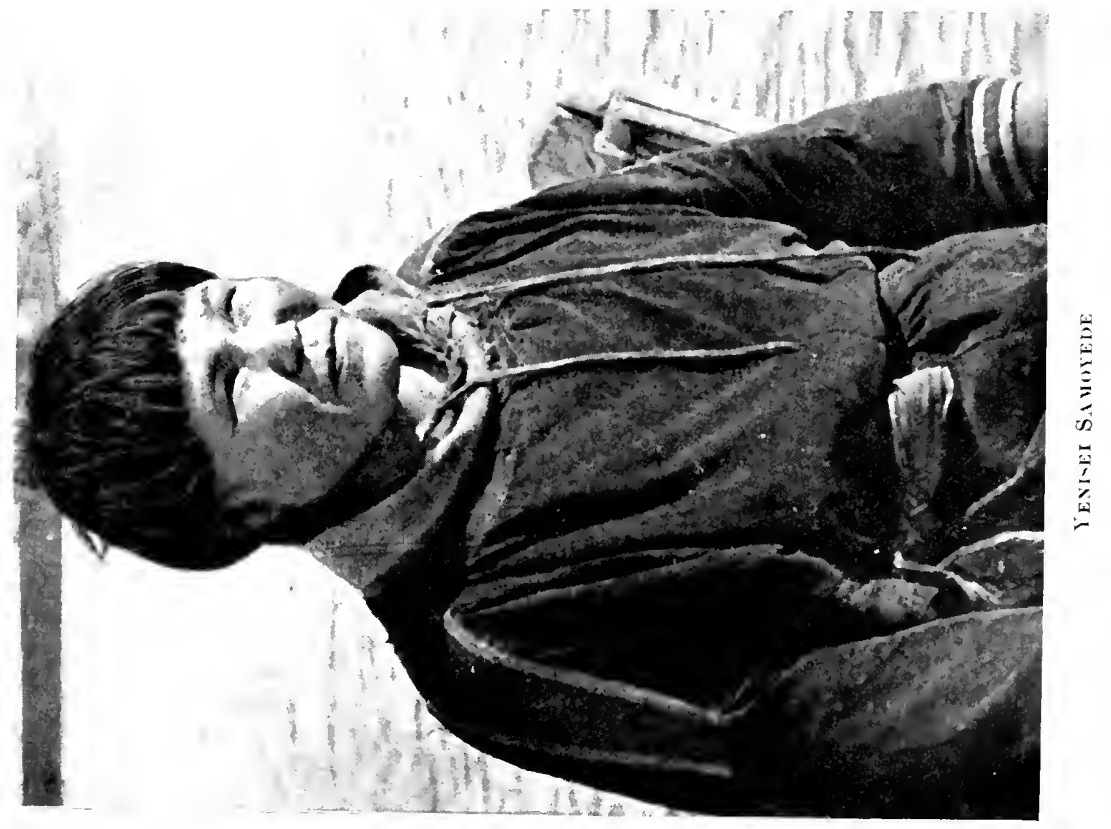




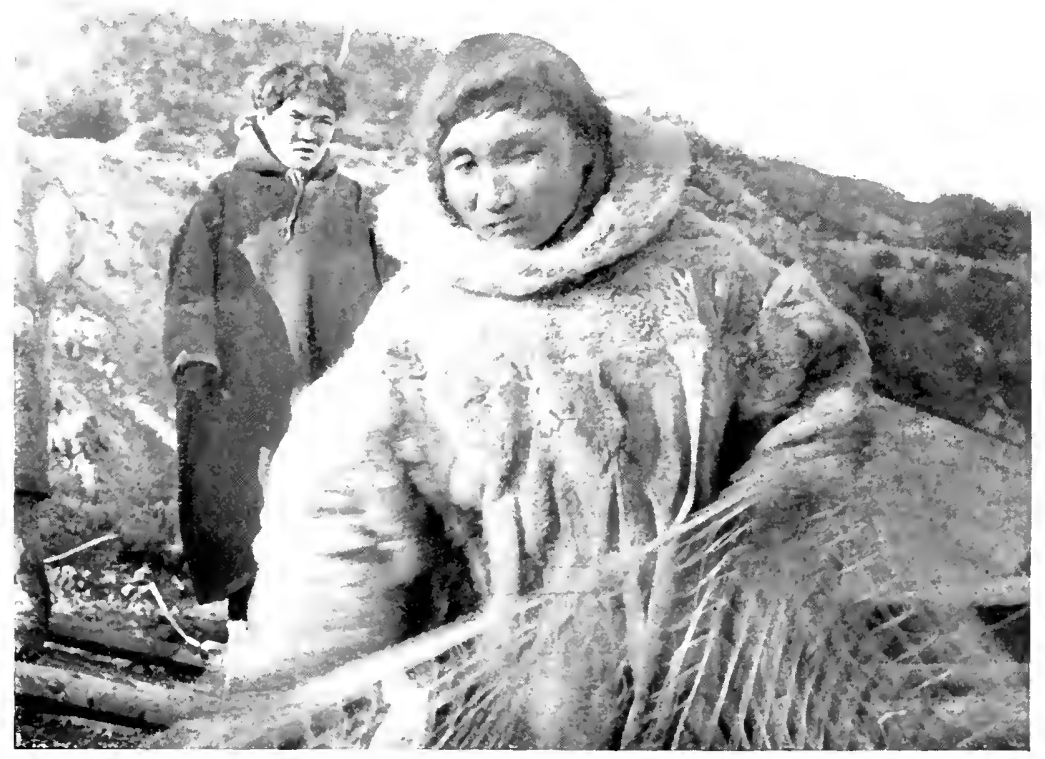

Ienak

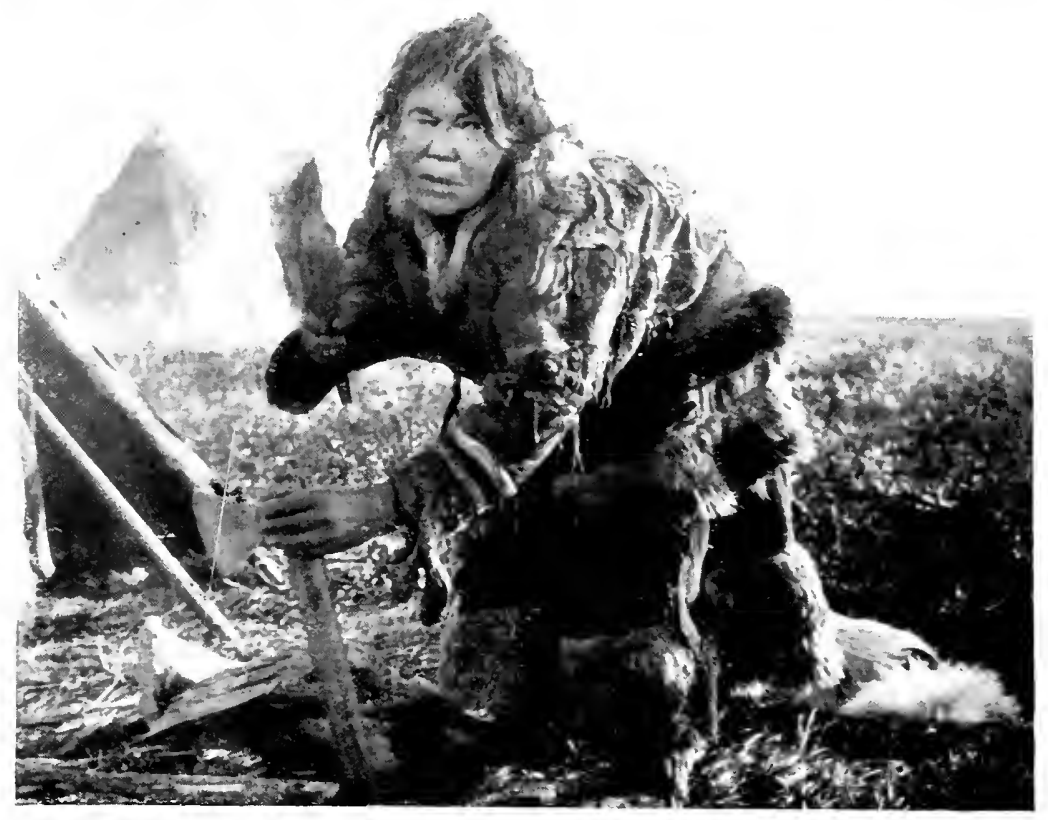

ULD WOMA, OF IIIE YeNisti SaMOLEDES 


\section{WAITING TO GO ON}

grass out there in the spongy bog. So I had to give up that bird too. We were pretty hungry, and we had some food with us, but there wasn't so much as a dry spot to sit down and eat upon, and it was not very tempting to stand still with our soaked legs in that nasty drizzle.

After tramping about all day we, too, had had enough, and more than enough, and made for home straight across the island. But here, for the first time, we came upon a broad lake; we went along it, thinking we should get round, but there was no end to it, and it took us farther and farther out of our way. So we had to go back and try the other way round. After that we came upon endless swamps, where we sank in everywhere, often to high up the thighs. It had been drizzling all day; now it started to pour. When at last we drew near to the "convent" on the shore from which we had come, drenched to the skin by bog below and rain above, a covey of fine big ptarmigan flew up. Their wings flashed so white through the cold grey rain. The dog set after them in full cry. They seemed to settle far away in a swamp, but were not to be found again; after having done her bark the pointer would only follow at my heel.

When we reached the shore, our boat was gone. It had returned to the ship, we found out afterwards. We then had to call at one of the tents, where by signs and extraordinary gestures we contrived to make some of the Samoyedes understand that they would have to row us aboard; which they did with great glee, as soon as they made out what we wanted.

We now had a strong wind for some days, which raised a good deal of sea in these broad channels, and it was no weather for going far in boats so heavy to pull as ours. We stayed on board most of the time, developing 


\section{THROUGH SIBERIA}

photographs during the day and playing cards in the evening; while Loris-Melikov and Lied hung over their chess-board from morning to night, except when Lied had to superintend the discharging and loading of cargo. Only Christensen and the keeper of the animals had to go ashore sometimes to cut grass for the camels. There was plenty of it to be had on the low green shore that ran out to the west of us.

There were several on board who had had the idea of carrying on a profitable bartering trade with the natives, with special hopes of acquiring valuable furs ; and they had left home provided with objects for barter. Our worthy Danish steward had spent 24 kroner on glass beads and necklaces and other finery, which he thought would prove irresistible to these people. But they were greatly disappointed. Whatever furs there may have been had been sold long ago to the Siberian traders. Nor must it be supposed that these natives are so childlike as to allow themselves to be taken in by a few glass beads. They know just as much about money and money's worth as any of us ; nor are their prices for skins so very much lower than those charged at home. Poor steward, he was inconsolable over the capital he had invested in such a bad speculation; for these things he had brought were now worth nothing, and he said he might just as well throw them into the sea.

One of the attractions Lied had offered us, in inviting us to come on this trip, was the hope of being able to treat us to a steak of mammoth beef at the mouth of the Yenisei ; as the year before a frozen mammoth had been found in the tundra near Golchíkha. For my part, though it might be quite amusing to eat a steak of such a strange animal, which moreover had lain frozen in the ground for so many thousand years, I did not feel greatly tempted; I could not help thinking of ptomaine poisoning 118 


\section{WAITING TO GO ON}

and other unpleasantness in connection with the big animal that had died a natural death.

To me, therefore, it was not an irreparable disappointment, when Lied came and told us that unfortunately he would not be able to keep his promise about the mammoth steak, as the dogs of Golchíkha had been digging up and eating that mammoth all the winter, and in the spring a Russian Government expedition had come and carried off what was left. It is one of the most extraordinary and puzzling things, though, that we meet with here in this country, so remarkable in many ways : this question of the large extinct animals, usually the mammoth, but sometimes also the woolly rhinoceros, that lie practically intact, with bones, flesh, skin and hair, inclosed in the eternally frozen soil.

How did they come there? How did they meet their death ? How can they have been frozen in such a short time that these gigantic bodies have been preserved? These are riddles that many of the cleverest men have tried to solve for nearly a century and a half, since the first well-preserved woolly rhinoceros was found in Siberia in 1771. But I have never seen an explanation that seemed to me entirely satisfactory.

It is clear that these huge bodies must have been frozen stiff in a comparatively short time after the animals died; they must probably have died in the winter, and in some way or other they must have been protected from the warmth of the sun in summer, so that they have not thawed again to any appreciable extent; for otherwise the soft parts, such as flesh and skin, would soon have decomposed and could not have been preserved to our day; preserved, too, so well that dogs at any rate can eat them. Baron Toll told me that during an expedition to the Lyakhov Islands, near New Siberia, his dogs dug out of the sand-slopes some 


\section{THROUGH SIBERIA}

bones of frozen extinct animals, and ate the marrow in them.

Formerly, it was an easier matter to explain such things. Then one only had to make a deluge or some other convulsion of nature put an end to the animals, after which a glacial period suddenly came on to freeze and preserve them. In our day we do not treat nature so casually. We think that, even at a great distance of time, her behaviour was not very different from what it is now. In the main the same processes have always made themselves felt.

If we had glaciers to help us, which these clumsy animals might have walked over, falling into crevasses and being frozen and inclosed, then it would be easy to understand, supposing these glaciers had persisted to our time. But that will not do. Even if the glaciers were there at that time, which $I$ do not believe, it is unlikely that animals should be preserved in so many different places by such pure accidents. In the next place, of course, they generally lie frozen within the Siberian soil itself, in strata of sand or clay, and not in ice, as Baron Toll has clearly proved.

We might, then, be more inclined to suppose that the animals were drowned in going over thin ice on the rivers in winter, and were frozen into the ice; or that they died on the river-bank in winter, and in the following spring were carried by the flood and drift-ice northward to colder regions, as Middendorff thought; and that by the flooding of the river they were carried into the tundra, and covered by the flood-water with a layer of sand and mud, which protected them from thawing. But even this explanation does not meet the case.

Some (like Schrenck and Nehring) have tried to explain it by supposing that these big animals perished in snow-storms on the Siberian tundra in winter, and 120 


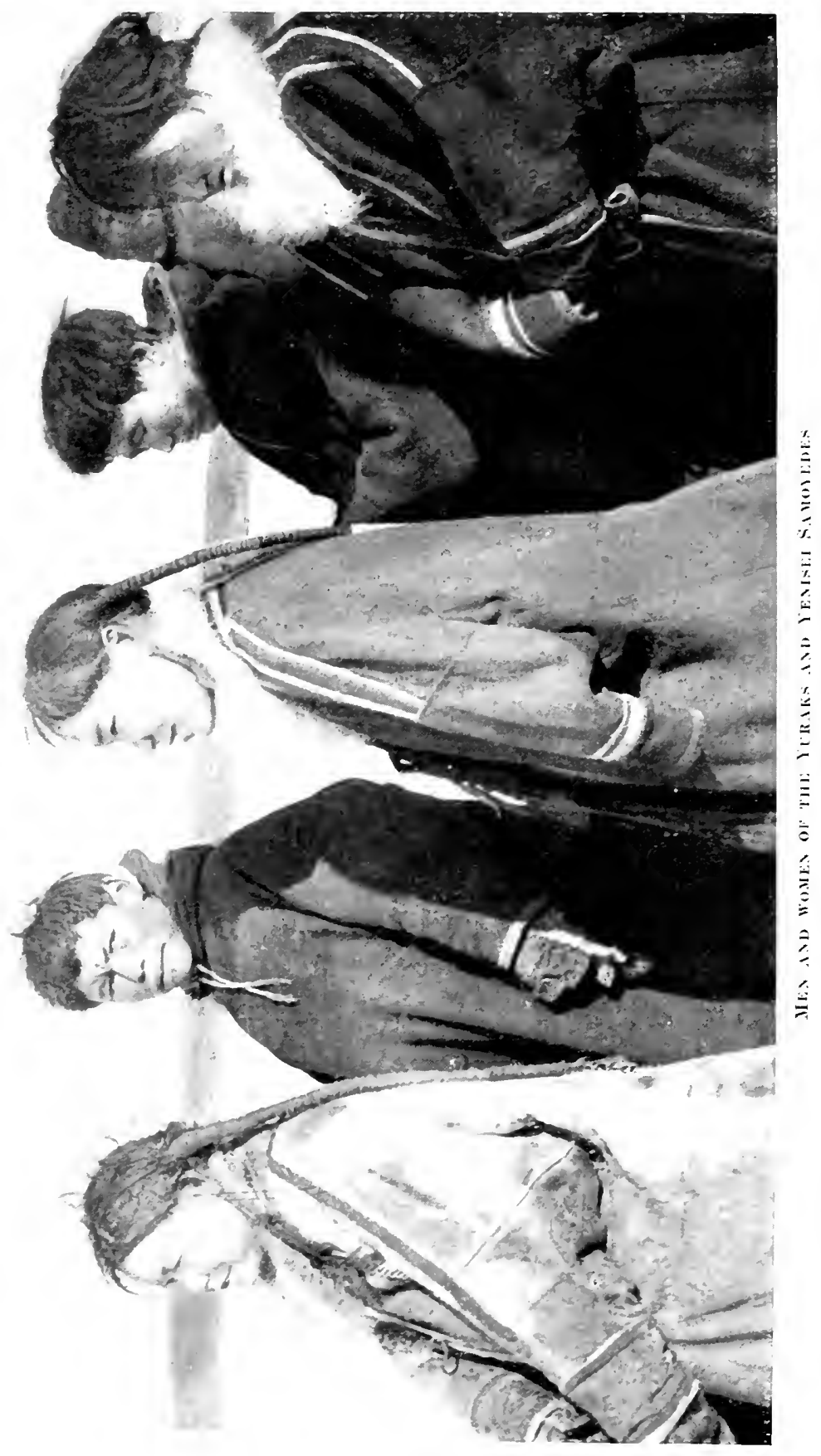




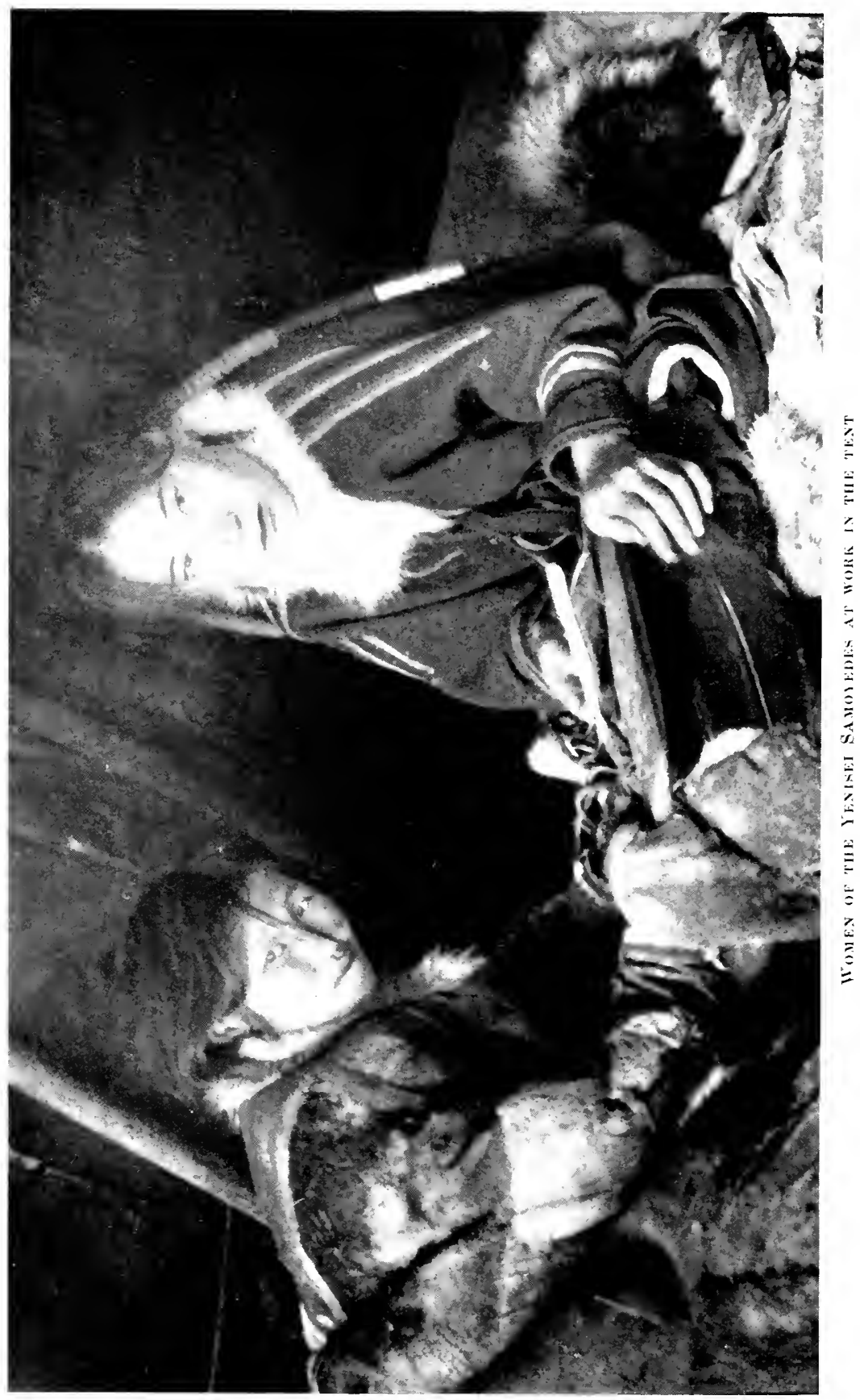




\section{WAITING TO GO ON}

were buried and frozen in the snow. But to avoid the difficulty that snow melts again in spring and summer, they were obliged to assume that these layers of snow were transformed into glaciers, which have lasted till our time, and have been gradually covered with layers of earth and sand and clay. In addition to the improbability of such a hypothesis, there is the difficulty mentioned above, that the mammoths are not as a rule found in ice.

Others (Brandt, for instance) have assumed that the big, clumsy animals may have stuck fast in the bogs and met their deaths in this way, as may happen to the elk in Norway. But if the bog was soft to a depth great enough for the animal to sink into it, how can it then have been permanently frozen? As we see, there are difficulties enough.

I should, therefore, be more inclined to think it happened in this way: that the animals died a perfectly natural death, near a great river, in autumn or winter. The ground below them was thawed by their bodily warmth and heavy weight, and the animal sank in a little way, until the whole of it froze and it was left frozen fast in the ground. In the freshets of next summer it was flooded over, but the cold water was not able to thaw it in the short time, and it was then covered with layers of mud and sand which the flood-water brought with it. In this way it was protected from thawing again. Next winter the new layers froze, and the next flood brought a fresh deposit on the top. This, as far as I can see, is most in accordance with what my vanished friend, Baron Toll, supposed.

Tuesday, September 2. Fine weather at last, and in a Samoyede boat, rowed by Samoyedes, several of us went to the westward, to visit the natives on Lebiashiy 


\section{THROUGH SIBERIA}

Ostrov. It is extraordinary how shallow it is the whole way, with low islands; you cannot approach within several hundred yards of the shore. Then we crossed the first channel, west of Nosónovski Ostrov. It cut its way through to the northward like an arm of the sea, with low islands on both sides. We could see no land on the north, so the channel might have run right out to sea for that matter.

There was mirage everywhere, both on the north and south ; as soon as the low coast recedes a little, it seems to be raised into the air and to have bright water under it. It is so every day here. I have never seen it so general and regular before; it must be due to the river water, which comes from the south, being a good deal warmer than the air; a thin layer of air is then warmed over the surface of the water, and at the boundary of this layer there is a total reflection of the almost horizontal rays of light which come from the slightly higher land far away, and from the sky above it; there is thus formed a reflection of the sky and land, below the real land, which latter we see by the direct rays that go straight to our eyes through the colder layers of air above. At the same time the water surface at the horizon is lowered by refraction. It is thus the same phenomenon as the Fata Morgana in the desert, which causes the thirsty traveller to rejoice at delusive images of objects far away mirrored in bright water. This form of looming is therefore not due to refraction raising the land into the air, as people seem often to think.

The southern point of the narrow island west of the channel was relatively high, and on it lived the trader. There were other mud-huts, besides two or three tents and one or two timber houses.

This island was divided by a narrow strait from the 122 


\section{WAITING TO GO ON}

larger island to the west; on it stood four tents with some Samoyedes from the west side of the Yenisei, but mostly Yuraks. There was also a mud-hut belonging to a Russian, who bought fish from the natives.

As we landed on this island, a boat's crew were engaged in taking their seine on board to go out fishing. There were two brothers who were Yuraks; they had quite a Semitic look. The rest of the crew were Samoyedes. The two brothers owned 72 reindeer together, and these were over on the tundra to the east of the Yenisei, while they stayed here fishing. One of the Samoyedes, who looked a good deal poorer, judging by his clothes, had only 10 reindeer. On my saying that surely that was not enough to live on, he merely replied that indeed it was not.

We then went to see both the Samoyedes and the Yuraks who were in the tents; there did not seem to be any very great difference between them.

We also called on the chief of the Yuraks and his two wives. He was an elderly man of powerful appearance. His type of face was not unlike a Reindeer Lapp's; but the curious thin moustaches which hung down from the corners of his mouth, without any hair in the middle of his upper lip, gave him a certain Chinese look. The elder wife was old, faded and blear-eyed, with a face like a dried apple. She, too, had some resemblance to the Reindeer Lapps. He said himself, pointing at her, that she was no longer of any use, and therefore he had taken a younger wife. She was young enough to be his daughter. She had quite a pleasant appearance, and seemed well-satisfied and proud of her dignity as princess; though one might imagine a more enviable position than that of being the old man's wife. But women are often like that.

$\mathrm{He}$ told us that he was under the jurisdiction of 


\section{THROUGH SIBERIA}

Obdorsk, and formerly had to go there every winter to pay the tax which, as chief or stárost, it was his duty to collect from the tax-payers among his people; but now he was allowed to pay it at Dudinka.

His name was Yabtung Alyo, and his tribe (ordá) was called after him; it was thus the Ordá Yabtung. Every grown-up Yurak has to pay a tax of $10 \frac{1}{2}$ roubles, whether he is poor or rich, and, one might almost say, whether he is alive or dead. At certain intervals a census is held, and it is then decided who is to pay taxes. After that these assessed people have to pay every year till the next census, no matter whether they die in the meantime.

In this tribe there were 32 souls who had to pay taxes. In 1902, 19 of them paid 250 roubles; the rest refused to pay. In 1910 , only 88 roubles came in. It is not so easy to do anything with those who refuse to pay, on these great expanses, where it would be difficult enough to find them, even if one had the men and the time to search for them.

The prince complained greatly of the high tax, for which they get nothing in return. And what could they get, these nomads, which would be of any value to them ? They get no education, no schools, no priests, no doctors, no roads, no communication of any kind; unless we reckon the steamers that go up and down the Yenisei, bringing them traders who make money out of them, and do their best to impoverish them by buying their furs and giving them new wants, which they formerly got on very well without. To say nothing of the traders having brought them spirits.

The most they can see that the Government has done for them, besides levying taxes, is to take some of the fishing rights from them, which used to be theirs entirely. Russians have to some extent acquired the 124 


\section{WAITING TO GO ON}

right of fishing in the same places ; in fact, the natives' fishing rights over certain reaches have been sold by auction to Russians, who have then come and fished there in the belief that they had acquired the sole right, but soon found that in any case they had to share it with the natives; and the latter have also been allowed to keep some of their old fishing places for themselves.

I dare say there are some who will consider it an advantage received from the State that these natives can sometimes have their children baptized; but I hardly think there can be much in that, and the ministrations of the priest seldom extend so far as the marriage ceremony, which they are more inclined to manage for themselves, it appears.

Prince Yabtung Alyo thought it specially unjust that he and his people should pay so high a tax as $10 \frac{1}{2}$ roubles for every man, while the Yenisei-Samoyedes on the east of the Yenisei only have to pay $3 \frac{1}{2}$ roubles for every working man. It cannot be denied that this seems rather unjust; but the reason is, no doubt, that the Yenisei-Samoyedes are considered to be poorer than the Yuraks-though there were no signs of exaggerated prosperity among these Yuraks either.

They have been made to feel the first accompaniments of civilization, these natives, in the shape of taxes and duties; farther than that the State has not gone at present. Perhaps the advantages will come some day; but by then these people at any rate will have been a good while under the grass.

Our friend the prince also produced from a chest the documents and letters he had received from the Government, setting forth his duties and rights-mostly duties. He showed them to Vostrotin and Loris-Melikov, and got them to look at them and explain what was in them, as of course he did not understand a word. Then there 


\section{THROUGH SIBERIA}

was a fresh discussion of the position, and our prince again energetically maintained the great unfairness of so heavy a tax being imposed on him and his people, who had such great difficulty in meeting it.

One might suppose that the natives thought it a fine thing to be a chief or stárost, but we had the impression that it was rather a bother to them, which they would have gladly declined if they dared. In any case it seemed that our friend here would have preferred to resign the honour. It is true that a chief or stárost has to be chosen by his tribe, but as far as I could make out the election takes place in this way: a Russian policeman comes to the tribe, finds out the man who speaks the best Russian, and then tells the others that he is the one they are to elect; and so it is done. The stárost gets no pay for his work, but a great deal of trouble in collecting the tax, and besides that the long journey, now to Dudinka, but formerly all the way to Obdorsk. It used to take him two months there and two months back, simply for one hour's stay, he told us.

Here, at any rate, these natives had no shamáns, and it was not easy to make out whether they had them elsewhere. They would not say where they kept their idols, but only laughed when we asked about them. Christians they are no doubt in a way, and they carry with them their little ikons, which hang on the tentpole like other household gods. And they are baptized too, many of them in any case, at Dudinka or Obdorsk, when opportunity occurs.

The island was perfectly flat inland, with clumps of osiers, grass, and moss, and small pools here and there. It seemed, however, to be rather drier than Nosónovski Ostrov, where I had landed a few days before.

At the trading-station on the other side there were 126 


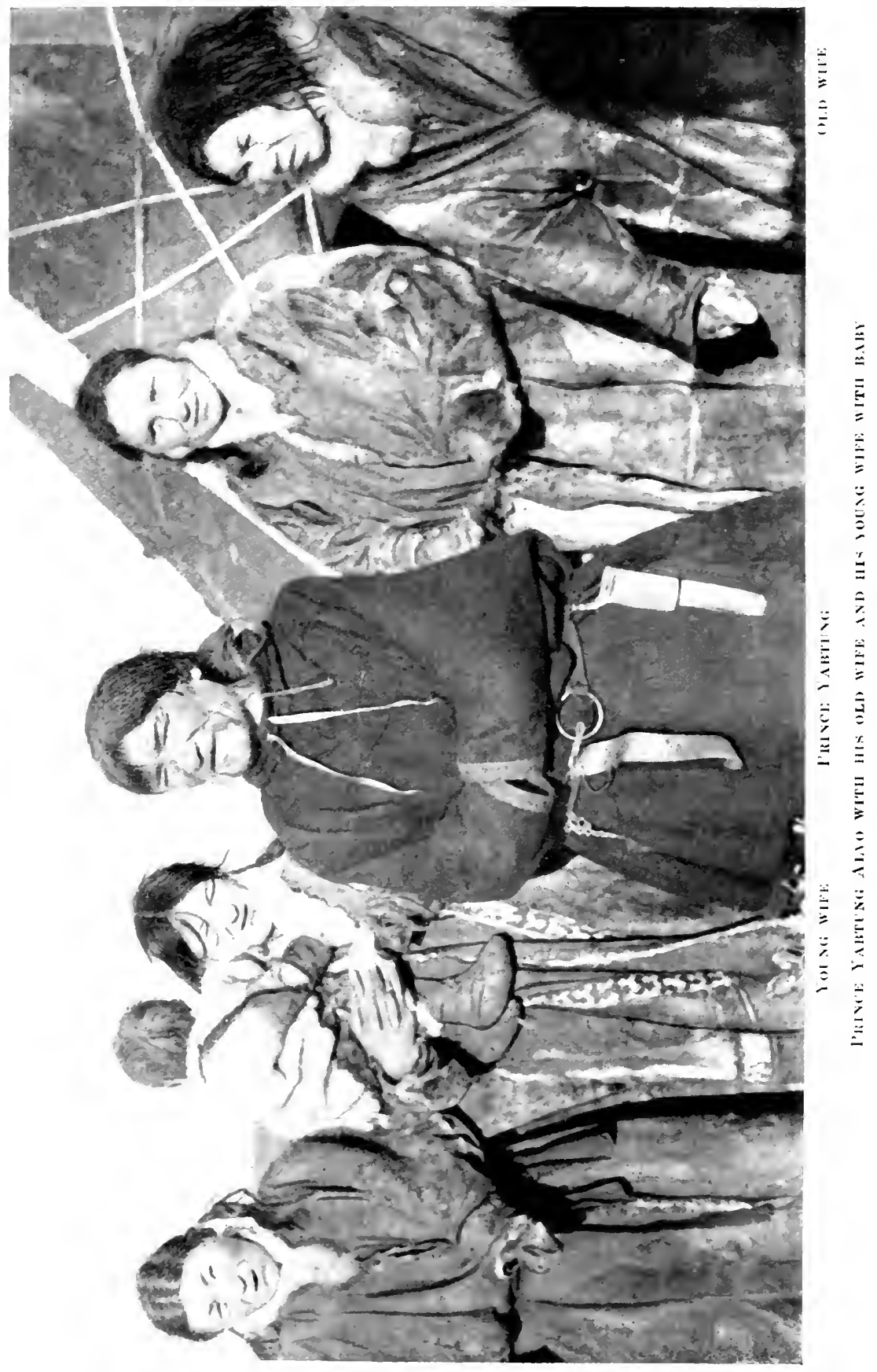




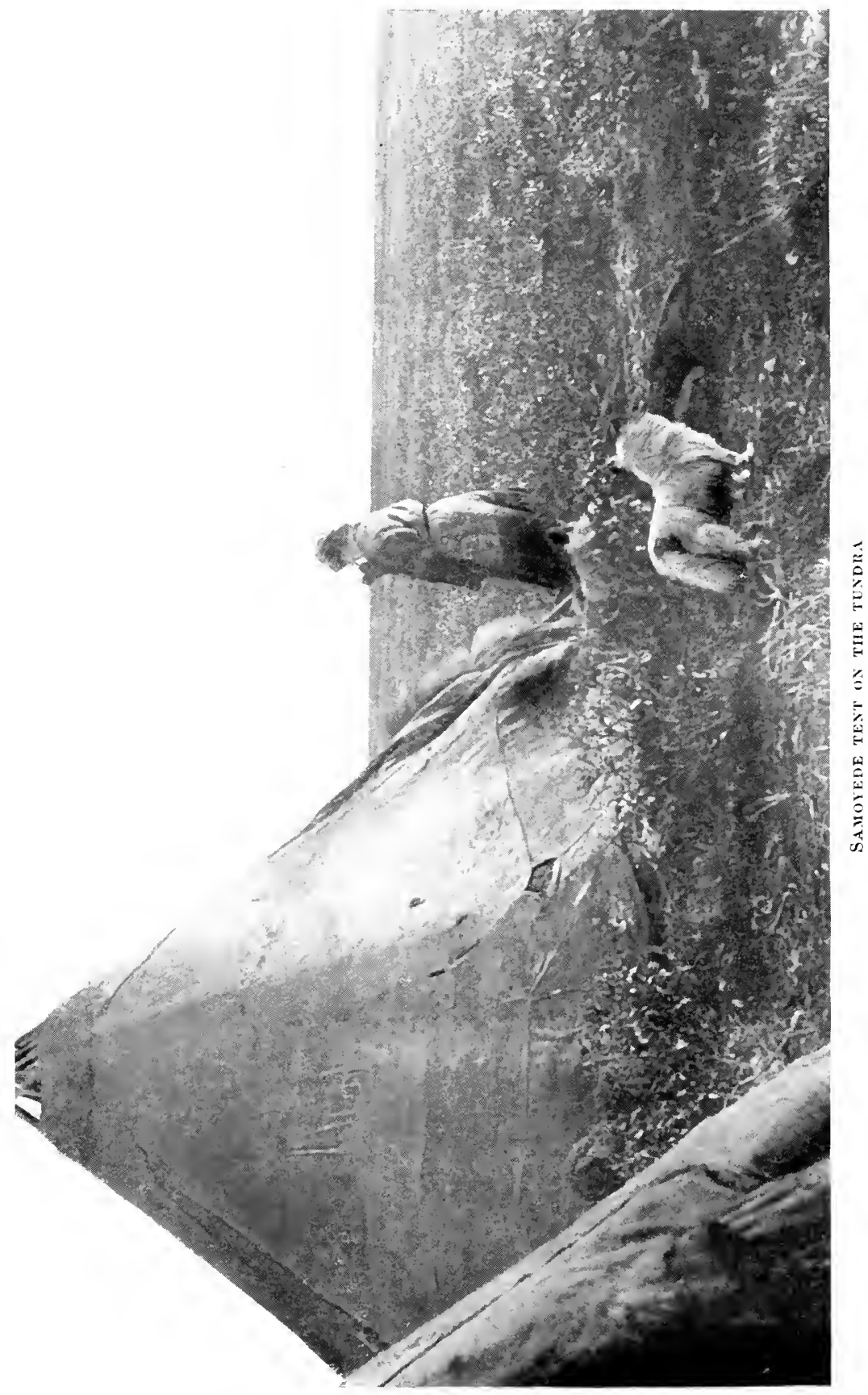




\section{WAITING TO GO ON}

several Russians, both men and women, and it must have been a busy place, judging from all the barrels on the shore.

There were also some Dolgans living there in two or three mud-huts. They are the aristocracy of the tundra, Vostrotin said. They are fonder of finery than the Samoyedes or Yuraks, and like to wear brightly embroidered clothes. We could see that by a healthy and well-grown girl, who laughed incessantly from inward merriment. Her best coat was covered with the most gorgeous embroidery.

The Dolgans seem to be nearly related to the Yakuts. They are reindeer nomads who live on the tundra, and are thought to have come from the east, from the country about the river Lena. The children of the Dolgans were gentle and attractive. They looked healthy and well-fed, but they gave one the impression of being of somewhat mixed race. The men we did not see, they were out fishing.

There was also a Tungus woman, married to a Russian, who was the mother of quite attractive daughters. The society here was thus pretty mixed, and they all looked gay and happy and contented.

At this place we saw some powerful, long-legged sledge-dogs, which were tied up and probably belonged to some of the fishermen, who used them for travelling up and down the river in winter, and sometimes also with their boats in summer, when the dogs go along the bank and tow the boat. They were bigger and stronger than the dogs of the reindeer Samoyedes, which are not used for driving, but for herding the reindeer.

As we approached the Correct on our way back, Christensen suddenly saw them hoist the flag at the main-top. What could that mean? But not long afterwards one of our Samoyede rowers shouted something 


\section{THROUGH SIBERIA}

and pointed to the south; and there we saw the masts of a vessel.

We were soon on board; the vessel had come nearer ; we could see with the glass that she was not large, she had two masts and looked like a small motor-boat. Then it was clear that she could be nothing else than the little Government motor-boat Omul, which is used for fishery inspection on the Yenisei. But what had brought her here? She was steering straight for us. Somebody said that Mr. Wourtzel, the engineer, who was to have been one of our party, had ordered this boat to meet him at the mouth of the Yenisei, and perhaps he had not countermanded it when he was prevented from joining us.

She came up past us, dipped her flag, circled round us and anchored on the inside. A boat came alongside with the captain, a good-tempered little rotund fellow in a round sealskin cap; the whole man looked like a little seal. As we had supposed, the boat had come all the way from Krasnoyarsk at Wourtzel's request to fetch people from the Correct, they did not know their names, and she was now at our disposal.

So now we could start for the south at once. This was quite unexpected. We had supposed we should have to stay here another week or so, until the loading was finished, so that we could go up the Yenisei with the tug-boat and lighters; and in that case we should not have reached Yeniseisk before the end of September at the earliest. As I have said, I had long ago given up hope of meeting Mr. Wourtzel at Krasnoyarsk; but now a new hope suddenly dawned, and things were lively on the Correct, getting ready for our departure.

The accommodation on board the Omul was not very great: there was a little saloon with two sofas, and a sleeping cabin beyond with three berths; but 128 


\section{WAITING TO GO ON}

that was just enough for us three passengers, besides the Omul's captain and engineer. The saloon was so small that when one came from the deck to pass into the sleeping cabin, those who were sitting on the sofas had to get up to let one pass, and the flaps of the table had to be let down; even then there was only just room for the little captain's round stomach between the table and the door.

We passengers had to supply our own food, and for cooking there was only a Primus stove. But an excellent and obliging cook there was, named Alexei ; and we had no difficulty about food, as by the kind care of Captain Samuelsen we took with us from the Correct such an ample supply of provisions of different kinds that we had not half finished them when we reached Yeniseisk. We were also able to buy plenty of fresh fish and red caviar on shore, and fresh bread was baked for us on board during the night, so that we had a supply for the first part of the voyage.

We decided to start next morning. And then we were busy packing and writing a few hurried letters for the Correct to take back to Norway.

Wednesday, September 3. Early this morning another big steamboat, the Oryol ("Eagle"), arrived, towing a lighter. She was on her way north to Golchíkha. A big, fine paddle-boat which had once belonged to Vostrotin and his company; he had bought her in Glasgow, where she had been a passenger boat on the Clyde and had been called the Glenmour. At that time she did 14 knots, but now her speed was somewhat less. She burned chiefly wood.

The captain came aboard to see us. He was a Finn, and a sturdy man to look at. With him 


\section{THROUGH SIBERIA}

came two young students in their military-looking uniforms. One of them was a nephew of Vostrotin. A third student came aboard a little later; he, too, was a nephew of Vostrotin. He had just passed his legal examination; but during the summer months he was second captain on board the steamboat, and was responsible for the mercantile part of the enterprise.

He told us that they had just discovered two thieves on board, who had got the money for their tickets by playing cards with the passengers; but then people had missed money from their pockets as well, so they were taken in charge by our gendarme and policeman and locked up on one of the lighters. This was unfortunate for them, as their best business would have been on the way back up the Yenisei, when people were returning from their fishing and trading with money in their pockets, and would be likely to get drunk.

In the course of the morning, before we left, yet another steamboat arrived, the Yeniseisk, and with her came an officer of gendarmes with several of his men and a policeman from Turukhansk, besides whom there was certainly a detective on the Oryol. And all these people, we may suppose, had come on account of the Correct's voyage.

We now had one custom-house officer, two customhouse soldiers, one gendarme officer, two gendarmes, two policemen, and perhaps a detective, in all eight or nine men. To these must be added a captain on the Turukhansk and a eaptain for each of the lighters, making twelve or thirteen. Compared with the fact that there were only eight men to do the work of discharging and loading, this did not seem a reasonable proportion. But then I should mention that eight 130 


\section{WAITING TO GO ON}

labourers arrived by the Yeniseisk, so that the work would go on faster.

This was the steamer that was to tow our lighters up the Yenisei, but she had with her her own lighter with coal. That made four lighters to take upstream, and it would have been a slow voyage for us. 


\section{CHAPTER VII}

\section{UP THE YENISEI}

The deepest ehannel : A place feared by skippers : Motor trouble : Pimen's Grave and its legend : Karaulnoye : Yurak camp : Kasanskoye, a brownie : Lukováya Protóka : The river bank and the excavating power of the stream : The first trees : Sturgeon soup : Ananyino and the steamer Lena : Siberian peasant types resembling Norwegian : In seareh of an expedition : Steamboats and lighters on the Yenisei and the ice-drift : Autumn fishing : A Yenisei-Ostiak and a civilized Samoyede

$W^{\mathrm{E}}$

then said good-bye to our kind hosts on board, Captain Samuelsen and Mr. Lied, to the steward, mates and crew, and to the Correct, which had been our home for a few pleasant weeks. It was also good-bye to Mr. Christensen, whose company we should thus be deprived of on the way up the Yenisei, as he had to wait for the loaded lighters. Then we took our leave of the Russian officials, the captain of the Turukhansk, the pleasant custom-house officer and the rest. We went aboard our new vessel, got under way, and steered southward in the rain and a stiff head-wind through the broad channel between the islands.

The course we had to follow was as a rule the deepest channel of the river. It is true that the Omul did not draw more than 7 feet, but that was quite enough to put us aground on some of the numerous sand-banks, if we went outside the fairway, which is not very wide. This is just the channel that the sturgeon follow in their 132 


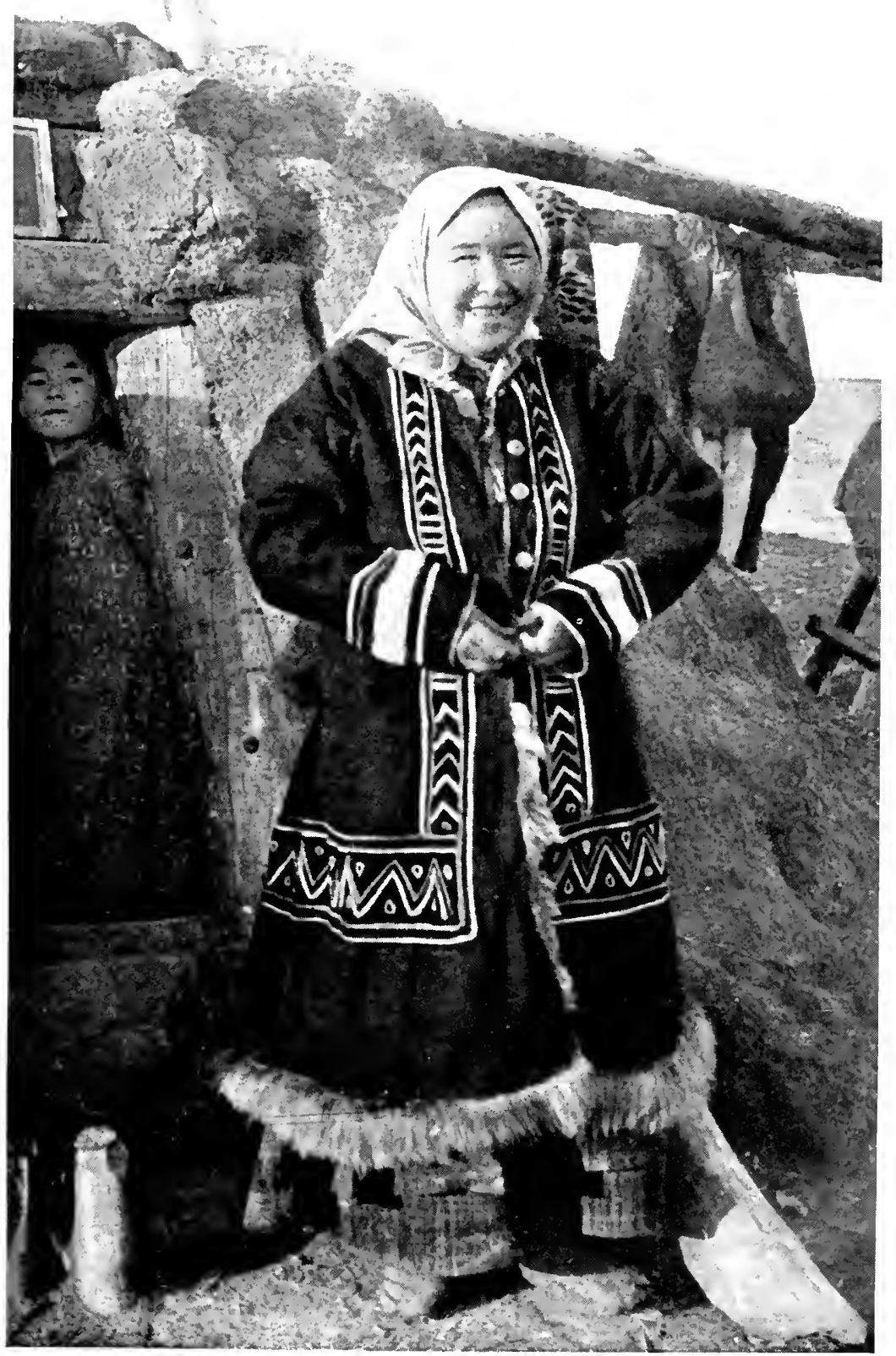

A GOOD-HUMOERED DOLGAX WOMAX 


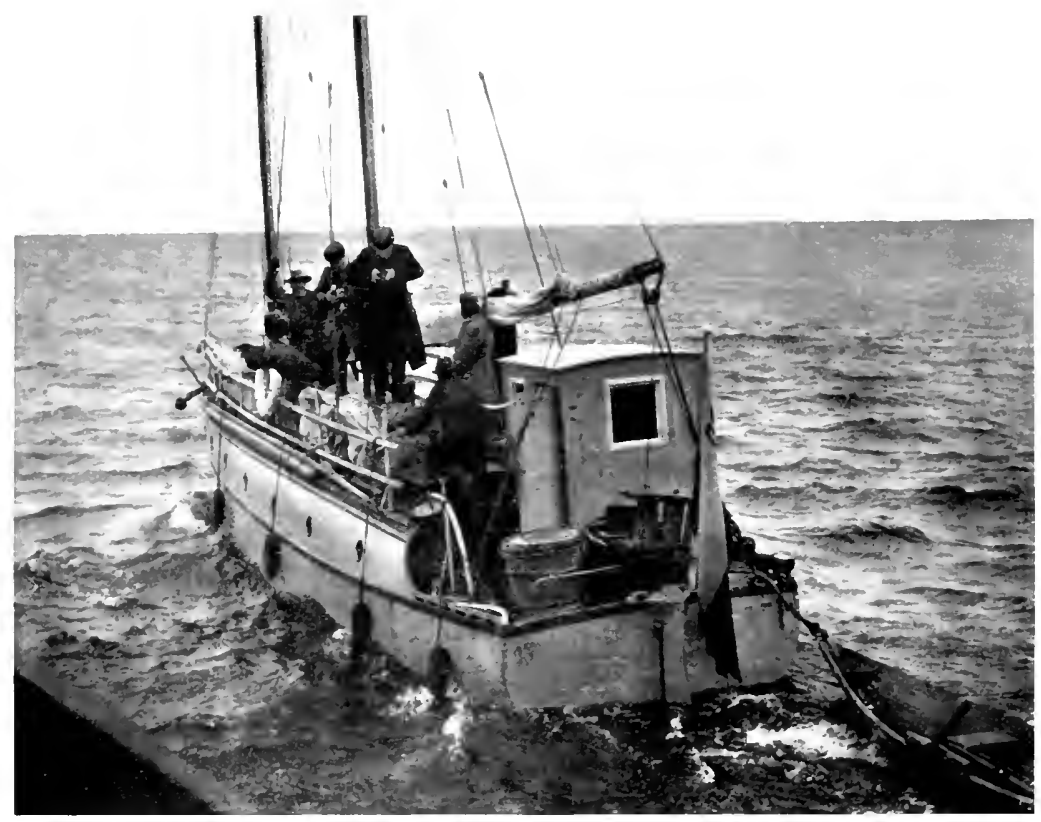

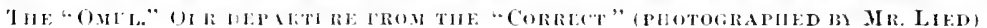

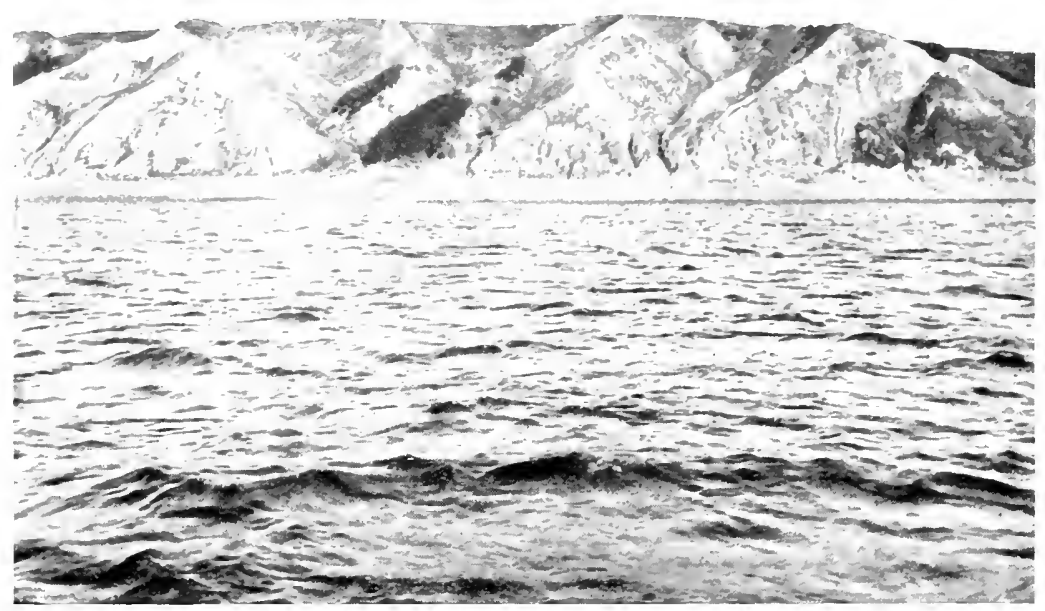

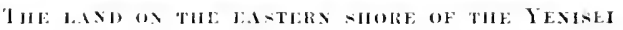




\section{UP THE YENISEI}

migrations up and down the river, and we used often to say that we had to keep the same course as the sturgeon.

As I have pointed out before, this channel follows the east bank of the river for a great part of its length. No detailed chart of the river, giving its depth across its whole bed, is in existence. Admiral Vilkitsky has certainly drawn an interesting large-scale chart of the Yenisei from Yeniseisk to Golchíkha, on which the channel is marked; but it is not a chart that anyone who did not know the river could sail by. There was no difficulty in our case; we had a good pilot on board, who knew all the banks in the river and promised that, however drunk he might be, he would take us safely to Yeniseisk.

But the trouble was that there was no one on board who could relieve him, and as he could not very well take the wheel for the whole twenty-four hours, we were obliged to anchor every evening. But he knew it was important for us to get on quickly, and therefore did not give himself much time for sleep. As soon as daylight came, about five or six o'clock, he was back at his post, and he never left the wheel till evening.

As we approached the south end of the channel between the islands there was a good deal of head-sea, and the little Omul began to pitch as if she were in the open sea. Vostrotin told me this bit of the river was that which the captains of steamboats were most afraid of on the voyage up and down the Yenisei. There might be so much sea here that they thought it was not very safe to tow lighters.

When we have settled down more and stowed away some of our things, I dare say the boat will be habitable enough; but at present she is a little crowded, and the thought that perhaps we may have three weeks of her 


\section{THROUGH SIBERIA}

before reaching Yeniseisk is not altogether cheerful, for there is not much room to move about in.

On the evening of the first day the engineer seemed pretty festive. As a rule he was a quiet, inoffensive sort of fellow, but no doubt the vodka had flowed rather freely on board.

Then the engine refused to work the propeller, for some unknown reason. They told us next day that the injection pump was drawing water as well as petroleum ; but we came to the conclusion that the trouble was not so much water in the engine as brandy in the engineer. Whatever it was, or was not, we were obliged to anchor between Pimen's Grave and Selo Tolstyi Nos (i.e., thick nose village).

It was a fine night. When I came on deck, about midnight, the sunset glow lay deep red, like a slow, smouldering fire, over the surface of the river on the north, with dark shreds of smoke-like cloud in front of it. Venus shone just above, and over Venus and the sunset gleamed an arch of northern lights. It was an extraordinarily beautiful sight. High up the sky was deep blue and starry, beside us the surface of the water reflected the sky, and beyond it lay the low bank and the endless tundra.

'There is a strange story about this Pimen's Grave, which lies inland to the north of us. He is said to have been an exile in Catherine's time. He had to live here, but wanted to be hanged instead, and asked a gendarme to hang him; but the gendarme would not, and told him to wait. Meanwhile, Pimen dug his grave and made everything ready, and now he insisted on being hanged. The gendarme again asked him to wait, as they could now see the boat coming from the south, and he might as well be patient till it arrived; but Pimen had no more time, and so he was hanged. When the 134 


\section{UP THE YENISEI}

boat arrived it brought the Empress Catherine's pardon.

Afterwards his grave became holy. The natives think that candles are always burning on it, and when it blows, the wind makes the candles burn still more brightly. Travellers who pass it must offer a prayer at this grave in order to have a successful journey. If they neglect this, they will be stopped in some way or other. A skipper and his wife, who are now living at Yeniseisk, once passed by without offering the prayer. They had bad weather, were driven back and delayed for eighteen days at this spot. But then the skipper prayed at the grave, and they were able to go on.

Now we haven't prayed at this grave either, and perhaps that is what is wrong with the engine. What will happen to-morrow ? It is a nuisance when motors go wrong ; I can see us in my mind's eye lying here with a disabled motor until at last the tug and lighters come along and take us in tow. This is not an edifying thought.

Thursday, September 4. But luckily the engine was going as usual early this morning, so no doubt it was only a case of too much vodka the day before.

Then we went on to the south, and at 8.30 A.v. we arrived at Karaulnoye (i.e., the guard-house), where there is a big house which has quite a lordly appearance. We anchored and went for a walk ashore.

Somewhere about 1879 Baron von Knop established a depot here for the trade through the Kara Sea. At that time great expectations were formed of the future of this route; but they were disappointed. It is now an important centre of the fish trade on the Yenisei, and is owned by a rich merchant of Krasnoyarsk, who is called the Turukhansky knyas (i.e. prince). His people live here both summer and winter. 


\section{THROUGH SIBERIA}

We were well received, and shown into the great, light drawing-room, which had four or five windows and old faded papers on the walls. The old Russian who managed the place was very keen on politics; he was delighted to get a chat with Vostrotin, and to be able to explain to him how things ought to be managed in Russia generally, and particularly in Siberia.

There was also a younger Russian, a big, fine fellow with brown hair and beard, who looked something like a saint. He was the engineer of the little steam-launch they had there.

In the yard outside the house we saw a cow, which must have been the most northerly cow in this part of the world. It was very far north for Siberia; we werc here in latitude $70^{\circ} 5^{\prime} \mathrm{N}$. She looked very well, though, and I had to photograph her with the girl who looked after the farm. There was rich grass growing round about, and it seemed as if there must be good pasture. The cow looked fat enough too. In one place down by the shore the grass had just been cut and cocked; but I saw no sign of a decent hay-field, though it must have been easy to find enough land for one.

On the flat shore to the south of the house stood a solitary Yurak tent. On the beach lay one of the ordinary heavy fishing-boats that they use, and besides that a little light canoe, hollowed out of a tree-trunk (vyetka). It was the first of that kind I had seen, and was probably used for shooting on the water. It had so little resemblance to the rest of the Samoyedes' outfit that I am inclined to think it came from the Yenisei-Ostiaks, among whom I afterwards saw similar canoes.

Up on the hill above the house I found several Yurak sledges which had been left behind while the Yuraks were engaged in fishing. These sledges, packed with 136 


\section{UP THE YENISEI}

all the things they do not want to drag about with them while fishing, are simply left here on the tundra until they come back in the autumn to go to the east again. Nobody, among the natives at all events, would think of touching the things.

Behind the houses I saw a number of dog-sledges of various sizes. They were of the form that the Russians mostly use here, the old man said. There were also several sledge-dogs wandering about. They were big and powerful, and looked well; a good deal bigger and longer in the leg than those we had from the Ostiaks for the Fram expedition in 1893.

When we were going away, the old man and the younger Russian, the engineer, came with us down to the beach. When we were in the boat, the engineer stepped down to the water's edge, bowed to us ceremoniously, crossed himself several times and made a long speech to Vostrotin, saying that as a member of the Duma he ought to see that the people had a better spiritual education.

Later in the day we stopped at a Yurak camp farther south. It consisted of three or four tents, and there was also a Russian living there, who had dug out a hut for himself like a cave in the sand-hill. He was staying there to buy up fish from the natives.

We managed to buy a sturgeon that had just been caught; but otherwise there was no fresh fish to be had. We saw the tackle they used for sturgeon: fixed lines with hooks, which were baited with a little dried fish; as far as I could see, it was a little lamprey, about 6 inches long or so. We also saw small nets which they use in the lakes for catching chir, pelatka (a trout-like fish with red flesh) and kundsha.

In the afternoon we stopped again at Kasanskoye, where one or two Russian houses stood on the height 


\section{THROUGH SIBERIA}

above the river on the east side. Our men had ordered bread here on the way down.

As we approached the houses up a long slope from the river, one of the doors suddenly opened and out came a tiny little man with a long, curly brown beard and a strangely gentle face. He was a perfect brownie, with a queer elf-like smile. It was a sight to see the little chap stand there on the doorstep talking to the big, powerful Vostrotin, who was anything but elf-like.

We were asked into the house, which was neat, bright and cheerful, with whitewashed walls, upon which hung a colour-print of Peter the Great, pictures of saints and photographs of Russian priests, together with coloured pictures of Parisian ladies in extremely décolleté dresses, whose swelling corsages threatened to burst the last restraining stitch.

The wife was a nice-looking woman of a little over forty, while the manikin, who was her husband, was only about fifty. They had many children, from a married son of twenty-two to a little child in arms, and doubtless another one expected before very long.

The husband was born here and had never been so far as Turukhansk. The wife was also born in the neighbourhood, about forty miles away.

In the house alongside lived an elderly man and his family; but they had typhus. One was already dead, and most of those in the house were ill. The man himself was poorly, had high fever and was terribly hoarse ; but that did not prevent him from coming out to speak to us, and he had an animated talk with Vostrotin about his affairs and about his taxes, which were far too high.

This was the house where the crew had ordered bread. They came and fetched it, but we did not like the idea of that bread with all the typhus in the house, 138 


\section{UP THE YENISEI}

and so the men pitched the whole supply into the river without touching it.

Four or five miles from Kasanskoye there is a good harbour on the east side of the river at Lukováya Protóka, in latitude $69^{\circ} 48^{\prime} \mathrm{N}$. It lies inside a sandbank and some islands, well sheltered, and has the advantage, which is rare here, of deep water close inshore. The only thing against it is that the entrance is rather shallow ; but it must be possible to dredge it, though there is a difficulty with the ice, which scrapes up the bottom when it comes down in the spring. If the entrance were made deeper, this harbour might be available for large ships, and one would imagine that it would be the very place for discharging and loading the vessels that are to come from the west through the Kara Sea, and the lighters that will come down the Yenisei to meet them.

We had now come near the southern end of this great widening of the Yenisei estuary, which is full of islands and sand-banks. Soon the channel turned to the east, and we entered the narrower bed of the Yenisei proper.

The banks of the Yenisei, like those of all these rivers, have acquired their peculiar form from the great yearly changes in the height of the water. During the great flood of early summer the river rises between 15 and 30 feet-near the mouth, where the river is so wide, the rise is of course not so great as here, where the channel is narrower. The flood water, which runs at a greatly increased rate, undermines the banks on both sides, and the layers of sand and clay fall into the river.

In order rightly to understand how much the excavating power of a river increases with its velocity, we must remember that the power of flowing water to remove stones and gravel is increased by the sixth power 


\section{THROUGH SIBERIA}

of its velocity. Thus a river, the velocity of which is doubled in flood time, has a 64-times greater transporting power. From this it will be easy to understand how rivers in flood can excavate their beds so forcibly and carry such quantities of gravel with them.

By this undermining and collapsing of the banks, a steep slope is formed above the average highest level of the water, which is sharply marked by a straight line along the bank. Wherever no fall has recently taken place, this slope is overgrown with grass and moss, and farther south with bushes and small trees.

Below the sharp high-water line the bank consists chiefly of bare sand and gravel, and in some places larger stones, and slopes evenly and smoothly down to the water's edge, beyond which there is generally a shelving, sandy bank far out into the river. But, as remarked before, there is a great difference between the east and west banks in this respect. The east side is as a rule markedly higher and steeper than the west. This, as I have said, is an effect of the earth's rotation, and it is very striking everywhere in the district we are now going through.

The high east bank in particular is also much scored and excavated by rain-water and brooks and small rivers, which have dug channels and little valleys. It is an extremely instructive model on a small scale of the way in which erosion takes place in the mountain systems of the earth. Then, here and there, great landslides had occurred, through undermining in the spring, and everything was effaced.

Towards evening, as we were going on up the east side of the river, a remarkable thing happened. We caught sight of the first small trees projecting above the side of a little valley farther in. They were small larches (larix sibirica). There were not many of them. They were 140 


\section{UP THE YENISEI}

scattered over the ground and looked more like bushes than anything else. But soon there were rather more of them, and these were thus the first beginnings of forest that we met with here in latitude $69^{\circ} 43^{\prime} \mathrm{N}$, , or about the latitude of Tromsö.

At nine o'clock we anchored off Khetinsky Island, opposite Krestova.

That evening we were to have sturgeon for the first time, and our excellent Alexei made us the national dish selanka, a strong soup with pieces of the fat sturgeon floating in it; it is also flavoured with olives, capers, pickled gherkins, tomatoes and anything else of that kind. The sturgeon is eaten in the soup. It is a remarkably good fish, and the whole thing was excellent. But it is characteristic of the Russians that their national dish should be a soup. A Russian dinner without soup is unthinkable, and the soup is actually the principal dish of the meal.

Friday, September 5. This morning we saw a steamer ahead. She was the Lena and was lying at anchor at Ananyino to unload a miscellaneous cargo from the lighter that was with her. We also stopped to get petroleum for the engine from the same lighter.

This takes a long time, and Vostrotin and I, therefore, went ashore for a walk. There were four or five houses standing in a row on the top of the river-bank. A rich trader owns this place, and does a large trade with the natives on the tundra. This was evident also from the numerous sledges of every kind that lay all over the slope below the houses.

I saw there a big house-sledge with one large room, which was covered with tarpaulin, and probably also with skins, to keep it closed and warm; and there was a cooking-stove in it as well. This sledge was drawn by eight reindeer over the tundra. There were several 


\section{THROUGH SIBERIA}

sledges with waggon roofs that were used for transporting goods. A great number of other sledges lay in rows; they were all used for sending goods into the tundra to sell to the natives, and as many as three of these big sledges might be despatched at the same time.

The trader sold this place some years ago, but bought it back last year. He has never come back to live here, for all that. One winter, a few years ago, a band of robbers went through this country up the Yenisei ; they plundered wherever they went and killed several people. The trader from here was in the tundra at the time, on a business journey. He heard of the approach of the raiders from the natives, abandoned all his goods, and fled to another tribe of natives, with whom he was acquainted, and thus escaped; for when the robbers found his goods, they forgot to follow him up. But since that time the trader has been so frightened that he has never ventured to live in these desolate northern tracts.

They are like little kings, these traders of the northern Yenisei ; they rule the natives pretty much as they please. The man here was well spoken of; his brother, on the other hand, who had also been a trader, and lived farther south in a large house near Dudinka, had been hard on the natives. He treated them badly in every way, and even went so far as to put out their eyes. Those who were in debt to him, and whom he himself had put in his debt, he stripped to the skin; he used to visit them on the tundra, take all they had, and leave them pitilessly to starve. But this went so far that the Government took the matter up, and the man was promptly banished to the Lena district. There he started trading again, but while travelling by boat on the Lena he was killed and thrown into the river by 142 


\section{UP THE YENISEI}

some men he was travelling with, who had seen that he had money on him.

Here at Ananyino I again saw many fine, powerful sledge-dogs. All traffic during the long winter is, of course, accomplished with sledges, which are drawn either by dogs or reindeer. With reindeer you get on faster, I was told; but with a team of good dogs of this kind you do not travel very slowly either. They reckon that they can go 90 versts at a stretch without feeding the dogs.

They are fond of their dogs and look after them well. In the peasants' houses there is always a big bakingoven, built of stone, between the rooms. The top of this oven is broad and flat; in winter it is in great request as a sleeping place, and the wife often sleeps there. But when they come in from a journey out of the cold, whoever may be lying there has to move, so that the tired dogs may sleep there.

I had a look at the dog harness that is most generally used here along the Yenisei. It is a back-harness, with the trace lying over the back; but they were also acquainted with the other method, which is much used by the Obi-Ostiaks, with a band round the animal's body and the trace running between its hind legs. The dogs are harnessed four together in front, with the leader a little in advance of the others; then the other dogs come behind, made fast alternately on each side of the trace. They usually have six or eight dogs in a team.

It was curious to see the different types of Russians in this country. Many of them bore a great resemblance to Scandinavians ; there was in particular a fair, mildmannered boy of eighteen here; if one had not known, one would have taken him for a Norwegian peasant boy. Many of these Russians were fair, with blue eyes and tawny hair, often curly. Tall, powerful fellows many 


\section{THROUGH SIBERIA}

of them were too. One might almost be tempted to think there had been some connection with Scandinavia here.*

We looked in on a young married couple, two decent people. The two rooms they lived in had the same whitewashed walls and were bright and clean. As usual there was a large baking-oven in the wall beween the rooms, as well as a little iron stove in the inner room to give warmth on the coldest days of winter, when the temperature goes down to 40,50 or 60 degrees below zero (F.).

On board the Lena was a Russian who was to have joined the Brusilov Expedition in a scientific capacity; he was a geographer, he said. He had expected to find the expedition somewhere here in the north. "But where?" I asked him. Well, he didn't know exactly. Brusilov would go to Dickson Harbour for coal, if he could get there, he thought, and so he would have to look for him there. But had he a boat to take him there? No, he hadn't. And had he any reason to suppose that Brusilov would get there? No, he hadn't that either. It was not quite clear to me how he was going to look for him in that case. Going out in this way to hunt for an expedition in the Arctic, seemed to me rather like looking for a needle in a haystack. I have seen many careless ways of preparing for a polar voyage, but this beat them all; and if the rest of the expedition was as thoroughly equipped as this specimen, the result is not to be wondered at. He confided to me, by the way, that there was little probability of the

* A man in Krasnoyarsk told me that Nikodem, the first bishop of Yeniseisk (1861-1873), in a book on Mangaseya, has written about Norwegian intercourse with this former town on the Tas, and about Norwegian coins found among the shamáns of that district. I have not yet had an opportunity of seeing this book.

144 


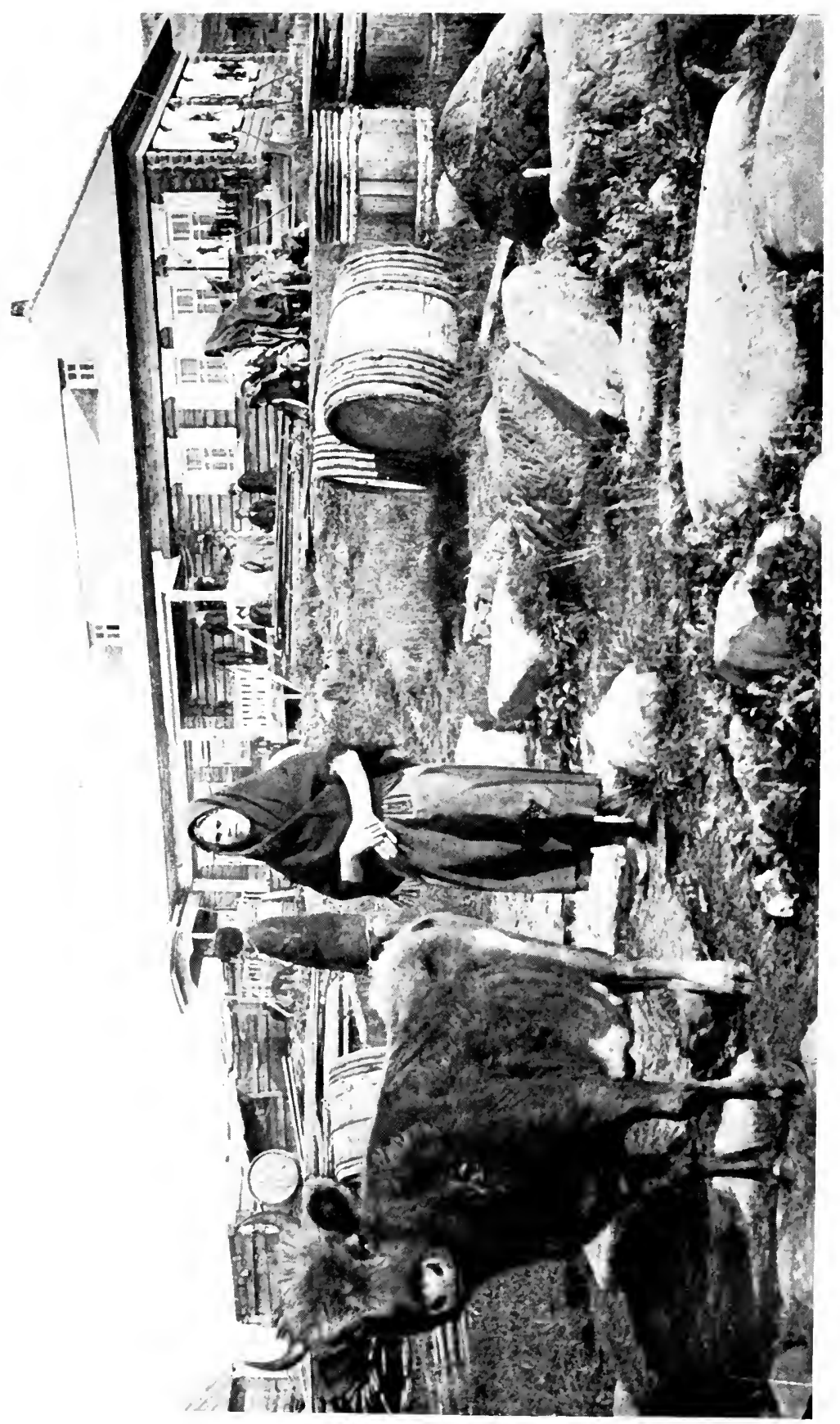

 


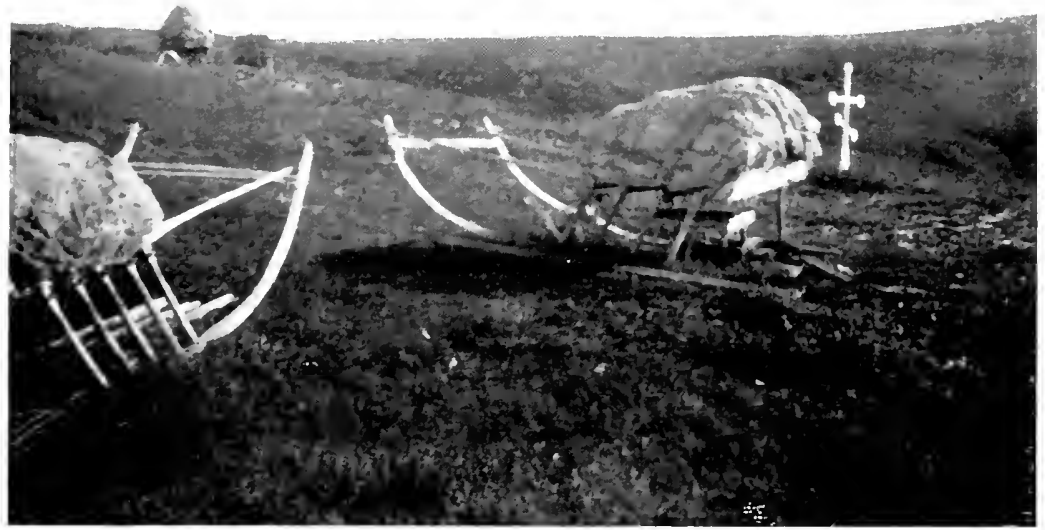

YURAK SLEDGEK LEFT ON TIE TUNDRA AT KARALLNOYE

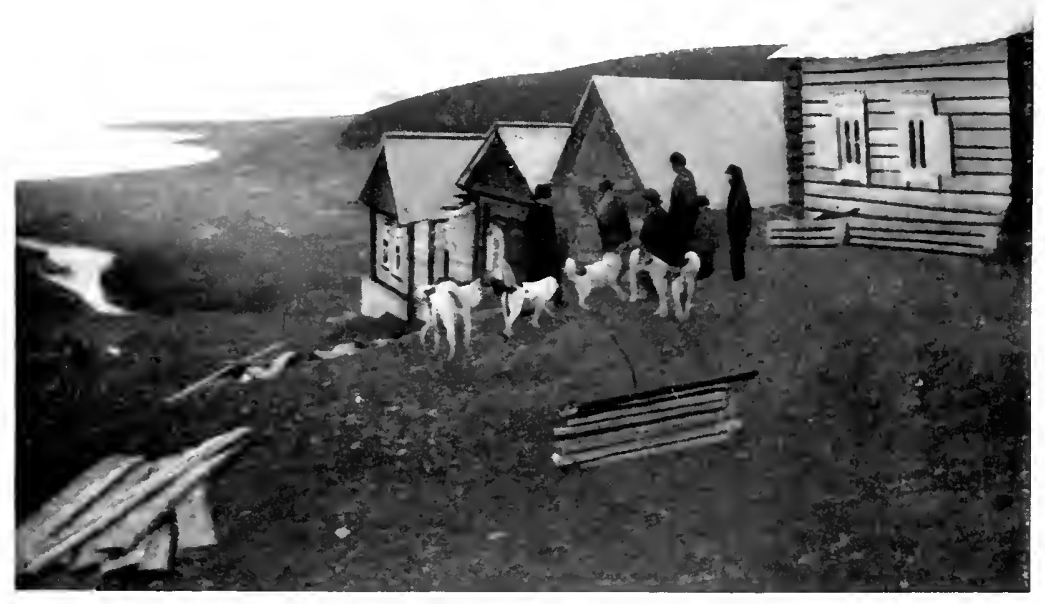

Axamiso 


\section{UP THE YENISEI}

expedition being alive, as neither captain nor crew had any experience of ice; and they were badly fitted out, too, he thought. There seemed to me to be something heroic all the same, in setting out to join this expedition. Well, after all, he thought he would go in the Correct to Vardö and so home to Dorpat, he said.

I come back to what I said at Tromsö about the inexcusableness of such carelessness in the preparations for polar expeditions.

But our man here had other difficulties to contend with besides that of finding the expedition he ought to have joined. As he was leaving, he took Vostrotin aside to ask for a loan of a few hundred roubles ; for he would prefer to stay the winter here, he said ; there was so much scientific work to do. Unfortunately he had forgotten to bring enough money for that from Krasnoyarsk, and it was equally unfortunate that we had not enough with us to help him. It appeared, poor fellow, that he had done all the work he could in Krasnoyarsk during the winter to raise money. He thought he would borrow something from Lied on the skins of the bears and white foxes that would be shot by this same Brusilov expedition, which he now considered to have no chance of coming back.

On the Lena was also the deputy chief of police from Turukhansk in full uniform. He made the sixth or seventh policeman we saw here; but this one was only taking a holiday to have a look round, he said.

Another official on the boat was the sub-director of the Government flotilla on the Yenisei, which consists of steamboats and lighters. He it is who has charge of all this transport up and down the river.

It is strange what resemblances one sees among men of the same profession. This man was a stout, broad fellow with a pleasant, merry face and a heavy moustache, 


\section{THROUGH SIBERIA}

who was so like our former genial harbour-master at Christiania, Bassöe, that one might have been taken for the other. This one was also an active, capable man, who kept things stirring.

All this time we were filling up with petroleum, which is a long business, and the lighter was discharging goods into a big boat that takes them ashore, which is longer still. They sometimes stop for several days at each place. These shelving banks make it impossible to go alongside, so that unloading has to be done by boats, and it is slow work.

It is true that our friend the geographer and expedition-hunter thought it scandalous, the way they wasted time in this country. He had been chafing at this on the trip down the river; there would have to be a reform, he would see to that and write about it ; it was absurd not to take the lighters alongside and use a gangway instead of these boats. What he was going to do about the shelving banks, he did not say.

It was all kinds of goods that were being discharged : mostly sacks of flour, and stoves made of thin sheet-iron, bedding and many other things. The quantity of goods carried down the river by the three Government tugs and nine lighters varies from year to year. This year, for instance, as the catch of foxes had been good and people had money to spend, they ordered a lot of things, and there was much to be taken down the river. If the fishing also turned out well, there might be large quantities of fish to take back. But in some years there were not many foxes, and perhaps the fishing was poor as well, and then the cargoes were light.

These three Government steamboats and nine lighters which are now running on the Yenisei were bought in 1905, at the time of the war, and brought here with the idea that they would be wanted for the traffic up 146 


\section{UP THE YENISEI}

and down the river which would result from a development of the sea-route through the Kara Sea to the estuary. This came to nothing. It is true that, in order to encourage the traffic, goods for Yeniseisk were exempted from duty that year; but next year the Government changed its mind, and only a few classes of goods were exempt ; and with this the sea-route once more came to an end of its own accord.

The tugs and lighters then had no other freight than the fish and the usual cargoes down and up the river, and they involve a great annual expense to the Government, which would therefore prefer to sell the whole fleet. To begin with there was six steamers, but two were wrecked by the ice a few years ago, when they had chosen bad harbours for the winter at the mouth of the Angará ; during the breaking up of the ice in the spring one of them, a paddle-boat, was carried by the ice one verst down the river, and broken and twisted like a cork-screw, so that she sank in several pieces, after losing her boiler on the way.

The other was carried by the ice 500 versts down the river, before she was crushed and went to the bottom. Some lighters also got adrift that time and suffered some damage, but they were brought to land with difficulty and saved.

A third steamboat was sold and taken round to the Obi, where she is now running. Two of the steamers were bought in England, the others in Germany; the lighters are of the kind that is used on the Rhine.

At last our oil-tanks were filled and we were able to go on. The trees began to be a little thicker here and there in the valleys, and they were gradually getting higher ; but still there was nothing that could be called forest.

In the afternoon we went ashore on the low west 


\section{THROUGH SIBERIA}

bank of the river at Levinski Pesók (i.e., Levin's sand), where the captain and crew were to buy fish for salting for the winter. They were mostly Russians who lived here, in a few mud-huts on the slopes above the long, flat sandy shore. They were at that moment engaged in fishing with seines, several boats' crews of them.

The fishing is done in this way. A man stays on shore and holds a long line made fast to one end of the seine, while the boat rows out as far as the line will reach; then they begin to cast the seine as the boat rows along the shore down stream. When they come to the end of the seine, they row to land as fast as they can with the line that is made fast to the lower end; and then the thing is to haul both ends ashore as quickly as possible. It is hard work, and they generally wear broad belts of birch-bark round their waists and pull with them. When the middle of the net is coming near the shore, one of them wades out to see that it comes in properly and the fish do not get away. They caught some fish, mostly muksun, in the casts made while we were therc; but it was nothing very great.

On the whole they were not very well satisfied with the fishing this year. They had caught some seld a few days before, and it promised well, they thought, until three belugas came blowing up the river; then the fish fell off again. Here we met with the same superstition that it is the whale or the beluga that drives the fish to land and up the river, but may also drive them out again. These belugas were still above here, they thought, as they had not seen them go out again. In any case, it is interesting to know that the beluga goes so far up the river. The ringed seal is said often to go as far up as they.

Here we saw an unusually large and powerful sledge-dog. In size he was something like a small 148 


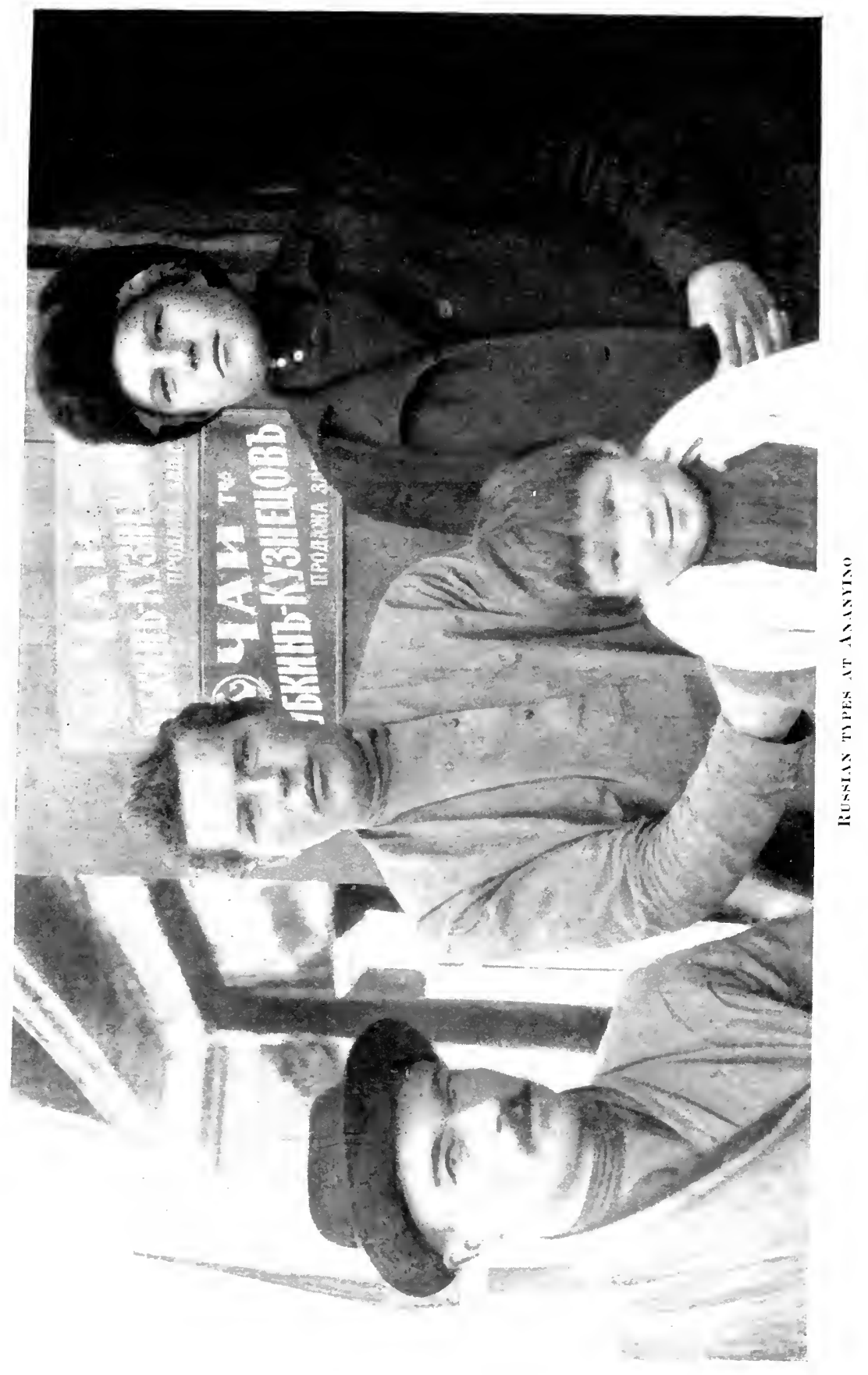




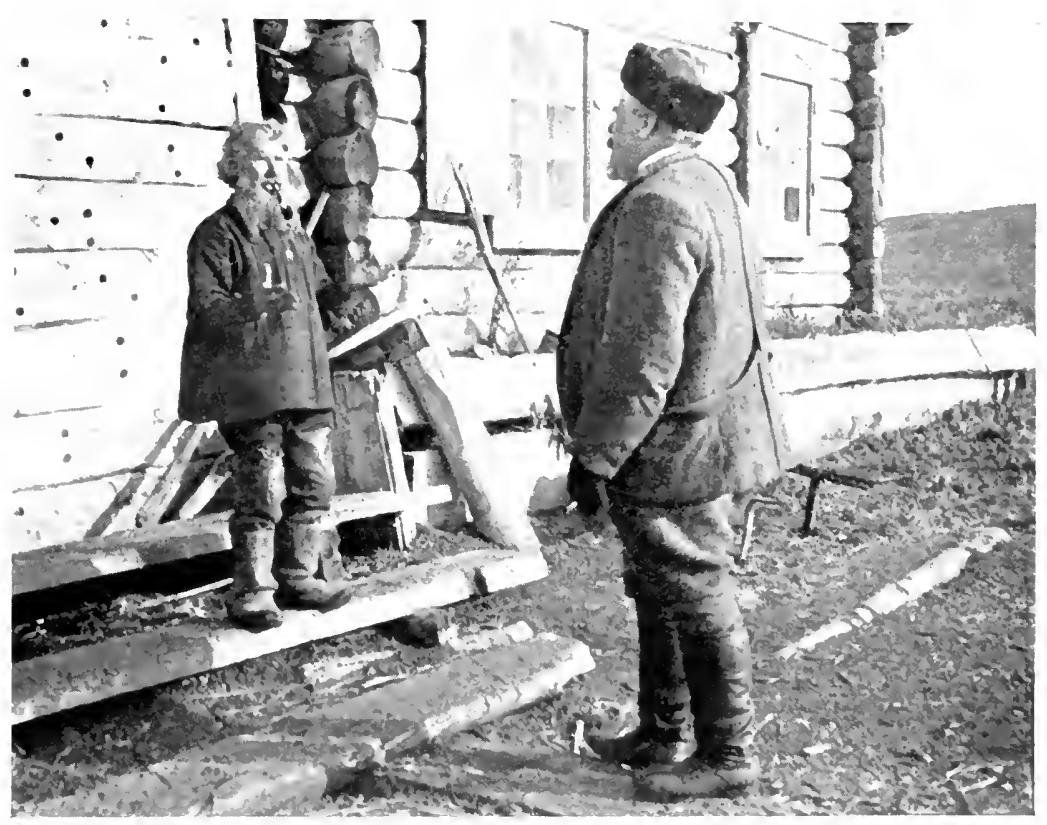

K.MAYKOSE. TUE LITTLE MAY IXD MR. VO-TROTIS

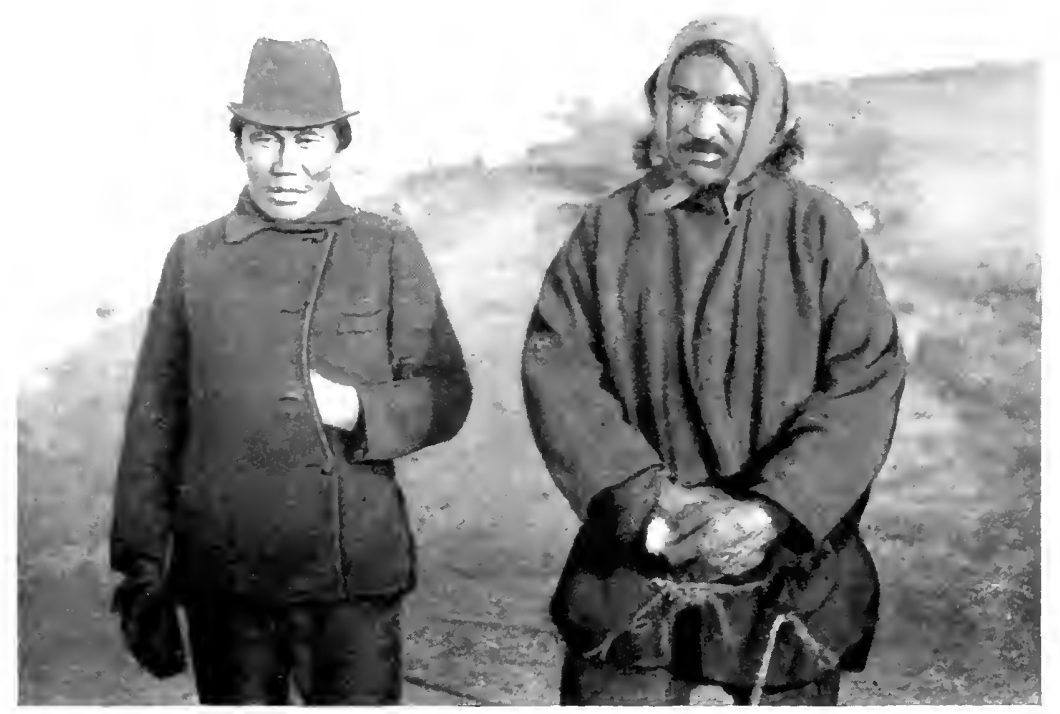

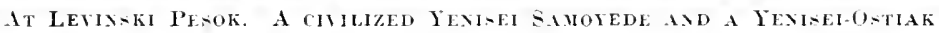




\section{UP THE YENISEI}

St. Bernard. They said it was not uncommon for sledge-dogs to be as large as that. They are strong pullers, but not so fast as smaller dogs.

For the first time I met here a Yenisei-Ostiak. He had a handkerchief tied round his head like a woman, as is their usual custom. He had strongly-marked, projecting eyebrows, black moustache, a light brown skin and long black hair; he looked very like a gipsy, and was quite different from the natives we had seen hitherto. There were also one or two Ostiaks in the place, we were told, and a Yakut, but they were out fishing. They were hired men, working for the Russians who had the fishing there.

We also saw a Samoyede, who wore an old stiff felt hat and looked exactly like a Japanese. He was the son of poor parents, and had come from the north to some Russians at a place farther south on the river. There he had gone to school and learnt to read and write, we were told, and now he had almost forgotten Samoyede. He seemed to be remarkably shrewd, and was a buyer of fish here for the trader at the station to the south, where he came from.

Among the Russians were several old, grizzled, bearded fishermen who were so like our old fishermen in Norway that you could not tell the difference.

There was a nice-looking Russian boy with such a pleasant smile and such splendid teeth that I could not take my eyes off him. Altogether I have been struck by the beauty and whiteness of the teeth of many of the Russians here, both men and women. 


\section{CHAPTER VIII}

\section{DUDINKA TO THE KUREIKA}

Dudinka : Political exiles : Caucasia : A discoverer and his strange tales : Thin forest : Coal measures : Movement of rivers to the right : Large rocks carried by the river ice : Forest, taiga and tundra: Hay in stacks : Still flat forest land : The first beds of rock : Sushkóv : Epidemic among hares and squirrels : Want of medical aid and epidemics : The forest often burnt : Thin forest and frozen soil : Hardiness and utility of Siberian timber : Origin of the Arctic drift-wood : The Yenisei-Ostiaks and their origin : The Kureika : In the forest : Graphite : Outside the world : Fog : The first hill

$\mathbf{A}^{\mathrm{T}}$ last the fish business was concluded, and the for salting. We were able to go on, and soon we arrived off Dudinka, the Moscow of the north, the most important place in the whole district; for this is the centre of all traffic and trade eastward over the tundra to the Khátanga and Anábara.

The place stands on the high east side of the river, and as usual the houses were up on the top of the slope. But I could hardly believe my eyes : there was a house up there far bigger and longer than anything one would have expected to find in this part of the world. With its long rows of windows and doorways it looked like a fairy palace, standing up there against the sky in the setting sun. It was the house of the principal trader of the district and was just now being reconstructed; the owner himself was ill and had gone 150 


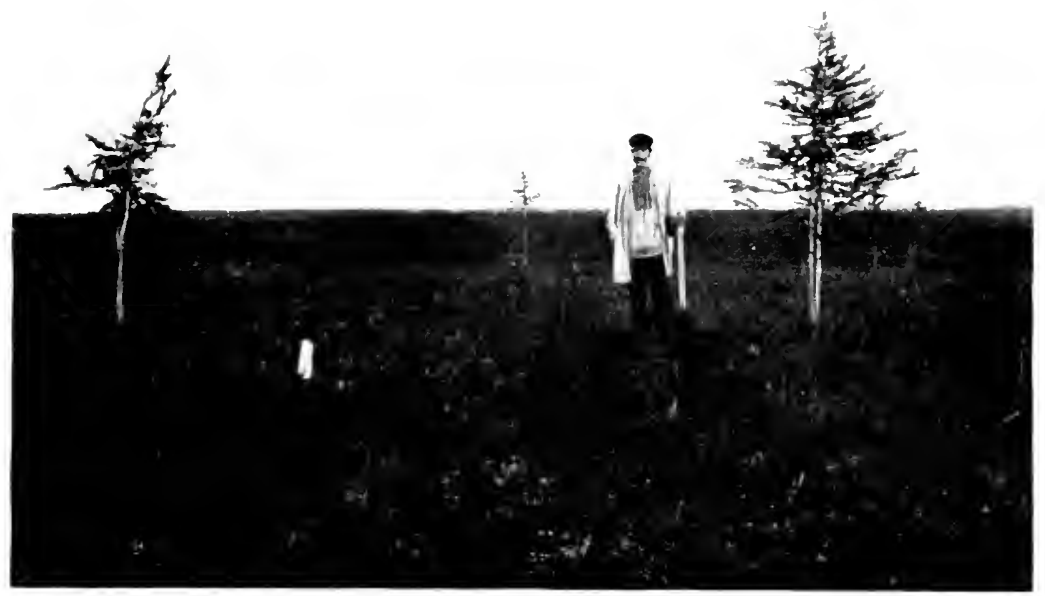

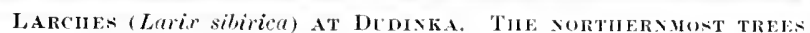

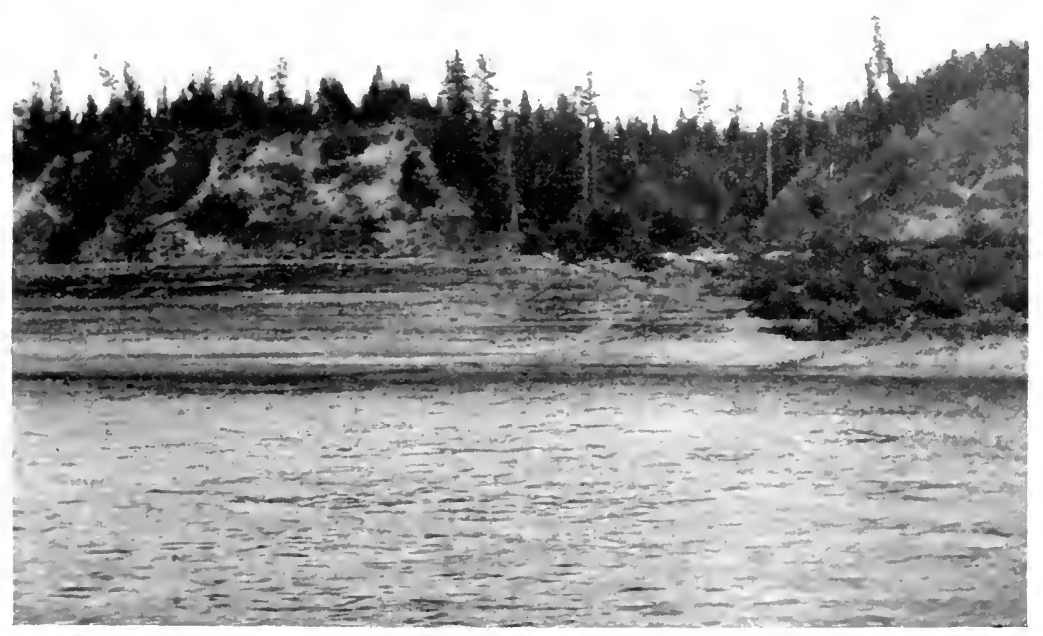

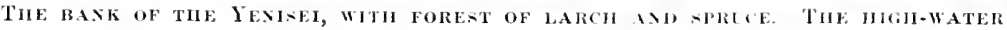
LINE IS DINTINCTLY AEEN 


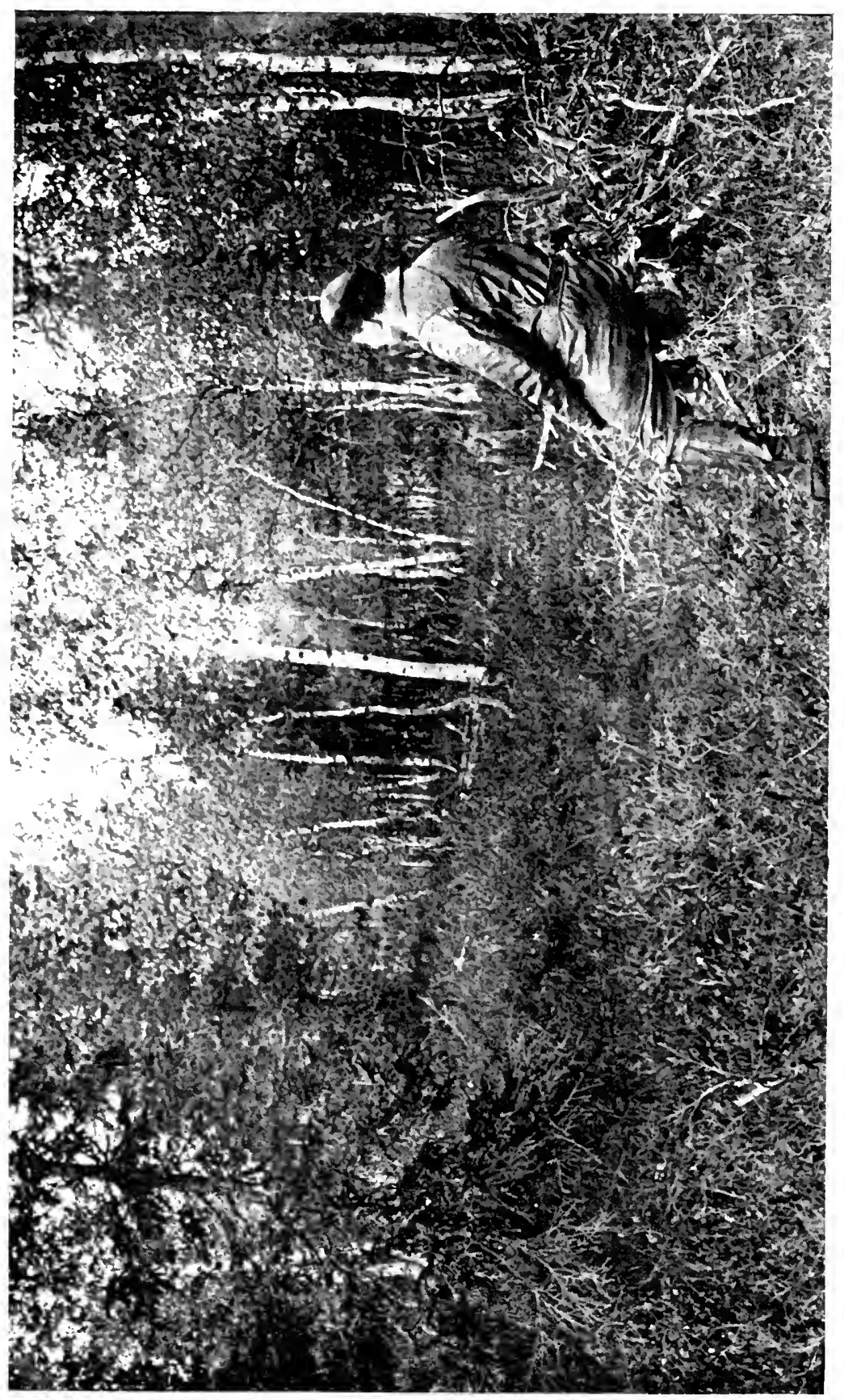




\section{DUDINKA TO THE KUREIKA}

away. He was reported to be the fairest and most honourable trader in these parts, and a good man to the natives.

There was a pretty little church, with a belfry and no fewer than seven bells. There was also a French shop, Revillon's, where we bought a coffee-pot, glasses, plates, and various other things to supplement our scanty messing outfit.

In the shop at the big house we got bread, biscuits and cigarettes, which, of course, are smoked by all Russians, even up here. I was not a little surprised when I took up the dark brown packets of cigarettes and saw the name NORA on them in big white letters, above a handsome woman's head in white relief. Strange - the first thing I bought in Siberia was these cigarettes, and there I came upon Ibsen. I must confess it flattered my national vanity to find that he and the woman's movement were so well known even here that it paid to name cigarettes after his feminine champion. I did not remember at the time how many there were who could read in this country. The cigarettes were very cheap, but not good, as we found out afterwards.

We wanted to get some reindeer meat, too, but there was none to be had. Some Yuraks with reindeer had been there ; but they had just gone east over the tundra a few hours before we arrived.

Two young political exiles lived here, we were told. While we were making our purchases, Loris-Melikov went out to call on them. As he came up to the house where they lived, he heard singing and a guitar accompaniment which had a strangely home-like sound. They were no doubt trying to pass the time with a glass of wine and memories of home. He was well received, and was not a little surprised to find two countrymen 


\section{THROUGH SIBERIA}

from the Caucasus, and from the very same place that he came from, so that they knew his family there. Truly it is a small world. A little latcr I went and called on them, and was well received.

One of the exiles was an Armenian, twenty-four years old; he had lived at this place since 1912; at home he had belonged to the political party called Dashnaktsutyun, the object of which was the foundation of an independent Armenian kingdom in the Caucasus. He had been exiled to Siberia for five years, and he had now served three of them.

The other was a Georgian (or Grusin), and was rather older. He had lately come to Siberia, lived in a village higher up the river, and was here on a visit to his countryman. He had been exiled for three years, but did not know for what reason. He had been visiting a sick friend at Rostov on the Don, when he was suddenly arrested and sent to Siberia without trial, as usually happens. The policeman or detective had said he had seen him at Rostov in 1899, when there was some trouble there. The Georgian admitted that that was correct; he had been there at that time; but he had no knowledge of any kind of revolutionary movement. The prefect at Turukhansk, however, told us later on that he was accused of being concerned in some larceny case or other, probably of a political nature. He was a remarkably handsome type, dark, with a short black beard and brown, melancholy eyes, as soft as velvet, though there might be fire in them at times. They are generally reputed to be a fiery people, these Georgians, and they do not think long before striking. He was a nobleman, and knew Loris-Melikov's cousins well.

Here, then, these exiles had their quarters; but they complained of the entirely unoccupied, inactive life they had to lead. There was nothing for them to 152 


\section{DUDINKA TO THE KUREIKA}

do, except to read. No work for them was to be had here. They might have found some amusement at least in shooting, but that was out of the question, as the exiles are not allowed to have arms. The only other thing was a little fishing when they had the chance, and, otherwise, they had to let the summers and winters slip by as best they could, till their time was up and they were free again to return to life and the world.

The political exiles receive 15 roubles a month from the Government, so that they may not starve to death ; but as soon as they earn any money themselves by work, this monthly allowance is stopped.

These 15 roubles (£1 $11 s$. 8d.) a month may thus easily act as a premium on laziness, even though they may be given for philanthropic reasons.

Nor is this enough to live on in this country, where everything is fairly dear. And when the exiles come to the place assigned to them as a residence, the peasants there cannot, of course, let them starve, but are obliged to give them board and lodging for what they are able to offer, which as a rule is only these 15 roubles; and this may be a severe tax on the peasants as well. But these two exiles had no difficulties of that kind, as they seemed to be comparatively well off.

The Armenian's father had come all the way from Caucasus last year to see his son. But he reached Yeniseisk too late; the last steamer of the season had just started for the north. He could not wait for the chance of an occasional boat, as he had to be back in the Caucasus for the vintage. So he started on the long journey home again without having seen his son, and, what was perhaps worse, without the son having seen him and heard all the news from home.

As we were going aboard in the twilight, a man came and spoke to us on the shore. He had been on Baron 


\section{THROUGH SIBERIA}

Toll's expedition, and also with the search-party that went to Bennett Island to look for traces of it. His name was Nikíphor Alexéyevich Bégechev, and he was staying here waiting for the winter to go to the Khátanga and Anábara. He lived by hunting, and had several times been eastward to the mouths of these two rivers. He had also discovered a new island there, he said, in latitude $74^{\circ} \mathrm{N}$., and longitude $118^{\circ} \mathrm{E}$., 3 minutes south of Preobrasheniy Island (Transfiguration Island), which was visited by Nordenskiöld. The newly discovered island was supposed to have an area of about 10,000 square versts (4400 square miles), and he thought there were about 2000 square versts of coal. It is not quite clear to me where this island can lie. In any case it cannot be in the latitude and longitude he gave, as that would be right out at sea, and moreover, we sailed straight across it in the Fram on September 15, 1893. His longitude must be altogether wrong, taken from old Russian charts; and Preobrasheniy Island, as determined by Nordenskiöld, lies in about latitude $74^{\circ} 45^{\prime} \mathrm{N}$. (and longitude $113^{\circ}$ E.). If the new island lay 3 minutes south of this island, it would have to be the peninsula the north-eastern point of which has been given the name of Cape Preobrashenskoye on Nordenskiöld's chart, and on which he has marked "Höga berg" ("high mountains"); to the south of it is a wide bay called "Nordvik Bay." The man's discovery then, may be the finding of a strait across the peninsula from this bay to Khátanga Bay, and there is nothing extraordinary in that, as these coasts have never been properly charted. But what is extraordinary is that he should have found room for an island of 10,000 square versts; the length of the island would then have to be about a degree of latitude. The 2000 square versts of coal are in themselves no trifle ; for this would corre154 


\section{DUDINKA TO THE KUREIKA}

spond to a square of about 45 versts in length and breadth. He has probably put in a few 0's too many.

Last year he had left two men behind on this island; he asserted that he had papers signed by them to prove that they stayed behind voluntarily. But when he went back there this spring, he found them both dead.

He travelled there with reindeer. In one month he had got 18 polar bears, and he also found walrus on that coast. I asked if he used poison and traps for catching bears and foxes; no, he only used his gun, and he claimed to have shot 10,000 roubles' worth of game last winter; but that again sounds rather fantastic.

He looked big and powerful, this man, as he stood there in the twilight, telling us all these strange stories. He had a clean-shaven face full of character, which was a little like Amundsen's after he had shaved his beard.

On the beach lay a square lighter, made of thick planks nailed together. It was of the kind formerly in general use - and still used a good deal-for floating corn and flour and other goods down the Yenisei all the way from Minusinsk. It looked more like a Noah's ark than anything else. These lighters are never taken up the river again; they are sold as timber, taken to pieces, and the planks are used for building in places which have no forest near them; in towns like Yeniseisk the pavements are also made of planks from these lighters.

Inland of Dudinka there is a hillock with scattered scrub, from the top of which there is said to be an extensive view over the tundra. This was the first high ground we saw on our voyage up the Yenisei. Unfortunately our time was too short to go there.

There was nothing much in the way of trees, only 


\section{THROUGH SIBERIA}

a few stunted larches scattered here and there, with long intervals between. They might be about 10 feet high; but they were old, 100 to 150 years or so.

Some 60 miles across the tundra here from the Yenisei there are rich coal measures; the coal is as good as the best that comes from Cardiff, it is said. 'They have been known for many years, but no regular working has yet been started. Five hundred tons of coal were mined in 1905, and carried with reindeer over the tundra to Dudinka, where they were used by the Government's great expedition and proved to be excellent, we heard.

There can be no doubt that these coal measures might become of great importance in the future. To lay a railway line over the 60 miles to Dudinka could offer no difficulty, in spite of the soil being eternally frozen. Any quantity of coal could then be brought down to the Yenisei, which would make a great difference to steamship traffic on this great river.

But we had no more time to stay here; we went on and anchored 10 versts higher up, by Kabatskiy Island (i.e. Tavern Island). We had a good deal of sea there during the night, and the cable was straining all the time. There was a stiff breeze from the northeast and it set up a nasty short sea, which rose against the stream. It was strange that here, again, in the Yenisei we should be afraid of dragging our anchor, and should have such difficulty in finding a decently sheltered harbour.

Saturday, September 6. We proceeded in the morning through the same monotonous flat landscape. The river winds along with the same flat banks on both sides. At the bottom is the shelving sandy foreshore, often with pebbles, then comes a steep slope, formed of sand and gravel, and then above that the sharp line, where grass 156 


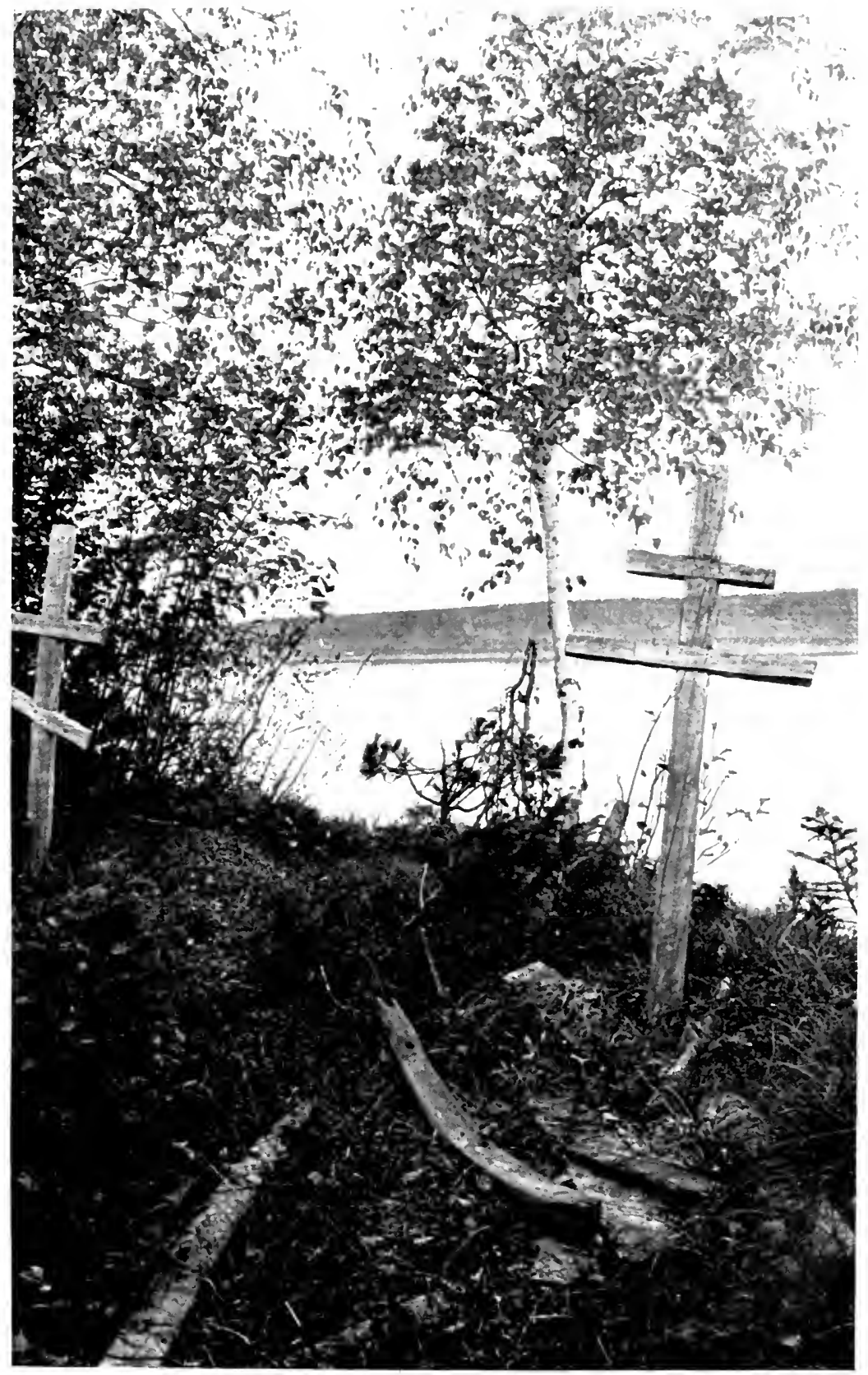

OLD NATIVE GRATEN IN THE FORENT AT GLREIKA 


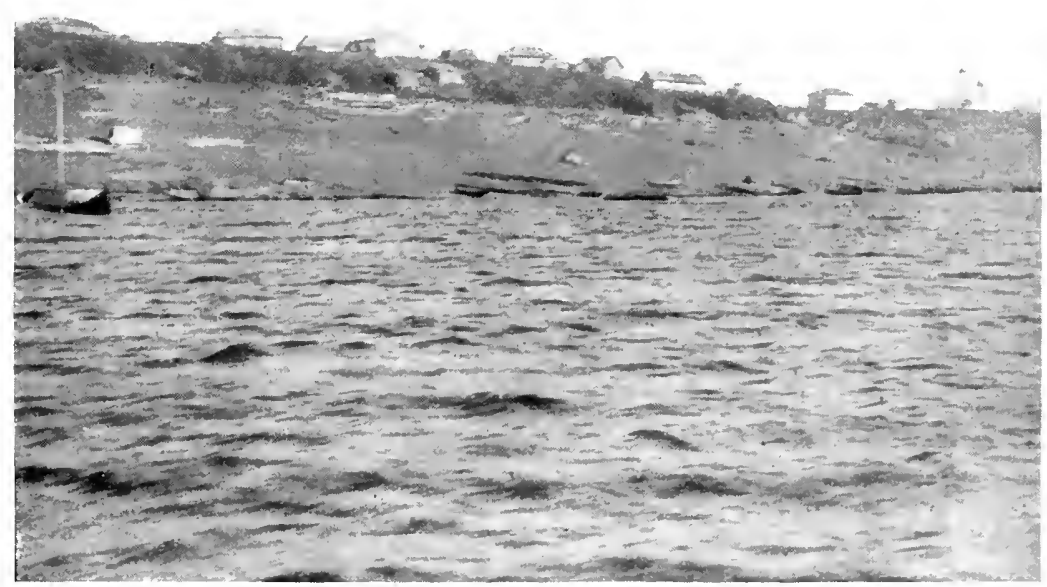

TroLTAKII MONAATIR

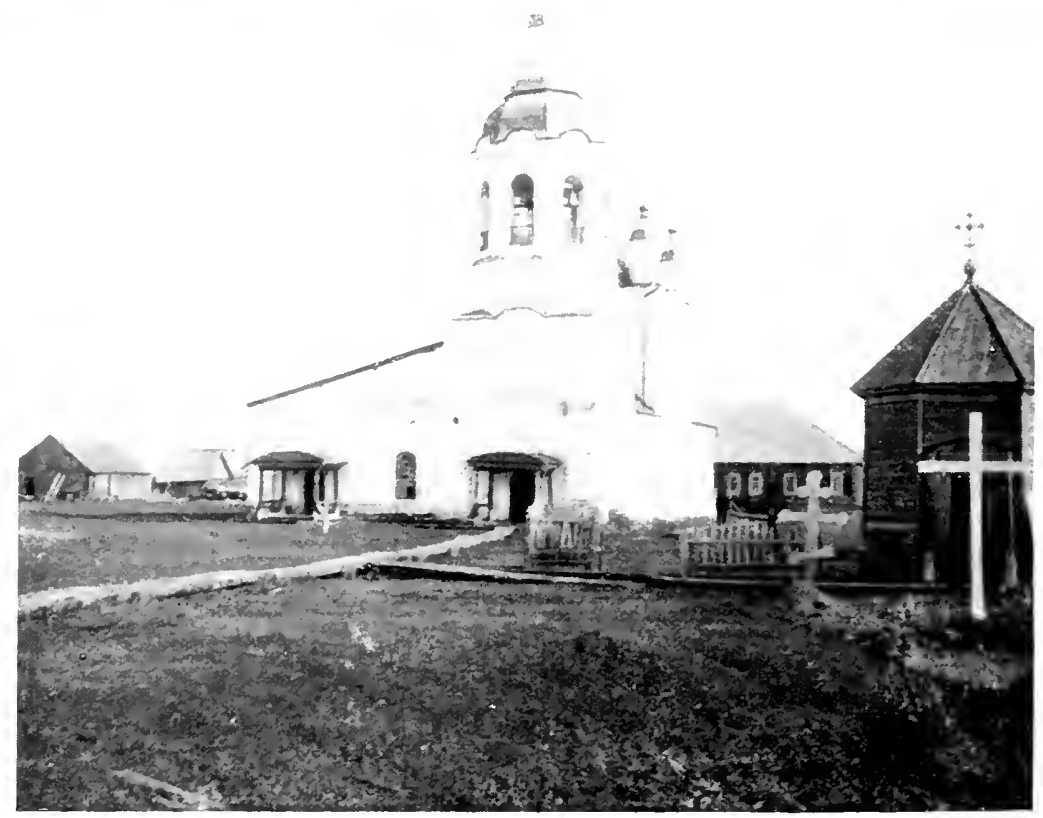

TIE CHI RAL OF THE: TROLPNKIY MOXANTERY 


\section{DUDINKA TO THE KUREIKA}

and moss and trees begin. Up to this line the river rises every spring, and the difference in the water level may be more than 30 feet.

It is striking how much higher and steeper the east bank is than the west everywhere along here. As I have said before, in these regions, where the soil consists entirely of loose material, it can only be due to the effect of the earth's rotation.

I sit and ponder over this as we glide along past the bank. It was the well-known naturalist, von Baer, who first pointed out this remarkable feature in the Russian river's, and explained it as an effect of the earth's rotation; but, of course, he met with much opposition. I am reminded especially of a paper $I$ once read by the German oceanographer Zöppritz, in which by a mathematical calculation he tried to prove that the effect of the earth's rotation on running riverwater could only be to make the water slope a little, so that it would be slightly higher on the right side than on the left, but otherwise it would have no effect; and the excavating power of the river, he thought, must remain precisely the same on both sides of its bed.

That was it, as far as I can remember. But here Zöppritz made the gross blunder of assuming that river-water at every depth flows with the same rapidity over the whole width of the river. If that were the case, his argument would be right. But as it is never the case in nature, he is wrong, especially where the river is a wide one. If we suppose for a moment that the river flows through a lake, it will be obvious that the stream cannot be equally divided over the whole width of the lake, but the running water must, on account of the earth's rotation, have a strong tendency to follow the right-hand shore, especially in high 


\section{THROUGH SIBERIA}

northern latitudes. But the same thing must also happen in a wide river. The water does not flow at the same rate over the whole width of the river; the most rapidly flowing water will, therefore, have a tendency to make for the right side of the bed. We must, therefore, expect as a rule to find the strongest stream on that side; and when we remember that the transporting and excavating capacity of water increases by the sixth power of its rate of flow, it will be easy to understand that the river-bed must be dug deepest there, and that the stream will wear away the right bank more than the left.

If the river is comparatively narrow and deep, this is less marked, as there is then less difference between the rates of flow. From this it is not to be wondered at that in so wide and shallow a river as the Yenisei there should be a great and striking difference between the right and left banks, wherever the soil is loose, so that excavation is relatively easy.

Bedded rocks are not to be seen anywhere here, only sand and clay. In many places I have seen horizontal stratification high up in the landslips of sand and clay along the bank. The strata have mostly been deposited under the sea, and the whole of this flat country was a sea-bottom at no very remote time, geologically speaking. Many marine shells have been found in these strata which bear witness to that. Then the sea has receded (or the land has risen ?) and the former great submarine plains have come above the sea. To a small extent they are also covered on the top by old river deposits.

Sometimes the clay in the landslips is remarkably dark in colour. This may indicate that it is bituminous (carboniferous), or that it is mixed with layers of peat; though this does not seem very probable. 158 


\section{DUDINKA TO THE KUREIKA}

I saw rocks, large and small, all the way along the shore; sometimes fairly big, as much as half the height of a man or more. Only in a few places did these rocks lie up on the bank itself above high-water line. Most of them were on the flat foreshore near the water. I never saw them imbedded in the strata in the steep slope of the bank, and it did not look as if they could have been washed out of these strata; they are most likely to have been carried to their present position at a comparatively recent time. It was chiefly along the east, or right bank that I saw these rocks.

Some of them are fairly angular, not unlike erratic blocks from the Ice Age, while others are more rounded by water, though few of them have attained the form of round boulders. I can see no other explanation than that these rocks have been carried by the riverice, in any case the larger of them; but it must be admitted that in some places they are so large that it seems difficult to imagine how even the ice could manage them; they may sometimes be nearly the height of a man. But it has an immense force, this ice, especially in the spring, when it is crushed together in huge masses and carried along by the rushing flood. It may then push large rocks before it bit by bit along the bottom and sides of the river. Even if they are only moved a little way each time, this would mount up in the course of years. Smaller stones, that are frozen into the ice and are carried with it when it breaks off from the bottom, may be transported for long distances at one time.

How far these stones may have been transported I do not know, as I had no opportunity of examining the nature of the rock, nor of finding out where the different rocks occur in this country. But in any case they must 


\section{THROUGH SIBERIA}

have travelled a good way, as there is no bedded rock for a long distance up the river here.*

Even the natives seem to find these rocks remarkable, and have no idea of how they can have been brought to their present positions. Middendorff mentions an enormous block lying on the Yenisei below Dudinka, to which the Samoyedes make sacrifices, "because," they say, "so heavy a stone can have been brought here by none other than the Creator himself." This is something like the popular belief with us: the large erratic blocks from the Ice Age are called giants' stones, which have been thrown or carried to the spot by giants or trolls.

A beautiful sunny morning with blue sky; it is grand, and almost warm, to stretch oneself in the sun on deck.

Imperceptibly the trees have become thicker and thicker as we have gone south, and now we have real forest; rather thin and with no very big trees, but still forest, mostly larch, but with a few firs here and there, and some birches, which are already quite yellow. Autumn begins early here.

And this forest, that we are now slowly gliding into, is the most extensive forest in the world. From here it spreads unbrokenly to the cultivated tracts and steppes of the south, and far to the south of Lake Baikál-an extent of more than $\mathbf{1 2 0 0}$ miles in a straight line from north to south-and from the Urál Mountains on the west to the Pacific and Kamchatka on the east, more than 3700 miles, a single continuous mantle of forest, only broken by the broad waters of quietflowing rivers. This is the Siberian taigá.

* Farther north on the coast of Siberia I saw in 1893 large rocks which I considered must have been brought there by glaciers during an Ice Age ; but I am still unable to form an opinion as to how far south this theory may hold good.

160 


\section{DUDINKA TO THE KUREIKA}

What endless, monotonous, slightly undulating plains, with shallow valleys along the rivers and water-courses. At first they are almost entirely bare, with only moss and a little grass, up in the far north-the desolate tundra; then a few osier-beds here and there; then willow and alder and a few birches scattered far and wide. But then the forest begins, thin at first; then thicker and higher; but the country remains as monotonous as before. And yet-and yet it has its own strange attraction. One's thoughts are drawn to this wide horizon ; one longs to follow the nomad in his free, unfettered life over these boundless plains.

Even the tundra and the taiga have their poetry, their melancholy and their bright dreams in the great, simple features of this eternal round-in summer, when all is green; in the russet of autumn with the blue lakes and the reedy streams; in the endless white mantle of winter, with the gleaming sun and the crackling frost and the raging snowstorm; and then the long winter night, while the moon sails calmly over the great white surface-and at last the spring, when life awakes once more, and the brooks begin to murmur beneath the snow, and patches of ground appear, and flocks of birds come up from the south, geese and ducks and snipe, by thousands and millions.

North of Potapovskoye a house stood high up on the hill in the forest, where a criminal exile lived. $\mathrm{He}$ had been there many years, was married to a Dolgan woman and had several children. A man in a red blouse came running down from the house. He stood and waved again and again; he wanted to get us to land, probably having a message to send, or perhaps he wished us to take him on board; but unfortunately we had no time to stop. 


\section{THROUGH SIBERIA}

On the flat green bank on the west side were some groups of large white birds. I also saw a flock of them to the north of us; then they rose and flew in a long line, with long, outstretched necks. They were swans on their way south.

Here and there on both sides of the river we began to see low green meadows, on which the hay had been cut and made into large stacks; there, I suppose, it has to stay until it is fetched in the winter. It was strange to see this, as here they have the great forest and can help themselves to as much timber as they please; it has no value. Nor have the people much to do in winter, in this country, where the forests are left to take care of themselves. One might suppose, therefore, that they would cut down a few trees and put up some sheds for the hay, instead of having all the trouble of making stacks, and then getting a great deal of it spoilt by wet in the autumn and snowed under in winter. It made me think of Norway, where we even take timber far into the mountains to put up sheds for the mountain hay. But, perhaps, in old days our forefathers had not got beyond haystacks either, some hundreds of years ago. It may take some time yet for the Siberian peasant to get as far as a barn; he will have to learn to build a cow-house first.

Another thing is that here the hay is not worth so much as with us. It is only wild grass, long and coarse, and therefore probably not so much damaged by wet either. In Yeniseisk the price of hay varies between 8 and 12 kopecks a pood, usually about 10 kopecks, or about $14 s$. a ton. In times of scarcity and famine it may rise to 20 kopecks a pood. But in Krasnoyarsk prices are much higher. Hay is, as a rule, about 20 to 30 kopecks a pood, and in time of scarcity it may go up to 50 or 60 kopecks; that is, about $70 s$. or $80 s$. a ton. 162 


\section{DUDINKA TO THE KUREIKA}

In the evening we had a stiff head-wind and rain, so that we could not stay on deck, where we generally spend the whole day, to see the country we are passing through. I must say it is a tiresome life having to sit still so long, for one cannot stretch one's legs much on this little craft; though for my part I walk up and down the short deck as much as I can. But we are making good progress and have no right to complain.

At 9 P.M. we anchored in pitch darkness off Sultanovski Selo. On the chart it is called Palavinaya, which means "half"; no doubt half-way between two stations.

I can hear the murmur of the forest out there in the darkness-a familiar sound. It is like the voice of the forest at home. Here, too, the forest whispers eternally over the endless plain.

Sunday, September 7. Still on to the south. We begin to see a few cows and horses grazing along the bank, and that has an almost home-like look.

The same woods of larch and fir, with a good deal of yellow foliage among them, mostly birch, but also aspen, and here and there some deep-red mountain ash trees-the same flat land, without a single ridge, however small, to be seen over the bank of the river, which is here rather lower than it was farther north. It cannot be much more than 60 feet high on the east side, and on the west it is still lower. The trees are not high, nor do they stand very close together, but they cover all the land.

It is like seeing horizon after horizon of the same blue, rolling water, when one is at sea. Here we are sailing on the river, day after day, with the same river surface, the same flat banks, the same flat, endless forest country-before and behind us the river and its banks disappear below the horizon, and as soon as 


\section{THROUGH SIBERIA}

the slopes are a little way off, in front and behind, they appear to be hanging in the air, with bright water below them, in which they are reflected with a reversed image ; and this mirage is more pronounced the farther off they are. This is evidently caused, as I said before, by the water being so much warmer than the air. At 6.30 P.M. the temperature of the water was $9.9^{\circ} \mathrm{C} .\left(49.8^{\circ} \mathrm{F}\right.$.), while that of the air 6 feet above the surface of the water was $8 \cdot 2^{\circ} \mathrm{C} .\left(46 \cdot 7^{\circ} \mathrm{F}\right.$.).

On the right bank, just opposite Selo Igarskoye (in latitude $67^{\circ} 27^{\prime} \mathrm{N}$.) we saw for the first time some outcrops of rock. These knolls were quite low and only just rose above the sandy bank. Seen through the glass the rock looked like a rather loose schist, with layers sloping towards the south and east.

A little farther south, at Cape Karmakul, there were also some rocky knolls low down on the left bank. The name, Karmakul, seems always to be connected with stony or rocky places, as, for instance, in Novaya Zemlya. The word is not Russian, but might perhaps be derived from the Pomors or Samoyedes?

There was no indication that the altitude of the land in this district was different from elsewhere. The rocky knolls were covered over with the same horizontal strata of sand and clay and to the same height as usual ; but in many places on the bank there were great heaps of stones, and these may have been, to a great extent, simply the remains of outcrops that had weathered and fallen to pieces.

It was a fine evening, and the nights are quite mild now.

We anchored at 8.30 off Sushkóvo (latitude $67^{\circ} 6^{\prime}$ N.). We went for a walk ashore in the dark and called on the people of the only house there was. It was one of the mail-stations along the river. We found only 1.64 


\section{DUDINKA TO THE KUREIKA}

women and two young boys and some small children at home. The men were out fishing. They all lived in two large rooms, where there was not space for a man to stand upright under the beams. There was also a cabin close by, where they told us with pride that the priest lived when he came there once a year.

The woman of the house was from Turukhansk, and had never been any farther than that. She could not read or write; but Vostrotin thought the man probably could not either ; that may seem rather surprising for a postmaster, but it is rare to find people who can read and write in these parts, beyond scrawling a few signs for their fishing accounts. The man, whose age was twentyseven, was born here, where his father and grandfather had also lived.

There was a girl there, who had come from the Angará with her father and an elder brother for fishing in the summer and hunting and trapping in the winter, while the mother and the younger children stayed on the Angará.

The Government pays for carrying the mails, and these people kept 20 reindeer, chiefly for the mail and for posting. During the summer the reindeer were looked after by an Ostiak somewhere in the forest. Besides them they had two cows and one horse. But fishing in summer and trapping in winter seemed to be their chief source of income.

There was a good deal of game in the forest here, capercailzie, black-game, some hazel-grouse now and then, hares (but none last winter *) wild reindeer and some elks, besides foxes, both red and white, and not a few

* It is worth remarking that, as I afterwards learned, the catch of squirrels farther south has been very poor for the last two years and especially last year; the squirrels seem to have disappeared. The great variations in the number of these rodents must certainly be due to the ravages of epidemics, as in the case of the lemming. 


\section{THROUGH SIBERIA}

bears; three or four of these had been seen not far away a few days before we came. Wolves were not numerous here.

As we were going, the girl from the Angará asked for some medicine, as she had felt poorly for some time. Loris-Melikov gave her some antipyrin and other things. It cannot be said that they are well off for doctors here. There was supposed to be a surgeon in the district; but apart from him there is only one doctor for the whole of this Turukhansk district of a million and a half square versts (about four times the size of Norway). He lives in Turukhansk, and has three surgeons and one midwife in the whole district. It is obvious that they do not go very far. They cannot even manage to vaccinate a reasonable proportion of the natives.

When, therefore, there was an epidemic of smallpox here a few years ago, its ravages were frightful, and the doctors were powerless. With contributions from the Siberian members of the Duma the Red Cross Society sent out an expedition from Krasnoyarsk, but too late in the spring, when the snow had already begun to melt. They got past Turukhansk, but could not penetrate any farther into the tundra on account of the state of the ground. They went far enough to find tents where all was still; the occupants lay dead within, five or six of them, and outside lay the dead reindeer, those that had not been able to break loose and escape. In some tents they found people still alive, but in a terrible state, without fire and nearly starved to death, covered with sores that were not yet healed. How many such tragedies the great tundra conceals!

We have now left Samoyedes and Yuraks behind and are in the land of the Yenisei-Ostiaks and Tunguses. There were a couple of Yenisei-Ostiaks here. One of them was sitting by the fire in a birch-bark tent near 166 


\section{DUDINKA TO THE KUREIKA}

the shore as we landed. He had not a particularly Asiatic look.

As we came down to the shore to go aboard, the owner of the place and his men were just coming back from fishing. They had only caught a few big pike, which looked unpleasantly thin and voracious with their huge heads and jaws. One pike was as long as the boy who was carrying it ashore. In the boat was the other Yenisei-Ostiak and we wanted to see him too. We struck a match to look at his face, but we thought he looked as if there was a good deal of Russian blood in him. They were evidently very mixed, these Yenisei-Ostiaks.

Monday, September 8. On to the south. The same landscape, but beautiful sunny weather and a wind, so that we can use the sails. It is curious how the trees on both sides are mostly foliferous everywhere here; the high larches and firs, and the Siberian cedar, which is also beginning, tower up here and there like giants above the foliage, which is chiefly yellow birch, with some alders and osiers among it, and scattered splashes of red mountain ash. The coniferous forest has been destroyed by fire over and over again in course of time along this river. Careless travellers or fishermen land to cook food-or nowadays to boil water for their tea -and leave their fires behind without taking the trouble to put them out. Then the forest often catches fire, and the flames may spread unhindered over an immense range. Nobody takes any notice of this. The forest has no value here.

So it has gone on from time immemorial. First it was the primitive hunters and fishermen who went up and down along the river. In recent centuries the Russians have joined them. One cannot, therefore, expect to find the primeval forest undisturbed any- 


\section{THROUGH SIBERIA}

where along a river like this. It will consist chiefly of younger trees. In the district we are now going through it is even difficult to find a continuous stretch of large coniferous trees. There are therefore many foliferous trees, which are usually the first to grow again when the old forest has been destroyed by fire.

Another curious thing is that all this forest is so thin. There is so much space between the trunks, and the trees are not really big either, even where they grow tallest. But, of course, it must be remembered that all these trees here grow on frozen soil. On the top there is a shallow layer which thaws in the summer, but underneath the soil is eternally frozen, and there are often thick layers of white ice which never thaws. The roots of the trees cannot, therefore, strike down, and must grow horizontally along the ground near the surface. Even the fir cannot strike its tap-root downwards here, as it would immediately come upon frozen soil and ice. It will, therefore, be understood that these trees must have more room for their roots than they would require if the roots could go farther down, and there must, therefore, be more space between the trunks; nor can there be so much undergrowth, as the roots are in the way.

I sit here pondering over the riddles of this forest. Here we are still in latitude $67^{\circ} \mathrm{N}$., and the climatic conditions are far less favourable than anywhere else, even in northern Norway. The mean temperature for the year is here below- $10^{\circ} \mathrm{C} .\left(14^{\circ} \mathrm{F}\right.$.), whereas even in Finmark it is above freezing-point. It is true that the summer here is very warm. 'The mean temperature for July may be about $12^{\circ}$ or $13^{\circ} \mathrm{C}$. $\left(53^{\circ}\right.$ to $57^{\circ} \mathrm{F}$.) perhaps, but even that is not very much higher than we can have it in Nordland and West Finmark.

How is it then that the trees grow so well here, and 168 


\section{DUDINKA TO THE KUREIKA}

on a frozen soil, too? Admitting that the soil is good, deep and rich in mould, that is not sufficient to explain the rapid regrowth of the forest, even where large tracts have been burnt. One is reminded of many places among our mountains, where the climatic conditions may seem to be at least as favourable as here, but where it is extraordinarily difficult to get the forest to grow again when once it has been cut down, even though the soil may be quite good.

I can only suppose that it may have something to do with the description of tree. These trees here, the Siberian larch, the Siberian spruce and the Siberian cedar, must in many respects be capable of greater resistance than our kinds of tree. It does not seem likely that our spruce or our fir would thrive here.

But if this is so, it seems to me that it would pay to make the experiment of introducing trees from here on our soil, especially where the climatic conditions are difficult for our own kinds, as they are up in the mountains, where the forest is now dying out. I cannot help thinking that this Siberian larch, for instance, would get on well, even where our spruce succumbs; and there is the additional advantage that under fairly favourable conditions it grows uncommonly fast. Larch-wood has the property of resisting decay remarkably well, being, as far as I can judge, something like juniper in this respect; but larch-timber is said to float badly and be liable to sink.

It may well be imagined that precipitation and the snow conditions in winter may have something to do with the growth of the larch. Here the winter is unusually cold, with little and dry snow, so that the trees are not broken down much. In Norway we may have heavy falls of wet snow, which are very bad for the trees. But I see no cogent reason for supposing that it would 


\section{THROUGH SIBERIA}

be so very much more difficult for this Siberian larch to support the snow than it is for our spruce. It is true that it often has large branches up near the top, but, on the other hand, it sheds its needles in winter.

The Siberian spruce must also be more hardy than ours, since it can grow here in such conditions.* And then there is the Siberian cedar (pinus cembra), which yields an extremely valuable wood for all kinds of furniture and modelling work, as it does not warp like most other woods, even fir and spruce. Besides this, cedar-cones contain the edible cedar-nuts, which are a source of income to many people in Siberia; oil is prepared from them. This tree can grow tall and thick and luxuriant, with its long, bushy green needles, even here on this frozen soil.

Here we can see how it is that the Siberian trees drift to sea in such quantities. There are plenty of them overhanging the river-bank. The flood water undermines the bank, which slips into the river; the trees lose their hold with their spreading roots and fall. Then the flood takes them next spring and carries them out to sea, where they drift with the ice and are, perhaps, finally cast ashore somewhere on the coasts of the Arctic Ocean, or drift right over to Greenland and provide the Eskimo with the wood they require for their boats and implements.

We saw many of the Yenisei-Ostiaks' birch-bark tents along the banks, especially on the low west side, where I could count as many as eleven tents along the river at one time; they had come there to fish. I had been wishing to see as much as possible of this mysterious

* Since uny return our director of forests, Mr. Saxlund, has told me that he particularly wishes to make experiments with the Siberian spruce in Norway, as he thinks it must offer great advantages, even more than the Siberian larch.

170 


\section{DUDINKA TO THE KUREIKA}

people more than any other; but we had no time to stop here, and I was promised that we should find plenty of them farther south.

They are unlike any other people in Siberia. Their peculiar language does not seem to be related to any other living language in this part of the world; it must have an altogether different origin. It does not appear to be agglutinative, like the so-called Altai languages, such as the Samoyede, the Finno-Ugrian, the TurcoTatar and others; but it is rather a one-syllable language originally, more like Chinese. But the YeniseiOstiaks and their language have not been investigated since Castrén's days until quite recently, when a Russian, Anuchin, has spent some time among them, and the Finnish philologist, Kai Donner, has also visited them for a few months.

Where these people originally came from it is not easy to decide. But in any case it is certain that they must formerly have been far more widely spread on the south than they are now, and it is probable that those now living are a last remnant of a race that in former times was widely diffused in Asia. The Norwegian scholar, Dr. Andreas M. Hansen, has even put forward the hypothesis that these Yenisei-Ostiaks belonged to the same race as the short-skulled primitive people which inhabited Scandinavia before the Germanic immigration, and which, perhaps, was spread over a great part of Europe. Indeed, he goes so far as to make them related to the Hittites, Pelasgians and other ancient peoples of southern Europe and the Mediterranean countries.

If this were so, these Yenisei-Ostiaks might claim no ordinary share of attention. But even if such hypotheses as these may rest upon a slender foundation, it is in any case certain that these Yenisei-Ostiaks are 


\section{THROUGH SIBERIA}

an extremely interesting people, who deserve closer investigation than has hitherto been bestowed on them. Especially as they seem to be rapidly dying out, their total numbers being probably between 700 and 900, in any case not 1000 .

In his interesting book "Aus Sibirien," which I have with me on board, Dr. Radloff maintains that the Yenisei-Ostiak people, or Yeniseians as he calls them, must formerly have been widely diffused to the south, and must have lived in the Altai and on the northern slopes of the Altai and Sayan Mountains. He finds, for instance, that in the district in which the River Tom rises, three-fourths of the river names are YeniseiOstiak, the only explanation of which can be that a people speaking their language or one closely akin to it formerly inhabited the region.

Radloff thinks that they were the same people as are mentioned by Chinese historians as dwelling in these districts in the seventh century, and are called by them Bila or Gelochi. In fact, he thinks the Kirghizes, whom the Chinese until the ninth century called Hakas,* were also originally a kindred tribe, with a kindred language; and all these peoples are described by the Chinese as originally blue-eyed and fair-haired.

It was not until later that the Kirghizes adopted a Turco-Tatar language, and now they are included among Tatars. Through intermarriage with surrounding tribes these people may afterwards have become more or less dark-complexioned and black-haired.

Some years ago the Finnish philologist, G. J. Ramstedt, on the basis of Castrén's notes on the YeniseiOstiaks' language, suggested what seemed to be weighty

* Other Chinese names for this people were Kan-kuen or Kienkuen, and Ki-ko, and later (in the thirteenth century) Ki-li-ki-sse (i.e. Kirghiz). 


\section{DUDINKA TO THE KUREIKA}

reasons for regarding this language as a branch of the Indo-Chinese linguistic stem and as nearly related to Tibetan. This would give us a wide extension to the south for these people, and would also help to explain the fact that the Chinese historians first mention them as white and un-Turkish in appearance.

They are too tempting, these dark riddles of the remote antiquity, the migrations and the origin of peoples, especially here in this immense country. We cannot solve them, our knowledge is far too deficient. -But here comes our smiling Alexei to announce that dinner is on the table-an announcement that is always just as welcome as the dinner-bell on the biggest ocean liner. To-day it is a fine grilled sturgeon, a dish at which Alexei is a master.

At five in the afternoon we anchored at the mouth of the River Kureika, where there was an oil depot from which the $O m u l$ had to replenish her supply.

When we went ashore, the first sight that met our eyes was a tame wild goose, which stood calmly on one leg looking at us, and then waddled up to the house. It had been brought to the people here this summer by natives who had caught it as a gosling. It now made long excursions, flying right across the Yenisei to the west bank, but always came back to the house. It was so tame that I afterwards saw the woman carry it in, petting it and stroking it, which it seemed to like.

While Vostrotin went to the house to have a chat with the people and discuss their affairs, Loris-Melikov and $I$ went into the forest.

It was wonderful to be in the woods again. There was rich soil, firm and dry to walk on, with bilberry and marsh whortleberry bushes, as far as I could make out, but no berries to be seen; they had all been killed by frost in the spring, we were told. It was flat inland, 


\section{THROUGH SIBERIA}

with no chance of finding a single mound from which to get a view over the forest-clad plain. Otherwise it was not very different from a forest at home, and one was apt to forget that we were still far north, somewhere about the Arctic Circle, or a little to the south of the latitude of Bodö ; we were just in latitude $66 \frac{1}{2}^{\circ} \mathrm{N}$.

There were many birches and few large coniferous trees to be seen, though smaller ones were shooting up everywhere among the birches. There was spruce, very like our spruce, but with smoother bark on the young branches; there was also larch, and a luxuriant green tree very like a fir, with long needles, like those of the New Jersey scrub pine. This was the so-called Siberian cedar, which is really a sort of fir (pinus cembra). It is highly prized among the natives, because the seed of the cones is small nuts, cedar nuts, which are good to eat, and farther south great quantities of them are gathered every autumn; but as it is rather troublesome to climb up the trees, it appears to be usual to cut them down in order to gather the nuts, and then let them lie. As I said before, timber is of no value here. These are the nuts that are brought by the Russians in large quantities to places in Finmark, and are there called Russian nuts.

Of these varieties we here and there came upon single trees of the size of a good big timber spruce at home. These were no doubt the remains of a forest of larger trees that had once been here, but had probably been burnt. Otherwise there was almost nothing but small trees, with patches of bog here and there; we saw some alders, and a kind of sallow now and then among the birches.

As we went back towards the house we saw some wild briar bushes with red hips. There was rank high grass in some places and all kinds of herbs. Cloudberries were also said to be common, but they had no 174 


\section{DUDINKA TO THE KUREIKA}

berries this year either. Much of the ground under the trees was covered with the withered white hair of "mare's tails" (Equisetum), which grew there to a good height and in great quantities.

In walking back through the forest, we suddenly found ourselves on the slope above the river. The slope was overgrown with the most luxuriant forest vegetation, and yellow birches hung over the sandy bank far below. It was just like coming out of a primeval forest.

As we were following a path leading to the house along the slope, we unexpectedly came upon two wooden crosses which stood under the birches at the very edge of the clearing. They were two old graves in this sylvan solitude; a beautiful spot had been chosen for them, but long, long ago, and they were now almost entirely overgrown and hidden by the birch forest.

On one of the graves lay the remains of an old sledge, which showed that in any case that was a native grave, probably of Yenisei-Ostiaks. They put sledges on their graves, no doubt in order that the dead may travel in them to the land beyond. As we went on towards the house we came upon two more graves, even more overgrown by birches than the first.

The people of this place only stay here during summer to buy fish, which is salted; they return to Yeniseisk before the winter. The man told us that just now there were great numbers of geese and ducks a few miles up the Kureika River; they had been collecting for their migration to the south; but the people had no time to think of them, they were all so taken up with fishing. There was also a lot of game in the forest, they said, capercailzie, black-game and hazel-grouse.

All the graphite that was brought by the lighters down the Yenisei to the Correct came from a place about 60 miles up this Kureika River. There were 


\section{THROUGH SIBERIA}

nearly 30 tons of it, which were brought here in two journeys by the Angará boat that lay on the shore. There was a lot of graphite up there; but it was not worked, and this was only taken as a sample.

They are badly off for communication with the world in this country. As we were sitting in the house, Vostrotin told us of his experience here thirteen years ago. He was then going up the Yenisei from the estuary, and met policemen farther down who were going round to tell the fishermen that those of them who were still on the roster as soldiers would have to go at once to Yeniseisk and from there to Krasnoyarsk, as there was a mobilization. Vostrotin could not find out the reason of this mobilization; the policemen did not know that, and he could not imagine with whom Russia was at war. When at last he got as far as this Kureika River he was told that the Tsar was at war with seven other Tsars, and that things were going well for "our Tsar." Who these seven Tsars were, nobody could explain; but they were Angeleska* and Franseska and a few more; that was all he could find out.

On arriving at Yeniseisk, Vostrotin heard that it was the Boxer rising in China that had led to armed intervention by the Powers and the combined march on Peking. The English and French were there right enough; if we add Germany, America, Italy, Japan and China, that makes seven.

Vostrotin was not very proud of the condition of his country, as regards education, newspapers and intellectual interests. He compared it with what occurred to him in Norway in 1899. He had then been on the Murman Coast, at Alexandrovsk, waiting for Admiral Makárov in the Yermak, which did not come.

On the way back he came to Hammerfest, and while

* This was originally the designation of Queen Victoria. 


\section{DUDINKA TO THE KUREIKA}

taking a walk outside the town he went into a little hut to get something to drink. He found the peasant or fisherman who lived there, and was given some very good milk. He then asked for news of what was going on in the world. The man, who could talk Russian, answered that the Dreyfus case had been taken up again, and gave Vostrotin all the details of the trial. Vostrotin thought there was rather a big difference between this poor fisherman in a desolate part of Norway, who regularly read his newspapers and knew the details of the Dreyfus case, and the prosperous traders in Siberia, who did not even know with whom their country was at war, when they themselves were called to the colours.

Here in Siberia, however, the question is not merely that there are no papers, but that only a small fraction of the people would be able to read them, if there were any.

I privately wondered whether, after all, this was as great a loss as people generally imagine. Think of all the mud they are spared, and all the dirty politics that they don't have to touch. But I did not say this aloud.

Tuesday, September 9. We had not gone far from the mouth of the Kureika next morning, when we came into a thick fog and had to anchor. We could not see the bank close to us. It was a heat haze, which occurs when the vapours from the warmer river water are condensed in the colder atmosphere. As soon as the power of the sun increased, after a few hours, it cleared again and we were able to go on; and by midday we had the most glorious sunshine. We then saw to the north of us a blue wooded ridge inland. It must have been north of the Kureika. It was low; but still it was really a ridge that rose above the plain-the first hill we had seen on the whole voyage up the Yenisei, if we except the little mound at Dudinka. 


\section{CHAPTER IX}

\section{TROITSKIY MONASTIR, AND ON TO THE SOUTH}

Troitskiy Monastir and Turukhansk : Decline : The pristav : The guarded treasure : A plundering raid : The monastery church : Legend of a saint : A travelling priest : Tea with the pristav : The school : The town : A political exile : Convicts in caves : Yenisei-Ostiaks' tents : Canoes : Miroyédikha and beds of rock : Political exiles travelling : Villages : Moonlight : More luxuriant forest : Our pilot : The Yenisei-Ostiaks, their poverty-stricken life

\section{$W^{\mathrm{E}}$}

E had hoped to reach Svyato-Troitskiy Monastir (i.e. the Monastery of the Holy Trinity) that evening, but had to anchor for the night some distance to the north. It was too dark to go on.

Wednesday, September 10. But next morning, about half-past nine, we arrived. While still a long way off we could see the lofty white church of the monastery with its cupolas shining on the top of the river-bank over the forest and flat country, and by its side the green roof of a big house rose above the line of trees. On coming nearer we could also see a row of lower timber houses round it. This was the village.

A few years ago this place became the seat of the administration of Turukhansk district, and it is, so to speak, the capital here. Turukhansk formerly held that position; but it is inconveniently situated on the tributary Turukhan at some distance from the Yenisei, and thus off the line of traffic up and down that river. 178 


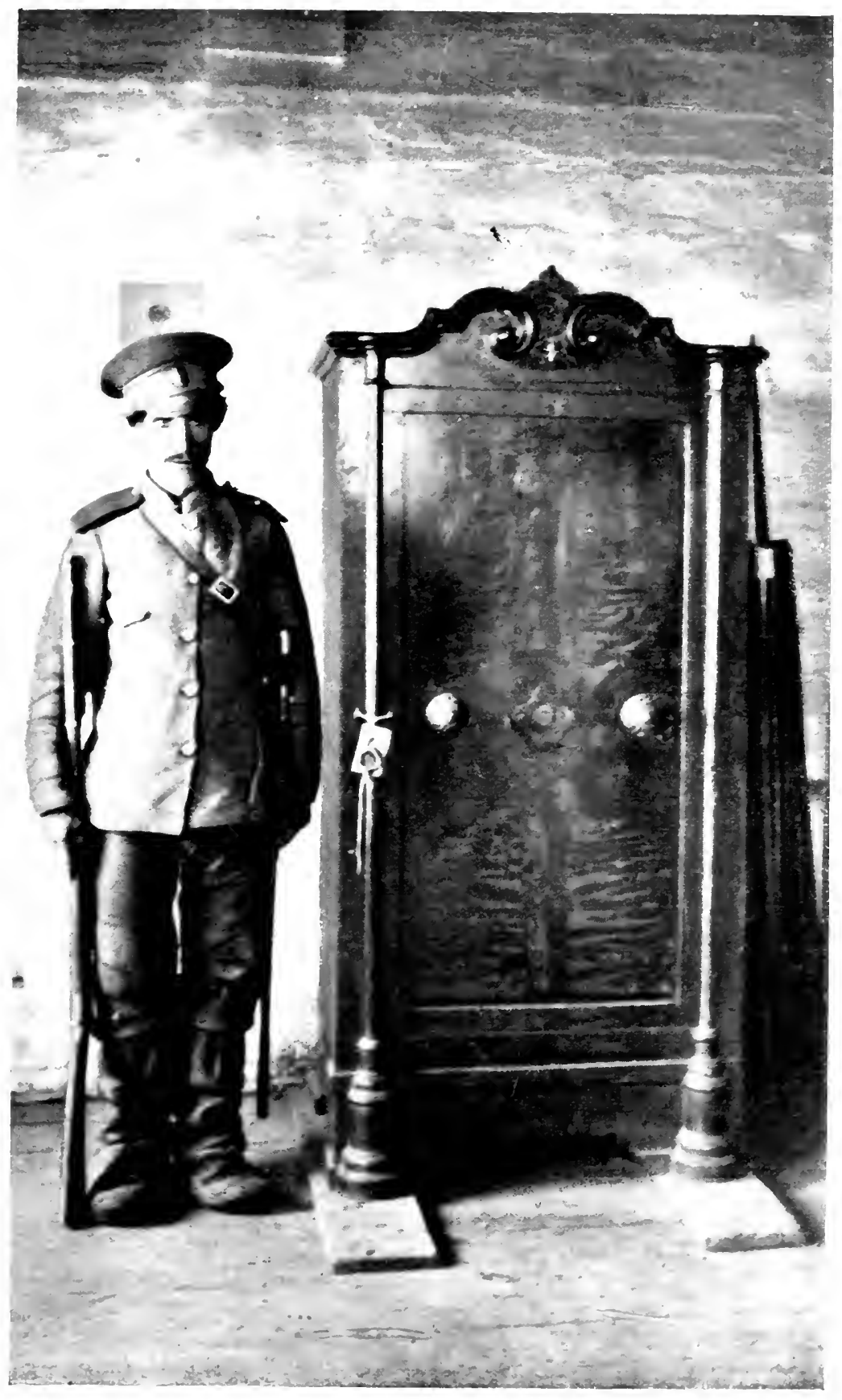

COANAK GOARDMG THE GOYERNMEXT'S MONEY 


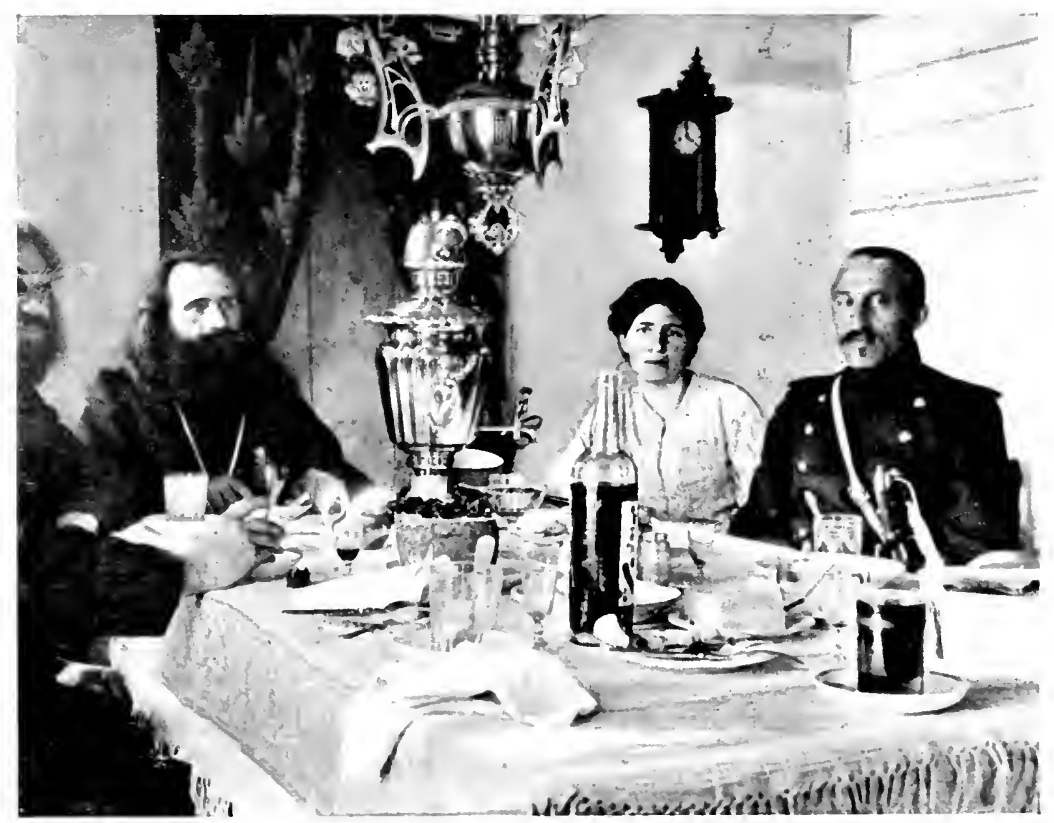

LAXCH WITH THE PRISTAY AXI) MH WIFE

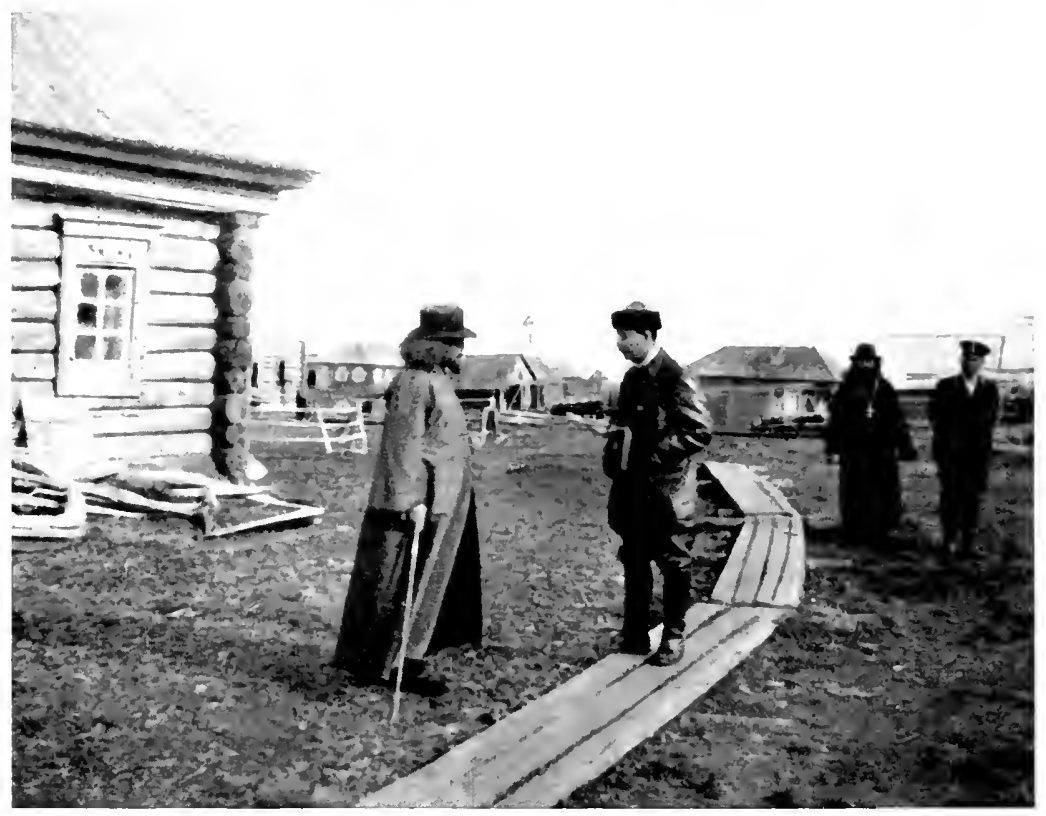

IX THE STREET OF TROITSKIY JONASTIR 


\section{TROITSKIY MONASTIR, AND TO THE SOUTH}

When, therefore, the Government buildings were burnt by robbers some years ago, it was thought that the opportunity ought to be utilized of moving to a more suitable place; and the choice fell upon the village here, by the well-known old monastery, where the great tributary, the Lower Tungúska, falls into the Yenisei.

But not all the citizens approved of the choice, or cared to be so near the clergy, I understand; for all the land about has been owned by the monastery from of old, including the islands in the river, where there is plenty of grass and good pasture. For the right of grazing and cutting hay the people have to pay a tax to the monastery, which places them in a position of dependence; even if this brings them a little nearer to the clergy and doubtless also to heaven, most of them would, nevertheless, prefer to be free; and, therefore, there were some who would rather have moved to the village on the south, with the attractive name of Miroyédikha (i.e. the myrrh-eaters), which stands on a firm, rocky soil, and where a good little harbour might be made, from what I heard.

It is strange how things have turned out. Turukhansk was founded when Mangaséya was taken and burnt by the Yuraks in 1662; and it then became the most important town in this part of the north, with over 600 inhabitants and an important fair. Its importance decreased after 1822 , when it ceased to be a town and became a village. Then it was destroyed by the 20 robbers, and now the centre of administration has been moved here, and new houses are being built. How long will it remain here ?

It seems, on the whole, that there has been a great decline all over the northern part of this country. In 1727 there are said to have been 1500 Russians living along the lower course of the Yenisei, and according 


\section{THROUGH SIBERIA}

to an old Russian map of the Yenisei estuary, dated 1745 , which appears to give a remarkable mass of detail, there was a fairly dense population the whole way, especially along the east side of the Yenisei, from Dudinka northward, right up past Dickson Island and eastward to the mouth of the Pyasina.

According to information gathered by Sidórov, there were, in 1824, 46 Russian homesteads north of Turukhansk, while at the time he wrote, in 1863, there were only 27. And now, I suppose, there are still fewer. About 1830, says Sidórov, 25 boats used to go from Yeniseisk to Turukhansk, and 30 traders carried on business there. They also did a large trade with the natives on the tundra, between the Yenisei and the Anábara. But now, in 1863, he says, only two good-sized boats and two smaller ones go from Yeniseisk to Turukhansk, and the trade with the tundra has entirely ceased.

In our time there is certainly more traffic and a livelier trade again, but it can be nothing compared with what there was once. This must be chiefly due to the fur trade, which was once so valuable, having greatly declined owing to too many animals being caught.

As soon as we had anchored we went ashore. On the bank were the first crows I had seen in Siberia. They flew up with the same flight and pretty nearly the same "voice" as our crows at home; but they were quite black. Crows-they are a sign of civilization; farther north along the river we have only had the company of gulls, besides geese and ducks.

We turned our steps at once towards the church, as we were told the post office was near it, and we expected letters. After passing the church we reached a long wooden building which, as we afterwards heard, belonged to the monastery, but was temporarily rented by the Government. This was the post office, and 180 


\section{TROITSKIY MONASTIR, AND TO THE SOUTH}

there also lived the highest official of the district, the chief of police, or perhaps more correctly the prefect of police (pristav). $\mathrm{He}$ is a sort of governor of the whole district of Turukhansk, which extends north as far as the Arctic Ocean.

There were no letters. Nor did we get any news of the world, later than what we had ourselves brought from Norway. I found out a long time afterwards that, as our letters were addressed to Turukhansk, they went to the old town on the tributary, where we never went, instead of to the new. And there they lay peacefully waiting, while we stood here bitterly disappointed.

Then we had to go to the other side of the passage, and call on the prefect of police, or pristav, Mr. Kibirov, a quiet, really pleasant and good-natured-looking man, who received us in a very friendly way. There was not a trace in him of the savage cruelty that one expects to find in so powerful a man in this country of convicts and exiles. He came from the Caucasus, so here again Loris-Melikov found a countryman. He was an Ossetin (pronounced Assetin), and they are the wildest people in the mountain districts of the Caucasus, and are often enough robbers, Loris-Melikov told me; but this one looked anything but wild or predatory. The Ossetins are Tatars (Cherkesses) and. Mohammedans, but our Ossetin here and his Ossetin wife were towns-people and Christians.

We arrived quite unexpectedly; but the pristav immediately went out and put on his full uniform with sword, which he wore in our honour all the time until we left.

The most remarkable thing I saw there was an almost empty room by the side of his office, with an iron safe containing the Government's money, by the 


\section{THROUGH SIBERIA}

side of which stood a Cossack with rifle and sword to guard the treasure. But he had not a very terrifying appearance, this guardian; he was a weak and innocentlooking fellow, who told us, indeed, that he was a descendant of the first Cossacks that conquered the country, and that there were not many of them left. One of these Cossacks stands every day by the side of that safe from morning till night. This custom was introduced after the robbery a few years ago.

Along one of the walls of the same room a number of cases were stacked. They contained vodka that had been taken from illicit liquor-sellers; but this was probably only a small fraction of what ought to have been taken. As every one knows, the Government has a monopoly of the sale of spirits in Russia and Siberia, and in the Turukhansk district all trade in liquor is prohibited on account of the natives. It is true that the Russian traders are allowed to take home a reasonable quantity for their own use, but they may not sell or give it to the natives. If a trader is found in possession of more vodka than he may be supposed to require for himself, it is taken from him. But, curiously enough, a good deal of liquor finds its way to the natives for all that, as we had several opportunities of seeing.

There are 10 Cossacks in this town; but there are 20 political exiles and convicts. In the whole Turukhansk district there are 90 political exiles, and last year alone 35 political exiles and convicts arrived, having been transferred to the district after serving part of their sentences. Ten of these Cossacks do not appear to be an overwhelming force for keeping these people in check; but for that matter they all looked about equally peaceable and harmless, exiles and Cossacks and police, as far as I could make out; only 182 


\section{TROITSKIY MONASTIR, AND TO THE SOUTH}

a few of the released convicts had an ugly look; and many of the people here are not very pleased at this addition to the population. On the other hand, they rather like the political exiles, as they are often worthy and capable men, who may be very useful.

But things are not always so peaceful as they now appeared. This is proved by the raid which $I$ have mentioned more than once. It was five or six years ago that a number of political exiles banded themselves together to the south of this place, between Turukhansk and Vórogovo, with the object of escaping from Siberia, plundering as they went. They were about 20 in number and had procured arms in various ways. They had evidently heard of the American system of " hands up," and they entered houses and took what they found. If anyone resisted, he was shot. In this way they went down the Yenisei plundering one village after another. It was at the beginning of winter, so they drove in sledges with horses and reindeer, which they easily procured without payment. It was mostly food and money that they took. In this village, at Troitskiy Monastir, a trader was killed and money taken. On reaching Turukhansk they seized the public buildings, shot the prefect of police and several traders, took the Government funds, amounting to 30,000 roubles, and then set fire to the buildings. After that they went on in the same fashion down the river to Dudinka, and from there across the tundra with reindeer towards the Khátanga and Anábara, with the idea of going on eastward through Siberia to America.

Meanwhile news of the raid had reached the Governor-General at Irkutsk, and he declared martial law over the whole country, and sent a strong detachment of soldiers northwards from Krasnoyarsk. From Dudinka a party of soldiers took reindeer over the 


\section{THROUGH SIBERIA}

tundra in pursuit of the fugitives, and came up with them before they had reached the mouth of the Khátanga. The house they were in was surrounded and a regular battle took place, which ended in more than half of the fugitives being shot down. The rest were captured and taken back to Dudinka and up the Yenisei. On the way some of them tried to escape, but were shot before they had gone very far; five out of the twenty reached Krasnoyarsk alive and were there hanged, as far as I know. The Government's 30,000 roubles were traced, and more besides, and some of this money is said to have found its way back to the State coffers.

But one could not imagine the possibility of such warlike excesses when standing in this peaceful office talking to this amiable man, who invited us in the kindest way to drink a glass of tea with him and his wife; the tea would soon be ready.

Meanwhile we went out to look at the monastery church. We were well received at the church door by the priest, or rather the abbot of the monastery. He looked very holy, had fine blue eyes, a straight nose and a well-shaped mouth. It was a perfect Christ head, with divided beard and long hair in curls over the shoulders; but the beard and hair were black. He showed us round.

The church contained large, well-lighted chapels. The saint, Vasiliy Mangaseiskiy (i.e. of Mangaséya), was buried there. His sarcophagus stood in the first large room we entered. Vasiliy was a man from the government of Yaruslav, in Russia, who came to Mangaséya on the Tas and lived there, and was buried there in the seventeenth century. But after that town had been taken and burnt by the native Yuraks in 1662 , the monk Tikhon of the monastery of Yeniseisk dreamed one night, so I was told, that he must go and 184 


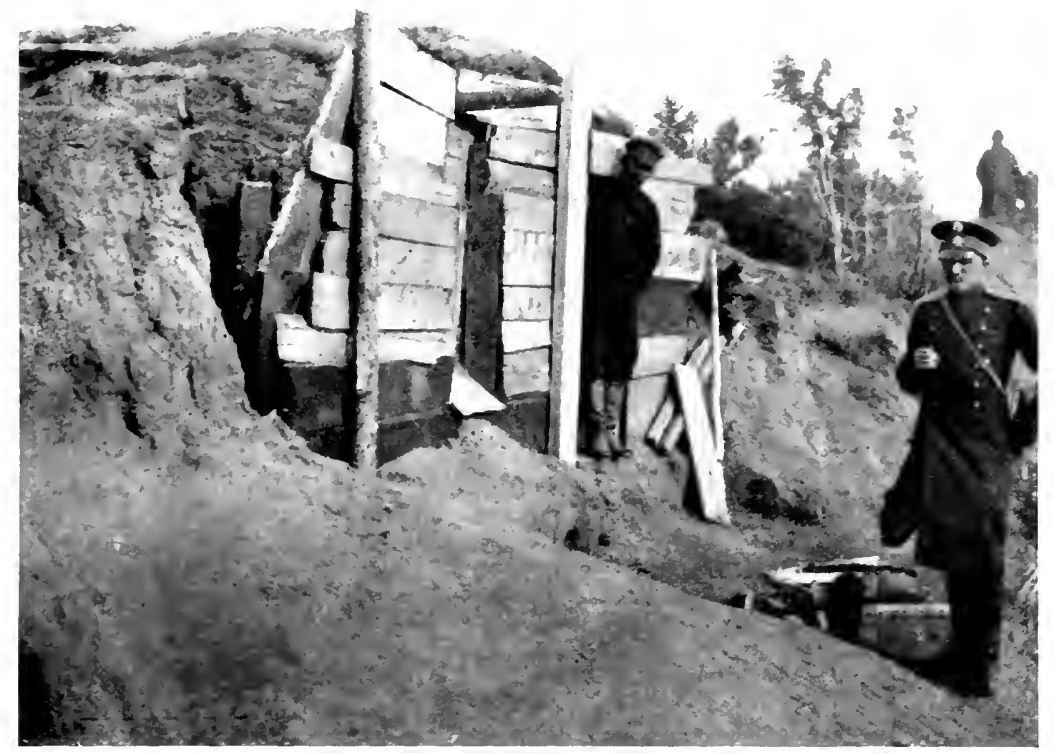

RELEASE CONVICT IN HIS "CAVE" DEG OLT OF THE GANHILL. THE PRISTAY ON RIGITT OF PICTERE

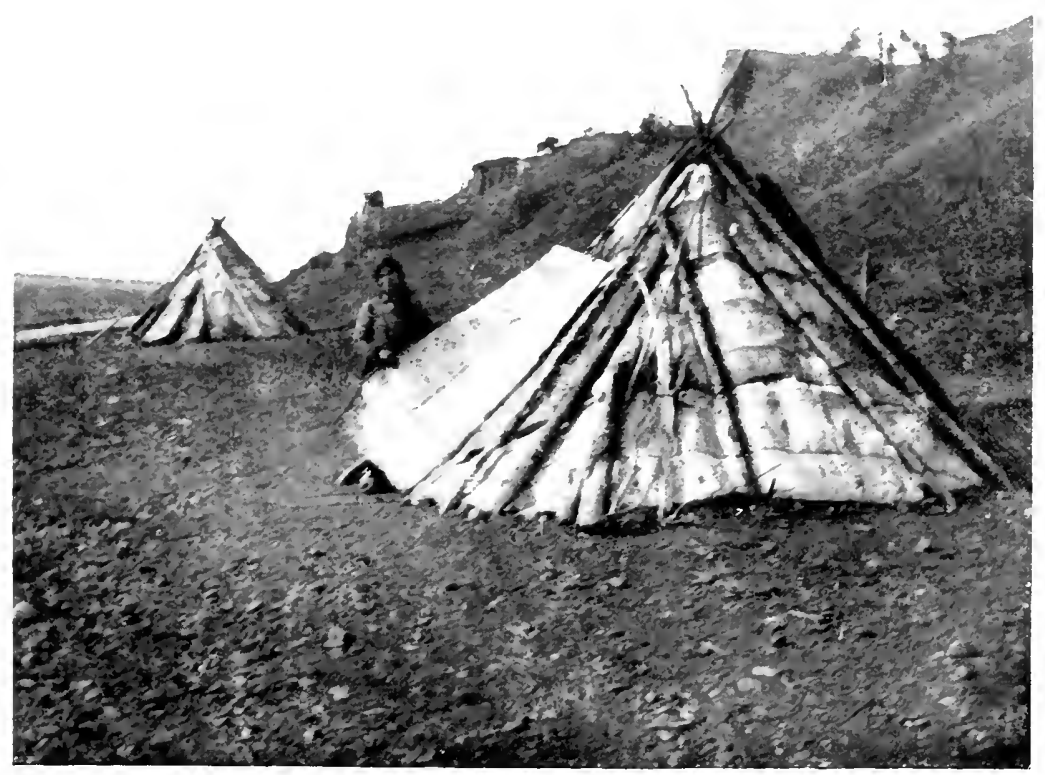

BIRCII-BARK TEXTS OF TIE LESISEI-GTIAKS, WITI THE IILTS OF TIIE CONIICTS IN THE: SANDHILL ABOVE 


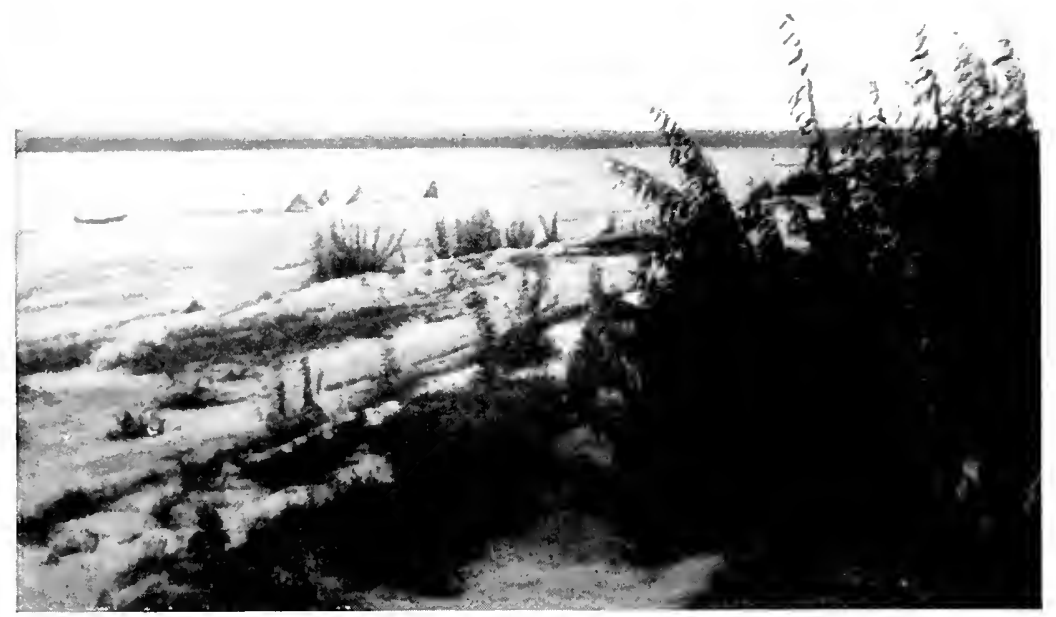

SINDY FORESIORE ON TIE: WESTERS SIDE OF THE YENISFI, WITI BIRCII-BARK TENTS (SEPTEMBER 10)

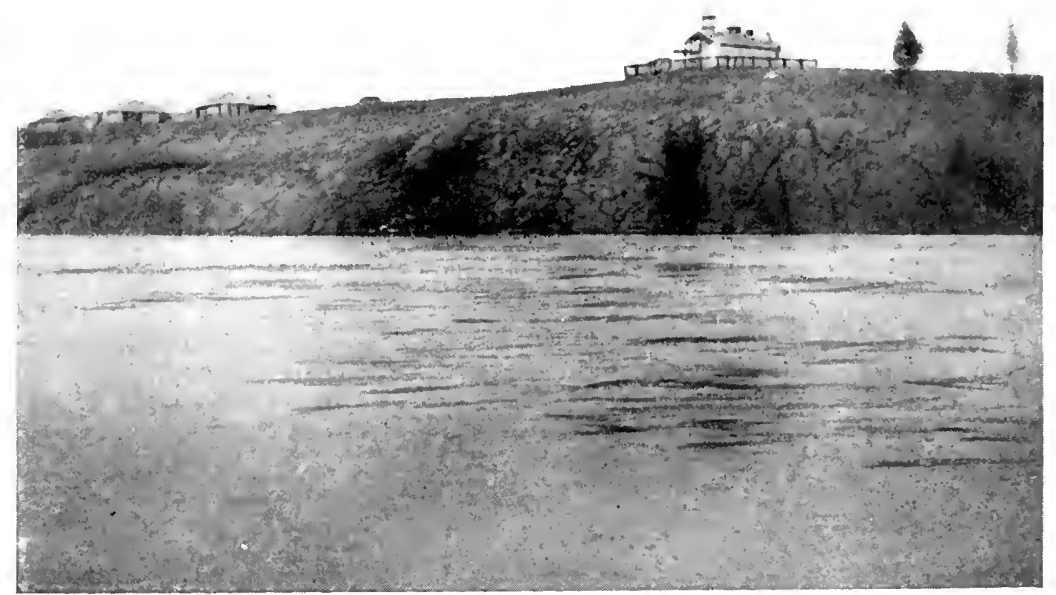

MIROYEDIKIIA. ROCKY BANK 


\section{TROITSKIY MONASTIR, AND TO THE SOUTH}

fetch the holy man's bones ; and he went off, dug him up, put him on a reindeer sledge, brought him here over the tundra, and then this monastery was built. This was, therefore, some time after 1662 .

The other version of the legend of this Vasiliy Mangaseiskiy is that in the days of Mangaséya's prosperity he occupied the position of clerk to one of the richest merchants of that town. As he was a pious, faithful and upright man, the merchant had entrusted him with the management of his whole property. One night, when Vasiliy was at early mass in his master's house, he had the misfortune to be robbed of a quantity of goods by thieves who broke into the warehouse. The merchant suspected Vasiliy of being accessory to the crime, and handed him over to the voyevod, that he might be forced to confess. The youth was put to the rack, but as he could not be made to bear false witness against himself, the exasperated merchant gave him a blow on the head, so violent that Vasiliy gave up the ghost. He was then pronounced to be a hardened sinner, and his body was thrown to the dogs without ceremony.

But more than half a century later a miracle happened. Tikhon, the founder of the monastery of the Trinity here, heard one night during his prayers a divine voice bidding him go to Mangaséya, which was already abandoned, and fetch the mortal remains of the unjustly slain Vasiliy, and convey them to this sanctuary. Ever obedient to the divine commands, Tikhon at once set out, and covered on foot as a pilgrim the long, unknown and trackless journey to Mangaséya. Arrived there, in the depth of winter, he beheld a green, flowery meadow, and on it lay a youth just fallen asleep, as it seemed to him, and wrapt in the most blissful dreams. The aged man knelt by the side of the youth 


\section{THROUGH SIBERIA}

and offered up a devout prayer. Then he took the dead Vasiliy in his arms and set out at once for home. And with his precious burden he travelled in the keen winter cold over the wastes of snow, but round about him he saw nothing but green grass and fragrant flowers. Without food and without repose he went more than a thousand versts on foot, and knew neither hunger nor weariness. The whole journey occupied no more than a few days, which is a sufficient proof that Vasiliy had been a holy and righteous man in the sight of God ; and therefore he is to this day honoured by the people round about as a real saint, although he has not been formally canonized.

We also saw a terrific iron collar there, to be worn over the shoulders and locked round the chest. It was of a formidable weight, and was worn during his whole life by Tikhon, the founder of the monastery; so he, too, was a very holy man. That he had the iron collar on when he went off to fetch Vasiliy Mangaseiskiy, I am not prepared to assert. Another precious treasure was a great Bible, the New Testament. It was bound in silver, with images of saints and decorations in relief on the outside. It was a gift from the Empress Anna Ivanovna (died 1740).

At present there are three or four monks and six or seven novices in the monastery. They own most of the land about, and the pastures on the islands in the river ; and this, as already remarked, is an unfortunate circumstance for the settlers who are now coming here.

There was a priest here on a visit; he was a missionary to the Yakuts and Tunguses on Esseiskoye Ozero, a great lake, which lies a long way off within the tundra, in the direction of the Lena. He spent every winter there, but often went away on visits in the summer, and this summer he was staying here. He did not understand 186 


\section{TROITSKIY MONASTIR, AND TO THE SOUTH}

the language of the natives, and had to speak to them through an interpreter. Although he, too, wore long hair and a cassock and a priestly hat, he looked as if he might belong just as much to this world as the abbot did to heaven. He made an uncommonly straightforward and practical impression. He was keen on politics, and to Vostrotin's great joy he was a liberal, so those two had much to say to each other.

After seeing the church we went back to the pristav's to drink a glass of tea together with the priests and the superintendent of the telegraph station here, which was nearly ready. They were working on the line northward from Yeniseisk, and it was now open as far as the village of Vórogovo, about four days' journey north of Yeniseisk. But by the winter it would be completed to this point, and it is to go as far north as Dudinka. So even these regions will soon be drawn into the mighty power of the telegraph.

The glass of tea to which the pristav and his amiable wife had invited us, turned out to be a solid lunch with several cold dishes and cakes and heady wine, and it was not so easy to do justice to the repast when the guest had just come from a breakfast on board; nor was the position made any easier by the fact that the guest did not understand a word of Russian, and the hosts not a word of any other language.

There was much conversation during the meal, chiefly, no doubt, about Siberian affairs; it was the visiting priest who had most to say, he and the local member, Vostrotin, and probably it was all very interesting, if one had been able to understand any of it; but it was carried on in Russian. The only thing I could do was to photograph the company.

But time was getting on and we could not stay too long, as we had to use the daytime for our journey. So 


\section{THROUGH SIBERIA}

we thanked our kind hosts, said good-bye and, accompanied by the pristav and the two priests, went out to see the town and make a few purchases before going aboard again.

The school at the monastery we had to see. It appeared to be a well-built, warm house with light, clean rooms. It was a boarding-school with one room for boys and one for girls; but it was empty now. The priest who was on a visit was the only person living there. There was no schoolmaster just now ; the last one had been a political exile, who had been allowed to teach for a few months; but now there was nobody to be found. Vostrotin told me that some years ago there were six schools in the Turukhansk district, which has an area of a million square versts, several times larger than Norway. Now there are only two schools left.

We walked through the town. A small part of it was an old village which had lain here by the monastery, with its wide street and its comfortable, low peasants' houses; but all the northern part had been newly cleared in the forest, and there they were now erecting the Government building, hospital, school, and a doctor's house; but this had been burnt down again a few weeks before. A big granary had also been built, which is to contain 300,000 poods (4800 tons) of corn as a reserve for the population. As yet there was not more than 3000 poods there.

All these buildings were being erected at the expense of the Government, but a private person had contracted for the work. As assistant architect he had a political exile, who had been sentenced to Siberia for life and had also lost all civil rights; but in ten years he would be able to recover his civil rights and start afresh. $\mathrm{He}$ seemed a cultured and engaging man, and he walked with us for some way. Loris-Melikov was astonished 188 


\section{TROITSKIY MONASTIR, AND TO THE SOUTH}

to find how well the political exiles were treated. This man, for instance, was spoken to and treated by the others exactly like an ordinary person; even the pristav himself, who was walking with us, talked to him. This did not strike me as very strange, but I saw too little of the political exiles in Siberia to form any decided opinion as to the manner in which they are generally treated.

There were said to be some Yenisei-Ostiaks in tents down on the shore. This was what interested me most and I hurried to get down there. On the edge of the river-bank we passed three or four huts, or half caves, dug out in the sandy slope. They were temporarily inhabited by convicts, who had been pardoned this year and assigned to this commune, where they obtained the rights of peasants, but were not allowed to go outside the district of Turukhansk. They had come from penal servitude, and were no doubt desperate criminals. One of them was at home. The pristav went in and told him to come out, so that I might photograph him at the door of his cave. There was not much room inside. I saw some carpenter's tools, so the man was probably a carpenter. He was a cunning, swarthy fellow, who looked capable of anything. It seems to be a doubtful advantage for a place to have its population increased in this way; especially if it happens often, as they say it does in Siberia.

In the Ostiak tents, which lay just below these huts, none of the men were at home. They were out fishing for herring. There were only two old women and some youngsters, who came out to talk to us. They were thinly clad; their ragged skirts fluttered in the strong wind, showing their bare legs above the knee, and they found it cold standing there with the blast going through them, while I photographed them. Inside the tent they sat cross-legged, broiling fish on skewers 


\section{THROUGH SIBERIA}

stuck aslant in the ground by the side of the embers. Outside on the shore lay a birch-bark canoe with a hole in the bottom. It was quite small, no bigger than a Greenland kayak. They said it was a Tungus canoe that had drifted down the river. The Ostiak canoes, as a rule, are not made of birch-bark, but of a hollowed-out tree trunk. A good canoe of that kind lay on some barrels down on the beach; it was like those I had seen among the Yuraks farther north.

But we were now in a hurry to get away, as we had to go on to the south as quickly as possible. The first thing was to get hold of Vostrotin; with his political interests he had, of course, much to talk over with people, to get an idea of their affairs, as he has to look after the interests of the country in the Duma; and he had completely disappeared. At last, after turning back and searching through the town, we found him, if not exactly in the temple, at any rate engaged in deep discussion with the priests and scribes.

After still more waiting - after saying good-bye four times, and after I had beguiled the time by photographing the last chat of all after the fourth good-bye-I was rejoiced to see him tear himself away and get into the boat. Then there was a fifth cordial good-bye, and we rowed aboard, weighed anchor, and stood out into the Yenisei, while the two priests with the pristav between them walked slowly in the sunshine up the long beach towards the monastery-church, back to their secluded, peaceful life-and as before the cupolas and spires of the church shone white against the blue sky high above the forest, and we could still see them a long way off.

As something went wrong with the motor, we had to stop for some minutes on the other side of the river. There were some birch-bark tents on the flat sandy shore, and I hoped to find Yenisei-Ostiaks, but they 190 


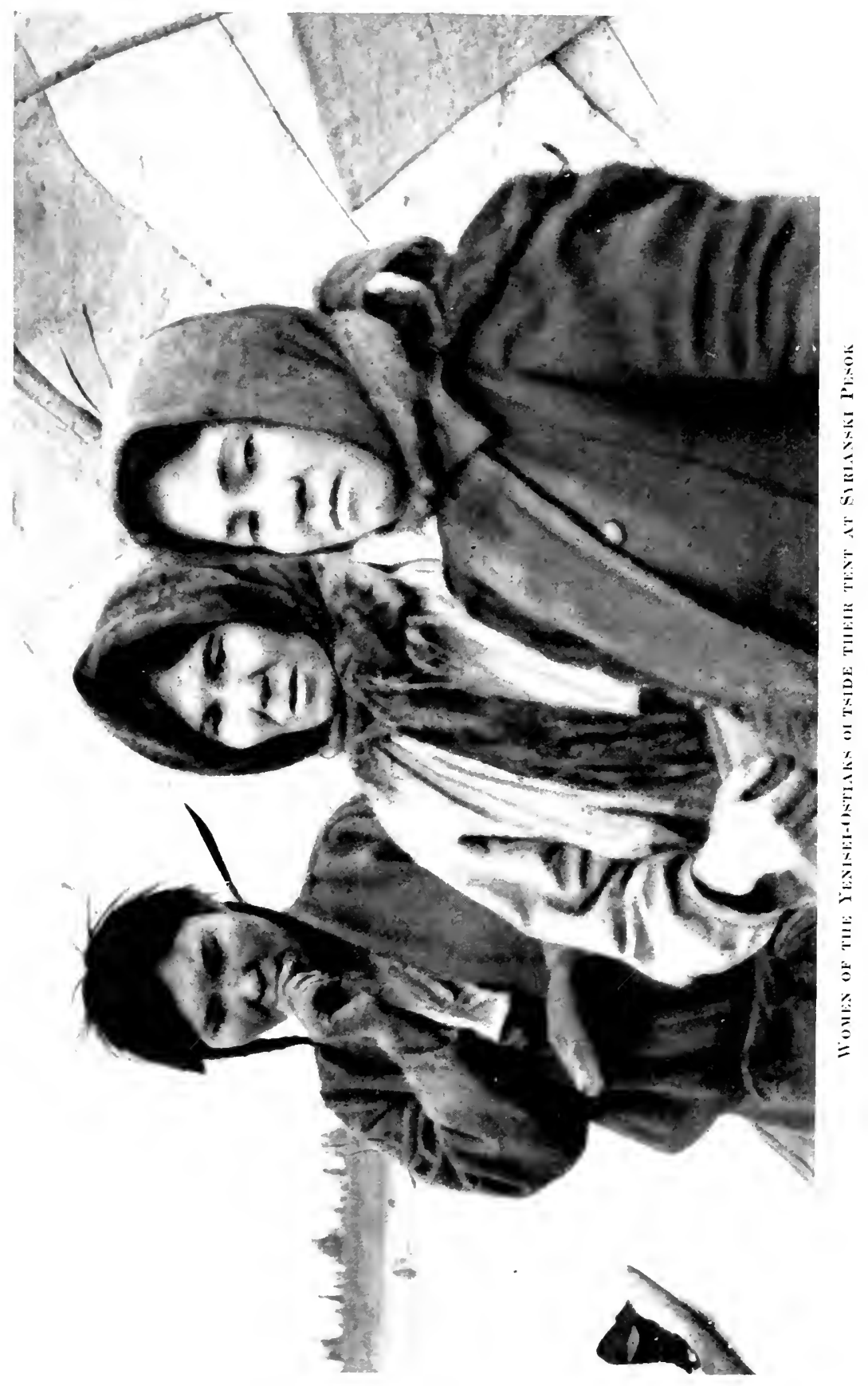




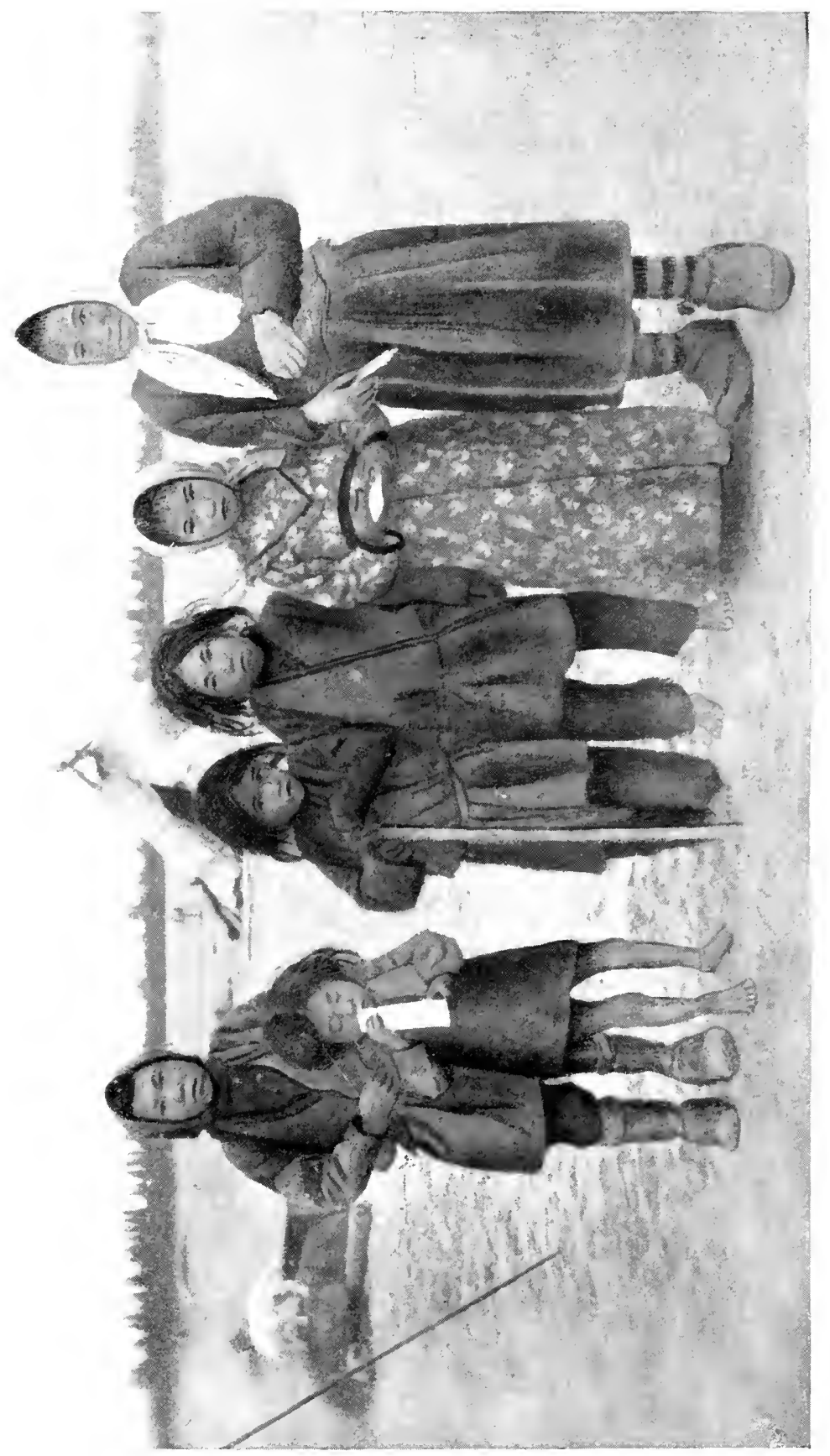

 


\section{TROITSKIY MONASTIR, AND TO THE SOUTH}

were only Russian tents. In one of them we found some people, who had come from farther south and had been fishing here for a time; but they had only got 10 poods (360 lbs.) of fish. The general opinion is that there is no longer so much fish in this upper part of the river, since so many people took to fishing in the lowest part, down towards the estuary. The rest of the tents belonged to people from the town at Monastir. They had come here to fish; but there was nobody in the tents now. Vostrotin bought some wild duck, which were a welcome addition to our larder. These Russians had shot them up a river which runs into the Yenisei, where they were abundant just at this time.

Farther south there was the same landscape as before, the same banks, the same flat country inland, covered by the same forest, with a few coniferous trees standing up above the foliage here and there, while in other places the pine forest was more continuous, and the trees were beginning to be larger and more fit for timber than they had been farther north.

At the village of Miroyédikha, on the east bank of the Yenisei (in latitude $65^{\circ} 36^{\prime} \mathrm{N}$.), the river-side consisted of rock from a good way to the north to at least 4 miles farther south. It was a greyish-blue rock which seemed to be calcareous, as far as I could see in going past on the water. The remarkable thing about these beds of rocks is that the river-bank was of pretty much the same height here as elsewhere, both on the north and south, where it was composed of sand and clay. The country inland was just as flat, whether the beds of rock came to the surface or were covered by loose strata. I could discover no hills or ridges, nor any difference on the whole.

It is true that at Troitskiy Monastir I had seen a low, blue, wooded ridge, far away along the Tungúska; 


\section{THROUGH SIBERIA}

and it is probable that these beds of rock here at Miroyédikha have some connection with that ridge, and with the hilly country along the Tungúska, up which one cannot go far without coming upon rapids. But how are we to explain the fact that all this country on the Yenisei is alike perfectly flat and stands at the same level, whether we are passing over bedded rocks or loose strata? Is it an old plane of marine denudation, formed at the time when these loose strata were deposited? But the surface must consist to some extent of old river deposits. Has there been fresh water here, perhaps, and has this loose rock weathered down to the surface of the fresh water, while the depressions between have been filled up with fluvial deposits? Such conditions can scarcely have lasted long enough. Or can we perhaps suppose that, with the severe weathering that takes place here, a ridge of loose rock projecting above the plain might in course of time weather down to the level of the latter? It is not likely that it could be so entirely levelled with the plain. The wind might do it ; in the desert it files away projections with drift-sand and fills the depressions; but can such conditions have prevailed here? It is not easy to say anything about this, without having made an cxamination ashore. Whether there were bedded rocks on the low west bank of the river I cannot say. It did not look like it.

There was a very rapid stream, and we made little headway with the motor, so little that two row-boats that followed could almost keep up with us, as they could take advantage of the eddies in the little bays.

We met a boat full of men. It came drifting down stream. One man lay at his ease with legs stretched athwart the boat, reading a newspaper aloud to the others who sat behind him. There was also a man at 192 


\section{TROITSKIY MONASTIR, AND TO THE SOUTH}

the oars, and another aft with the steering oar. As they passed us, the rower stopped and they all stared at us, except the one who was reading; he only raised his head, turned and gave a glance in our direction, and then settled himself again and went on reading. What kind of exciting reading it was we could not make out. They were political exiles, the others said, probably on their way to the nearest village. How they recognized them as political exiles I do not know ; unless, perhaps, it was because one of them at any rate could read, and because they all seemed so deeply interested in what he was reading.

At 9 P.M. it was quite dark, and we anchored for the night. There was a stiff breeze which tore at the rigging. Inshore of us, on the edge of the forest at the top of the bank, the reflection of a fire shone among the tree-trunks out into the black night. It must have been telegraph workmen who had a tent there with a fire in front of it.

What a strange incomprehensible attraction there is in a light like this in the forest. I sat on deck looking at it, while the wind increased and lashed the water against the side of the little craft, and she pitched more and more on this mighty river, which winds away to the north through the endless flat forest country. This monotonous, confined life on board, with so little space, no doubt makes one impatient, for I actually find myself wishing I could see what the faces are like that are staring into the fire over there, and how those men live -longing to sit beside a fire like that beneath the murmuring forest, while the flames of big logs throw dancing shadows over the tree-trunks, and the daylight dies away in a narrow streak under the roof of trees far in the west, and the night falls thicker and thicker. Ah, that forest ; and here it is vaster and more infinite than 


\section{THROUGH SIBERIA}

any we have seen before, this endless taigá. Assuredly men were not made to live in towns.

Thursday, September 11. Early next morning we resumed our voyage, but with a stiff breeze against us, and we made little way against wind and stream. Still the same landscape, but with bigger trees. There is now more spruce, better timber. In some places the pine-forest has been burnt, and there is nothing but foliage-trees. Every day, as we have come up the river, we have seen here and there wood-stacks large and small, piled up on the edge of the forest at the top of the river-bank. These are for the steamboats, which lie to near the bank when short of fuel, and take a supply of wood from these stacks.

This morning I saw a low ridge far away to the south-east ; but otherwise it is the same flat country as before ; here and there we pass a village. We frequently see horses on the bank, and can tell that we are coming farther south and into more populous country.

It is a curious thing about these villages, how they have appeared and how they have increased, almost without our noticing it. In the far north there was only one house, or a group of houses here and there along the river-bank, where a trader lived, or where there was a mail station. Then we saw a few more houses at each such place, but it was still a long way between the settlements. Then the number of houses increased, and they began to arrange themselves in a street, until here they have become real villages, and the distances between them have also become shorter. They are all pretty much alike. The low, square, well-kept timber houses stand in a row on the flat ground at the top of the river-bank. They all have the same steep incline below them, down to the flatter foreshore, where nets are hung to dry and boats are drawn up. The chief difference 194 


\section{TROITSKIY MONASTIR, AND TO THE SOUTH}

between them is whether they have a church or not: a church-town is, of course, far superior to an ordinary poor village.

What these people live by is not easy to say. Mostly no doubt by fishing in the river, and trade with the natives, especially in furs, of course - and then there is cattle, and here and there a few reindeer are kept. But as yet there is no agriculture to be seen.

A beautiful mild evening. Although there is a headwind, one can stay on deck without an overcoat and feel warm. But we are still in latitude $64^{\circ} 40^{\prime} \mathrm{N}$., farther north than Namsos. It does not seem that Siberia is as cold as its name. The winter is cold, of course, but the summer may be broiling hot. The worst thing about summer is the gnats; there are clouds of them, and small horse-flies, too, which are even worse. Vostrotin says that they make the cows thin, and that the cattle are fatter in winter, when they stand in the cold and have to be fed on hay, than when they are out on the green pasture among the gnats and flies in summer.

But what in heaven's name is that yellow blaze that suddenly flares up on the edge of the forest over on the south-east; it looks like a forest fire! Oh, it is only the moon slowly rising over the river-bank, while every tree-top is sharply outlined against it. It mounts higher and higher, and sends us a quivering band of light over the surface of the water. It is nearly full, as it comes up clear of the black forest. The disk and the streak of light are a deep orange against the blue vault and the blue water. And what a power it has; the whole expanse of heaven becomes a marvellous dream of night and solitude. Not a cloud in the skyonly a few dark banks low down in the south-west. Along the skyline on the north-west there is still a deep 


\section{THROUGH SIBERIA}

red afterglow of daylight, which passes through yellowish green into the boundless blue higher up, arching over us with hundreds of pale stars. Along the southern horizon there is a veil of purple light below the moon.

We are driven to the south by the regular beat of the engine while the mighty, never-resting mass of water under us glides onward to the north, spreading on all sides its dark blue surface, like watered silk, rippled by the wind between the smooth eddies, which flow on, ring after ring, till they merge into one another out in the darkness. And then on both sides there is the riverbank and the endless black forest.

At 9 P.M. we anchor under the high east bank. By about midnight the moon has set. The sky sparkles with a thousand stars, strangely brilliant. It must be the dryness of the atmosphere within the great continent that makes the sky such a deep blue and the stars so brilliant, and brings out such an infinity of them as one does not see near the ocean. There is shelter here, and smooth black water under the bank. How still it is ! A faint whisper across the water is, perhaps, the ripple of the waves against the western bank-and a low murmur comes from within the forest.

Friday, September 12. Early in the morning we go on to the south. The woods are rather more luxuriant than farther north, but there is still the remarkable feature that on the east side of the river we have a much higher and steeper bank, and lofty coniferous trees, with a few foliferous in front along the edge, while the west bank is lower and more shelving, and for the most part has only foliferous trees. Almost everywhere here the deepest channel follows the land on the east. Only here and there, especially where the river makes a turn to the right, it may happen that the channel lies near the 196 


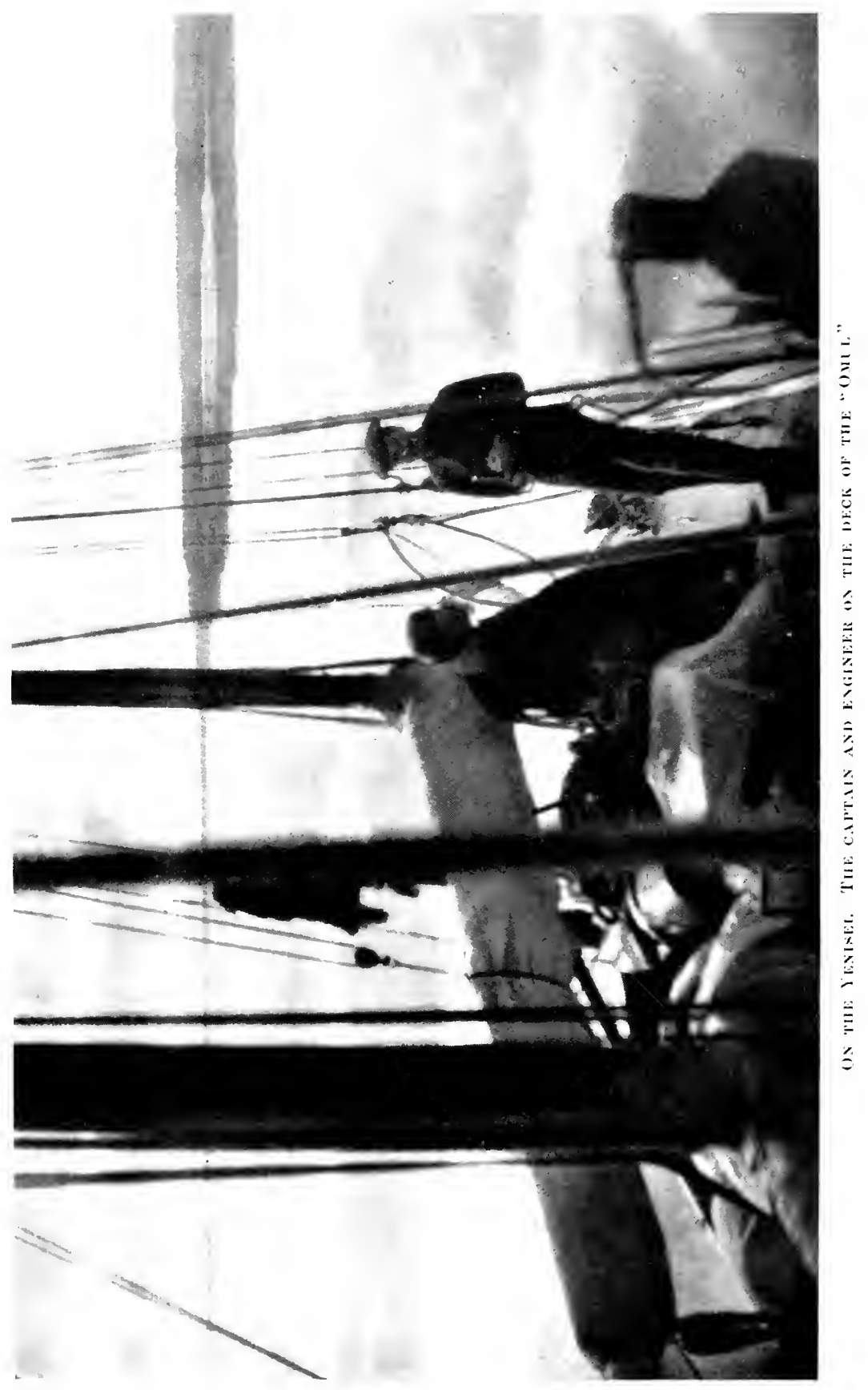




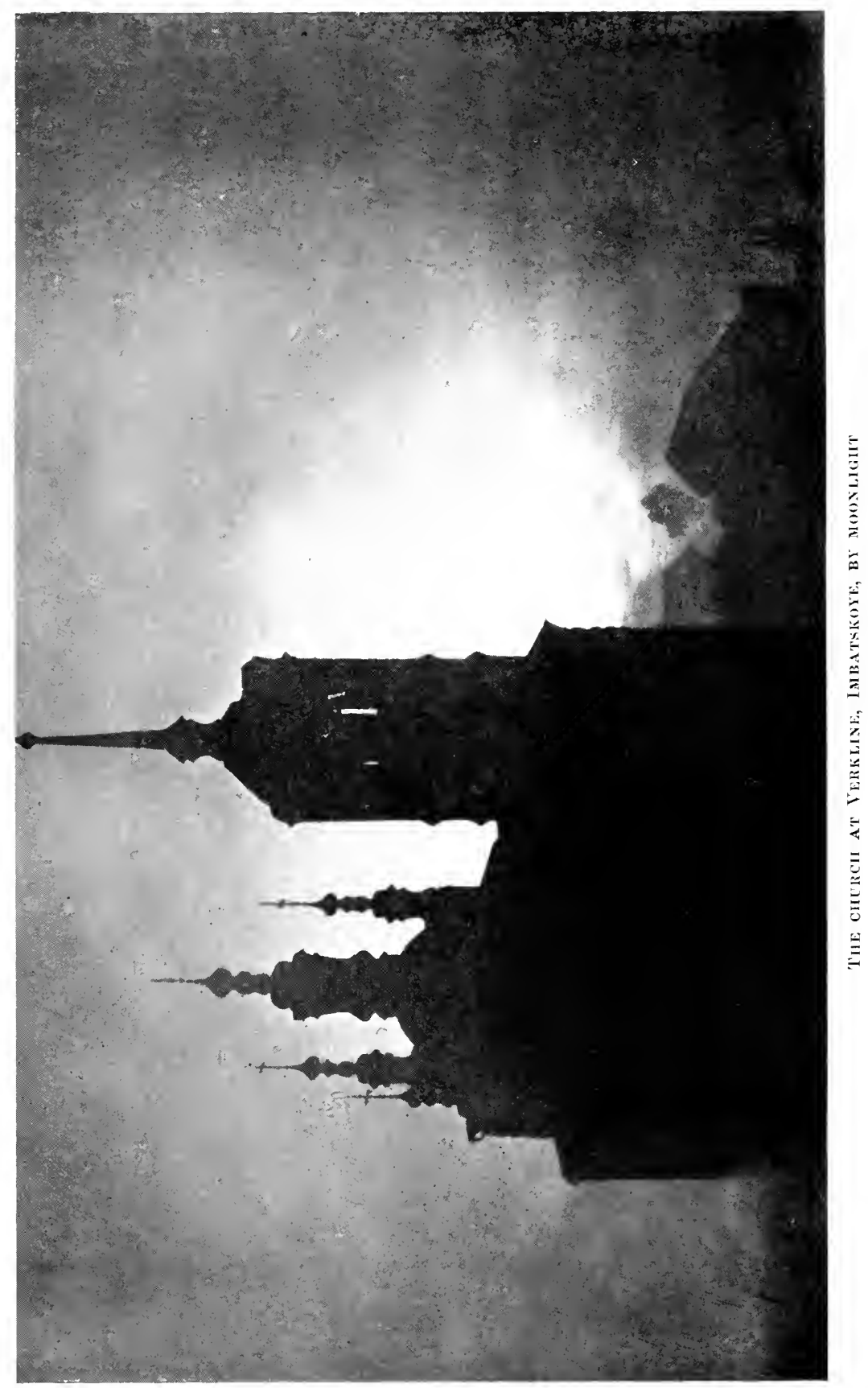




\section{TROITSKIY MONASTIR, AND TO THE SOUTH}

west bank for a short distance, and in such places this bank is usually somewhat steeper than the eastern.

It is glorious sunny weather. I cannot help admiring our pilot; he stands there at the wheel steering from morning till night without a rest. I see he even has his meals in the wheelhouse. He looks a pleasant, good-natured man, and he greets me with such a friendly smile all over his face, and such a roguish twinkle in his little eyes when I come on deck in the morning. He seems to be a shrewd and capable fellow. I have often wanted to go up and have a chat with him and hear about his life. But then there is the trouble about the language; it drives one mad to travel in a country where one can understand nothing and cannot make oneself understood.

But Loris-Melikov and Vostrotin talked to him a good deal. He was a Tatar from Yeniseisk and a Mohammedan, and could read his Koran in Arabic. $\mathrm{He}$ had travelled far and wide in this part of Siberia. His father was a fisherman on the Yenisei and had his own boat, in which they went up and down the river to fish, so that he learned to know these waters at an early age. He had also travelled with traders as far as the Khátanga and Anábara. He had even been as far as Obdorsk. Of the natives he had seen most of the Tunguses, and had much to say about their manners and customs. He spoke Tungus and other native languages.

On a winter journey with a trader over the tundra far north, he put his right arm out of joint in lifting a weight. There was nobody there who knew how to put it in again, and no doctor within reach. He came back to Dudinka in a helpless condition; the arm remained out of joint, and is still so. It hangs loosely down and he cannot raise it; but in the course of years 


\section{THROUGH SIBERIA}

he has got so far as to be able to use the hand a little and move the forearm. He manages his pilot's work, which is chiefly steering, with the left arm; but what that man must have suffered before the pains in the shoulder-joint gradually passed off. Anyone who has himself tried an arm out of joint will know about that. Now, he says, his shoulder does not hurt him any more ; though he has certainly had rheumatism in it.

In the afternoon, about five, we came to a low, flat sandbank in the middle of the river, called Syrianski Pesók. On it stood the birch-bark tents of some Yenisei-Ostiaks, and as the motor wanted cleaning, we stopped there for the night. When we landed we found only women and children in the tents, besides a cripple of a man, lame and bent, with a bandage over one eye. The men were all out fishing. All the grownup people understood Russian. There were two elder women, both of whom had babies. One of them had her infant in a basket-work cradle, which was hanging inside the tent and looked very much like a violin-case. This is the usual form among these Yenisei-Ostiaks.

The younger woman was rather dark-complexioned, whether it was the colour of her skin or want of washing. Her face was short and broad, with broad cheeks and a frank and winning expression. She had a long, green coat or gown, and her child was also dressed in green. It looked like the same piece of stuff. As we were coming, she went off to her own tent, which was a little farther on, and did not stop when we spoke to her, whether it was that she was afraid of us or what. We had to overtake her, and Loris-Melikov gave her one of Lied's necklaces of green glass beads. Lied had bought a lot of this sort of finery for the natives and had given it to us, so that we might make an impression with it. She just stood still with the necklace in her hand and asked 198 


\section{TROITSKIY MONASTIR, AND TO THE SOUTH}

what she was to do with it. Loris-Melikov explained that it was to wear round the neck. Whether she cared for it we never found out; but at any rate she became more tractable, and we were able to take some photographs of the women and children and the crippled man.

A fourth woman came up, carrying a child, from a tent farther off. We wanted her to stop so as to get her in the picture; but she rushed into the tent with her child and all our shouting was of no use. After a while she appeared again, rigged out in shabby Russian clothes, with a handkerchief over her head. Now she was ready to be photographed; but we would rather have had her as she was before. An elderly man then came up, with a handkerchief tied round his head, in the way they often wear it. He had a longer and narrower face than the first man; but he, too, looked somewhat paralyzed. Finally, a strongly built elderly man arrived, with a good, powerful face, which showed more signs of race; and with him was another woman. He told us that he was blind. The male sex seemed to be rather defective just here.

There appeared to be two types of face among these people : a short and broad face, more typically brachycephalic, with heavy cheek-bones, which was most marked in the dark young woman, in the first crippled man, and in this bigger man who arrived last. Then there was a rather longer type of face with a more Aryan look, faces that we might often see among our people at home; this type was seen in the other man, and in a couple of the elder women. Whether these features were due to mixture with Russians or were original, I cannot say. Should the latter be the case, one would have to suppose that the other type was due to mixture with other native races (?). They 


\section{THROUGH SIBERIA}

were all dark-haired, and I saw hardly any sign of oblique, Mongolian eyes.

On the shore lay a canoe, hollowed out of a treetrunk; but as the tree had probably not been big enough the canoe was raised with a board on each side, which was fastened with treenails. The first cripple with the bandage on his head offered at once to go out in the canoe, so that we saw how they rowed them.

What we saw here in this little canoe may have been just the way in which men learned to build large boats and ships. First they crossed their rivers on a tree-trunk, or several tied together; then they found out how to hollow out the trunk with fire, to make it lighter, so that it could carry more and was easier to propel. Such boats of hollowed trees wcre also used in Europe, e.g. in north-western Germania in the time of the Roman Empire and even later. But then the hollowed trunks were found too small, and they had to fasten boards at the sides, as we saw here, to prevent the water from splashing over. The boards might either be fastened with treenails, as here, or sewed fast with withies or roots of trees. They were found to answer well, and could even be made fairly watertight. They added more boards, one above the other, in the same way - and thus the boat built of boards was invented, and the gradual further development to the building of large ships followed of itself.

At last a boat came with three younger men, who had a healthy look; but one of them looked more like a woman, and I thought at first he was one. Another was also rather womanly in appeararance. They had been out fishing and trapping; they had three capercailzie hens and a big pike. We wanted to buy a capercailzie hen of one of the men, but he wanted it for himself. We then bought one from the other. We also bought some 200 


\section{TROITSKIY MONASTIR, AND TO THE SOUTH}

sturgeon that had been caught some time before, and some fresh sturgeon-caviar, besides a wolverene skin (for ten roubles).

The fishing was poor, as everywhere in this part of the Yenisei. No "herring" (seld) had come yet. It looked as if they were almost suffering want, these people here, and they were poorly clad, all of them. They told us, it is true, that they now kept reindeer; that is a thing they have taken to lately, as the Yenisei-Ostiaks formerly knew nothing of reindeer-keeping. On the whole, I had a lively impression of what an uncertain existence such a poor people of hunters and fishermen really leads. If the fishing and hunting fails, as may happen often enough, they have nothing to fall back upon, except some dried fish from the summer and a little meal from the traders, but that does not last long; and then, in this case, they had these reindeer. Otherwise, famine was certain, and often enough they starve to death.

These people had twenty reindeer. While they were engaged in fishing they let the deer run loose in the forest a good way off and caught them again in the autumn. They do not want looking after, they said; they were easy to find again, and there were no wild reindeer there to draw them away. Nor were there many wolves.

The summer, when there is fishing, ought, of course, to be the easiest time for them. But even now they were in difficulties; and then they would have to dry a lot of fish against emergencies later; but it never lasts long-and then in winter they are, to a great extent, dependent on what game they can find in the forest. If they get an elk, of course, they can live well for a long time, but as a rule it is mostly ptarmigan, wood birds and other small game, with now and then a bear; though when they are hungry they will also eat both 


\section{THROUGH SIBERIA}

wolf and fox; but for days these hunters may wander through the forest without being able to find anything to bring home to an empty tent, where many hungry mouths are waiting. Hunting for fur animals is what gives them most money to buy food from the trader in the nearest village; but it has declined, and has not brought in much the last few years; last winter the squirrels had practically disappeared. If, then, the fishing also fails, there is not much with which to pay the trader for meal and other things. Nor can they afford to keep good nets and seines, so that the fishing becomes uncertain. Sturgeon they have to catch with the hook, but it is not a very paying way of fishing, nor one that can be reckoned on. Just now they seemed to be catching birds as much as fishing.

Loris-Melikov got a good many words of their peculiar language written down; as already mentioned, it is entirely different from all the other languages of Siberia. As we went aboard, they accompanied us in their boats, to receive payment for what we had bought and to stare at our boat and all our tackle. 


\title{
CHAPTER $X$
}

VERKHNE-IMBÁTSKOYE TO SUMARÓKOVA

\begin{abstract}
A boat drawn by dogs : Verkhne-Imbátskoye : The church : Moonlight : At the priest's : River transport with dogs : Snaring capercailzie : Mirnaya by moonlight : Ridges : Thicker forest, including fir : Sumarókova : A drunken gathering : A pleasant trader : The Yenisei-Ostiaks, their life and their destiny : We visit them on the beach : A shaman : Old religion : Caucasian political exiles
\end{abstract}

1ARLY next morning, Saturday, September 13, we went on up the same river, through the same country, and in the same sunny weather. The forest became noticeably thicker, and coniferous trees began to be plentiful on the west bank as well as the east.

After passing one of the villages we caught sight of a boat being towed along the bank by dogs. There were three men in the boat. One of them sat aft, steering with an oar to keep the boat clear of the bank, while two dogs trotted along the edge of the water and pulled the boat by a long line. They went quite fast, and were nearly able to keep up with us for some distance ; the dogs trotted along with a will and seemed quite pleased; they were only driven by shouts. This is a common means of progression here, and is fairly rapid; a great deal of the mail is carried in this way between stations upstream. Going downstream they generally take the dogs into the boat, at any rate where there is a strong stream. With a boat drawn by dogs they usually reckon to go about ninety versts up the river without 


\section{THROUGH SIBERIA}

feeding the dogs. It is not such hard work against the stream as one might think, since close to the bank they can take advantage of eddies and slack water.

At about eight in the evening we anchored at the village of Verkhne-Imbátskoye (in latitude $63^{\circ} 9^{\prime} \mathrm{N}$.) ; as, when the $\mathrm{Omul}$ was going north, her crew had seen many Yenisei-Ostiaks here, and I was anxious to see them; I was beginning to fear that perhaps we might not meet with very many more of them farther south. As soon as we had anchored, boats came off to ask the same question: "Where are the seld ?" and we could give them no consolation. Unfortunately, the Ostiaks had left a few days before, and now there were only a couple of tents with women left. We saw the light of them in the darkness on the other side of the little river that runs in here. It could not be helped; we could only hope to find some higher up the river. We were told that there were six boats, with several families in each boat, about three versts farther down the river, where we had been; but it would have taken time to go back, and time was what we could least afford, if we were to reach Yeniseisk and Krasnoyarsk by the dates fixed.

The moon had risen, and we took a walk ashore to the church, which with its white walls and its cupolas and spires towered fantastically from the high riverbank towards the moonlit sky, like a scene from the Arabian Nights, over these endless, melancholy wooded plains of the Yenisei. We went into the church and were taken upstairs by a boy. I thought we must be going up into the gallery, where we heard very loud singing; but we entered a fine Russian church with a large altarpiece, or rather altar-wall, with ikons in different places. It was from this church itself that the singing came, and it was loud in all conscience, enough to break the 204 


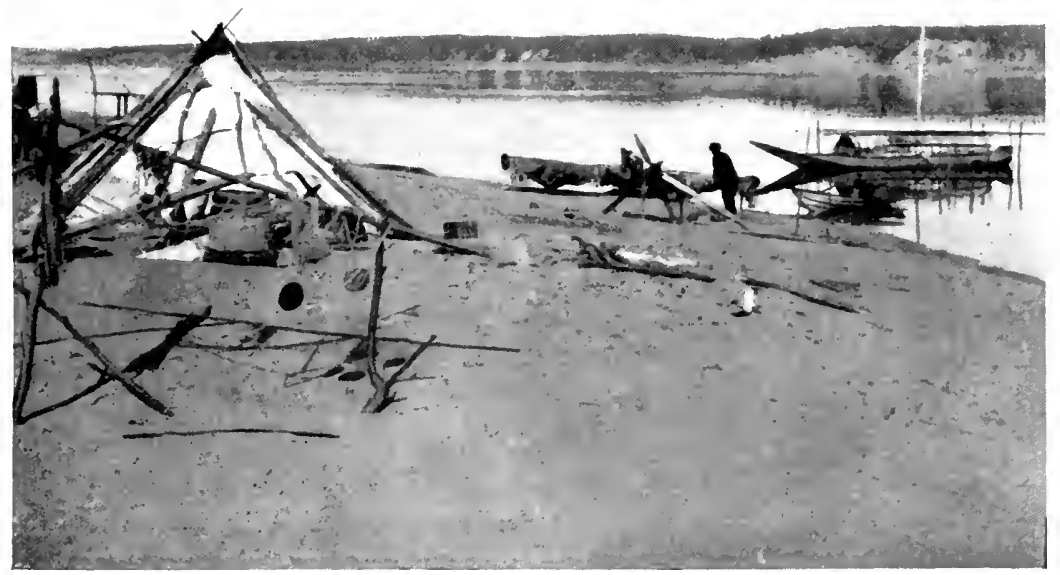

BIRCH-BARK TENT OF YENISEI-(INTIAK ON THE ANDY FORESHORE ON TILE WEST BANK OF THE YENISEI (SEPT. 14) WITH IIOLSE-BOAT LYING OUTSIDF:

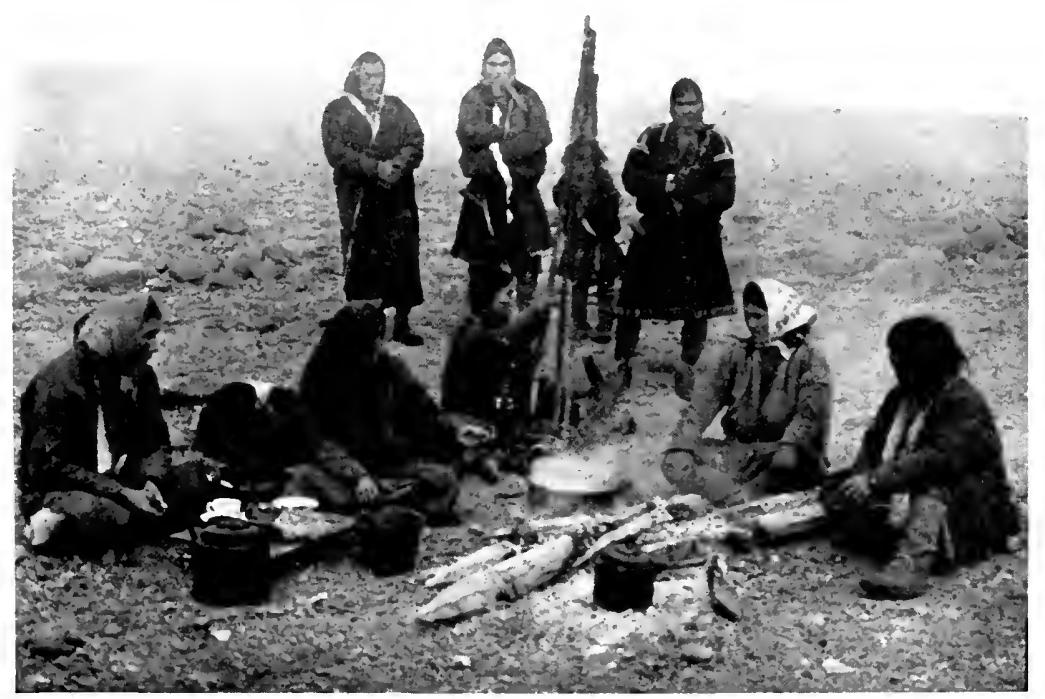

GROUP OF YENISEI SAMOYEDEG AT SCMAROKOYA 


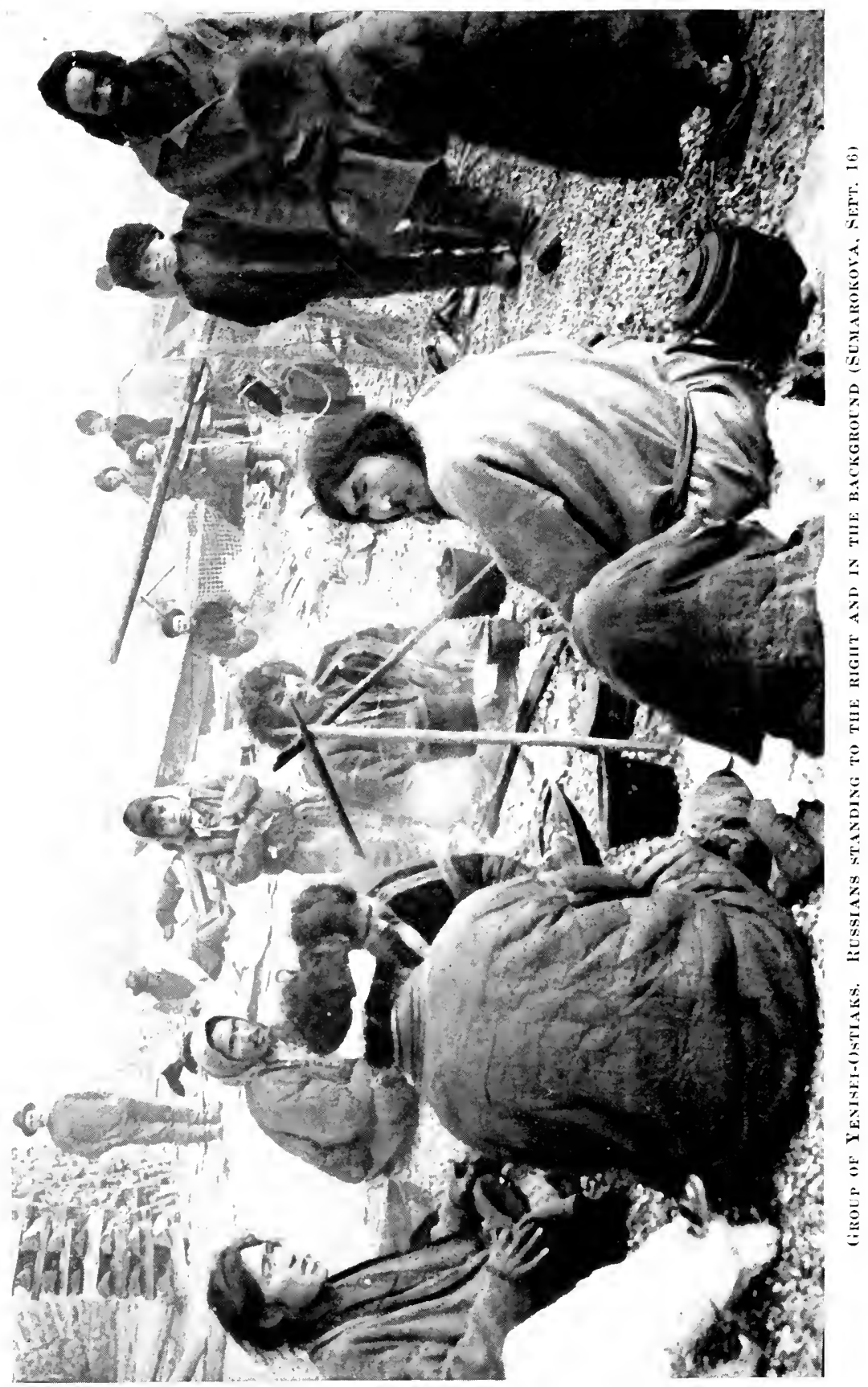




\section{VERKHNE-IMBÁTSKOYE TO SUMARÓKOVA}

drums of one's ears. There was a crowd of men and boys practising for the next day, and as far as I could make out the object was to see who could yell loudest.

The priest, with the usual long hair and Christ face, came towards us in his long blue cassock, with a friendly and clerically solemn expression. He was a remarkably handsome man, with a high forehead, a fine, clearcut profile and calm, gentle eyes; he might well have sat for the Christ in Leonardo's Last Supper. He told us that this was the summer church, and below it on the ground floor was the winter church, where it was warmer. While we were talking he was kind enough to go behind the dividing wall that concealed the powerful singers and tell them to keep quiet while we were there, and that was a blessed relief to our ears. He said there was soon to be a christening, if we liked to witness the ceremony; it would take about half an hour. WV also saw the small object which was going into the water, and which was being carried by a very attractive godmother. It seemed a strange time for a christeningpast eight in the evening ; but no doubt they take things as they come in this country.

Meanwhile I went out into the moonlight. A wonderful evening! A cosy light came from the low timber houses along the edge of the river-bank, and on the " promenade" in front of the houses could be heard the voices of people, sauntering up and down in the moonlight. As I went along, a fine and powerful man's voice suddenly broke into song from the doorstep of the next house, which lay in darkness. It was a melodious Russian song, and it was wonderfully effective in the calm night. Then it stopped; a door was slammed, and the voice had withdrawn into the house. It was certainly a political exile. Loris-Melikov came after 


\section{THROUGH SIBERIA}

me from the church, and we walked a little way along the road. A young couple passed us. I could see that she gave him her hand again when they were past, and the soft, insinuating tone of her voice showed plainly enough that flirtation flourished even in these latitudes. Loris-Melikov said he could tell by her accent that she was a Jewess. They were also political exiles, no doubt, who were consoling themselves as well as they could. Another couple appeared, and Loris-Melikov had a chat with them. They were from Tomsk, and had come here on their marriage; the husband was to have travelled on business. But they were short of funds, and had been here ever since. She was coquettish and would have liked to gossip; and she went on chatting, while he stood there growing more and more sulky and impatient, and trying to get her into the house.

When we came back to the church, the christening was unfortunately all over, so we did not see it; but to make up for it the priest took us downstairs and showed us the winter church, which was quite as gorgeous as the summer church above. The pictures on the reredos were the usual ones of saints, the Virgin Mary and Child, and so on. They were for the most part painted by a political exile from Krasnoyarsk. He must have had a certain facility with the brush, though perhaps not much originality.

We then went for a moonlight walk through the village street, accompanied by the priest. The street had a sort of side-walk of planks; but otherwise the ground was cut up by the feet of cattle, which had sunk deep in mud and cow-dung, making it difficult to walk, even where it was dry. We found a shop, and were able to make some purchases towards completing our still defective culinary outfit.

I wanted to take a photograph of the street by 206 


\section{VERKHNE-IMBATSKOYE TO SUMARÓKOVA}

moonlight, but had to give it an exposure of ten minutes. This was in front of the future telegraph station, a timber house that the Government had rented for 240 roubles a year. While I was busy with the camera, a man who lived next door came and looked on, and when he heard what I was about, he at once told his aunt, who lived in the house beyond the telegraph station, to hold a candle for me in the window, so that I might see to photograph, and his wife had to do the same in the house opposite. A woman came out of it in her nightdress and held a candle on the doorstep, and more women arrived from various quarters to assist. No doubt they thought that in this way the photograph would turn out better. I went away from them, leaving the shutter open. When I came back in ten minutes to close it again, the aunt had also come out of her house, and there stood three women in a row, laughing, with candles in their hands, evidently thinking they would come into the picture ; for they had posed nicely arm in arm, though I can't say they were standing still.

We visited the priest at his house. He had formerly officiated on the Khátanga, and had also been on the Anábara. But his father had been priest here, and now he had been transferred to this place. He told us a great deal about the people and their life here. There had recently been many Yenisei-Ostiaks at this spot, getting their supplies for the winter; but now they had gone back to the districts that they haunt. He also told us that the Russian traveller, Anuchin, had been here to study the natives, and that last winter the young Finnish philologist, Donner, had stayed here for a time to study the Yenisei-Ostiaks and their language. This was of special interest to me. I was aware that Donner, whom I knew, had gone to study the language 


\section{THROUGH SIBERIA}

of the Samoyedes on the Obi, and I was glad to hear that he had come as far as here, to this people, among whom, as a philologist, he would certainly have been able to do valuable work.

After receiving a present of bread from the priest and his amiable wife, we went aboard again at last in the fine moonlight.

Sunday, September 14. The same landscape to the southward, the same forest-but steadily becoming thicker and higher-and the same sunny weather. Since, as I said before, I was beginning to be seriously afraid that we should see no more Yenisei-Ostiaks to the south, we stopped, on passing some birch-bark tents in the course of the morning, and went ashore in the hope of finding some natives; but the tents were empty, and the only living creature we found was a sturgeon, which was swimming about in a little dammedup pond in the sand, just at the edge of the foreshore.

Later in the forenoon we passed a boat-load of people and dogs, crossing the river from the west side. As soon as they reached the east bank the dogs were put ashore with towing-lines and they came after us. For several hours they kept up so well that we could see them behind us. Here there was also a whole herd of cows on the bank. We could see that the country was becoming more populous, as we went south. We often saw ponies on the bank, and could count as many as thirty together. Once we saw a herd of tame reindeer, at least thirty animals, running along the edge of the bank in front of us; but they finally disappeared into the forest on the west.

Here and there I noticed small fences of timber and twigs, built from the water's edge up to the steep sandy slope below the forest. In one place there was always an opening in the fence. For a long time $I$ tried to make 208 


\section{VERKHNE-IMBÁTSKOYE TO SUMARÓKOVA}

out what they could be for, until I discovered that they were for catching birds, chiefly capercailzie cocks and hens, which frequent the shore. Snares are set in the openings.

In the evening we anchored off the village of Mirnaya (i.e. peaceful). Loris-Melikov and I took a walk ashore in the moonlight, at about eleven o'clock, to stretch our legs. The whole village was asleep; there was not a light to be seen in any of the windows. But the dogs were not asleep ; they made a fearful noise as we came strolling along the slope in front of the row of comfortable low houses which lay there with their handsome doors and windows in the moonlight, while the broad, shining river flowed on silently below. But the people did not seem to be disturbed in their sleep by this devilish barking and howling in every key. We thought it more considerate, all the same, to direct our steps to another quarter, and turned northward into the birch forest, where the white stems shone.

A path led for a long way among the trees. There were stacks of birch-logs about; but the trees had been felled at the height of a man's thigh. I thought they must have been cut down in deep snow during the winter; but no, there were leaves on the cut-off branches that lay there. I have never seen such stumps in my life before. So they won't take the trouble to bend down here, when they fell trees, for, of course, they have the whole forest at their disposal.

Here ran the new telegraph with its posts and wires, that was to connect thesc desolate forest regions with the great world. But there was no connexion now. There had been in the spring, as far as Verkhne-Imbátskoye to the north of this; but during the floods the river was so high that the masts of a steamboat carried away the wire, which was stretched across the river at 


\section{THROUGH SIBERIA}

the rapids, some way higher up. A passage had been cleared through the forest for this slender wire; but, here again, the birches had been felled at the same height. The stumps shone in the moonlight away to the northward.

The engineer worked untiringly all night at the motor, which had begun to go wrong. As we walked about on land we could hear the beats of his hammer on steel, ringing out in the stillness of the night. Over on the other side of the river an owl was screeching; and sometimes there was another sound, which must have been a loon.

Monday, September 15. Low wooded ridges were now beginning to appear on both sides of the river. From the landslips on the slopes it looks as if these ridges were made up of loose material, sand and clay, like the river-bank. But on digging into them, one would probably come upon firmer rock, and these deep, loose layers outside are no doubt formed by the severe weathering that covers everything here. It looks to me as if the flat tops of all these ridges are of pretty nearly the same height, and they may be the remains of a plain, which has been intersected and excavated by rivers and streams. But it is impossible to form any definite opinion about all this without having had time to land and examine it more closely.

The forest is becoming more luxuriant, and the coniferous trees are gradually getting higher. The fir has now appeared, and its red stems show up here and there among the cedars, spruce, and larches. It is remarkable what a number of different kinds of trees there are in the forest here; although one would call it a pine-forest, it has quite a yellow look from withered birch and aspen, with red mountain ash among them. Spruce seems to be most prevalent, together with birch. 210 


\section{VERKHNE-IMBÁTSKOYE TO SUMARÓKOVA}

There are now more larches again; for a time we saw few of them. Cedar is not so plentiful here as to form a continuous wood in any place. It usually stands here and there among the others.

Of foliferous trees, besides birch, there is mostly aspen, alder, and various kinds of willow; the larches have also begun to turn yellow, but otherwise the pronounced yellow tint of the forest is mainly due to the birch. There is a lot of it, and it goes far inland, so that the forest is quite yellow along the low ridges away from the river. Along the bank, especially on the low islands, there are meadows here and there among thickets of willow, and there we see haystacks. It is always strange to see them standing beside this great forest, where wood has no value; and yet even here they never build a barn.

Towards evening there was a beautiful island in the middle of the river. Lofty, straight pine-trees stood close together, forming a sort of crown in the middle of the bright water. The sun was just setting behind the dark forest on the west, and its rays fell on the tree-tops and over the country on the east with its wooded ridges flecked with gold, far away. There is good nyelma fishing here, and for this reason the island is called Nyelmovoiy Ostrov. Sturgeon is also caught here.

At seven o'clock we reached Sumarókova, where we were to take in oil for the engine. There was plenty of life on the shore when we arrived; people walking hither and thither, shouting and bawling; and along the low, sandy beach lay over thirty Yenisei-Ostiak boats, with a forest of masts. This was a joyful sight; now, at last, we should have a good look at these people. There were also some birch-bark tents here and there on the beach, within which lights were visible, and a few open fires were burning near the water's edge. High above this 


\section{THROUGH SIBERIA}

varied scene stood the village and church on the top of the bank, darkly outlined against the evening sky. 'The noise and shouting increased as we came nearer. It was easy to guess that vodka had been flowing freely, and Russians and natives seemed about equally drunk.

As we landed, we were immediately surrounded by reeling Yenisei-Ostiaks, half-drunk and whole-drunk, but all quite placid and in extraordinarily good humour. Here and there drunken people lay on the ground, bellowing and rattling in their throats like dying animals. They were mostly elderly women that I found lying among the nets hung up to dry and the boats of the village, which were drawn up on land. Others sat in an almost insensible state, leaning against the side of a boat. Some of them cautiously got on their feet and staggered a few steps, but soon fell down again and lay prostrate. If there happened to be anyone near them, they stood still and looked at him, without doing anything. I saw young girls stop and talk to these old people, as if there was nothing the matter with them and it was all quite natural.

When once the native has had a drop, he will sell anything he possesses to get more liquor. He is then like a morphinomaniac ; in fact, for a bottle of vodka he will sell again the goods he has just got on credit from the trader. This is the weakness of which many unscrupulous people avail themselves, in this part of the world as elsewhere, to fleece the natives; and for this devilish drink they can often coax them out of their treasures, especially, of course, the valuable furs they collect in the winter.

It was altogether a sad sight, and we left it and went up the river-bank to the village to call on a trader, whom Vostrotin knew, and who had sent a message asking us to visit him. The houses were the same snug, 212 


\section{VERKHNE-IMBÁTSKOYE TO SUMARÓKOVA}

low timber buildings as in all these villages. As we entered the low, cosy room with the usual small windows, we were received by the master of the house, a wellbuilt, pleasant man to look at, of about eight-and-thirty. He gave us a hearty welcome, but made a longish speech to Vostrotin, and deeply regretted that he had not been expecting us now ; he naturally thought we should come in one of the big steamers. If he had imagined that we should come on in this little boat, he would have taken care not to be drunk when we arrived. That was the politest thing I have heard, from a drunken man ; but it was impossible to notice anything wrong with him ; he walked as steadily as a soldier, and was perfectly pleasant and amiable.

We were introduced to his wife in the inner room, and had to taste her fresh-made caviar, which was firstrate. According to the hospitable Russian custom we also had to drink tea, of course; and then there was supper, a rye-bread cake with fish baked in it, which is a Russian national dish, and with it caviar and pickled gherkins, followed by tea with preserved wild strawberries in it.

The man told us that it was an eventful day, as to-morrow they were to celebrate the semi-anniversary of his father's death. "And as I'm a rich man, you see," he said, "I've invited the whole village to come here to-morrow. Every one who likes may come, and if they don't come, I shall be very much offended." Great preparations had been made in the way of food and drink, and we were obliged to sample the feast. It was a sort of rehearsal for it that had been held to-day. While we sat there, two of the fathers of the village came in to talk to our host. He excused himself, saying they had some important business to discuss, and went into the next room with them. After a while he 


\section{THROUGH SIBERIA}

came back; it was no go, he said; they had too much liquor in their heads to talk business; they would have to leave it till the morning, when they could see more clearly.

He had much to tell us about the Yenisei-Ostiaks. They were a poor, miserable people, who were dying out, he thought. They were all deeply in debt to the traders, some owing as much as 500 roubles each, or more, and during the last few years they had not been able to pay much of their debts, as the squirrel-catch had been poor, and this year had dwindled almost to nothingnor had the fishing been particularly good either. And on account of their poverty there were very few of them, if any, who had proper nets. The main trouble was liquor, he thought; unless the traffic could be stopped, they were bound to go steadily downhill. Of course, the sale of vodka was prohibited; but what was the use of that, when they got it just the same?

The Ostiaks had arrived only a few days before in these travelling boats of theirs, to make their purchases for the winter ; chiefly meal, which they get on credit, against an undertaking to sell their skins to the trader, when they get them. He said that as a rule they were very honest, and paid their debts when they could; hut they had little idea themselves of what they owed. " And let me tell you, I'm not such a dishonourable man, for a trader. When I ask one of the Ostiaks if he knows what his debts are, he may answer that they must be 500 roubles; and then I tell him that he only owes me 200 roubles."

When asked what he thought was necessary to preserve the Ostiaks from ruin, he replied that the only thing would be for the Government to take everything into its own hands and keep "us traders" out. This was plain speaking; but when the man went into the next 214 


\section{VERKHNE-IMBÁTSKOYE TO SUMARÓKOVA}

room for a moment, his wife followed him. When he and the wife came back, he told us she had scolded him for sitting here and talking so openly to strangers; but what he had said was true, all the same.

He made out that the Yenisei-Ostiaks were not mixed with Russian blood, as it hardly ever happened that Russians married them ; and the Ostiak women would not have illicit intercourse with Russians, he said ; that he knew from his own experience when he was young. He was by no means disliked by the girls in those days, and he had made proposals to an Ostiak girl ; but she wouldn't, for she was afraid he would give her a child, she said. His wife sat at the table listening to all this, but it did not seem to interest her at all-and, of course, it was a long time ago.

But meanwhile it was getting late, and we had to see about going aboard again. We expressed our cordial thanks to our amiable and communicative host and his wife, said "do svidanye" ("au revoir"), and he on his side protested once more to Vostrotin his unspeakable annoyance at being in such a condition when receiving so honourable a visit ; if he had only known beforehand, he would certainly have arranged to be sober. These were the last words we heard from him, and it was in vain that Vostrotin told him he had been pleasantness itself. As we went down to the boat everything was quiet, both in the village and on board the boats; they were sleeping off their liquor, both Russians and Yenisei-Ostiaks.

There is something unspeakably tragic in a destiny like that of the Yenisei-Ostiaks ; formerly, as it seems, the dominant people over a great extent of this country to the south-on the northern side, and no doubt also for a long way to the south, of the Altai mountains. Now all that is left of them is this small, poor, rapidly 


\section{THROUGH SIBERIA}

disappearing tribe along the Yenisei and some of its tributaries, where they eke out a wretched existence by doubtful and uncertain hunting and fishing, which moreover are declining every year. Thus, one of their former great sources of income, the sable, is now almost extinct, and the Russian Government will soon entirely prohibit its being caught. The Yenisei-Ostiaks complained bitterly of this, as may be imagined, since it means taking away their livelihood. True, there are not many for them to catch, but one or two might be picked up in the course of a winter, and a little animal like that pays a lot of debts. How were they going to pay them now? A people doomed to perish.

In his interesting book on the northern parts of Russia, Sidórov expressed the opinion that the decline of the various native races, and the famine among them, date from after 1805, when the granaries were started in Siberia, and the natives learned to appreciate bread. Before that time they only ate meat and fish, and were not badly off, he thought. There may be something in that; their wants have increased, but not their incomes. Otherwise there was, perhaps, at least as much truth in what the trader we were talking to here said about liquor having so much to do with the decline of these natives. Along with diseases that are communicated to them, especially venereal diseases and epidemics, liquor is no doubt their worst enemy.

The Government, undoubtedly with the best intentions, has prohibited the sale of liquor to the natives in the whole of the Turukhansk district. But what is the use of that, if the prohibition cannot be enforced? Nay, a prohibition of this sort may even have the opposite effect ; it makes liquor a disproportionately valuable article, when it cannot be sold legally; and the temptation may then be too great to use it for obtaining great 216 


\section{VERKHNE-IMBÁTSKOYE TO SUMARÓKOVA}

advantages. In the district to the south the sale of liquor is permitted, for which reason the price is lower there, and it certainly cannot be shown that the natives suffer more from it; it is not made so much of there nor do they have to part with so much of their belongings to get it.

To put a stop to the traffic is not so easy, without very strict regulations. One of the traders we talked to on the way, told us frankly that he had given the natives liquor when they came to the village to trade. "For," said he, "if I had not done that, one of the other traders would have given it them, and he would have taken away my customers, and had a call on their skins for the winter." And then nearly all these natives were already in his debt, he said, and so he would have lost the payment of the old debts besides. No, there was nothing for it but to keep them warm with vodka. For that matter, they did not get so very much of it. He told us that when they came to the trading station they generally had a round of vodka as a welcome, and then, when the business was finished, there was another round; and on these two rounds they often got more or less drunk, most of them. That was where the pleasure came in, and some of them, men and women, became almost insensible. He himself had often proposed to give them butter instead; but although they are fond of butter, and will even buy a supply of it for the winter, vodka is what they want above all, there was nothing else for it.

In these relations between the trader and the natives, who are given credit and are always in debt, there is a great resemblance with the state of things which formerly prevailed in the north of Norway, when all the fishermen were in debt to the trader, and it was the same in Iceland. Of course, it is a good thing for 


\section{THROUGH SIBERIA}

the fishermen and hunters when they are in want to have a trader to fall back upon, from whom they can get what is necessary, paying him when they can. But, on the other hand, it is easy to understand that in this way the people become entirely dependent on the trader, and there is a temptation for him to take advantage of their position. He obtains their skins and fish at a price that is to some extent fixed by himself, and he pays them in his goods, of which he also fixes the value. It takes an honest man not to avail himself of the opportunity of making a profit on both sides ; and no doubt the result is that the fisherman and hunter often do not get what they ought for their catch. If liquor be added as an auxiliary on the side of the trader, the conditions are made even more unequal.

There were now assembled at Sumarókova most of the Yenisei-Ostiaks that are to be found in this neighbourhood. There might have been about a couple of hundred of them in the boats here. I was told that the whole tribe of Yenisei-Ostiaks numbered about 700 in all, but Donner writes to me that the total should be about 900 , and that is probably more correct. They live along the Yenisei and its tributaries northward, from this district here to some distance beyond Turukhansk. But it is rapidly dying out, this race.

As I have said, not very long ago they must have been spread over great tracts of Asia and were divided into several tribes. Of one of these, the Kottes, Castrén, before the middle of last century found only five men left, who lived on the Agul, a tributary of the Kan, which flows into the Yenisei.* Other kindred tribes had at that time entirely disappeared, or had been absorbed

* The last of the Kottes who spoke his own language died only about six years ago, as Mr. Kai Donner tells me he discovered when travelling in the district of the Kan.

218 


\section{VERKHNE-IMBÁTSKOYE TO SUMARÓKOVA}

in the Turks and Tatars. Castrén thinks that in his time there were scarcely $\mathbf{1 0 0 0}$ of the Yenisei-Ostiaks liable to pay taxes, so that with women and children there would be perhaps three times that number; but it is not easy to say how accurate Castrén's figures are. According to Sidórov's information, the public books gave the numbers of Ostiaks in the Turukhansk district in 1862 as 888 men and 716 women; but whether these Ostiaks are all Yenisei-Ostiaks, or whether some ordinary Finnish Ostiaks are included, I have not been able to find out. And now they have dwindled down to about 900 in all. It can be understood that such a people may easily die out, living in such close contact with the Russian colonists and leading such an uncertain existence, entirely dependent on fishing and hunting.

When we came aboard there was much talk of what we should do next morning. Should we start at 4 A.M., as the pilot wanted to do, so as to pass the Osinovski rapids in daylight, or should we sacrifice three hours in order to see a little of these Ostiaks in a sober state ? It was no doubt the last opportunity we should have of seeing any of this dying race. The choice was a difficult one ; it was important to reach Krasnoyarsk in time, and the rapids could not be passed in darkness. We decided to wait, nevertheless; but Nature made the choice easier for us. At five in the morning, when we were to have got up and gone ashore to see if any of the natives were about, there was such a thick fog that we could not even see the bank off which we lay, and there was no question of leaving here just yet.

We turned in again and went ashore at about seven when we could hear signs of life beginning on the beach. Fires had been lighted on the shore near several of the boats, and each family was making tea and cooking breakfast; more and more people were beginning to turn out and 


\section{THROUGH SIBERIA}

sit on the beach in groups round the tea-kettles. They were still mostly women; the men came tumbling out of the boats one by one, and went off to the fires and tea-kettles. They were sober now.

These boats are roofed over with boards covered with birch-bark, forming a sort of cabin along the greater part of the boat, and they seem to have a comfortable sleeping-place for the whole family inside, much the same as in a tent, but lower. They must be really snug travelling-boats, and there is plenty of room inside the little houses. They are perfectly flat-bottomed, these boats, and have a curious long prow forward, which stretches far over the beach when they put in. It is, of course, intended to enable one to land more or less dryshod along these shelving banks. They also have a peculiar gangway with steps cut in it, to put out from this prow on to the beach, so that they can reach far in, even when the boat takes the ground a good way out.

The impression I had of the first Yenisei-Ostiak I saw, that they reminded one of gipsies, held good here also in some measure. I found several faces, both of men and women, which might well have been gipsy faces. But, for the most part, I am bound to say they had a somewhat less European look. It appeared, however, that there might be a strong admixture of Russian blood in some of them. This might seem most visible in many of the men, of whom some few had quite brown hair, and two or three fair, or at any rate brownish beards. But whether this was due to mixture with Russians, or was original, cannot be said with certainty. If this race was a fair one to begin with, then we should rather suppose that the numerous dark people among them were due to mixture with other native races, especially, perhaps, Tunguses and Samoyedes; but this may be uncertain - in any case the dark ones were in a great majority. 220 


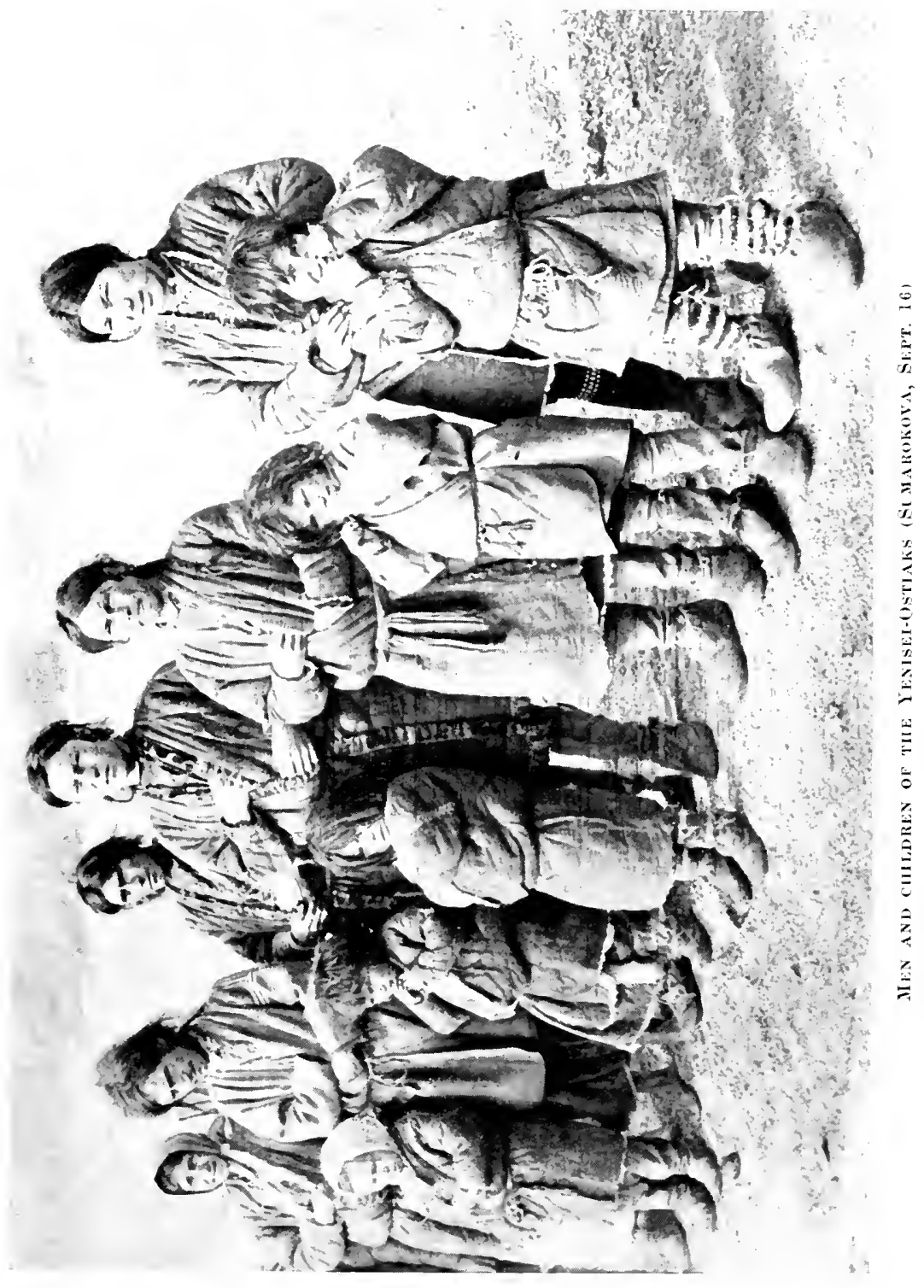




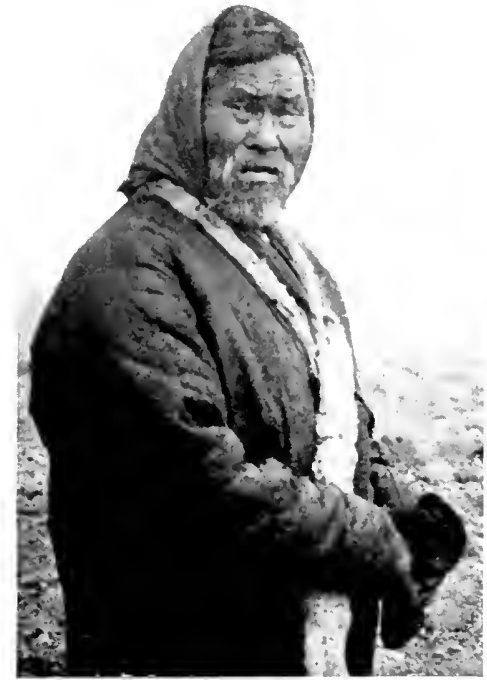

YENISEI-OATIAK (SIMAROKONA, SEPT, li

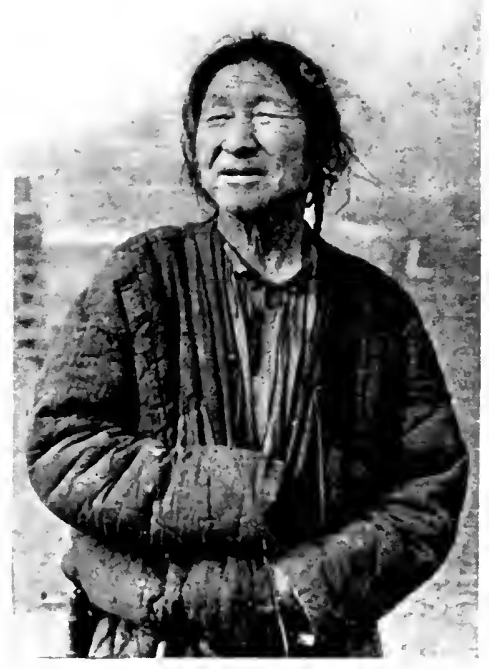

IEXISEI.OSTAK WONAN (SEPT, 16)

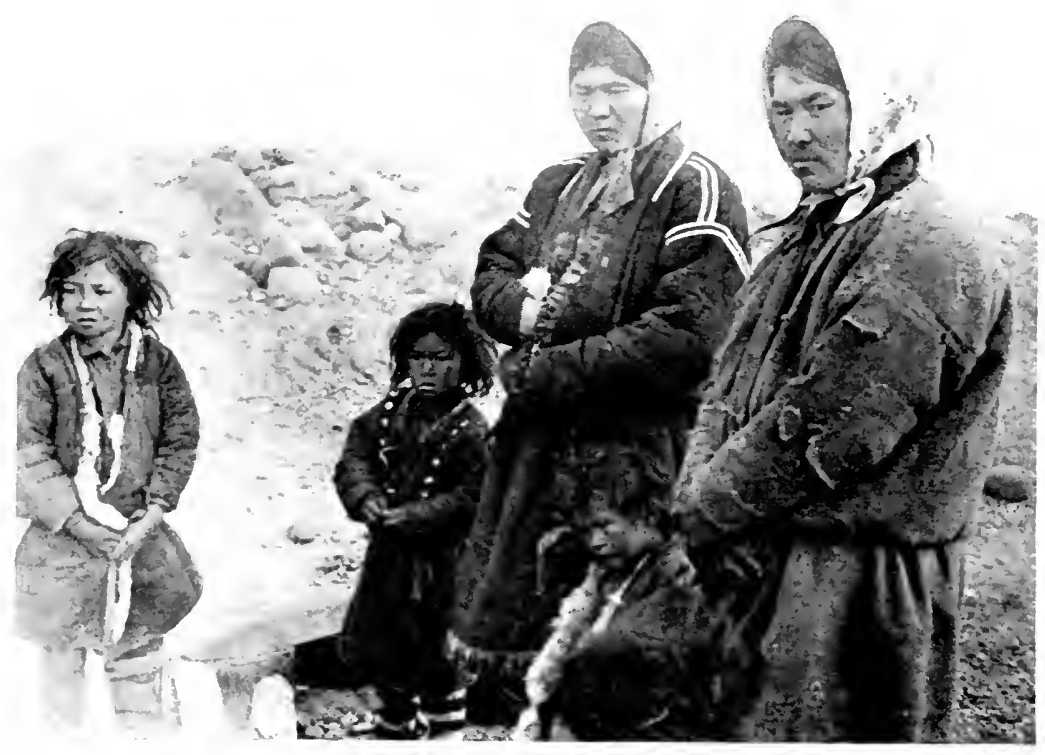

YENISEI(TSTAKS, WOMEN AND CHLDREN (SUMAROKOVA, SFPT, 16) 


\section{VERKHNE-IMBÁTSKOYE TO SUMARÓKOVA}

The growth of beard in many of them was more pronounced than one would expect in an Asiatic people like this, even though there was not so very much beard to be seen. The women looked, throughout, more Asiatic than the men. Several of them appeared to be typical short-skulls, but had not oblique eyes.

Here, again, I thought I could distinguish several types of face, especially among the men. While some faces were short and broad, with a nose relatively flat and broad below, there was another type of longer and narrower face, with a nose quite sharp, longer and narrower, more like an ordinary European. In a few cases, where the eyebrows were drawn up a little at the outer end, this might give the eyes a somewhat oblique appearance. Which of these types was the more original and genuine for Yenisei-Ostiaks, it is difficult to say. The first, short and broad type of face has more resemblance to the surrounding peoples, Tunguses on one side, Ostiaks on the other, and Samoyedes on the north. The other was more peculiar, but might be supposed to be more mixed with European blood, although it did not exactly remind one of the Russians either, and the growth of beard was much more scanty. The great majority of both types had dark hair, often black, though a brownish tinge was also common; the pronouncedly short-skulled type undoubtedly tends to be darkest. The complexion, or colour of the skin, was fair in all cases, and not so yellow, or yellowish-brown, as one finds it, for instance, in the Tunguses.

At one of the fires a woman was engaged in cooking a porridge of dark rye-meal with lumps in it, which she squeezed out with her shapely little hand and threw into the porridge. It seemed to be a sort of middlings. It was for the dogs, she said, in reply to our question; and it was exactly like dog's porridge at home. Close 


\section{THROUGH SIBERIA}

by sat a man eating his breakfast. He had a long face and a grizzled beard, and it seemed to me that he must have a good deal of Russian blood. For that matter, there were several with grizzled beards, which are not usually seen among the natives. Vostrotin asked him how much he owed the trader. Five hundred roubles he replied, stuffing his mouth with small fish and drinking tea meanwhile. Last winter he had only caught four squirrels ; * and the fish he had caught this summer only amounted to three poods (108 lb.). Besides that there were a few elks' skins last winter. That was not much to pay his debts with. Others answered that they had got four poods of fish, some five, some as many as ten. Only one had caught 100 poods (3611 lb.); but that was in some of the tributaries of the Yenisei, and they were only small fish.

It must be said that, in spite of their poverty and possible future destitution, they seemed enviably happy and contented; and now they were all getting ready to leave, as soon as they had had breakfast. They had got their goods and had their spree, and now they were homeward bound for the forests where they pass the winter. Soon we saw them beginning to get their boats ready, and there was a busy scene all along the beach. They stow many of their things on the top of the roofs of the boats, and the women were now occupied with this.

While we stood talking to the man with the long bearded face, who sat cross-legged by the fire eating, we heard the continual, monotonous singing of a man's voice from the interior of the boat that lay close by. When Vostrotin looked in on him and asked if he

* As already mentioned (p. 165), this remarkable lack of squirrels must be due to an epidemic among them, which has attacked the hares at the same time.

222 


\section{VERKHNE-IMBÁTSKOYE TO SUMARÓKOVA}

was still drunk, he answered that he was not drunk at all; he only sang because it was his habit. $\mathrm{He}$ came trotting out of the boat, sat down by the fire and lit his pipe, and he was really perfectly sober. Soon some more came, a whole collection, from the other boats and a tent close by; there were ten or eleven men, besides a couple of women and some children from the boat here. There were many good types among them; most were dark-haired, and with only one or two exceptions they were entirely beardless, but it is true that these were mostly young men, while the bearded ones were older. It is significant that only the men were loafing about like this, smoking, staring, chatting and doing nothing, while the women worked first at preparing the breakfast, and then at getting the boats ready. Among us it is rather the ladies who are supposed to waste their time in gossip.

We went on to another part of the beach farther south, where there were many boats lying, and the Ostiaks sat on the sand round the tea-kettles eating their breakfast in the middle of the Russians, who were getting their nets ready to go out fishing. There was much life and movement. Out on the boats the women were busily engaged in making ready for the start. At the same time the fog was beginning to lift, and the sun was shining brightly above it. A number of women and men were sitting in a tent at breakfast, and an entirely naked youngster lay in a cradle.

Here we were told that they had a real shaman among them. As we wanted to see him, he was at once summoned from one of the boats and led by the hand by a younger man; for he was quite blind. Yes, he was a shaman, he said, but it would take some time to rig himself out to shaman to us, and besides he had to have a special tent for it. As the weather was 


\section{THROUGH SIBERIA}

already fairly clear, we could not wait long, we wanted to get away. But he might have time for the lesser shaman dress, he thought. It was fetched by his assistant. 'The costly treasures were kept in a little square wooden box, which looked new and had a cross carved on the outside. Then he and the wooden box were taken to a special tent, and there he seated himself, cross-legged, with the box before him. Together with a lot of young Ostiaks we crowded into this tent as well as we could and sat down on the ground.

The casket was now solemnly opened, and proved to contain a copper crown with a cross on it, something like an old mediæval royal crown; but Vostrotin and Loris-Melikov said afterwards that it was a Russian bride's crown. There was also a stomacher with a cross and ornaments like a chasuble, and it was obviously a clumsy imitation. He set the crown on his head and put on the stomacher. Then the performance was to begin - but suddenly the blind man paused and said that the contribution must first be paid, a rouble for each of us, otherwise it was impossible for him to shaman. Three roubles were handed over; he felt them and rang them, to make sure that they were good. Is it not strange that the priesthood of all nations throughout the ages, whether heathen or Christian, should be such good judges of coin?

Then at last he was ready; and all at once he started a strange, monotonous song in a tremulous voice full of trills, while incessantly making the sign of the cross, like a Russian priest, and bending forward; then he lifted his face to heaven, stretched his arms upwards and raised his voice, as though invoking the lord of heaven. After that he bent his head forward again towards the ground and gave a low muttering, no doubt to conjure the spirits of the earth. Altogether 224 


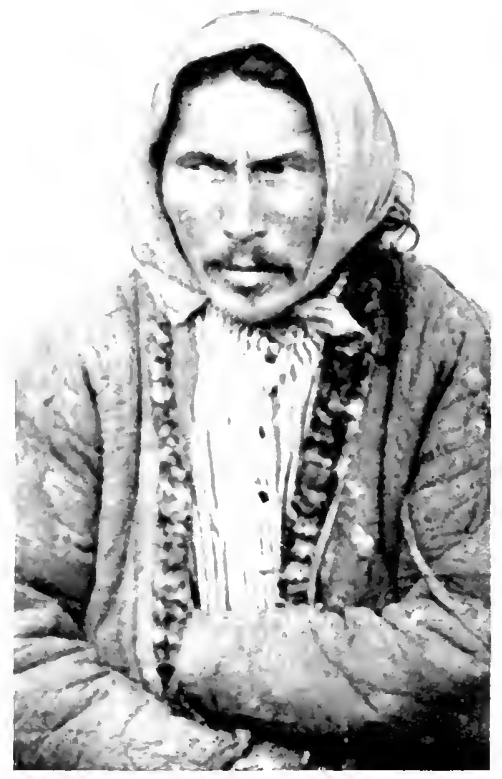

YENISEI-USTIAK (SFPT. 16 )

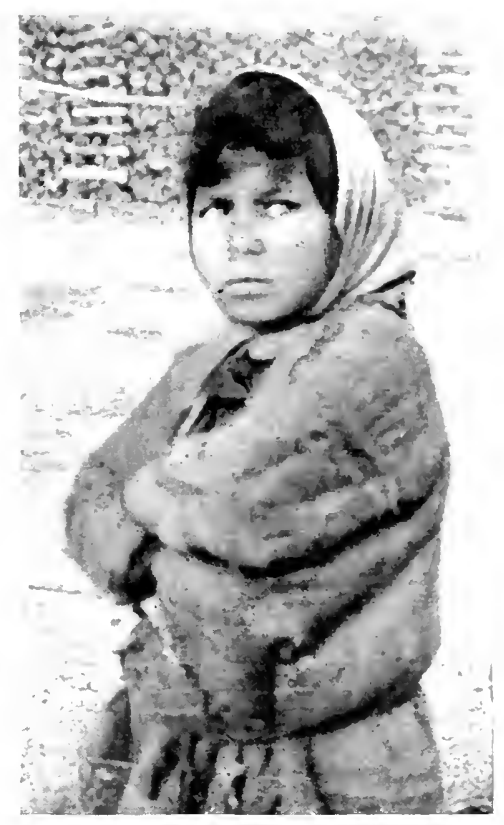

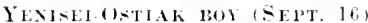

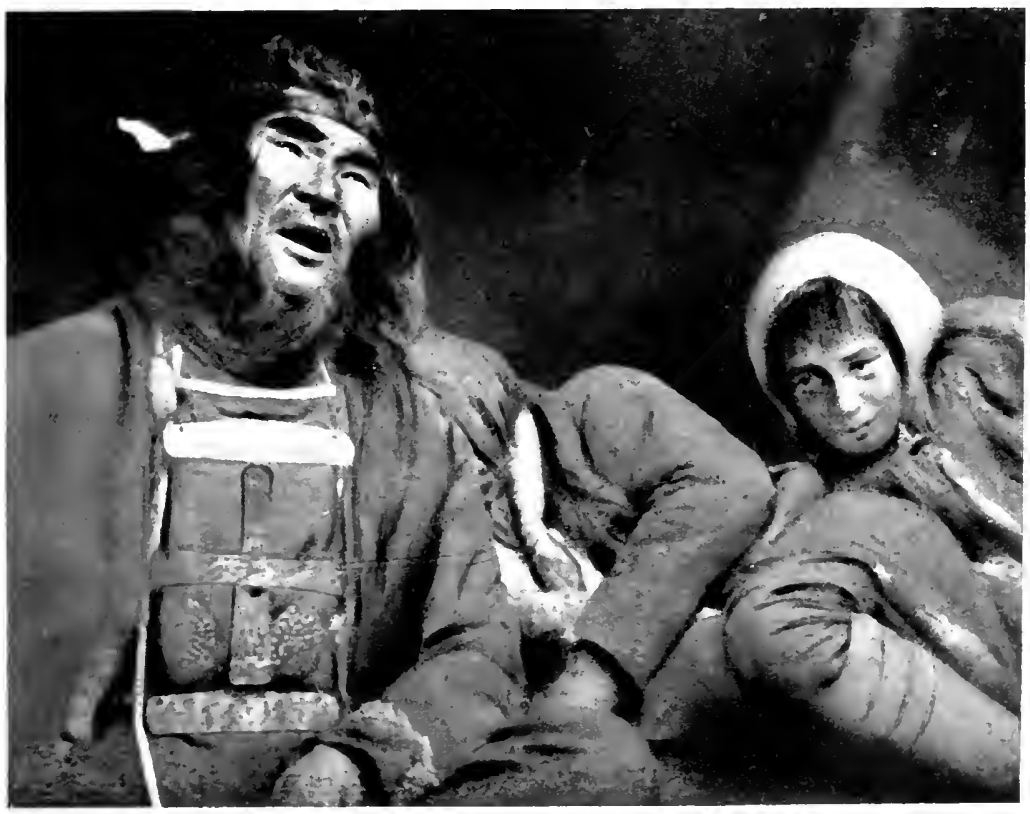

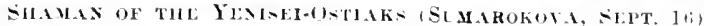




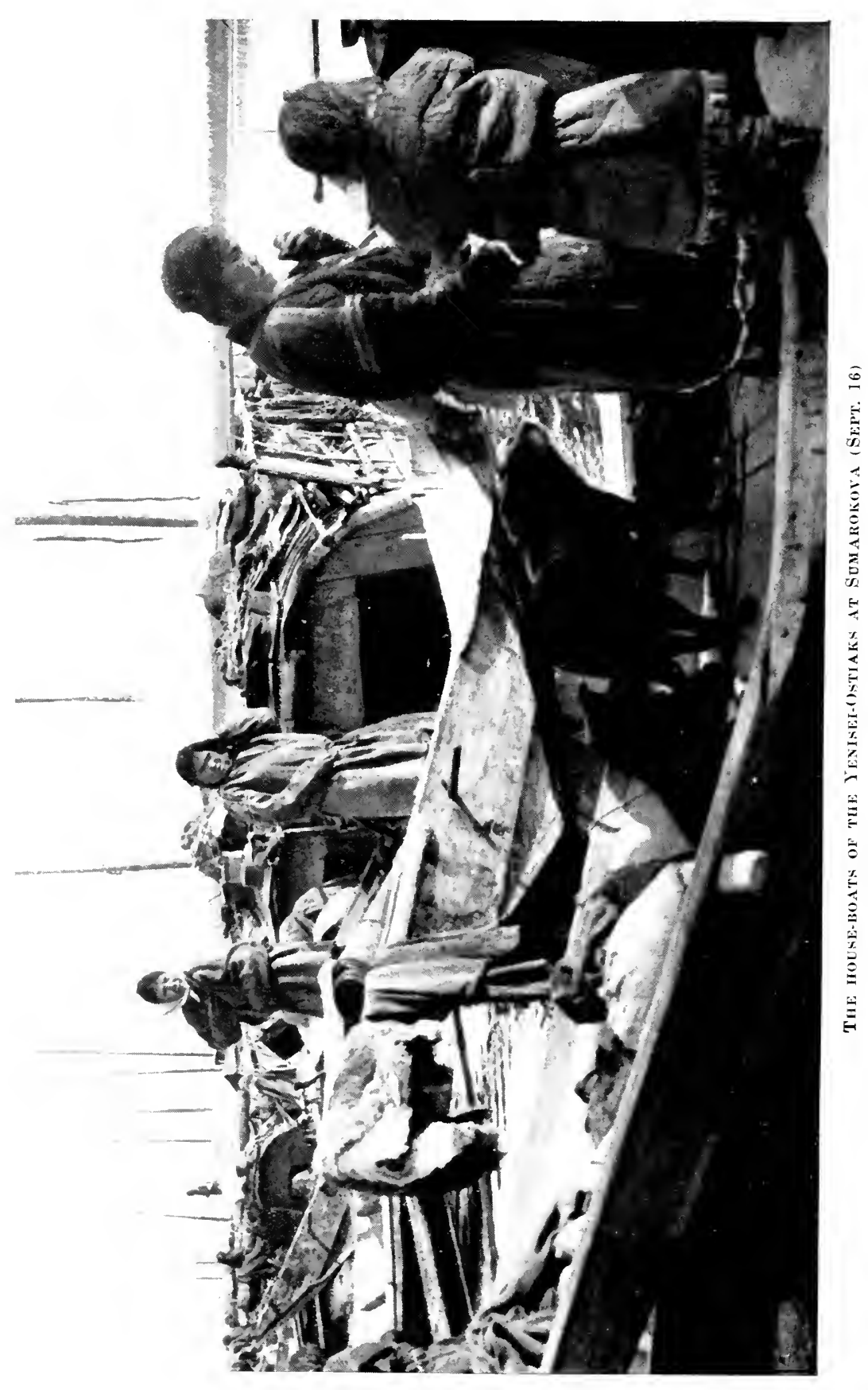




\section{VERKHNE-IMBATSKOYE TO SUMARÓKOVA}

he was a great actor, and imitated the priests as well as he could.

But now the excitement increased. He took off the crown and put it on his assistant, while he himself sat up on the little wooden box. The singing grew louder and the gesticulation more violent; now and then came a refrain, or whatever it was, which had to be repeated by the listeners; or perhaps it was more like what is heard in church, when certain sentences are uttered by the whole congregation. Soon the exaltation increased still more, he had to get higher up and rose to his feet; evidently he was now drawing near the lord of heaven and a wild note came into his voice. But at that moment a dog barked outside the tent. He broke off abruptly and became perfectly silent-sat down and mumbled something about having being interrupted by the dog, "and that is an unclean animal, because it eats excrement," he said. Therefore he had to begin all over again. And then the whole performance was repeated, with the same monotonous singing the whole time, while the voice rose and became more insistent, with more and more tremolos.

At the same time he began to prophesy, saying that there was a foreigner in the tent, and that there was one who stood near the Tsar (this must have been Vostrotin, who is a member of the Duma), and then there was a third, who was a wily fellow and one to beware of - no doubt this was intended for Loris-Melikov, who is a diplomatist. He also informed us that a great universal war was soon coming. But we had no time for more, we wanted to be off.

When he has the great shaman dress on, he is arrayed with figures of bears and other beasts of the forest all over him; and if the performance is carried on long enough, the shaman really works himself up into a 


\section{THROUGH SIBERIA}

complete ecstasy, which is transmitted to the listeners in the tent, so that they may all become quite wild.

Castrén says of the religion of the Yenisei-Ostiaks that even if they are Christians, they worship three mighty divinities. These are the god of heaven, whom they call Es; an infernal female deity, whose name is Imlya, and the god of earth; that is, the bear. As to the bear, they imagine that it is not an animal like all the others, but that its animal semblance is only a disguise which conceals a human creature and a divine power and wisdom. The same conception, says Castrén, is also general among the Tunguses, Samoyedes and all Finnish tribes; and, we might add, it is the same conception that survives in our fairy tales, where the bears are often princes in the form of animals, and in the common popular notion that the bear has the strength of ten men and the wits of twelve. The Yenisei-Ostiaks also make the bear the guardian of the whole infernal realm of spirits, a power which he shares with Imlya, but both appear to be subject to the heavenly god.

The shamans naturally stand in a peculiarly intimate relation to these super- and subterraneous powers, from whom they derive their faculty of curing diseases, warding off evil spirits and predicting the future ; they are something like our wise women in Norway, who are also a remnant of ancient heathendom.

Meanwhile the weather had cleared and there was no time to waste. We had to go aboard and away as soon as we could. Several of the Ostiak boats were also ready to start. It was picturesque to see them being poled out from the shore, while the morning mists rolled away from the country to the south, and the sun shone on the mists and on the bright water behind them. There was life and activity everywhere. Many of the people were standing on the roofs of the boats 226 


\section{VERKHNE-IMBATSKOYE TO SUMARÓKOVA}

and stowing away the things that were handed up to them.

Here, again, Loris-Melikov came across some countrymen, two Armenian political exiles. One of them, a smith, was of pretty nearly the same type as himself; and this smith told him that the pristav (prefect of police) at Turukhansk was a kind man, especially to Armenians. He also said that they received their monthly allowance of fifteen roubles, even if they did a little work; but they did none in this village; for the people there were so poor, he said, that it would be only taking away their work. Altogether there were six exiled Caucasians here at Sumarókova. A loose talker of a trader we met next day at Vórogovo, however, thought these political exiles were a plague to the country. It was not very surprising that they would not work; those at Sumarókova had stripped his son of 700 roubles at cards, he asserted ; but as to the truth of that, it is as it may be. If the son was anything like the father, I can only suppose that he had honestly deserved it. 


\section{CHAPTER XI \\ FROM SUMARÓKOVA TO YENISEISK}

Ridges along the river : The goldfield : Monastirskiy island : Osinovski rapids: Winter fishing for sturgeon in the rapids : Work on the river-bottom in frost : Vórogovo, the first telegraph station : Manure of no value in Siberia : Can only telegraph in Russian characters : A Tungus : A pleasant trader and an unpleasant one : Romance of the forest : Agriculture and cattle-raising : Continued difference between the west and east banks : The village system and freehold farming : Manuring and rotation of crops : Timber sawn by hand : Nasımovo telegraph station, but still only for Russian characters : Unsuccessful bread-hunt : Aground : Kholmogórovo: Sturgeon : Rotten fish : Arrival at Yeniseisk

A 10 A.m. we weighed anchor and stood out again A to the southward from this lively trading place, where one Ostiak boat after another was putting out from shore. Soon the whole fleet would set out for the forests and leave the village to celebrate the semi-anniversary of the death of the trader's father. If the feast itself came up to the rehearsal we had seen the evening before, it must have been lively. Now the question was, how soon we could reach the rapids. Much of the day was gone; but the motor was working well, there was calm, sunny weather, and we made good headway.

The ridges, which we had seen farther north inland to the east of the Yenisei, here reached the river ; and to the south of Sumarokova they pass to the west 228 


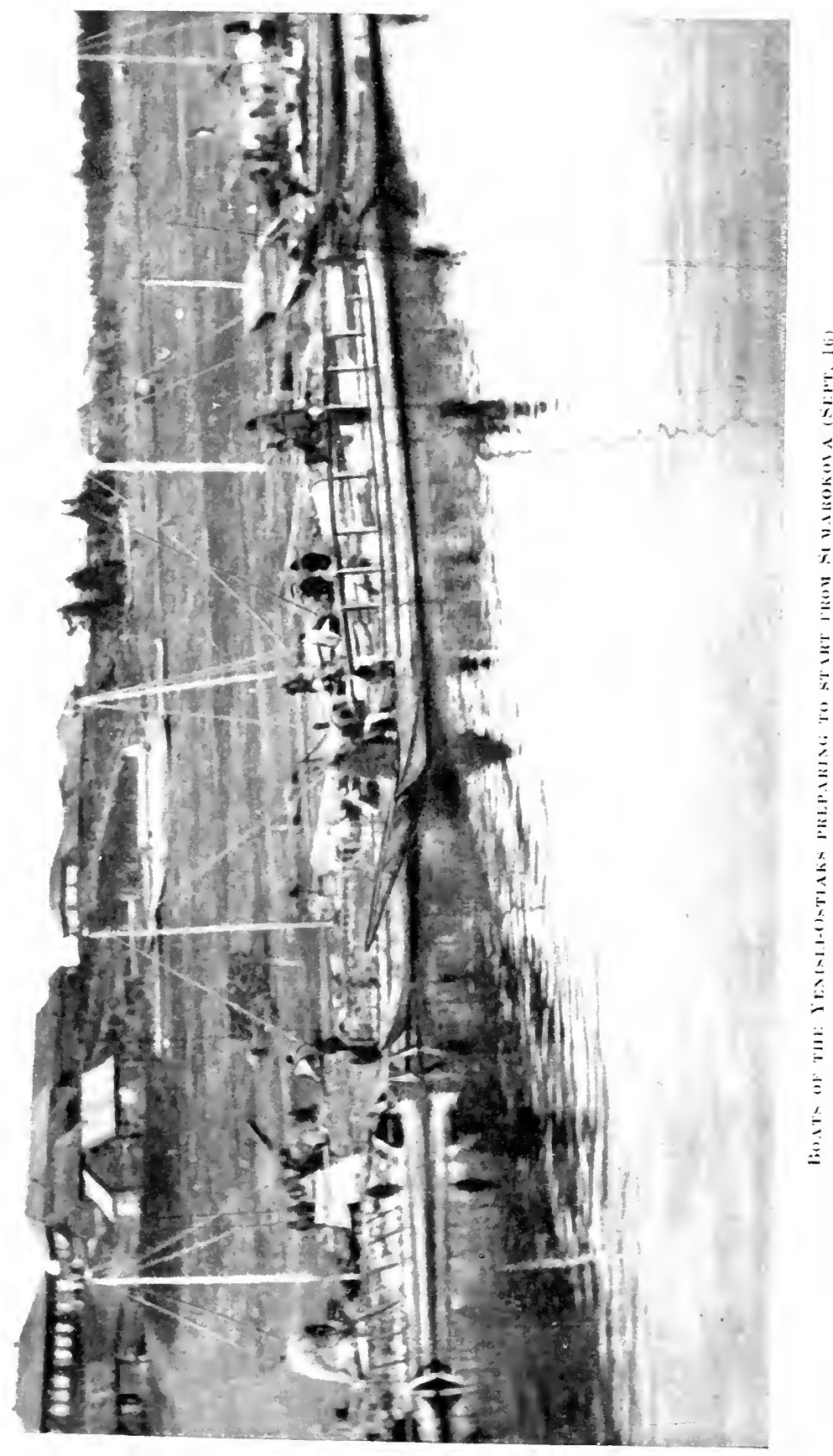




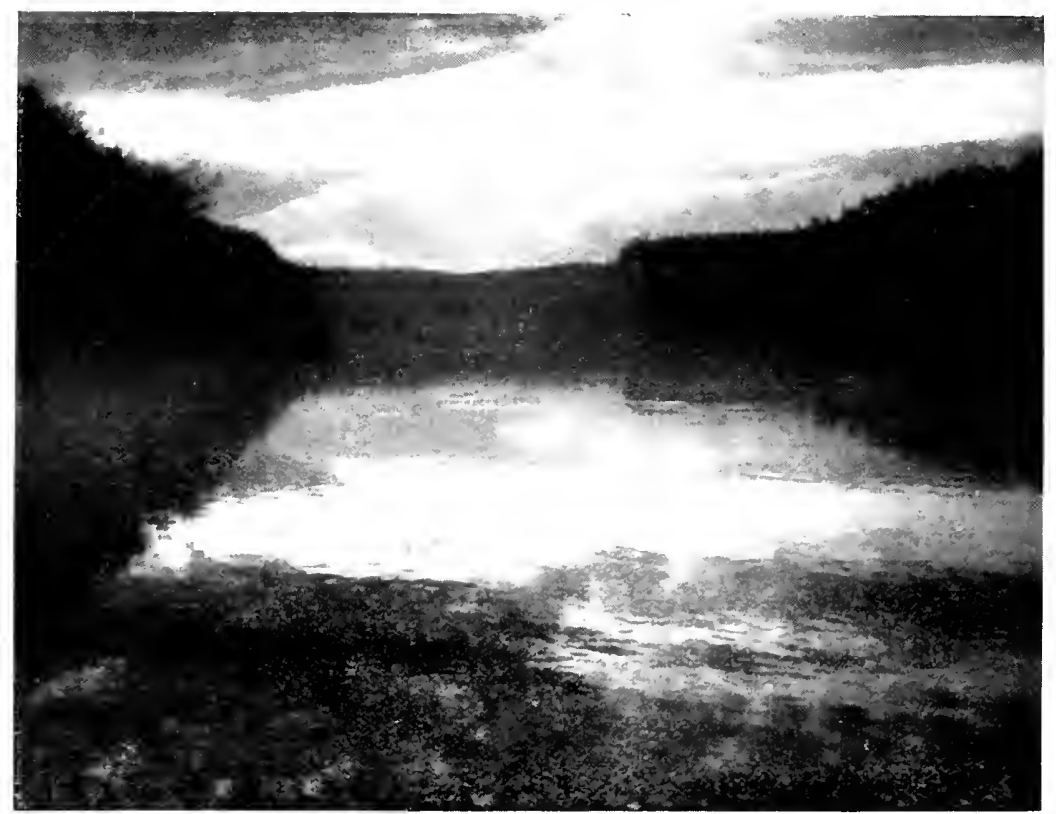

AT THE RAPULS NEAR MONASTIRAK (SEPT, 16)

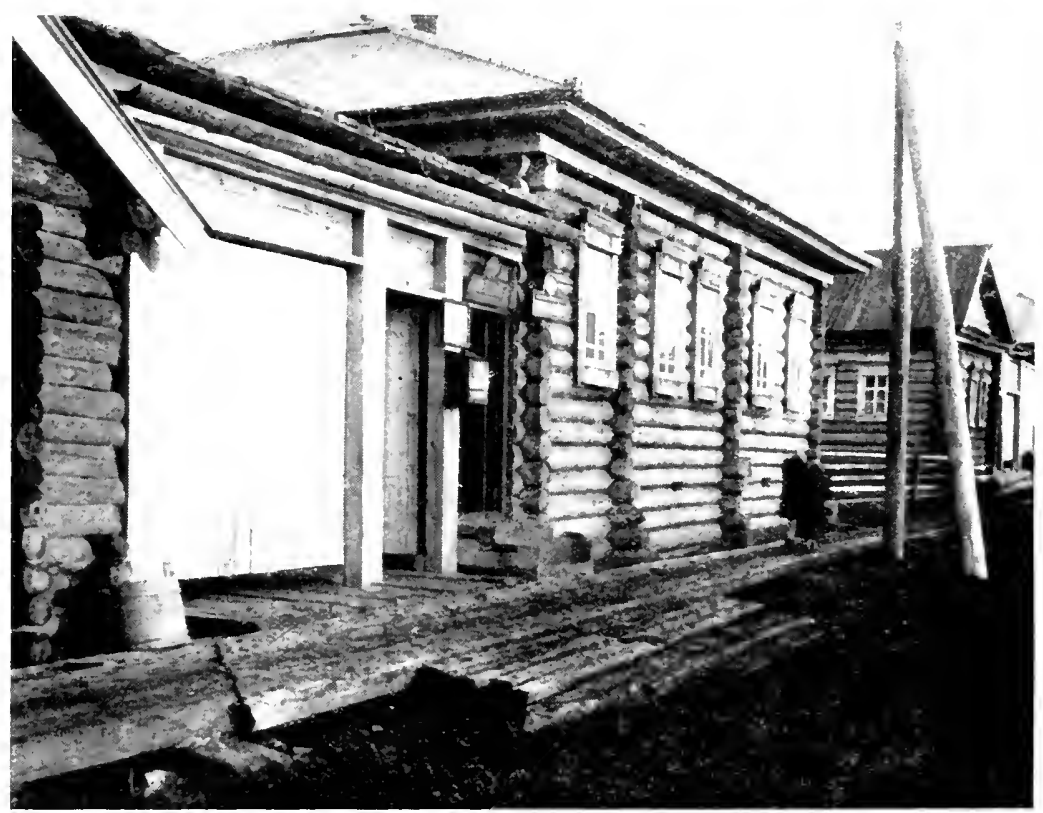

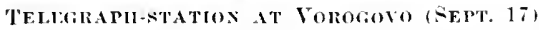




\section{FROM SUMARÓKOVA TO YENISEISK}

side and follow the course of the river southward, and the land on that side therefore rises suddenly to an unusual height. The east side is here much lower and flatter; but there, too, a ridge extends southward a little way inland, joining the river farther south, where the latter makes a bend at right angles. Here the other bank again becomes low, as the ridge southward from Sumarókova goes on in a southerly direction inland, and no doubt extends towards the hills at the rapids to the south.

As far as I could see at a distance, these ridges consist to some extent of loose material. There were great landslips of sand in many places along their sides; and small streams had dug out deep channels or little valleys with fresh landslips down the slopes. And there was nothing but sand and clay to be seen anywhere. But probably this is only on the outside, and one would doubtless come upon beds of rock by going far enough into them.

We passed the Podkámennaya Tungúska (i.e. the Tungúska below the mountains), where the gold country begins. Along this river inland towards the mountains on the east and southward on the east side of the Yenisei, is the richest goldfield in this part of Siberia. From what Vostrotin, who has gold-mines of his own, told me gold was first discovered near the Angará in 1838, and also farther north in the forties. There is a story that the first grains of gold were found by natives in the crop of a capercailzie. There was soon a rush of people who came to wash gold along all the rivers. At first they came from the Ural, and then from Petersburg and the whole of Russia. In one district 20,000 poods (320 tons) are said to have been got out, and in another 18,000 poods (288 tons) ; together 38,000 poods (608 tons) of gold in the two richest Yenisei districts. 


\section{THROUGH SIBERIA}

About half of this quantity was obtained in a small tract along two little rivers on the north and south sides of the watershed between the Pit River and the Podkámennaya Tungúska.

All this gold brought both advantages and disadvantages to the district. To the villages along the Yenisei in the district where gold was found in the mountains, it was of course a great source of income, as the placer miners gave them a market for their goods ; besides which many of the inhabitants themselves became mine-owners and wealthy people, as could be seen in many of these villages to the south. But the price both of labour and of produce rose, and this was anything but an advantage to the villages along the river in Turukhansk district to the north of the goldfields, where they had little or no income from the mines, but only enhanced prices for everything they required; while there was little more demand for the things they were able to supply, though they could sell their fish somewhat more advantageously. It may therefore be supposed that this enhancement of prices due to the mines has contributed to the decline of the northern portion of the Turukhansk district.

We were now beginning to approach the rapids, but it was already drawing on towards evening. There were fine wooded islands ahead. The banks had the look of a well-kept park with a mixture of foliage, mostly birch, besides the various conifers, and with a floor so clean that one involuntarily looked for gravel paths along the bank under the trees. Then the rock began on the western shore, and after that on the eastern : argillaceous-schist in inclined layers, here and there with white veins. Ahead of us were steep, waterworn rocky sides crowned with forest, exactly like the banks of a river in Norway; and in the middle of the river lay a 230 


\section{FROM SUMARÓKOVA TO YENISEISK}

steep and lofty rocky island, Monastirskiy (Monastery Island).

The ridges on both sides of the river must be composed of rock. Their height is fairly uniform, and they seem to stand at about the same level as the ridges consisting partly of loose soil farther north. The ridges on the east side are perfectly flat on the top and seem to fix the level of a platform out of which the river has cut its bed. The stream became stronger as we approached the rapids past Monastirskiy, which lay in mid-channel.

And then the gorge opened out and the mighty mass of water came flowing smoothly down towards us-a grand sight. The water was rushing with white crests past all the points of rock, but everywhere else it flowed swiftly and smoothly, with whirlpools here and there and eddies rising to the surface. The boat trembled in the current, as she worked her way forward under the wooded cliffs.

We took advantage of the slack water along the bank as much as possible; but after passing Monastirskiy we had to go right across the rapids to the little island on the other side. We steered diagonally through a mighty mass of rushing water. It was already beginning to grow dark. Above us heavy, threatening clouds hung over the lofty, black cliffs, and below us was this irresistible mass of flowing water. One felt oneself in the power of mighty forces. Beyond the little island in the channel we passed into a calmer backwater; but soon we were in midstream again, until we came under the land right over on the other side of the river.

The evening grew steadily darker, with deep blue clouds over the western sky and a glimpse of the sunset between them. The mighty waters still rushed under 


\section{THROUGH SIBERIA}

us, dark and rapid. The whole effect was one of gloomy power. Higher up the gorge narrowed, and the rapids swept through it more furiously again. We had to forge ahead by the bank. After passing this place we came once more into calmer water and were able to go a good distance before anchoring for the night at about seven o'clock off the end of a little sandy island. On the bank to the east of us there was the light of a fire; no doubt some fishermen were camping there.

As we came up this last part of the rapids, before reaching the island, we saw many huts on shore. The fishermen live in them in the winter to catch sturgeon under the ice in the pools among the rapids, where it may be 200 fect deep; the sturgeon stay there a great part of the winter.

Wednesday, September 17. Early next morning we went on up the rapids. The channel was here marked by red and white beacons and brooms and larger sea-marks, as the navigation was difficult, with many banks and rocks.

Vostrotin told me how they make use of the severe winter cold here for removing rocks and banks from the bottom of the river. They cut a broad groove in the ice of the river, taking care not to go so deep that the water breaks through. By the next day a fresh layer of ice freezes underneath this thin part, and by removing a sufficient quantity of ice daily and allowing new ice to form below and on the sides, they are able to go deeper and deeper through the water, right down to the bottom. Thus a shaft is formed surrounded by thick walls of ice, where they can work comfortably and dry-shod, and rcmove what rocks and banks they wish from the bottom. It seems a good way of turning harsh nature to account.

Vostrotin also told me that they use a somewhat similar method in prospecting for gold in river beds and in marshy land. In the river, of course, they can 232 


\section{FROM SUMARÓKOVA TO YENISEISK}

easily get to the bottom in this way and take specimens of the strata underneath, to see whether they contain gold. On the marshy ground by the side of the rivers they often proceed in the following way : in the winter, when everything is frozen, they make a fire on the surface, which melts the soil to a certain depth. They take away the thawed earth, make a fresh fire, which again melts the soil under it, and so they go on till they reach the desired depth. By making a series of these holes side by side to a suitable depth, it is easy to obtain a section of a river valley from one side to the other, and across the river, in order to see whether there are gold-bearing strata at any depth.

It was an autumnal morning, with drizzling rain and a cold wind, but in the course of the day the weather cleared and the sun broke through again. On this day we had an event to look forward to: that of coming into communication with the world for the first time. We could expect to reach Vorogovo during the afternoon, and there was a telegraph station. Were any telegrams awaiting us? Above the rapids the banks became lower again, and were formed of loose strata, mostly sand as before, and the country again appeared to be tolerably flat.

In the afternoon we passed a boat full of fishing-nets. In the boat were some women, and a man sat aft steering, while a man and a dog walked along the bank and towed the boat upstream with a long line. They had been out to try the fishing and were on their way home. Farther on blue sinoke was rising from a row of tents, which stood among willows near the flat sandy beach, where boats were lying and long lines of nets were hanging to dry. The whole scene looked like a wild Indian camp from one of Cooper's romances, and we might have expected to see Deerslayer with his long 


\section{THROUGH SIBERIA}

rifle and the familiar Indian chiefs with eagle-feathers in their black hair appear through the thicket of willows on the bank before the wigwams. But instead of them we only saw some peaceful Russians sitting idly in the sun, while the boat, towed by the man and dog, came up to them.

Far away I could already see the white walls and cupolas of the church at Vôrogovo, high above the plains and the forest. With the glass I could also see the roofs of the village. We now had to get ready the telegrams that were to be sent; for we could not stay long. We should have to go on if we were to reach Yeniseisk by the 21st.

At last, at about four o'clock we anchored and went ashore. The main road from the shore up to the village, as usual in these Siberian places, led over a mountain of nothing but cowdung, which year after year had been swept out of the streets over the river bank, till it had filled up a great part of the foreshore. The streets themselves consist for the most part of cowdung, and one sinks deeply into it on stepping off the planks, which are laid along the streets as a side-walk. They are specially bad after rain, as on this occasion. The Siberian farmer has not yet got as far as manuring his land. He thinks manure does harm to the soil. Nor has he got as far as building cow-houses, where he could collect the dung. Therefore the cows mostly roam at large in the streets.

As soon as we reached the top of this hill, Vostrotin of course met an acquaintance, a trader, who greeted him effusively as an old friend. He had a powerful face with a fair brown beard, just like a Norwegian peasant. I afterwards heard that he was one of Vostrotin's political friends, who had supported his election. He showed us the way, driving the cows off the planks 234 


\section{FROM SUMARÓKOVA TO YENISEISK}

for us, and we arrived at the little telegraph station, which was also post office and savings bank.

A telegraphist in uniform appeared at the counter. There were no telegrams for us; so one had to console oneself with the old saying that "no news is good news," for bad news usually travels fast enough. But they could not accept telegrams here written in our usual Roman characters; they could only manage the Russian ones. This made it impossible to send a telegram home to Norway, or anywhere else outside Russia. But at any rate, with the help of my kind friends, I could telegraph to Mr. Wourtzel in Russian, to say that I hoped to reach Krasnoyarsk by September 25; and Vostrotin could telegraph to his brother in Yeniseisk and ask him to send a telegram in some Western language home to my children, telling them that I was still alive and asking them to telegraph to Yeniseisk at once.

To look after the telegraph there were four men, who of course were all in uniform, in this land of uniforms. But apparently there was not very much for them to do; one telegram had arrived during the last two weeks, I was told, and four men might easily manage that. This was almost worse than the Norwegian telegraph station at Spitsbergen during some winter months; when, from what I heard there, the Norwegian Government earned more by selling the puppies of the station sledge-dogs than by sending telegrams. Vostrotin had some telegrams of his own to send, and so had Loris-Melikov, and these four telegraph men had more work to do than they had had for many months.

When we had got this done, Vostrotin naturally had to go off to his friend the trader and buy a lot of provisions. He always took great care of our cuisine, and regarded himself as our host in his country; and 


\section{THROUGH SIBERIA}

a good host he certainly was. Inside the trader's shop I found a drunken Tungus, who was distinguished by his yellower skin from the natives we had met hitherto. His face was tattooed. A crescent-shaped figure extended from the outer corners of the eyes downward over each cheek. This seems to be a common form among the Tunguses; Middendorff gives illustrations of several similar tattooings. It was strange, by the way, that we had come across no Tunguses on the whole trip, although there are plenty of them in these parts; but the explanation is that the Tunguses are comparatively well-to-do, and have reindeer to look after ; they therefore keep more in the forests and do not fish much in the rivers like the poorer Yenisei-Ostiaks, who have only their dogs, wives and children, and a few belongings which they take about with them.

But we had to see about getting aboard again. Meanwhile a trader had found Loris-Melikov down on the beach and asked him why we had been buying from that miserable fellow, the other trader, who had nothing, except what he had stolen from him. He was the biggest man in the place, he said, and we ought to have come to him. This was the same man who talked about the exiles at Sumarôkova and said they had fleeced his son at cards. Vostrotin afterwards told us that he had lately established himself there, and that he was a conservative, while the other man was a liberal. Before we left he came rowing out to the Omul to make us a present of a dried fish.

While waiting for our crew, who had also gone ashore to send telegrams, we could sit on deck watching the scene on the beach, where by degrees a number of men, women, and children had collected to look at us and our boat, which of course was something of an event in their not too varied life. They were attractive, honest types, 236 


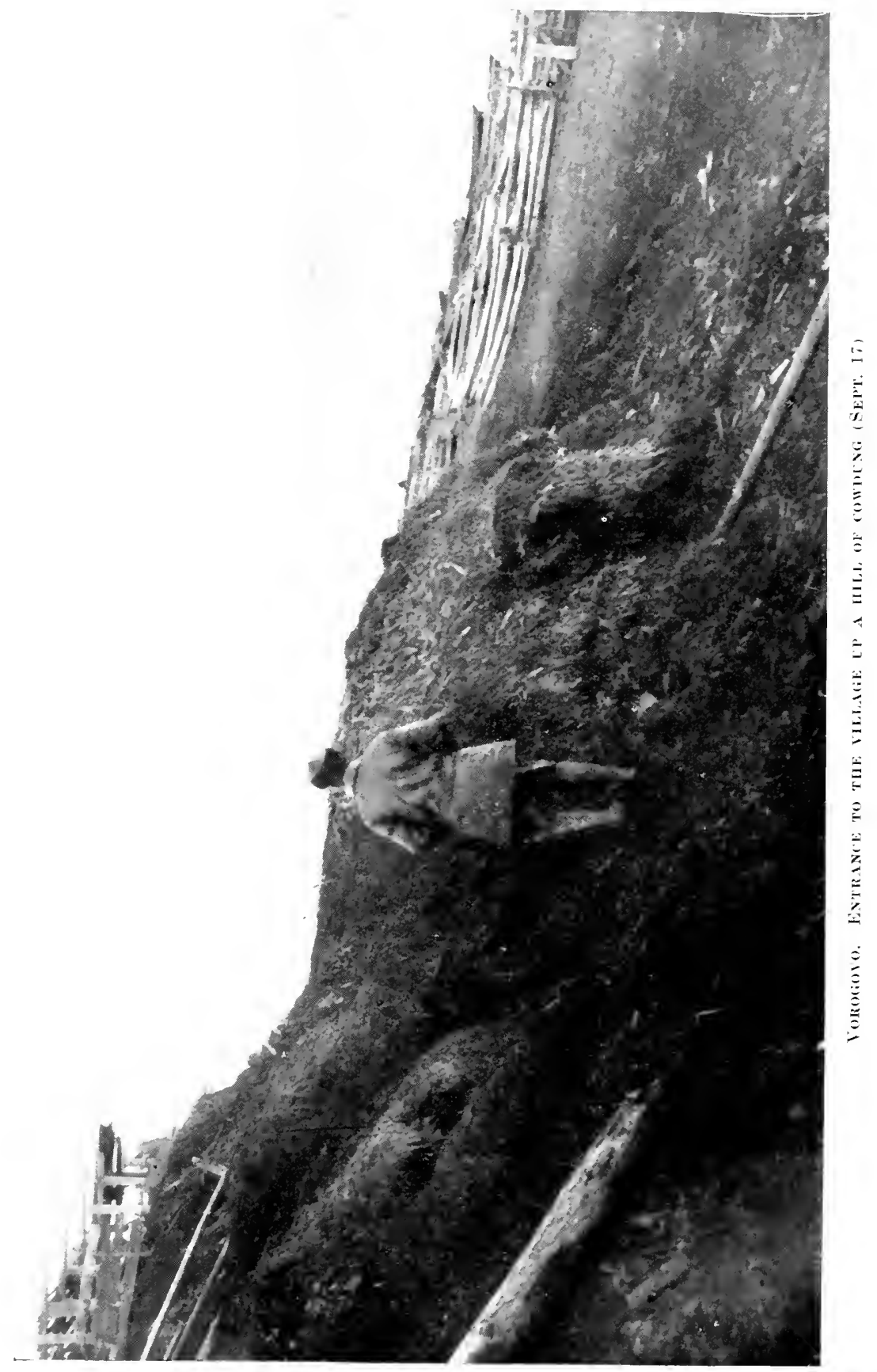



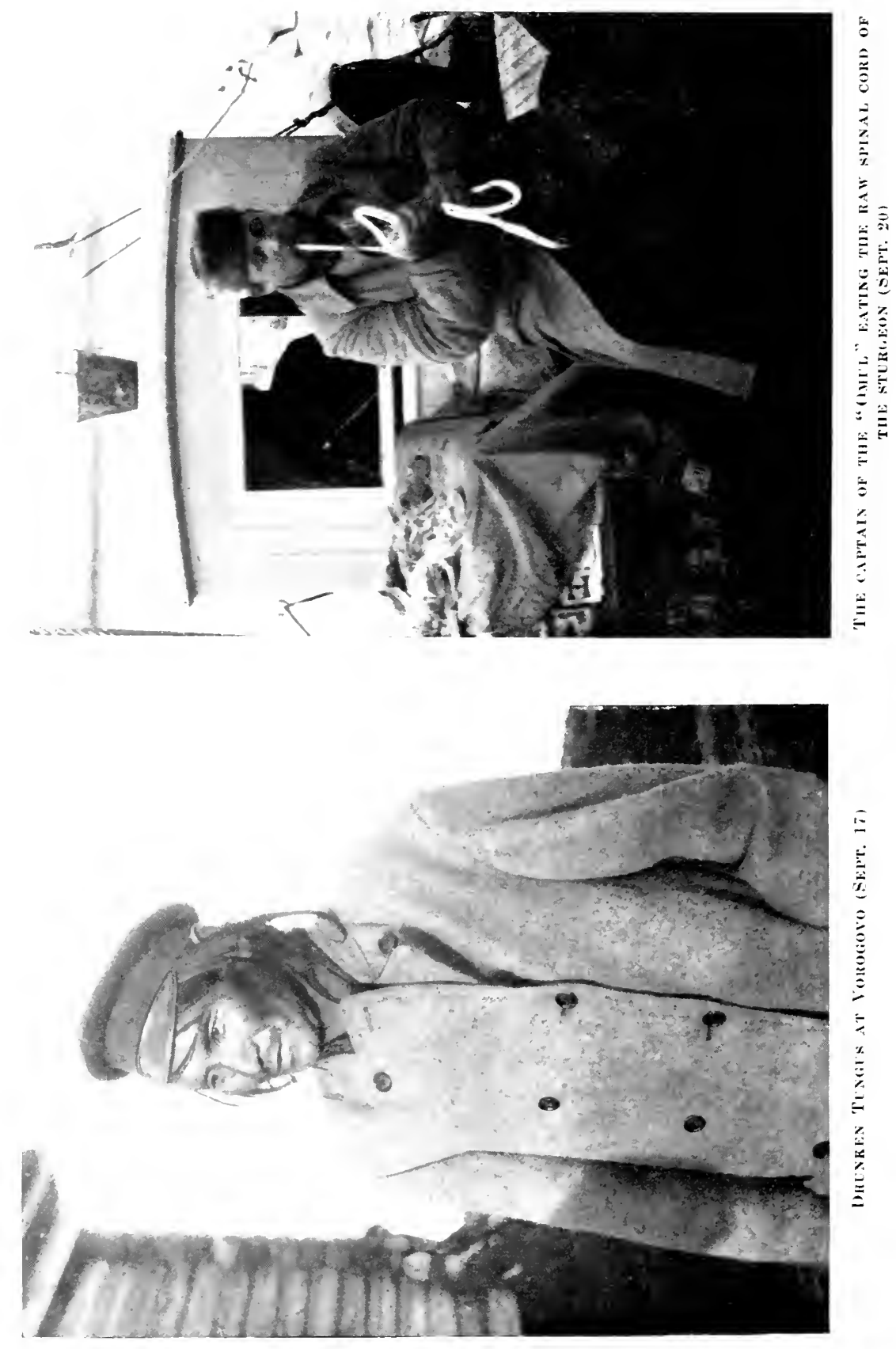


\section{FROM SUMARÓKOVA TO YENISEISK}

many of them, and not a few were fair, and would not have looked out of place on a landing-stage in a Norwegian fjord.

But there, to be sure, comes the youngest uniformed telegraphist; so he has time to go out, in spite of our telegrams. But perhaps there is no more hurry about them than about anything else in this country, and anyhow the other three can do some of the work. He joins a group of girls that are standing there and they talk and laugh together. Then comes another fellow with a bag of provisions and a kettle, and there is an eager discussion. They go down to one of the boats lying there, put the things in and get it ready. Evidently they are going for a row this evening, or perhaps for the night as well. They laugh and are so bright and cheerful that they must be going to enjoy themselves. Now they are ready and shoving off, and away they go with the telegraphist at the steering-oar ; and the telegraph station and our telegrams will only have three men to attend to them.

Then our crew returned, we weighed anchor and went on at about half-past five. We kept going for a long time that evening in the bright moonlight and fine weather, to make as much progress as possible, and anchored at 10 P.M.

The night was perfectly calm and wonderfully beautiful. A sky so vast and blue, the water as smooth as a blue mirror, reflecting the river bank with its great birches. To the east of us the black forest rises up the steep ridge, to stretch away over the boundless plains. It fades away in the hazy moonlight. One feels the unbroken stillness within that great forestworld, on the floor of which the trees cast deep shadows in the faint moonlight. How strange it is that these endless wooded plains, with their rivers and their natives, 


\section{THROUGH SIBERIA}

have never had the same attraction for the childish imagination as the primeval forests of America with their Redskins. Names like Yeniséi, Léna, Angará, Tungúska, Baikál, with their Ostiaks, Tunguses and Yakuts, have never sounded the same to a boy's fancy as the Hudson River, the Delaware and the Great Lakes, with their Mohicans, Delaware Indians, and Sioux. Is this merely because the forests of Siberia have never had their Cooper? The life here may certainly be equally romantic, and it is still going on.

But just as the great forests with their Redskins along the Hudson and Delaware have long ago vanished, and their place has been taken by cultivated fields without beauty and by somewhat prosaic farmers, so will also these forests and these natives disappear. In a hundred, nay, in fifty years, the forests will certainly be gone, and the wandering hunters with their tents and their furs will be seen no more. There will be nothing but a trivial flat country with cultivated fields, like the uninteresting plains of North Germany, but with room for millions of human beings. Then, as now, the moon will still shine down upon the quietly flowing surface of the Yenisei, but this great stillness will be gone. Already the silence has been invaded by a new kind of life. Far away in the wilderness on the east they are working in the mines, to find that almighty metal of good and evil, which has brought happiness to so many, but perhaps ruin to still more.

It is cold on deck to-night. The sails are frozen stiff and covered with rime for the first time on the trip. Autumn is coming on. Over the river to the south hangs a white bank of fog beneath the moon. It is to be feared we shall have thick weather again to-morrow morning.

Thursday, September 18. The fog did not come, 238 


\section{FROM SUMAROKOVA TO YENISEISK}

but rain instead. At 6 A.m. we went on through much the same flat wooded country as before, to the north of Sumarókova, except that the height of the land varied a little more, with quite low, rounded ridges. There were also more and more meadows to be seen along the bank, with hay in stacks.

We are beginning gradually to come into the agricultural region now, but it seems to me that for a long way to the north the conditions must be good, if not for agriculture, at any rate for cattle-raising and dairyfarming. There is splendid deep soil, rich in mould, and if the forest were cleared and the land brought under the plough, it would certainly give a good yield; besides grass, root-crops thrive well for a great distance to the north, and in any case the kind of farming that we see in our Norwegian mountain-valleys might be carried on here with great advantage, when once the land was cleared; but that is of course the difficulty. The forest has no value, or so little that it does not pay to fell it for the sake of timber. In the present conditions it is and will be an enemy, which must be overcome in order to provide pasture and room for cultivation. So much labour is involved in cutting it down and getting rid of the roots, that it is doubtful whether it would pay the man who did it, though the next generation would always benefit. And the difficulty is increased in a country where the climate is not so favourable that corn may be sown at once and yield a return.

The forest belongs to the State, and there is no difficulty in getting grants of whatever land one may require for cultivation or for clearing. But it cannot be expected that colonists will flock to these northern regions, when, at any rate up to a few years ago, they could get almost as much as they wanted of the fertile 


\section{THROUGH SIBERIA}

land farther south in the open grass and steppe country, where they only have to plough and the land yields a rich crop under a milder sky. But the turn of these regions will come, and cattle-raising and dairy-farming especially are bound to flourish here. What a rich country, what immense future possibilities.

It is quite autumn all at once, after the summerlike weather we have had-drizzling rain and a cold wind. The great birches have already shed their leaves and spread their bare branches in the moist and heavy air. But we are only a little past the middle of September. This is about a month earlier than at home, and we are in latitude $60^{\circ} \mathrm{N}$., or about the same as Christiania.

As we lay at anchor in the evening, at Yartsevo, we got some delicious cowberries aboard, as well as bird cherries, which are commonly eaten here in Siberia. Altogether there are many wild berries here, cloudberries in abundance-though we have not seen any-raspberries, bilberries, and strawberries. Wild red and black currants are also said to be found far to the north; I heard of them even north of the Kuréika, but did not see them.

Friday, September 19. We are hurrying on faster and faster now. This morning we started at about half-past four. We must make the best use of our time, if we are to reach Yeniseisk on Sunday.

From beyond latitude $60^{\circ} \mathrm{N}$. southward we now have a steep wooded ridge of rock along the eastern side of the river, while the western side is quite low and consists of loose soil. The villages lie on the low west bank. It it curious that here again we meet with the same remarkable difference between the right and left banks of the river. There is no getting away from it that this is due to the earth's rotation, even though there may here be the additional factor of an actual difference 240 


\section{FROM SUMARÓKOVA TO YENISEISK}

in the geological structure of the strata at the same level on the two sides of the river. Along the right (east) side the hill country begins to rise towards the east. while on the west side there is flat sandy country with low shelving banks. I account for this by the river having moved eastward, to the right, over the sandy plains, until it came upon the rock, when it flowed along it until, in the neighbourhood of the rapids, it was forced to cut its way through and turn off to the right, after having first formed a widening with many islands. Even though it may appear that the Yenisei in this region follows a line of dislocation in the beds of rockwhere the soil on the west side has sunk to a lower level, while the rocky soil has remained standing as a "horst" in its original position on the east side-it may nevertheless be due to the deflecting effect of the earth's rotation that the river has actually arrived at this line of dislocation, having been stopped by it in the course of its movement to the right.

Farther south, in the neighbourhood of the village of Sergyeeva the country is again perfectly flat and low, as it was farther north, and no ridge was to be seen from the river on either side.

We have now really entered the corn-growing country, which extends for an immense distance to the south, right into Mongolia. But everywhere the village or mir system prevails, where the people live in small communes (mirs), owning the land in common, and the fields that each man is to cultivate are divided at longer or shorter intervals among the inhabitants of the village, a division which is frequently attended by a good deal of quarrelling and dissension. I cannot help thinking that this system must hinder any higher development of agriculture; since it is obvious that, if a man owns his land himself, and knows that it will be his for life 


\section{THROUGH SIBERIA}

and will belong to his children after him, he has far more inducement to clear it and cultivate it, than when it jbelongs to a commune, in which he has his plot of land, or rather his many scattered small plots of land, assigned to him for a few years, or even when he may hold it for several years.

And this view has now been adopted by the Russian Government. The weak points of the mir system as affecting the cultivation of the land have become fully recognized. A series of recent laws gives the peasant the right not only to claim the holdings which his family has occupied for a number of years as family property, but also to have the holdings rearranged and collected into a freehold. In particular the former Minister Stolypin did much to assist development in this direction, with the support of the opinion that had long prevailed among the most capable of the peasants themselves. In European Russia large areas of land formerly held in common are now annually parcelled out into freehold farms. That Stolypin intended to introduce the same reform in Siberia, I see by a report he made after his visit to that country in 1910. What keeps it back is no doubt chiefly old custom ; the peasant of Great Russia has brought with him the village system and common ownership from his European home, where it has a development of many centuries behind it. There have been, and may still be, advantages in common ownership ; much of the work can be carried out in common, and perhaps it is more entertaining, life is less lonely. In any case most of the Russian peasants are not yet prepared to live alone, each in his farm, like the Norwegian peasants. And as regards Siberia, there is another thing to be considered : in that great country, where so many people, not always of the best sort, are roving about, it may be awkward to live in a lonely 242 


\section{FROM SUMARÓKOVA TO YENISEISK}

farmhouse; one would be more exposed to attack and robbery.

But it is not difficult to see that a great change is in progress in this respect, even in Siberia, in the last few years. In 1911 land was allotted to 255 families in possession as freehold farms; but in 1912 such allotments were made to 3354 families, that is, nearly thirteen times as many; the movement had extended so rapidly that in $\mathbf{1 9 1 2}$ all the land was taken up that had been surveyed for colonization in separate farms, and in January 1913 there was only so much land available as had been set aside for this use at the close of 1912 . In addition to this there is the right which, as we have seen, the older colonists now possess, of having land apportioned to them out of the common ownership of the mir of which they have been members, if they wish to adopt the system of freehold farms. This parcelling out is now constantly going on in several places. Thus, in the districts of Yeniseisk and Kansk 12,760 dessiatines $(34,452$ acres) of land were in 1912 transferred from common ownership to separate farms.

But with this village or mir system, as it has existed, and still for the most part exists, it is not to be wondered at that Siberian agriculture is still in its infancy. Take, for instance, this question of manure, which even here in the corn-growing country lies in hills, forming a sort of rampart towards the river in front of every single village. It looks as if they wanted to defend themselves against civilization and progress, which might be brought by the traffic along the river.

For that matter there is doubtless a reason even for this failure to use manure. There is so much space here and so few people that there may still be enough virgin soil to be had, or soil that has lain fallow for a long time and does not require manuring. The peasants 


\section{THROUGH SIBERIA}

plough up the unused grass land, sow corn and get a rich crop the first few years. But when, after four or five years or so, the crop begins to fall off, they leave that piece alone and plough up a fresh one, where they proceed in the same way. This is exhaustive farming, but, as I say, there is plenty of land, and they do not see why they should not farm it in this way, which is easy and cheap.

It is significant that the Government hand-book for colonists mentions that besides seed-corn and seed for kitchen gardens, grass seed is also to be obtained at the depots for agricultural implements that have been established for the colonists in many places in Siberia. Special stress is laid on the importance of grass-sowing everywhere, and on its necessity even in the steppe districts; for in these districts, where the dung is used as fuel, any improvement of the soil by manuring is out of the question, and a judicious rotation must therefore be introduced, with grass to follow the corn when the soil becomes impoverished. But as to the treatment of manure in other parts of Siberia nothing is said.

As already remarked, they do not build barns for the hay; but a worse thing than this is that they do not build cow-houses either. There is only a fenced farmyard in which the cows are collected for the night, and over this they usually put up a roof to protect them from the rain. The sides are often open, but in winter boards are put up to act as a screen against the worst of the wind and snowdrifts. But the temperature is about the same inside and out, and there are no such things as stalls for the cows. When we remember that in winter the temperature may be as low as 40 or 50 degrees below zero, this does not seem to be a reasonable way of keeping cows. Just think 244 


\section{FROM SUMARÓKOVA TO YENISEISK}

how much superfluous fodder they have to fill themselves with to keep up their warmth, and how little milk they can give. I asked how they managed about feeding the cows, when they had no stalls, so that each cow got its proper supply. Oh, they said, that was all right. They just threw it in, and each cow could eat as much as it liked. I was told that they usually reckoned that a horse ate half a pood (18 lb.) of hay a day, and in winter more than a pood (36 lb.), and that a cow ate about the same, at any rate not less.

Another thing which gives one an insight into the conditions in this country is that all boards and planks are sawn by hand. Even Yeniseisk, a town with about 12,000 inhabitants and quite 1000 timber houses, has no saw-mill, everything being sawn by hand-power. Imagine the quantity of wood that must be required daily for every kind of use in a town built of timber, and what a waste of man-power there is here. Krasnoyarsk, on the other hand, which is also to a great extent built of timber, with something like 80,000 inhabitants, really has a couple of saw-mills, but even there a great deal is still sawn by hand. I thought it must be because labour was unusually cheap here. But no, it was not. On the contrary, it is dear, a couple of roubles a day. The gold-mining is responsible for sending up all prices, especially that of labour. What wonders could be performed in such a country even by a traction-engine, burning wood and shavings, and a circular saw.

It must however be acknowledged that much is now being done to develop the country, and great improvements have taken place in the last few years.

At half-past nine in the evening we anchored at Nasimovo, where there is a telegraph station. We went ashore to inquire for telegrams. After a good 


\section{THROUGH SIBERIA}

deal of searching in the moonlight down the long street of the village we found at last a house formerly belonging to a rich old owner of gold-mines, in a garden with a large wooden gateway, a really grand gateway, richly carved with lions on the solid square gate-posts. After some knocking it was opened to us. There was really a telegram for Vostrotin, the first we received; but still I was unable to send any off, as here again they could not manage the ordinary Roman characters. In other words, it was impossible to telegraph beyond the borders of Russia; there may be some advantage in having, not only one's own language, but one's own characters which nobody else can make out, but I can't say it is convenient, if one has to form part of this little world.

We also wanted some bread, as there was none left on board. We had to go on a voyage of discovery to find some. But the whole village was asleep, except the dogs, who were all the more wakeful and started a concert wherever we went, which soon spread over the whole place. At the first trader's we tried we had to knock at the gate for a long time before a man came and opened it and we entered the yard. He got hold of the trader, who had to turn out of his warm bed. Unfortunately he could not get us any bread; his wife had been ill and none had been baked for a long time. Then we had to go all through the village again to the other end, and try a fresh trader, while the dogs kept up an even louder music than before. We found the gate in the moonlight, a big, showy gate; for he owned gold-mines, this man. There was the same knocking and the same waiting. At last we got hold of this trader too; but unhappily bread was not to be had. His wife had gone away, as far as I could make out. Yet a third place was tried; as we fared no 246 


\section{FROM SUMARÓKOVA TO YENISEISK}

better therc, we gave it up and went aboard again; but the crew wanted bread and went ashore to ransack the village; they too returned empty-handed.

From the edge of the forest to the south of the village we heard the music of a concertina and women's laughter. It was the young people who were amusing themselves there. Down by the shore we heard the chatter of boys, who were splashing in the water and playing in the moonlight late at night, while the others were asleep.

Saturday, September 20. I was roused at six this morning by the boat heeling over to my side and some of Loris-Melikov's toilet bottles rolling down, followed by a map. What on earth was it? There could not be any sea here, and the boat still lay over on her side. It felt as if we lay still. I was now wide awake; we must be aground! Now I could hear the engine going full speed astern, and I saw our well-fed captain, who had been sleeping soundly, squeeze his round stomach between the table and the door to get on deck.

By moving aft some kegs containing the fish bought by the crew, now nearly rotten, and then pushing off forward with long poles, we soon came off again, and we had not lost many minutes. It was the first time they had been aground during the four years he had been on the boat, the captain said. But this was not through any merit of his ; for in spite of these four years he did not yet know the channel and the banks in this river. The way it happened was that the pilot wanted to light a cigarette, and as there was a wind, he had to turn round to strike the match, and meanwhile the boat ran on to the sandbank on the land side.

During the forenoon we stopped for a little while at Kholmogórovo to get the bread for the crew which 


\section{THROUGH SIBERIA}

was not to be had at Nasímovo. Here we also got sturgeon and fresh caviar. Then a boat came alongside with water melons from the Minusinsk district. We could see that we were coming south into more fertile regions.

We saw them take the sturgeon out of a floating fish-well, in which they are kept alive, often for several days. These fish-wells are large wooden boxes with gratings, like those we use in Norway, and they lie anchored out in the river. A man took out first one fish, then another, with a big gaff, examined them and, if he did not want them, threw them back, regardless of the big holes he had made in them with the gaff. So he went on till he had found fish of the right size. Then the sturgeon were tied together by their heads and tails and carried up to be weighed, and then put aboard, where they were laid on the deck and were still alive the next day. They are patient creatures, and they are treated like dead fish. There does not seem to be much life in them, though, even when they are in the river; but what there is, must be tenacious and keeps going a long time. Vostrotin tells me that from Yeniseisk they often send sturgeon to their friends as far off as Minusinsk. They stuff damp moss or oakum into the gills, and the fish may live for a week, he says. This is like the Greenland sharks in the Arctic, which I have seen lying on the ice with life in them for many days, even after they had been cut open.

It is extraordinary how much they get out of this fish ; first there is the caviar, then the flesh, which is regarded as a great delicacy, whether fresh or salted and dried. The fish has a lot of yellow fat, and a dried sturgeon is fatter than any smoked salmon. Then there is the spinal cord, which may be eaten raw, but is also dried, cut up into small pieces like coarse 248 


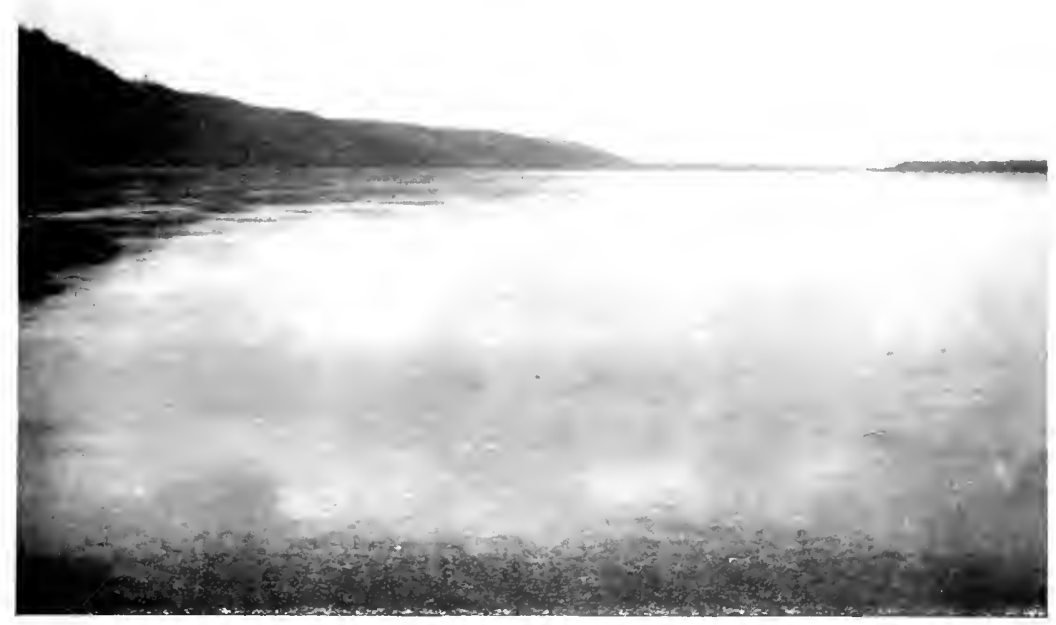

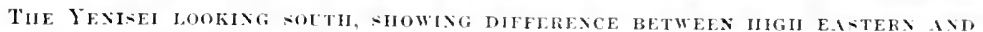
LA)W WEAFEM BAXKS OF TIE RIVER (SEPT, 19 ,

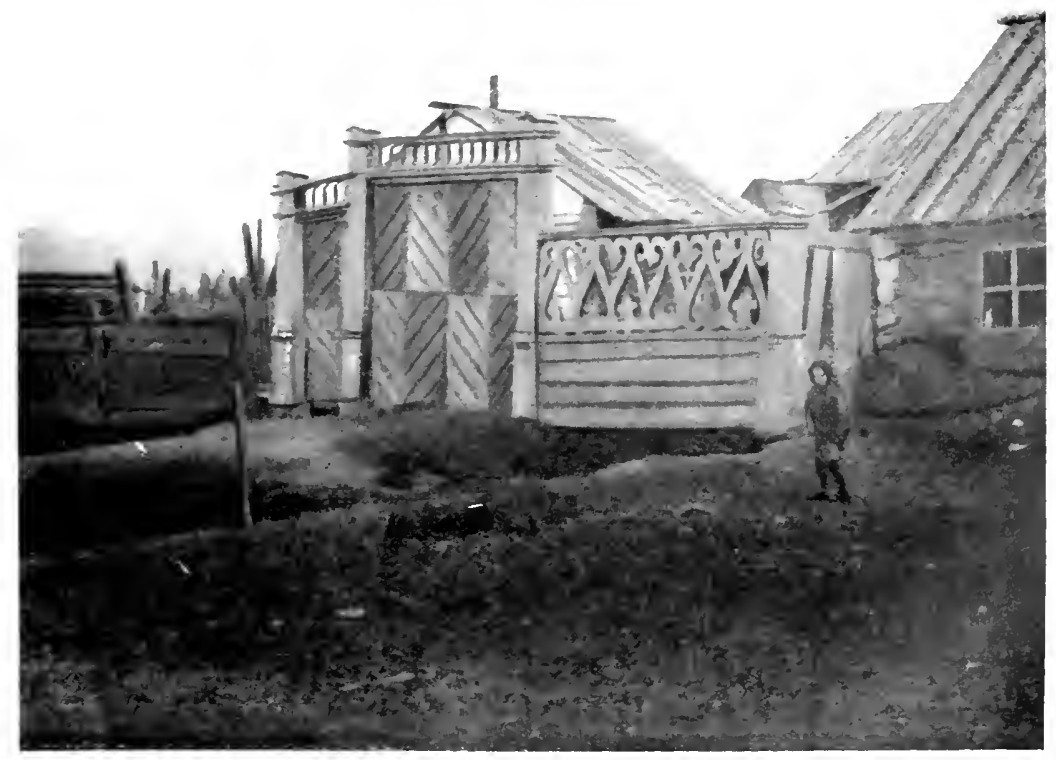

A SIBERIAN GATEWAY 


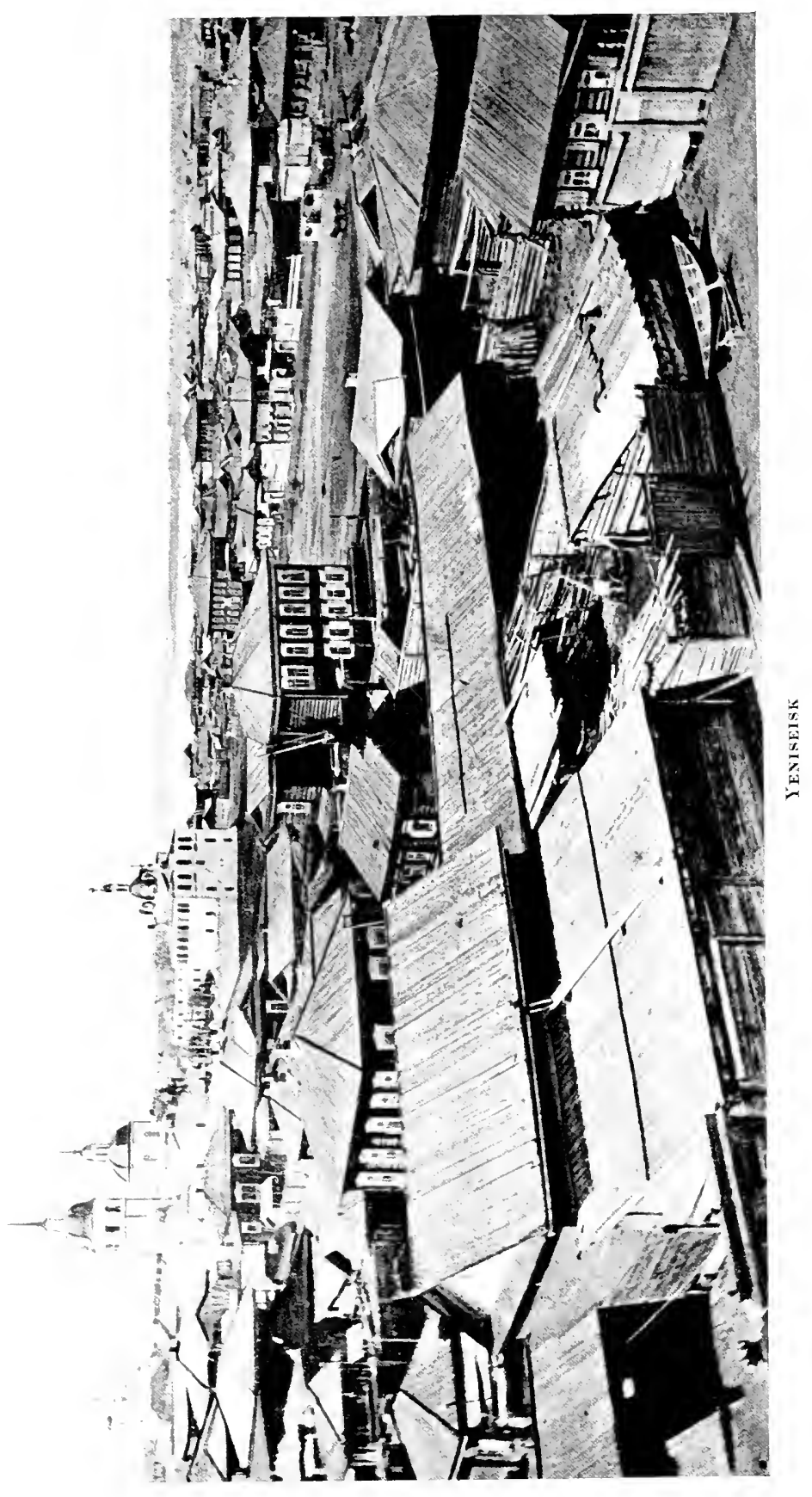




\section{FROM SUMARÓKOVA TO YENISEISK}

groats, and much used for baked fish-cakes, with fish inside and dough outside, the national dish that we had at Sumarókova; they are remarkably good, these coarse groats, which swell in the cooking and are like large sago.

They were now very busy on board dealing with all this new fish. The sturgeon were cut up, cleaned, washed, and then salted; that is, what was not going to be eaten fresh. But apart from that the crew had a sad piece of work before them. All the herrings (seld) they had bought at Levinski Pesók, north of Dudinka, had gone bad and had to be thrown overboard. It was the captain who had first bought this fish for salting, but he did not know how to treat it; and when the herrings began to go rotten he had sold the whole lot to the crew, who were glad to have it and salted it over again. But now it was all spoilt. They had to wash it and go through the whole stock; but it ended in the greater part being thrown overboard as unfit even for their use. As is well known, the Russians do not like to salt their fish too much, and their salt fish is usually more or less tainted, and doubtless far from wholesome food. I should think that the prevalence of scurvy among them is to be attributed in great measure to this bad salt fish.

The autumnal weather is gone again and it is delightfully sunny and mild. I can sit on deck to write, while the river bank glides by in its golden glory. This is certainly not the cold Siberia I have read about, and yet we are past the middle of September.

We kept going far into the evening, so as to be able to reach Yeniseisk as early as possible the next day. It was dark and overcast, but the moon was behind the clouds and we could just see the river ahead and find our way, while the forest stood black on both sides. 


\section{THROUGH SIBERIA}

Our worthy pilot was as anxious to get on as we were. It was about half-past ten when we finally had to anchor; but now we had only sixty versts more to Yeniseisk, and even if the stream was strong here, we could be certain of arriving in the course of the next day.

Sunday, September 21. In the grey dawn we were on our way again upstream. The country was flat, but we saw ridges inland on the eastern side of the river. At last we were approaching the great town; by one o'clock we could see towers far off, and as we came nearer the cupolas and spires of many white churches rose high above the river and the plain, green and gleaming with gold. How many churches I do not know, but I saw at least twelve or thirteen. The rest of the town was mostly low timber houses with a few higher houses of white masonry among them.

But now we saw through the glasses that there were a lot of people on the promenade along the bank and down by the quays. Were they only out for their Sunday walk? But the whole place was black with them. Could it be that they were waiting for us ? Did they know we were coming? I had a sudden suspicion of Vostrotin; perhaps he had been telegraphing; he seemed so busy with his glass. The little Omul worked her way perseveringly against the stream, which runs here at the rate of three knots; and by half-past two we at last came alongside the lighter that lay moored off the shallow bank and formed a landing-stage.

The promenade and the lighter were black with people, and there was a great reception, headed by the mayor with a chain round his neck, the isprovnik in full uniform, the principal of the school, also in uniform, and other notables. There were speeches of welcome in Russian and German, and presentations and everything 250 


\section{FROM SUMARÓKOVA TO YENISEISK}

else that was strange and unexpected to us who came from the far north. We were made to feel that we had accomplished a great and important voyage.

Then we were put into a carriage and driven to a large and handsome brick house, a regular palace, belonging to Vostrotin's sister-in-law, Madame Anastasia Alexeyevna Kitmanov, who received us cordially with genuine Siberian hospitality. It was indeed a change to come into these big rooms after the Omul's little cabin. 


\section{CHAPTER XII}

\section{YENISEISK TO KRASNOYARSK AND BEYOND}

Letters and telegrams : Siberian hospitality : Yeniseisk : The population : At the boy's school : A Georgian exile : The municipal lunch : The Museum : At the girls' school : A late lunch : Overland to Krasnoyarsk : Wild driving with tarantass and troika : Broad roads: Unsafe conditions, thieves : Arrival at Krasnoyarsk : Hospitable reception : The town and neighbourhood: An easy method of ferrying : No Ice-Age : A game of football and the Sokol movement : The Museum : Meeting of the Geographical Society and big dinner : Farewell at the railway station : Kansk : Discussion of the sea-route to the Yenisei : Reconstruction of the railway-line : The express train

UR first visit was naturally to the telegraph office, and to the post office, which was at the same place. Being Sunday, it was supposed to be shut, but the superintendent opened the office himself and received us well. There were no telegrams, unfortunately; but here at last they could deal with Roman characters and I was able to telegraph home. Letters there were for me, but I could not get them, as they were locked up and the man who had the key lived outside the other end of the town. When the superintendent understood that I wanted to see my letters, he at once sent a messenger for the key. Meanwhile we were invited into his house and introduced to his wife; and from the balcony on the first floor we enjoyed a view in the afternoon sun of the 252 


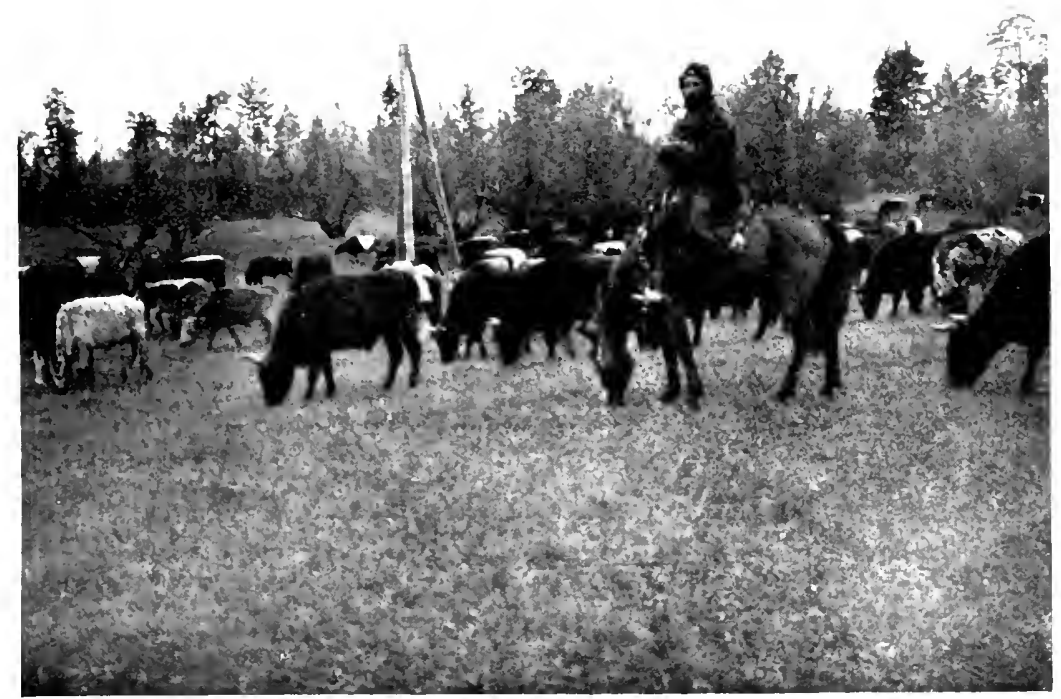

DRONE OF MONGOLAN CATTLE, WITI MOTTED IIERIBNAN ROLLINA A CIGARITTE: (SEPT. 24)

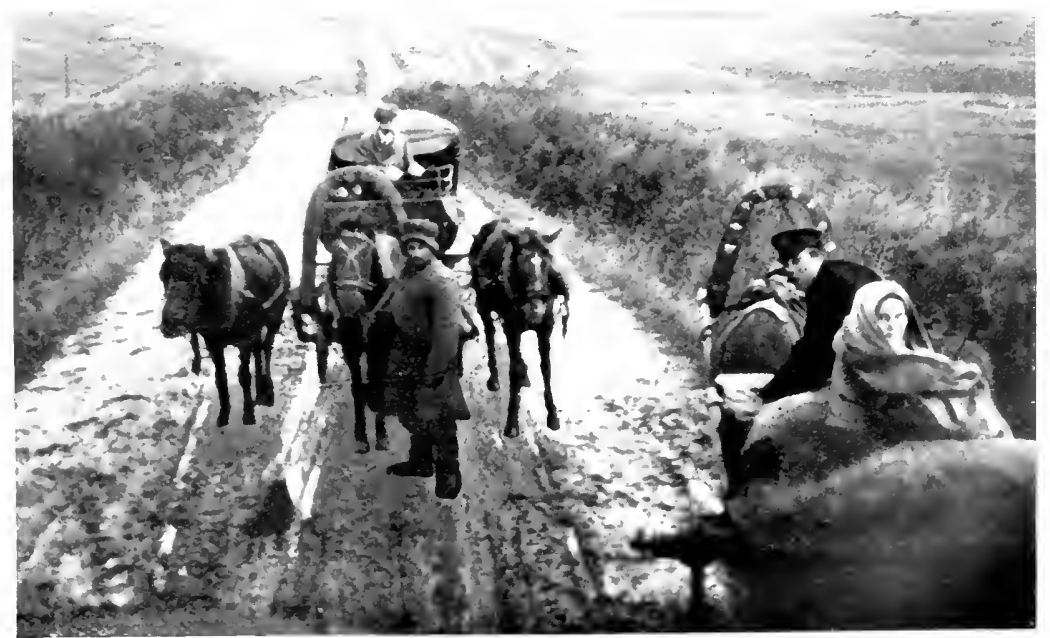

A SIBERIAN IIGII ROAD. IX TIE BACKGROCND IS THE SPOT WIERE TIE MAIL-DRIVER WAS KILLED (SEPT. 25) 


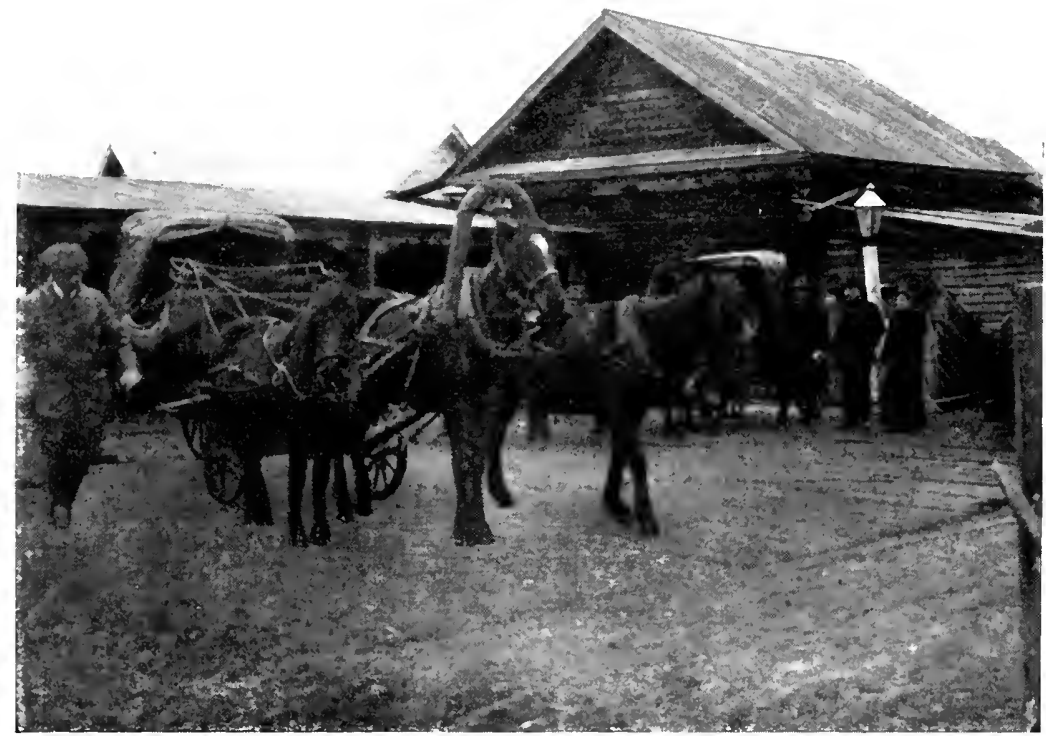

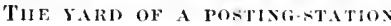

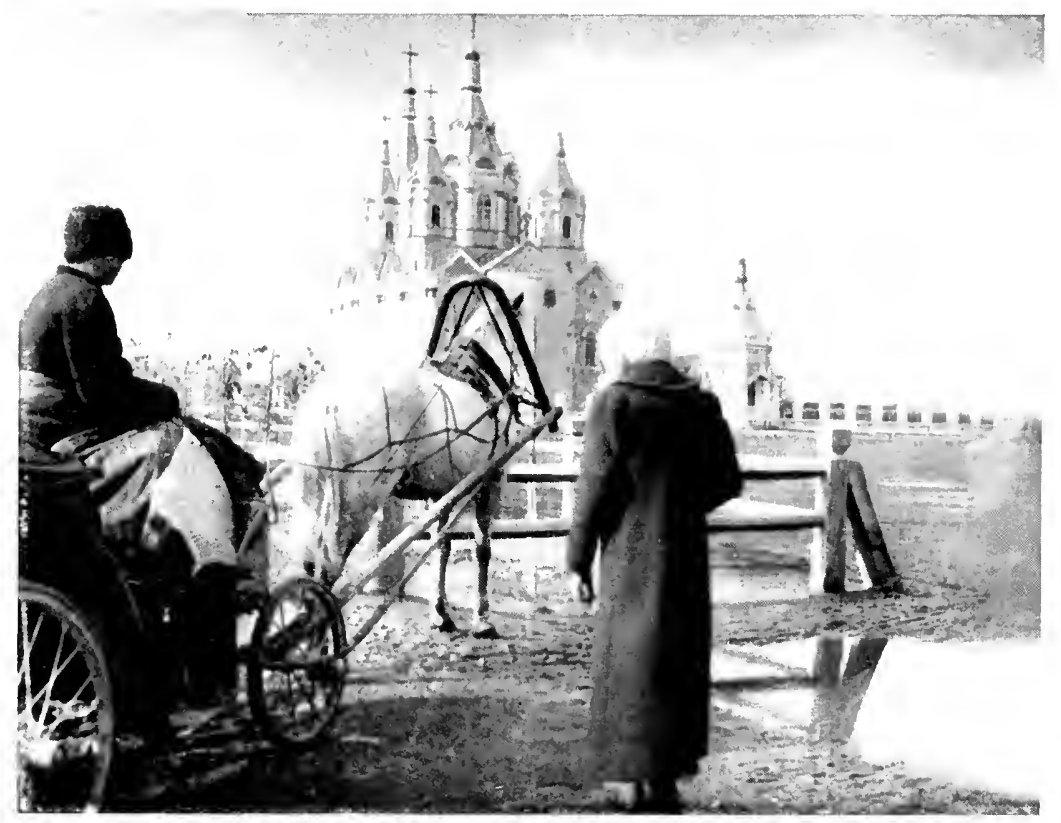

THE CATHLDRAL OF ILIANMOYARKK (SEPT, 26) 


\section{YENISEISK TO KRASNOYARSK AND BEYOND}

harbour and the Yenisei and the country we had come from.

Half an hour elapsed, and then an hour, but no key came. The superintendent sent another messenger, this time on a bicycle. How the boy could ride along these muddy streets, full of deep ruts, was a mystery to me, but anyhow he disappeared. Meanwhile we heard that a telegram was lying at Krasnoyarsk for me from Mr. Wourtzel. I had to get it telegraphed on here; and now we had something else to wait for.

At last the key arrived, and I got my letters. All was well at home. So far everything was satisfactory, and no more than two letters had gone astray of those I knew to have been sent. Then at last the instrument began to tick and Wourtzel's telegram came. He had been delayed for four days and would not arrive at Krasnoyarsk till September 29; he asked me to wait till then, and to go on with him by express train to Vladivostók, and from there to the Amúr District. I certainly had no objection. That gave me four days more. So after all we need not have hurried so much to get here in time; but now we were here and all was well.

Oh, how we enjoyed that afternoon and evening in the comfortable house, with these pleasant people, being well looked after by our amiable hostess and her charming daughters. It was a luxury to be able to stretch oneself in these large, light, and airy rooms. They seemed to keep open house all day in this hospitable home ; there was a long table always laid in the big hall, and their friends came and went, or sat down to a glass of tea or something to eat, as they pleased.

Yeniseisk lies in a flat plain on the left bank of the Yenisei, with little forest, mostly meadows, around it. It is an old town, but nevertheless makes a sort of 


\section{THROUGH SIBERIA}

colonial impression, chiefly no doubt, owing to its low timber houses, its broad and regular streets and the flat country. If we except the splendid churches and a number of other large buildings, it really does not appear to be any more than a very big village, of the same kind as those we had seen before. It consists chiefly of low, square timber houses, sometimes of two stories but just as often of one; the same low, square roofs of boards, the same windows, the same enclosed yards with big gates in front of them-and then these broad streets. There is space enough here, ground costs nothing, so why should they not build well away from one another and make the streets roomy and easier for driving; there was no paving that cost any money. For the most part they seemed to drive over the ground just as it was before the town was built, and then no doubt a certain amount of road-metal or gravel had been laid down. The mud and the ruts were just as deep as in the villages, only there was not so much cowdung. Along the side planks were laid down to walk on; otherwise walking in these streets on wet days is a somewhat troublesome business, unless one does not mind being covered with mud. And for this reason most people prefer to drive.

The town has about 12,000 inhabitants. From of old it has been the centre of trade with the northern districts, and its proximity to the gold-tields, from which large revenues have poured into the town, has not been the least important factor in its prosperity. As no railway touches the town, communication is mostly by river, southward to Krasnoyarsk and northward to Turukhansk and beyond. The traffic is considerable, and there are a number of steamers, besides lighters. But now there is much talk of a railway to Tomsk, or else to Achinsk. 


\section{YENISEISK TO KRASNOYARSK AND BEYOND}

The chief staple of trade has always been the valuable furs, which the Russians bought from the natives, in exchange for goods, meal, sugar, tobacco, tea, etc. Now there is in addition a considerable trade in fish, which is caught and salted, partly by natives, partly by Russians, along the river down to its estuary in the north. To this, as has been said, the market of the goldfields has been added during the last century, and this is not the least important.

There is also some agricultural population in this district, but it is not yet very numerous; it does not become so until farther south, although it is certain that even here there would be favourable conditions for agriculture, cattle-raising, and dairy-farming. Our hostess, Madame Kitmanov, has her own estate in the neighbourhood of Yeniseisk, and it was her own butter, her own cream and her own honey that we ate.

The inhabitants of a town like this are to a great extent Russians, who originally came out, some as colonists, but some again as exiles and convicts, and have remained here permanently and have left descendants. As to the influence which the constant influx of convicts in Siberia has had on the population and on their descendants, somewhat exaggerated ideas seem to be entertained. I met a foreign immigrant who said I did not know what a horrible, barbarous country I had come to. But he could tell me that it was a misfortune to be condemned to live here, he knew that from twenty, or it may have been thirty years' experience (I don't remember the number); a man with higher intellectual interests lives as it were in a desert, you see, for there isn't a decent person among them, they are criminals, the whole lot of them; and he pressed my hand warmly in gratitude for my being a cultivated person who understood him. Of course I had to express due sym- 


\section{THROUGH SIBERIA}

pathy with such intellectual isolation, but at the same time was bound to say that my own impression was altogether different; I had, in fact, met so many attractive people. Oh, he said, you don't know them; nothing but criminals, nothing but criminals, the whole lot of them.

To be sure, criminals are not the element one would choose for propagation, according to modern eugenic principles; but it must be remembered that a large proportion of those who have been exiled to Siberia were political prisoners, or religious sectarians whom the Holy Russian Church did not want in Russia. In other words they were people who had convictions, and were moreover willing to suffer for them-they were among the best elements of the Russian people, and might well be regarded as desirable for the transmission of the race. We may therefore expect a population which, while doubtless somewhat mixed, may contain much ability. That this has not yet manifested itself to any great extent, may be due to external conditions; to the dormant state in which, to a certain degree, this country still lies. But one day, when the nation is fully awake and the latent forces are set free, we may perhaps hear new voices even from Siberia; for it has a future before it, of that we may be sure.

Monday, September 22. There now awaited us a festive reception in many forms. At 10 in the morning we were invited to visit the higher school for boys. We went into each class-room and saw all the boys, who looked healthy and cheerful and active. Then they were all mustered in the large hall of the school. The little girls from the girls' school also came in, and I told them about the voyage of the Fram over the Polar Sea from 1893 to 1896, and showed them on a 256 


\section{YENISEISK TO KRASNOYARSK AND BEYOND}

big map how we had sailed along the north coast of their great Siberia and then drifted in the ice. I spoke in English, of which they did not understand a word; but Vostrotin interpreted, and they seemed to be interested and grateful for our visit, which lasted about three hours. The whole boys' school got a holiday that day; as we left we saw them rushing home through the streets, and I am sure that at any rate these boys blessed us.

I went into a barber's to have my hair cut. The man was a Georgian from the Caucasus, so here again Loris-Melikov, who was with me, met a fellow countryman. He was a political exile, who had taken up the business of a hairdresser and found it paid him well.

The Mayor and Corporation gave a big lunch in our honour in the Club at half-past two, and all the notables and most important business men of the town were present. There was good-will and cordiality on all sides, and great enthusiasm for this sea route through the Arctic Ocean which had again been tried in the Correct's voyage, and for which we, or perhaps I in particular, quite undeservedly received the honour, although we had only made the trip as invited guests. It was almost as though we were inaugurating a new era in the history of the town and of Siberia. All this, and much more, was expressed in a long series of speeches in fluent Russian, of which I did not understand a word; but some of it was translated. Then the principal of the school made a speech, if you please, in Esperanto, of which I understood just as much and which was not translated, as there was nobody else who understood it either. I replied to all these speeches in English, which none of our hosts understood, but which Vostrotin translated into Russian; but the reception given 


\section{THROUGH SIBERIA}

to his words made me strongly suspect that the translation was a good deal better than the original.

During the afternoon after the lunch we made a round of the town museum, where we found a valuable ethnographical collection, with objects from the various tribes in the district of Yeniseisk. The Yenisei-Ostiak collection interested me particularly, but there were also objects collected among the Tunguses, Samoyedes, etc.

From Yeniseisk we were to drive overland to Krasnoyarsk, as that is quicker than taking the steamboat up the Yenisei. However, we sent most of our baggage by the boat, so as not to have too much in the carriages. I should have been glad to start the next morning, so as to have the day before us and to be able to see something of the country to the south ; but this was entirely impracticable, it was explained to me. As I had visited the boys' school, I was bound to visit the girls' school as well; and then the masters of the boys' school were giving us a lunch which we must not decline. This would not delay our departure very much, as in any case we should have to have lunch before starting; it was to begin at twelve, and a promise was given that it would certainly be over by half-past one. So this programme was arranged.

Tuesday, September 23. At ten o'clock, then, we visited the girls' school, a large and handsome building with a great many pupils, of which our hostess, Madame Kitmanov, is directress. We were exceedingly well received by all the young ladies, with a speech in German by Madame Kitmanov's young daughter, and with the presentation of a large bouquet of flowers. Then we went to each of the classes and greeted all the pupils and heard about all that the girls learned: Russian, foreign languages - French, German, and English-history, chiefly Russian, geography, natural 258 


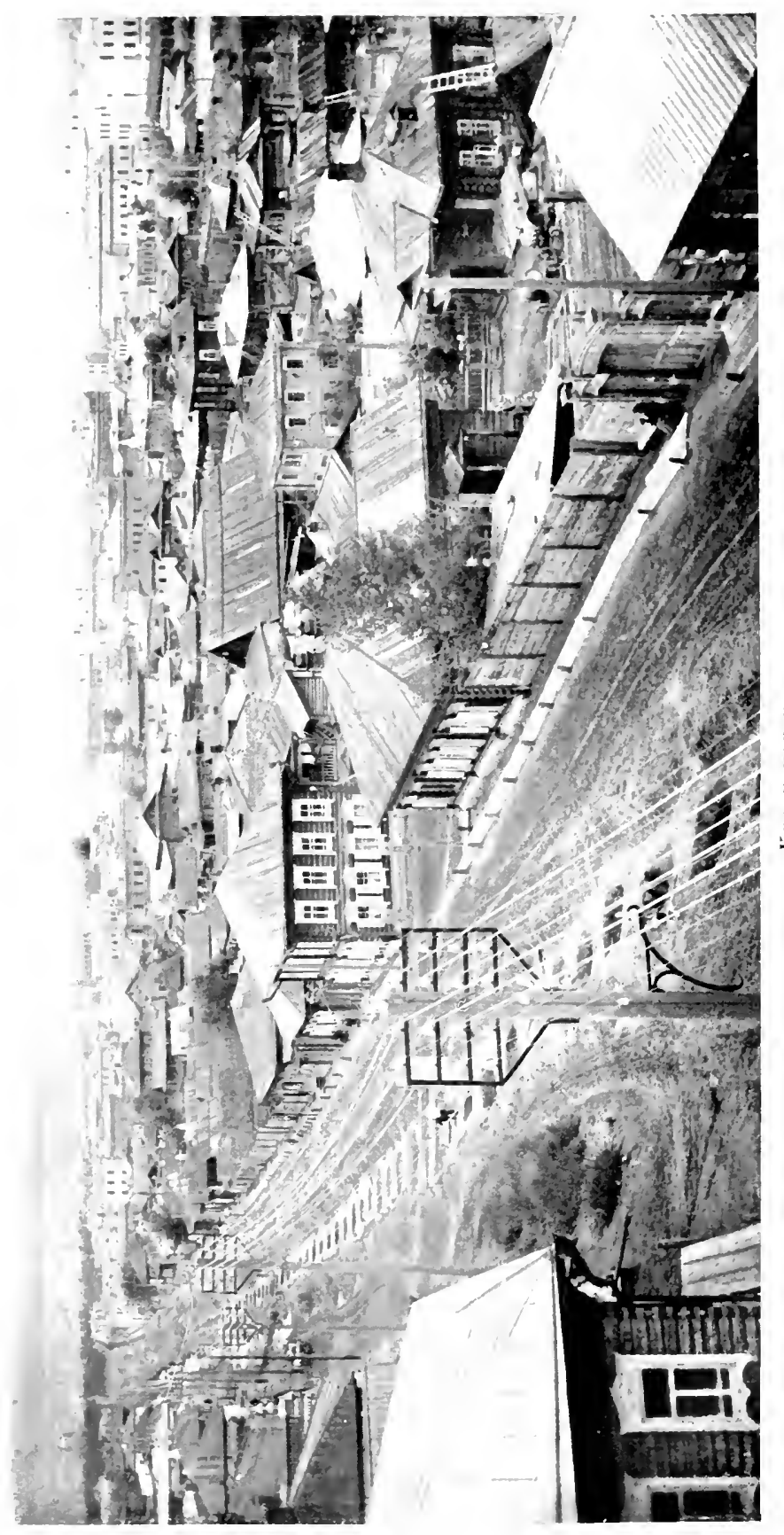

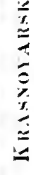




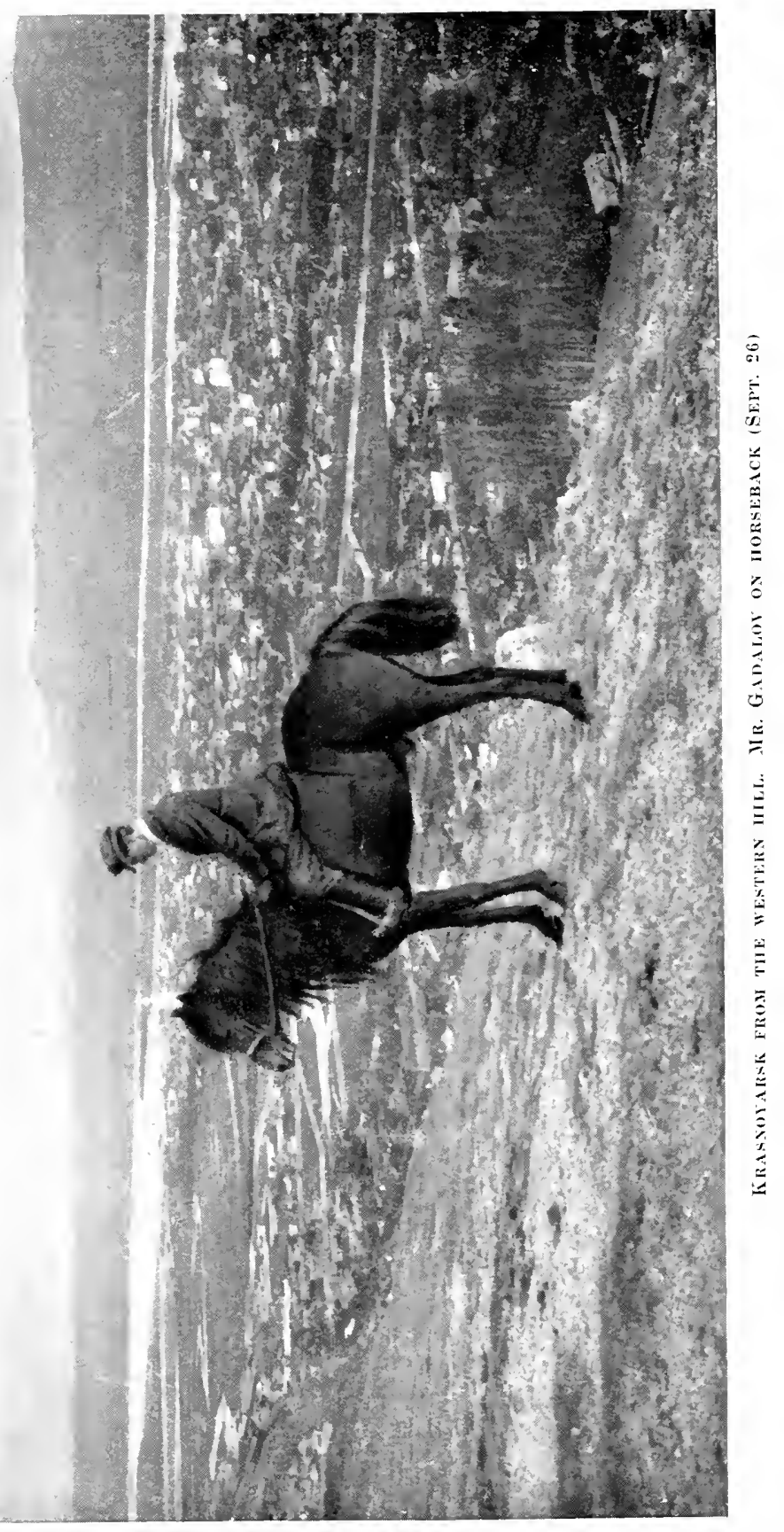




\section{YENISEISK TO KRASNOYARSK AND BEYOND}

history, arithmetic, and so on. They certainly received a good education; and the school seemed excellently equipped with all appliances and had large and airy rooms.

After that I went through the museum again to have another look at the ethnographical collections. Then I simply had to go and see a primary school for boys, which was a State institution, and a primary school for girls, which was supported by private contributions as the State does not consider itself obliged to educate more than the boys. Then at last we went off to the lunch at the high school. As I said, it ought to have begun at twelve, but it was one o'clock before we sat down, and it lasted till four. There is no hurry here ; Siberia is still a country that has a superabundance of time, as of everything else ; they may think themselves lucky for having so far escaped the nervous stress that we know too well in Europe. But there was great enthusiasm and cordiality, which were voiced in many speeches. I witnessed there a convenient custom that I had not seen before; when the guests were tired of waiting between the courses they got up and went for a walk in the corridors or in the neighbouring rooms, lit a cigarette and strolled about for a while; and there one might see reverend prelates in their long robes, or other gentlemen and ladies filling up the time, after which they came in and sat down again.

Even a Siberian lunch comes to an end, and at last we were able to say good-bye to our kind hosts. A few necessary purchases had to be made in the town - then aboard the Omul to say good-bye to the captain, the pilot and the crew; and then there was packing to be done, while the seventh class of the girls' school, without my knowing anything about it, had been sitting at Madame Kitmanov's from three o'clock, waiting for 


\section{THROUGH SIBERIA}

four hours to say good-bye to me and give me a big bouquet.

At last, at 7.30 P.M., everything was packed and lashed on to the carriages; we climbed up into these remarkable vehicles, got under the tarpaulin and a sort of hood, and found inside a regular bed of straw and pillows. Just as I had arranged myself on this couch, in a half-lying, half-sitting position, and it was beginning to dawn on me that one might be quite comfortable, or at any rate warm, in there, Madame Kitmanov's kindly hand came and pushed a big pillow behind my back, just under the loins. This worked wonders, and for a moment $I$ thought it impossible to sit or lie more comfortably-but then we were off in the pouring rain and pitch darkness on our wild drive to Krasnoyarsk, while Madame Kitmanov and her daughters and all her household shouted and waved their farewells in the flickering light of lanterns.

The roads were wet after a month's rain and very uneven. The wheels sank in deep in many places, and often there was one hole after another, especially before we got out of Yeniseisk, and in every village we passed through. Going at full gallop as we did, this springless tarantass shook so that one could only think a broken bone or two was the cheapest one would get off with. I was often anxious about my teeth; one had to keep them well set all the time and not allow oneself to be surprised by a hole in the road in an unguarded moment when one's mouth was open. But strangely enough everything held, we were warm and comfortable in our tarantass, and we had chiefly to thank Madame Kitmanov's pillows that we were not smashed to pieces and could even get some sleep at times. After a while the rain stopped and we went forward rapidly. 260 


\section{YENISEISK TO KRASNOYARSK AND BEYOND}

To avoid the trouble of moving our things from one carriage to another and lashing them at each stage, Vostrotin had his own private tarantass, and Loris-Melikov and I had also taken one for the whole journey, in which we travelled together, so that we only changed horses and coachmen. The tarantass is a four-wheeled carriage which is generally used for travelling in Siberia; it is specially suited for these long distances, where one has to travel night and day and sleep in the carriage, if one wishes to arrive in reasonable time. It cannot be called an elegant conveyance, this tarantass, but it is strong and well suited for its use, which would knock our European vehicles to pieces in a very short time. Steel springs it luckily does not possess, as they would soon be done for ; instead of them the body of the carriage is borne on two long, elastic poles, which rest on the axles of the front and back wheels; but in order to stand the jolting these poles have to be thick and strong, so that there is not very much spring in them. Wheels, axles, and everything must be strong and firm. The carriagebody has a coach-box in front, on which the well-wrapped driver sits, shouting incessantly to his horses; behind is a sort of hood, from which in wet weather, as now, a tarpaulin is stretched to the coach-box, shutting in the back part of the carriage entirely.

There is no seat to sit upon inside the carriage, and we passengers lie on the floor as well as we can. There is room for two in each tarantass. Straw is laid on the bottom, and generally pillows and mattresses as well, or rugs, to fend off the jolts and give one a tolerable berth. Then one covers oneself over with blankets or furs, or whatever there may be, and if it were not for the desperate shaking on these roads, the tarantass would be an ideal vehicle for long journeys. When 


\section{THROUGH SIBERIA}

once accustomed to it, one can even sleep. I could not help thinking of how often I had sat nodding and dozing in a Norwegian kariol or stolkjerre, without being able to find a convenient position. In a tarantass one could sleep the whole time, if it were not for the bumping.

The tarantass is usually drawn by three horses, troika, which is the commonest team on these roads; but such grand people as ourselves of course had also four, sometimes. The horses are always harnessed abreast. The middle horse goes in the shafts, under the big wooden bow that is so characteristic of all Russian vehicles. To this the shafts are made fast, and the idea must be to keep them clear of the horses' sides; but this bow is big and heavy, and a lot of work is spent upon it; it is handsomely carved and painted, and on it the bells are hung. The other horses are harnessed on each side of the middle one. They are supposed to gallop, while the middle horse trots. They have to keep well out to the side and not crowd in on the middle horse; for which reason they generally go with their heads turned far out, and this looks very curious.

We drove continually night and day until we reached Krasnoyarsk, with the exception of the thirteen stations where we changed horses. But there we often had to wait a confoundedly long time, although the horses were supposed to be ready, as the people had been given notice of our arrival and were expecting us. Things are not made so easy for the majority of travellers. The peculiarity about these Siberian posting-stations is that, while the stations are appointed by the Government, there are no fixed rates for posting, and the postmaster is free to ask what he likes. It is the same with the droshkies in the towns. You first have to bargain and agree about the price, and you may often be 262 


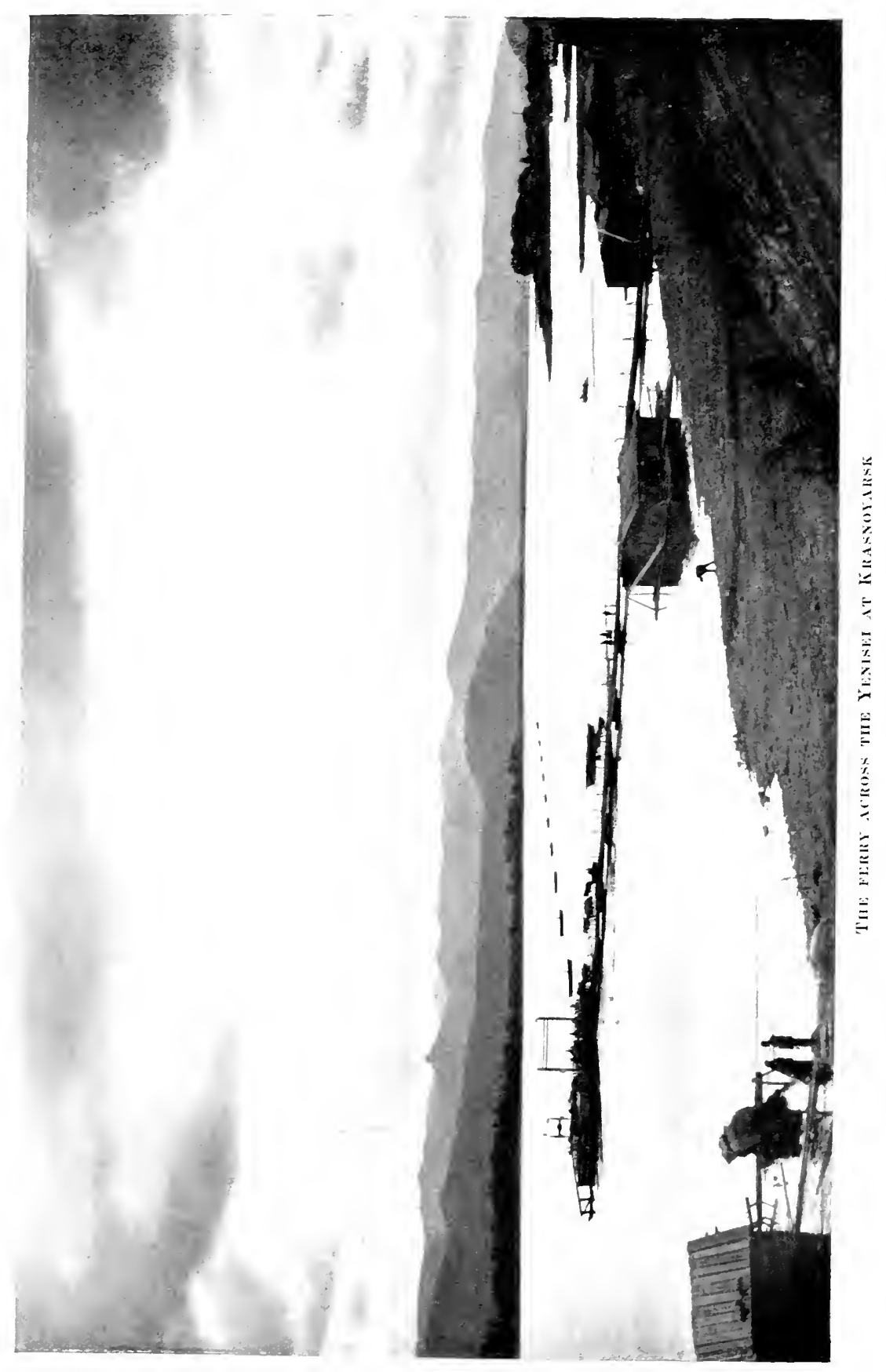




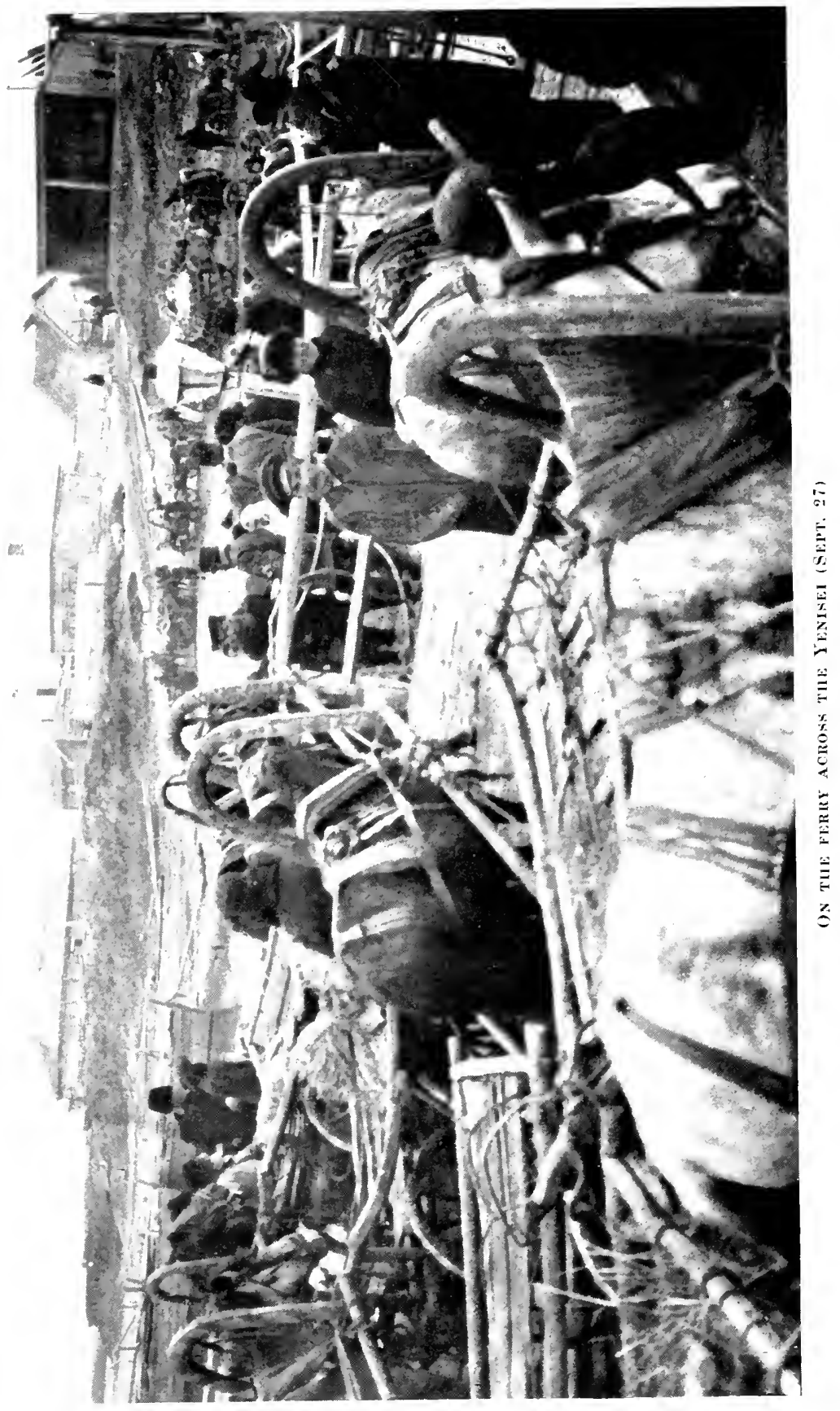




\section{YENISEISK TO KRASNOYARSK AND BEYOND}

told that there are no horses to be had, so that more money may be demanded for procuring them.

But we had no difficulties of this kind. The Isprovnik of Yeniseisk had shown me, as a foreigner, the great compliment of issuing an order to all post-masters and others to do everything in their power to help us on as quickly as possible. If some slight difficulty was raised at one or two places, on the pretext that the mail had just gone, that all the horses that were any good were engaged, and so on, a word or two from Vostrotin was usually enough to smooth the way.

But all the same a little patience was required at every station. There was much to be done before we could be ready. The wheels of each carriage had to be taken off and carefully greased, and I could easily understand the necessity of that, after experiencing their wild driving. Then the horses had to be harnessed and brought out and put in. Then the driver wanted time to rig himself out, and probably also for a final glass of tea before starting-and then, of course, time is not very precious here in Siberia.

At last he got up on to the box ; we stowed ourselves inside again and arranged our pillows and rugs, and then we were once more on the road.

It is almost inconceivable that any kind of conveyance can stand this driving, but they are strongly built, these vehicles. And it is certainly a fortunate thing that they have no steel springs, for even if the springs had lasted out, we should not have done so ; we should soon have been sent into the air and far out over the side of the ditch, when there was a jump over one of the deep holes in the road. And whether the road is rough or smooth, the pace is always the same, a gallop if possible. The coachman drives his horses incessantly with cries and shouts, and one jumps up 


\section{THROUGH SIBERIA}

and down inside the carriage, thinking the soul must be shaken out of one. When I reflected that we had to drive 330 versts $(210$ miles) in this way, I never expected to hold together so long.

But it is a strange thing, one can get accustomed to a lot, and gradually one found out positions which made it fairly supportable ; and when about midnight we arrived at a station to change horses, one was so comfortable that it seemed quite a bore to turn out for a glass of tea. But on reaching the ground it was undeniably a grand feeling to be able to stretch one's limbs a little and see that they were still sound and serviceable.

Inside the station we were cordially received, as it happened that the woman there had formerly been housekeeper at Vostrotin's, and there was no end to what she wanted to do for us. We entered a large, bright, comfortable room, where a samovar was steaming on the table, and glasses soon appeared and the tea was poured out-the glorious Russian tea, which was certainly not least welcome at this hour of the night. And then came a collation of all kinds of viands.

Strange it is that here in Siberia people seem to be just as good-tempered in the middle of the night as they are in the daytime. It made no difference if they were called up, they always received us with equal hospitality and gave us a welcome-nor did the lateness of the hour have anything to say to our getting horses. They seemed to be used to people travelling day and night. I was constantly reminded of how difficult it sometimes is in Norway to get people to attend to travellers' wants at night. How often, when in a hurry, I have met with sour faces and infinite difficulties when it was a question of providing horses at night; and yet they have not the same excuse as in Siberia, that the 264 


\section{YENISEISK TO KRASNOYARSK AND BEYOND}

roads are not altogether safe at night from people who may make themselves unpleasant.

This good, kind woman entertained us while we were at supper, and while she went to and fro and waited on us, she told Vostrotin all about the posting business, and about their life and how everything was going, and about the horses and the driving; and then she made minute inquiries as to how everything was with him and his. Of course I understood no more than was translated to me, but the kind, honest expression, and the friendly old-fashioned, homely feeling of it all, that I could understand. It was just as it used to be at home in old days, when people considered themselves as belonging to the family and shared each other's good and evil fortune long after they had been parted, and often as long as they lived. I wonder whether that order of things was not better than that which many people now want to introduce, in which human beings are to become more or less machines, without any interest in each other, and society at all costs is to be divided into a lower class which is oppressed, and an upper class which oppresses, but which when all is said and done is doubtless just as much oppressed.

Then it was good-bye and away again into the black night, along the jolting road, while we tried to doze, or even to sleep, as well as we could.

At last, after a few more stations, day began to dawn over the undulating plain. It was not so flat here as farther north, where we had been, and there was remarkably little forest. It was usually far away, while around us were grassy plains; and then daylight came and we could see more of the country. It became more and more hilly, with ridges running southward. Generally we saw wide, undulating plains, almost devoid of trees, and with cultivated land here and there. On 


\section{THROUGH SIBERIA}

the whole drive we did not go through a single wood. Now and then there was a village; but they lay far apart, and the peasants must often have to drive a great distance to the fields where they work. Sometimes we passed herds of perhaps several hundred cows, belonging to these villages.

So we went forward ceaselessly, stage after stage over these endless tracts, and on the box in front of us we had driver after driver, a new one for every stage; but they all behaved and drove their horses in the same way.

They are a race by themselves, these Siberian drivers. Their ambition is to get on fast and to show that they can drive their animals, and the activity they display is unremitting. Now they lash them with the knout; or perhaps I should say they do so without stopping. Now they give long melancholy howls, full of all the misery of life, but suddenly change to short, lively exclamations and cries of "Hoi, hoi!" Then come long speeches to the horses, which they always address as their nearest relations and call by all sorts of pet names, both proper and improper-my dear daughter, my brother, my little birch, my sweetheart, my mistress. And then they abuse them and inform them that their mother was no better than she ought to have been, and worse things than that.

Meanwhile the spare, active horses pull for all they are worth over the heavy, soft roads, where the wheels sink in deep and where the mud spurts incessantly and splashes us pitilessly all over. The middle horse, as I said, is generally supposed to trot, while the two side horses go at a gallop; but a fresh word of command puts them all into a gallop, and then they dash wildly through all the filth, while we are sent bounding into the air.

266 


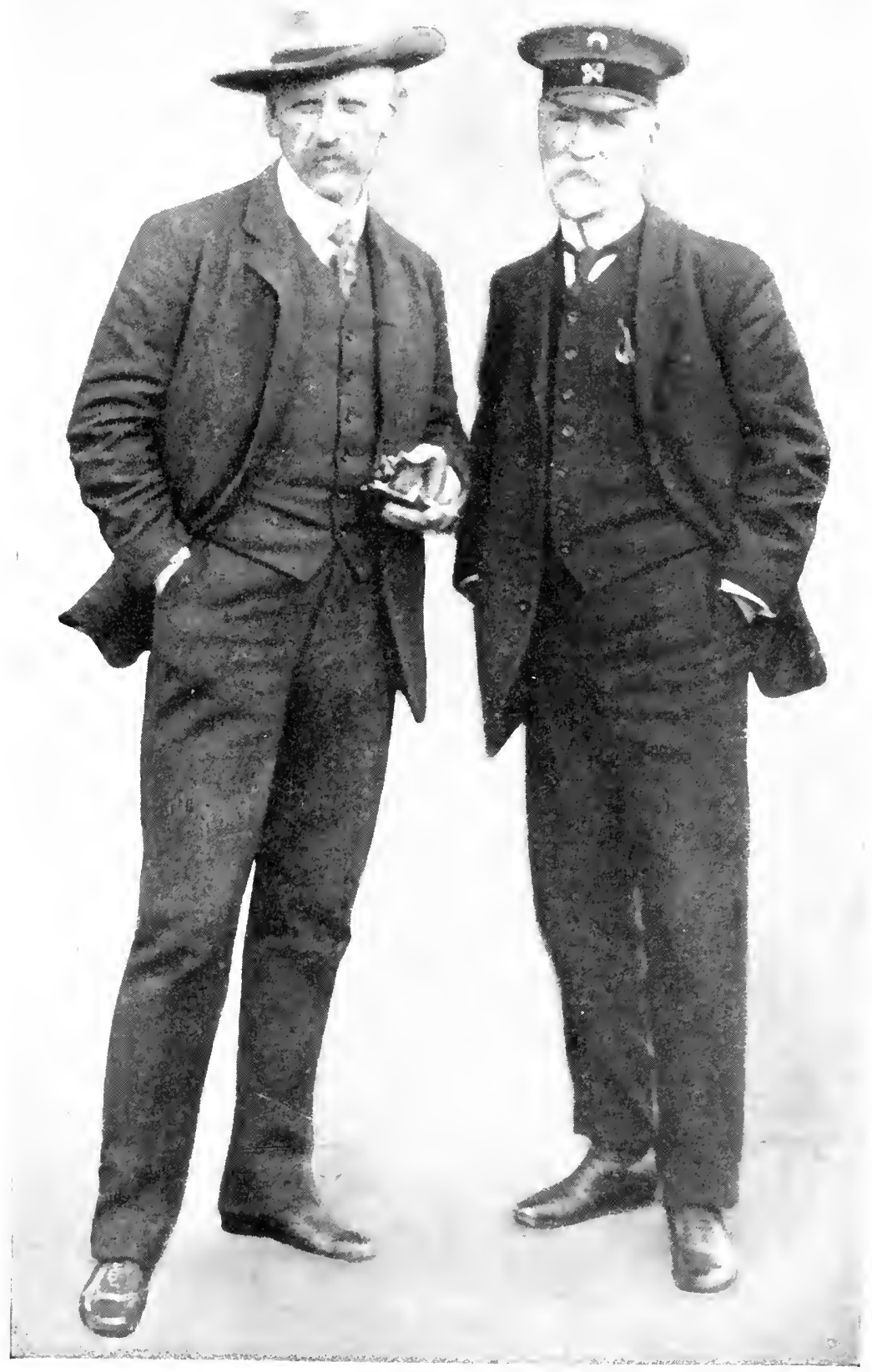

HR. WOCRTEL ANI THE AT THOK 


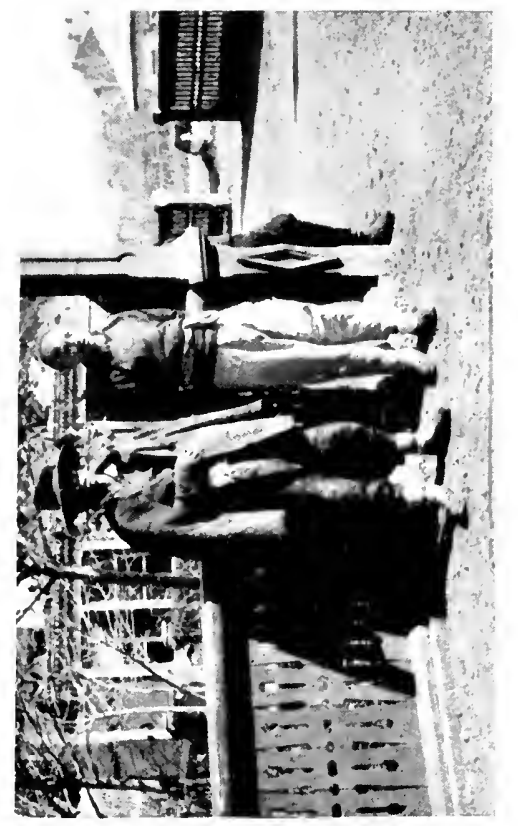


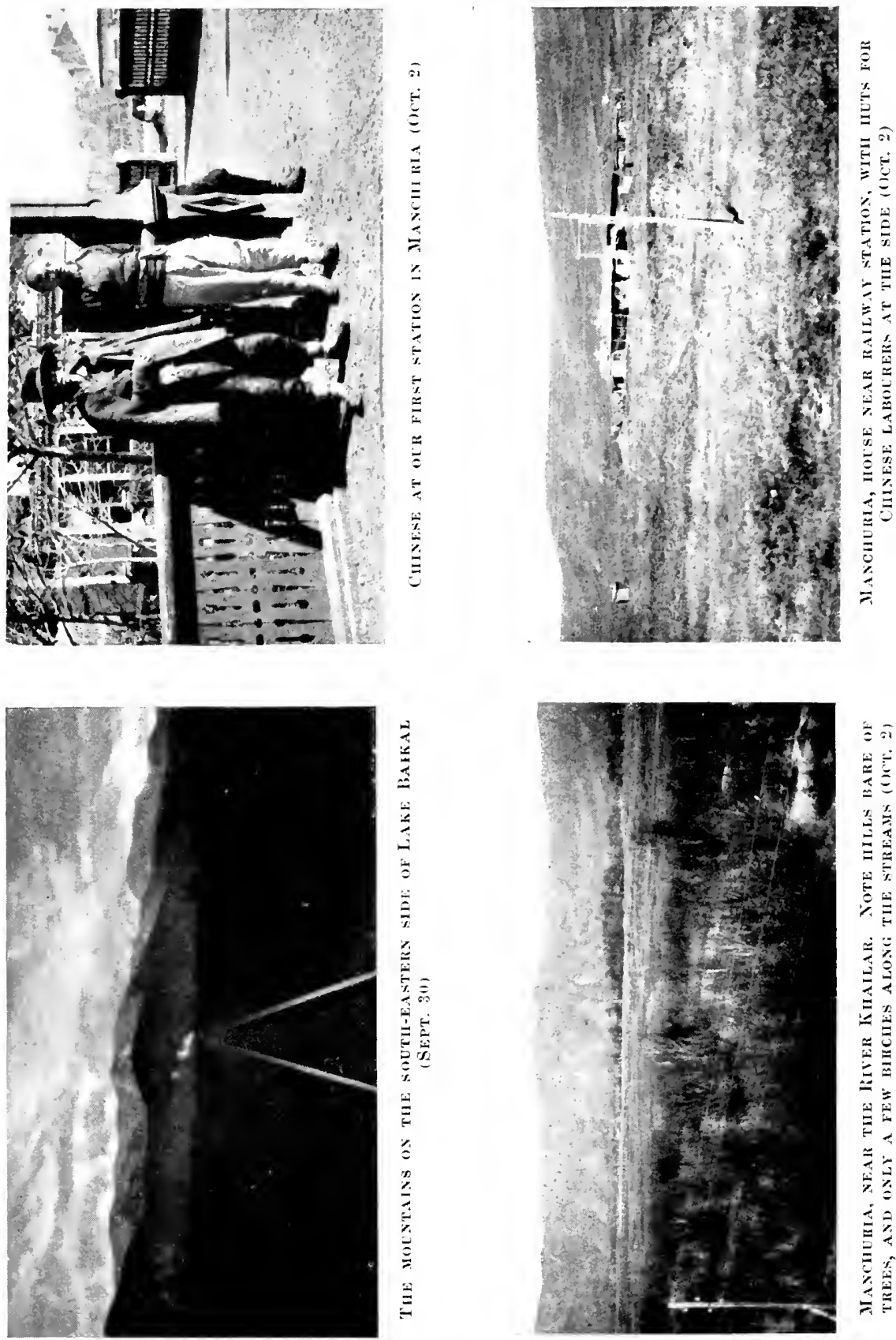

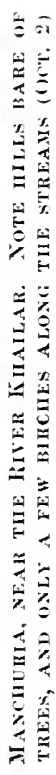




\section{YENISEISK TO KRASNOYARSK AND BEYOND}

These roads, by the way, show how cheap land is here, for they are broad beyond all reason. First the road itself has a great breadth, at least double that of a Norwegian high road. But after all this is not so strange, as the making of it cannot cost very much; all that is done is to lay some gravel on the top of the ground, which is otherwise left almost as it was. And over this gravel one drives, as well and as long as one can. But then by the side of these roads there are broad stretches of grass for riding and walking over-and driving over too, when the roads themselves become too impassable. Besides this the telegraph line has a broad lane where all trees and bushes have been cut down, and where one can also ride and drive at a pinch. If we add all this together, it gives a broad stretch of ground which, if it is not all regular road, at all events may serve for traffic.

Towards evening we met a large drove of cows, several hundreds of them. These cows had been bought by a Yeniseisk trader in the Minusinsk district and were now on their way north. As far as I could see, the herd was simply driven forward across all the meadows and the cows grazed where they happened to come, without anybody's leave being asked, and I suppose it would never occur to anyone to make an objection. In this vast country there is room for everybody, and the grazing of a few droves of cattle more or less makes no difference.

The drove was in charge of some mounted herdsmen. One of them presented a very striking appearance as he sat on his pony, rolling a cigarette, in the middle of the herd, with the cows grazing all round him. They were comparatively large and powerful animals and looked well. Originally, no doubt, they were Mongolian cattle, of which a good deal is imported. From China a considerable quantity of horned cattle comes into 


\section{THROUGH SIBERIA}

Siberia; they are big, fleshy cows, good for slaughtering, but give little milk.

Thursday, September 25. Across the undulating land we are now beginning to see blue mountains far to the south; indeed, there are even sharp peaks and rounded summits on the ridge. This is the northernmost part of the Sayan Mountains, near Krasnoyarsk, or, more correctly, the Gremyachinsk range.

At several stations the elder of the village had appeared to show us honour. These elders are chosen by the peasants themselves. At the last station but one before Krasnoyarsk not only the elder, but the Isprovnik and the telegraph superintendent, besides two or three representatives from the village came to salute us. The telegraph superintendent brought a message from the Mayor of Krasnoyarsk, asking if we could not arrange to arrive in the daytime. This was in the forenoon; we could not count on reaching Krasnoyarsk until towards evening, and if we were to arrive by daylight, we should thus have to spend the night at the next station, where we were due at about three in the afternoon. But time was short; I had much to arrange about the further journey, and I had letters waiting for me at Krasnoyarsk. It could not be helped; unwilling as we were to disoblige the citizens of Krasnoyarsk, we could not afford to wait; but we would press on as much as we could so as to arrive early in the evening.

So now we drove on as fast as we could ; and fast it was in all conscience - a gallop most of the way, through long stretches of cultivated fields, or with meadows on both sides, and through villages, always at the same pace; and the carriage shook and bumped and jolted and jumped worse than ever, especially when going through villages; indeed, in one of them the road was 268 


\section{YENISEISK TO KRASNOYARSK AND BEYOND}

so bad that we had to drive round the whole village over the surrounding land.

We left the last station, the thirteenth, at about halfpast four in the afternoon, and from there it was thirtyfive versts to Krasnoyarsk. The thing was now to get in before it was too dark; and the driver plied his knout incessantly, and the horses went at a gallop, while the man uttered his peculiar howls, now long and plaintive like a dying dog, now sharp and merry cries of "Hoi !"

Before leaving Yeniseisk we had been warned by a friendly and prudent official and many others against driving this last bit into Krasnoyarsk by night, as it was not safe. The amnesty on the occasion of the Romanov Jubilee had set free, not political exiles, but a mass of convicts, who had since made the roads unsafe at night in this part. Not long before there had been an attack on the mail; the horses had been shot, the mail-carrier murdered and the mail containing money taken. The thieves, of course, had never been caught, they seldom are here. We drove past the place before darkness came on. It was a desolate rolling plain all about, which seemed well suited to work of that kind. A wooden cross was supposed to mark the spot. They put these up wherever people have been killed in Siberia, so that passers-by may say a prayer for the soul of the dead man. But we did not see the cross and said no prayer.

We could not allow ourselves to be frightened by such things, and were more inclined to laugh at the possibility of our being attacked. It is a fact that strangers and foreigners are not as a rule attacked in Siberia, chiefly perhaps because the robbers assume that they always travel well armed. This was not precisely the case with us ; I for my part had no other weapon than a pocket knife. My gun I had sent by the steamboat. And, after all, we were scarcely justified in laughing at the 


\section{THROUGH SIBERIA}

chance of an attack; for on arriving at Krasnoyarsk it was found that all the ropes that fastened our baggage to the back of the carriage had been cut and were hanging loose. Fortunately the provident Madame Kitmanov had also had some sacks wrapped round our things, and these had kept them from falling off. We had noticed while going along that there were some loose cords dangling about the wheels and making a noise, and we said something about it, Loris-Melikov and I ; but we had paid no particular attention to it. It cannot have been so very long after we had passed the scene of the former attack that we noticed the sound of loose cords, and then it was already getting dark. The thieves must have jumped up behind the carriage and cut the ropes, but then they were probably scared by somebody coming to meet us, and made off. While going along, with all the shaking and noise, it is of course impossible to hear or notice anything that may be happening behind.

It had begun to rain as we went on. Cossacks came several times riding towards us to see how far we had come and how long it would be before we got in ; for we could guess that they were waiting for us at Krasnoyarsk.

Then at last we came near, at about half-past seven, in black darkness and streaming rain. The electric lights of the town had a brilliant effect from the height over which we came; and then we saw flickering bonfires and other lights before us on the plain. As we came nearer we saw a great black moving mass in the light of the big fires; then there was a glimpse of a triumphal arch with Norwegian and Russian flags, and dark forms flitted to and fro in front of the bonfires, waving torches.

Our carriage was positively stopped. by the dense swarm of people that gathered about us with a roar of 270 


\section{YENISEISK TO KRASNOYARSK AND BEYOND}

cheers. We had to get out, and were received by the Mayor, the President of the Geographical Society, a representative of the Governor, who was away, and many more. There were speeches and hurrahs and cheering, while the rain poured down, and the bonfires and torches shone just as brightly in spite of it. In short, the whole scene was fantastic. Here had all these people, and many more, been standing in the rain waiting for us since three in the afternoon. It was embarrassing, but it was not our fault.

Then Vostrotin and I were put into a buggy with two fine black horses, while Loris-Melikov got into another carriage, and we went at a trot downhill into the town, through the electrically lighted streets to the handsome house of Mr. Peter Ivanovich Gadálov, where we were cordially received by him, his wife, daughter, and son, and where I was to stay as his guest.

And so we had reached our long desired goal, Krasnoyarsk, and that on the very day we had planned, September 25, which may be called hitting it off well, when we think of the thousands of miles we had travelled since leaving Christiania, and of the many different changes. Here I had still three days in hand, before leaving for the east with Mr. Wourtzel; but this hospitable town was determined not to let these days go by unemployed. Such a "great event" as our arrival had to be celebrated; in fact, they even wanted me to give a lecture on our voyage, which I promised to do. But then there were many preparations to be made; first of all it would be a good thing to wash off some of the dust of travel, to change one's clothes and to sit down in the company of my two companions of the road at the festive board of my new hosts, who were untiring in their attentions. At such moments I often wonder whether life has any brighter moments than those of 


\section{THROUGH SIBERIA}

arrival at a journey's end, be it at the tent through the driving snow, at the mountain hut with its open fire through the fog and rain, or at a palace like this after the long shaking on the road.

Friday, September 26. The first thing to be done next day was to arrange about lantern-slides for the lecture. I had developed most of my negatives on the Correct and on the Omul, where the bathroom had been turned into a dark room for Vostrotin and me. One of the curators of the Krasnoyarsk museum undertook to prepare slides from the negatives I chose, and he did it extremely well. Then I had to find a shop for photographic supplies, where I could get fresh films and plates for my cameras to last for the rest of the journey; most of those I had brought were already used. That too was easily managed, with Vostrotin's help. The next thing was to find a bank and get some moneyand then there was some necessary replenishing of my wardrobe, which after so much knocking about was not in the best of order.

Vostrotin then took me for a drive and showed me the sights of the town. We saw the cathedral of the Nativity, which presents a fine appearance from all sides, with its lofty towers and gilded domes. The gold-mine proprietors of Krasnoyarsk began the erection of the church in 1843, but in 1849 the vaulting fell in, and the wealthy mine-owner Shchegolióv built it up again and decorated it at a cost of about $£ 50,000$. When a rich Siberian wishes to do something for his country, he builds a church. We also visited the public park, which passes for the largest in Siberia. It was autumn now of course, and the flowers were gone, but there were many sorts of trees, conifers, birches, and others, and it was easy to guess that this must be a delightful place in summer, when everything was in full bloom. The town has broad, 272 


\section{YENISEISK TO KRASNOYARSK AND BEYOND}

straight streets. There are some brick houses in the principal streets, but most of the houses are of timber.

Krasnoyarsk is beautifully situated on the left bank of the Yenisei, in a plain surrounded by mountains on both sides. On the west are the heights we had driven over on the evening before. The hill rises sharply from the western limits of the town, and is composed of red sandstone with a layer of red marl, from which the town has its name. Krasno in Russian means red, but it also means handsome. Opposite the town, on the eastern side of the Yenisei, the mountains are somewhat higher and more rugged. They are partly built up of eruptive rocks, and their sides are covered with thin forest.

A little above Krasnoyarsk the Yenisei breaks through a pass in the mountains and in places narrows to a width of only three or four hundred yards, running at the rate of five or six miles an hour. But then the river expands to a width of a mile or more, and on approaching the town it divides into two branches round picturesque low islands covered with birchwoods.

Here, as everywhere, there is a great difference between the usual height of the water and its height during the floods of spring and early summer. The difference may be more than 30 feet, and this gives the banks their usual characteristic appearance, with the long bare foreshore stretching down to the water.

In the afternoon my host had provided good saddlehorses, as he had heard that I wanted to see a little of the neighbourhood of the town and its geology. In the company of his young son I then had an enjoyable ride over the heights on the western side of Krasnoyarsk. There were treeless, undulating moors beyond. The rock seems for the most part to be loose red sandstone ; 


\section{THROUGH SIBERIA}

but, as everywhere here, the rock is covered by thick loose strata, formed by severe weathering during long ages. As it seems that there cannot have been any Ice Age here, at any geologically recent time in any case, all this weathered material has remained on the spot. The plateau is scored by valleys of water erosion; here and there the streams have cut their way into the sandstone and formed deep and narrow gorges.

At one time, perhaps, these moors were covered with forest, although I found no sign of it. But then the forest was probably burnt long ago and the moors transformed into grass land, which remains more or less unproductive ; there was no cultivation to be seen, except down in the valleys, and not much there either.

Saturday, September 27. As my incomparable host had found out that I should be glad to see something of the mountains and of the structure of the country on the other side as well, east of the Yenisei, he provided horses early next morning, and I went off again with young Mr. Gadálov and the curator of the museum.

A little above Krasnoyarsk a bridge nearly 1000 yards long carries the railway across the Yenisei ; but there is no road-bridge over the river and one has to take a ferry. The main ferry is arranged on a very handy and practical principle, as the force of the stream is used to take it across. A long cable is anchored some distance up the river, and rests upon boats or floats down the stream. The end is made fast to the ferry boat, which has a big rudder. Then, by means of the rudder, the ferry-boat is laid in an oblique position, so that it cleaves the stream, and it is carried across from one side to the other, like a pendulum, right in to the quay; horses and people go ashore and others are taken aboard, the rudder is put over the other way, and the ferry swings back again to the other bank. Thus it goes to and 274 


\section{YENISEISK TO KRASNOYARSK AND BEYOND}

fro all day long, without any more trouble than that of moving the rudder.

But there is not a little traffic over this broad river, and long rows of horses and waggons often stand waiting to cross, especially on the days when a fair is held in Krasnoyarsk, as happened to be the case just now. One has to allow plenty of time for crossing.

And we too had to wait our time. It was a great holiday and had been a fair-day the day before, so there were many people about. It was amusing to look at all these people; healthy, cheerful, and pleased they seemed to be. Now they were on their way home to the villages, with their horses and empty telegas, and women and girls were in their best town finery. As soon as the crowded ferry came in to the quay, the horses and carriages came ashore till the ferry was empty and then it was soon filled again with a stream of waggons and horses and people. They put off from land and we ploughed across the river quite fast, until we came in to the other side. But it was only an island that we landed on, and after riding across it we found another ferry.

At last we were on the mainland on the opposite bank and could ride, first southward at a sharp trot over the plain along the river, and then up the valley between the mountains till we reached the granite rocks, which I particularly wanted to see.

To one accustomed to our ice-worn, rounded mountains in Scandinavia, it was strange to see the forms here. The valleys had a distinct appearance of having been excavated by running water, and not worn by ice like ours; and these ridges of granite that stood up, jagged and wasted, high above the surrounding mountains, afforded clear evidence that the land had been exposed to weathering by wind and running water and 


\section{THROUGH SIBERIA}

frost for immense periods, until these harder beds had been left standing as ruins of what had once existed, and all the rocks around them had been carried away by rainwater and streams and wind. Later on, in many parts of Siberia and the Amur district, I saw similar sharp, jagged and worn ridges of granite, or other hard rock, towering high above the surrounding country. They show that there cannot have been any Ice Age or any glaciers here throughout long geological periods, as otherwise they would have been worn away. The rocky ground about them was covered by a deep layer of fragments and loose soil, which must have been due to the extensive weathering. Indeed, there was hardly a proper talus of large stones to be found under these steep walls of rock, such as we should inevitably see in Norway. Even the talus was weathered, and to a great extent covered by small stones, mould, and vegetation. There was abundant vegetation on the ground among the trees, but the forest itself was somewhat thin and consisted chiefly of small trees, many of them foliferous.

In the afternoon the Krasnoyarsk sports club and schools gave us a great exhibition of football on the town athletic ground. Of late years a strong athletic movement, known as the "Sokol" movement, has spread throughout the Russian Empire, but curiously enough it originated among the Czechs in Bohemia, where it celebrated its Jubilee in 1912. Sokol means hawk. The movement has had the support of the Russian Government, and Sokol clubs have been formed everywhere in the Empire, including Siberia. The Russian skaters who have been the Norwegians' most dangerous opponents in the struggle for the world's championship, are members of these clubs. We were given a warm reception on the ground by the active youth of Krasnoyarsk in their light football clothes, 276 


\section{YENISEISK TO KRASNOYARSK AND BEYOND}

and it was a fine thing to see their keenness and proficiencyat the game. After saying good-bye to this body of congenial young men and their interested and pleasant masters, we visited the excellent municipal museum, where we were received with ceremony by the staff and directors. It contains valuable collections of different kinds, in the departments of natural history, archæology, ethnology, etc. It was the last named that claimed my chief interest for the moment, especially the collections from the Yenisei-Ostiaks, Tunguses, Samoyedes and other peoples; and under the skilled guidance of the museum staff I here learned, in the fading daylight, a great deal about the past and present of the country.

Sunday, September 28. Next day came the meeting of the Geographical Society. I told them about our voyage, showed my slides and spoke of the prospects of regular navigation through the Kara Sea to the Yenisei estuary. Vostrotin was again kind enough to interpret. The cordial and interested way in which we were received by the large audience gave me, perhaps, a more vivid impression than anything else had done of the great importance attached in this part of Siberia to the future development of the maritime connexion with Europe. Nor is this to be wondered at; in spite of the railway they feel that their most important products are shut in, and it gives them a bright hope for the future if they can find an outlet for them in this way. And it must be said that these great rivers seem to be made for the traffic; the transport of goods down them is extremely easy, and they all point northward to the Arctic Ocean as the solution. Thus it was that the town received us so well, merely because we had taken part in this voyage as guests, without any idea that we were doing a meritorious thing. 


\section{THROUGH SIBERIA}

In the evening the Mayor and the Geographical Society gave a big dinner in our honour; there were many warm-hearted speeches and much enthusiasm, and telegrams of welcome even arrived from Irkutsk and other parts of Siberia.

Monday, September 29. At five next morning I was accompanied to the railway station by my kind hosts. There, to my surprise, I also found our host of the previous evening, the pleasant and warm-hearted Mayor, to whom I had said good-bye a few hours before; besides the President of the Geological Society and many others who had come to say a last good-bye. LorisMelikov and Vostrotin could not yet part company, and wanted to go with me to Irkutsk; but there were no tickets to be had for the train, all the seats had been already booked in Russia. Then, at 5.35 A.M., the express arrived. It was covered with snow as it came into the station, and this gave one a feeling that after all one was in Siberia. Then we met Mr. Wourtzel, who received me cordially in his saloon-carriage, and in his pleasant company the long voyage to the east was now to begin, through what was to me an entirely new world. There was room enough in his big carriage, and he immediately invited Vostrotin and Loris-Melikov to travel in it as far as they liked.

Then it was good-bye to the excellent people of Krasnoyarsk, the train began to move, and we were off along the endless track eastward. After the long bridge over the Yenisei a great part of the line lay through flat country, most of which, as far as I could see, was capable of cultivation; it looked as if it only wanted ploughing, and here and there we did see cultivated fields. The fact that one sees so much uncultivated land in Siberia, even in the most accessible districts along the railway, is no doubt to some extent explained 278 


\section{YENISEISK TO KRASNOYARSK AND BEYOND}

by what I said before about the Siberian farmer not using manure, but being obliged, after exhausting a piece of land, to let it lie fallow for many years, twenty perhaps, before he can sow it again. The first important station was at the town of Kansk, which stands on the Kan, a tributary of the Yenisei, and has about 10,000 inhabitants. The Mayor of this town had met us in Krasnoyarsk to welcome us on our arrival, but here again he appeared at the station with a deputation from the town, and there were speeches and replies during the few minutes that the train stopped. Everywhere the same lively interest in the development of this trade route through the Kara Sea. The demand for it becomes greater year by year, they say.

We went on through the same flat, rolling country, with immense tracts fit for cultivation; but now there was also a good deal of forest. Wourtzel's carriage was the last in the train, and the saloon formed the back part of it, with large windows at the sides and at the end, so that we had a full view of the railway line and of the landscape on three sides.

We had great deliberations in the saloon as to how the trade route between Norway and the Yenisei could best be secured and what were the first steps to be taken to this end. We discussed the best arrangement of wireless stations, the dispatch of motor-sloops to investigate the extent of the ice in the Kara Sea, how aeroplanes might be used for constantly reconnoitring the ice conditions in that sea, in connexion with the wireless stations, and so on. The construction of an efficient harbour for discharging and loading in the northern part of the Yenisei and the transport up and down the river were discussed with Vostrotin, who has these questions at his fingers' ends. By degrees a whole programme was drawn up under the shrewd 


\section{THROUGH SIBERIA}

guidance of Wourtzel. I could not help admiring the facility with which he mastered all these proposals, entirely new to him, and at once saw both their advantages and their weaknesses.

But then these negotiations had to be suspended, since Wourtzel, as engineer-in-chief of railway construction throughout the Russian Empire, had to examine the line. I must explain that a great extent of the line we were now travelling on was being entirely relaid. The curves of the old line were too sharp and trains could not be run at the desired speed; besides which the whole track was being made double. The war with Japan had shown that a single line was not sufficient to carry the necessary traffic, at any rate in war time. After leaving the Correct and the $\mathrm{Omul}$ and transferring ourselves to terra firma, we thought we had left behind all possibility of wanting a pilot; but it is a fact that we had to stop several times here to take a pilot aboard the train; the ground was treacherous and at times we had to slow down. In many places here they have great difficulty in ballasting the line firmly enough; the ground is constantly giving way.

Thus after all the changes of our long journey: first the Norwegian railway and steamer, then the Correct and the Omul, and then the tarantass on the high road, we three fellow travellers found ourselves at last in the express from Petersburg to Vladivostok, Peking and the Pacific. It has been repeated to triteness that nowhere in the world does one travel so comfortably and well as on the Russian railways and this express in particular is known for its comfort and luxury. But I shall not attempt to describe it, for one excellent reason because I saw very little of the train, except on the long journey to and from the dining-car, for those meals which were not served 280 


\section{YENISEISK TO KRASNOYARSK AND BEYOND}

in our own saloon. For I had the good fortune to travel with Mr. Wourtzel in his carriage the whole time, and there we had our own magnificent comforts, and saw nothing of the other passengers, except when we were in the dining-car. But certain it is that one travels at one's ease in these trains. The Russian gauge being broader than that of other countries makes the carriages larger and broader, so that there is plenty of room in them. A smooth-running train is particularly important to one who constantly wants to write, and in this respect the traveller in Siberia is well off.

One became quite at home in this magnificent carriage, and it is always a pleasure to me to look back on the time I spent there, in the agreeable and entertaining company of my good friend Wourtzel, while the wide country glided past our windows, spread out like a map. During the uninterrupted journey to the eastward, one's soul seemed to expand and to absorb little by little a whole new continent. One's only anxiety was that it would be impossible to digest all these impressions and get them arranged in their right places. New sights were continually presenting themselves; but one impression recurred with ever increasing strength : that there is still room enough on the earth, and it will not be overpopulated just yet; for here there are endless expanses, with great possibilities only waiting to be turned to account. And of these expanses we saw more, and ever more, the farther east we came. 


\section{CHAPTER XIII}

THE COLONIZATION AND DEVELOPMENT OF SIBERIA

The population of Siberia : Russia's steady expansion : Former views on Siberia : Emigration to America : Improvements in recent times : Immigration to Siberia : Siberia's internal politics : Wealth of Siberia : Loans and aid to colonists : Extent of the partition of land : Economic position of the settlers : Profits of agriculture : Room for many : Colonization has two sides for a nation

T $\mathrm{T}$ may seem strange to many that an agricultural L country like Russia should have possessed Siberia for three centuries, with its almost inexhaustible wealth and its boundless extent of fertile land, without making more out of it than she has done. If we exclude the recently acquired territories in Central Asia, the population of Siberia and the East Asiatic provinces may be put at about eleven millions. In other words, the population of this immense country is less than $\mathbf{5 0}$ per cent. greater than that which we find in the thinly populated Scandinavian Peninsula, in spite of the fact that vast regions, especially in southern Siberia, offer far better conditions of life than the greater part of Scandinavia.

A Russian author, who has written about Siberia, its great possibilities and natural wealth, says that the melancholy history of the country confirms in a certain degree the opinion entertained of Russia by several foreign inquirers - that she understands well enough how to conquer new countries, but not how to colonize them. The Russians are said to have no aptitude for 282 


\section{COLONIZATION AND DEVELOPMENT}

a continued, stubborn, purposeful work of civilization. This last assertion may be doubtful, but it must be admitted that Russia has shown a remarkable power of expansion. From the earliest foundation of the Russian Empire at Moscow, about 1500, to our day, its territorial increase has had no parallel in the history of the world, with the exception of the British Empire. During the whole of this period the Russian Empire has grown at the average rate of fifty-five square miles a day, or 20,000 square miles a year, or a territory as large as the Kingdom of Norway every seventh year, unceasingly, until it has reached its present extent of 8,723,600 square miles. But the growth of the population in the conquered provinces has been slow until quite recently. During the 300 years that Russia has been in possession of Siberia, up to the close of last century (1896), perhaps three million persons immigrated to that country from Russia. If we compare this with the fact that little Norway has sent out 366,670 emigrants, chiefly to America, in twenty-five years (1886-1910), it cannot be called much for mighty Russia.

As an example of the small success attending the Russian Government's management of its lands in the past, the case of Alaska was cited in 1909 in a Russian official quarter; this country, which was sold to the United States in 1867 for $7,200,000$ gold roubles $(£ 760,000)$, is said to have brought in $150,000,000$ dollars in the year 1905 alone. It is also stated that the wealth of the peninsula of the Chukchis (near Bering Strait) is exploited by the Americans, while the Russians themselves derive little benefit from it.

The reason for the slow development of the great and rich territories in Asia is doubtless partly to be sought in the fact that until recently the desirability of encouraging and colonizing them was little understood 


\section{THROUGH SIBERIA}

in Russia; indeed, they were even looked upon as rivals, which it was undesirable to encourage, but which were rather to be exploited for what they were. In addition to this there were many other factors. Perhaps the most important was that Siberia was used as a convict colony, a place to which turbulent and unpleasant elements, which it was undesirable to keep in Russia, might be exiled. Siberia thus got a bad name and became a dreaded land, to which people were disinclined to resort of their own free will. The great distances in these immense expanses were also of course a great hindrance, before the railway was made. Emigrants suffered incredibly during the long journey on the difficult Siberian roads, and an active administration from Petersburg, which might promote the development of the country, was almost impossible. Then there was serfdom, which until the reign of Alexander II. (1861) contributed to make emigration difficult, as Russian peasants were not allowed to leave their native soil.

It is remarkable that while Russia had these vast territories lying more or less idle, she sent every year great numbers of emigrants across the ocean to America. In the ten years 1891-1900 at least half a million Russians went to the United States alone, and in the following seven years, 1900-1906, 485,850 Russians crossed the Atlantic from German ports alone.

But in the most recent years, especially since the war with Japan in 1904-1905, a complete change has taken place in the Russian view of Siberia and its development; the eyes of the authorities have been opened to past neglect and to the enormous importance of the country's future. A great step towards better times for Siberia was the decision of the Government that in future it should not be used for the transportation of criminals; and in recent years, especially since the 284 


\section{COLONIZATION AND DEVELOPMENT}

Japanese War, great efforts have been made on the part of the Government to encourage the colonization of the Asiatic provinces. The sums that have been devoted by the Government to this end in the course of years afford a good illustration of the increase of the work. While previous to 1896 only a million roubles a year or less were applied to this colonization, this sum increased between 1896 and 1905 to about 2,900,000 roubles a year; in 1906 it had become about five millions, in 1907 thirteen and a half millions, in 1908 nineteen millions and in 1909 twenty-two and a half millions. It has thus steadily risen, until this year, 1914, over thirty millions have been voted for this purpose. In other words between 1905 and the present time the amount has increased more than tenfold.

Immigration to Siberia from Russia has increased on a somewhat similar scale in recent years. While, as I have said, in the 300 years previous to 1896 altogether some three millions of people immigrated from Russia, in the period between 1896 and 1905 the immigrants numbered 1,370,000 and between 1905 and 1913, including the latter year-that is since the colonization of the Asiatic lands was placed under the direction of the Department of Agriculture-at least three millions of colonists have settled in Siberia. In the words of the official report, "it is obvious that such an addition of new forces is already of great importance to Siberia and will become of even greater importance in the future." The population of governments like those of Tomsk and Yeniseisk has doubled during the ten years from 1902 to 1912 . New towns have grown up with American rapidity. The area of land under cultivation has in many places increased by two or three times, and the quantity of new produce thrown upon the market has in some cases been so great 


\section{THROUGH SIBERIA}

that the roads are no longer sufficient to carry it. The following figures will help one to understand the variations in immigration : during the period between 1896 and the Japanese War of 1904, the number of immigrants varied between 100,000 and 200,000. On account of Government encouragement immigration increased greatly after the war. In 1906 the country was still paralyzed and the immigration was then 216,600 . But then it rose rapidly : in 1907 it was $57 \%, 000$; in $1908,759,000$; in $1909,707,500$; in $1910,353,000$; in 1911, 226,000; in 1912, 259,600 and in 1913, 327,000. According to the official reports the cause of the decline in immigration since 1909 is, in the first place, that in the previous years, 1907 to 1909 , it had reached a disproportionate height, after having been checked by the war and by the revolution. But in addition to this, the most recent years have been unfortunate ones in Siberia, but favourable ones in Russia; the development of agriculture and the operations of the peasants' bank (for the purchase and sale of land to the peasants) have increased so much in the districts from which emigration chiefly took place, that conditions have greatly improved there. During the five years, 1909-1913, with the help of the peasants' bank, 10,600 square miles of land have passed into the peasants' own hands in these emigration districts, and this of course keeps many people at home, who would otherwise have emigrated to get land of their own in Siberia. But the most important reason for the restriction of colonization may nevertheless be that the supply of free and easily accessible land which is more or less ready for cultivation, has greatly diminished. The tracts lying near the Siberian railway are already taken up, and year by year the colonists have to go farther and farther away to more difficult regions, such as the taiga 286 


\section{COLONIZATION AND DEVELOPMENT}

and the southern districts of the Kirghiz Steppes, which are partly desert. The land in the Altai which belongs to the Imperial Cabinet, and which the Emperor gave up to colonization, is already all parcelled out. Formerly there was also a good deal of land that was taken from older colonists who had too much, and which was fit for immediate cultivation; but there is now little of this left, and the struggle during the first few years of a settler's life has become harder. The great wave of immigration to Siberia, which culminated in 1908, could not be kept up; as already stated, it was due in part to the long stagnation during the war and the revolution, as well as to the encouragement and aid of the Government. There was then a greater influx of settlers than the country was prepared to receive, and a reaction was bound to come. In 1911, with 226,000 persons, immigration was not much greater than in 1898-1900, when it was between 203,000 and 223,000 persons a year, but then, as we have seen, it has risen steadily in the last two years.

It is easy to understand that its great distance from the seat of government has not been a fortunate thing for the development of Siberia. According to the Russian system all the long threads of administration are collected in Petersburg and the distances to the various parts of Siberia, especially in former days when there were only roads and rivers for transit, made it impossible to obtain a complete view of Siberian affairs and requirements. Apart from anything else, the mail there and back took many months, and even now it is not rapid. There must also be great difficulties in directing and regulating so extensive a colonization in such a widespread country, especially when this has to be clone from Petersburg, so far away from the districts where settlement and clearing are taking place. 


\section{THROUGH SIBERIA}

It seems likely that local self-government would be to some extent successful, in enabling those things to be done which were best calculated to promote the prosperity and development of the separate districts. But as things now are, while the Siberian towns have communal self-government, this is not the case in the country districts.

Two parties have therefore declared themselves in Russia's Siberian policy. Adherents of one party, who form the majority of the inhabitants of Siberia, maintain that in order to promote the prosperity of the country it will inevitably be necessary to grant communal self-government (zemstvo) to the country districts, with power to decide all questions affecting the daily interests of the commune and to levy communal rates for the construction of roads, for schools, etc., instead of this being done, as now, by the Government, which collects all taxes. It is thought that this would be both an easier and more satisfactory arrangement.

In opposition to this the adherents of the other political view point out that Siberia has no aristocracy and no large landowners, it is a country of peasants, and the great majority of these do not possess the necessary qualifications for the proposed self-government ; indeed, only a small fraction of them can read; the conditions would not correspond to those prevailing in Russia, where there is an upper class to take the lead, and it would be an unfortunate arrangement for Siberia itself. But the former party holds up the government of Viatka in Russia as a proof that this self-government without an upper class is capable of leading to good results. Viatka has a population exclusively of peasants and, as regards order and development, it is considered to be one of the best governments in Russia. The government of Perm is also quoted. 288 


\section{COLONIZATION AND DEVELOPMENT}

There is even a large party in Siberia which is in favour of home rule, and thinks that in so extensive a country as Russia, one central Government and one Duma, which have to deal with all matters, great and small, cannot have the necessary comprehensiveness of view and cannot sufficiently identify itself with the local interests of the various districts. They therefore maintain that Siberia ought to have its own Duma and its own local governments, the business of which would be to deal with all matters that concerned Siberia alone and were of no direct interest to Russia. To this the Russian Government party makes much the same objections as have been raised by English Unionists to home rule for Ireland - that it might easily result in Siberia feeling herself to be a separate country, whose interests do not always entirely coincide with Russia's, and it might relax the sense of Russian unity and lead to a want of cohesion within the Russian Empire.

To this the other side objects that it is impossible to imagine that Siberia, either now or in the future, can have interests which will conflict at any point with those of the whole Russian Empire; and that it must be remembered that the present population of Siberia, if the small fraction of natives be excluded, is not a conquered people like the Irish, but is entirely Russian, feels and will always feel itself to be Russian and an inseparable part of the Russian Empire, and will always be sharply antagonistic to the Asiatic peoples on the south and east. Indeed, they go on to say that under a system of self-government with more local interest, more local knowledge and energy, the development of Russia's eastern provinces would be in a great degree accelerated, and her power in the East would thereby be considerably strengthened.

It is not likely that a political programme such as 


\section{THROUGH SIBERIA}

this has any prospect of being realized in the near future. But although there may thus be a division of opinion in Russia as to the line of advance by which the goal may be most surely reached, all parties are agreed that Russian colonization in Asia ought to be promoted by all the best means available. That this view is also held in Government circles is clear from the report of the Department of Agriculture for the five years 1909-1913, where it is insisted that, while much has been done for this colonization, it is still not enough, and that it is important " to develop energetically the work already begun in the colony districts, by better preparation of the land that is to be colonized, by the making of roads and wells, the building of hospitals, by postal communication, and by extending the work of education and building churches and schools. It is also important to teach the colonists of older standing better agricultural methods. Some efficiency in farming is as necessary in Siberia as elsewhere." It is further recommended that "future colonization ought preferably to be concentrated along the frontiers of Asiatic Russia, the settlers in these districts being given the maximum of Government assistance. It is also necessary to hasten the projected system of railways in Siberia, especially the Southern Siberian main line through the Kirghiz Steppes. Railway construction opens up large new fields for colonization and strengthens the old ones," etc.

Siberia, as has been said before, is a rich country and well worth developing. It is remarkably abundant in minerals. Specially famous is its gold, of which more and more is continually being found, chiefly in Central and Eastern Siberia. In the government of Yeniseisk gold has been found in many places, both in the central part, where great quantities have been 290 


\section{COLONIZATION AND DEVELOPMENT}

extracted, and in the south; in the government of Irkutsk there are particularly rich gold-fields, some of which are reputed to be the richest in Siberia; in Transbaikalia many gold-mines are working; in the Amúr District gold has been found in many places along the rivers, and there are some who believe it will turn out to be the richest gold country in Siberia; in the Ussúri District gold has also been found, and even on the Anadyr, north of Kamchatka, gold is said to occur in abundance. In Siberia gold is still extracted to a great extent by very primitive means, often, indeed, simply by hand washing, and by the introduction of machinery the yield might be increased many times. From a report of 1908, gold-washing in Siberia employs about 45,000 workmen, whose wages amount to between thirteen and seventeen millions of roubles annually, and the vield in pure gold, for Siberia not including the Ural, is given as more than 2000 poods (32.8 tons) a year.

Siberia has other mineral wealth besides gold. Iron is abundant, but imperfectly exploited; there are also copper, silver, and lead. Precious stones and valuable minerals also occur in places, and there are mineral springs, but at present all these are turned to little account. Coal is found in many parts, some of it of good quality ; in the eastern maritime province and in Sakhalin alone there is thought to be enough to supply the whole navigation of the Pacific. But the working of coal-mines is still in its infancy in Siberia, and it has a great future. In Sakhalin rich oil-wells have been discovered, which, it is asserted, might supply the whole of Siberia with petroleum, and, indeed, Australia as well. That Siberia possesses endless forests has often been mentioned, and that their value is in reality enormous is a matter of course; the difficulty consists in transport, and in most parts this renders them for the 


\section{THROUGH SIBERIA}

present almost valueless. But there are many places, especially in Eastern Siberia near the Pacific, where the timber can already be turned to good account. That the great Siberian rivers have valuable fisheries has also been mentioned, and these are capable of further developmènt.

In spite of all this, Siberia's greatest wealth, beyond comparison, consists in its immense areas of arable, and to some extent fertile land, by far the greater part of which is still lying idle or is turned to poor account. As has been truly said, the real gold of Siberia is its black soil; but until the most recent times one of the most serious obstacles to the development of agriculture has been the lack of communications. Before the Siberian railway, of course, everything had to be carried by road or river; the importation of heavy things like agricultural machinery was practically impossible, and it was equally difficult to provide for the export of agricultural produce, so that the farmer might easily be left with a surplus on his hands. Nor has the Siberian railway removed all the difficulties. Even if the railway freights are put fairly low, they are nevertheless too high for such products as corn, when it has to be carried from such distances as Central Siberia. Therefore, as has been said, the inhabitants, especially of the provinces of Yeniseisk and Irkutsk, look to the sea route through the Kara Sea to the Yenisei estuary as the great hope of this part of Siberia.

The Siberians themselves take a lively interest in the development of their country and clearly see its great possibilities. But it cannot be denied that, on account of the views of Siberia which prevailed for centuries, this country has been sadly neglected and its development has been fettered. It is therefore still a long way behind the times. But Western Siberia is a good 292 


\section{COLONIZATION AND DEVELOPMENT}

example of how little is required to produce a complete revolution in this respect, and how susceptible of development the Siberian farmer really is. In the course of a few years a handful of active and capable Danes have brought about a complete change in that part of the country, by introducing Danish dairy methods and teaching the farmers to make butter, so that in barely fifteen years the Western Siberian export of butter, which before that time was nothing, has become a real factor in the world's market. As an illustration of this growth it may be mentioned that in 1898 the butter production of Siberia was 149,000 poods, in 1906, $2,970,000$ poods, and in $1909,8,600,000$ poods $(140,870$ tons). A train of refrigerator-vans now runs daily carrying butter to the Baltic from as far east as Novo Nikoláyevsk on the Obi, and the butter is then taken by steamer to England and Paris. Great areas which were formerly backward, have risen to prosperity owing to this trade. In the same way other parts of Siberia may certainly wake to new life with good administration and the example of capable men.

When we think of the immense work involved in the regulation of such a number of emigrants every year and the allotment of suitable land to them all, a work which, as has been said, is entirely controlled from Petersburg, it is not surprising that shortcomings may have been perceptible here and there; but every year has seen an improvement in this respect. The mere work of examining, surveying, and parcelling out the land to be alloted to settlers required a whole army of surveyors, whose services it was not always possible to obtain; in former years therefore it happened often enough that when the colonists arrived, they could not all be provided with land at once, but had to wait; and many provisional inquirers (khodoki) who came to 


\section{THROUGH SIBERIA}

choose land, had to return, after spending their money in vain. Besides this, roads had to be made through the new countries, railways constructed, and in many places depots for corn and other things provided, so that the settlers might not be destitute on arrival and during the early days of their work. Medical attendance and nursing had to be provided for the sick, who are liable to be numerous on such long journeys, when people are crowded together in anything but hygienic conditions. In many districts it was also necessary to dig wells before the settlers arrived, and many other preparations were to be made.

It may easily be understood that with such immense areas it has not been possible, with the best intentions on the part of those in control, to comply satisfactorily with all demands. The consequence has been that, especially in former years, a number of settlers became destitute and could not hold their own; after losing all they possessed, they were often compelled to return to Russia. The lot of one of these returned colonists is not an enviable one ; before he left his home in Russia he had sold all he had to procure ready money. This was spent on the journey and in his attempt to make both ends meet in Siberia, until at last he has to return empty-handed, as a beggar-and then he has to try again to make a living at home, where, perhaps, he found it difficult enough to get on before. On an average about 10 per cent. of the emigrants returned home every year. But in this respect also there seems to have been considerable improvement recently, judging from the official reports. Thus in 1911 the total number of emigrants who returned to Russia was about 68,600 (30 per cent.), while in 1912 it was about 32,700, and in 1913 about 23,000 (7 per cent.); as we see, there is a marked decline, and this refers to all districts, except 294 


\section{COLONIZATION AND DEVELOPMENT}

the provinces of Yeniseisk and Irkutsk in 1912. But the cause of there being no diminution in the number of returned emigrants from these districts is said to have been the loss of seed-corn in that year owing to spring rains and late spring frost, which reduced many of the colonists to destitution.

To guard against families of settlers being given land which does not suit them, the Government, as early as 1887, enjoined that, the year before setting out, the family should send a man, who is called a $k h o d o k$, to the district in which they intend to settle, so that he may examine the land and choose a piece that he thinks will be suitable. The best time for examining the land is the spring, from April to June; many cautious people go out before the winter is over, to acquaint themselves with the life of the colonists and with the country; but for fear the land might be taken by others, especially when too little land has been surveyed for allotment, they often choose their piece of land before the snow has disappeared, and in such cases the value of their examination must be doubtful.

Settlers can obtain a loan from the State, if their land is not favourably situated near the railway but in such regions as the taiga, where a great deal of clearing is necessary, or in the steppes, where wells have to be dug, or in the Far East. The condition for the granting of these loans is that the family must have sent a khodók in advance to choose their holding. This is of course a provision against imprudent and badly equipped settling. In difficult regions, and in the provinces of the Far East, in the Amúr District, the Ussúri province and in Sakhalin, the loans may be as much as 400 roubles. In Transbaikalia they may be between 250 and 400 roubles, according to the 


\section{THROUGH SIBERIA}

situation of the land. They are granted on easy terms : nothing has to be paid for the first five years, but after that they are paid off in the course of ten years in instalments of equal amount. In certain difficult districts the second half of the loan may be remitted. Families of settlers who have sent no khodók in advance can obtain no assistance, and have to put up with what land is left after all the others have received theirs.

Settlers also enjoy other forms of relief. They are thus exempt from taxes and land-tax for the first five years after settlement. For the following five years they have to pay half the amount of the taxes, and after ten years they all pay the same as the older inhabitants. But the communal rates - to the mir or village, if they are members of one, or to the district - have to be paid immediately on settlement, even if the rates are in money. Settlers above the age of eighteen are granted three years' postponement of military service; in the eastern maritime province and in Turkestan six years' postponement is granted to those above the age of fifteen. Thus a great deal is done to relieve the settlers in their toilsome life.

Much is also done to improve agriculture. Thus great efforts are made for the importation of modern agricultural machinery, and the Government has established depots where these appliances can be supplied to the settlers. Here again there has been a great development. In 1909 the Government had sixty-four of these depots for agricultural machinery in Siberia; but in 1913 their number had increased to 300. While the value of agricultural machinery imported into Siberia in 1898 was 211,900 roubles, and in 1900718,200 roubles, in 1906 it had risen to $2 \cdot 6$ millions of roubles, in 1909 to $4^{\cdot 6}$ millions, and in 1913 to $8 \cdot 4$ millions, which is an 296 


\section{COLONIZATION AND DEVELOPMENT}

enormous increase in those few years. The greater part of this machinery naturally goes to Western Siberia, which still ranks first in agriculture, but a considerable quantity goes even to the eastern provinces, to the Amúr and Ussuri Districts.

To illustrate the dimensions of this colonization of Siberia, it may be mentioned that according to the official reports the area of new land that has been surveyed and parcelled out for colonization during the last five years (1909-1913) amounts to eighteen million dessiatines, or 75,850 square miles, and 350,000 families, containing about two million souls, have settled. This means about 15,000 square miles a year, or an agricultural district equal to the whole area of Norway in eight years. But to this we have still to add six million dessiatines, or about 25,000 square miles, of the land belonging to the old villages or mirs, which was brought under cultivation for the first time in the course of the same five years. This is no small gain of land to mankind every year, and in these five years it has provided homes for a population nearly as large as that of the whole of Norway. During the same time 9500 versts, or about 6300 miles, of roads have been constructed.

Formerly there was much extravagance in allotting land to the colonists, but when it was seen that a great part of this land was not cultivated, more economy was practised in its distribution, and much of the older land has been taken back. According to a law of 1881, all the older land in excess of fifteen dessiatines to each male was to be taken from the villages and used for new colonization. And the usual scale of allotment is now eight to fifteen dessiatines - i.e. $21 \cdot 6$ to 40.5 acres-of land to each male member of the family.

New land for freehold farms is allotted in parcels of twenty-five to fifty dessiatines $(67.5$ to 135 acres $)$ of 


\section{THROUGH SIBERIA}

arable land to each family, without regard to the number of males.

According to the official reports the economic position of the Siberian settlers is considerably better than that of the Russian peasants. The area of land they occupy is about nine times as large as they had at home. In Siberia it is reckoned that an ordinary settler's farm contains about $38 \cdot 3$ dessiatines (103.4 acres) of land, while in the mother country the average is only 4.5 dessiatines. A medium farm in Russia is estimated to contain $2 \cdot 4$ dessiatines under corn and $0 \cdot 6$ dessiatine of pasture. In Sibelia these figures are increased to $5 \cdot 4$ dessiatines under corn and $6 \cdot 1$ dessiatines of pasture. And with all this the general level of prosperity is considerably increased in Siberia.

Before leaving home the ordinary settler has on an average 239 roubles in money or other property, whereas in Siberia the corresponding property may be placed at 466 roubles. In this way the colonist in Siberia has not only covered all his expenses of moving, but has doubled the capital he brought from home. In reality the increase is more than here appears, as the settler arrives at his future home with, on an average, 161 roubles, and at the end of eleven years this is increased to 466 roubles. Every year the condition of the settlers improves, the area of sown land and pasture increases and the general prosperity grows. On the whole it appears that, when the settlers have once got over the first difficult years, they are as a rule quite well off. But of course with increased opportunities of exportation from the interior of Siberia, the conditions would be further improved in a great degree.

While Western Siberia in recent years has been more and more devoted to dairy-farming and the production of butter, the agriculture of Central Siberia 298 


\section{COLONIZA'TION AND DEVELOPMENT}

is still chiefly occupied in raising corn. In a country like the Yeniseisk province wheat, rye, oats, barley, flax, hemp, buckwheat, and potatoes are cultivated, while at the same time, of course, a good deal of hay is made. The quantity of rye and wheat sown per dessiatine $(2.7$ acres) is 14 poods (505 lb.) or less, of oats 17-20 poods (614 to $722 \mathrm{lb}$.), and of flax $5-5 \frac{1}{2}$ poods (180 to $198 \mathrm{lb}$.). The average yield of rye and wheat is 70-80 poods per dessiatine (17 to 19 bushels per acre), and of oats as much as 100 poods (38 bushels per acre). On new ground the yield is even greater. The best years for corn are the dry years, when the growth is better. In rainy years, especially on new soil, the corn is liable to become sensitive, and is often damaged by autumn frosts and covered with snow.

For the sake of comparison the following figures are given* of the average yield in Siberia as a whole, in Russia and in Norway, for the years 1906-1909, from the official reports, which have been kindly communicated to me by the Norwegian Central Statistical Bureau.

\begin{tabular}{|c|c|c|c|c|c|c|}
\hline & & & & Wheat. & Rye. & Oats. \\
\hline \multirow{2}{*}{\multicolumn{2}{|c|}{ Siberia }} & \multirow[b]{2}{*}{ - } & & $9 \cdot 0$ & $9 \cdot 5$ & $16 \cdot 6$ hectolitres per hectare \\
\hline & & & & $10 \cdot 0$ & $10 \cdot 5$ & 18.4 bushels per acre \\
\hline \multirow{2}{*}{ Russia } & & \multirow[b]{2}{*}{ - } & & $7 \cdot 0$ & $9 \cdot 1$ & $14 \cdot 6$ hectolitres per hectare \\
\hline & & & & $7 \cdot 8$ & $10 \cdot 1$ & 16.2 bushels per acre \\
\hline \multirow{2}{*}{\multicolumn{2}{|c|}{ Norway }} & \multirow[b]{2}{*}{$\cdot$} & & $22 \cdot 4$ & $24 \cdot 9$ & $35 \cdot 6$ hectolitres per hectare \\
\hline & & & $\cdot 1$ & $24 \cdot 8$ & $27 \cdot 6$ & 39.5 bushels per acre \\
\hline \multirow{2}{*}{\multicolumn{2}{|c|}{ Nordland }} & \multirow{2}{*}{ - } & $\cdot\{$ & - & $\begin{array}{l}15 \cdot 6 \\
17 \cdot 3\end{array}$ & 25.8 hectolitres per hectare \\
\hline & & & & & 173 & 28.6 bushels per acre \\
\hline
\end{tabular}

The figures given above for the province of Yeniseisk are therefore a good deal better than the average for

* It is reckoned on an average that 77 kilograms of wheat go to a hectolitre, 72 kilograms of rye, and 48 kilograms of oats. 


\section{THROUGH SIBERIA}

the whole of Siberia, and the latter again is higher than the average for Russia, but both these are strikingly below the yield in Norway, even in Nordland, the most northerly agricultural district of Norway, with the severest climate. According to the figures quoted, the land in the province of Yeniseisk yields from five to six times the quantity sown of rye, wheat, and oats. In Norway the land yielded on an average, in the years 1906-1910, 7.9 times of wheat, 11.7 times of rye, and 8 times of oats. In Nordland it yielded $4 \cdot \%$ times of rye and 6.3 times of oats. That the land in Norway yields so much more per hectare than that of either Russia or Siberia cannot be due to the soil, since this is certainly far better, for the most part in any case, in the last-named countries, but it must rather be due to higher and more developed farming; we work and manure the land comparatively well, while in Russia manure is little used, and in Siberia, as we have seen, not at all. If in spite of this the soil of Siberia yields more per hectare than that of Russia, this is due to there being still so much virgin land available.*

* The following figures from the official reports on the extreme eastern provinces of Siberia may be of interest. In the Amur District, corn is only sown in the spring; winter grain does not succeed, as the winter is too snowless and cold. It is mostly oats, wheat, and rye, as well as barley and buckwheat. The crop varies greatly; on new soil it is large; summer rye yields on an average 100 poods per dessiatine (21 hectolitres per hectare, or $23 \cdot 3$ bushels per acre), wheat from 110 to 120 poods (21.5 to 23.4 hectolitres per hectare, or 23.8 to 25.9 bushels per acre), and oats up to 150 poods per dessiatine (47 hectolitres per hectare, or 52.1 bushels per acre). On old plough-land the crops fall off more than a quarter : summer rye yields on an average 75 poods per dessiatine (15.7 hectolitres per hectare, or 17.4 bushels per acre), wheat 80 poods ( $15^{\circ} 6$ hectolitres per hectare, or $17^{\circ} \cdot 2$ bushels per acre), and oats 100 poods $\left(31^{\circ} 3\right.$ hectolitres per hectare, or $34 \cdot 7$ bushels per acre). Potatoes generally yield a good crop, averaging up to 1000 poods per dessiatine (1500 kilograms per hectare, or $12 \mathrm{cwt}$. 1 stone per acre). 300

In the Ussuri province wheat, summer rye, buckwheat, millet, peas, 


\section{COLONIZATION AND DEVELOPMENT}

After the hosts of colonists that have poured into Siberia in recent years, it was only to be expected that most of the easily accessible land favourable for agriculture should be already taken up; but if one would ask how many there is still room for in this country, it would be difficult to find an answer; for if we consider the boundless expanses that are still lying idle and how insignificant the cultivated tracts are in comparison, it is easy to see that, for the present at any rate, the resources of new land are practically inexhaustible. It is true that a large number of colonists are now obliged to seek a home away from the open and almost ready grass land, and to go into the taiga, where the work of clearing is more difficult. But the forest soil is good and fertile, and when it is once cleared, this part of the country too has a great future before it.

beans, maize, oats, barley, hemp and flax are sown; winter rye much more rarely, as there is little snow in winter and it may be easily frozen. To every dessiatine are sown about 9 poods of wheat, 8 poods of summer rye, 11 to 12 poods of oats, 9 poods of barley, etc. The following are considered good yields : of wheat, 100-120 poods per dessiatine (19.5 to 23.4 hectolitres per hectare, or $21 \cdot 6$ to 25.9 bushels per acre) ; of winter rye, 80-90 poods (17-19 hectolitres per hectare, or 18.8 to 21 bushels per acre); of oats $120-140$ poods $(37 \cdot 6$ to 44 hectolitres per hectare, or 41.7 to 48.8 bushels per acre), etc., and of potatoes, 1000-1200 poods (1500-1800 kilograms per hectare, or 12 cwt. 1 stone to 14 cwt. 4 stone per acre). A medium crop, on the other hand, is about as follows: wheat $50-60$ poods per dessiatine $(9 \cdot 8$ to $11 \cdot 7$ hectolitres per hectare, or 10.8 to 12.9 bushels per acre) ; winter rye 50 poods $(10.5$ hectolitres per hectare, or 11.6 bushels per acre); oats $65-75$ poods (17 to $23 \cdot 4$ hectolitres per hectare, or $18 \cdot 8$ to $25 \cdot 9$ bushels per acre), and potatoes 500-700 poods per dessiatine (750-1050 kilograms per hectare, or 6 cwt. to 8 cwt. 2 stone per acre).

It may further be mentioned that in Tomsk, which is considered the most fertile district in Siberia, the most important crop is summer wheat. From 6 to 8 poods are sown per dessiatine; the yield is large, averaging over $70-80$ poods per dessiatine $\left(13 \cdot 6\right.$ to $15^{\cdot} 6$ hectolitres per hectare, or 15 to 17.3 bushels per acre), and in some years it may be as much as 150 poods or more per dessiatine (29 hectolitres per hectare, or $32 \cdot 1$ bushels per acre). 


\section{THROUGH SIBERIA}

How many millions of people a well-cultivated Siberia would be able to hold it is impossible to estimate, but certainly a great many.

In the last few years an increase has been noticed in the immigration to the eastern districts, to the provinces of Yeniseisk and Irkutsk, and to Turkestan. At the same time there has been a decrease of immigration to Western Siberia and to the steppe country, which already have a fairly large population, and where most of the good land is already occupied. But with a higher farming than that hitherto practised in Siberia there is no doubt that even these countries will be able to support a population many times greater than the present.

As I have said, the Russian nation has a great task to perform in conquering these vast areas of our earth's surface for itself and for mankind. But there may be two sides to the significance of the colonization of new countries to a nation's future. One is the increase in external power through greater expansion, and with this the increase in prosperity. But the other side is the internal weakening that it may lead to, through the nation being drained of its best powers to the advantage of the new countries. In a small country like Norway, where we have had far too much emigration for many years, we are not slow to see the harmful internal effects of this on the nation. But these are less noticeable in a great nation like the Russian, and it may be that here the case will prove entirely different. True, the lesson of history, ever since the times of the Greeks and Romans, has been that it is a somewhat doubtful advantage to a nation in the long run to have great and extensive colonies. After a time the increase of power and the enhancement of prosperity-leading, perhaps, to excessive affluence-do not compensate for 302 


\section{COLONIZATION AND DEVELOPMIENT}

the decline which results from the comparatively favourable conditions of life in the colonies enticing away many of the more efficient elements in the nation, while the less efficient remain at home and continue the race, the quality of which is thus gradually deteriorated. This was in any case one of the causes of the decline and fall of the mighty Roman Empire; and we may well suppose nations like the Spanish and Portuguese to have been enfeebled in a similar way by their great oversea colonies. That the colonies have not been altogether an advantage to the British nation in this respect, owing to the constant drain of valuable forces, is also quite possible. But that anything similar should be the case with the Russian nation is more doubtful. In the first place its population is so vastly greater; and in the second, it is doubtful whether it is precisely the best elements that have hitherto emigrated to Siberia. But another consideration, perhaps of still greater importance, is that the greater part of Siberia cannot be regarded as a new country, but rather as an eastern extension of Russia itself ; it is not a colony, but a greater fatherland, which still has room for many millions of the Slav people on its boundless plains. 


\section{CHAPTER XIV}

\section{IRKUTSK TO VLADIVOSTÓK}

Irkutsk : Baikál : The line to the south of Baikál : The mountains : No Ice Age : The nature and fauna of Lake Baikál : Transbaikalia, its formation and climate : Petrôvsk iron-works and political exiles : Over the Yáblonovi Mountains, the watershed between the Arctic and Pacific Oceans : Chitá : Mr. Wourtzel at work : In the Celestial Empire : The Khulunbuir plateau : Great Khingán : Chinese : Barim : Along the northern border of Eastern Gobi : Russian hospitality : Over the East Manchurian mountains : Chinese settlements : Forest fires : Illicit opium growing : The Khunkhus robber bands : A train of returning colonists

$\mathbf{A}^{\mathrm{T}}$ ten in the morning, the day after leaving there was a great and distinguished reception at the railway station; we were met by the presidents of the Bourse, the Chamber of Commerce, the Geographical Society, representatives of the Governor-General, and many others. There was the same lively interest in the prospect of regular communication by way of the Arctic Ocean and the Yenisei estuary, and the same hopes of a new development of this route. For Irkutsk and the whole surrounding district, including the Baikál region, would also benefit. Goods can be carried from far up the rivers which flow into this lake - the great Selengá, for instance-across the lake and down the Angará, all the way to the mouth of the Yenisei. There are certainly some rapids in the Angará, but they are not so bad as to be impassable for lighters 304 


\section{IRKUTSK TO VLADIVOSTOK}

and rafts in their present state, and plans are on foot to construct locks at some of the worst. Their construction is assured, if this regular trade route through the Kara Sea becomes an accomplished fact, as is hoped. Unfortunately we had no time to stop here and see the town, which lies on the other side of the river. We only saw it in the distance, with its churches, the palace of the Governor-General and other large buildings, * as we went up the Angará, and crossed this river higher up. In contrast to the Yenisei and the other rivers we had hitherto seen in Siberia, the waters of the Angará are remarkably clear, so that one can see the bottom at a depth of many fathoms. This is of course owing to its feeders running through mountainous country, and to its flowing out of the great mountain lake, Baikál, the deepest lake in the world, where the water has plenty of time to clear.

Then at last we reached this, the Holy Lake, to which we had looked forward with such great expectations. It is called by the Mongolians Bai-kul, the rich lake, or Dalai-Nor, the holy lake. $\dagger$ One had heard much of its natural beauty; but there was a thick mist, so for the time being we saw nothing of our surroundings. At Baikál, the first station we came to, there was a harbour for the great ice-breaker and ferry, the Baikál, which formerly carried the trains across the lake to the railway line on the other side, and was said to be able to go through ice four feet thick. She is one of the largest ice-breakers in the world, and her hull is built very like the Fram's fore and aft. But she could not manage the ice in winter. For repairing this icebreaker and other vessels on the lake, a large floating

* Irkutsk has about 130,000 inhabitants.

$\dagger$ According to another account the Mongolians and Buriats call the lake Bai-gal, which is said to mean the abode of fire. 


\section{THROUGH SIBERIA}

dock has been constructed, which we also saw in the harbour. It was this traffic across the lake which was a source of so much difficulty during the war with Japan, when large bodies of troops were constantly being sent to the East. In winter rails were laid on the actual ice of the lake. The former Traffic Minister, Prince Khilkov, himself directed the work. The railway carriages were drawn across one by one by horses, and the locomotives had to be taken across in pieces, as otherwise they would have been too heavy for the ice.

Since that time the line round the south of Lake Baikál has been completed; it was a great piece of engineering and there were many difficulties to be overcome along the steep mountain sides. From Baikál station on the western shore to Mysováya station on the eastern, the line is 151 miles long. Along its first part, to Kultúk station at the south-western end of the lake, the shore is particularly steep, and on this piece, the length of which is fifty miles, the line runs for four miles through tunnels. On the other side of the lake a great deal of the land was marshy, which made it necessary to build a great number of bridges, 189 smaller and thirtyfive larger bridges. The line was a very expensive one to build; it cost 219,717 roubles per kilometre (£37,304 per mile).* But then the line was only a single one, and the experience of the war had shown the necessity of a double track. This led to an entire reconstruction, which is now in progress and will soon be completed.

On this line we are now travelling along the southern shore of Baikál. Gradually the mist disperses sufficiently

* For the sake of comparison it may be mentioned that the most costly line in Norway, the Ofot line, which runs through difficult mountainous country with steep gradients, cost 250,888 kroner per kilometre ( $\{22,296$ per mile), and the Bergen line, which runs over the mountains to the west coast and has long tunnels, cost 135,461 kroner per kilometre ( $£ 12,022$ per mile).

306 


\section{IRKUTSK TO VLADIVOSTOK}

to enable us to look up the nearest mountains. They are not high here, but fall abruptly to the lake, and the line constantly runs through tunnels. As the day goes on the weather clears more and more and we see the mountains on the southern shore. They are higher, with valleys between. There is fresh snow on the mountains ; they are wooded right up to the top, with only al ittle bare rock here and there, and there are no real snow-slopes to be seen.

The mountains do not appear very high, nor do they as a rule attain a greater height than 6000 feet above the sea, or some 4500 feet above Lake Baikál. Khamar-daban on the south-western shore, in the direction of the Selengá, is $\mathbf{7 4 0 0}$ feet above the sea, or 5900 feet above the surface of the lake; that is, nearly 1000 feet more than the depth of the latter. Otherwise the mountains seldom rise higher above the lake than the bottom of the latter descends below the water. The outlines of the mountains are broad and even, not cut up as Alpine scenery usually is, and it is rare to see a tendency to any form of peaks. Along the south side of the lake we pass valley after valley full of dark, solemn spruce forest, stretching up between the mountains, just like secluded forest valleys at home in Norway. It is fine country, but cold, they say, except on the other side of the lake, where the sun has great power. Here, on this side, part of the soil is perpetually frozen, and the trees grow above the frozen layers. The lake is usually frozen over with firm ice in the middle of December or beginning of January, and the ice then lasts as a rule for four or four and a half months. They drive over the lake with sledges for three months of the year.

Curiously enough, even here in this cold country the forms of the mountains do not indicate that they 


\section{THROUGH SIBERIA}

have ever been worn away by ice; I was unable to discover in passing any certain signs of an Ice Age. On the slopes along the south-western side of the lake, high rocks, jagged points and knolls were often to be seen. This seems to point to severe erosion, produced especially by frost, and by the great differences of temperature in this part. In any case it seems impossible that a mountain of this appearance can have been abraded by ice in any recent geological period. But it certainly cannot be for want of low temperature that they have had no Ice Age here. Even now, the mean annual temperature on Lake Baikál is below freezing-point, or about $30^{\circ} \mathrm{F}$. Mr. Wourtzel told me that when constructing the railway here on the south side of Baikál they encountered difficulties owing to the soil in some places being perpetually frozen.

Here we saw the immense labour involved in doubling such a line as this. All the tunnels had to be widened, besides the whole permanent way; new supporting walls of ferro-concrete had often to be built up from the very edge of the lake; in many places where the curves were too sharp for high speeds, new tunnels had to be bored through the rock, and where bridges occurred, a new one was generally built by the side of the old, to carry the new line.

The whole time we had this mighty mountain lake beside us. Its area is 13,197 square miles. It is the third largest fresh-water lake in the old world, Victoria Nyanza and Tanganyika being larger. But it is the deepest lake in the world; in fact, the deepest depression that exists on any of the earth's continents. Its depth is 4992 feet. It is deeper than even the Sognefjord in Norway, which is 4133 feet deep; and as the surface of Baikál lies $\mathbf{1 5 1 5}$ feet above the sea, its bottom thus reaches a depth of $\mathbf{3 4 7 7}$ feet below sea level. 308 


\section{IRKUTSK TO VLADIVOSTOK}

The lake is also remarkable for its long, rather curved shape, like a crescent. It stretches in approximately the same direction, and to some extent with the same curve, as the great mountain-chains farther east, such as the Yáblonovi, the Great Khingán, the ranges of Eastern Manchuria, the Sikhota-Alin, and indeed, the Japanese chain running through the islands of Japan and Sakhalin. Baikál must be regarded as having been formed by a subsidence of the earth's crust. This subsidence must be supposed to have taken place gradually in the course of ages by dislocations similar to those which are always connected with earthquakes; and even now the surroundings of the lake do not appear to have come to rest, as slight earthquakes and disturbances are of frequent occurrence in its neighbourhood. The subsidence must in any case be partly very ancient, but it has certainly been continued to recent times. The mountains round the lake consist in part of eruptive rocks of various age, syenites, porphyries, etc., and in some places, basalts. Then there are crystalline schists and gneisses, besides sedimentary rocks of Silurian, Devonian, Jurassic, and also Tertiary age.

At the place where the great River Selenga falls into the lake, a submerged ridge, which no doubt must have been formed in the course of ages by the river mud, runs right across it. The Selengá has also formed a large delta far out. By this submerged ridge the lake is divided into two great basins, the larger and deeper of which is the great north-eastern part, the smaller the south-western, which is also deep and goes down to 4746 feet, while the depth over the ridge itself is only 1745 feet. The valley through which the Angara flows out of Baikál does not form any natural continuation of the depression of the lake, and the river channel 


\section{THROUGH SIBERIA}

must have been formed by the water which filled this huge subsidence in the earth's crust having begun to run out of it where the edge was lowest, the running water having thus in course of time dug its channel deeper and deeper. When one sees the outlet of the Angará from the opposite side of the lake, it looks something like a notch cut in the mountain ridge.

The lake has a peculiar fauna. On the islands there are quantities of gulls and herons, and even cormorants (phalocrocorax carbo). It also has its own species of seal (phoca baicalensis), which must originally be the ringed seal ( $p h o c a$ hispida), that has come from the Arctic Ocean up the Yenisei and Angará to the lake, where in course of time it has become modified and has formed a new species. The Buriats, whose name for it is "nyerpa," catch much of it, chiefly on the ice in spring, when they steal upon it behind a sail set on a little sledge. This is, curiously enough, very nearly the same method which is employed by the Eskimo for catching the ringed seal when it is lying on the ice in the Greenland fjords. There is abundance of fish in Baikál and in the rivers that run into it. Sturgeon is caught in the lake and in the rivers, chiefly the Selengá. Several fish of the salmon family are also caught. The most important of these are omul and grayling (thymallus Pallasii, Valenc.), or in Russian khârius, which seems to be the same as the Norwegian name for grayling, harr (khar being equivalent to harr). It may seem surprising that the lake should be so rich in fish, as it is famous for its unusually clear water, and this does not indicate any abundant plankton life in it. A curious form, which is peculiar to Baikál, is the deep-water fish golomyanka (comephorus baicalensis), about $10 \frac{1}{2}$ inches long, which is only found in the deepest parts of the lake, over 2000 feet. The 310 


\section{IRKUTSK TO VLADIVOSTOK}

crustaceans of the lake, which have been collected by the Russian expeditions, have been described by Professor Ossian Sars. They are remarkable for showing, contrary to what is usually the case in lakes, a great wealth of species, which are peculiar to Baikál; in fact there are even entirely peculiar genera; many curious amphipods in particular are found there. These many forms must have been evolved in the lake itself, and this shows, amongst other things, that the lake must be very ancient ; for the development of so many local species, and indeed so many entirely new genera, of crustaceans, besides species of fish and mammals, must have taken a long time.

The shores of the lake, which for the most part rise fairly steeply from the water, are little inhabited by men. Permanent settlements on any large scale are only found at the mouth of the Selengá, on the great delta formed by that river. Then there are some dwellings on the shore immediately opposite and on the island of Olkhón, besides a few at the south-western extremity at Kultúk. Round about the lake are many places which the natives regard with much superstition and which are objects of their worship. This has doubtless given rise to their designation of the lake as holy.

We rushed on all day along the shore of this huge lake, through tunnels and cuttings, round promontories and past valleys, with constantly changing and beautiful scenery. But all of a sudden we came upon great stretches of burnt forest, which always makes the same hopeless impression with its black stems, bare and scorched. But what does it matter here? The forest still has no value. For the most part it seemed here to consist of the usual Siberian spruce and silver fir; besides these there are Siberian cedar, fir and 


\section{THROUGH SIBERIA}

birch, and along the rivers balsam, poplar, alder, etc. Among the bushes are wild raspberry and wild currant. There is a rich and varied flora in these regions.

But it was now getting on towards evening, and we came into Mysováya station on the south-eastern shore, immediately opposite Baikál station; here it was that after our long and pleasant companionship I was to separate from my two fellow travellers, Vostrotin and Loris-Melikov, who were going back by the ferry to take the train to Irkutsk and on to Krasnoyarsk. And as from our windows we had a last glimpse of them going down to the quay in the fading daylight, Wourtzel and I went on our way to the east. The railway still follows the shore of Baikál for a short distance, until it reaches the delta of the Selengá, after which it runs up the valley by the side of this great river.

We had now reached Transbaikalia, which is looked upon as the most beautiful province in Siberia, with its mountains and valleys, its great rivers among the mountains and its forests everywhere. It lies between Lake Baikál on the west and the Amúr District and Manchuria on the east; on the south it has Mongolia. It is a country rich in gold and other metals, and in minerals and precious stones, but it is little developed. It appears also to possess numerous and valuable mineral springs. It was long one of the most dreaded places of banishment in Siberia, and many an exile has dragged out his days in its mines. The country is thinly populated by native tribes, the most numerous being the Mongolian Buriats, and on the north there are some Tunguses. On account of the bad name the province has acquired as a place of exile, it has been very difficult to get it colonized by Russians. Its area is 236,711 square miles, and in 1911 it had a population of about 869,000 , of 312 


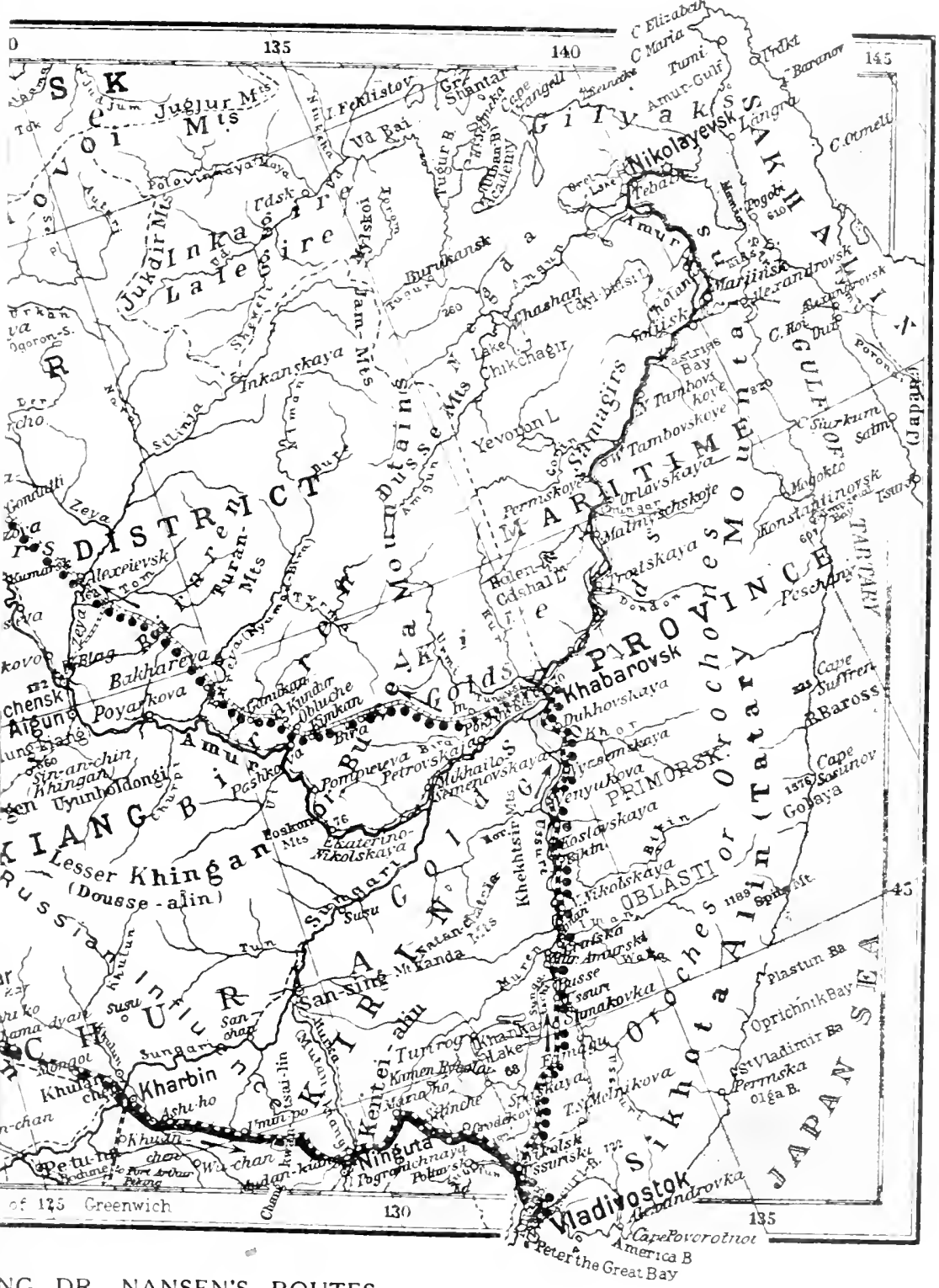

NG DR. NANSEN'S ROUTES. 


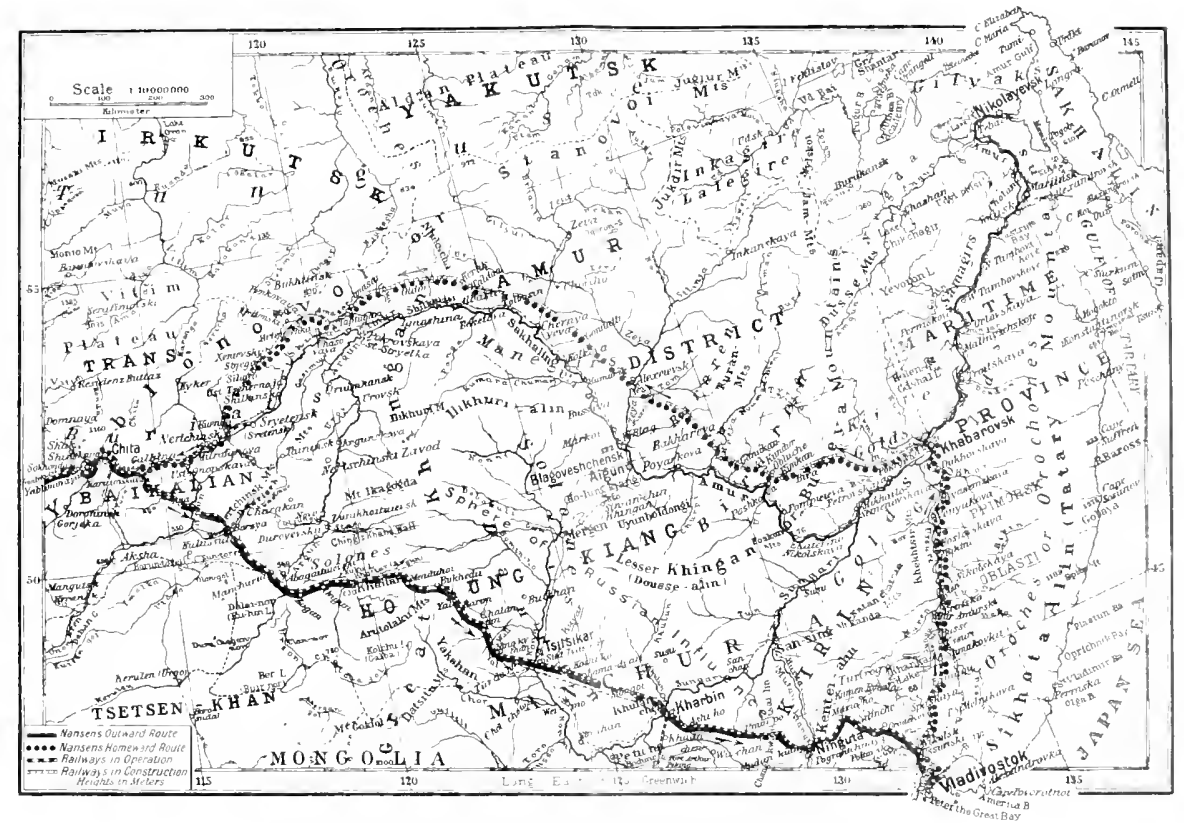

MAP OF EASTERN SIBERIA SHOWING DR NANSEN'S ROUTES 


\section{IRKUTSK TO VLADIVOSTOK}

whom 591,000 were Russians. There is a large number of Chinese, including all the workers in the gold-mines.

Over the greater part of Transbaikalia the soil is perpetually frozen. Another characteristic feature is that on account of the slight covering of snow in winter, many rivers and lakes often freeze to the bottom. The mean temperature for the year is between $-1^{\circ}$ and $-4^{\circ}$ C. $\left(30.2^{\circ}\right.$ and $24.8^{\circ} \mathrm{F}$. $)$; the winter is cold, the mean temperature in January being between $-20^{\circ}$ and $-28^{\circ}$ C. $\left(-4^{\circ}\right.$ and $-18 \cdot 4^{\circ}$ F. $)$; but on the other hand the summer is very warm, the mean temperature for July being between $15^{\circ}$ and $20^{\circ} \mathrm{C}$. $\left(59^{\circ}\right.$ and $68^{\circ} \mathrm{F}$.), and as this is the most important point for cultivation, the conditions for agriculture and cattle-raising are quite favourable in many places, in spite of the frozen soil. True, there is little precipitation ( $7 \cdot 8$ to 11.7 inches), but most of it occurs in the summer months. The soil in many places is very good, especially where there is what is called forest-steppe (i.e., forest alternating with pasture) with black earth.

As we travelled up the valley it became quite dark, and we could see nothing of our surroundings. After leaving the Selengá at the town of Verkhne-Udinsk, from which there is a connexion with the caravan road southward to Mongolia and China, the railway follows a tributary, the Udá, for a while, and then commences the ascent of the slopes of the Yáblonovi Mountains (i.e. apple mountains; the same range is also called the Stanovoi).

Wednesday, October 1. During the night we passed the Petróvsk iron works, which belong to the Imperial Cabinet, and in which many prisoners have had hard times. It was to this place that a number of the participants in the military revolt of December 14, 1825, on the accession of the Emperor Nicholas I (the 


\section{THROUGH SIBERIA}

" Decembrists"), were exiled and put to hard labour with pitiless severity. At first they were banished to Chitá, then here. By the special favour of the Emperor the wives of the exiles were permitted to follow them from Chitá. Among them were Princess Trubetskói and Princess Volkónsky, and many other ladies of high position, who lived here for many years in their private houses, while their husbands were kept in the prisons and served in the iron works.

From Petróvsk the line follows the valley along the River Khilók, a tributary of the Selengá, and we approach the highest ridge of the Yáblonovi Mountains. There is hardly anything but firs here, a sign of thin sandy soil. No large trees are to be seen, nor do they stand close. On account of the frozen soil below, all the roots, even those of the fir, grow horizontally over the surface. The trees thus offer little resistance to the wind, and being at the same time scattered, great numbers of them are laid low, and their roots stretch up into the air almost as high as the trees themselves. There is little precipitation, and the soil is dry, with only a thin layer of mould above the stony ground. When we consider the frozen subsoil, it will be understood that this district does not offer very favourable conditions for agriculture ; nor, in fact, is there any sign of settlement; even the natives cannot succeed here. The landscape we are going through offers little variety; the mountains consist of low, rolling and uniform ridges, clad with the same thin forest of small trees.

Between Sakhandó and Yáblonovaya stations the railway crosses a depression in the highest ridge of the Yáblonovi Mountains, $\mathbf{3 5 7 5}$ feet above the sea, or about 2000 feet above Lake Baikál, and this is the highest point on the whole Siberian and Transbaikalian railway. We are here on the watershed between the River 314 

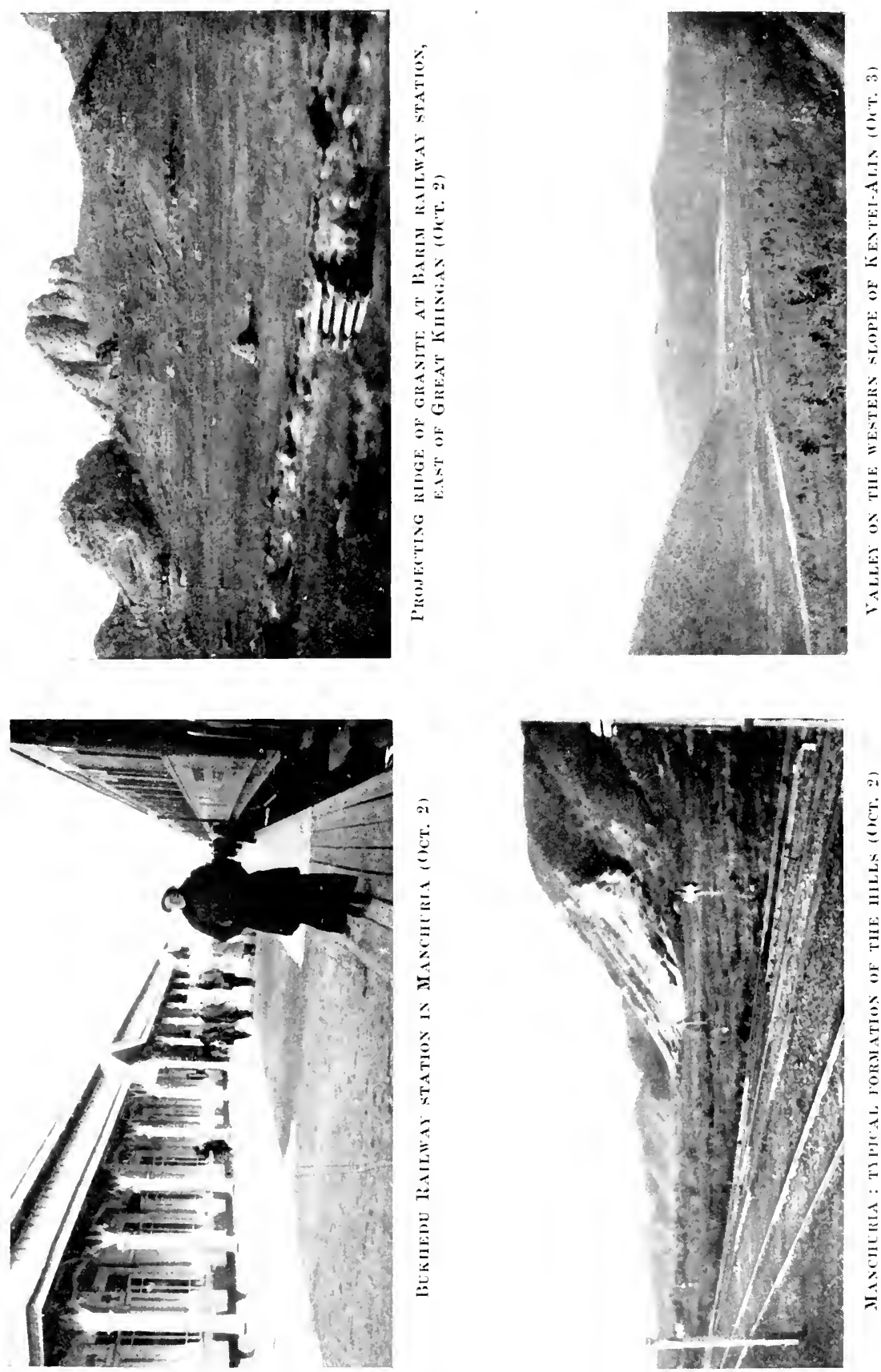

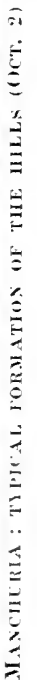




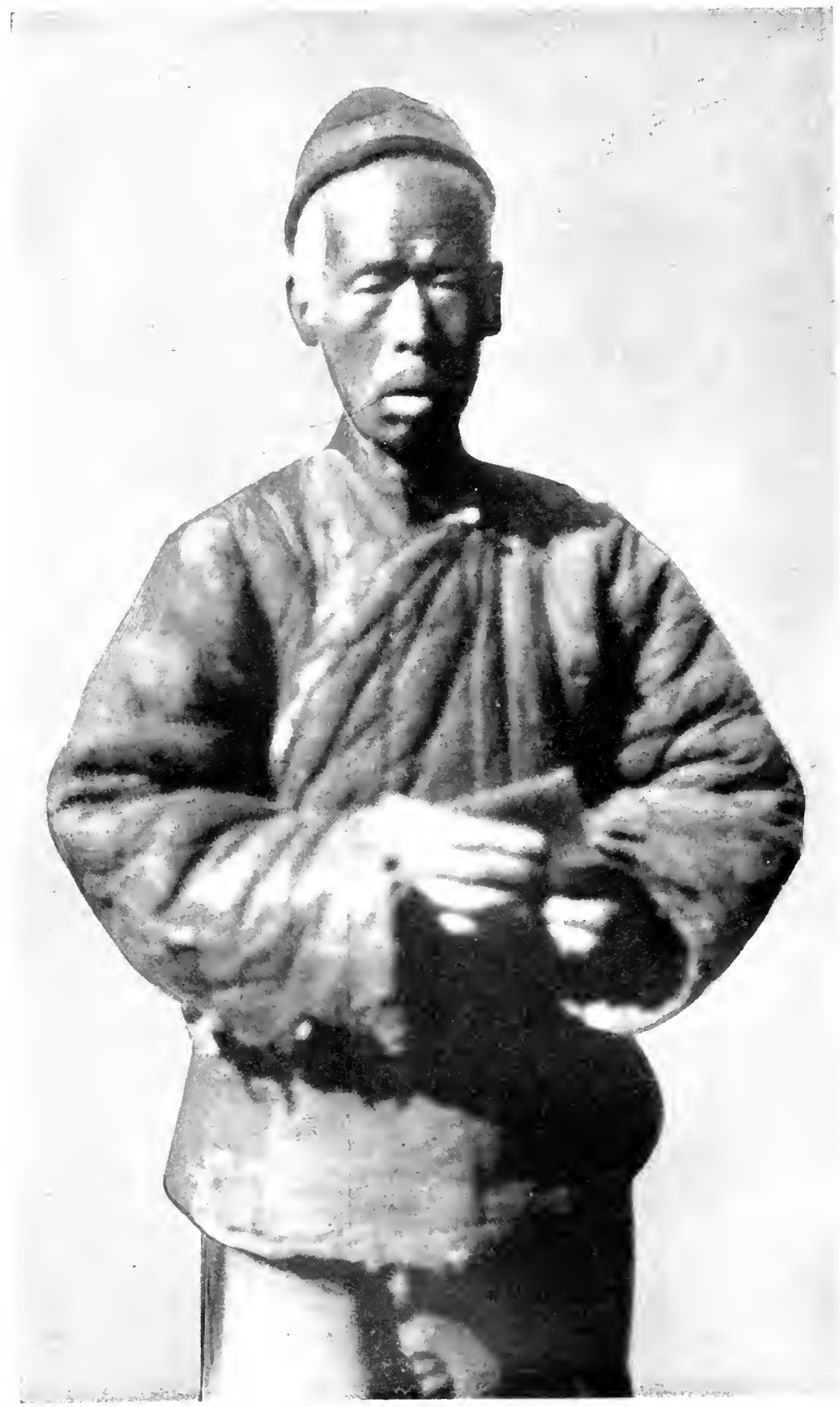

Chinamax at a Raliway -tation (1) 


\section{IRKUTSK TO VLADIVOSTOK}

Khilók, which flows into the Selengá and then into Lake Baikál, being continued by the Angará and Yenisei, on one side, and on the other the River Ingodá, which runs into the Amúr. Just to the north of us, and within sight, rise the sources of the Vitim, which flows into the Lena. This is thus the watershed between the Yenisei and the Lena on one side and the Amúr on the other; that is, between the Arctic Ocean and the Pacific.

On the other side of the watershed the line descends rapidly. The low ridges are everywhere covered with thin forest. Farther down there are stretches of pasture here and there, but still no settlements to be seen. But beyond Yáblonovaya station we began to see a few cornfields among the pastures. The country is here wide and undulating. Then we arrived at the town of Chitá, which stands in the middle of an extensive grass country, and we saw ploughed fields and green patches of cultivation here and there. This is the most important town in these parts and the capital of Transbaikalia. At the beginning of last century it was a Cossack post with a couple of hundred inhabitants; but the little village was entirely transformed when the Decembrists were sent here in $\mathbf{1 8 2 5}$ and had to build their own prisons, while their wives built their own houses in the "Dámskaya," or "Ladies' Street," which has kept its name to this day. According to the census at the close of the nineties, the town had about 11,500 inhabitants, but it has grown enormously in the last few years, especially since the war, and I was told that the population is now 70,000 or 80,000 . The town is well situated on the plain, where the little tributary Chita falls into the River Ingodá. The latter joins the Onón to form the River Shílka, which again joins the Argún to form the Amúr. Small steamers can reach 


\section{THROUGH SIBERIA}

Chitá from the Amúr when the water is high, and rafts can descend the river, so that there is a connexion with the Pacific by way of the mighty Amúr.

We followed the course of the Ingodá for some distance. Here again it struck me that the right bank of the river, in part at any rate, has higher ridges and steeper slopes than the left. There is some cultivation in places, but it seems to be little compared with what might be done.

After passing Karimskaya station, about sixty miles east of Chitá, the line divides into two branches; one goes on to the eastward along the river to the Amúr line which is now being laid, and to Sryétensk on the Shílka (connecting with the steamers down the Amúr), while the other branch, which we followed, crosses the Ingodá by an iron bridge and goes to the south-east into Manchuria, forming the Eastern Chinese line. Beyond the Ingodá the line rises sharply to the watershed between that river and the Agá, which falls into the Onón. The gradient is here 16 feet in 1000, which is twice as steep as any other on the Siberian railway. We therefore had to have an auxiliary engine to take us up to the top, and the speed was slow. There were fir-trees everywhere, except where birches had taken their place; but signs of forest-fires were to be seen on every hand. The stumps were left, black and sometimes broken off, and the birch had been the first to grow again. In spring and early summer it is very dry here, so that a forest-fire easily spreads; when once it begins, it may burn for weeks in these parts. But this is of no great consequence, as even here timber is of no value, except as fuel on the railway, but for that birch-wood is chiefly used.

Mr. Wourtzel worked without stopping the whole way. At the stations his engineers appeared and 316 


\section{IRKUTSK TO VLADIVOSTOK}

travelled on in our carriage, delivering their reports of the work on sections of the line, while Wourtzel dictated telegrams and letters. At Chitá we were joined by two engineers who were in charge of the western section of the Amúr line, and as usual there was also a secretary with a typewriter. The work done was discussed, plans for future work were made, budgets were drawn up and new proposals written out. Of course I could not make out a word of all this Russian; the only things I caught were the amounts, and I never heard less sums mentioned than so many million roubles as being still required. Where we in Norway should round off our figures into so many thousands, here they round them off into millions. And the secretary had his work to do ; the typewriter clicked day and night. Then, as fast as the things were written, they went into an envelope and off by post to Petersburg.

When Wourtzel was not at work on his budgets and plans, he was sitting at the window, studying the road-bed and the gradients and curves and supporting walls. No error, however small, escaped his practised eye and was not instantly called attention to. But now he was free in this respect, as we had entered on the Eastern Chinese system, where the work is not under his direction. There is not, however, another man in the whole world who has the direct control of anything approaching the immense extent of railway construction that is in his charge. He once told me how many thousand kilometres it was, but my memory fails me and I will not venture to repeat the figure; it was a large one, in any case, as it is bound to be, seeing that it includes all the railways that are being made throughout the Russian Empire. 


\section{THROUGH SIBERIA}

\section{MANCHURIA}

Thursday, October 2. So now we are in China, the Celestial Empire-we crossed the frontier last night -but it certainly does not look very celestial here. A strange impression I had on opening the window this morning. Brown, rolling plains of grass, with low, bare heights surrounding them. If it were not for the grass this might well be the desert of Gobi. No sign of human habitation to be seen in any quarter, not a tree, not a bush, nothing but dry, brown grass. Just the same, horizon after horizon. Then we come to a river winding through the plain; this is the Khailár. There are some bushes and scrub along its banks, and here and there a solitary birch-tree. But still not a hut, not a human being. Desolate land - not even a trace of man's activity, except this line of railway traversing the brown carpet. The river runs in the opposite direction to that in which we are going; it flows into the Argún, and then into the Amúr.

We are here on the Khulunbuir plateau, about 2000 feet above the sea. It is a continuation of the Mongolian plateau with the wide steppes on the south and west, and it extends far to the northward and into Transbaikalia. One might be in doubt whether we are in Mongolia or Manchuria, as the country agrees rather with one's ideas of the former; but politically we are within the Manchurian frontier. I thought the soil must be parched here, as these ridges have no trees, and we are not very far from Gobi-these steppes are to be regarded as a continuation of it; but then there is water enough in the river, besides swamps and stagnant ponds over the plain. What can be the reason? Is it dried up at certain seasons of the year? Not far to the 318 


\section{IRKUTSK TO VLADIVOSTOK}

south the soil is fairly saline, and there is saline and brackish water in the lakes. At last we came to some low houses, but they were only for railway men. They were built of stone, as of course there is no timber for building. Here and there rocks projected through the dry, brown carpet of grass on the slopes of the ridges round about ; but for the most part the rock was covered with deep, loose layers of weathered débris. In this climate, with its great differences of temperature and its cold winter, weathering seems to proceed rapidly; but on account of the slight precipitation and the flatness of the country, not much material is carried away.

Farther east there was a little birch forest on the heights here and there, but it was remarkably thin, only a tree now and then, and the trees were small. At some of the stations there were great stacks of birch-logs. The engines burn chiefly wood; some coal has certainly been found in these parts, but it is of poor quality. Once more the same interminable grass country. We are slowly mounting the western slope of the Great Khingán range.

The widely extended, but low mountain masses of Great Khingán rise slowly from the Mongolian and Khulunbuir plateau, at a height of about 2000 feet, on the west, and from the lower plain on the east, which is continuous with Eastern Gobi, and has an altitude at Tsitsikar of about 500 feet. The mountains, so far as they are known, do not reach a greater height than between 3500 and 4000 feet, and there are no snow mountains among them. The slopes are everywhere long and gradual with low, undulating ridges, and even the summits have rolling lines and do not rise high above the flat floors of the valleys. 


\section{THROUGH SIBERIA}

Here and there we see a few haystacks on the level ground between the mountains; so there is some sign of men. In many places the soil looks black and rich; it must be good mould, and it is deep too, often several feet, as one can see in the cuttings along the line. It looks as if only waiting for the plough; but there are no men. It is a severe climate, though, here in northern Manchuria. 'The mean temperature for the year is below $-2^{\circ} \mathrm{C}$. $\left(28 \cdot 4^{\circ} \mathrm{F}\right.$.), and in winter it is liable to go down below $-50^{\circ} \mathrm{C} .\left(-58^{\circ} \mathrm{F}\right.$.). The mean temperature for January is about $-26^{\circ} \mathrm{C} .\left(-14 \cdot 8^{\circ} \mathrm{F}\right.$.). But then the summer is warm ; the mean temperature for July is over $20^{\circ} \mathrm{C}$. $\left(68^{\circ} \mathrm{F}\right.$.), and that is of course what matters most to agriculture. And then there is this advantage that, even if precipitation is slight, most of it occurs in summer, on account of the southerly and south-easterly winds that are then prevalent. The rainy season usually begins in July. On the other hand, there is little snow in winter, when the winds are mostly northerly and north-westerly. The time will surely come when this great expanse of steppes will be cultivated and inhabited; but it does one good to see such wealth of land; there is still room enough and to spare for men on this little earth of ours.

At the stations here I met the first Chinese. They all wore pigtails and looked splendid; big, stout, powerful frames, with a healthy, contented expression of face. One involuntarily felt oneself to be in the presence of a race that still has a future before it. It was curious, however, to see what great differences there were among these Chinese types; some of the faces were long and narrow, but most were broader and rounder. They must be a very mixed race.

That it really is arid here on this prairie and on these bare hills, and that this is the reason of the lack 320 


\section{IRKUTSK TO VLADIVOSTOK}

of trees, in spite of the river and the pools of water that I saw, seems evident from the fact that in a few places some stunted birches grow up the sides of the valleys, only along the streams. If the soil were not arid, these birches would be able to grow in other places as well.

Then we slowly climb higher, towards the crest of the Great Khingán. Here the birches stand rather closer together, but they are small, with only a few larger trees here and there; and the forest is still remarkably thin, with a couple of yards between the trees or bushes, and no undergrowth, only bare, grassclad ground. There is no other tree to be seen than birch; I only saw one solitary little larch, perhaps three feet high, in a ditch near the line. Then we entered the tunnel, three kilometres long, under the crest of the Great Khingán. Coming out on the other side, one was struck by the sudden change in the scenery. The mountain slopes more steeply, with well-developed valleys, and the birch forest is now mixed with bushes of dwarf oak, which form thickets and covers the whole mountain-side. Here and there are solitary higher oak trees, the sessile-cupped oak. Farther down I saw many stumps among the thin birch forest; they must have been the stumps of conifers, but they were black and burnt. So here again there were formerly great pine forests which have been burnt.

The difficulty of the steep descent from the Great Khingán has been got over by a fine piece of engineering. The line makes a great loop down in the valley, returning and passing below itself. As we went on to the eastward, the country was the same brown, desolate prairie that we had had to the west of the Great Khingán, although at the next station we already came upon a few green, cultivated fields; but these of course belonged to Chinese, who are the most efficient agri- 


\section{THROUGH SIBERIA}

culturists. Here was a typical Chinese village, with its houses crowded close together and a lofty fence all round, to shut them all well in and keep all the filth among the houses. Close by lay a Russian village, which was the opposite of crowded; it seemed rather to be trying to spread itself as much as possible over the plain. And why not?-there is room enough here. Russian officers and soldiers were about; this is a Russian military station, one of many along this line, their object being to protect the railway from interference and to secure communication with the Russian East.

Farther on it was the same bare prairie, with thin, low forest along the ridges, mostly birch and oak, and long stretches without a sign of habitation; but here and there we saw a few cows and ponies, and even a flock of sheep. Here again the hills are low and undulating and uniform, and there is little variety in the landscape. It is curious how little rock is visible, although the slopes may often be steep enough. As a rule everything is covered with a layer of loose débris, often containing large loose stones. This is not unlike a glacier-till, but it is formed by the severe weathering of the rock, which has transformed part of it into fine gravel and sand, while other parts have been left in the form of large stones. When one comes upon the rock itself, as shown in some of the railway cuttings, one can see that it is quite worn on the top, and large stones stick up among the gravel; there is no distinct line of division between the rock and the loose material above it. The gravel is usually covered by a thick layer of mould.

At Barim station, the second at which we stopped on the eastern side of the Great Khingán, high crests and rocks of granite projected above the ridge over the 322 


\section{IRKUTSK TO VLADIVOSTOK}

valley, and there were quantities of large fallen rocks scattered over the slopes. These jagged crests of harder rock are left standing like ancient ruins and, as has been said before, they afford a good standard of the severe weathering of all the looser surrounding soil. They show that here again there cannot have been any Ice Age with a sheath of glaciers for long geological periods.

At Barim there is another Russian military post, with long, low houses for the officers and soldiers. All day we travelled through the same desolate landscape with the same brown prairies sparsely covered with small trees and bushes, and the bare brown heights beyond. There were still few signs of habitation besides the scattered houses along the line which have been built for the railwaymen. The extent of these deserted steppes is immense, hundreds of miles on every side, beyond the Great Khingán and far into Mongolia on the west. As the Khingán Mountains gradually disappear on the west against the glowing sunset, the heights around us become lower and lower, and we shall soon be on the perfectly flat plain which extends far to the eastward, to beyond Kharbin. We are near the northern boundary of the Eastern desert of Gobi, and are travelling along the frontier of Mongolia.

The plan was that Mr. Wourtzel should go straight on to Khabaróvsk and stay there a few days to confer with the Governor-General, before resuming our journey through the Amúr district. He proposed therefore that I should go and see Vladivostók in the meantime, which I was very glad to do. But as I knew no Russian, he had telegraphed to the direction of the Eastern Chinese line at Kharbin, asking whether they could not provide somebody who spoke German or English, to accompany me to Vladivostók. 


\section{THROUGH SIBERIA}

Friday, October 3. At 2 A.M. we at last arrived at Kharbin, three hours late. The Russian General, who is at the head of the Eastern Chinese line, had been at the station to receive us, but as he could not wait all night in uncertainty, we now found as his representative Baron Harald von Hoiningen Huene. He came from Esthonia, spoke German as his mother tongue, and said he had been sent to accompany me to Vladivostók and to stay with me as long as I might wish. He had just come back, two days before, from a long stay in Europe, when the General asked him on the telephone if he would make this trip with me, and he was ready at once. There we see Russian hospitality! A better and more entertaining travelling companion I could not have had.

There was something or other wrong with the axles of our carriage, and on the suggestion of the chief guard it was decided to leave it here for repairs. Mr. Wourtzel intended to take two ordinary compartments for us for the rest of the journey; but the railway authorities immediately had another whole carriage coupled to the train and placed at our disposal for as long as we wanted it. I must say, one is splendidly treated in this country.

We now heard that the Governor-General had gone from Khabaróvsk to Vladivostók, and as it was he whom Wourtzel had to see, the latter decided to go on with us to Vladivostók, and we travelled together in our new carriage.

When I woke and looked out of the window in the morning we were in a mountain valley with ragged, uneven rocks running up the sides and quantities of large stones strewed over the slopes and on the floor of the valley, so that the river ran through stones and talus. We were now on the eastward slope of 324 


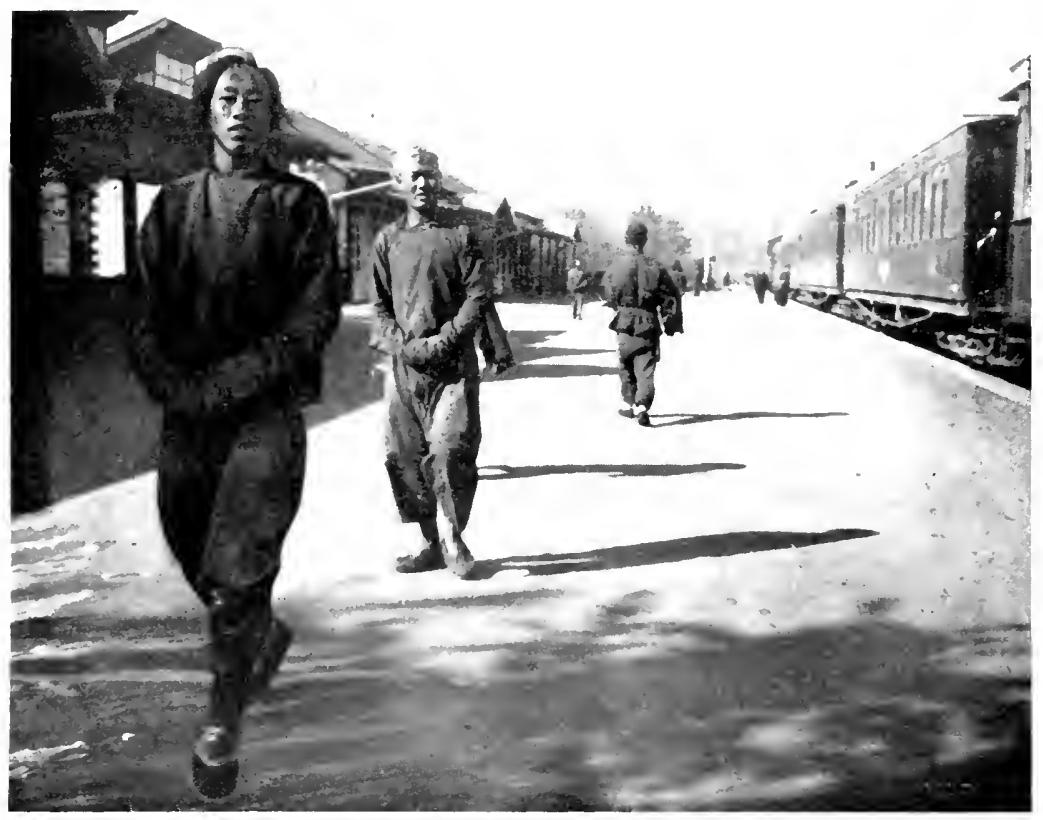

('MNESE AT A RALWAY STATION (UCT. 3)

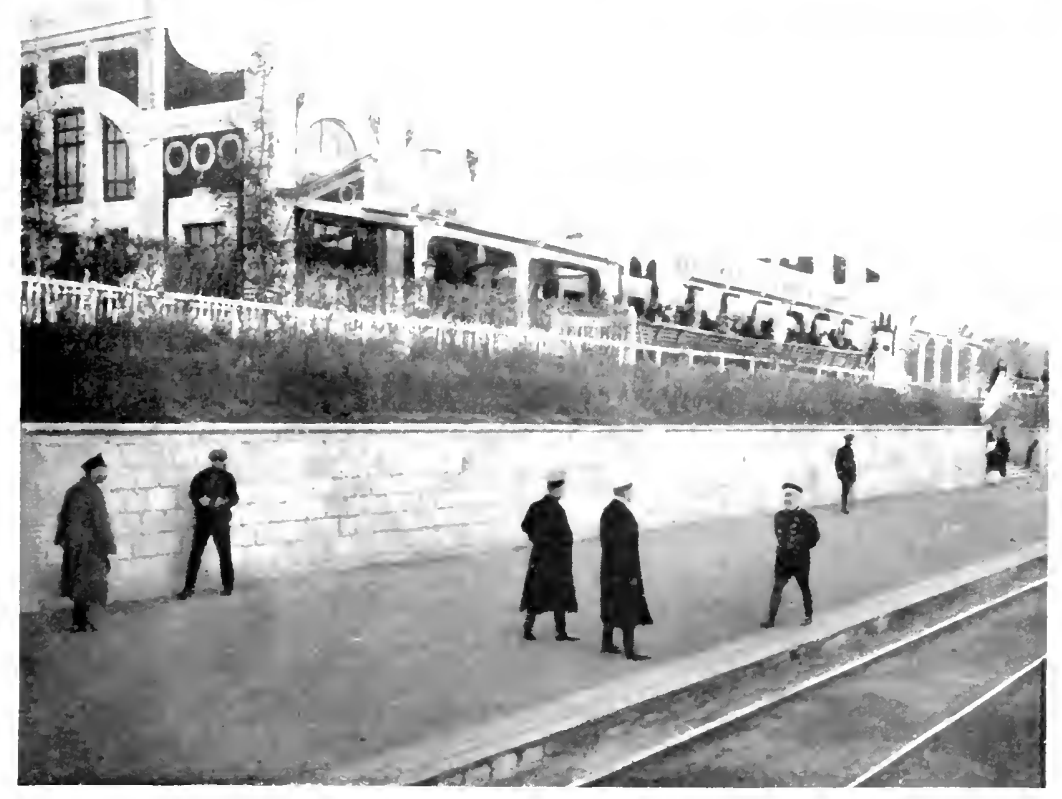

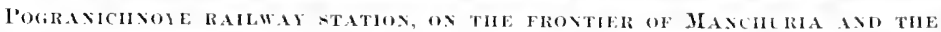
USAURI PROMIVE (beT. 3) 


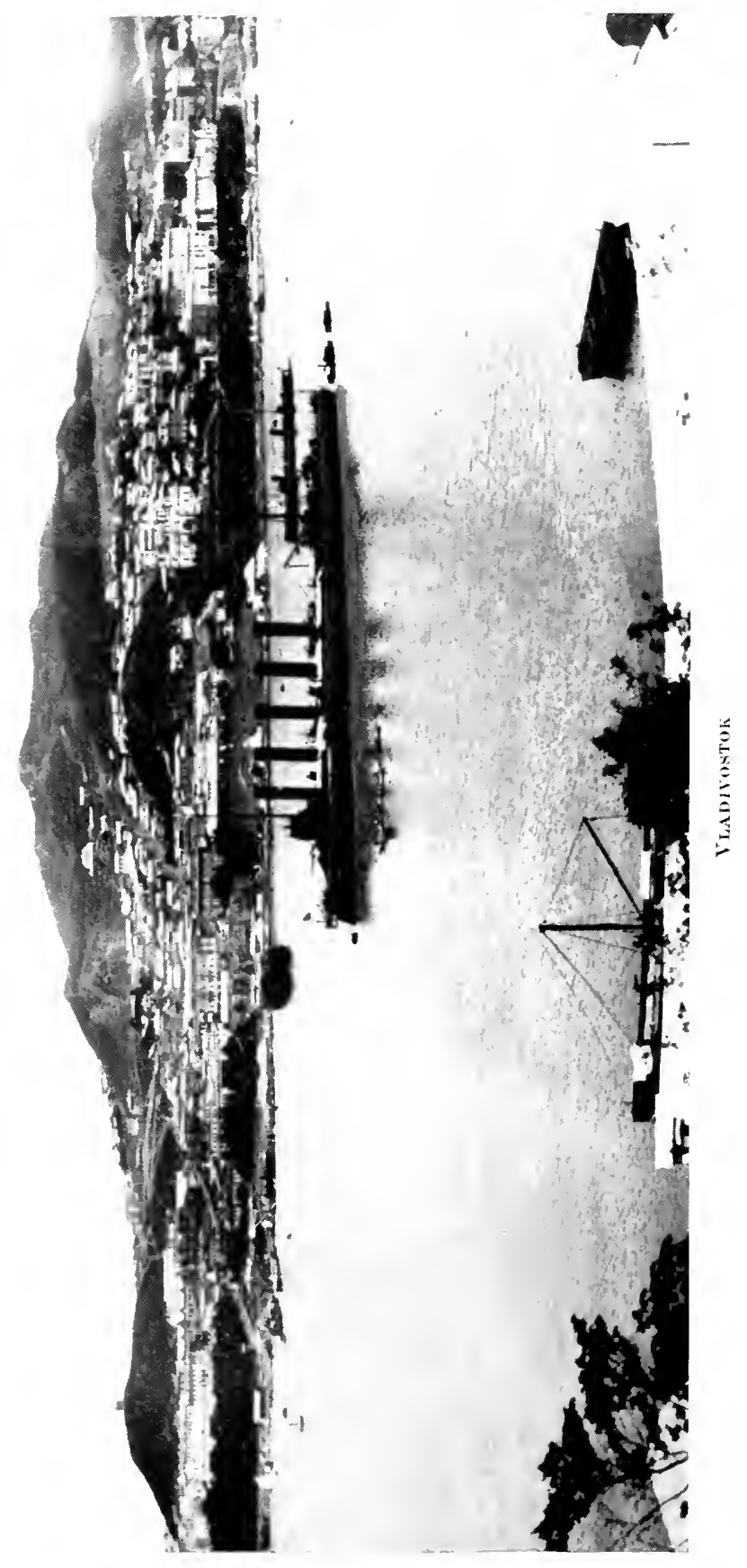




\section{IRKUTSK TO VLADIVOSTOK}

the Chang-kwan-tsai-lin (Shao-bo-shan) range. Unfortunately we were already past the mountain itself, which I should have liked to see; it has big forests and fine scenery, the Baron said, and as yet I have seen no large forests in these parts, nothing but desolate, monotonous scenery, with very little variety in its forms. The forest covers a great extent of the western slopes of Chang-kwan-tsai-lín, and consists largely of cedar, besides larch, from what Baron Huene told me.

Much cedar timber is felled in these forests, to be taken by rail to Vladivostók and shipped from there. There are eight sawmills in the forests, belonging to the great firm of Skidalski of Vladivostók, which exports over a million roubles' worth of cedar yearly. At one of the stations we saw many trucks loaded with cedar planks. This cedar, as already mentioned, is a valuable wood; but still it is strange that it can pay with the long transport, first by rail to the coast and then the sea voyage. The railway journey alone is at least 250 miles.

We soon came down to the plains by the Mután, a tributary of the Sungarí; here too there was to some extent the same brown prairie as before with rolling hills, either bare or covered with thin bush, mostly dwarf oak, and only a few somewhat larger trees, a kind of sessilecupped oak. But there was a considerable increase of cultivated land here, as we advanced. Here and there were ploughed fields, and patches of cabbages and other vegetables, millets and beans; and haystacks too. The people here are Chinese, and they are industrious and capable agriculturists.

We can clearly see the importance of a railway like this to the cultivation of the land. Before the line was made all these steppes were practically uninhabited and uncultivated. Since the railway was opened, and 


\section{THROUGH SIBERIA}

especially in the last few years, since 1906, there has been extensive settlement of Chinese agriculturists, and a great export trade has resulted, chiefly of the soya bean, and of corn; besides which an important sugar industry has grown up. On the construction of the railway the Russians acquired from the Chinese Government a broad strip of land on both sides of the line; the Chinese are therefore at liberty to settle outside this strip. But here they are little by little bringing the whole country under cultivation, and this colonization has been greatly encouraged by the Chinese Government. Between this belt of cultivated land along the line and the agricultural districts of Manchuria to the south there are now great expanses of uncultivated and almost uninhabited steppes. The same is also the case on the north, until one comes nearer to the rivers Sungarí and Amúr.

Time after time we passed forest fires, the smoke of which extended for great distances. It is easy to understand why there is so little forest here ; it is constantly being burnt. The grass in the valleys is burnt off twice a year, in autumn or spring, so that the withered grass may not check the growth of the fresh, green grass in spring. But if this sets fire to the woods on the hillsides, nobody cares very much, and they may burn for weeks, without anyone being able or wanting to stop the fire.

We are crossing the broad plain of the Mutan between the Chang-kwan-tsai-lín on the west and the Kentei-alín range on the east. We can still see mountains and peaks behind us to the west; some of them look fairly high, but their altitude cannot be so very great, as even the highest mountain in the whole of Manchuria, the volcano Peik-to-shan on the border of Korea, is no more than 8000 feet high. There is a steep ascent 326 


\section{IRKUTSK TO VLADIVOSTOK}

from the plain, as much as 15 in 1000 in places, with many curves up to the ridge of Kentei-alin, and then down again in the same way on the other side. In a few places on the summit of Kentei-alín we saw woods of spruce and a few larches near the line. But the trees were small and far apart and many of them had been burnt. One cannot expect to see much forest anywhere along the line; in the first place, because sparks from the engine often set fire to it; as the fuel is wood there is a continual stream of sparks, which easily catch the dry grass. In the second place, of course, the railway requires timber-for construction, maintenance, and fuel-so that the forests naturally tend to disappear in its immediate neighbourhood.

After a descent to another river, the Murén, which falls into the Ussúri, there was in the course of the afternoon another ascent, with even more curves, up to the saddle of the Lau-yu-ling range, on the frontier between Manchuria and the Russian Ussúri province.

Baron von Hoiningen Huene, who has for many years been attached to the Manchurian line and has had special charge of the supply of timber to the railway, has travelled a great deal in these parts in his official capacity and can give much interesting information about the country. Formerly the only cultivation to be found here was that of opium, which is prohibited in China. It was carried on secretly far away in the woods. When shooting high up in the lonely forest tracts on the slopes of the mountains, one might suddenly come upon fields of the poisonous red poppies hidden away in secluded valleys. Only a narrow path led to them through the forest. Here the Chinese had established themselves to grow the poison and avoid the Chinese Government, and here they produced the opium, and then carried it, well secreted in their hollow bamboo 


\section{THROUGH SIBERIA}

canes, to the towns, generally to Kharbin, where they managed to sell it in spite of the Chinese police and Customs; for it was difficult to see that their sticks contained so dangerous an article; but of course its being so strictly forbidden made it all the more profitable to sell.

In the great forests among the mountains the Baron had often come across robber bands of the dreaded Khunkhuses ; but he had always found them pleasant and easy to get on with. These Khunkhus bands are mainly composed of men who in some way or other have fallen out with society. The Baron thinks that some of them were originally illicit gold-washers, who found gold along the rivers in these out-of-the-way regions, and carried on their washing in secret without paying dues to the Chinese Government. Then by degrees it became known, and they were driven up into the forests, where, for want of other means of livelihood, they took to robbery, and they were constantly being joined by all kinds of criminals who for one reason or another liked this free life.

They have organized a regular system of tribute. They know pretty well how much every man makes in their district, and consequently how much to extort from each individual without ruining him. The inhabitants then have to pay this to the Khunkhuses as the price of being left in peace. There are no taxes to be paid to the State here, so the Khunkhuses think they can take over the business with advantage. And they do so most emphatically. The Baron thinks that the firm of Skidalski of Vladivostók which exports cedar from these mountains and owns some eight sawmills here will next year have to fork out 20,000 roubles to the Khunkhuses. If it is not paid, their managers will have their throats cut, as happened one 328 


\section{IRKUTSK TO VLADIVOSTOK}

year, when the tribute was not forthcoming at the right time. All traders travelling through the country have to pay a round sum to escape with a whole skin. Those who do not pay are captured, and have the choice of buying their freedom or being hanged. Those who pay are thereby protected from all molestation. This is plain and straightforward treatment; the whole thing is organized on the same lines as it was in mediæval Europe.

They live in entrenched camps in the forests high up among the mountains, and it is not easy to get at them; for they live above the thick and, in summer, entirely impenetrable jungle. Narrow paths, made by and only known to themselves, lead through the jungle up to the camp. This jungle is a wilderness of swamps and thickets, trees and creepers interwoven among the stems. One of these creepers is said to be a wild fig, the fruit of which is quite edible.

The Khunkhuses assemble in the spring and carry on their business all the summer; but they dare not stay till snow comes, as then it would be easy to follow their tracks. They then separate and the cash collected in the course of the summer is divided. They return to China with their booty, to Chefu or Peking, or wherever it may be, and pass the winter as peaceful labourers, or as rich men living on their means, to vanish with the migrating birds in the spring, when they again assemble in the forests. The year after the war between Russia and Japan was a specially good one for them, as so many goods were required in the districts ravaged by the war, and so many traders were on the road. When their money was divided in the autumn, it came to 400 roubles a man.

Baron Huene once came to a camp where there were 900 men. These camps are well fortified, and every 


\section{THROUGH SIBERIA}

man is armed with a Mannlicher rifle and a Browning pistol. The Baron once had a message requesting him to meet them for diplomatic negotiations. When he arrived at their camp, they pointed out to him how unreasonably expensive it must be for the Russian Government to keep all these soldiers along the railway to guard the line. They had considered the matter and offered to take over the whole protection of the line for a moderate annual consideration, which would be much cheaper; and they thought they could do it quite as well as the soldiers. But the offer was not accepted; the Government prefers to keep its soldiers there all the same; not the least of their uses has been to protect the line against the Khunkhus bands.

It seems strange that such brigandage can go on year after year in our time; but the Chinese Government takes no effective measures to stop it, not being very greatly interested; and to the Russians it is not so simple a matter in a foreign country, and with the subjects of another Government to deal with. Nor can it be so very easy in these desolate, uninhabited and trackless forest regions, and great efforts would be needed to catch them. But the Baron thinks the simplest way would be to take advantage of the winter, when the jungle is not so overgrown and it is easier to make one's way; then it would not be difficult to search the tracts where they have their haunts and hidingplaces in summer, and their huts and provision stores might be destroyed. During the winter these mountains are inhabited by Chinese who call themselves hunters for furs, but who are really auxiliaries of the Khunkhuses. They are expert gardeners who grow vegetables and other things for them in summer. Then they catch fish, which is dried and stored, and they collect supplies of game in the course of the winter; so that the Khun330 


\section{IRKUTSK TO VLADIVOSTOK}

khuses find stores of provisions when they come in the spring. But if all these stores were destroyed, the Baron thought their existence up there in the summer would be made practically impossible.

It is difficult enough, however, to come to close quarters with these people, even when they are found. For instance, if mounted soldiers approach a wood, where Khunkhuses are ambushed, the latter fire on the soldiers at long range with their good Mannlicher rifles and then make off into the wood and hide their arms; when the soldiers come up, they meet some peaceful and innocent Chinese walking along the forest path. Only the other day some were caught like this near Kharbin.

At one of the stations here (Selinkhe) we met an endlessly long train of high goods-waggons; it was full of colonists on their way back to Russia. It is usually reckoned that of the settlers who come out to the East, on an average 10 per cent. go back again; indeed, the percentage has been much higher in some years. In these goods-waggons, the comforts of which are not great, many of them are often crowded together, and they have to arrange themselves as best they can, with their wives and children; their journey is not a rapid one, they go on when the line is not occupied by other faster trains and they may be a month or two on the way. It is a sad sight, one of these trains full of disappointed hopes. They sold all they possessed in the village at home and went off with great expectations to the new home that was to be made in the East; but there they found only discomfiture, and perhaps distress, until they were forced to go back again, to appear as beggars in their native village.

Then we arrived at the frontier station of Manchuria, Progranichnoye (i.e. on the frontier); a large and handsome station built in rising terraces like a place of 


\section{THROUGH SIBERIA}

amusement. We were still at the altitude of the border mountains, Lau-yu-ling; but beyond the frontier we began to go downhill; we had left the Celestial Empire behind us and were slowly descending to the plains by the River Sui-fun, which flows into Amúr Bay, an arm of Peter the Great Bay. There seemed to be fertile tracts around us here, but darkness had fallen and we could see little of the country, except the fires here and there over the fields, where the grass was being burnt off. In the course of the evening we passed a big burning haystack, which had caught fire from the grass. As a rule the grass is burnt in one, or more often two rings round every haystack to protect it, but here this had not been successful. The flames rose high and had a fantastic look in the black night; we were able to form an idea of the sight there must be at night, when the whole mountain is on fire and the forests burn for days and weeks.

Towards midnight, three hours late, we came at last to Vladivostók. 


\section{CHAPTER XV}

THE USSÚRI REGION, VLADIVOSTÓK AND KHABARÓVSK

The Maritime Province, area and population : Natural features, climate : Natives : History : Vladivost $6 \mathrm{k}$ : The Ussúri line : Seeing Vladivostók : The Ussúri country : Cultivation : Khabaróvsk : Bridge over the Amúr : Difficulties of the work : The exhibition : A valuable stag : The museum, native sledges : Golds

W $\mathrm{E}$ have now arrived at the most important country of the Russian East. This is the Primorskaya Oblasty, or Maritime Province, the borderland on the Sea of Japan. It extends from the Korean frontier on the south, about latitude $42 \frac{1}{4}^{\circ} \mathrm{N}$., to the coast of the Sea of Okhotsk on the north, in about latitude $56^{\circ} \mathrm{N}$. Its eastern boundary is the sea, and its western is formed by Lake Khánka and the River Ussúri, which falls into the Amúr near Khabaróvsk, from whence the boundary runs in a north-westerly and northerly direction. The country has an area of about 223,880 square miles, with an estimated population in 1911 of 523,840 people, of whom 360,437 are Russians. More than half this population occupies the southern and more fertile part, the South Ussúri country, which has an area of about 55,970 square miles, and had in 1908 already a population of 244,000 . In all these figures the garrisons of Vladivostók and Khabaróvsk are omitted, as well as the yellow men, chiefly Koreans and Chinese, who come into the province as labourers in the course of the summer. 


\section{THROUGH SIBERIA}

The country acquires its character to a great extent from the mountain range of Sikhotá-Alín, which runs in a north-easterly direction through the whole province, from the shore of Peter the Great Bay on the south, to the Sea of Okhotsk, north of the mouth of the Amúr, on the north. This is a very ancient mountain-chain with sharp flexures, the altitude of which has been greatly decreased by erosion in the course of ages. Its average height is between 3000 and 4000 feet; the highest summit is Golaya, with an altitude of between 5000 and $\mathbf{5 2 5 0}$ feet. The chain itself has a relatively steep slope on the east towards the coast, while on the west it falls more gently towards the Rivers Ussúri and Amúr, which to a great extent run through wide valleys. The mountains nowhere approach the snow-line and are everywhere covered with primeval forest, the endless taiga; but in the interior a great deal of this has been burnt by the natives and by the Chinese, in order, amongst other purposes, to facilitate the search for harts' and elks' horns, which are a valuable article in China, being used in the preparation of medicine.

The country, then, is throughout a low, undulating hill region. It has considerable low-lying plains along the lower course of the Ussuri, but these are in great part rather marshy with stagnant water, and are frequently exposed to devasting inundations, so that they are not well suited to agriculture. A great part of the soil of this country is said to be fertile, but the climate is not favourable, considering its geographical situation. Vladivostók, which lies in latitude $43^{\circ} 6^{\prime} \mathrm{N}$., that is, in about the same latitude as Florence and Nice, has a mean annual temperature of only $4 \cdot 6^{\circ} \mathrm{C}$. $\left(40.3^{\circ} \mathrm{F}\right.$.). In summer the temperature may rise above $30^{\circ} \mathrm{C}$. $\left(86^{\circ} \mathrm{F}\right.$.), and in winter it may go below $-25^{\circ}$ C. $\left(-13^{\circ}\right.$ F. $)$. The temperature for the year 334 

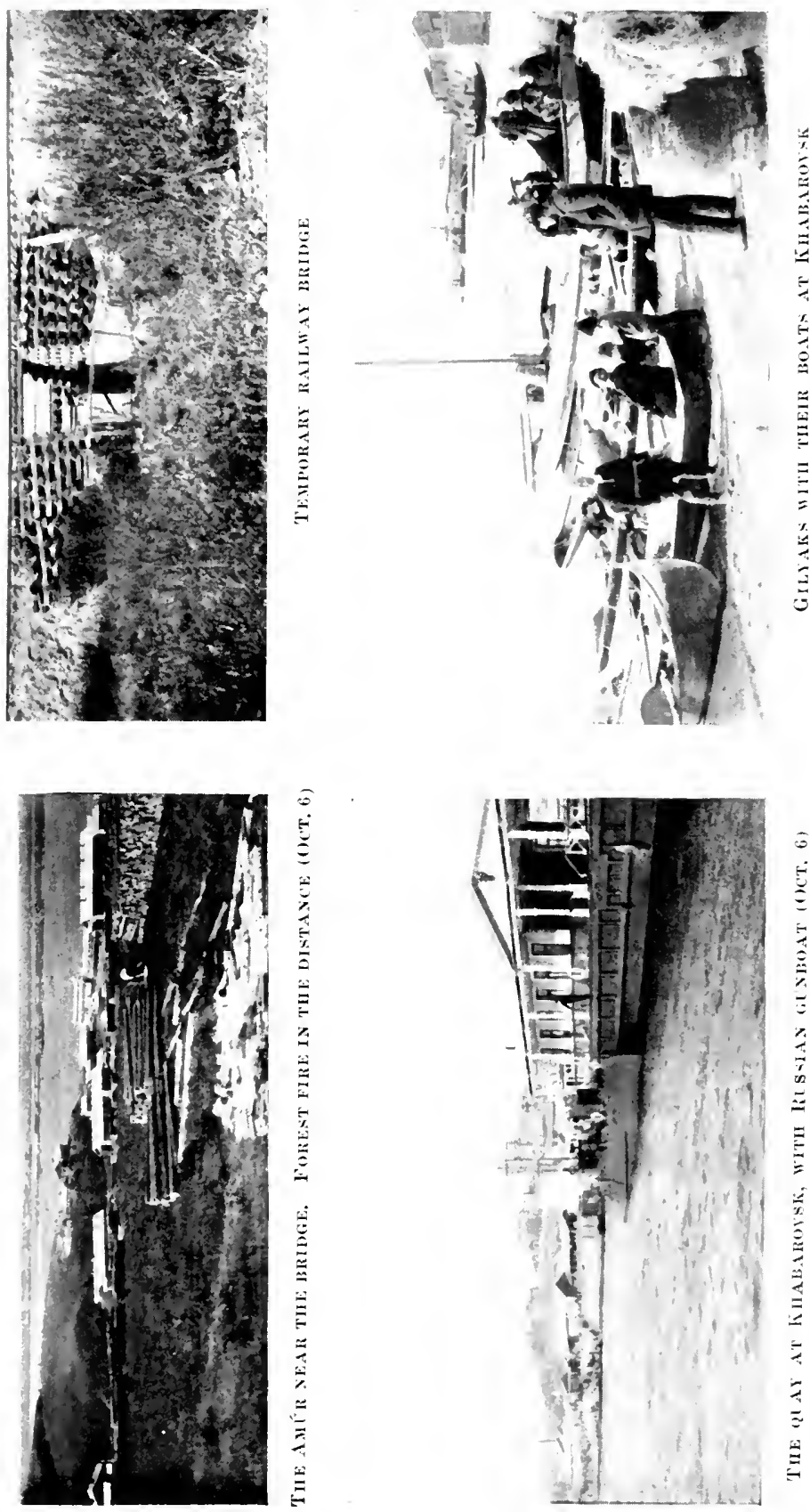


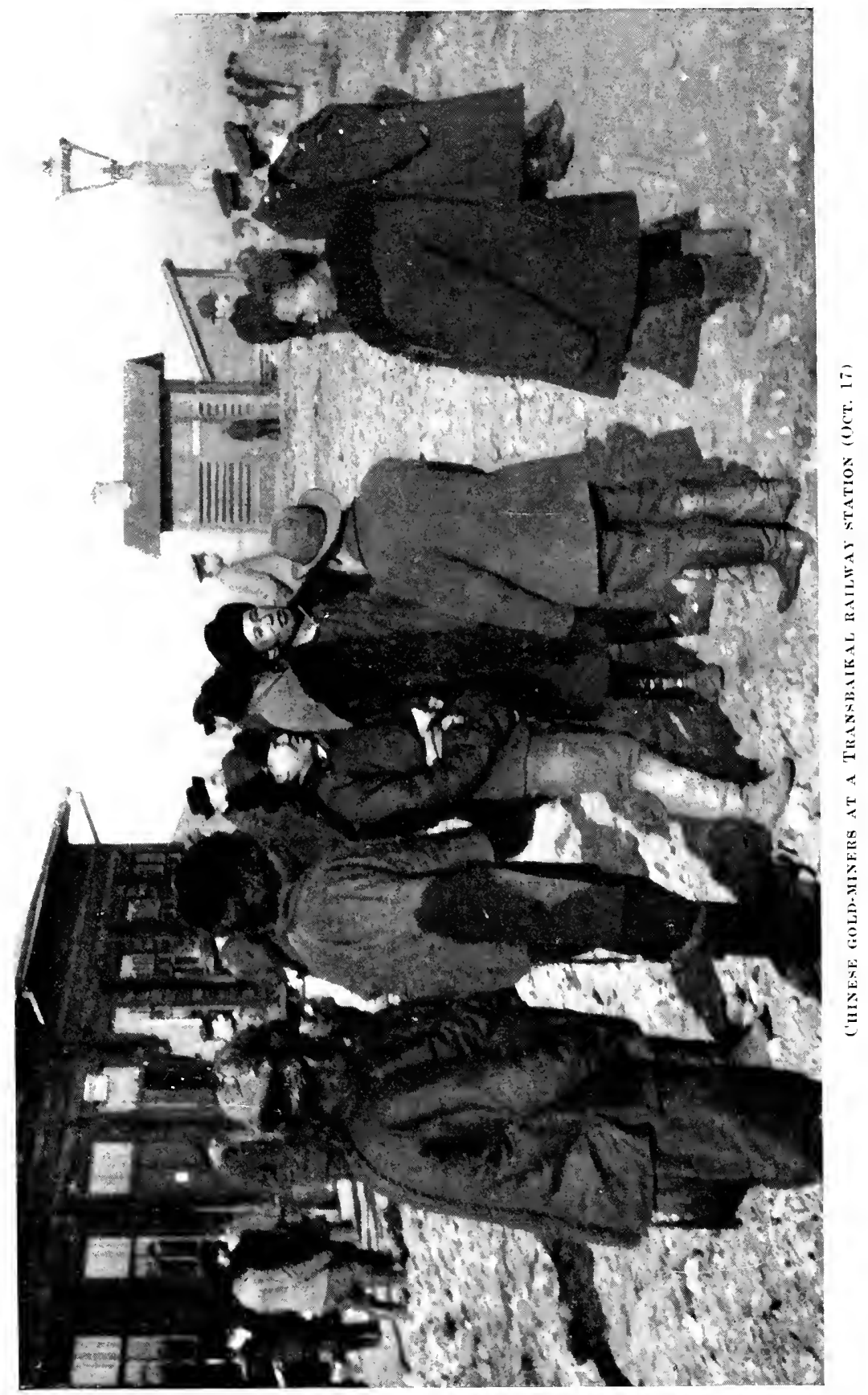




\section{THE USSÚRI REGION}

is thus lower than that of Christiania. At the town of Nikoláyevsk at the mouth of the Amúr, in latitude $53^{\circ} \mathrm{N}$., that is, a little more northerly than Berlin and a little more southerly than Manchester, the mean annual temperature is about $-2^{\circ} \mathrm{C} .\left(28 \cdot 4^{\circ} \mathrm{F}\right.$.). The temperature in winter sometimes descends to $-46^{\circ} \mathrm{C}$. $\left(-50 \cdot 8^{\circ} \mathrm{F}.\right)$, and in summer it rises above $30^{\circ} \mathrm{C} .\left(86^{\circ} \mathrm{F}.\right)$. The northern part of the country is little suited to agriculture, but the districts on the lower course of the Amúr and near its mouth are said to have good meadow land with large crops of hay. The southern section of the Maritime Province, in spite of its comparatively cold climate, offers favourable conditions for agriculture; the soil is fertile in parts; precipitation, it is true, is not great, but as here again it falls chiefly in the summer, there is no lack of moisture. In Vladivostók the precipitation is $\mathbf{1 4 . 5}$ inches, in Khabaróvsk 23.5 inches, and between the Sikhotá-Alín range and the Ussúri there is said to be a great rainfall in summer. On the other hand, there is little snow over the whole country in winter, on account of the prevailing northwesterly winds.

Formerly the whole country was inhabited by various tribes of Tunguses, such as the existing Oroches, the Golds, and others. They lived sometimes on the rivers, where they fished in summer, sometimes roaming through the forests, hunting sables, racoons, and other animals. The Golds of the Ussúri valley had also a little agriculture. In the districts on the north, near the mouth of the Amúr, is found that remarkable people, the Gilyaks, also a race of fishermen and hunters, but apparently not originally related to the Tungus tribes. Many students, such as Dr. Sternberg and Captain Arseniev, have recently suggested the possibility of their having come, like the Eskimo, the Aleuts and 


\section{THROUGH SIBERIA}

other peoples, from the north-east, from America, and of their being related to the American peoples. Here again we find the same extraordinary mixture of tribes of entirely different origin. Not far away, on the island of Sakhalín, dwells that curious race, the Ainos, who are distinguished from all other natives of Asia in particular by their great growth of hair ; they have long beards. It has been thought that they may be the last remnant of stems which were related to the Papuans and Australian blacks, and which once extended northward along the east coast of Asia.

We know little of the earlier history of the Ussúri country, and most of our knowledge is derived from Chinese historians. About 300 B.c., a stem called the Damalu occupied the coast to the east of SikhotáAlín, and to the west of the range lived another people, the Ilou, on the upper course of the Ussúri and westward to the Sungarí. These Ilou are also mentioned with certainty in northern Manchuria under the second Han dynasty in China (25-220 A.D.), and seem to have been a Tungus tribe; they were in the neolithic stage, were hunters, and lived, we are told, in caves in the mountains and forests. They had bows and arrows, and were practised in the use of boats. This Stone Age was immediately followed by the Iron Age, without any intervening Bronze Age. The Ilou hunted the bear, the elk and the stag, and are said to have been warlike and dangerous to their neighbours. But later on we hear that the Ilou had herds and a little agriculture.

Then, in the middle of the seventh century, the Bokhi, or perhaps more correctly, Bokhai domination was established in northern Manchuria. This was a Tungus stem, which little by little subdued the whole of Northern Manchuria, defeated the Ilou, and afterwards conquered the southern Ussúri country. This became 336 


\section{THE USSÚRI REGION}

a great and powerful kingdom, which reached its zenith perhaps in the ninth century, when it had no fewer than five capitals. During this period flourishing towns seem also to have grown up in the south Ussúri country; in fact, the town of Nikólsk itself is said to have been originally founded at this time. The numerous ruins of small towns, roads, and other works which are still found in the south Ussúri country and in the district of Ninguta, in Manchuria, near the frontier, are thought to date, for the most part in any case, from the Bokhai domination. But then this was destroyed by the Kidani tribe, or the house of Liau (916-1125), and a period of decline ensued. After that the Churcheni people became masters of these regions, and in 1125 the house of Liau was succeeded by the house of Tsin or Gin (1125-1237) ; "Tsin" means "the golden."

Then in the year 1237, this dynasty was destroyed by the Mongols, and the Ussúri country underwent varying destinies of which we know little, until the southern part of the country appears to have been entirely devastated during the ascendancy of Ninguta at the beginning of the seventeenth century and the campaigns connected therewith. Some of the people were taken prisoners, others killed, and the rest fled; the whole Ussúri district was laid waste. The old flourishing towns fell into ruin and were gradually overgrown with forest, and in that state the country remained for 246 years, until the Russians took possession of it in 1861. During this period an immigration of Chinese took place, partly as settlers, partly as rovers; these were the so-called Manses, to whom we shall refer later.

Captain Arseniev relates some interesting traditions of the legendary Kuan-yun dominion in this country. They remind one that there was once a time when the 


\section{THROUGH SIBERIA}

land was full of a rich, pulsating life, with roads and traffic and war. But all this vanished suddenly, as though at the nod of a supernatural power, and died away for several hundred years. The Russian colonist has established himself in the old fortifications, and when he ploughs or digs the ground he finds knives, arrows, metal ornaments and swords, or great jars and dishes. Not knowing their value, he perhaps glances at them for a moment and then throws them aside, out of the way of his ploughing, or lets his children play with them. The intrusive wave of modern European civilization will soon have effaced the last trace of vanished times.

Beyond comparison the most important city in the whole Russian East is that which bears the proud name of Vladi Vostok-that is, "Rule the East." Since the fall of Port Arthur, it has been the centre of Russian power on the Pacific, and perhaps in no distant future it may become the focus of great and important events. The Russian naval station on the Pacific was originally at Petropavlovsk in Kamchatka, where the harbour is closed by ice for a great part of the year. After 1860, it was moved to Nikoláyevsk at the mouth of the Amúr, but in 1872 it was transferred to Vladivostók; and after the few years at Port Arthur, it is back there again. Valdivostók has a situation of rare beauty on a peninsula, the high ground of which descends to a well-defended bay called " The Golden Horn" (Solotoy Rog), an arm of Peter the Great Bay. It is a splendid and well-protected harbour, and though it is frozen over for some months in winter, from the end of December tili the end of March, a channel is kept open by icebreakers, at any rate for larger ships, of over 800 tons. In 1910 the town had 89,600 inhabitants, not including the garrison, and of these 23,000 were women. There were about 53,000 Russians, 29,000 Chinese, 3200 338 


\section{THE USSÚRI REGION}

Koreans and 2300 Japanese. With its good harbour Valdivostók naturally forms an important centre for trade; but by the construction of the southern East Chinese line to Kwan-tung and the foundation of the seaport of Dalniy, Russia herself has provided Vladivostók with a dangerous rival, at any rate for the trade of Manchuria. But the position of the latter port has improved again since the war, for all trade within the Russian frontier. Of course the construction of the railway to Khabaróvsk and the Amúr was of great importance to the town and to the Ussúri country as a whole; it was completed in 1896 and 1897.

Saturday, October 4. In company with Baron von Hoiningen Huene, I went out the first thing in the morning to see the town. The great timber merchant, Skidalski, had had the great kindness to send his carriage and fine horses to drive us round. We saw the Chinese bazaars, where the housekeepers of the town get all their vegetables; all market-gardening is done by the Chinese, in spite of the war of extermination waged against them by the Governor. They are expert at this, as at most other work. We also saw the Japanese bazaars, and made some purchases there. But it is mostly cheap rubbish that crosses the Russian frontier, as the duty is too high for things of better quality. On the other hand, I was told that plenty of better articles were to be had at Kharbin, where there is no duty. The streets were alive with the various races of the East. Besides the numerous Chinese and Japanese, the Koreans were conspicuous by their white dress. Some of them are Russian subjects and live in a quarter of their own on the west side of the peninsula, but we had not time to see it.

The policy of the present Governor-General, Gondatti, is to drive the yellow population, especially the 


\section{THROUGH SIBERIA}

Chinese, out of the whole of this eastern government, as he foresees a danger in an inundation of them. Chinese who are found in the streets without having their passports in order, are often taken by the police in large numbers, put on board the first steamer that comes, and sent back to China. It was asserted that they are not even permitted to go home and fetch their things. But this is not an unmixed joy to the Russian inhabitants. When, on the day following one of these raids, the housewives go into the town to make their purchases, they find to their annoyance that the price of vegetables has gone up a few kopecks. The Chinese market-gardeners regret with a shrug of the shoulders that they have been deprived of their labourers and consequently cannot supply their vegetables at the old prices. This is a pretext, but it is their way of taking revenge, and one can hardly expect them to be satisfied with this policy. Against the Japanese the police cannot proceed in this fashion, much as they might like to do so. According to the treaty with Japan after the war, the Japanese have the same rights as the most favoured nations and may travel and reside where they please, although the universal belief among the Russians is that every single Japanese is a spy.

We took a drive up on the heights and had a grand view of the town, the harbour, the promontories and the islands outside. There are defences and forts everywhere. We also saw the numerous fortifications on the landward side, line after line. The whole gives an imposing idea of inpregnability-but in the farthest distance, behind it all, on the south-east, there was a streak of blue. It was the Pacific, which I saw for the first time.

All these heights were once overgrown with thick forest, mostly oak, of which we saw some remains on 340 


\section{TIIE USSURI REGION}

the other side of the Golden Horn. But the trees have now completely disappeared from these heights, partly through wanton destruction, partly through being felled for the sake of the fortifications. But the landscape still retains great beauty.

On returning from the heights we visited the town museum, where, amongst other things, there is a valuable ethnographical collection, with objects belonging to the Golds, Gilyaks, Oroches, Kamchadales, Chukchis, and other peoples. Here I was able to study the different types of ski and dog-sledges used by these peoples of Eastern Asia. But it is remarkable what a great resemblance there is in the forms of these appliances throughout the whole of Siberia. One reason for this may be the great diffusion of the Tunguses; with their many different tribes they are spread all the way from the Yenisei to the Pacific.

In a steamboat kindly placed at our disposal by the port authorities, we made a trip towards the entrance of the Golden Horn. One saw defences and forts and guns on every island and tongue of land wherever one turned, which to the unwarlike mind of an ordinary traveller gives a certain discordant impression of discomfort and unrest in the midst of such beautiful and peaceful scenery. Along the shores in many places were thick woods of oak, which still kept their leaves, though they were somewhat yellow. But then the entrance opened out and we looked straight out to sea, into the Pacific-though strictly speaking it was not the ocean itself, only an arm of it, the Sea of Japan. Far out on the horizon in the middle of the entrance, lay a rocky island, and on it a fort-and on the rocky heads that jutted out far away on both sides were also forts.

Then we turned back. Seen from the harbour the 


\section{THROUGH SIBERIA}

town appears very picturesque, rising in terraces up the many heights. One can scarcely conceive a more beautiful situation; it reminds one a good deal of Naples; of course, there is here no Vesuvius in the background, but to make up for it there is this beautiful harbour and all the islands outside.

The train left for Khabaróvsk at four in the afternoon, and $I$ had to take leave of my amiable and entertaining companion, Baron von Hoiningen Huene. Mr. Wourtzel had employed his time in Vladivostók in work, and had still many things to discuss with the Governor-General, who travelled by the same train as far as Nikólsk.

The southern Ussúri country, through which we first passed, is very fertile, and, as already mentioned, this is the most thickly populated part of the country; much agriculture is carried on, especially in the districts near Nikólsk and towards Lake Khánka.

Sunday, October 5. Farther north, towards Khabaróvsk, the line traverses a rich country, which certainly has a great future, when it is sufficiently cultivated. There are wide plains of arable land along the railway between two mountain-chains. Far to the east of us all the way we had Sikhotá-Alín, which with its outliers slopes gradually towards the plains of the Ussuri and its many tributaries. To the west of us, not far away, on the other side of the Ussuri and in China, we could see a ridge, the Khekhtsir, stretching northward along the river as far as the Amúr; and here in its southern part it may reach a height of between 2000 and 3000 feet. The Ussúri wound through the plain to the west of us, meeting its tributary, the Bikín. It is a fine country, with wooded hills, sometimes conifers, as on the southern, higher parts of the Khekhtsir range, sometimes leaf-bearing trees, birch, oak, and aspen, 342 


\section{THE USSÚRI REGION}

nearer at hand. There is a luxuriant vegetation; cork-trees also occur and other valuable kinds, and wild vines are found in the forests, but the wild grapes are said to be small and sour. The land here is supposed to be cultivated in a way, and we see corn-fields here and there; but still the cultivated patches lie far apart, and very much more might be done. But this is probably due to the primitive system of agriculture, which causes the greater part of the land to lie fallow. There are immense tracts of undeveloped land, mostly prairie, with scattered trees. To a great extent this land is owned by the Cossacks who live in the villages, and, as far as I can understand, they cannot be particularly industrious agriculturists. They prefer to lease their land to Koreans, who are active and pay their rent, while they themselves are fond of passing their time in the taverns.

We often saw small mud huts in the fields. They lay far apart, and must have been the dwellings of the Koreans. They build their huts in the middle of the fields in which they work. They are frugal and industrious, and besides farming they carry on marketgardening. They are therefore growing richer, while the Cossacks who do nothing are becoming steadily poorer. There are great stretches of prairie between the villages, or the places where we see scattered settlements. This prairie has coarse, dry grass, which looks worthless. For this reason it is burnt, as I have said, in the autumn or spring. We now see smoke on every side; grass and forest are being burnt indiscriminately. The air is entirely filled with it, and the hills are shrouded in a thick grey mist. The sun is red as blood and partly hidden by the smoke, though it is still high in the heavens. It is a fantastic scene with the rapidly increasing twilight and the red, smoke-filled sky. 


\section{THROUGH SIBERIA}

This train crawls on with long stops at the stations. It is more like a local line here, and it is worked at a rate to which one is unaccustomed in places where the pulses of life beat more quickly. The line is leased by the Eastern Chinese railway and is under the same management, and not yet connected with the rest of the railway system of the Russian Empire. But as soon as the Amúr line is completed and this connexion is established, there will no doubt be a change.

At last, at 10 P.M., we arrived at Khabaróvsk, and were cordially received at the station in the dark by the Mayor, the President of the Geographical Society and some of its members, the Eastern Siberian traveller, Arseniev, and others. Wourtzel and I took a droshki for the long drive from the station into the town, but this was noticed by the manager of the great German firm of Kunst and Albers, which has a branch here, and he and his wife immediately got out of their elegant carriage and insisted on our taking it, while they took the droshki-they are certainly hospitable people in this country. We drove to a restaurant to have something to eat. It was chiefly filled with officers and engineers and their wives. Like Vladivostók, Khabaróvsk is an important garrison town, and its social life therefore receives it stamp from the officers, and now, of course, during the making of the railway, from the engineers as well. There was some good music by a German pianist and an Italian violinist. They played several Russian tunes, and then a Russian gipsy melody, which was as melancholy as these endless mournful steppes. But all at once a familiar strain began; it was Solveig's Song, and the mountains of Norway gleamed high above the plains. Strange, here again, so far away in the East and so unexpectedly, to come 344 


\section{THE USSÚRI REGION}

upon Grieg and Ibsen, played by a German and an Italian. Truly the world is no longer a big place.

Monday, October 6. We spent the night on board the steamer belonging to the Amúr line, where there was plenty of room and every comfort. The boat was named after Mr. Wourtzel. Early next morning we steamed down the Amúr, while Khabaróvsk lay before us in the morning sun. The town is finely situated on several heights, at the confluence of the two great rivers, Amúr and Ussúri. It is of medium size ; in 1908 it had 34,452 inhabitants, excluding the garrison, and of these 15,482 men and 9431 women were Russians. In 1910, the population was estimated at 51,500. As everywhere in this part of the East, the women form a small minority.

As we steamed down past the river bank with the public park alongside of us, and the statue of the founder of the town, Count Muraviev Amurskiy, on the high point immediately above us, it struck me forcibly that here again this broad and mighty river had high steep banks on its right side, while on the left were spread flat islands and low plains. These are something in the nature of a delta formation, due to the confluence of the great rivers, the Ussúri on one side of the Amúr and the Tungúska on the other.

Our object was to see the building of the great bridge which is to cross the Amúr a little below Khabaróvsk. It will be, so far as I know, the second longest bridge in the world, the Forth Bridge being a little longer. It will be 7827 feet long, and will have nineteen piers. Five of these are being temporarily built of wood, while fourteen are of ferro-concrete from the start. On the islands, where several of these piers are $b$ ing built, there is a regular town of good, comfortable timber houses for the workmen. This town has grown 


\section{THROUGH SIBERIA}

up in a year, on what was previously a swampy, uninhabitable wilderness. And in a year or two, when the bridge is finished, the whole town will disappear again.

There are great difficulties to contend with in working on this watery marsh-land, where all foundations have to be sunk into the rock below; and it lies deep. And the work must be carried on summer and winter, in order that the bridge may be finished in reasonable time. It is almost worse in the summer, as the gnats and flies are an intolerable nuisance, and then there is the heat. In winter it is certainly cold, but frost has its advantages in working on such marshy ground as this. It may be utilized in many ways for freezing the wet clay and mud, which thus become easier to deal with. The health of the many workmen here collected was relatively good, but the doctor told us that there were many cases of scurvy; most of them, curiously enough, among the immigrant workmen, but not among the Koreans who live here permanently, and who have their own little village on the other side, outside Khabaróvsk.

We went back to that side to inspect the work on the tunnel which is to go through the ridge on the south side of the river, where also the station is to be built, seven versts from the town of Khabaróvsk itself. From the height above the tunnel we saw masses of smoke, which came rolling over the plains on the northern side of the Amúr. It looked as if the whole prairie was on fire. They were burning off the dry grass, but it looked as if a good deal of forest had also caught. It gradually increased until the whole sky was filled with clouds of smoke, which came drifting over Khabaróvsk, and the sun was turned to dark orange in the middle of the day

On returning to the town I visited the great exhibi346 


\section{THE USSÚRI REGION}

tion that had been held here this summer and had just closed. The various products of this colony were here collected, and a good impression was given of the wealth and possibilities of the country. Its mineral wealth was represented, especially the gold and the gold-washings. Then there were agricultural products of all sorts, as well as agricultural machinery and appliances, which seemed to show that farming is making great progress here, perhaps more than in many parts of Siberia. There were also many specimens of home industry, which I had not expected to find in these parts, and exhibits from schools for home industry and other institutions. The history and ethnography of the country were also shown in various ways, and there was much to be learnt on these subjects under the expert guidance of the able traveller and student of these regions, Captain V. Arseniev. The shapely lines of a Tungus birch-bark canoe showed how this ancient and widely diffused people has a sense of elegant forms, even in their boats, in contradistinction to other Siberian peoples, such as the Yenisei-Ostiaks. One finds the same thing in their other gear, their ski, for instance ; it is evidence, in any case, of an ancient civilization which has been highly developed within its own domain.

Not the least interesting part of this exhibition was a little zoological garden that was attached to it. Amongst other animals I here saw the valuable deer (cervus Debovskii, Swinhoe), called in Chinese khoalo (in Korean sashif), which is only found in the neighbourhood of Vladivostók, and the horns of which are used by the Chinese for making an elixir of life, and fetch a high price. A similar deer, the so-called moral deer, is found in Southern Siberia, and is there kept in captivity for the sake of its horns, which, I was told, were sold 


\section{THROUGH SIBERIA}

to the Chinese for as much as $£ 2$ a pound, an animal being worth $£ 50$; but the horns of the Vladivostók deer are said to be still more valuable.

The town museum was also visited, and there Captain Arseniev showed me many interesting things collected from the natives in these regions, whom he has specially studied in the course of his travels. I there saw long ski covered with hide, which were used by the Oroches, and they seemed to be very like those of the Samoyedes; but shorter and broader ski, like the ordinary Tungus ski, were also used where the snow was loose. They were all covered with skin from the legs of deer or elk. There were also various forms of sledges, dog-sledges and reindeer-sledges, from the Oroches, the Golds, the Gilyaks, the Chukchis and the Kamchadales. I found to my great astonishment that in many details - for instance, in the runners being bent up behind and lashed to the longitudinal bars of the sledge, which of course gives it increased strengthseveral of the most eastern forms, though not the western ones, bore a remarkable resemblance to the ski-sledge which I constructed for the crossing of the Greenland inland ice in 1888, and which has since become the type of sledge used on all polar expeditions. As far as I know, I can have had no knowledge of these forms at that time; but there are certain things which suggest themselves.

In the port of the town, down on the bank of the Amúr, I had the opportunity of making a brief acquaintance with the natives of these parts, the Golds ; they lay there in their boats, in which they had come from the Ussuri. In their features they looked very like Tunguses, but in their dress they were entirely Russian; and as in addition one of them had absorbed so much Russian vodka that he fell prostrate before us 348 


\section{THE USSÚRI REGION}

and kissed the ground under our feet, there was not much enjoyment to be got out of them.

At six in the evening we were given a big dinner by the Mayor, the Geographical Society and others. Here again I was asked to give a lecture. I then spoke about our voyage to the Yenisei and about the chances of future regular sailings to the Yenisei estuary; and I met with the same cordial reception and found the same deep interest in the development of Siberia, although what I had to say was of no direct importance to this region. 


\section{CHAPTER XVI}

\section{RUSSIA IN THE EAST. THE YELLOW QUESTION}

Russia's great task in the East : Altered situation in recent years : Seriousness and significance of the situation : Position of the Russian domination in the East : Her long line of communications : Colonization : Immigration and population : Difficulties : Immigration of the yellow race : Koreans, Chinese (Manses), Japanese : The yellow peril : Indispensability of the yellow race : Hostile feeling among the Chinese : Serious outlook

T $\mathrm{T}$ is impossible to travel through the great tracts 1 that still lie uncultivated, or in any case, little cultivated, in these eastern Russian provinces on the Pacific, without being struck by the gigantic task with which Russia is here confronted in the development of these countries, in order to strengthen her power in the East, and thereby to create a secure bulwark for herself and for European civilization against the advance of the yellow race. It is a problem the solution of which is of importance to the whole of Europe. Its importance however was perhaps not clearly realized by anyone before 1904. The general opinion was that Russia's undisputed position in the East was not threatened in any quarter, and that she was free to make her own dispositions there. The whole of Manchuria was already half Russian, and Korea was under Russian influence.

But then came the war with its great and unpleasant surprises, when Russia discovered that she had entirely 350 


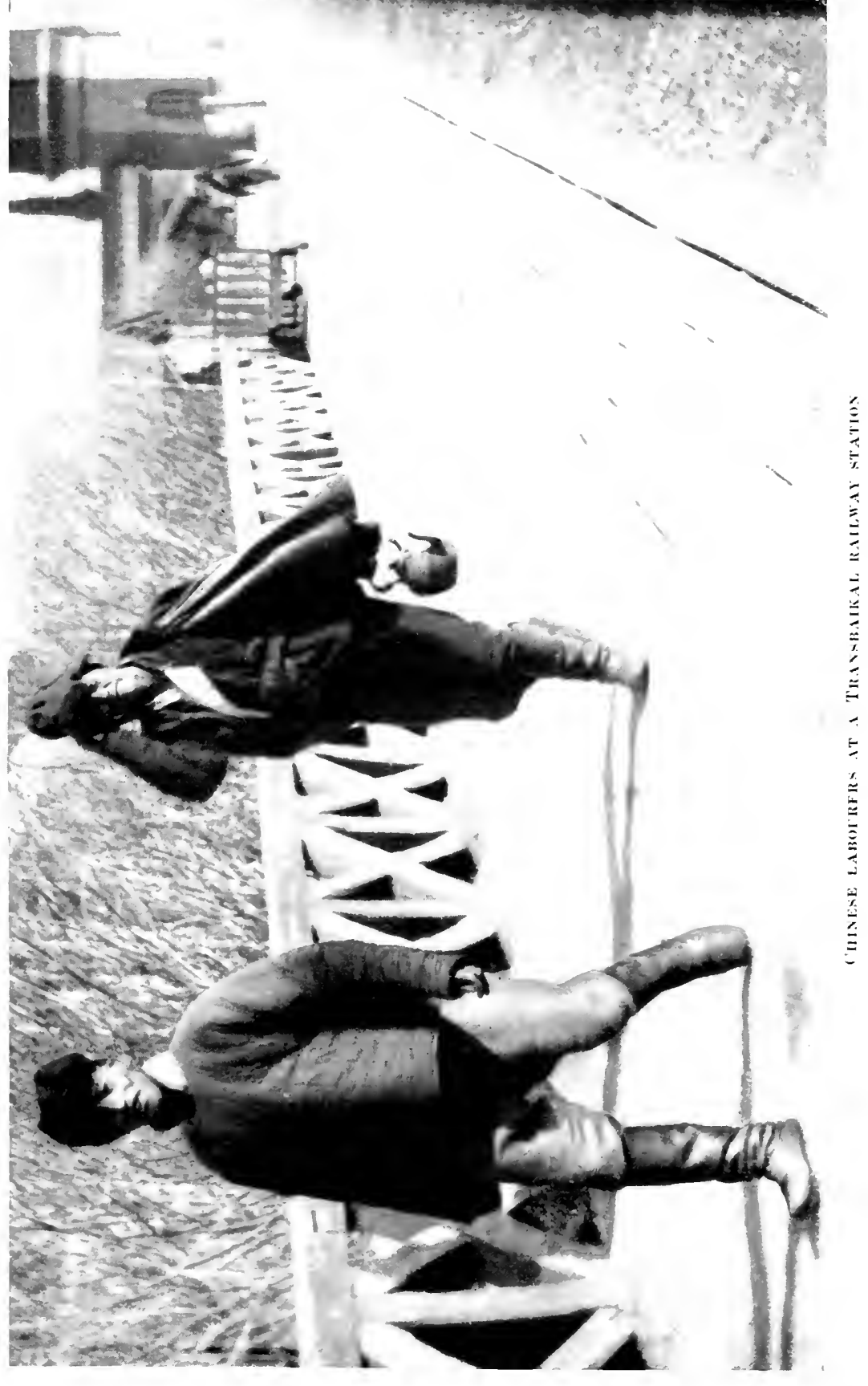




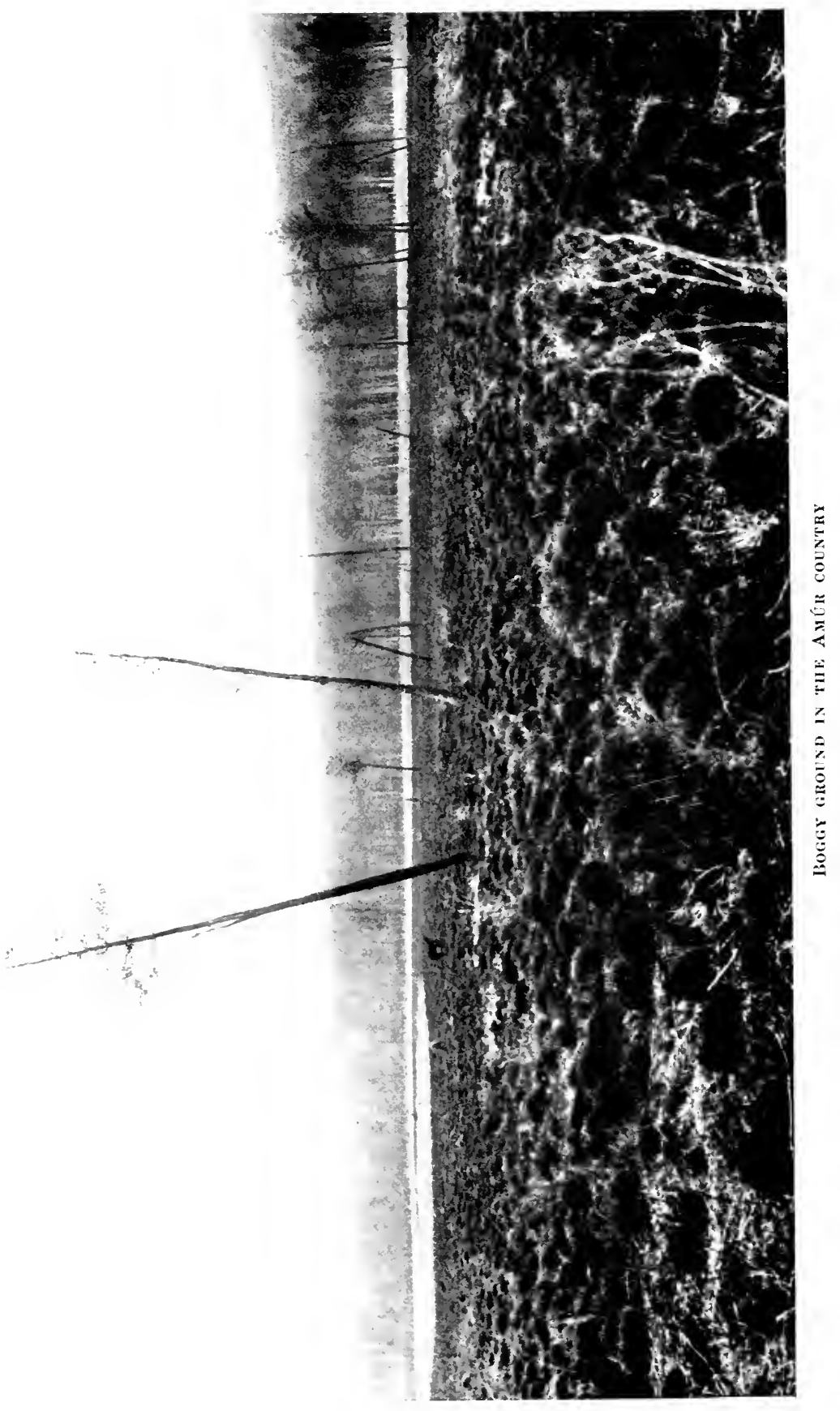




\section{RUSSIA IN THE EAST}

underestimated her neighbour across the sea on the east. Japan had grown into a great Power; not merely an equal opponent, but by her purposeful advance a threatening danger, greater perhaps than any yet encountered by Russia. This in itself has entirely changed the situation-and nevertheless other events have occurred which to an attentive observer may be fraught with even more important consequences in the future-I allude to the recent revolutionary changes in China. The modernization of that immense Empire, which has now been accelerated by the revolution and by the transformation of the empire into a nominal republic, or in any case into a more modern form of government-all this appears to involve far-reaching possibilities in foreign politics ; China has abandoned her former almost indifferent passiveness for a more active rule, which in the future will certainly pursue a more definite policy towards Europeans. Should this be the case, and should China seriously embark upon European methods of warfare in support of this policy, like Japan, and perhaps in concert with herthen no European Power, not even a Russia, will be able to resist the Celestial Empire, with its hundreds of millions of efficient inhabitants.

Great changes have thus taken place in East Asia since, over fifty years ago, Russia succeeded in acquiring her eastern provinces-the whole Amúr District and the Ussúri province as far as the border of Korea-without striking a blow, merely by diplomatic negotiations. A few sailors having hoisted the Russian flag at the mouth of the Amúr, the Tsar Nicholas was able to confirm the incorporation of this territory in his Empire in the words : "Where the Russian flag has once waved, it shall never be hauled down again." And to the new naval station and base of Russian power 


\section{THROUGH SIBERIA}

in the East he was able to give the order " rule the East" ("Vladi Vostok").-But since 1905 Russia's policy on the Pacific has had to abandon the offensive for the defensive. She was forced to retire from southern Manchuria, and instead of her ceaseless expansion, she has had to devote her energy to strengthening her position within the territory she now occupies.

We find a pregnant expression of how this great question must appear to a Russian statesman in the speech delivered by the Foreign Minister Isvolsky in the Duma on March 11, 1908, when he maintained that by the treaty of Portsmouth, Russia "had lost nothing that was her historic inheritance, but had only restored territory that had long been Japanese in reality, such as South Sakhalín, or that had been the fruit of enterprises which were not in keeping with Russia's real powers, such as the extension of the Empire of the Tsar to the southern part of Manchuria and the Kwan-tung peninsula. The heroism of the Russian soldier remained unaffected, and the unity of Russia unshaken." And he further declared that thenceforward Russia would be clearly conscious that the frontiers of her possessions in Asia were an immovable historic inheritance, that any danger threatening them was a danger to the whole Russian Empire, and that it was therefore her highest duty to stake everything upon the preservation and development of these possessions.

It is easy to understand that Russian public opinion demands the maintenance of this position, cost what it may. Should Russia be defeated in a trial of strength with the yellow race-and such a trial seems inevitable sooner or later-and should she lose her eastern territories, perhaps as far as Baikál, her prestige as a great Power would suffer so greatly that such a possibility 352 


\section{RUSSIA IN THE EAST}

must be avoided at any price-indeed, we may add that it must be avoided not merely for the sake of Russia herself, but for that of Europe-a defeat of this kind would have far-reaching consequences to the whole of European civilization. It is therefore a great problem with which Russia is here confronted, perhaps the greatest of any on her whole extended frontier. But its solution will present great difficulties even to this mighty Empire, and will for a long time to come demand the efforts of her best powers.

Before we go further into this question, a brief retrospect of the history of the Russian domination in this part of Asia may be of interest. Just as the conquest of Siberia was begun by a pure accident-when the robber chieftain Yermak, being outlawed in Russia during the reign of Ivan the Terrible, went beyond Urál, won there a new empire for the Russian Tsar, and received his pardon as a reward-so has this conquest been continued more or less by a series of casual adventurers. This has also been the case in these eastern regions. After the foundation in 1640 of a new voyevodstvo at Yakutsk on the Lena, to serve as a base for further discoveries and conquests on the east, a Cossack chief named Vasiliy Poyarkov made his way in July 1643 with a detachment of Cossacks up the Aldán, a tributary of the Lena, to the Stanovoi Mountains. With ninety Cossacks he crossed the mountains on ski, taking arms and equipment with them on hand-sledges; they descended into the Amúr country by the River Séya, and were forced to winter there. Sixty Cossacks died during the winter, but Poyarkov went on down the Séya to the Amúr, and was thus the first European discoverer of that mighty river. Here they constructed primitive boats, and this bold adventurer succeeded in navigating the river as far as its mouth. In the summer of 1646 he even ventured 


\section{THROUGH SIBERIA}

upon the Sea of Okhotsk and went northward along its coast. But after a voyage of three months his frail craft were wrecked at the mouth of the River Ulya. After wintering there among the Gilyaks and forcing aid from them, he penetrated overland to the River Maya, which flows into the Aldán, and thus reached the Lena again and came back to Yakutsk after an absence of some years.

This remarkable journey gave the impulse to the conquest of the Amúr country, in the first place by the daring Cossack chief, Yeroféi Pávlovich Khabaróv. With a small band of Cossacks Khabaróv reached the upper Amúr (near Urka) in 1650; but here he met with opposition from the native Daurs under their chiefs. After many engagements, and after obtaining help from Yakutsk, he vanquished them, and thanks to his firearms and artillery he advanced victoriously in the following years and founded the Russian dominion there. In April 1653 the little band of Cossacks encountered for the first time an army of the masters of the country, the Manchu Chinese, and defeated them. But the Chinese returned with reinforcements, and the struggle was continued for many years with varying success by the numerically far inferior Cossacks. The Russian fortified station of Albasin was several times besieged by superior forces; once, in 1686, by 5000 infantry, 3000 cavalry, and forty guns, while the town was defended by a few hundred Cossacks.

The end was that by the treaty of Nérchinsk, September 9, 1689, the Russians were obliged to restore all their conquests on the Amúr to the Chinese. This peace has been called the darkest point in the history of the Russian Empire. According to the treaty the frontier between Russia and China was to be the Stanovoi "range of mountains extending to the sea"; 354 


\section{RUSSIA IN THE EAST}

the eastern frontier of the Chinese Empire was not fixed, but the present Russian Ussúri province was regarded as within the Chinese sphere. Thereby the Russian advance in the East was paralyzed for a long time; and, important as it might be for Eastern Siberia to find an outlet to the sea down the mighty Amúr, that way was nevertheless closed. The great distances and the defective land communications made it impossible to send a force strong enough to be a match for the Chinese, and the Russians had no fleet of transports sufficient to convey their troops by sea. Their only base on the Pacific, the naval harbour of Petropavlovsk in Kamchatka, was closed by ice for a great part of the year, and had no communications by land.

It is not till the middle of the nineteenth century that we again find the Russians on the Amúr, once more by chance and chiefly owing to the energy of a single man, and, as it seems, even against the wishes of the leading circles in Petersburg. It was on August 13, 1850, that the young naval officer Nevelskiy, with a few row-boats and a handful of sailors, reached the mouth of the Amúr and hoisted the Russian flag on the shore, at the spot where Nikoláyevsk now stands. With the powerful support of the able Governor Muraviev the Tsar was persuaded to approve of the young man's bold step, and this gave the impulse to the occupation of the Amúr countries in the following years. Thus even during the progress of the Crimean War Russia obtained a great and important extension on the east, and in 1858, by the treaty of Aigun with China, Governor Muraviev, on whom the Tsar afterwards conferred the title of Count Muraviev Amurskiy, succeeded in getting the acquisition of these territories recognized in international law. And by the new treaty concluded by the Russian Ambassador, Count Ignatiev, at Peking in November 


\section{THROUGH SIBERIA}

1860, the Russian Empire on the Pacific was extended on the south as far as the frontier of Korea; and the Rivers Ussúri and Amúr became the frontier towards China. Thus these great and important tracts were acquired without a single shot being fired. It was in similar peaceful fashion that by the agreement with China of 1896, Russia obtained the right to build the Eastern Chinese railway through Manchuria; the Russians then established themselves there, even forcing Japan to give up Southern Manchuria, which she had taken from China in the war of 1894 ; and by the treaty with China of 1898 Russia acquired the Kwan-tung peninsula with Port Arthur and Dalniy. But from there she was expelled in less peaceful fashion by the Japanese War.

If we glance at a map of the world and see the thin thread of railway line which is Russia's only communication with her eastern provinces on the Pacific, and remember that since the destruction of her fleet in the East all reinforcements in case of trouble have to be carried along this thin thread against the advancing hosts from the east and south--then we shall easily understand the urgent necessity of getting these eastern provinces settled as quickly as possible and peopled by a powerful national Russian community, which would itself be strong enough to resist, at any rate for a time, an invasion of the Russian frontiers, and would be capable of supporting the armed forces necessary for such operations. It is therefore natural that Russia's efforts, first to improve the communications with these eastern provinces, and then to increase their colonization, have been redoubled and are increasing year by year.

But the difficulties are great. In the first place there are the great distances. Between Petersburg, 356 


\section{RUSSIA IN THE EAST}

the centre of all Russian administration, and Vladivostók, the future focus of Russian power in the East, there is a railway journey of over 6000 miles, which even by the most rapid express trains takes nine days and nights. In the next place, the actual colonization of these distant provinces involves great difficulties of various kinds.

The beginning of Russia's colonization of the Amúr territories was that in the spring of 1857, a regiment of three sotnias of Transbaikal Cossacks, chosen by lot, received orders to settle with their wives and children along the Amúr. It was with sorrow that they left for this new, unknown and wild country. They were conveyed down the Amúr on rafts. They were divided among small villages or stanitsas (Cossack posts), usually twelve to eighteen miles apart, along the river, where they were to till the land and provide themselves with means of subsistence. Their task was to defend the frontier towards China and to provide postal communication between the Amúr District and Transbaikalia. The land they were thus ordered to clear and cultivate was for the most part a perfect wilderness ; a great deal of it was swampy jungle, and it was only on the plains where the Séya joins the Amúr that there was any considerable population of Chinese Manchus. With admirable courage the Cossacks took in hand their difficult work of colonists, cleared the forests, drained the marshes and provided arable and pasture land. In this way the army of Cossacks of the Amúr was formed; then in the course of years a gradual immigration of Russian peasants took place.

After these territories had been formally ceded to Russia by the treaty of Aigún, some battalions of Cossacks from Transbaikalia were also given orders to settle in the valley of the Ussuri, along the Chinese 


\section{THROUGH SIBERIA}

frontier, from the Amúr down towards Lake Khánka. This was a still harder task; these Cossack families, with women and children, were of course exposed to all kinds of hardships and sufferings on the long voyage by raft down the Amúr and then up the Ussúri, and their cattle suffered want and were often lost. No other means of transit except by the rivers existed in summer in that roadless country. When at last they arrived in a more or less exhausted state, they were assigned land by the authorities, without its having been ascertained whether it was suitable for agriculture; the main thing was to get them spread along the frontier at proper distances so that they might attend to the mail and posting services and furnish an armed defence for the country, or at any rate look as if they did so.

In such conditions it was not an easy matter to make new homes, open up new country and find means of livelihood. It was a hard life and they suffered much want. Then, in the following year, the Ussúri overflowed its banks and laid the whole country under water ; this came quite unexpectedly upon the settlers, who of course did not know the habits of the river, and their courage was broken. It did not make matters any better when a whole army of soldiers under punishment received orders to settle with the Cossacks along the Ussúri.

The consequence of all this was pure misery, and the Cossacks declined both materially and morally. They were anything but capable of resistance in case of a Chinese revolt, as in the year 1868. In bad years they had no reserve to fall back upon and there was famine. This led to a number of them having to seek aid from the more prosperous Chinese, the Manses referred to later, borrowing money at usurious rates and becoming more or less dependent on them. Little 358 


\section{RUSSIA IN THE EAST}

by little the Cossacks, who were in reality poor farmers, had to take to the natives' mode of life and support themselves by fishing and hunting; while the intention was that they should be permanently settled along the frontier of the Empire. Thus it was that the army of Cossacks of the Ussúri was formed.

But by degrees Russian peasants began to immigrate to the Ussúri country also, some from other parts of Siberia, some from Russia. Some settled in the fertile southern Ussúri country, to the south of the Cossacks' territory, while others established themselves among the Cossack stanitsas farther north; but here the best land had already been given to the Cossacks, although they could only use a small part of it. The peasants therefore had to be content with inferior land, or go out into the taiga and clear new land. The adjustment of these relations between the Cossacks' land and the peasants' colonization has caused the authorities many difficulties and has taken many different turns. Even if the Cossacks had been given too much land, it was an awkward matter to take it from them again; but in 1911, the Tsar decided that the Cossacks' land along the Amrú and Ussúri was to be allotted to colonists to a reasonable extent.

These immigrant peasants were certainly better farmers than the Cossacks, many of them, in any case ; but they too were not always able to cope with the difficulties which are inseparable from the settlement of a wild, roadless country like this. When, therefore, misfortunes and bad years occurred, the peasants often enough fell into destitution and, like the Cossacks, had to seek assistance from the Chinese (Manses) on whom they too became dependent.

At so great a distance from Russia, colonization naturally proceeded slowly in these eastern provinces, 


\section{THROUGH SIBERIA}

especially before the railway was opened. To the Amúr district settlers only came overland through Siberia, while to the Ussúri province a number of them also came by sea. To the latter about 250,000 Russian peasants have immigrated between 1859 and the present date, not including the Cossack population. According to official statistics, the total population in 1911 was 523,840, of whom 360,437 were Russians. Chinese and Koreans working in the country during the summer but not permanently settled there are not included in the census. During the first period, from 1859 to 1882 , there were only 5705 peasant colonists, or 238 a year. Between 1883 and 1899 45,196 Russian immigrants arrived, or 2659 a year. But since that time, especially after 1906, there has been a very great increase.

The number of immigrants to the Amúr district has been smaller; in 1911 it had a population of 286,263, of whom 242,304 were Russians; here again labourers of the yellow race, or Europeans who were not settled in the country, are not included. In 1911 19,503 Russians emigrated to the Amúr district and the Ussúri province together, and in 1912, 25,115. But on the other hand 3507 emigrants (i.e. 18 per cent.) returned to Russia in 1911, and 2151 (9 per cent.) in 1912.

Emigrants from Russia had naturally many hardships to suffer formerly during the year or year and a half they spent on the Siberian roads, before finally reaching their destinations in these eastern lands. Even in recent years the journey by rail is not an easy matter. It takes between a month and six weeks by the long colonist trains, which are often overcrowded and in which the hygienic conditions are not of the best, with the packed goods waggons in which they travel. At the terminal stations, from which they are distributed to their destinations, accommoda360 


\section{RUSSIA IN THE EAST}

tion has often been very deficient, and the hospitals have sometimes been overcrowded to such an extent that 100 , or even 150 , patients have had to be taken in where there is computed to be space for twelve beds, and three beds are said to have been placed one above another.

When at last the settlers and their families have come safely through all their difficulties and reached their allotted lands, they must at once begin, worn out and exhausted as they are after the long journey, the hard work that is always involved in settlement: building houses, clearing the land and adapting it for the plough, thus creating the conditions of life. This takes time, and meanwhile it may be difficult to find means of livelihood. Most of those who come are probably not precisely the most capable farmers of the mother country; they are often men who have had a difficulty in making both ends meet, and their capacity for work has not been improved by the toilsome journey. It is thus easily intelligible that these settlers are placed at a disadvantage from the start in their competition with the yellow race, the Koreans and Chinese, who are their superiors as agriculturists, as well as in industry and hard work.

The difficulties attending this colonization are, as I have said, many and great; but the Russian authorities have had their attention directed to them, and in recent years have introduced many reforms for facilitating and regulating colonization; as already mentioned (see p. 285), the Government devotes increasing sums every year to this end.

Yet another class of immigrants was given to these territories through the annual transfer to them of exiled convicts, or of convicts who after serving their sentences settled there as free peasants. But this 


\section{THROUGH SIBERIA}

was not a supply of labour which seemed desirable for these important provinces, and here again there has been a change in recent years; no more convicts are to be sent there.

But side by side with the Russian colonization, a steadily increasing immigration of yellow men has been going on, especially of Koreans and Chinese, and to a less extent of Japanese. The immigration of Koreans began after the country became Russian; they have crossed the frontier since 1860. The reason was the periodical recurrence of bad years in the Korean border provinces, through which the people fell into the most frightful destitution. Arable land had also become scarce in their native country owing to exhaustive farming; but perhaps not the least of the causes was the shameless extortion of the Korean official class. In 1869 especially, there was a wholesale immigration of Koreans to the Ussúri country; on account of heavy rains northern Korea had suffered so severely that there was a complete famine, and 7000 Koreans crossed the frontier in a miserable condition. At first, the Russian authorities did not adopt an unfriendly attitude to this immigration. As the Koreans are capable farmers, they contributed to improve the condition of the Ussúri country and to make living cheaper there. A number of Koreans were even transferred to the Amúr district.

But when this immigration increased still further, anxiety began to be felt, and a possible national danger was seen in this large increase of the non-Russian population. In 1882, an edict was issued according to which only Russian subjects could acquire land in Siberia; only in exceptional cases might the Governor-General give foreigners permission to do so. An agreement was also entered into with the Korean Government, whereby the Koreans who had immigrated before 1884 362 


\section{RUSSIA IN THE EAST}

should be admitted to Russian citizenship, while later arrivals were to be allowed to remain in the country for a time, but would then be obliged to sell their immovable property and return to Korea. This provision was not put in force until 1891, when a great number of Koreans were forced to sell their property and go either to Korea or to Manchuria, where they were assigned new land by the Chinese Government. But this did not stop the immigration of Koreans to the Ussúri country; many came and were assigned land for short periods, besides which a large number became tenant-farmers, especially of the land belonging to the Cossacks. This had a demoralizing influence on the Russian population by tempting them to idleness. While the Koreans turned the land to account, the Cossacks became more and more inclined to spend their rent in the taverns on drink and cards. At the same time there was an annual immigration of yellow labourers, who arrived in the spring and returned to Korea in the autumn with their savings.

There has never been any intermixture of the Korean and Russian colonists. The Koreans as a rule do not live in villages like the Russians, but prefer to build their huts in the middle of the land they are to cultivate, which of course has the great advantage of facilitating the supervision of the fields and of saving much time that would otherwise be spent daily in going to and from their work. Their farming is also quite different from the Russians'; they work the soil far more carefully, get better crops, sell much corn and hay and arrive in course of time at a certain degree of prosperity. They are therefore to be regarded as an efficient population, which may be desirable for the rapid development of the country.

As stated above, when the Russians took possession of the country, they found the southern Ussúri 


\section{THROUGH SIBERIA}

district occupied by a Chinese population, the former masters of the land. These Manses, as they are called, were often unmarried men who formed small communities, and they were not always people of the best kind. The immigration of Chinese rather increased after the country became Russian ; the Chinese authorities in Manchuria no longer had any influence there, and the Russian authorities scarcely had more in that roadless country. The Manses therefore felt themselves more and more to be the real masters of the country, and had free play. An additional factor was the discovery of rich gold deposits on the Russian side of the frontier. At the close of the sixties the Chinese population was estimated at about 40,000. Of these about half had fixed habitations and carried on agriculture together with hunting and fishing, while the rest led a roving life for the most part, forming Khunkhus bands which struck terror into the population by their brigandage, or digging for gold and searching for fungus, horns, and the ginseng root, so highly prized by the Chinese.* Moreover the Manses ruthlessly fleeced the natives and often reduced them to complete slavery. When it comes to fleecing natives, no Euro-

* The ginseng root is the Chinese panacea, which often fetches treble its weight in gold. In 1869 it is said that a root fetched $\mathfrak{E 2 5 0}$; about 1900 the price was lower, $\mathfrak{f 8}$ to $\mathfrak{f} 9$ a pound. The genuine Manchurian and Korean ginseng is derived from the root of Panax ginseng, C. A .Meyer (=Panax quinquefoleum, Lin., var. ginseng, Regel et Maak), which is a native of Korea and northern China, and is cultivated in Japan. According to the universal belief in China, the root ought to be shaped as much as possible like a man in order to have great virtue as a remedy; this is something like the mandrakc in mediæval Europe. The root is a cure for all diseases, keeps off evil spirits and prolongs life; in fact, it renders its wearer immortal. Hart's horn and elk's horn are much used by the Chinese in the preparation of medicine and pills for many ailments. Fungus is used by the Chinese both for food and medicine. For this information $\mathbf{I}$ am gratefully indebted to Mr. Fonahn.

364 


\section{RUSSIA IN THE EAST}

pean is a match for the Chinese. They poison them with their pernicious Chinese spirit, khanshin, and they also give them opium; they coax their sables and other valuable furs out of them at a ridiculous price, and charge heavily for their own goods which they supply in return; they contrive to get the natives so deeply into their debt that they can never be free, but must always procure them furs. They use their power over the natives to make them fear the Russians as their enemies and see in the Chinese their friends and saviours.

The Manses frequently become well-to-do and, as already mentioned, the Cossacks and peasants have often been compelled to apply to them for assistance in time of famine, thus falling into a position of dependence. Another thing that tends in this direction is the fact that most of the colonists, at any rate in the southern Ussúri country, were Little Russians, who are certainly capable farmers, but are not accustomed to forest country and have no home industries like the Great Russians. They therefore had to employ Chinese as smiths and for other handicrafts, and thus became dependent on them to this extent. In addition to all this, it was provided by the treaty of Peking in 1860 that Chinese subjects were not to be punished by the Russian authorities, even for minor offences, but were to be handed over to the Chinese authorities. This gave the Manses a privilege of which they knew how to avail themselves in dealing with the Russian population, and the Chinese therefore remained more or less masters of the country.

To the Amúr district there was also a great immigration of yellow men, chiefly Chinese. In the days before the Russian domination there were, as stated above, large settlements of Chinese Manchus on the plains of the Séya. Besides these permanently established 


\section{THROUGH SIBERIA}

agriculturists, a constantly increasing number of Chinese labourers flocked to the mines, and traders to the towns, especially Blagovéshchensk. Since the Boxer outbreak of 1900 and the unfortunate events at Blagovéshchensk, when so many Chinese were driven across the river, their numbers in the Amúr district have grown less.

The immigration of Japanese to the eastern provinces was small in former years, in comparison to the great numbers of Chinese and Koreans.

With the steady influx of yellow labourers before the outbreak of war in 1904, Russian labourers were in a minority, in places a small minority, in the Amúr district and the Ussúri province. Of 487 industrial undertakings in the Ussúri province, 192 belonged to men of the yellow race, and employed no Russians. The other 295 belonged to Russians, it is true, but they employed yellow labour. While the war was in progress there was, strange to say, a fresh immigration of Chinese; this was due to a great shortage of agricultural labourers, as the Cossack armies, both of the Amúr and the Ussúri, besides a number of the peasants, were under arms. After the war the immigration of Chinese and Koreans increased still more; but in addition to them there was now a large number of Japanese.

In 1904, before the war, it was estimated that the Amúr and Ussúri country contained a Russian population of about 380,000 , while there were about 60,000 immigrant Chinese and Koreans, including those who were Russian subjects. At that time, then, the number of the yellow race corresponded to about 16 per cent. of the Russian population. In 1908 the latter was put at about 500,000, while Chinese and Koreans reached 120,000 ; thus in four years the percentage had risen from 16 to 24 per cent. as compared with the 366 


\section{RUSSIA IN THE EAST}

Russian population, or the number of yellow men had become about a quarter of that of the Russians. If we consider that the Russian figures include women, children and old men, the position is even less favourable. The immigrant Chinese and Koreans are for the most part labourers in the prime of life, and among the 120,000 we can only include 10,000 women, old men and children. This gives an able-bodied army of 110,000 , while that of the Russians cannot be put at much more than 130,000 on the figures quoted. This means that there is almost one yellow labourer to every able-bodied Russian.

In Transbaikalia, which lies nearer to the Siberian railway and to Russia, the proportion of yellow men to Russians was perhaps even more unfavourable. But at the beginning of 1909 the influx of Chinese and Koreans in search of work increased still more, and reached a height formerly unknown. As far as the railway statistics afford information, there must have been at least three times as many yellow immigrants to the Ussúri and Amúr country and to Transbaikalia as in the previous year. Indeed, at the station of Manchuria, on the frontier of Manchuria and Transbaikalia, there were five times as many Chinese in search of work as there had been the year before. No wonder the situation was considered serious in Russia, and that, as a Russian has expressed it, there was reason to recall the words of $\mathrm{Li}$ Hung Chang in 1900, when the Russians occupied Manchuria : "Russia will come to regret having approached so near to China and having interferred in Chinese internal affairs, when she sees the Siberian territories becoming Chinese."

Whence comes this great influx of the yellow race? In the first place it is due to the simple reason that there is a perceptible lack of labour in the East; the 


\section{THROUGH SIBERIA}

exploitation of its great natural wealth, its agriculture and its mines, demands a large supply of labour, which it is at present impossible to provide without the help of the yellow men. But there is the additional circumstance that the yellow labourer, Chinese or Korean, is superior in competition with the European, and one often hears it asserted by Russians that without him it would be impossible to live there.

The frugality of the Chinese is well known, and it enables him to work for so much lower wages than the European labourer. In addition to this he is on the whole more capable. It is true that $I$ often heard it asserted that a Russian navvy could do more work in a day than a Korean, and probably more than a Chinese; but he required higher wages, because his way of living was so much more expensive. But a comparison of this sort is not altogether just; it overlooks the fact that the Chinese and the Korean are not nearly so well nourished as the Russian. If they were all put on the same diet, it is unlikely that the Russian labourer would perform more or better work than the yellow ones. Besides this, the Chinese and Koreans are industrious and steady workers, which is not always the case with the Russians out here.

Then there is the fact already alluded to, that the yellow men are clever craftsmen, who carry on a number of handicrafts and have therefore become almost indispensable in many places. That a Chinese business man is everywhere the successful rival of a Russian or European, is well known. And these qualities, as the Russian writer Bolkhovitinov puts it, are more dangerous than either the Chinese army or navy.

One can understand the alarm of the Russian authorities at the danger that seems to threaten here; and the employment of Chinese labourers is now for368 


\section{RUSSIA IN THE EAST}

bidden in the Ussúri and Amúr countries. Indeed, they may not even be employed in the construction of the Amúr line, a prohibition which in the opinion of many appeared to involve insuperable difficulties. The originator of this anti-Chinese policy is the present Governor-General of the eastern provinces, Nikolai Lvovich Gondatti, who enforces it with great rigour. I have already described how Chinese, whose papers are not in order, are summarily arrested and sent back to China.

It will be understood that important arguments may be urged in favour of this policy. But on the other hand there are many Russians, and eminent men among them, who look upon the question in an entirely different light; and I received the impression that there was also a strong feeling in the opposite direction among a large part of the Russian population of these districts. One heard it said: "What is the object of this? We cannot get on without the Chinese. Sufficient Russian labour cannot be provided, and if the Chinese are driven out, the conditions of life will become impossible and necessaries will be so dear that we shall not be able to live here." A man told me, by way of example, that he had a Chinese cook, against the law; when people came he had to hide him; but if he were obliged to part with him, he would not be able to get any other. And so it was with everything. If it were the Japanese, one was told, then it would be right enough; they are not indispensable, and there are more and more of them; but against them the authorities can do nothing.

A Russian author writes of this same "yellow" question: "Look at the life of a townsman. A man in Khabaróvsk, for instance, lives in a house built by Chinese labour of Manchurian timber; the stove is 


\section{THROUGH SIBERIA}

made of Chinese bricks. In the morning the Manchu vanyka brings water from the well. In the kitchen the Chinese boy gets the Tula samovar ready. The master of the house drinks his Chinese tea, with bread made of Manchurian flour, from a Chinese bakery. Then Chinese and Koreans come and offer their produce, eggs, vegetables, fruit from Shanghai, and so on. The boy runs to the bazaar to fetch Mongolian meat, and cooks the dinner. The mistress of the house wears a dress made by a Chinese tailor, and the master gets into his chetchuncha when the warm weather begins. In his yard a Korean is at work chopping wood." Even Senator Ivanitzki says in his report on conditions in the East that the prohibition of the importation of yellow labour may possibly be desirable from a political point of view, but not from that of political economy or agriculture. "Brutal regulations of this kind can only be enforced to the detriment of the economic life of the frontier provinces," are his words.

It is adduced as one of the great economic objections to yellow labourers that these thrifty people, who arrive in the spring and return in the autumn to their families in Korea, Manchuria and China, take with them the money they have saved in the course of the summer, and in this way no inconsiderable capital leaves the country every year. But to this it is objected by those of the opposite view, that the money taken out of the country by the yellow labourers is of little account in comparison with the increase of values which they leave behind in the shape of work performed. With the help of these efficient agriculturists large tracts of new land have been developed, old arable land has been well worked and the crops have been increased; in this way the conditions of life have been improved, the price of necessaries reduced, and-not least in importance 370 


\section{RUSSIA IN THE EAST}

-the capital of the country is increased in the form of newly cultivated land, which yields a return in interest in each succeeding year. If there is to be a hope in any near future of seeing these frontier provinces so developed and so thickly populated as to be of real value to the position of Russia in the East, then this is only to be done with the aid of yellow labour. If this development is to wait until it can be carried out by Russian immigration and Russian labour alone, it will take too long, and in the meantime the still thinly occupied provinces may fall into foreign hands, and all the men, all the labour and all the money will have been sacrificed for the benefit of a foreign Power.

I have also heard it maintained by well-informed and eminent Russians that the hostile policy towards the Chinese and the harsh treatment to which they are often exposed are unwise ; it is making enemies of them unnecessarily and driving them over to the side of the Japanese. Formerly the Chinese looked upon the Japanese as their natural enemies, while on the whole their feelings towards the Russians were not unfriendly ; in fact, it is asserted that the latter understand far better than the Japanese how to treat them ; a Russian, even of high position, is never so insulting and overbearing in his behaviour to the Chinese as a highly placed Japanese.

But it must be admitted that in recent years things have happened which have somewhat changed this state of affairs, most of all, perhaps, the unfortunate events of 1900. During the Boxer rising in China in that year, the Chinese suddenly attacked some Russian steamboats plying on the Amúr, and stopped them. Hostile bands of Chinese also assembled on the Amúr, immediately opposite Blagovéshchensk. At that time there were between 10,000 and 15,000 Chinese living 


\section{THROUGH SIBERIA}

in that town and its vicinity. Fearing that these might be in league with their countrymen on the other side of the Amúr, the Russians then drove them into and across the river, without there being boats to take them : several thousands are said to have been drowned, and masses of bodies were afterwards seen floating downstream. The Chinese on the other bank replied by bombarding the town across the river, and forty Russians were killed in Blagovéshchensk. The Amúr Cossacks in turn took a cruel revenge for this by attacking and destroying the town of Aigún and other Chinese settlements on the southern bank.

After the cessation of the disturbances the expelled Chinese demanded the assistance of their authorities in Manchuria in recovering their property. But, as Bolkhovitinov puts it, this property, "it will be remembered, had been made over by the Russian Government, after the flight of the Chinese, to the Amúr Cossack army, in recognition of its signal services during the Chinese troubles of 1900." The Russian writer fears this question may easily lead to unpleasantness in the future.

Another unfortunate circumstance affecting relations with the Chinese was the march of the Allies on Peking and the profanation of the Emperors' graves by the Europeans. As the Russians are the Europeans of whom the ordinary Chinese has heard most, it was natural for him to make the Russians responsible for this also. Nor was the Russian occupation of Manchuria calculated to arouse friendly feelings among the Chinese. And then came the defeat of Russia at the hands of Japan, whereby her prestige in the East received a severe shock. The result of all this is that the Chinese view of the Russians has changed in recent years, and according to the assertions of those well 372 


\section{RUSSIA IN THE EAST}

acquainted with the state of affairs, a hatred of this foreign nation is now smouldering among the Chinese, which was kindled by the sanguinary occurrences of 1900, and has been fed by later events. It is therefore considered that there would be every reason for adopting a friendly policy towards them; whereas the way in which they have been treated recently has not been calculated to soften their feelings.

It has also been pointed out as significant of the situation that the awakening of China began by the provision of a modern army, of which a very considerable force is now stationed in Manchuria; she is no longer the weak country she was in 1900. Furthermore the Chinese Government has strongly encouraged the colonization of Northern Manchuria along the Russian frontier. The Russians themselves have contributed to this colonization by their construction of the railway. The Chinese are laying down a Decauville railway northward through Manchuria from the Eastern Chinese line to Tsitsikar and on to Mergen, and this railway will certainly be continued right up to the Amúr.

It will be understood that Russia's position in the East has become essentially different from what it was formerly; Russian statesmen here have great problems of the most serious kind to solve and the question has many sides. The Russians are therefore well aware that the future may bring complications which will tax even the forces of mighty Russia, whether the antiChinese policy be persisted in or not. Indeed, so serious is the situation that a few years ago-during the debate on the new railway through the Amúr district-warning voices were not wanting in the Duma and in the press, which described the future in very gloomy colours; and Russian policy in the East was characterized as not far short of adventurous. 


\section{THROUGH SIBERIA}

It was pointed out that the line which had been built at such expense through Southern Manchuria is now in the hands of the enemy, and will become a weapon against Russia; the same thing might befall the line that is being constructed through the Amúr district, it was thought. It was stated that if China goes on as she has begun, she will in a few years possess an army trained on European lines of 4,000,000 men; and even with a smaller army of this kind, if China were to operate in conjunction with Japan, what would Russia be able to put into the field against them? It was thought, no doubt, that the hope of being able to hold the eastern provinces against such a Power was a small one; and if they were lost, all the labour and sacrifices that have been sunk in their development would fall into the hands of the enemy, in the same way as with the southern Manchurian railway. Even if this be an exaggeratedly pessimistic view of the future, the dangers here pointed out are nevertheless of such a kind that no one can be blind to them. If Russia finds herself opposed by a Japan and a modern China at the same time, the situation may be very serious, even if she has no difficulties in another quarter. But if we may imagine the possibility of a great part of the Russian forces being tied in Europe, it will be a good deal worse ; and perhaps it is not altogether unlikely that, if the Eastern Powers are deliberately preparing for a serious trial of strength with the Europeans, they will take advantage of an opportunity of this kind. 


\section{CHAPTER XVII}

THE AMÚR DISTRICT AND THE AMÚR RAILWAY

Extent and natural features : Climate : Gold : Natives : Population : Access and railway projects : The new line : Labourers : Length and cost : Sections and engineers : Hygiene and schools : The Central Amúr plain : Drainage and arable land : Difficulties of the work : Fertility : Good farm land : By trolley and motor-car : The Little Khingán : A park of oaks : Birá : Forest country and game : Tunnels and frozen soil : Fertile land : The longest tunnel : Two motor-cars disabled : Liquor smugglers and brigandage : Deposits in an ancient lake

THE Amúr district is an inland country, cut off 1 from the sea on the east by the Maritime Province; on the south and south-west it borders on Manchuria, the Amúr forming the frontier ; on the west it marches with Transbaikalia, and on the north with the province of Yakutsk. It has an area of about 154,000 square miles, about a quarter as large again as Norway. From east to west it has an extent of over 600 miles, and from north-east to south-rwest of from 185 to 340 miles. It is a mountainous country made up of several comparatively little known ranges, which apparently do not exceed an altitude of 6900 feet. The Stanovoi (or Yáblonovi) Mountains extend along the northern boundary and form the watershed between the Amúr and the Lena. Between the rivers Séya and Buréya are the Turán Mountains, and farther east are the Buréya Mountains, which are approximately 


\section{THROUGH SIBERIA}

a continuation of the Little Khingán range from Manchuria. The mountainous country is scored in all parts by a number of rivers, which flow into the Amúr and have often excavated deep valleys.

The broad and mighty river Amúr, which is the great artery of this whole country, shows in part the same tendency that we found so marked in the Yenisei ; its right bank being steeper and higher than its left, which in many places forms low, marshy plains. One has the impression that the river has moved to the right until it was stopped by the Manchurian mountains; while on the left side it has left much low-lying country behind it. Two great plains are particularly conspicuous : the Buréya-Séya Plain, which extends widely from a good way west of the tributary Séya, southeastwards along the Amúr to a long way past the tributary Buréya. And then there is the Central Amúr Plain, which stretches from the Little Khingán, past the mouths of the Sungarí, Ussúri and Tungúska, to east of Khabaróvsk. While the latter plain is somewhat marshy, and therefore has been little suited for settlement, the Buréya-Séya Plain, on the other hand, has in parts excellent land, grass steppes and forest steppes, which may certainly become a great and rich corn country. Otherwise, the whole Amúr district is covered with forest : in the mountain tracts endless forests of conifers, and on the plains near the Amúr foliage trees to a great extent; mostly oak and birch, the white birch and black birch also to some extent; in this low country the vegetation is sometimes quite luxuriant and such southern trees as plum, apple, cork-trees and even wild vines are found.

The climate of the Amúr district is comparatively cold. The mean annual temperature of a great part of the country, in about the latitude of the Buréya376 


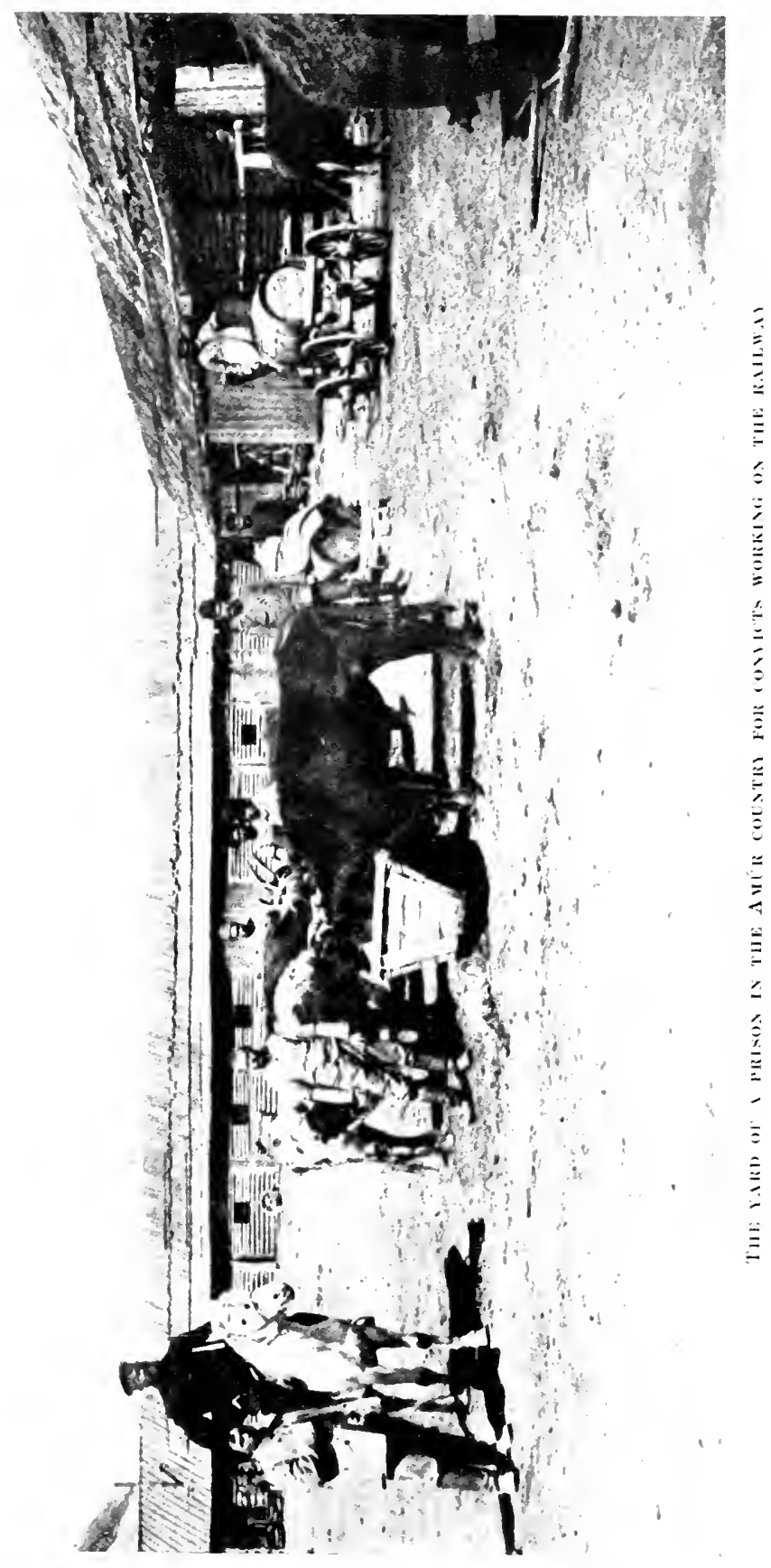




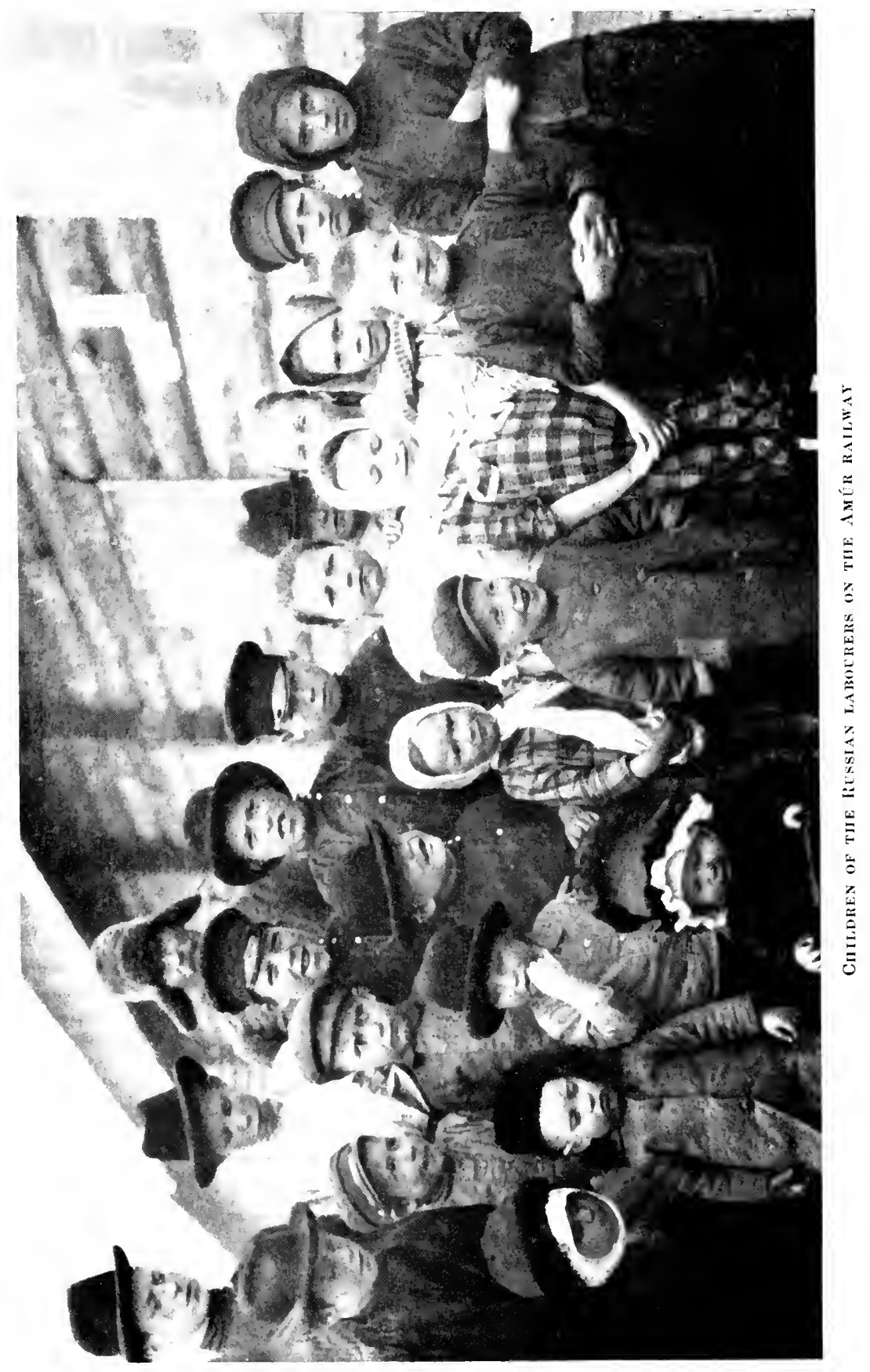




\section{THE AMUR DISTRICT AND AMÚR RAILWAY}

Séya Plain is in the neighbourhood of freezing-point, while farther south, near Khabaróvsk, it may be somewhat higher. But in summer it is very warm, which of course is important to agriculture. The mean temperature for July is above $20^{\circ} \mathrm{C}$. $\left(68^{\circ} \mathrm{F}\right.$.) for the greater part of the country. In places the thermometer may rise as high as $47^{\circ} \mathrm{C} .\left(116^{\circ} 6^{\circ} \mathrm{F}\right.$.). But the winter is cold: the mean temperature for January in the Buréya-Séya Plain may go down to $-25^{\circ} \mathrm{C} .\left(-13^{\circ} \mathrm{F}\right.$.), and temperatures of $-30^{\circ}$ and $-40^{\circ} \mathrm{C} .\left(-22^{\circ}\right.$ and $-40^{\circ} \mathrm{F}$. $)$ are not uncommon.

On account of the prevalence of south-easterly winds in the summer and northerly and north-westerly winds in the winter, there is much precipitation in summer, but little snow in winter; indeed, there is scarcely enough for sledging. This is unfavourable to vegetation, as it causes the ground to freeze to such a depth that it is slow to thaw in summer.

The country possesses valuable mineral wealth. It is especially rich in gold, which is found in many places, chiefly in the sand along many of the rivers ; and placermining is carried on over large sections of the country. In the course of the work on the new railway coal seams have also been found in several places.

The original native population of the Amúr district consisted of roving tribes, all belonging to the Tungus people: Manchus, Manegres, Daurs, Golds, Oroches or Orochons, and Tunguses proper. They were, to a great extent, fishermen and hunters who roamed along the rivers and in the widely spread taiga, while the Tunguses proper, as well as some of the Orochons, were reindeer nomads who wandered about the forests with their reindeer, but also carried on fishing and hunting. The number of the natives can scarcely be put higher than 4000 or 5000. They are among the most gifted and vigorous of 


\section{THROUGH SIBERIA}

the Tungus tribes. Many of them are extraordinarily skilful and persevering hunters, and a people like the Golds are famous for the masterly way in which they handle their boats up and down the rivers. But these primitive peoples are also steadily declining through contact with advancing European civilization, and unfortunately they, too, are doomed to disappear sooner or later, as the country becomes colonized.

Another race that is penetrating into the country simultaneously with the Europeans is that of the yellow men, both Koreans and Chinese, as we have already pointed out.

The total population of the Amúr District, in 1897, is stated to have been 120,306 , of whom 16,783 were non-Russians ; but in 1911 there were 286,263 inhabitants, of whom 43,959 were non-Russians, that is, chiefly yellow men.

The journey from Russia to the Amúr district was formerly a very long one. First, there were the endless roads through Siberia to Irkutsk and Baikál, the crossing of that lake by boat, the road again through Transbaikalia to the Shílka, and then the voyage by raft or boat down that river and the Amúr to the destination. The whole of the journey might take the emigrant a year or a year and a half. Since the construction of the railway through Eastern Siberia and Transbaikalia, the journey can be made by rail as far as the town of Sryétensk on the Shílka, and then by steamboat down the Shilka and the Amúr. But even this journey is a troublesome one, and it was of course a great disadvantage that there was no connexion between the Transbaikal railway and the Ussúri line.

It is no wonder, therefore, that projects were early formed for the laying down of a railway through the Amúr district, to connect the Transbaikal line, which 378 


\section{THE AMÚR DISTRICT AND AMÚR RAILWAY}

ended at Sryétensk, with the town of Blagovéshchensk, the largest place in the Amúr District, and with Khabaróvsk, where it would connect with the Ussúri line. In fact, an Amúr line was already surveyed and staked out between the years 1893 and 1896, when it was discovered that it would be both shorter and easier, and cheaper besides, to lay a line from Transbaikalia through Manchuria direct to the Ussúri line and Vladivostok. True, it would here pass over Chinese territory; but it was rightly supposed that there would be no insuperable difficulty in coming to an understanding with China. In this way the Eastern Chinese line was constructed with Russian money. Soon a Russian naval port was established at Port Arthur, which was in many ways more favourably situated than Vladivostók. The Amúr line was now entirely abandoned, and the attention of Russia was more and more directed to Manchuria, which was more fertile and offered even greater future possibilities than the Amúr District.

But then came the war of 1904-1905. After the peace the southern part of the Russian railway passed into the hands of the Japanese, and even in Northern Manchuria the position became such that the Russians could no longer consider their railway connexion with Vladivostók through Manchuria as sufficiently assured. It was therefore natural that the project of a line through the Amúr District should be taken up again. It was found to be necessary, for strategic reasons among others, to establish a connexion with the extreme eastern provinces by a continuous line of railway which lay entirely on Russian territory, and was so planned as not to be easily cut by a hostile force. It might have seemed desirable to lay it through the most thickly populated districts, near the Amúr; but it would thus have run along the Chinese frontier the whole way, and as it 


\section{THROUGH SIBERIA}

would there have been too exposed in case of war, it was determined to lay it farther within the country, where it would be more protected, but would run for the most part through entirely uninhabited tracts.

It is obvious that this increased the difficulties of building the line in many ways; there were no means of access, and the first thing to be done was to make roads through the wastes to bring the labourers and everything that was required; there was scarcely any labour available and it had all to be brought into the district. Nor was there anything for the maintenance of the labourers, and that, too, had to be carried; but in addition to this the country itself offered great difficulties. The climate in winter is so severe that most of the time it is impossible to work, except in the tunnels and on the bridges. But in summer the conditions are not very good either; it is hot, and there are fearful quantities of gnats, flies and other pests, which attack man and beast in swarms, so that it is often necessary to make smoking bonfires to keep them off. Nor is it easy to find drinking-water on these flat, marshy plains, and generally stagnant bog-water has to be drunk. Until roads have been made the country is often almost impassable. Across the wide stretches of bog, progress was frequently so difficult in summer that it was necessary to wait for the winter, when everything is frozen. Nor is it easy in the primeval forest-the taiga-which is marshy in many places, besides being full of trees blown down by the wind; great stretches of forest are often laid low by the storms, and progress is entirely impossible both for man and beast, until a way has been cleared. The building of the railway through the long tracts of bog, which often seem almost bottomless, also of course involves great difficulties. It is clear that the conditions of labour cannot be healthy in such wastes 380 


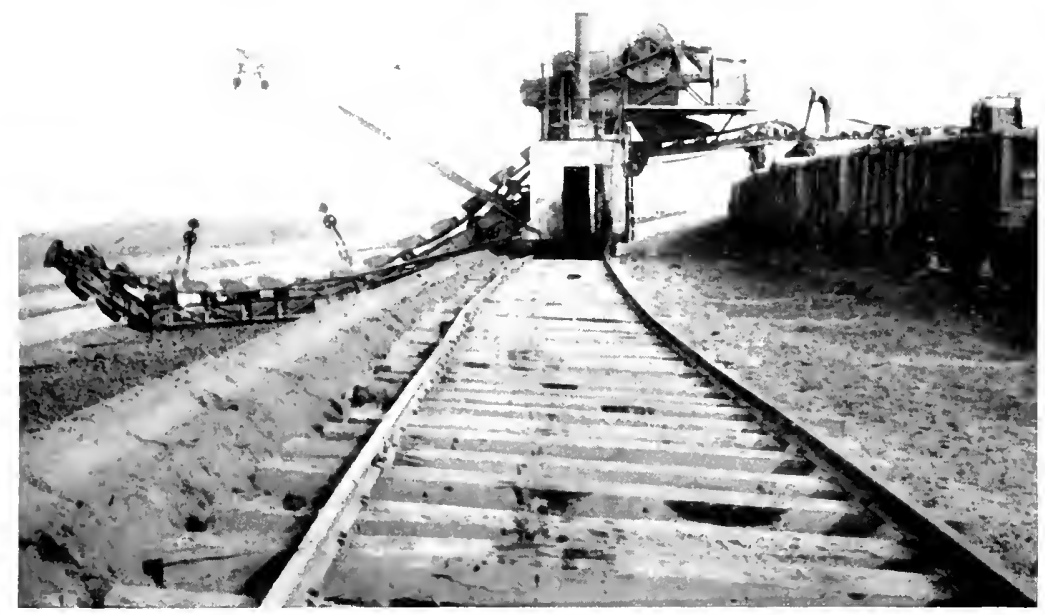

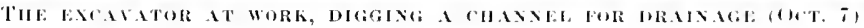

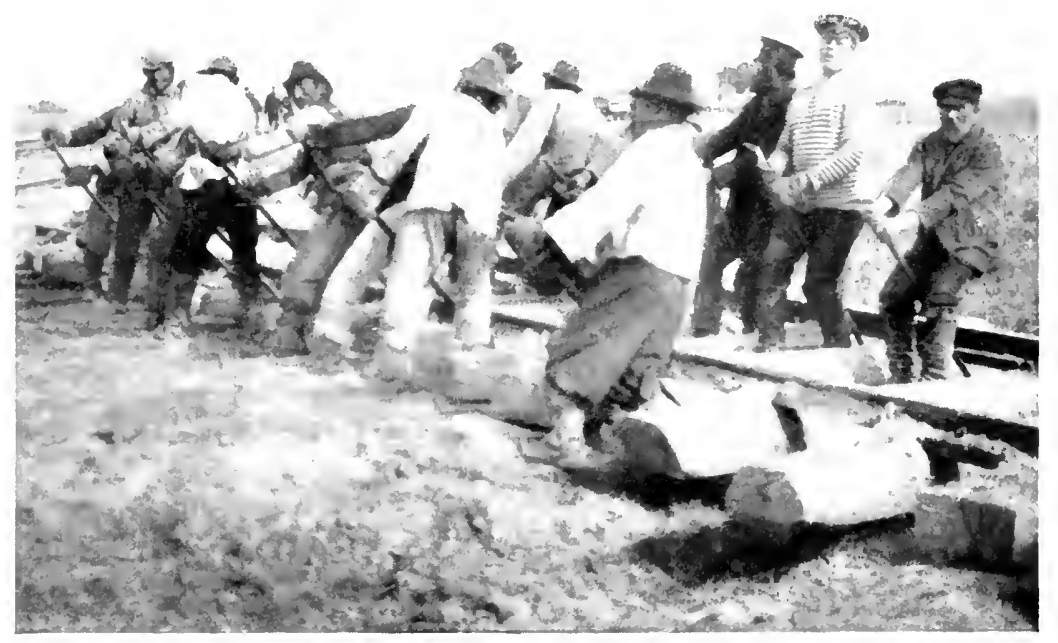

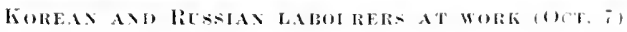




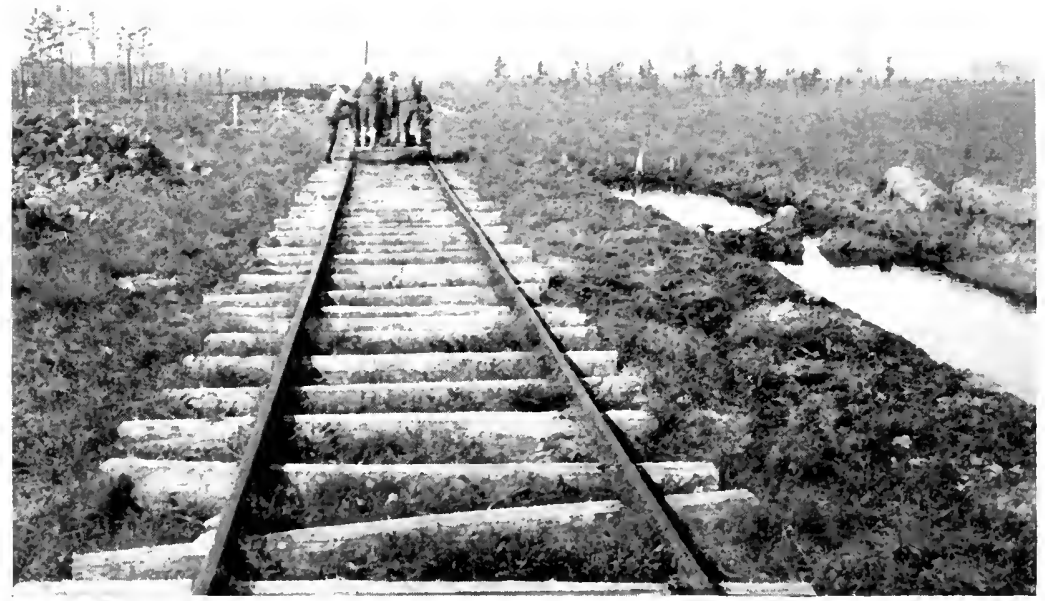

BY TROLLEY ACROSS TIIE MARAHY PLAINS (OCT. 8)

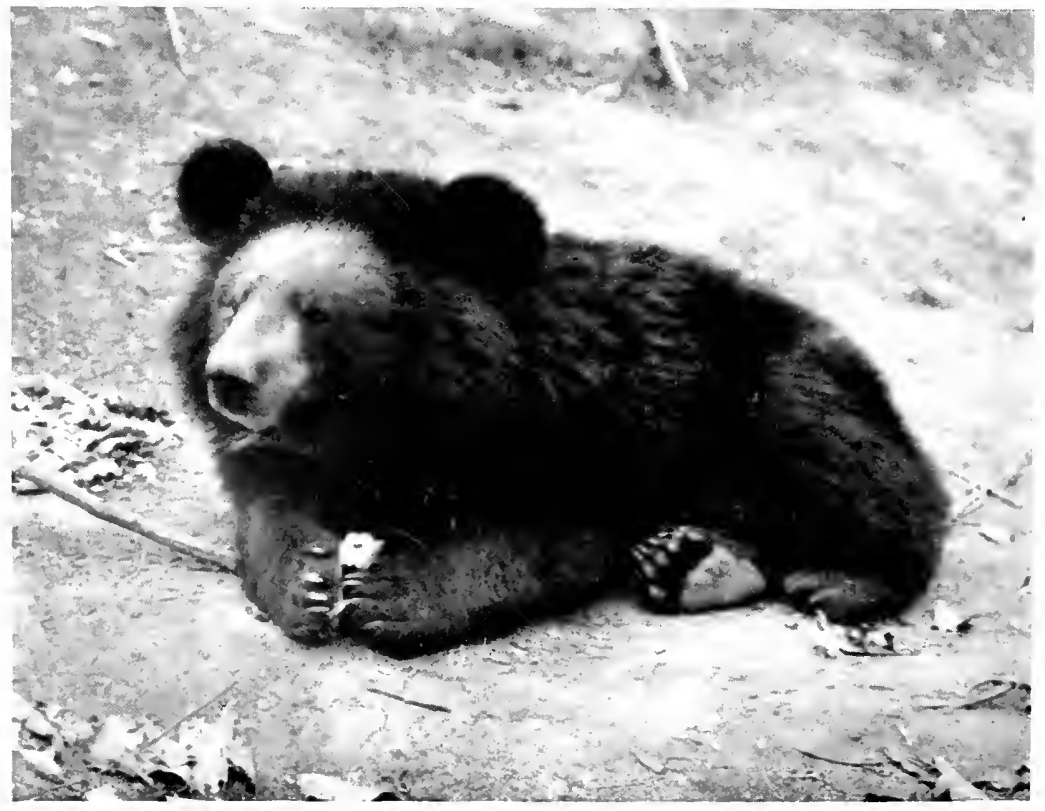

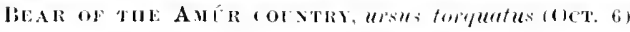




\section{THE AMÚR DISTRICT AND AMÚR RAILWAY}

until they have been more cleared and the worst of the bog-water drained off ; and it is asserted that during the preparatory work for the line 75 per cent. of the men fell ill. But as the work has proceeded, the conditions have improved, and they now appeared to be remarkably good in most places ; there were not so very many patients to be seen in the hospitals, other than those who had been injured by accidents.

The procuring of labourers for the railway was attended with very great difficulties, for it was decided that Chinese were not to be employed, and as there were few Russian labourers to be found in the district, they had to be sent all the way from Russia. But as most of the work cannot be continued in the winter, the majority of the men had to go out to the Amúr district in the spring and return to Russia in the autumn. The journey by train there and back takes them altogether about three months. The work usually begins in June, and most of the labourers finish at the beginning or middle of October ; that is to say, they are able to work for about four months; but from this must be deducted all the days on which they are stopped by rain. If we then calculate the wages of the labourers for all the seven months they are away from Russia, besides the expenses of their journey, the work carried out in this way is obviously very costly. During the last three years the number of Russian labourers sent to the East is given as 130,000, and in 1912 alone about 80,000 were sent to the Amúr District, their wages amounting to $30,000,000$ roubles. There is, of course, the advantage that all this money does not go out of the country, as it would if Chinese labour were employed. Another advantage is thought to consist in the fact that many of these labourers do not go back, but have land allotted to them and settle in the East as colonists. In the 


\section{THROUGH SIBERIA}

official report it is stated that 20 per cent. of the labourers bring their families out, and they form the advance-guard of the future colonization of these uninhabited wastes.

Another kind of Russian labour which is also largely employed on this line is that of convicts, who are kept in prison colonies at several places along the line. There have to be three soldiers to every ten labourers, and with this guard the convicts are taken out in the morning and brought back to prison in the evening. They all receive wages, which accumulate and are paid to them when they have served their term. They are therefore glad to get this kind of work.

The only yellow labourers whom it is permitted to employ in the building of the line are the Koreans, with the proviso that they must be Russian subjects, that is, permanently domiciled in the Amúr and Ussúri districts. There were at least a couple of thousand of them on the line, and they were said to be very useful in the marshy tracts, as they stand the damp far better than the Russians, who are unwilling to work in the marshes, while the Koreans have no objection to doing so.

The total length of the Amúr line, from Kuengá to Khabaróvsk, is 1830 versts, or 1213 miles. Its cost has amounted to fully $300,000,000$ roubles; that is, 154,000 roubles a kilometre, or $£ 26,150$ a mile.

The line is being constructed in four sections. The most westerly section of 183 versts, from Kuengá station on the Transbaikal line to Uryúm station, is under the engineer Boris Vasilievich Seest. Work on it was begun in March 1908, and the line is now finished and has been in use for some time. The second section is of 597 versts, between Uryúm and Kerák stations. The engineer in charge of its construction is Yeogéniy Ulianovich Podrutsky, and it is also about ready. The 382 


\section{THE AMÚR DISTRICT AND AMÚR RAILWAY}

third section is of 600 versts, from Kerák to Malinóvka, and its engineer is Vladimir Vladimirovich Tregubov. The fourth and most easterly section is of 450 versts, from Malinóvka to Khabaróvsk. Its engineer is Alexander Vasilievich Liverovskiy. Work on this section of the line was only commenced two years ago, and it is to be fully completed in 1914, when it will be possible to use the line as a whole ; but the work which will still take the longest time is the bridge over the Amúr to Khabaróvsk. A responsible position in the work on this line is that occupied by the doctor in chief, Sergéy Pavlovich Serebrennikov, who has superintended the whole medical service and has had charge of the hygienic conditions of all these thousands of labourers in this difficult country.

As mentioned above, the state of health among the labourers on the Amúr line appears to be good, and there were not many patients to be seen. Hospitals have been established at the larger stations. We went through several of them, and saw the wards, operating-rooms, baths, etc. ; they were all light, clean and well arranged, and it was a pleasure to see them. But there were not many cases in proportion to the space available, and many of them were accident cases. The railway often builds schools at the stations for the children of the workmen. We saw several of these and they made a good and pleasing impression; the rooms were large and airy, and on the walls hung all kinds of plates illustrative of botany, geography, geology, zoology, demonstrations of industry, and so on. Some of these schools had mistresses, others masters. Sometimes there were so many children that they had to be divided, some coming in the morning and others in the afternoon. The children all looked happy; it could not be seen that the climate had done them any harm. 


\section{THROUGH SIBERIA}

The country we are now about to traverse may be divided into four parts according to its natural features. First comes the Central Amúr Plain; then the mountainous country, which is to be considered as part of the Little Khingán range; after that the wide, flat Buréya-Séya Plain, and finally from the western border of this plain there is mountainous country all the way into Transbaikalia.

\section{ACROSS THE CENTRAL AMÚR PLAIN}

Tuesday, October 7. Before we turned out on the morning of October 7, the steamboat took us across the Amúr to the beginning of a little temporary branchline of the railway, built for the work of construction. When we came out at sunrise the little train stood ready by the shore, and we started in it across the flat country, the great Central Amúr Plain, over which we travelled till the next afternoon, about ninety miles. Here it is in the nature of a low, marshy delta, formed by the confluence of the two great rivers, Ussúri and Tungúska, with the Amúr, and in time of flood parts of it may be under water. It is chiefly composed of sand and clay, and to a great extent also of wide peat bogs. In the western parts, towards the hill-country near the Little Khingán Mountains, I saw gravel with pebbles, sometimes as large as one's fist. This gravel was useful for ballasting the line, but in most places there was none of it to be found. The soil was everywhere covered by a thick layer of dark mould and peat, which looked fertile, if it were only well tilled.

Large tracts of the plain are covered with grass ; in parts there is also thin forest, chiefly birch ; it is throughout very marshy, but it is remarkable what the drainage for the railway has done here in a short time. Great 384 


\section{THE AMÚR DISTRICT AND AMÚR RAILWAY}

stretches of what was formerly a complete swamp have now become good arable land, some of which is already in use, and this change has taken place since the winter of 1911-12. Mr. Wourtzel considered that the railway would soon pay for itself in this region merely by the new land which it would bring under cultivation. For part of this drainage-work great excavators are used, which we saw in operation. They run on a broad line of rails temporarily laid over the ground; they are driven by steam and look very like large dredgers. They dig broad channels in a short time, and neatly deposit the sand and gravel and mud they dig up to form the new permanent way on their other side, or load it into trucks, which carry it away to the place where the line is being built. The water is carried off in the newly dug channels, and the water-level, or height of the underground water in the soil, is lowered; thus the permanent way is drained, and at the same time the whole plain is made drier. It is a big piece of work; we saw a regular hill of sand which was in process of disappearing, simply to furnish material for embanking the line over the deep bogs. A side line has been temporarily laid to carry this material, and along it were many huts for the labourers; but all this will vanish again when the railway is finished next year. Here one is already impressed by the great difficulties the construction of this line has had to contend with; stretch after stretch of it runs through wet land, which may be best described as swamp.

The weather is so delightfully warm that one quite forgets it is October. The willows still have green leaves with some yellow ones among them, but many of the birches have lost theirs, although here and there some green leaves are left among the yellow ones. At the village of Pokrovka we visited the railway school 


\section{THROUGH SIBERIA}

for the workmen's children, and when Mr. Wourtzel introduced me to the master, the latter was evidently very proud of being able to show off his knowledge, and tell the boys and girls who I was and where I had travelled before, which he could safely do, as I did not understand a word of what he said. The master seemed to be a good sort of man, and the children looked healthy, cheerful, and in good spirits.

We lunched with the section engineer, Franz Kholevo, who had a comfortable little house and a pretty little garden, where a year before had been a marshy wilderness. We ate his own cauliflower and his own pork. He also had three cows. A little farther on we passed a village which was one year old. It already possessed a windmill, and not much more than a year before it had been a swamp where corn-growing was out of the question. In another place our train took us over an almost finished piece of line, where the engineer who laid it out two years ago could not proceed in the summer, as the bog was too soft; he had to wait until it froze in the winter. Now this land is ready for cultivation.

Having obtained a deep insight into the various aspects and difficulties of railway construction in such a marshy country as this, we arrived in the dark at the station of In, where we were to spend the night, quite a little town built for the railway men. It stands on the river In, a tributary of the Urmi, which again is a tributary of the Tungúska. Here we were provided with an ample supper, or rather dinner, by the restaurateur of the place, a handsome Georgian, who presented a fine appearance in his national dress, a long caftan with rows of cartridge-holes sewed across the chest; but the cartridges had long ago been replaced by corks. So here again we came upon Caucasians. 


\section{THE AMÚR DISTRICT AND AMÚR RAILIVAY}

It was evidently a good country for food that we had come to, as the table was liberally furnished; the meal began with all kinds of caviar, black and red, compressed and fresh. There is sturgeon fishing in the Amúr, and there are great quantities of Amúr salmon, khetá, which seems to me as good as ours, although connoisseurs insist that it is not quite so good. And it has the advantage of yielding this red caviar, which has such a splendid colour-like pale rubies. Besides many kinds of fish, there is a large supply of game in the forests here, and all these things appear on the table; first cold dishes-as though for a sakuska-and then hot ones as well, so that I imagined the dinner had started and ate accordingly. Then the table was cleared and we had apparently finished. But after that the soup came in, the good Russian soup, which showed that dinner was just beginning. What we had had before was only sakuska, or hors d'œuvre; and now came excellent fish, followed by one hot dish of meat and vegetables after another. This was repeated every single day while I was travelling through the Amúr District, and I could never remember about the sakuska. I always thought the dinner was over when it was just going to begin. Then we had glorious Caucasian wine, with that wonderful deep golden colour, the very sight of which is intoxicating. There was also fruit from Tashkend, great pears and swelling, juicy grapes, which we found everywhere in Siberia, even here in the Amúr District. It must be a wonderful country for fruit, Turkestan.

Wednesday, October 8. Beyond here the line was not yet sufficiently finished for us to go on by train, and we had to use trolleys. It was still the same flat plain, everywhere damp and marshy. The water was stagnant and it was difficult to find any fit to drink; in the wells it seemed clear enough, but smelt of sulphuretted 


\section{THROUGH SIBERIA}

hydrogen, even if they were dug fifteen feet down. It was chiefly open prairie, but here and there were large copses of birch with dazzlingly white stems. It is the "white birch" that grows here, and it is rightly named. Unlike our birches at home, it is white from the root out to the farthest branches, and it has a curiously light appearance, especially now that the leaves are gone. The effect is quite unnatural, as though some one had whitewashed them all over, as is done with fruit trees, except that here the branches are also white to the smallest twigs. Here again the trees are always far apart. As we come farther west we begin to see a few oaks among the birches, and here and there a solitary larch. Grass grows everywhere, even among the trees in the copses.

In the course of the day, as we trundled on to the west in our trolleys, we came in sight of blue mountains rising above the plain far ahead. They were the ridges of Little Khingán.

During the afternoon we came to the end of our trolley journey ; no more line had been laid, and thenceforward we had to use motor-cars along the uneven road which everywhere follows the railway, and is the first thing to be made through the country where the railway is to run. This road is to be kept up after the completion of the line, chiefly for strategic reasons ; as, if a piece of the line should be torn up by a hostile force, troops and artillery would still be able to advance by the road. Besides, it will also serve to give the settlers access to the stations.

There were two motor-cars at our disposal. One of them was a good, powerful road car for ourselves, of the usual type; the other was an armoured car to take our baggage. It was usually employed in carrying the mails for the railway in this insecure country. It was 388 


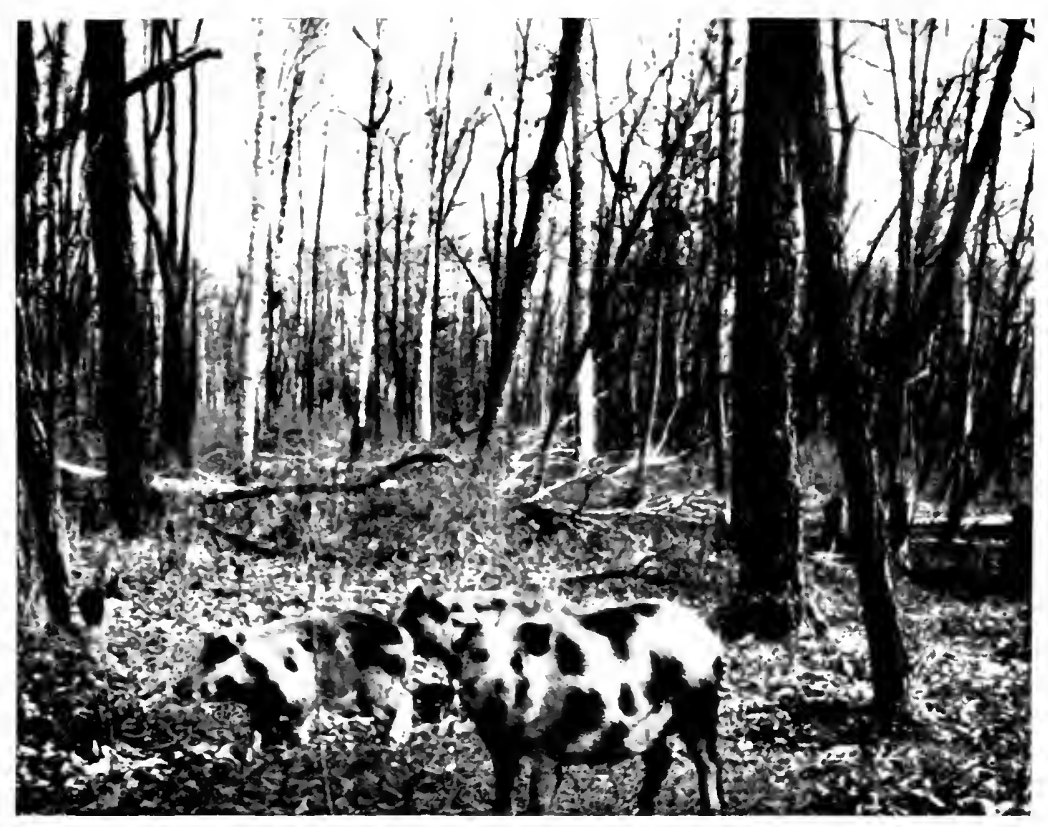

WA AND BIRCII IS TIE FOREST YEAL IIIRAH(ICT. 9)

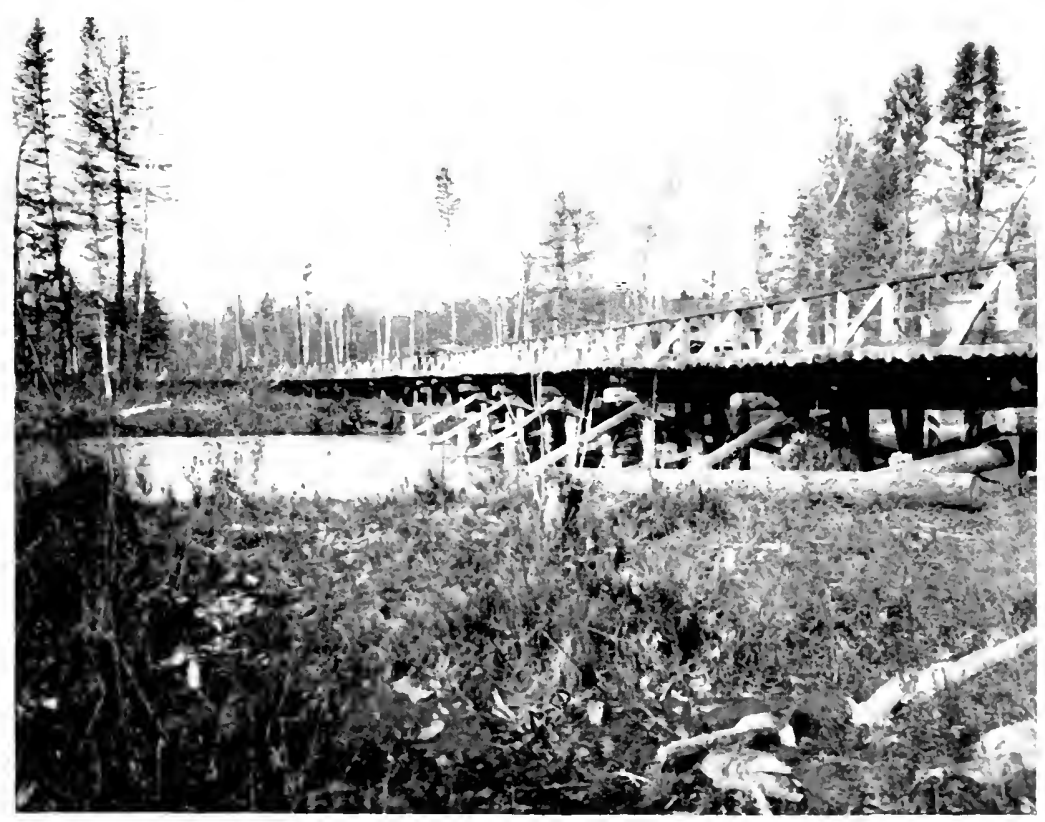

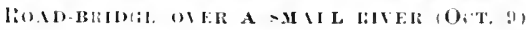




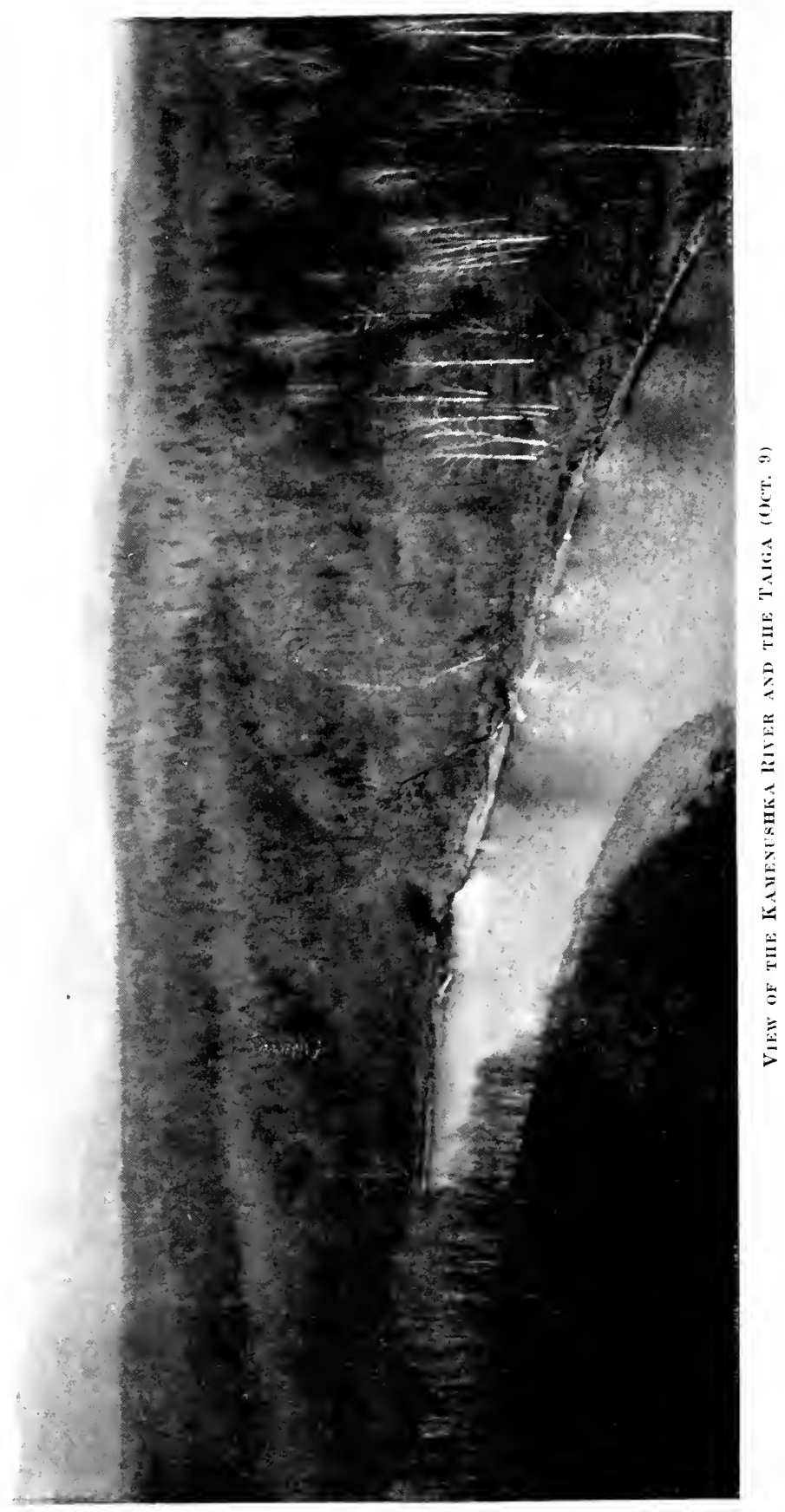




\section{THE AMÚR DISTRICT AND AMÚR RAILWAY}

armoured all over, with loopholes for firing; and when carrying the mail, which included the money for wages, it was always guarded by gendarmes or soldiers with loaded rifles. It had solid rubber tyres, not pneumatics, which might be punctured; but it shook a good deal in consequence on these roads.

We got on pretty fast in this way, too, with big jumps over holes and rough places, and it seemed a miracle that the springs and tyres held out; but we frightened the horses; they made for the ditches on both sides with their waggons and loads, and how they got out again we did not stop to see. Or sometimes the horses turned right round with their carts and tore off down the road before us at a mad gallop. Over the swamps the road was laid on planks, often for several miles at a time. As the car went over the planks, they danced and jumped under us and made a fearful noise.

\section{OVER THE LITTLE KHINGÁN}

We then began to approach the western boundary of the plain. We drew nearer and nearer to the hillcountry and the mountains; the landscape changed, the birches grew rarer or disappeared altogether, their place being taken mostly by oaks, and the road wound over the ridges through fine oak forests, up and down hill. It seemed strange that a "primeval forest" could look like this, with the ground so clean among the trees; it was more like a well-kept English deer park than an uninhabited country near the Amúr. But the reason must be that the natives have long been in the habit of burning off the long, dry grass, to provide better pasture for game; and perhaps the roving Chinese, who search for hartshorn, have done so too. In this way the forests also have often been burnt. As we 


\section{THROUGH SIBERIA}

came higher up among the hills, larches were mixed with the oaks, until a lot of spruce began to appear, and even a few firs. Then, through the forest beneath us, we suddenly saw a great river winding along the floor of a wooded valley, and behind it lay blue wooded ridges and mountains. We might have been in Norway. The river was the Birá, and after we had gone some distance farther through the forest with the river still flowing below us, the car stopped at a large settlement on the wooded slope. This was the station of Birá, where we were to stay for the night.

It is evening. The deep-red glow of sunset is fading behind the western mountains, and a half-moon is beginning to shine over the forest country. Darkness falls fast. The slopes yonder are quite black; but the undulating line of hills stands out against the blue sky, and the tree-tops in the foreground are sharply outlined. A cow-bell sounds from the forest away to the left. Does it not remind one of a Norwegian sæter ?

Thursday, October 9. I went for a walk in the grey of dawn to look at this forest country. Fresh, clear, with frost on the ground-how I longed to go after the hares among these hills. If one could let the dogs loose now ; soon it will be light enough for a shot, and then one would hear them give tongue along these hillsides. No mistake about it, there must be hares in these woods.

What a country for a sportsman! These immense forests-and quantities of bears and elks and wild boars, and great herds of roedeer, which are mostly to be found below on the prairies. There are lots of capercailzies and black game, besides ducks. What more can one want? And now and then a tiger comes along. $\mathrm{He}$ is big, quite as big as the Bengal tiger, judging by the skins I saw, but his coat is thicker and longer and 390 


\section{THE AMÚR DISTRICT AND AMÚR RAILIVAY}

his skin is handsomer. Last winter some workmen were living in a hut near to this spot. One of the men heard something moving at night outside the door. He went out with an axe, saw an animal before him, and brought the axe down on its skull. It was so dark that he did not see what became of it; but went back to the others and said that he must have killed some animal outside and thought it looked most like a roedeer. When they went out to see in the morning, they found a one-year-old tiger lying there dead. But when the man who had struck the blow saw it, he wept with terror.

Some time ago a couple of would-be sportsmen went shooting here. They had walked all day and it was getting towards evening, when they suddenly caught sight of two tigers among the trees. The range was short and they had rifles, but they dared not shoot and they let the tigers go ; but they dared not go home either, as it had begun to get dark. So they made a fire and stayed out all night; but they got no sleep for terror of these beasts, which might have been prowling round them in the darkness, and it cannot have been a very pleasant night. One of them, at any rate, was permanently cured of his taste for shooting.

But in spite of all this big game, I am now longing for a shot at a hare. Scent lies well on this ground, and this must be an extraordinarily fine country for hunting. One involuntarily longs to be able to give up one's time to the study of these forests, to search out the natives and share their life, and to accompany them on their hunting expeditions. They are hunters from the cradle and know the haunts of the game. But we must go forward, ever forward, to inspect the laying of this line, which winds through the forest and is to open up the way for that so-called civilization, which will gradually clear away forests and natives and game. 


\section{THROUGH SIBERIA}

We went at a rattling pace over the rough, frozen road, and could not complain of our progress, as in the first forty minutes we covered sixteen miles, in spite of two stops on the way.

We were now on the eastern slope of the mountain or hill-country which is to be regarded as a northern continuation of the Little Khingán range of Manchuria. Through this country the railway runs westward for a distance of 90 to 120 miles, until it approaches the great plain again on the other side. It consists, roughly speaking, of two low mountain ridges, an eastern and a western, with a more level plain between them. There was fine forest scenery in the eastern part : purple hills and mountains, one behind another, ridge upon ridge, with dark wooded valleys between. It was very like Norway. Conifers were everywhere, but in many places the forest consisted of cedar instead of spruce. It was strange, by the way, here, as everywhere in Siberia, how seldom one saw really big trees; the forest seemed often to consist of nothing but young trees; this is not because they are felled, but rather because they are wantonly burnt; and there is no end to these fires, one sees signs of them everywhere. Another thing is that, here again, the forest takes a long time to grow, as the winter is so severe and snowless. Now and then there were great marshy flats, on some of which larches were scattered singly, on others white birches-the immense wastes of bog extend far to the north towards blue hills, and the birch-stems form a sort of veil of white mist over the marsh below the purple distance.

There was a slow ascent along the river Birá, up towards the water-parting between it and the little river Khingán, which flows into the Amúr. A tunnel, 1400 yards long, has been made through the highest crest here. Before reaching it we stopped to lunch at 392 


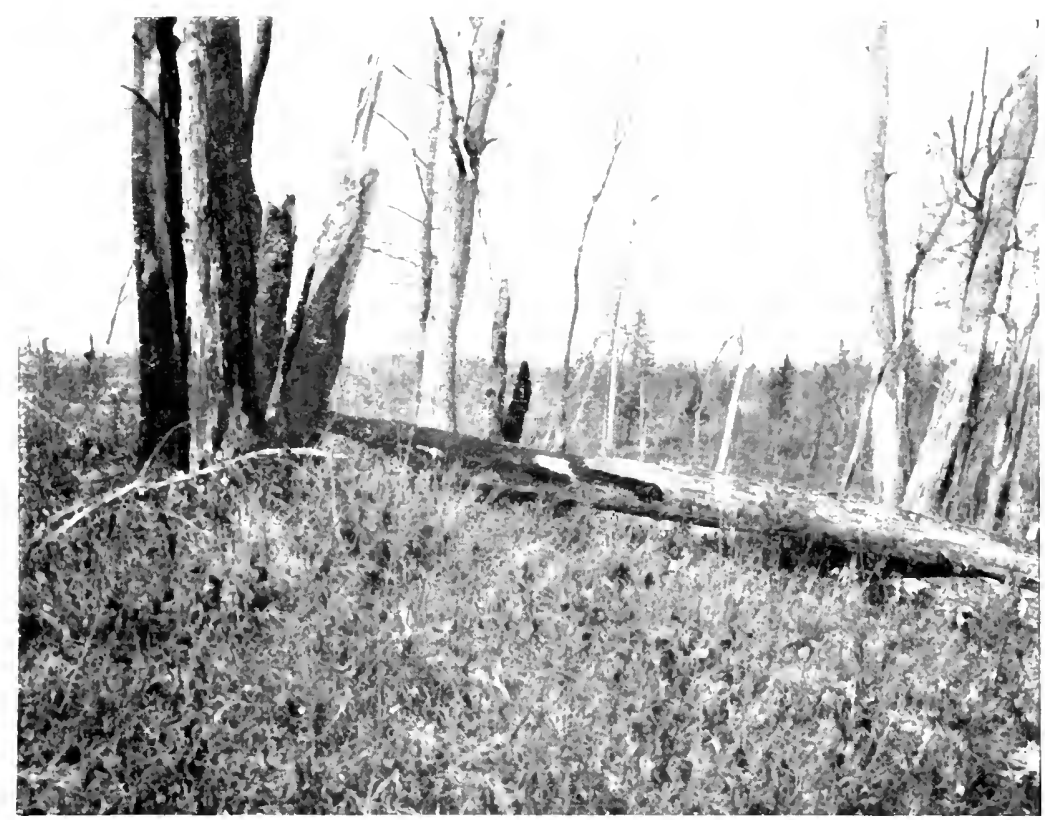

IBRST IUREAT NEAR THE KAMENUNHK I (UT, 9)

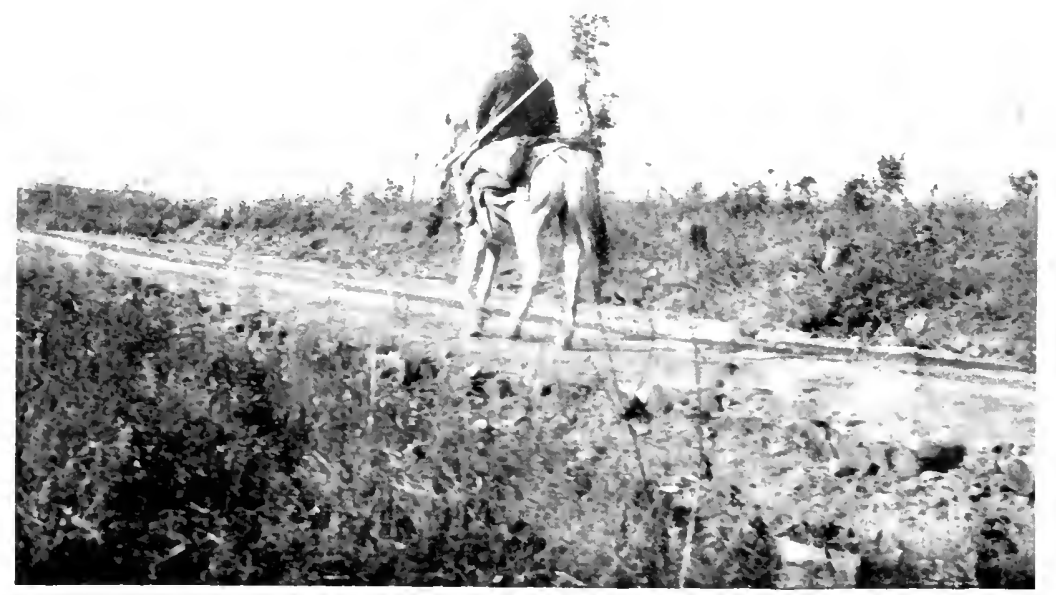

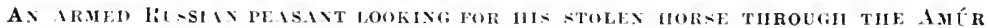
COLNTRY (UCT. 10) 


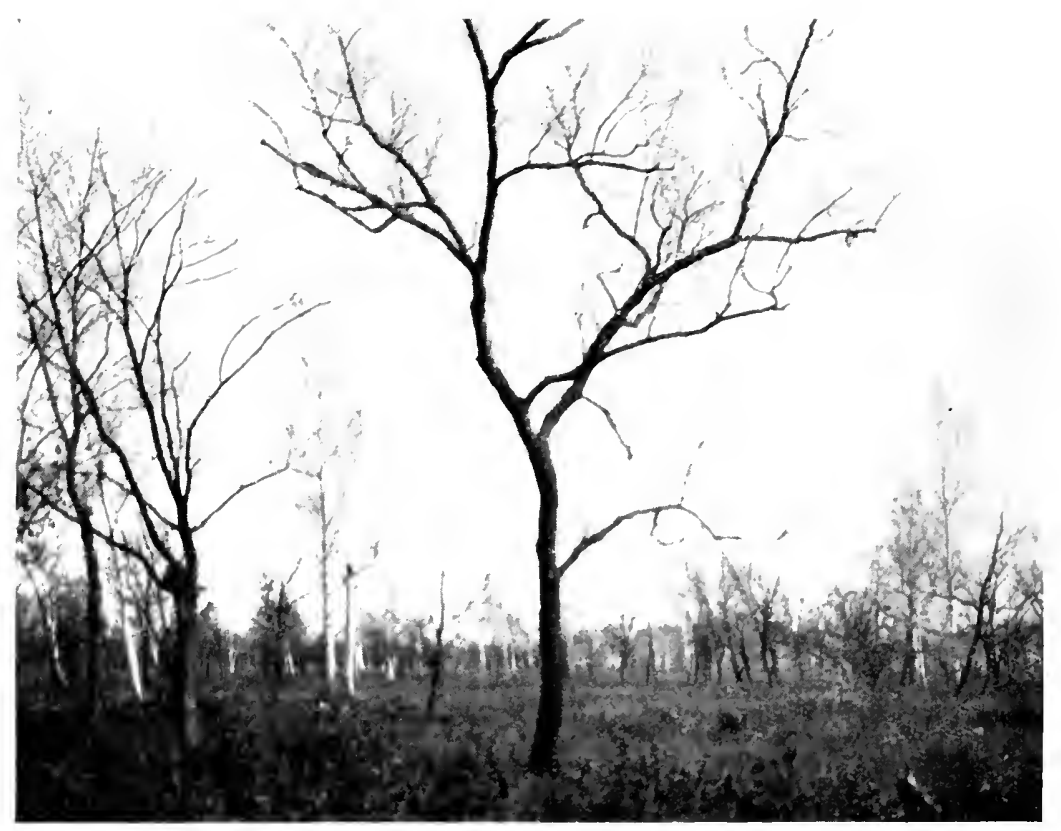

BiLACK AND WIITE BIRCIIES (GCT. 11)

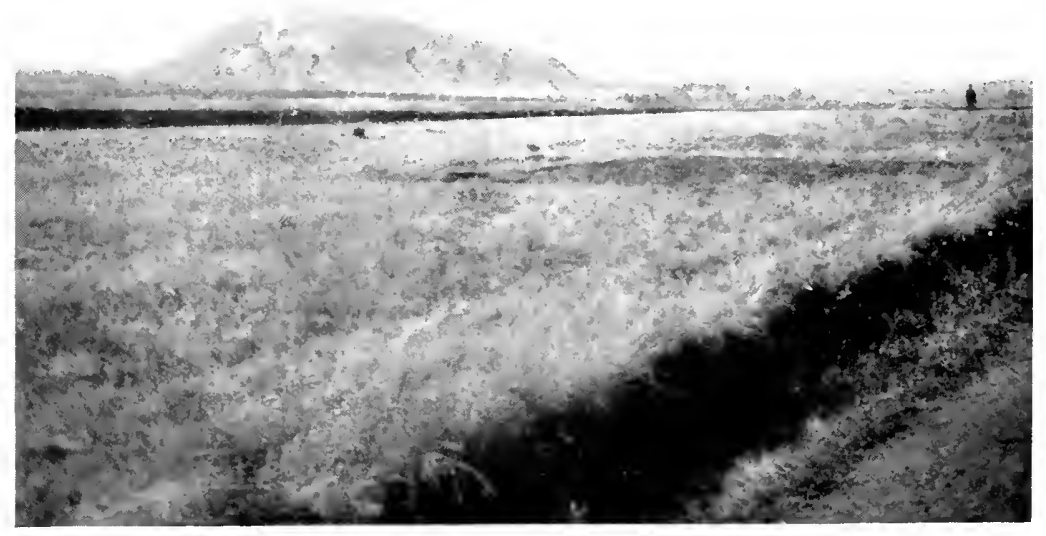

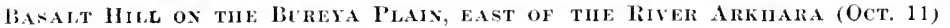




\section{THE AMÚR DISTRICT AND AMÚR RAILIVAY}

Kimkán station on the little river of the same name (i.e. the golden river), which falls into the Birá. This station stands about 850 feet above the sea. The soil here is often permanently frozen to a depth of 26 feet, and only 3 feet or so on the top are thawed in the summer, where the land is in its original state; but where there is cultivation, it thaws for at least 6 feet, and in course of time it will thaw altogether, they hope. On the level below the station they found first 3 feet of moss, below that 10 feet of peat, then 6 feet of pure ice, and below that again peat, which was frozen to a depth of 26 feet from the surface. The slope above this bog is drier and less frozen, and there potatoes and oats are now being grown, and all kinds of vegetables-indeed, beautiful flowers, and even maize, grow here in the garden. All this is the work of one year.

The ridge traversed by the tunnel is formed of porphyrite, which, however, contains such a quantity of china-clay that it turns perfectly white as soon as it is exposed to the air. At a distance it looks like shining marble. The interior of the tunnel is not frozen. During winter the frost in the ground does not extend more than 6 feet below the surface, and at this depth the temperature remains at about freezing-point the whole year round, from what the German engineer told me. But farther within the tunnel, at about 230 feet below the surface, the temperature was much higher. The engineer asserted that it was as high as $7^{\circ} \mathrm{C} .\left(45^{\circ} 6^{\circ} \mathrm{F}\right.$.). There is porphyrite everywhere in this district; whereas farther east, beyond the river Kamenushka (i.e. stonebringing), from which we had come, the rock was a loose gneissic granite, which weathers rapidly in the open air. To the west of the tunnel the railway descends again somewhat, but here deep hollows occur, across which the line is carried by huge embankments 80 feet and more 


\section{THROUGH SIBERIA}

in height. The embankments are built of stone and gravel from the cuttings. This is an imposing piece of engineering.

Friday, October 10. A little farther west there is a smaller tunnel, called the "little tunnel," only about 300 yards long, through another ridge, near the station of Obluche. This also goes through porphyrite, but of a somewhat harder, more quartziferous kind than the last. This tunnel is remarkable for the fact that the mountain is everywhere frozen to a depth of more than 250 feet below the surface. The temperature within the mountain has risen since the opening of the tunnel. The first winter it was found to be $-8^{\circ} \mathrm{C} .\left(17 \cdot 6^{\circ} \mathrm{F}\right.$.) a few yards below the surface; it has been constantly rising since then. We now found $-0 \cdot 3^{\circ} \mathrm{C}$. $\left(31 \cdot 5^{\circ} \mathrm{F}\right.$.) in a side level, about 130 feet below the surface, and at a depth of about 200 feet it was something like $-0 \cdot 1^{\circ} \mathrm{C} .\left(31 \cdot 8^{\circ} \mathrm{F}\right.$.). Such conditions of temperature are not found anywhere else about here; as a rule the soil is not perpetually frozen in this district, and in winter the frost only extends about 6 feet into the ground. The low temperature in this tunnel must be due to the disintegration of the rock; it is split through, sometimes with great open crevices, to depths greater than those which are reached by the tunnel. Refrigeration must take place in the following way: the cold, heavy air sinks through these crevices in winter, cooling the rock to low temperatures, and the water that has penetrated into the crevices freezes; while, on the other hand, the warming of the surface by the sun's rays in summer penetrates very slowly, and the warm air that is then formed in the uppermost part of the crevices cannot sink, as it is so light, so that the heavy, cold winter air remains throughout the summer in the depths, in any case to a great extent, where there is no draught. In this way a sort of ice-cellar is formed 394 


\section{THE AMÚR DISTRICT AND AMÚR RAILWAY}

down below, and the temperature remains permanently low, summer and winter. The disintegrated rock is also a bad conductor of the internal heat of the earth, which comes from below. Similar conditions are familiar in Norway in old mine-workings that have been closed, so that there is no longer a through draught; ice may be found in them all the year round. This is the same phenomenon of which the farmers of Hardanger take advantage, in making what they call their "kallhöl," which are caves dug in the talus of the mountain side. It freezes all through the summer in them, so that food can be kept there. This must be due to the cold air sinking through among the stones of the talus in winter and freezing the water below, while the warm air in summer has no power to penetrate downwards.

This tunnel that we walked through here was splendidly frosted everywhere. The walls of the sidelevels and the crevices were entirely covered with rime, so that they shone like the whitest marble in the light of our lanterns. The completion of this tunnel will be attended with great difficulties; the concrete cannot be poured in at the present temperature of the walls; the tunnel must therefore be warmed ; but what will happen then, will not great pieces of rock come falling down, as soon as the ice melts in the crevices? Yes, there are difficulties enough in work of this kind, and they have to be considered in advance, before the accidents happen.

Farther to the west the hills decreased in height and descended towards the rolling, grass-grown plains, encircled by wooded and slightly rising ground. On one of these wide plains lay the Cossack village of Esaulovka. It undoubtedly had good corn land, if it were only ploughed; but such enterprise is not to be expected of the Cossacks; they content themselves 


\section{THROUGH SIBERIA}

with cutting the hay required for their many horses, and for a few cows-we saw haystacks along the plain -and for the rest they live by hunting. Later in the day we came to Kundúr station, where the engineer, Skugarevsky, lives in a comfortable home, with a pretty garden and even a playground and swing for his children ; and the year before it had been all bog here; the German engineer told me that eighteen months ago he and his horse had stuck fast at this place and had been unable to go on. Now carrots, beetroot, potatoes, tomatoes, and even water-melons were being grown in the open air. It must be added that only two of them had ripened more or less, and we had one of these for lunch; but we were told they had been planted too late.

After an abundant lunch we went on again and gradually ascended towards the longest tunnel on the line, through the western ridge of the Little Khingán, or perhaps more correctly a separate range somewhat farther west. The tunnel is 1600 yards long, and runs through mica-schist. After going through a kilometre of the tunnel, which is not yet bored through, we went up over the ridge in the car, and then downhill again at a wilder pace than ever; the ruts were frozen, but had thawed a little in places, so the car swung from one side of the road to the other, and now and again we were shot up into the air. I was waiting every moment to be flung headlong among the tree-stumps, and all $I$ thought about was where I should prefer the stump to catch me. But nothing happened after all. When we had got to the bottom and along a piece of level road, we had to go up another hill and the gear was changed; but then the car refused to do any more ; the engine simply raced and we stood still. One of the gear-wheels had stripped; it would take four hours to repair it, and there was nothing to be done 396 


\section{THE AMÚR DISTRICT AND AMÚR RAILWAY}

but to wait for the armoured car which was following. We waited and waited, but it did not appear. It had been just behind us on the crest of the ridge. Time went on, it grew later and later. Then a man came by on horseback; he was asked to ride back and look for the other car, and then to fetch the horses and carriages which were following us as a precaution, in case of accident.

At last a troika arrived; the armoured car had broken a spring. So both cars were disabled at the same time; but this was not to be wondered at on such a road. Then another troika came up, and we went on with horses. Even then the pace was not very slow; the horses trotted or galloped incessantly; but now we were used to more speed and thought horses a slow means of progression, even at a gallop. I drove with the German engineer, Ratijen, who is in charge of the work on all these tunnels and has great experience in the boring of tunnels, as he has had a share in such work in Switzerland and elsewhere. We then passed the same man on horseback who had fetched the carriages for us ; he was a Russian, with a rifle slung on his back and bags hanging over his saddle. He told us with imprecations that he was out searching for his horse, which had been stolen by some smugglers. It seemed a somewhat hopeless task to look for a horse in this widespread country with its boundless forests.

The German engineer had much to say about the safety of the roads here, and about these smugglers, who carry on an illicit liquor traffic with the labourers, besides any kind of thievery that may offer. About six weeks before a contractor for one of the tunnels had been shot here in broad daylight. On going away for a few days he had been so unwise as to say that he would pay the labourers when he came back. It was thus clear 


\section{THROUGH SIBERIA}

that he would return with money on him ; so they just waited for him and shot him down in his carriage. The driver did nothing, whether it was that he was in league with the ruffians, or that they had threatened his life, he simply made off. The contractor had 3000 roubles in a breast-pocket inside his waistcoat, and 1000 roubles in a side pocket. The scoundrels found the latter sum and took it, but they did not give themselves time to make a further search before escaping to the woods.

These were perhaps the same ruffians who on the following day attacked two labourers on the open road near the houses. They knew that one of them had received his wages. They hit this man on the head with a stone to get him to say where he had the money; but it so happened that he had given it to another man a little while before. Then they were disturbed by somebody coming, and with an excuse for their mistake the villains jumped into their carriage and drove away.

A year and a half ago a small tradesman, who had been carrying on business here, was going home to Russia with his wife and children and his savings. At the farewell party the evening before starting he probably boasted a little too much about this money of his. A few days later he and his whole family were found murdered on the high road, and the money was gone.

It scarcely ever happens that these scoundrels are captured, as no one will venture against them; anyone who did so would be pretty certainly made an end of. They have been known to shoot in broad daylight one of the excise police, who have specially to deal with liquor smuggling, and are therefore the chief objects of their hatred; this was on the way to the station, with plenty of people about.

Next morning we were able to proceed by motor-car. 398 


\section{THE AMÚR DISTRICT AND AMÚR RAILIVAY}

We had now begun to leave the mountains behind us. The forest vegetation of the plain is mostly white birch and black birch. The white birch is fine and slender, with thin branches; the black is more vigorous, with spreading, gnarled branches, often more like oak, and its spread of foliage is broader. Then there are some oaks among them here and there, and on the heights the forest is generally nothing but oak.

The last tunnel in this district is at Ganukan, and it runs through a ridge consisting of gravel on the top, then sand with clay, and clay with sand in alternate strata, which may change within a few inches from coarse sand to fine sand, or to clay, and then to sand again; the strata are sometimes very thin, and may vary in thickness as they go. They must be river deposits, and the ridges of the same kind, on both sides of the broad, flat hollow to the west of the tunnel, seem to have about the same uniform height. These extensive strata may be supposed to have been deposited by a great lake which covered the whole Buréya-Séya Plain westward, at a time when the Amúr had not yet excavated its bed so deeply through the (Little Kinghán ?) mountains on the east. They must have been deposited near the shore of the lake, by rivers flowing into it; the frequent variations in them may then be explained by variations in the quantity of water brought by these rivers, which again was dependent on precipitation. After the waters of the lake sank, as the Amúr dug its channel deeper on the east, these deposits were excavated by smaller rivers which have formed the broad flat valleys we now see; and ridges came into existence like that through which the tunnel runs. Fresh-water shells have moreover been found in these strata. 


\title{
CHAPTER XVIII
}

\author{
FROM THE BURÉYA TO TRANSBAIKALIA
}

The Buréya-Séya Plain : On the Buréya : Abrupt variations in the water-level : Naming a station : Fertile soil but unpractical working : Curious effect of frost : On the Séya : A new town, Alexéyevsk : Hill country from the Séya to Transbaikalia : Gradual ascent : The forest : No sign of an Ice Age : We run over a man : Gondatti Station : Men's changing destinies : A dreary country : Storms and forest fires : Taldan : A spring and frozen soil : Origin of layers of ice in the soil ; Prisons in the forest : A dismal country, but gold everywhere : The Nuksha : Agriculture and cattle : Storms and forest fires : A wrecked train : Across the border to Transbaikalia : The Amasár : Convict labour and prisons : The highest point of the Amúr Railway : Rich gold-mines : Chinese allowed here : The Black and the White Uryúm

\section{THE BURÉYA-SÉYA PLAIN}

TIIERE were still undulating hills for some distance, 1 but they became lower and lower. And then all at once we found ourselves on the last ridge, and the plain of the Amúr lay before us, perfectly flat and immense, stretching as far as we could see, to the skyline on the north-west, and on the west to the blue hills far, far away on the other side of the Amúr, in China. It is the great Buréya-Séya Plain that we are here entering upon, and the railway now crosses it for about 150 miles north-westward to beyond the river Séya. As we drove on hour after hour, we saw cultivated fields with wheat in many places; there is good cornland here. Then a great rock, or round knoll, rose in 400 


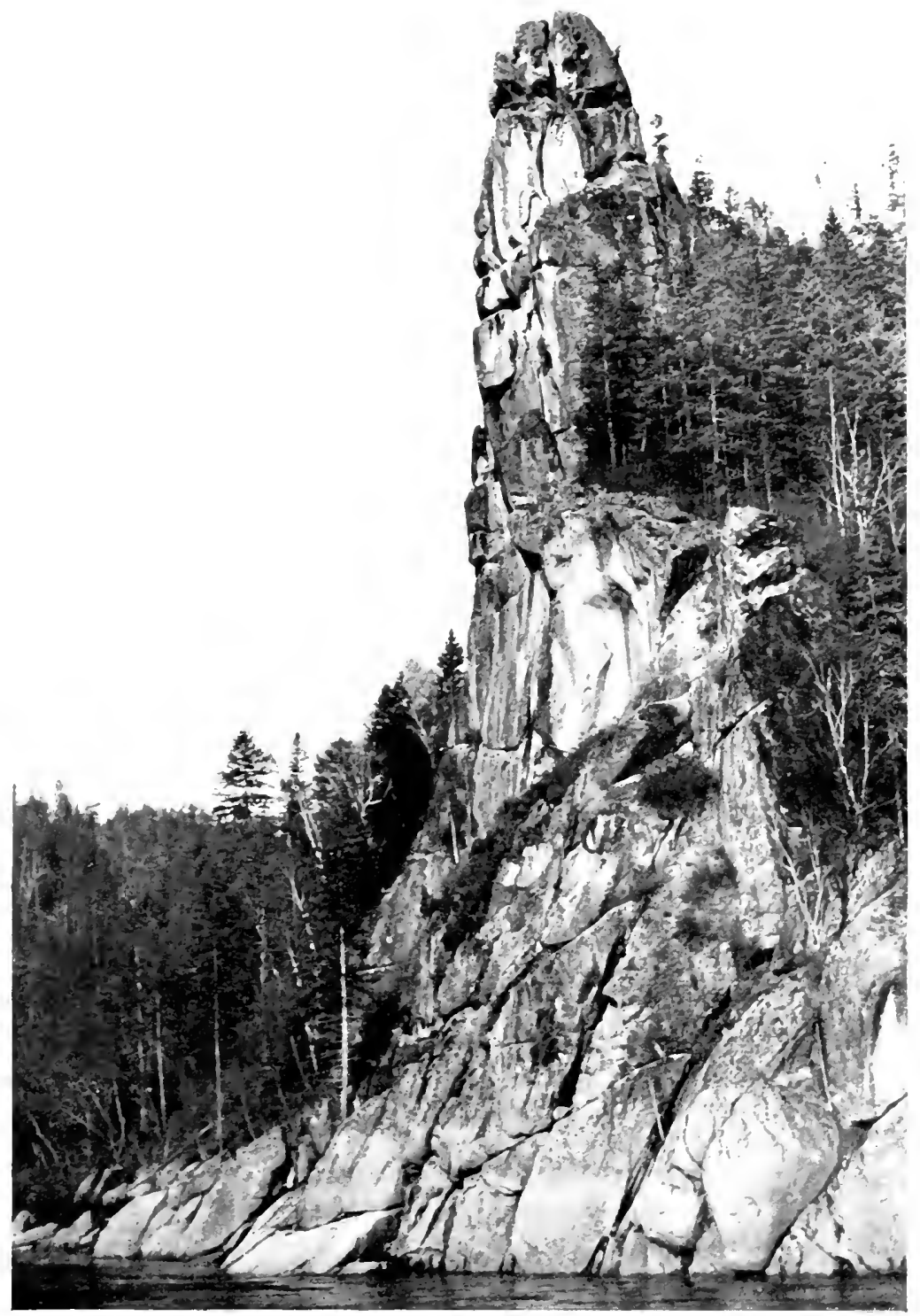

CLIFF OS TIE BCREYA RIVER WIERE, THF GOLD-MINER MIFD 


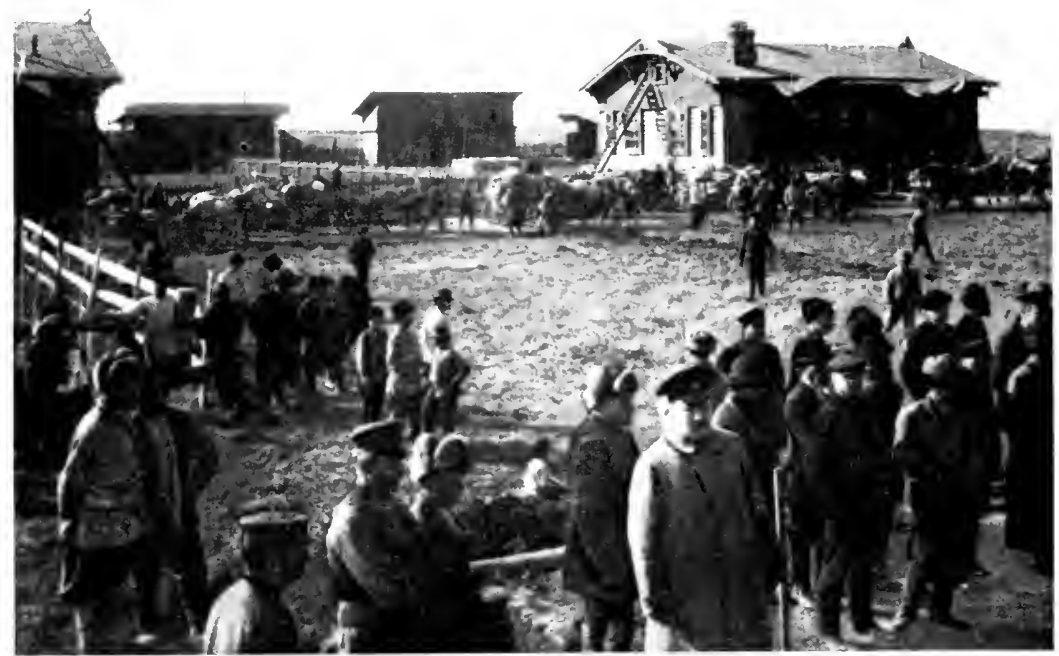

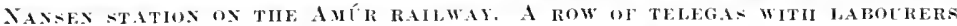
RETURNIS: HOME PASANG TIIE STATHON (UCT, 12)

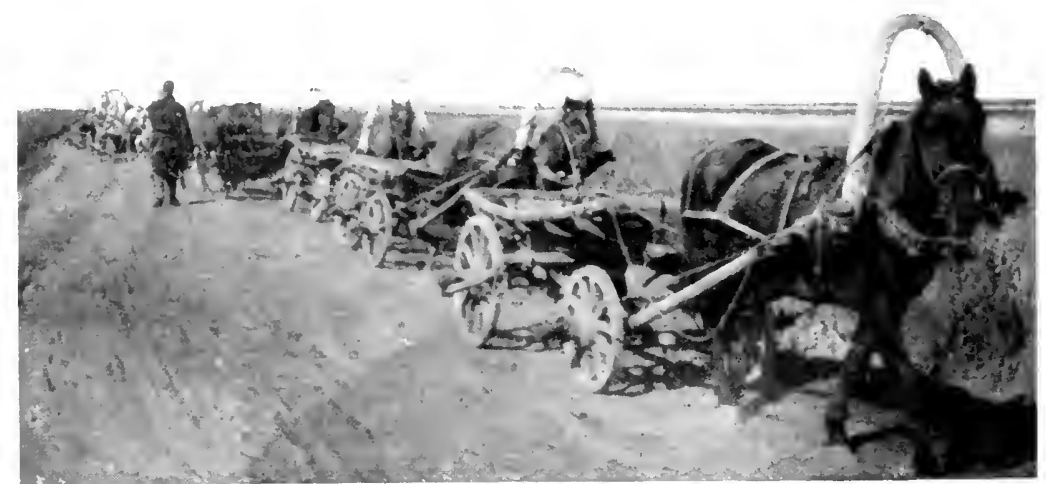

TEIEGAS RFTLRNING AFTER TAKING LABOCRERS HOME (IORSES SIIING AT OUR MOTOR-CAR) (OCT, 12) 


\section{FROM THE BUREYA TO TRANSBAIKALIA}

front of us; it was an outcrop of basalt standing by itself in the midst of the flat plain. The basalt had come up through a crack in the earth's crust, and from this little hill stone is being quarried for the work on the tunnel at Ganukan. The stone is hard and good, they say.

Late in the afternoon we arrived at the Buréya, the great tributary of the Amúr. Here we had to part from the motor-car and cross the river in a boat. The bridge, 600 yards long, is to be finished next year, but all we saw was some holes in the sand for the first pier. There was a big town here, with life and activity on every hand. Tradesmen have built their shops and stores, and a year and a half ago there was scarcely a house.

At sunset we made a trip up the river by a branch line leading to a quarry. There was fine scenery with hills on both sides and rich vegetation. Then came a glowing sunset, and after that the moon, and it was fully night before we came back. Much gold has been found on the banks of this river above here; but it often runs through ravines with sheer cliffs in a wild mountain country. A little way from here there is a lofty peak which rises abruptly from the river-bank. There is a story that some time ago a party of goldminers, who were descending the river in a boat, were wrecked at the foot of this peak. Their boat was dashed against the cliff by the rapid stream and smashed; they barely succeeded in saving themselves, but lost their food and everything else and had no means of going on ; the marshy forest is quite impassable. They starved to death; but before they died they scrambled right up to the top of the cliff to look for the possibility of help, and on the face of the rock below the summit they had scratched something about the 


\section{THROUGH SIBERIA}

rich finds of gold they had just made farther up in the mountains. But no one has since found that gold.

That night I was the guest of the engineer, Barkovski, and his amiable wife. Barkovski, who is superintending the building of the bridge over the Buréya, showed me some remarkable curves of the water-level in this river. After heavy rainfall in the mountains above, it may rise 6 feet or so in a few hours, and the rise occurs so suddenly that it is liable to be dangerous. In April last the river rose nearly 23 feet in a few days, and then fell again even more rapidly. It is obvious that in such conditions bridge construction is not easy, and the work has therefore to proceed in the winter for choice, when the water-level is constant and the frost can also be turned to account. A river with such a powerful stream and subject to such great floods will naturally have great excavating power, and thus it often runs through such deep ravines higher up.

Sunday, October 12. We had now come so far that the railway line westward was to a great extent finished, or at any rate could be used, and from the Buréya we went by train for a while; but then we came to a place where the rails were not yet laid, as they were short of them, and we had to go on by motor-car again over the plains to a new station, from which there was a train. Here, then, we were to say good-bye to our kind hosts of the Buréya, but the farewell in the railway carriage looked like being quite a solemn affair; all the engineers were present, and the engineer of the Buréya section, Mr. Alfred Augustovich Klare, made me a speech in German, in which he said that after travelling through the Amúr District and seeing the construction of the new line and viewing this great country, I had now arrived at the track which without interruption, except at one or two bridges, would carry me all the way to Petersburg; 402 


\section{FROM THE BUREYA TO TRANSBAIKALIA}

and that they would like to commemorate the occasion of my journey by naming this station after me. This was a complete surprise, and I could only thank them most heartily for this great and unexpected honour. It was a nice little station, lying on the plain in the midst of a fertile and partly cultivated country.

Then we went on again by train. Here we often saw fields of wheat as far as the eye could reach. Judging by the quantity of corn cut, it must be good, rich soil, and this gave a picture of what these great plains may become in the future. By degrees many villages have appeared along the line here, but the distances between them are great; and it must often be four or five miles from the villages to the fields, so that the people have to walk or drive all this way to their work in the morning and back again in the evening; to a foreigner this seems a meaningless waste of strength. But they probably find it safer in this country to live together than to be scattered over the plains; only rarely could I see a solitary hut by the roadside.

The engineers here gave me a very remarkable example of what the frost can accomplish in winter. A new bridge was built on wooden piles which were driven into the mud, but as the depth was great, the piles had to be joined. When the engineers returned last spring, the bridge was twisted quite out of the level; some of the piles were raised 12 inches. When they were dug out it was seen that ice had formed in the joints, forcing the balks of timber apart and forming a column of ice of the same section as the pile and 12 inches high. This must have happened through the water finding its way into the joints, where it froze, expanding as it did so and thus forcing the balks apart. But then the temperature of the ice was further reduced, and it contracted again. A small interstice was formed, 


\section{THROUGH SIBERIA}

where fresh moisture could penetrate, freeze, crystallize out again, expand, force the balks still more apart, and then contract on further cooling, leaving space for more water, and so on. On the sides round the ice the moisture may freeze in a similar way ; but as the frozen soil surrounding the hole offers too great resistance, the ice cannot expand in this direction, but must press upwards where there is less resistance. Iron bands had been placed over the joints in the piles, and these were attached with nails, which had naturally been forced out by the expansion of the ice; but these bands had, nevertheless, prevented the piles from sinking again when the ice contracted after freezing, and in this way fresh interstices were constantly formed.

Then we left the main line to follow the side track which runs down to Blagovéshchensk. This, the largest town in the Amúr district, stands at the confluence of the Séya and the Amúr. We did not go all the way down to the town; we only had to look at a bridge that is being built over the Séya a little above it. On the way there our carriage caught fire from sparks from the engine, which was burning birch-wood and sent out a regular shower of sparks. We had to tear open the sides of the carriage and put it out with water, as the fire had got in between the double planking. Then we reached the broad and beautiful Séya. The sun was just setting as we went aboard the paddle-boat, which had been built on the river here at Blagovéshchensk. There was a deep-red glow over the western bank, but dusk came on apace, the moon in the east increased in power and threw its pale reflection on the river, and the electric lights on the piers of the bridge twinkled against the darkening sky and sent their streaks of light over the water towards us. A lovely, warm evening - mild, soft air, as though it were summer. 404 


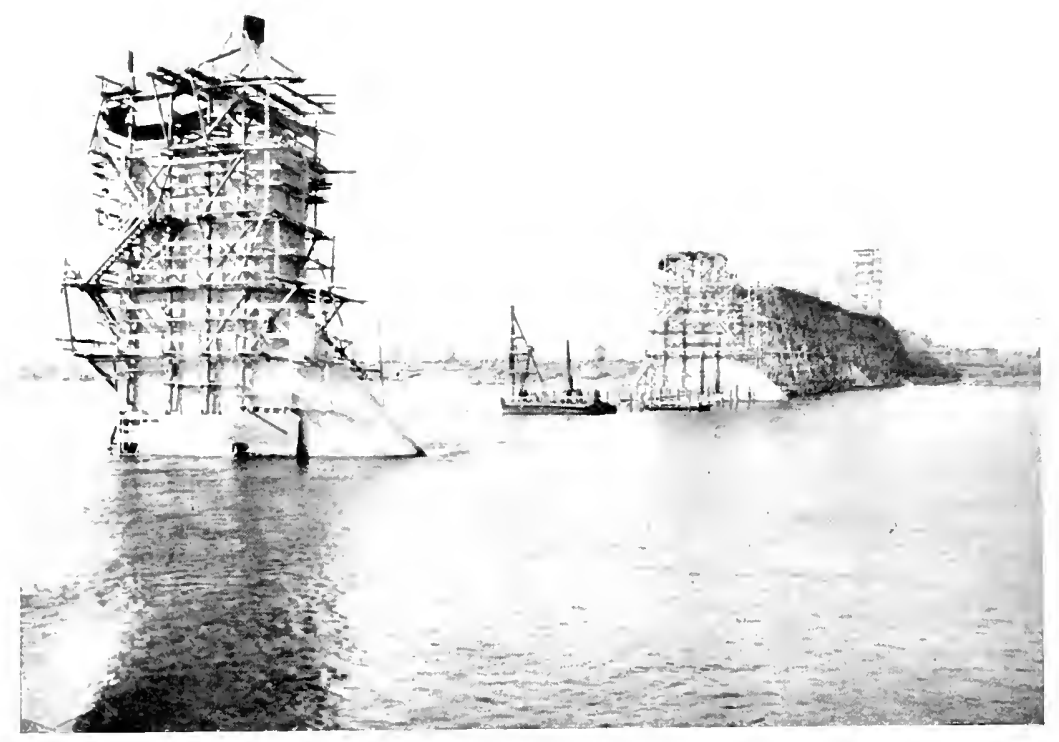

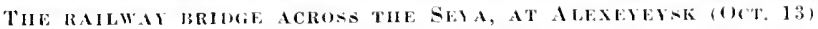

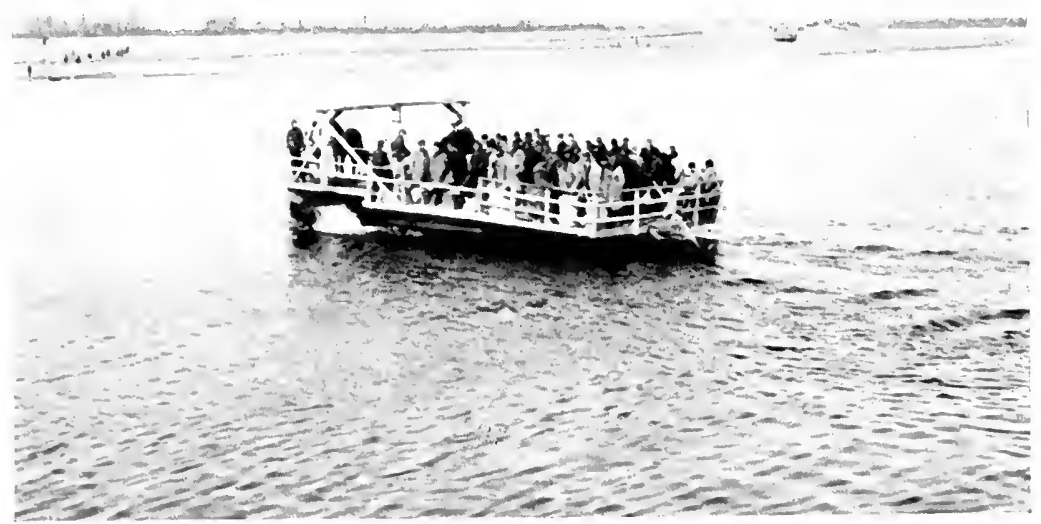

FERRY ACROSA THE SETA DRIYEN BI HORAE-CAPSTAN (OET. 13 , 


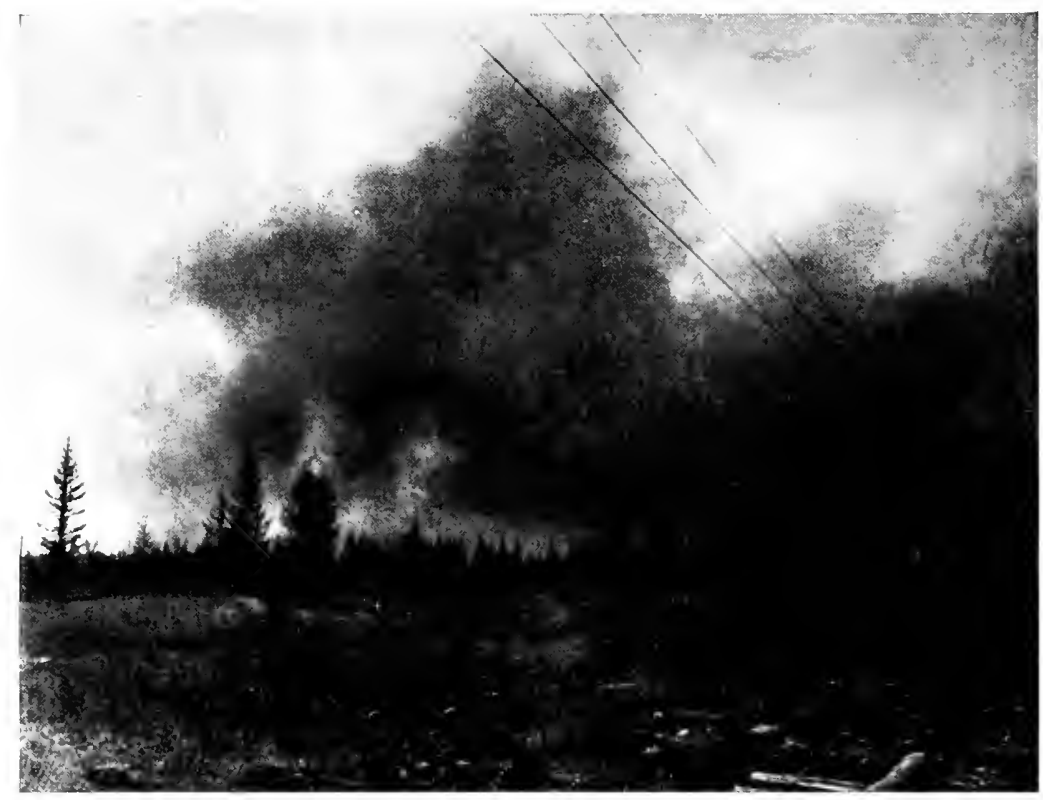

FOREST FIRE IN THE AMÍl COUNTRY

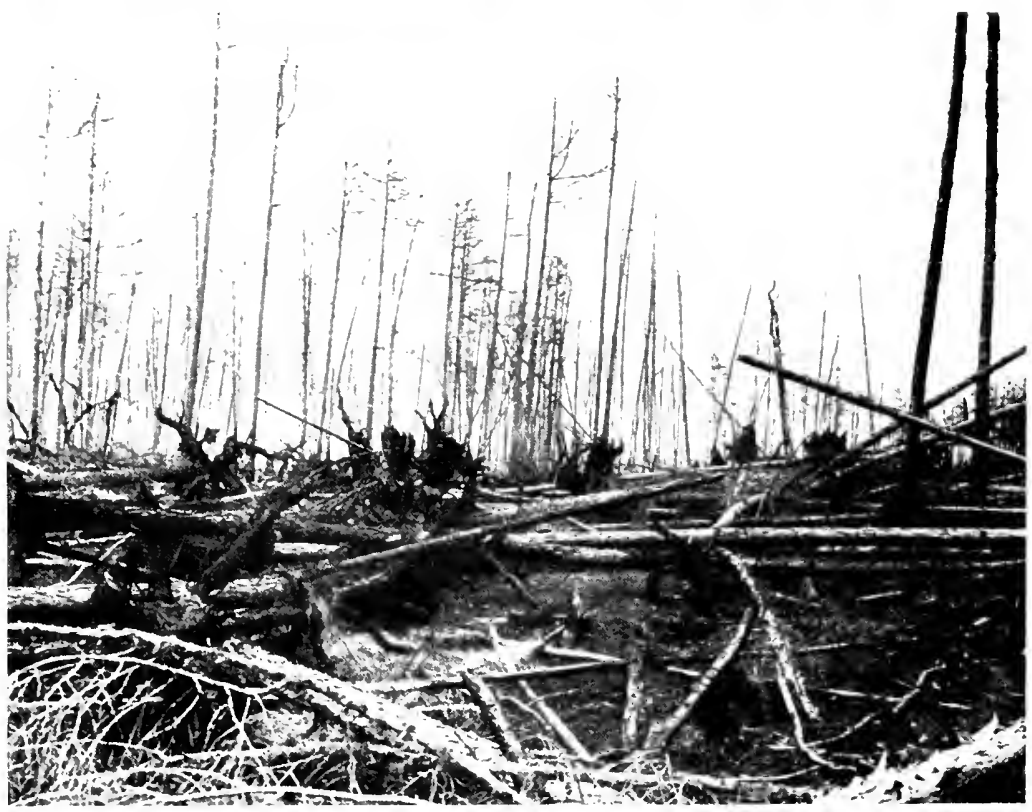

TREE FELLED BY STORM IN THE AMÚR COUNTKY 


\section{FROM THE BUREYA TO TRANSBAIKALIA}

We were now to go up the Séya in the steamboat until we reached the main line again, but we had to take in birch-wood before we could get away. There must be a great traffic here; during the short time we lay waiting, no fewer than three large steamboats went by, two downstream and one upstream, towing a big lighter. They steamed past, these boats, with rows of bright lights and lanterns and skylights reflected in the water, and it was a fantastic sight in these surroundings where, after the great uninhabited expanses, we seemed suddenly to have come into the thick of active life. The captain said there were 300 steamboats running here on the Amúr and its tributaries.

We have an uncommonly entertaining doctor with us for this part of the journey-Gusakovski, doctor to the railway. He tells me all kinds of things about the life here, but, as I have said, I do not understand a word of Russian, and he has not many words of any other language, so our conversation is carried on in an extraordinary fashion. On introducing me to the old captain, he said : "Altus mare lupıs"; he was right, our skipper was indeed an "old sea-wolf" of a Finn, who had been going up and down the Amúr here for seventeen years, ever since he brought out the first boats from Finland. But now he was tired of these fresh-water voyages between the "sand-dunes," he said, and was longing for the salt sea again; and he would soon give this up and go home to Finland.

The river was well marked out, with red lights along the western bank and white ones on the eastern at night, and I was told there were also good marks for the daytime. But this was quite necessary; for there was no mistake about its being a winding course, with bends and turns and sand-banks everywhere; the river wound in a succession of S's among these banks and when we 


\section{THROUGH SIBERIA}

least expected it we saw them lying dry in the moonlight by the side of us. In addition to this, it was almost impossible to steer properly. The vessel was constantly sheering in the changing stream, so that she was often several points off her course on one side or the other, and perhaps even worse were the waves of "dead water" that swept after us straight out from the stern over all the shallow places and often broke close to us, wherever the depth was less than 5 feet. The boat herself only draws $2 \frac{1}{4}$ feet. These " dead-water waves" here are in a way the same phenomenon as dead-water waves at sea; but here the boat sweeps up and carries along with her a big wave of the water lying over the shoals, whereas at sea she sweeps along with her a wave of the salt water lying below the uppermost layer of fresh water; nor is her speed reduced to the same extent here. It is also possible that the lower layers of the fresh water are made heavier by all the sand that is stirred up into the water, and that a real dead-water wave is thereby formed below the upper layers; as a rule, however, our speed is too great for such waves to impede us much.

It was a wonderful moonlight night; but we were in a shallow and difficult fairway. As we were sitting at supper, the boat suddenly heeled over to one side and we felt a bump. We had touched the bottom, but slipped over it.

Monday, October 13. At about two in the morning we ran aground again, and this time we were stuck for a couple of hours. As a rule it is pretty easy to get these boats off again, by putting a pair of sheers over the bow down into the bottom on both sides; the head is then raised by tackles, while the boat is shifted astern. There was a glorious sunrise in the morning over the Séya, which winds along through flat country; but 406 
here, again, we see that the river has higher ground with steeper slopes on its right, or western bank, while the land on the eastern side, the left bank, is quite low, with flat beaches. The hills on the western side are wooded, chiefly fir mixed with birch. The captain says that the wood of this Siberian fir is strong, but not a good timber for building, as it is so liable to split. Here, again, the trees are rather small and far apart, and there are bare patches among them; this is due partly to ill-regulated felling and partly to forest fires.

It is a rich river that we are ascending; there is gold everywhere in the sand here; enough in some places to yield three or four roubles a day by washing, Dr. Gusakovski told me; but as a rule it does not return a sufficient daily wage; later on, higher up the river at Alexéyevsk, we saw people sitting on the shore washing gold. There were several prosperous looking villages as we went on; for these districts along the river have long been inhabited, and it was here no doubt that the Chinese had settled.

We then approached the newly laid-out town of Alexéyevsk, where the bridge crosses the Séya, and while still far off we saw its piers rising above the flat country in the sunshine. We passed first a steamer towing a lighter, then another steamer, and then a moored dredger; here again was life and movement. Elsewhere on the same river we saw a big timber-raft drifting downstream, with men steering; they had their horses and all necessary household goods on the raft, on which they lived while going down the river. That is the old way of travelling in these regions; the steamers, the railway and the dredger belong to the new age. The piers of the bridge seemed pretty nearly finished. Beyond the bridge we saw a strange kind of ferry crossing the river, full of people; it was driven 


\section{THROUGH SIBERIA}

by a horse-capstan, two horses going round and working a wheel.

A large new town has been founded here, which has been named Alexéyevsk after the Tsarevich. The central offices of the whole Amúr railway are to be situated here; we went up to look at the site which will be occupied by all these buildings; but at present only one house has been built, and curiously enough it is an orphanage for the children of labourers who have died. We went over the house; it had large rooms with immense windows, so the children will have plenty of sunlight. Only three were there as yet. The first to come were two little girls who had been there since Easter. Their father was a labourer who had killed their mother, probably when intoxicated. The elder daughter, a girl of seven, had come in before her mother was quite dead, and seen her father in the act of cutting off her head. The daughter had given an account of how it all happened. What an awful thing, and what an impression for the receptive mind of a child to carry through life. The father was in prison, and would no doubt get penal servitude. The third child was a deformed boy of three, with rickets, so that he could hardly walk; the mother was dead and the father drank. A year before the site of this house had been a bog. In another year there will be a whole town of buildings here for the management of the railway.

We went on to the new town that was laid out a year ago. At that time there was not a hut on the site; now there were broad streets with blocks staked out, boulevards and promenades, and a large park also staked out. But as yet there were few houses. We visited the school, where there were already 250 workmen's children; so many that they had to attend in two divisions, one in the morning and the other in the 408 


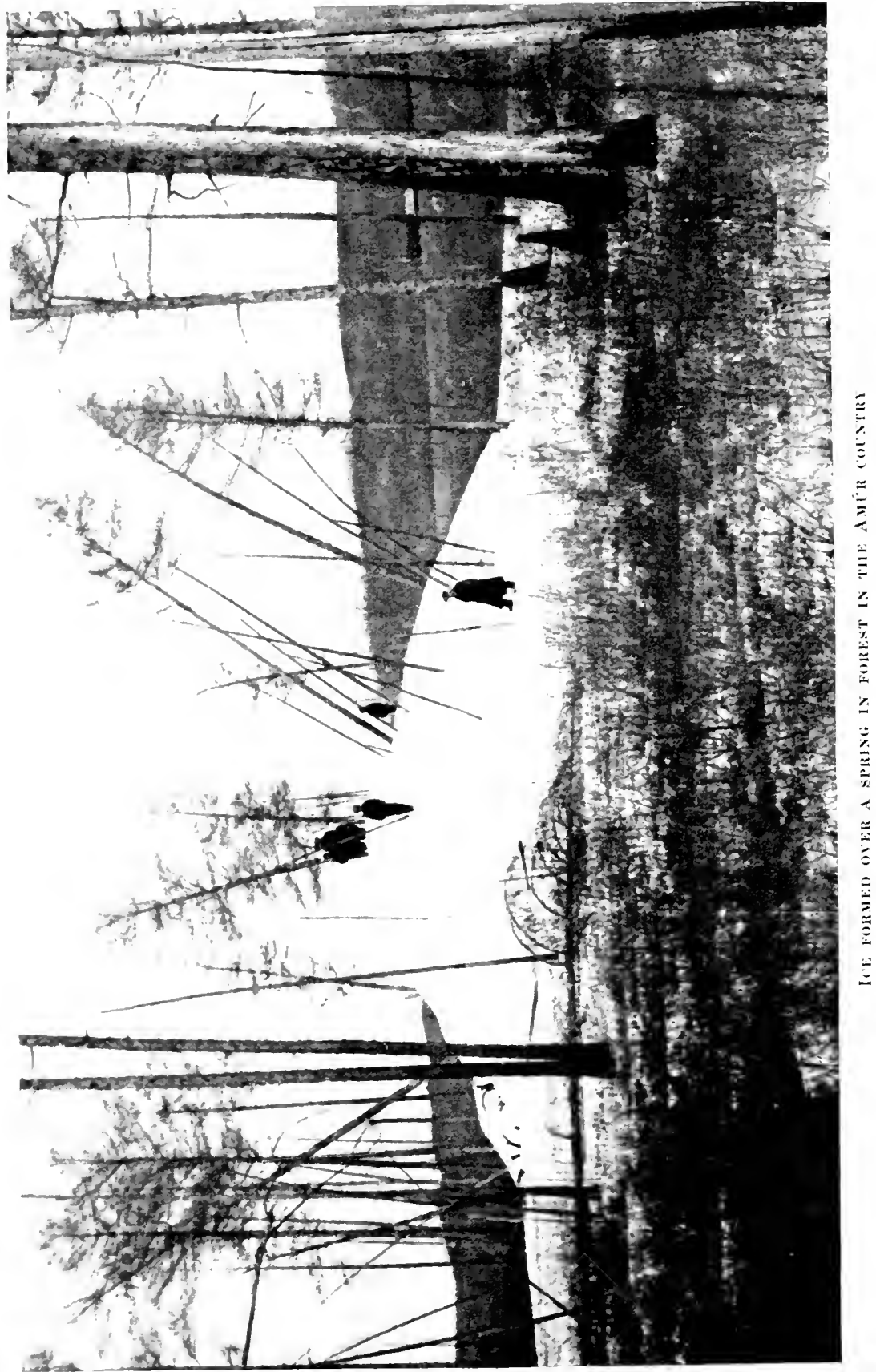




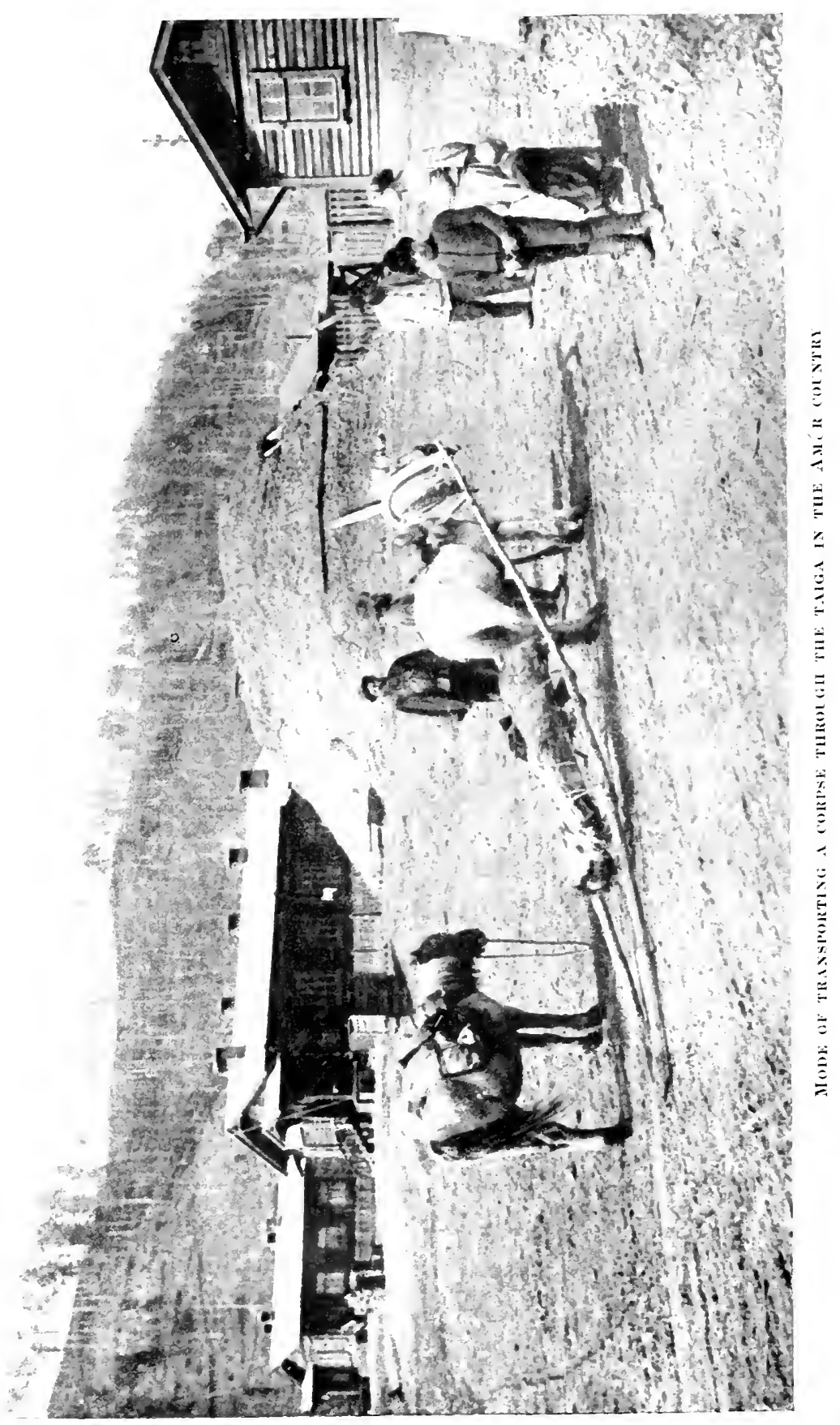


afternoon. There were three classes; the children looked healthy and strong. The town seemed to be well situated, on a flat sandy eminence; it was a good way down to the river, and this does not seem a happy arrangement for traffic; the best port is also some distance farther down; but there the land is lower and would hardly afford so healthy a situation for the town.

THE MOUNTAINOUS COUNTRY BETWEeN THE BURÉYASÉYA PLAIN AND TRANSBAIKALIA

From Alexéyevsk the railway proceeds to the northwest, about midway between the rivers Amúr on one side and Séya on the other, which latter in the whole of its upper course runs approximately parallel to the Amúr, until, a little to the north-east of Alexéyevsk, it turns at right-angles and flows to the south-west. The railway follows the highest line of flat country which forms the water-parting between the two rivers, and it ascends very gradually, at first over a wide, rolling plain, which is relatively fertile, and is what American geographers would call a typical " peniplain." The station of Gondatti, which lies on this plain, about sixty miles from Alexéyevsk, is $\mathbf{9 2 5}$ feet above the sea. The plain goes on beyond it, but ascends little by little to the higher hill country, until, after the station of Kerák, at a height of 2230 feet above the sea, the line reaches the watershed between the sources of the Séya and the little river Never, which falls into the Amúr. The line continues through hill country of somewhat varying altitude, until arriving at the border of Transbaikalia, where it ascends still higher.

The forest along this whole extent of country is fairly thin, and becomes thinner the higher we go. It 


\section{THROUGH SIBERIA}

consists chiefly of larch, interspersed with a good deal of birch, and here and there some fir and a little spruce. The trees are not big, as the winter climate is severe and there is little snow, so that the frost goes deep into the ground and takes a long time to thaw; in the higher regions the soil is perpetually frozen. In the country beyond Gondatti station, at an altitude of about 1000 feet, the conifers in the forest were scarcely high enough to make telegraph-poles, and they stood as far apart as usual. Higher up, at 2000 and 2300 feet above the sea, the trees became smaller still. They grow slowly; trees with a diameter of 8 inches near the root might be 120 years old. The hills were for the most part low, undulating ridges, with great flat stretches between them, and wide marshes, often treeless, or with larches or birches scattered singly over the ground. Here and there the hills showed a slight tendency to rise into peaks, which projected rather more boldly above the long, smooth, rolling lines. But generally there was one wooded ridge after another, as far as one could see.

It was remarkable that here again there was no sign anywhere of an Ice Age having existed. The hills and the sides of the valleys had not the typical rounded, ice-worn forms. Almost everywhere the ridges and valleys showed the forms of a country eroded by water. Nor was there anywhere a smooth, ground rock surface to be seen. And-most conclusive of all-these lofty, sharp crests of much weathered, harder rock (veins), which projected high above the flat country, could not possibly have maintained their position if there had been an Ice Age scouring the ground with its glaciers in any recent geological period. These rocky crests were often weathered in the most curious ways, which pointed to their great antiquity. 410 


\section{FROM THE BUREYA TO TRANSBAIKALIA}

During the afternoon, on our way from Alexéyevsk, the train suddenly pulled up in the middle of the line. What had happened? There had been an accident; we had run over a man. Some said that he had been walking towards the train, others that he had tried to jump across the line in front of the engine. Was he drunk ? Nobody knew. The other workmen, who had been a little way off, had not seen him coming. Poor man; there he lay, a fine, big, powerful fellow, with one leg severed at the knee and his skull fractured in two places. He was unconscious. The doctor put a tourniquet on his leg to stop the bleeding and bound up his head, but there was no hope. The arm hanging limply over the stick on which he was lying, was quite blue and cold, with no pulse that could be felt; but he still breathed. Several labourers were standing round, and some of them helped the doctor. There were women, too; but no tears or lamentation; it all seemed an everyday affair. Had he no friends then, this fine fellow? I saw a boot up on the rails, which no one had noticed; it was the severed leg lying where it had fallen, and there was ragged flesh, too, along the line. Then he was laid on a tarpaulin and carried into the train ; a man came with the severed leg, and it was put in after him. The engine whistled and we went on. Soon the laughter and talk in the carriage were going as merrily as before. But in the evening the man died. Outside the deep, calm night lay over the forest, and the moon was shining.

Tuesday, October 14. At Gondatti station, where we spent the night, we saw all kinds of vegetables, big cabbages, cauliflowers, carrots, beetroot, kohlrabi, tomatoes, etc., all large and flourishing ; they are forced there during the summer, in spite of the long, cold and snowless winter. The soil is good and the summer is 


\section{THROUGH SIBERIA}

warm, and so it can be managed, even though the soil in many places here is perpetually frozen, as soon as one digs a little way into it. But the summer appears to be rather short for corn. At a station farther on and rather higher, they had made a trial this year with oats, but they did not ripen; they said though, that, they had been sowed too late. However that may be, these plains are much exposed, winter comes early and goes late, so that it allows little time for the corn.

A strange country! A very cultivated and winning engineer gets in here and converses with interest on every kind of subject. He is quite a young man, but his hair is perfectly grey. The doctor tells me that in 1905, during the revolution, he practically had the rope round his neck and was going to be hanged in Tashkend. He was living in a little town there which had declared itself a republic, and he was suspected of being one of the leaders. He was condemned to death by court-martial. He escaped that fate by the aid of acquaintances, but what he had then gone through had made him grey before his time. He is now an engineer on the line here, and a very capable man.

We stop at a large station. On the platform a starchy prison inspector is strutting up and down in a smart uniform and shiny long boots, a regular swell, engaged in animated conversation. Three days ago he escaped as if by a miracle from a railway accident that happened a little farther on, when the train fell over a bridge.

It is a monotonous, dreary country we are going through, with the endless thin forest of birch and larch covering the plains, and the trees grow smaller as we go on. The melancholy of it !-and now it is sinking into the long, cold, snowless winter. But even this dreary scene must have its beauty-when spring comes 412 


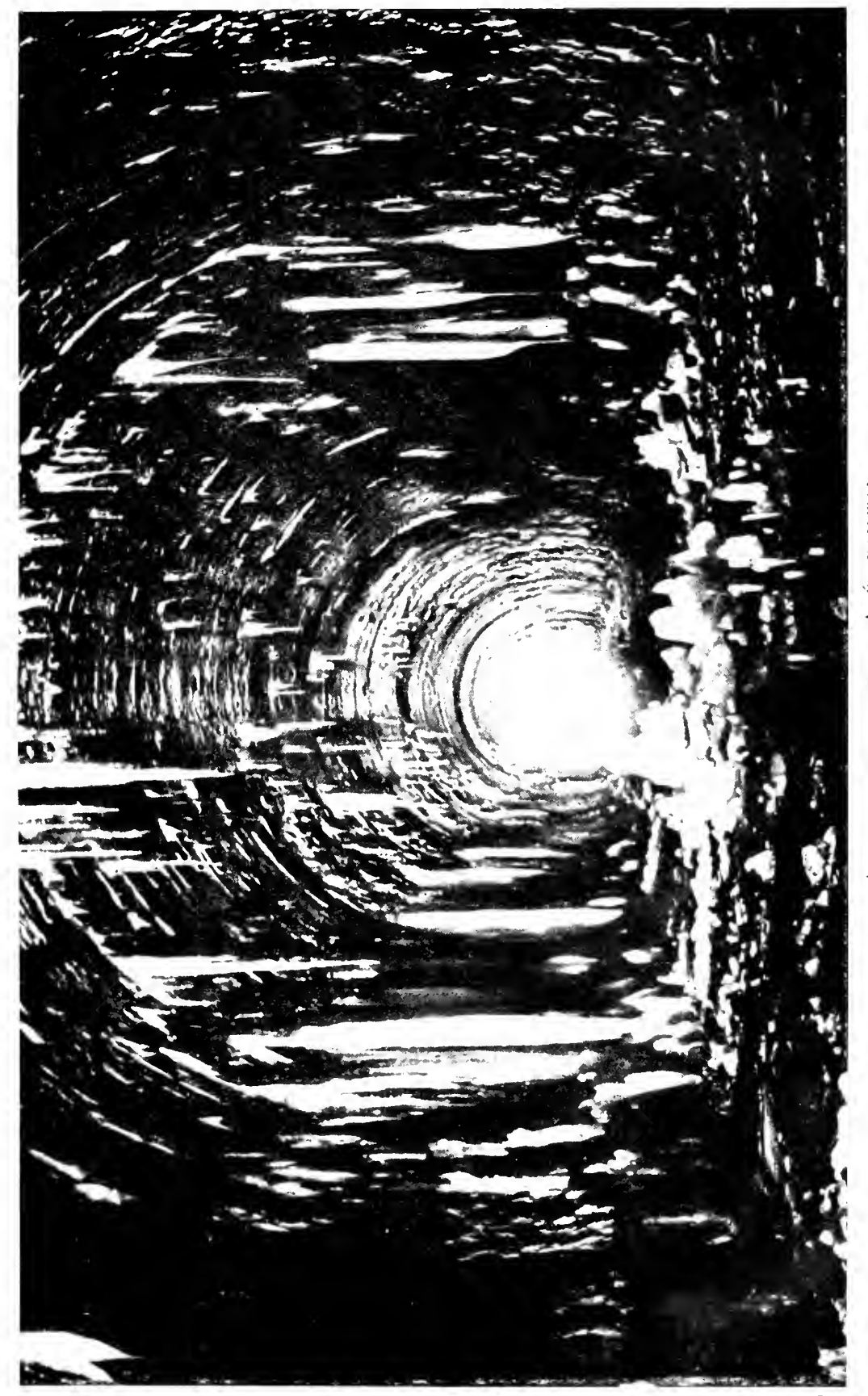




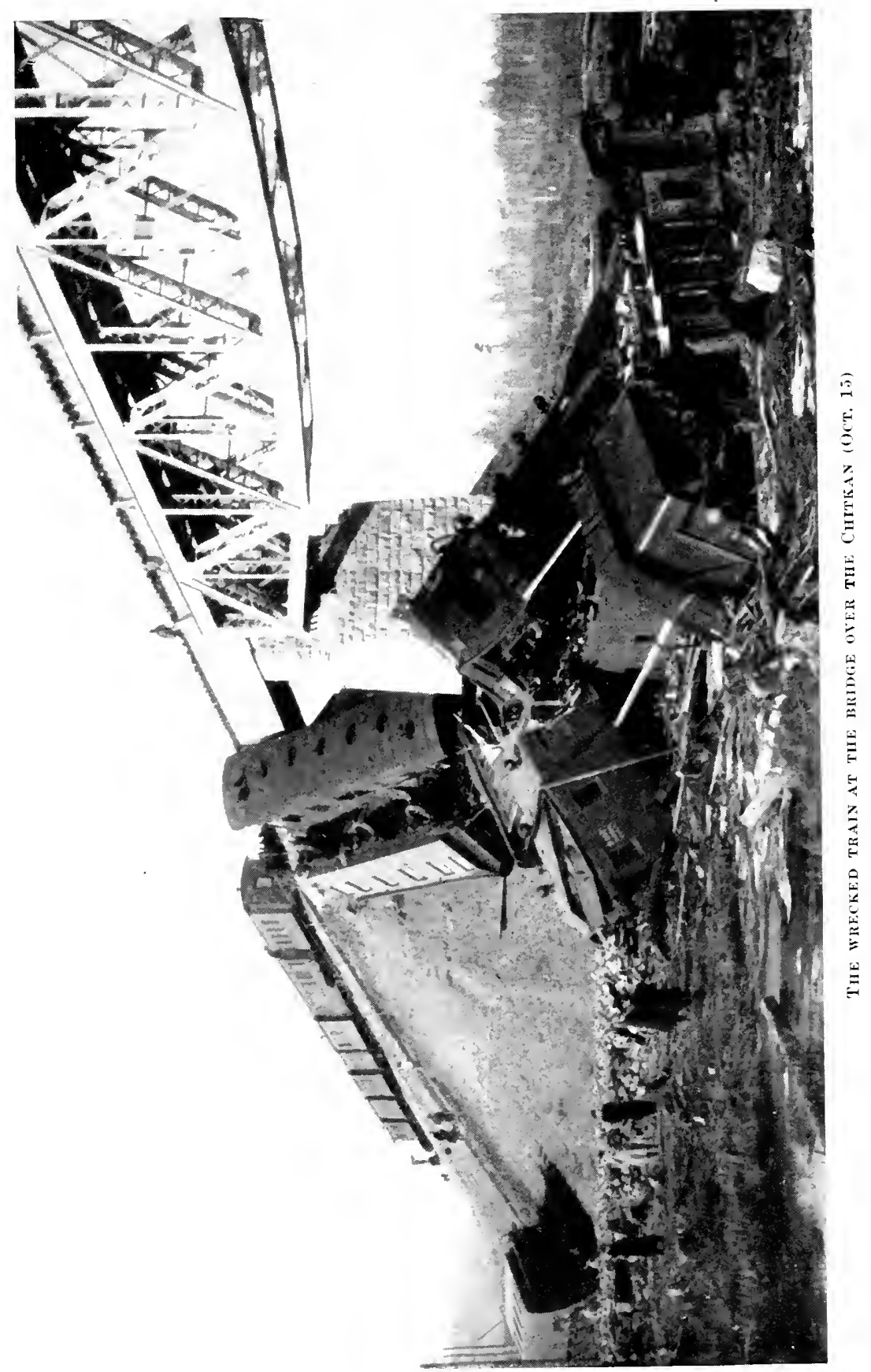




\section{FROM THE BUREYA TO TRANSBAIKALIA}

at last and the birches are shooting and the larches clothe themselves in fresh green. Ah yes !-but where in the world is not spring beautiful, with its bright, sprouting verdure, and its great promises-of what? For all that, it seems to me that here, among these thousands of slender white birches, spring must be even more beautiful than elsewhere, and must make even greater promises-which are never kept.

Great stretches of ground are covered with high birch-stems, all broken off at exactly the same height, and without branches. Were they killed by the heat, when the grass was burnt off, or was it rather the frozen soil beneath them? And then the storm came and swept away the dry tops, all at the same height. Then we come to a tract where all the birches lie prostrate, blown down by the wind. If possible, this is even more desolate and dreary. The doctor tells us that a year or two ago he was driving with horses over this stretch of country in a tearing storm. The trees were hurled down and their roots torn up for yards round. The wind is capable of laying the forest low for miles. He also tells us about the forest fires and how awkward they may be. At the end of March, two years ago, he and Miss Wourtzel, our engineer's daughter, who was a doctor at Blagovéshchensk, were driving with a troika between that town and Alexéyevsk, when they were caught by a forest fire. It was in a forest of oaks, where only the dry leaves burn, while the trees themselves remain standing, and the fire runs on from tree to tree at a rate of six miles an hour. They saved themselves by driving into a pond, where they stopped with the horses while the fire went past them. It whistled and howled like shrieking voices; but it only lasted a few minutes and then passed on; meanwhile, the smoke nearly suffocated them. 


\section{THROUGH SIBERIA}

In the evening we arrived at Taldan station, where we were to spend the night. We had now come up on to the high ground and had reached an altitude of 1463 feet above the sea, whereas Gondatti station, which we had left that morning, stands at 925 feet. It was cold and disagreeable, with a dreary, hopeless landscape, in spite of the moonlight. I took a walk with the doctor in the bitter wind, while the moon showed us the way. There is a regular town here of about 1000 people, all labourers and officials of the railway; the whole place, with streets and rows of new timber houses, has grown up in the space of a year or two, only to vanish again to a great extent. We visited the club which is always a feature of these railway towns. It had many large rooms, billiards and even a theatre, where plays, concerts, cinematograph shows, lectures and dances were given. We also paid a call on one of the engineers. Nobody could talk anything but Russian, and our conversation was carried on in an extraordinary kind of gibberish. The doctor was untiring in his attempts to make himself intelligible to me. When he wanted to ask if I would have a drink, he said: "Wollen Sie Schwanz trinken ?" which gave rise to a lot of merriment. Wishing to explain to me about the Russian lady who rode through here all the way from Vladivostók to Petersburg, he did it by saying: "Vladivostók, Petersburg, hop-hop-hop," which was perfectly intelligible. She rode, by the way, first from Chitá through Manchuria to Vladivostók, then from there through the Ussúri District and the Amúr District and all the way through Siberia and Russia to Petersburg on the same horse. She is thirty-six, lost her husband and four children in the same year, and is moreover of half-Tatar origin.

Wednesday, October 15. Wourtzel has not finished 414 


\section{FROM THE BUREYA TO TRANSBAIKALIA}

his work and still has much to discuss with Tregubov, the chief engineer of the third section, which we shall soon have left behind us. We must therefore stay here for the morning. Meanwhile, the rest of us took a walk to a spring a mile or more from the station, from which water is to be brought. The question of water-supply is, of course, very important to a railway; water must be provided at regular intervals, not only for drinking purposes, but above all for the engines. But here, where the ground is perpetually frozen, it is not so easy to find it. Borings had been made in several places without finding any; and then they came upon this spring in the forest, which was a great find. In winter a regular iceberg freezes over a spring like this; but here they had built a timber house over the place, which is warmed to keep the water from freezing, and it is collected in a tank. The temperature of the spring is about $+1^{\circ}$ C. $\left(33 \cdot 8^{\circ}\right.$ F.) summer and winter, and it yields 66,000 gallons of water in the twenty-four hours. From this place in the forest pipes are now to be laid to the station and protected against frost by turf and earth, in spite of the surrounding soil being perpetually frozen. If the water is continually in motion, the engineer thinks it will not have time to be cooled down sufficiently to freeze, even if it is not warmed. But it seems to me that this must be rather risky. From what depth this water comes is still a riddle to me. The engineer says it comes from some place about three miles away. It seems that it must come from higher places in the neighbourlood, and must be summer water, which with the warmth it has absorbed collects down in the ground, where it is not cooled down so far as freezing-point in the course of the winter; but this is curious, as most of the rivers and marshes about here are frozen solid. Three borings have been made round 


\section{THROUGH SIBERIA}

the spring, to find out its extent and power. The gneissic granite has been bored to a considerable depth, and the temperature of the soil there was not below freezing-point. The men were just engaged in boring another hole, in which they found water at a depth of only 6 feet, while the boring had now gone down 30 feet.

Otherwise, the temperature of the soil seems to vary greatly here. In the neighbourhood of the station three borings had been made to find water; one, in the flat bog below the station, to a depth of $\mathbf{3 4 7}$ feet. Three feet of peat were found on the top, then a layer of white ice 5 feet thick, below that sand, then rock, gneissic granite, and it was frozen right down to the bottom of the bore-hole. The gentle slope on which the station stands had been bored in one place to a depth of 360 feet ; but here there were alternate layers of frozen and unfrozen rock down to the bottom of the boring. At a third spot, on the same slope, a boring of 180 feet was made; but here the soil was only frozen to a depth of 125 feet, and the hole gave water, though not enough for the purposes of the station. In summer the soil thaws to a depth of 12 feet at the meteorological station up on the slope, I was told, while down on the bog it scarcely thaws to 3 feet, on account of the layer of peat, which is a bad conductor of heat.

I have pondered a good deal over these layers of ice in the soil of Siberia, and have come to the conclusion that most of the explanations that have been given are impossible; these layers cannot be ancient glaciers that have been left behind as fossils, and in some way or other have been covered with layers of sand and claynor can they be water that has spread over the country in time of flood, has frozen and then been covered with sand and clay by fresh floods (?), or anything of that 416 


\section{FROM THE BURÉYA TO TRANSBAIKALIA}

sort. The layers of ice must have been formed in the places in the soil where they are now found, and they cannot be older than the layers which cover them. This conclusion seems also inevitable from the fact that in the covering layers remains have in some places been found of a warmer period than the present, and it is difficult to imagine that ice has been preserved in the soil immediately under these layers which were being deposited.

Ice may certainly be formed in the earth in several ways. It is obvious, for instance, that water which penetrates into the eternally frozen soil through cracks or openings, must freeze there, as we saw to be the case in the little tunnel on the Little Kinghán (p. 394); and that ice which penetrates into the soil and freezes has the power of expanding, was shown by the piles of the railway bridge on the Buréya-Séya Plain (p. 403).* But no layers of any great extent can be formed in this way. The regular method by which the latter appear in the soil must, in my opinion, be what one might approximately call a process of condensation.

If the mean temperature of a place is so far below freezing-point that the constant temperature of the soil a few yards below the surface is below freezing-point all the year round, the soil will be permanently frozen

* Dr. Alexander von Bunge (in Verhandlungen der russisch Kaiserlichen mineralogischen Gesellschaft zu St. Petersburg, Zweite Serie, Bd. 40, 1903, p. 203) seeks to explain an ordinary occurrence of underground ice in Siberia in this way; he thinks it is formed by water which penetrates in spring through frost-cracks in the earth and freezes when it arrives at the levels of perpetual frost. By expansion and subsequent contraction it provides space for more water, etc., and thus the ice may grow. That ice may be formed in the earth in this way, we saw by the bridge-piles mentioned above, but not horizontal layers. Nor can these cracks be supposed to go deep, in any case not deeper than the layers in which the temperature of the soil is constant summer and winter. 


\section{THROUGH SIBERIA}

down to a certain depth. Now the soil, whether it consists of beds of rock or of loose strata, and whether it is frozen or thawed, is always somewhat porous, and it contains moisture and aqueous vapour. But, as the temperature increases with the depth, the tension of vapour must be higher at the deeper levels than nearer the surface. If, then, a thin layer of ice-which often seems to be formed in the earth in such conditionscrystallizes out at a certain depth in the perpetually frozen soil, this layer will continually increase through the condensation of aqueous vapour from the subjacent layers of earth, where the tension of vapour is higher. In this way the layer of ice may constantly grow in the course of years to almost any thickness. With the immense force of crystallization of water the ice will easily raise the layers of earth lying above it. It is also conceivable that in summer, when the layers of earth thaw above the ice, both aqueous vapour, and liquid water which penetrates to the upper side of the layer of ice, will be condensed and freeze upon the latter, with the result that it will increase on the upper side also, unless the temperature is high enough for the thaw to reach the ice itself.

That layers of ice, sometimes of great thickness, may be formed in the earth in this manner wherever the conditions are favourable, appears to me perfectly natural; and thus we have, in my opinion, a simple explanation of the frequent occurrence of this phenomenon in Siberia and elsewhere. The existence of such great differences in the temperature of the soil within short distances as we find here at Taldan and in other places, must be explained by differences in the heat-conducting powers of the soil. The general experience here is that the topmost layer of earth is of speeial importance. On the flat tracts, where the soil 418 


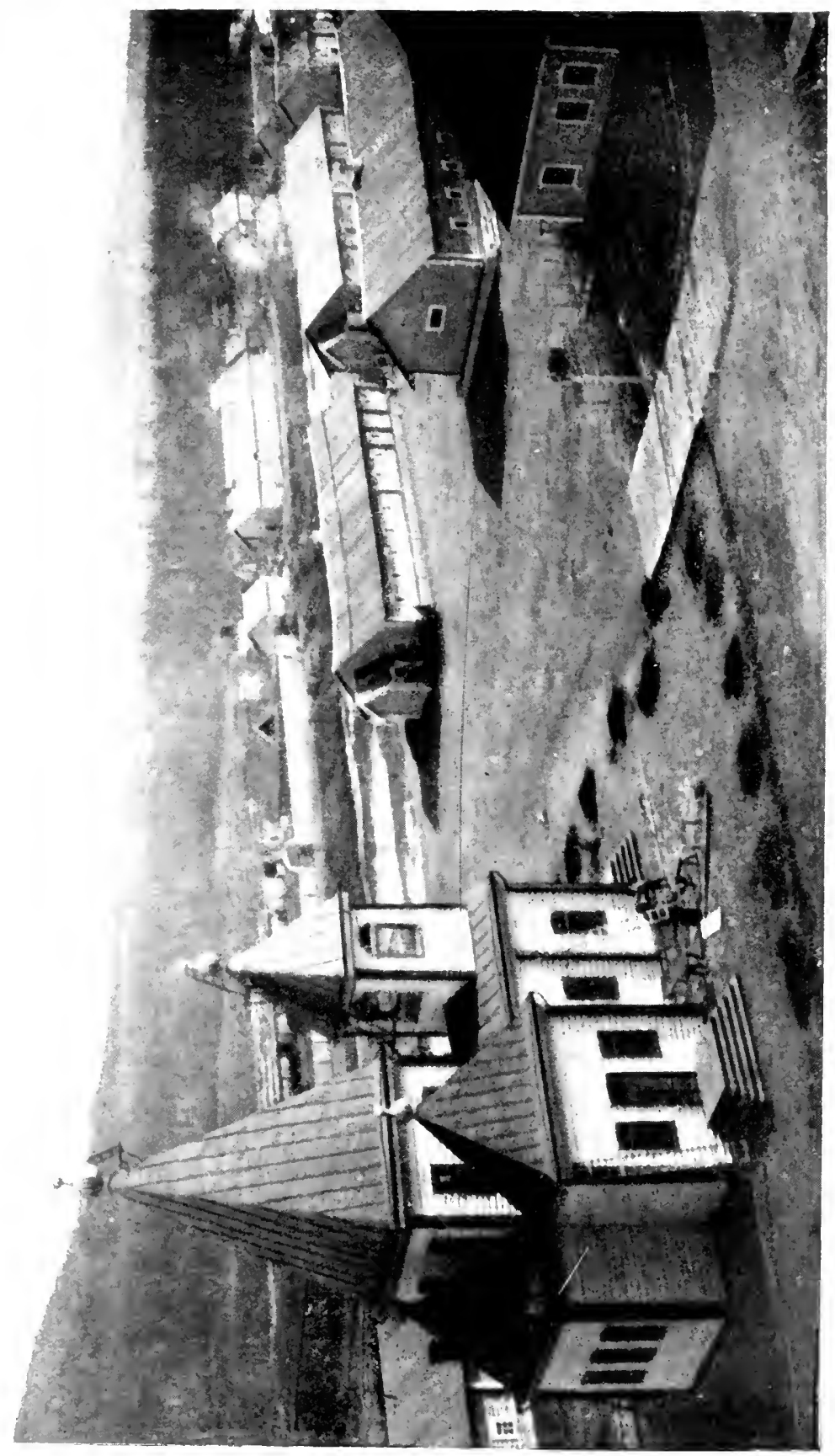

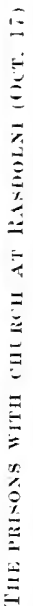




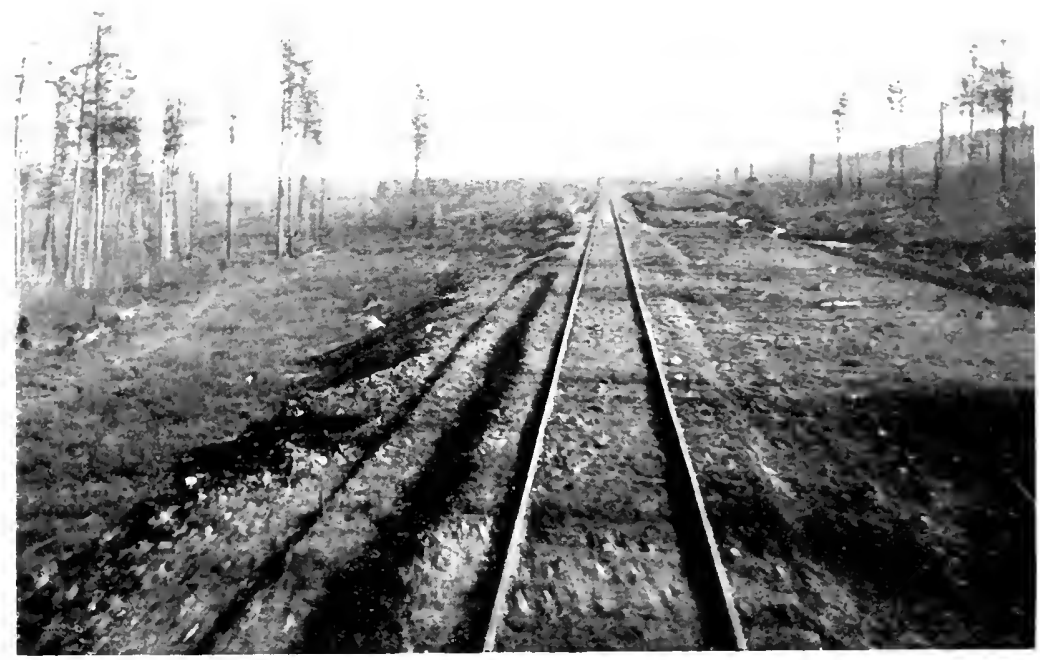

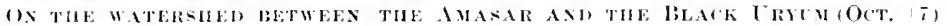

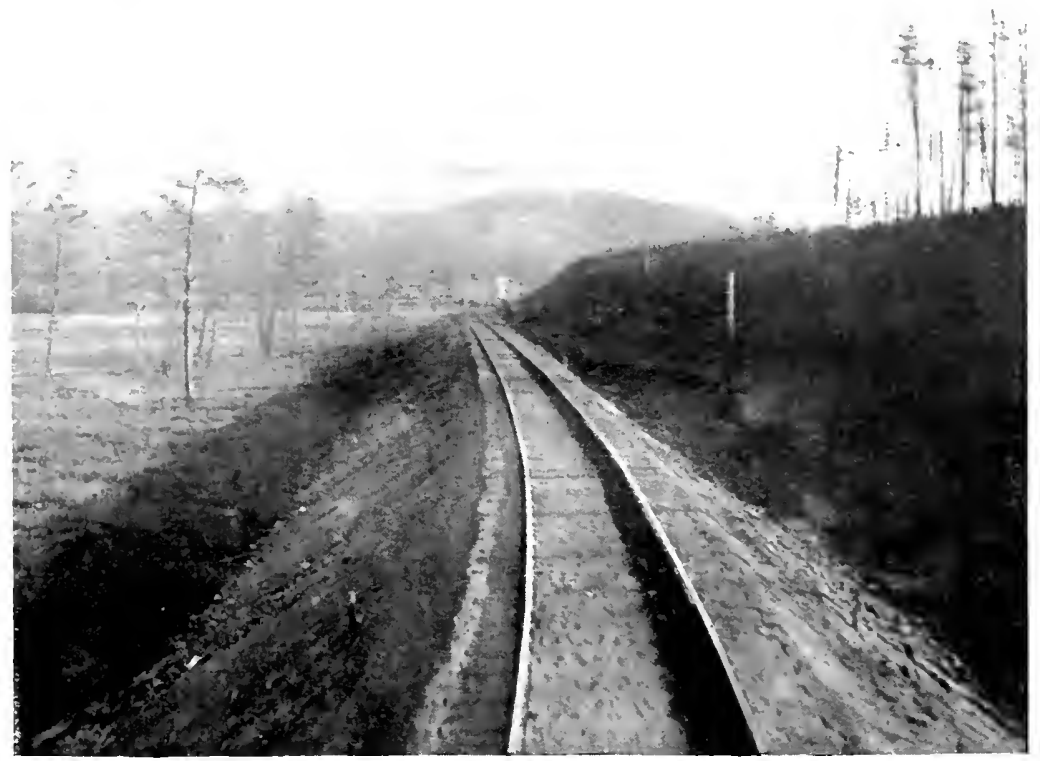

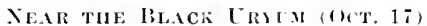


is covered by a thick layer of peat with grass, which is a poor conductor of heat, the heat of the sun cannot penetrate deeply, and the soil will be permanently frozen. But if the layer of peat is removed, the ground thaws to a greater depth in summer, and it frequently occurs that the permanent freezing of the soil disappears altogether. Variations in heat-conducting power from below also affect the question, of course. If the soil is intersected by cracks and openings through which the cold air can sink during the winter, it may also create a low temperature, as we have seen.

Here, at Taldan, the mean temperature for the year was not particularly low; we were told it was $-1^{\circ} \mathrm{C}$. $\left(30 \cdot 2^{\circ} \mathrm{F}\right.$.). As a rule one does not expect perpetually frozen soil with higher temperatures than $-3^{\circ}$ or $-4^{\circ} \mathrm{C}$. $\left(26 \cdot 6^{\circ}\right.$ or $24 \cdot 8^{\circ} \mathrm{F}$.), where there is a tolerable covering of snow in winter; but little snow falls here. As the mean temperature is so little below freezingpoint, it is easy to understand the occurrence of frozen and unfrozen soil in such proximity to each other.

Away in the forest near the spring was a whole collection of houses; they were prisons and held 200 convicts, who were working on the line and were guarded by the necessary number of soldiers.

This is a dreary and desolate country in all conscience, as one sees it in autumn, with its thin and stunted forest, its bare larches and birches, and its bogs already frozen. There is not even much game to be had; one of the engineers here had two setters, which went with us. He had shot five black game in three years. There are a few elks, no doubt, and some bears. Near the station there was a rocky crest, which appeared to be formed of a vein of porphyry. From the top of it one saw the rolling forest country spread out on every side, ridge after ridge, with low 


\section{THROUGH SIBERIA}

blue hills far away; and in the midst of the desolate forest lay these prisons, while a little way off the railway drew its yellow line of sand through the wastes of the taiga westward to the world and its life. But there is gold everywhere. Here by the station there is not enough to work; it scarcely comes to half a gram to the cubic metre. But twenty or twenty-five miles to the north there are rich gold-washings, where they find ten to twelve grams to the cubic metre. This is on the river Urkan, a tributary of the Séya. On a good day a man may wash out as much as fifteen roubles' worth, and last year-as far as I understood-a ton and a half of gold had been extracted.

On the grassy plain near the station about a hundred Mongolian oxen were feeding. They were the meatsupply for the labourers; but there were no haystacks to be seen, and the beasts were probably slaughtered when the pasture became too scanty towards winter. There is no difficulty in getting the meat to keep in this cold. Otherwise there was no sign of agriculture or grazing hereabout. But in one place farther on I saw some hay in stacks in the fields, which probably meant that some cows were kept, unless it was for horses.

We were still slowly ascending, until beyond Kerák station we came to a tunnel 1050 yards long through the crest of the Nuksha range, which forms the waterparting between the sources of the Séya on one side and the little river Never, which falls into the Amúr, on the other. The Nuksha ridge is a branch which runs from the Yáblonovi Mountains on the north-west and there forms the water-parting between the river Nuksha, which flows towards the Lena, and the Oldoi, which flows into the Amúr. The tunnel stands at a height of 2030 feet above the sea, and the crest of the mountain 420 


\section{FROM THE BURÉYA TO TRANSBAIKALIA}

is $\mathbf{1 4 1}$ feet above the tunnel. Here everything is frozen from the surface down, and only a thin layer thaws in summer.

It was a more picturesque and varied country that we were now entering, with more hills and valleys than we had had before, and we went on interminably through the forest, over heights with upward gradients and cuttings, and over lofty embankments more than 60 feet in height, in the most glorious moonlight until late in the evening, when we reached the station of Oldoi, where we stayed the night. I walked up and down in the moonlight for a long time in front of the train with the engineer in charge of machinery, who had lived for three years in this district at Taptugári station, farther on. He told me much about the life here. The soil is frozen hard everywhere, and may thaw in summer to a depth of about 6 feet at the end of July. But they can force good vegetables on the thawed layer in the course of the short summer. Potatoes come up about June 10, and in the early part of August everything may be frozen; but in that short space of less than two months things grow quickly. He had sowed three poods of potatoes in the middle of May, and had dug thirty poods (9 cwt. 2 qrs. 19 lb.) in August. In the same way with beetroot; he had sowed beetroot on about seven square yards in May, and got about five poods (1 cwt. 2 qrs. $12 \mathrm{lb}$.). The horses here are left out all the year round and have to feed themselves ; but there is hardly any snow in winter, so they can easily find grass, even if it is dry and stiff. It is cold, and they get thin, as may easily be understood when they have to stay out at night with a temperature of perhaps $-40^{\circ}$ or $-50^{\circ} \mathrm{C}\left(-40^{\circ}\right.$ or $\left.-58^{\circ} \mathrm{F}.\right)$; but they put on flesh again in summer. There is the curious point about the cows that the calves are not taken from them. They give no milk 


\section{THROUGH SIBERIA}

unless the calf is allowed to suck at the same time. It then gets half, while the people milk the rest. These are Mongolian cows. The engineer, who did not know this, bought a cow and killed her calf, so as to get the milk for himself; but he got nothing and had to kill the cow too. There is so little snow here in winter that sledging is impossible on land, they have to sledge along the rivers. It is a cheerless country, I must say, when the cold winter does not even bring the compensating advantage of good going for sledges and ski.

Farther on it is the same hill country with low ridges, but the trees are for the most part getting still smaller and thinner, and soon they will be only fit for fencing; here and there one sees a tree big enough for a telegraph pole, perhaps ; and the wind deals severely with this thin forest, which has such shallow roots and spreads them so far over the ground; great stretches of it are laid low and the torn-up roots stand straggling in the air. The forest fires also do their work, and in many places charred stumps and bare, broken stems tell the tale of their ravages. There is nothing but larch in this tract.

Then we came to the bridge over the Chitkan, where the railway accident I mentioned had occurred a few days before. The engine and eight carriages fell over the bridge. It was a ghastly sight; the fall was 50 feet or more. The engine had been telescoped like an opera hat, and was twisted as if it had been made of cardboard. The carriages had fallen one on the top of another, and the lowest one was entirely smashed; yet it was from this lowest carriage, which was so crushed that there was scarcely a whole board left in it, that three people were brought out; one killed-the guard -but the other two alive and only slightly injured. 422 


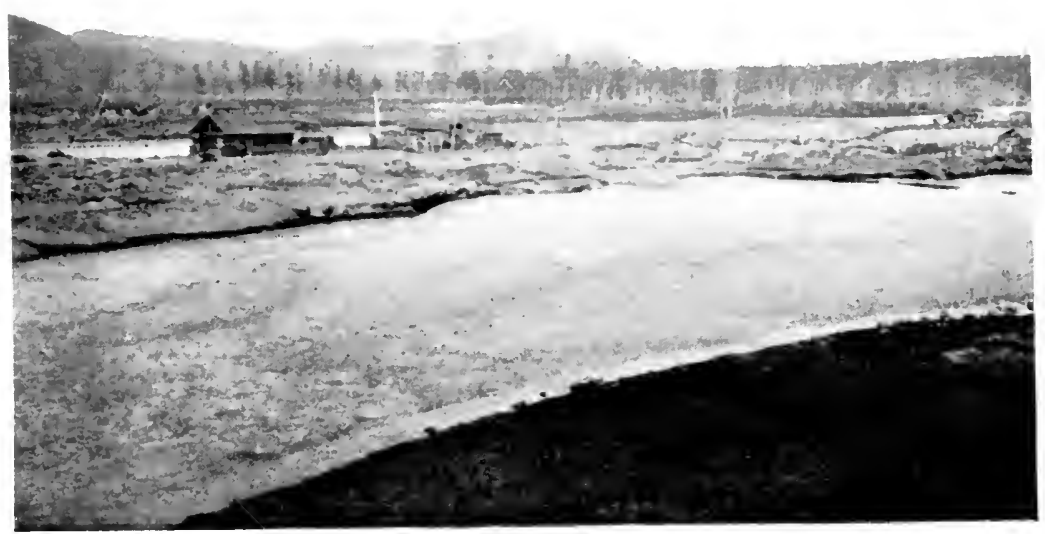

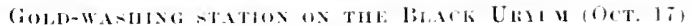

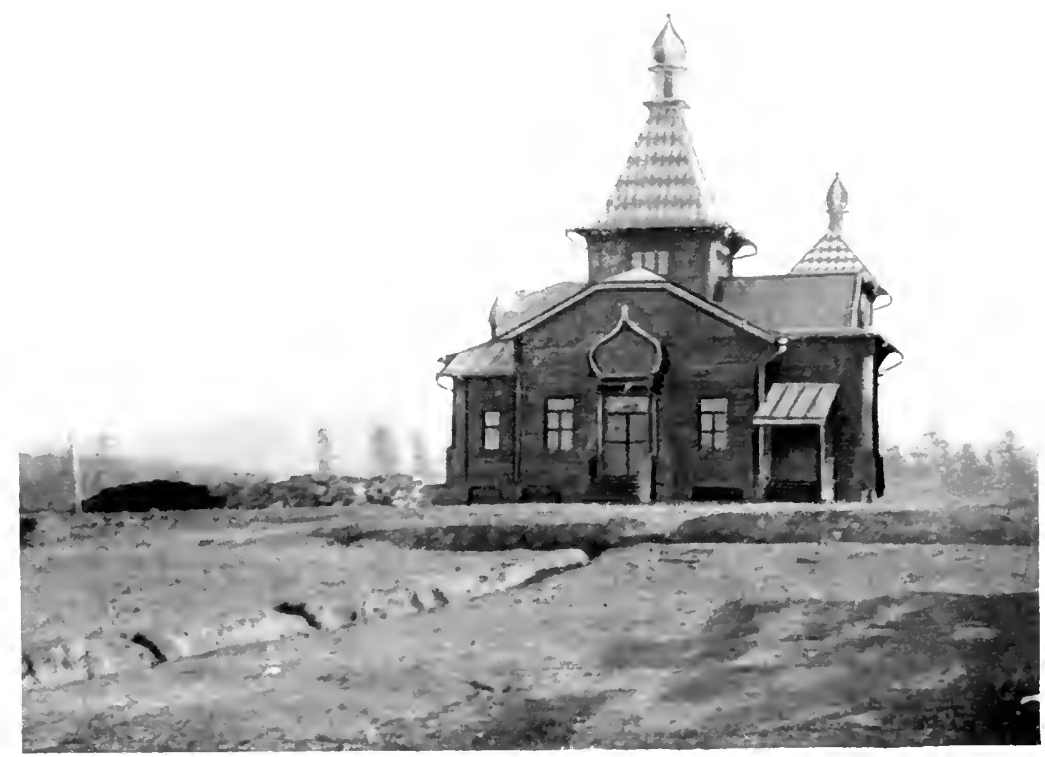

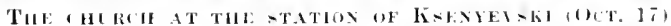




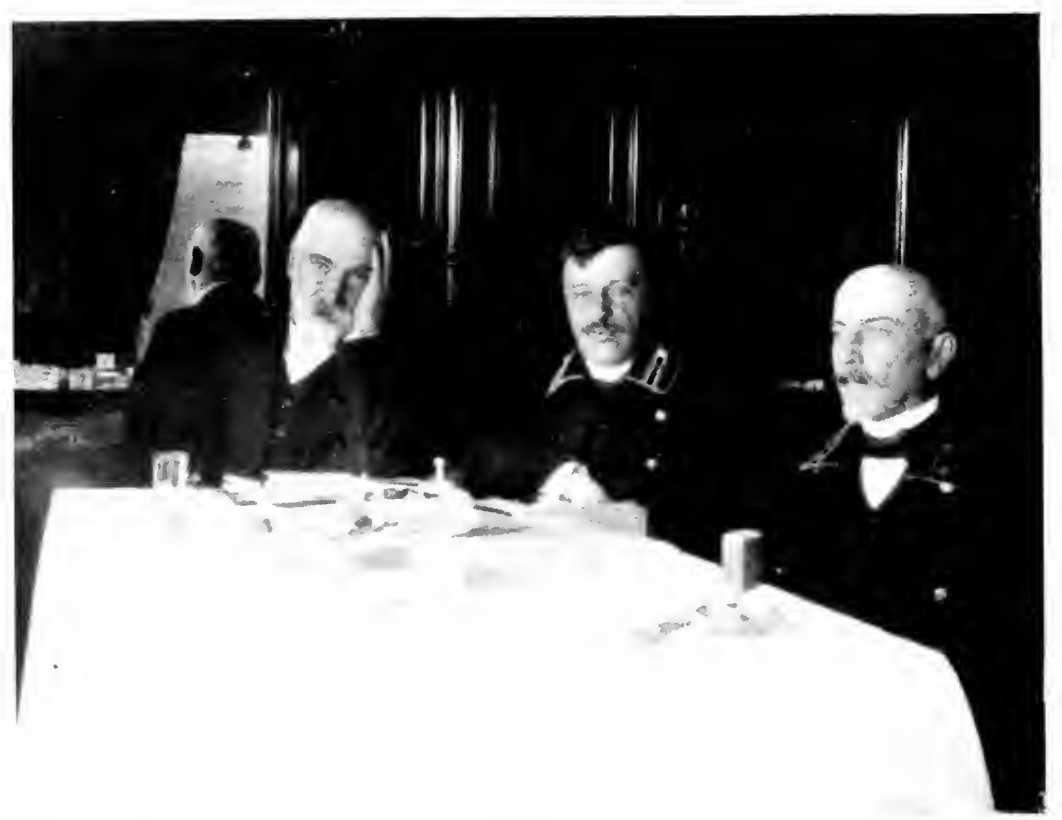

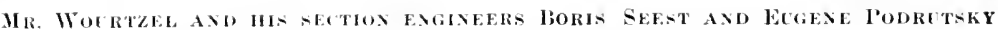
(LEFT TO RIGHT) IS TIE SALOON CARRLAGE (WOT. 18)

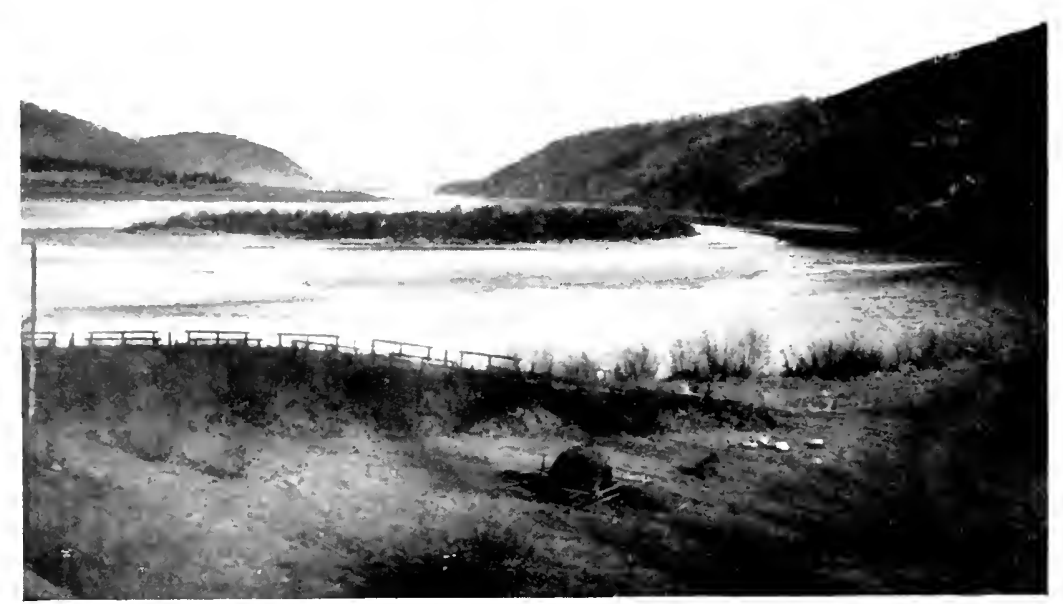

Alovi the River Sflexiga (UCt, 19) 


\section{FROM THE BURÉYA TO TRANSBAIKALIA}

The accident had happened in this way : the workmen were engaged in laying new, broader sleepers on the bridge, and to do this had taken up two of the rails. They had put up a red danger signal at the end of the bridge, but at the same time a trolley was standing on the line, and the rule is that trolleys must always carry a red signal; so the engine driver, on seeing a red flag, thought it was on the trolley. He nevertheless reduced speed as a precaution; but when the workmen on the bridge and on the line saw that he was not stopping, they began to call out and wave their arms. Then he tried putting on the brakes as hard as he could, but it was too late; the train was already on the bridge, moving at a very slow speed to the fatal spot, and it stopped altogether on coming to the place where the rails had been removed. But at that moment the engine lost its balance and fell over, dragging eight carriages with it. Fortunately these carriages were, for the most part, empty and only two men were killed; one of them the guard, as I have said, and the other a fireman, who fell under the engine. Both the engine driver and his assistant escaped with only scalded hands and faces from the steam. When the driver came to himself, he was lying half in the water of the river. He got up, began to wring the water out of the tails of his coat, and then ran away; and his assistant did the same, so dazed were they. The last carriage kept the rails; luckily the couplings snapped when the other carriages fell, and the ten people inside it did not even know what had happened; they only felt a slight jerk, but when they looked out, the whole train in front of them was gone.

It is still the same low hill country, with the same thin forest, mostly larch and with great bogs at intervals, and then flat valleys and rivers. There is gneiss, or a 


\section{THROUGH SIBERIA}

kind of gneissic granite, everywhere in this country; I saw no sign of stratification. Gold is present everywhere along these rivers, great and small, and goldwashing is carried on in many places.

FROM THE BORDER OF TRANSBAIKALIA TO THE KUENGA

In the evening, beyond the river Urka, we crossed the border of the Amúr District and entered Transbaikalia again. We now have a straight line before us, and can keep going with the train till late in the evening in the moonlight through the wild and desolate hill country, which is more broken up and varied than before. At first it sloped gently down towards the river Amasár, and we stopped for the night at the station of the same name. It was cold now, $-12^{\circ} \mathrm{C}$. $\left(10 \cdot 4^{\circ} \mathrm{F}\right.$.).

Friday, October 16. The line continues with a gradual ascent up the valley along the Amasár. Many convicts were at work on this part of the line; we saw gangs of them with their soldiers, and at Rasdolni there was a regular little town of prisons, with a big church in the middle. Beyond Penkovaya station the line winds upward at the steepest gradient permitted, 8 in 1000 , to the water-parting between the Amasár and the Black Uryúm. We are here about 2800 feet above the sea, the highest point on the whole Amúr line. On the other side it descends again in a great curve past Arteushka station, and then slopes gently down through the valley by the side of the Black Uryúm. From the top of this valley, near the waterparting, we had a distant view of the place where the celebrated gold-mines belonging to the Imperial Cabinet are situated, which are said to have produced between 424 


\section{FROM THE BURÉYA TO TRANSBAIKALIA}

the years 1868 and 1897 about 1500 poods (about 24 tons 4 cwt.) of alluvial gold; but now the yield of these mines is not so great. Gold-washing, however, is carried on in many places about here, and we saw it in progress on the bank of the river below us. All the workmen in these mines are Chinese, as soon as the border of Transbaikalia is crossed, and the mines are Imperial. Here, there is no prohibition of the employment of Chinese labourers.

The line continues to wind down through the valley of the Black Uryúm. To our left we have a range called the Ksényevski Mountains, after the Emperor's daughter. It attains altitudes of 4600 and 4900 feet above the sea, and forms the water-parting between the Black Uryúm and the Shilka. It is clad with a forest of conifers almost to the summit, only at the highest levels there are low dwarf cedars. We stopped at the fine station of Ksényevski, which lies on the slope of the Uryúm valley and has a population of about 1500. A pretty little church stood on the height above the station, from which there was a view over the broad valley to the hills around. From here the line continues to descend along the river to the station of Sbega (i.e. confluence), where the Black and the White Uryúm meet to form the Chernáya (i.e. the black river), which falls into the Shílka. After crossing four bridges in succession over the windings of these two rivers, the line again climbs slowly upward along the White Uryúm to the water-parting between it and the Aleúr, which flows into the Kuengá, a tributary of the Shílka. This water-parting is not so high as the last; it stands about 1970 feet above the sea.

We arrived at Uryúm station, from which the railway has been regularly working westward for two years already, and when we were dining at the next 


\section{THROUGH SIBERIA}

station, Silova, it gave one a curious feeling to hear the platform official come into the refreshment room and sing out, "Take your seats for So-and-so." We went on in the moonlit night through the hill country at a speed of thirty-seven miles an hour, without any further stops. Our journey through the unknown Amúr District by the still unfinished line is at an end. Tomorrow morning we shall be at Chitá, and on the way home via Petersburg. And then this long journey will be over. It is true that there are still four or five thousand miles before us, but that is not much by the scale we have grown accustomed to using. 


\section{CHAPTER XIX}

\section{HOMEIVARD THROUGH SIBERIA}

Along the Shilka : Climatic variations : Chitá : Along the Selengá : Baikál : Tulún : Krasnoyarsk : The country to the east of Krasnoyarsk : Rodichev; a politician's views of Siberia : Novo Nikoláyevsk : The flat steppes : The Urál and winter : Yekaterinenburg: Back to Europe : Perm and Víatka:

Farewell to Siberia

SATURDAY, OCTOBER 18. As I look out of the carriage window this morning, the country has completely changed. We are going up the valley along the Shilka, and the hills on both sides are covered by birch forest, interspersed with some firs. In many places the slopes are entirely grass-grown without trees, and a few aspens and other foliage trees are seen down on the level ground. The climate must be more favourable to forest growth, although the altitude is not so very much lower than yesterday; for the trees are much bigger and more luxuriant. The Shílka valley is fairly narrow where we are now travelling, and the mountains descend to the river on both sides; but then it suddenly widens out into broad grass plains, surrounded by low hills. Villages, large and small, lie along the banks of the river. These are no doubt inhabited by Cossacks, to some extent, in any case. What they live on is something of a riddle to me. There are no crops to speak of ; they grow a little oats, but it seldom ripens and is sown chiefly for green fodder; potatoes and other vegetables do well, and there 


\section{THROUGH SIBERIA}

is a good hay-crop; but the fishing in the river cannot be of much account. We see many Chinese at all the stations now; this is very different from the Amúr District, where we saw none. And so we rejoined the Eastern Chinese line, over which we had travelled a few weeks before south-westward to Manchuria, at the point where it crosses the Ingodá. We arrived at the large station of Karimskaya, which will doubtless form the terminus of the Amúr line. Henceforward we were to travel by the regular trains. Unfortunately the express for Russia had just left, and the next one would not go for two days; it would not have paid us to wait for it, and our carriage was therefore attached to the ordinary passenger train, which was the quickest one available.

Farther on I was struck by the size of the firs that grew up the hill-sides and on the level ground by the river ; it was almost like a Norwegian forest, and had it not been for the houses here and there, one might have been in Norway. On the level ground towards the river we saw one haystack after another scattered about. It is altogether different from the country we were travelling through yesterday; and this seems strange, as the highest point on the Amúr line, the waterparting between the Amasár and the Uryúm, was 2755 feet above the sea, and Chitá, which we are now coming to, stands at 2148 feet. This is not a great difference in altitude, but there is, nevertheless, a considerable difference in temperature. The mean temperature for the year at Chitá is about $-2^{\circ} \mathrm{C}$. $\left(28 \cdot 4^{\circ} \mathrm{F}.\right)$; at Nyérchinsk it is about $-4^{\circ} \mathrm{C}$. $\left(24 \cdot 8^{\circ} \mathrm{F}.\right)$, and at Ksényevski, the highest station on the Amúr line, it is also about $-4^{\circ}$ C. $\left(24 \cdot 8^{\circ}\right.$ F.). The mean temperature for December 1911 at the last-named place was $-39^{\circ}$ C. $\left(-38 \cdot 2^{\circ} \mathrm{F}\right.$. $)$; the mean of the daily minimum 428 


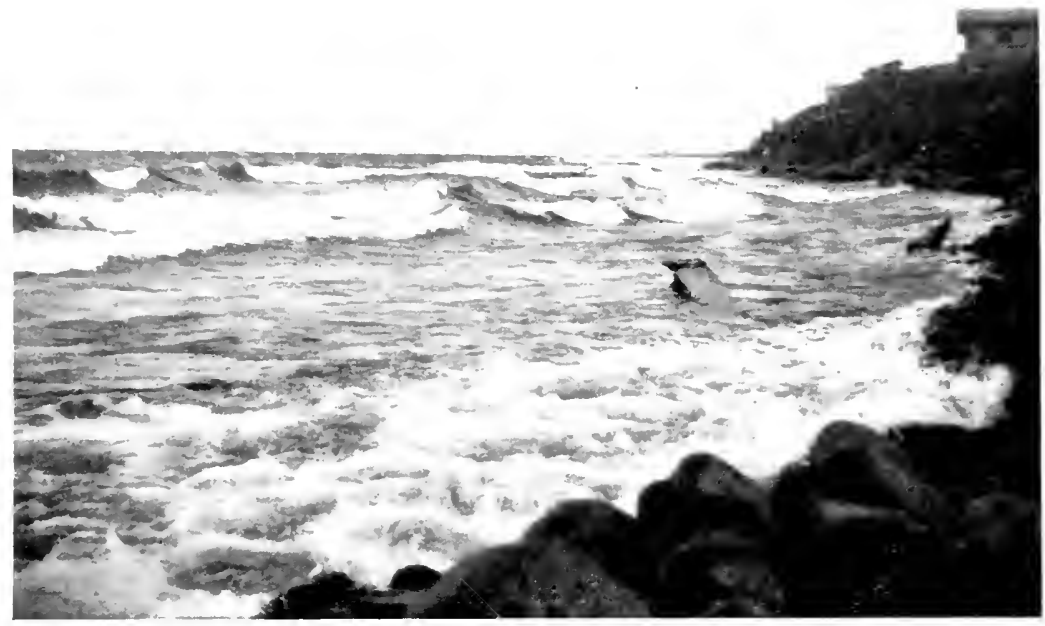

IAAE BAIKAL AT TAYKHOI (OCT, 19)

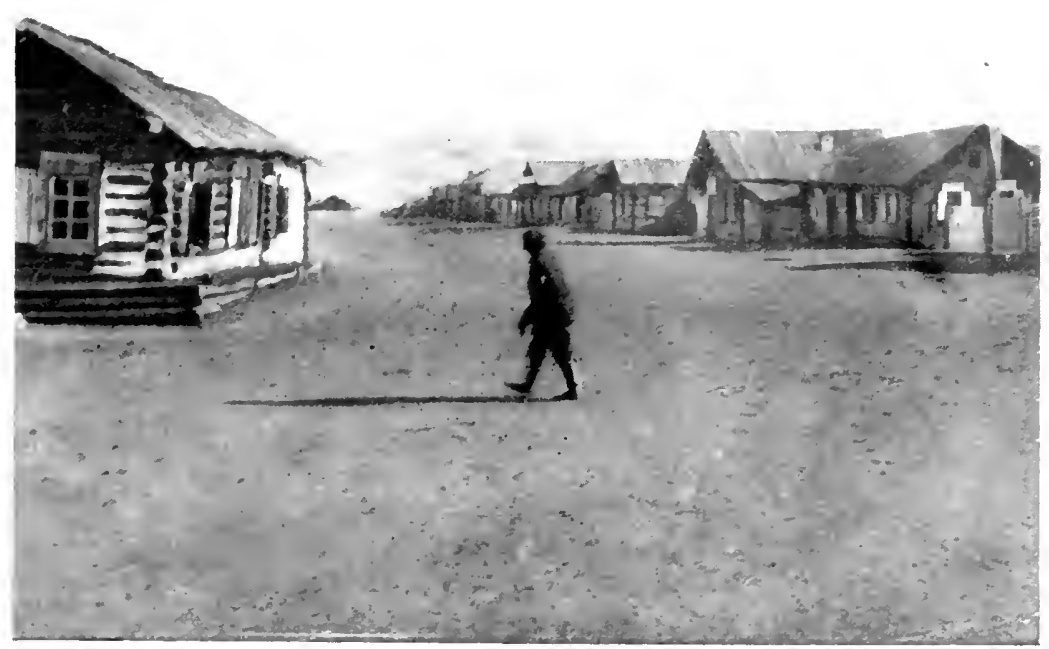

STREET IN A SHBERAN VILAGE (1)T. 19, 


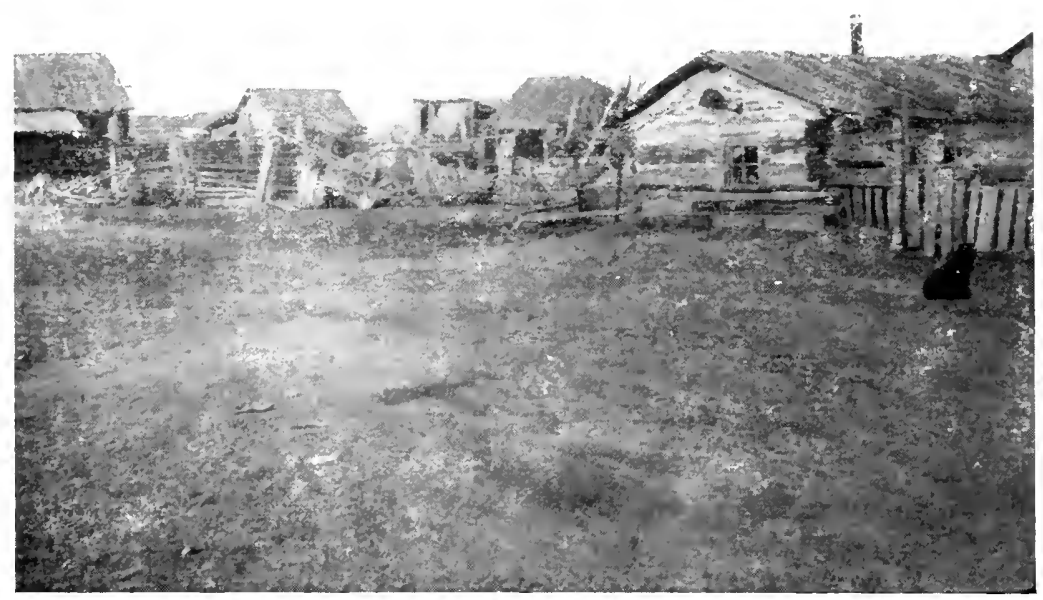

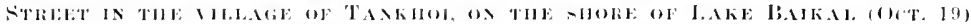

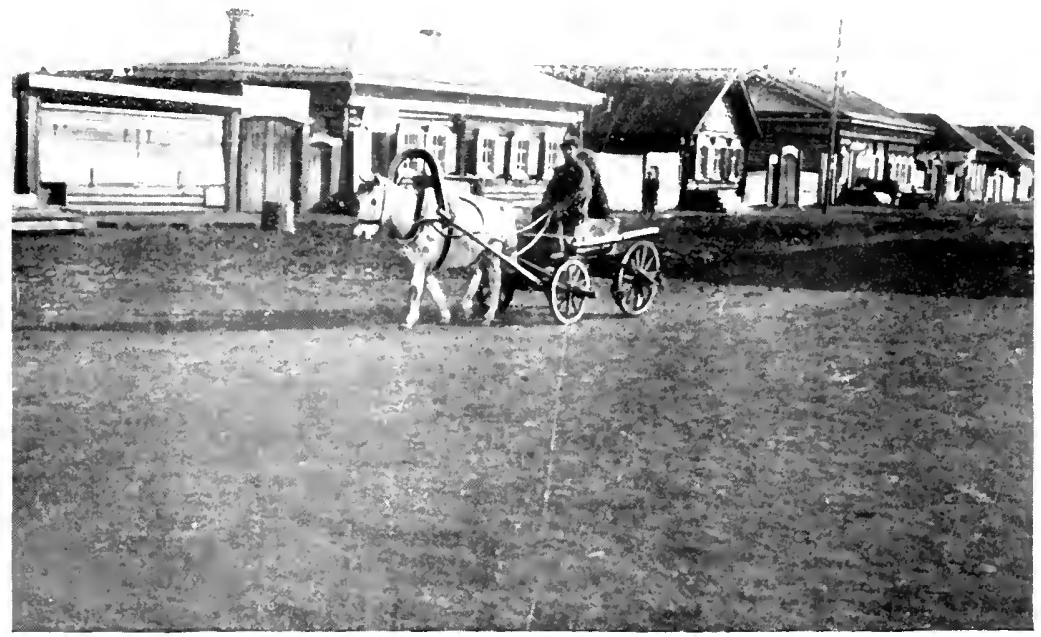

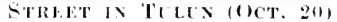




\section{HOMEWARD THROUGH SIBERIA}

was $-49 \cdot 7^{\circ} \mathrm{C} .\left(-57 \cdot 4^{\circ} \mathrm{F}.\right)$, and the lowest temperature was $-56^{\circ} \mathrm{C} .\left(-68 \cdot 8^{\circ} \mathrm{F}\right.$. $)$.

At Chitá we parted from the chief engineers, Seest and Podrutskiy, who live there, and then the train took us on homeward to Russia over the same wide prairies, with low hills covered with thin forest, which we had crossed on our way to the east. And again we climbed slowly up the ridge of the Yáblonovi Mountains and the watershed between the Pacific and Arctic Oceans, the Amúr and the Yenisei.

Sunday, October 19. Next morning the country became altogether mountainous again. The line runs through the valley by the side of the broad Selengá, with lofty, fir-clad hills on both sides. The forest is thick, and some of the trees are quite large. On the level ground at the bottom of the valley there are meadows with haystacks and fences, and here and there what look like stretches of willows. The country is still thinly inhabited, but the villages become more and more frequent as we come lower down. These wooded hill-sides and cultivated lands with fences of sticks, these cornfields and cows and horses on the pastures, with here and there copses of vigorous firs and fine birches, all have such an extraordinarily homelike look that I feel quite as if I were back in Norway. These split-stick fences and these fields, nay, sometimes even the houses, are exactly what one might see in Numedal or Valdres. Nor is there much difference in the horses, though the cows are certainly more Mongolian, many of them brown. Gradually the valley begins to widen and the hills recede. There is more and more cultivation, with one large village after another, their white churches gleaming over the valley; in one place there is even a large convent on the plain, where the Selengá forms its delta on Lake Baikál, and we see blue hills 


\section{THROUGH SIBERIA}

far away on the north-west, on the other side of Baikál. Then, all at once, this immense blue surface lies before us. It is dark now in the high wind, and the waves are breaking far out on this shelving shore of the delta. On the north all the land lies below the horizon, but on the other side, straight across the lake, the purple mountains rise in the distance. On the south-west they disappear again below the horizon for a space. And so we went once more round the south of Baikál.

Monday, October 20. During the night we arrived at Irkutsk, but our train goes on night and day without stopping, in sunshine by day and in moonlight by night. We have chiefly forest now, but meadowland besides, and some cornfields with villages scattered here and there. At Tulún station we have to stop for two hours, to let the express from Russia pass us. It cannot be called a fast train, this one we are travelling by. We have to console ourselves with the reflection that the mail trains, carrying the Russian mail, are even slower. This, by the way, is an important station, as a railway is projected from here northward to the Lena to connect the steamer traffic on that river with the Siberian line.

Farther on the country consists mostly of an undulating carpet of fir forest, and the jagged ridges to the south-west of us stand sharply outlined against the yellow evening sky. Down in the black shadows below us runs a brook, reflecting the yellowish-green sky like an eye in the midst of the great forest. Then the twilight vanishes abruptly, the stars sparkle in the blue vault and night reigns over the Siberian forests. In a little while the moon rises over the edge of the wood, and the bands of light steal silently far in among the tree-stems-in perfect stillness. And this whole forest world becomes a land of dreams. 


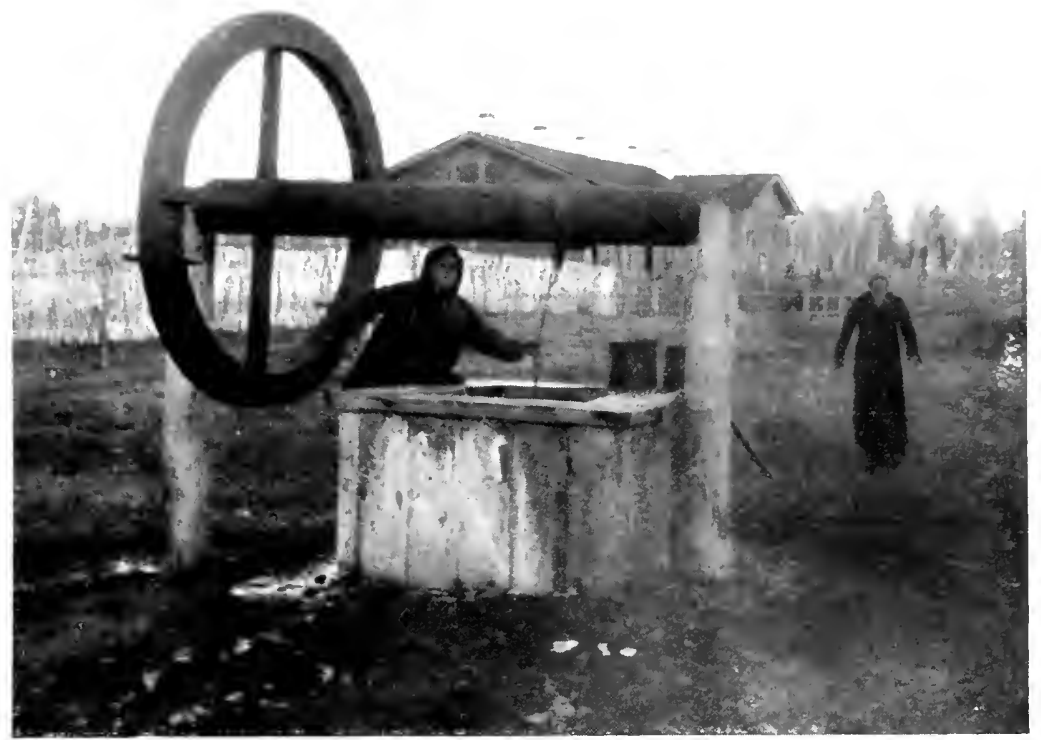

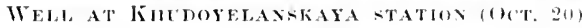

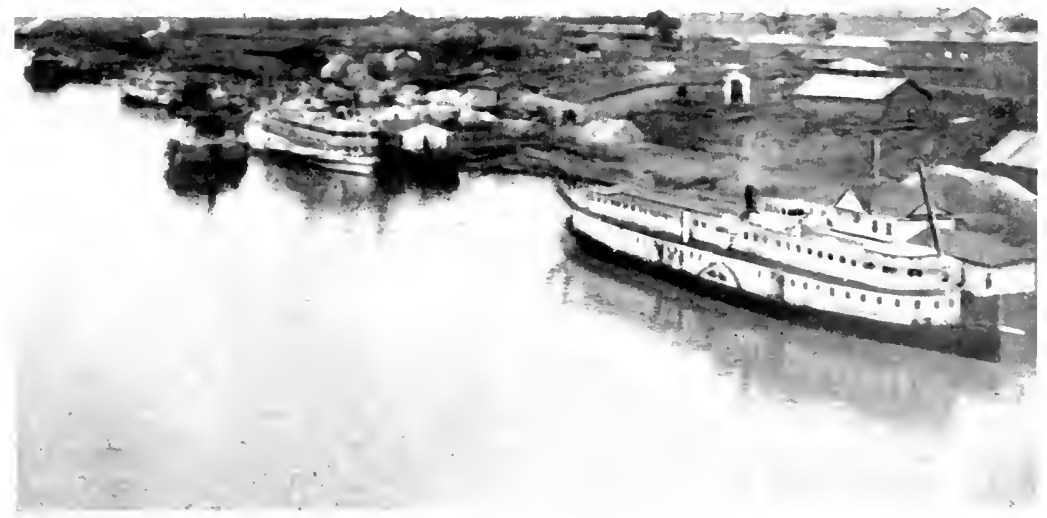

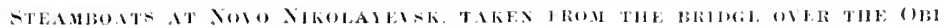
$(1, \mathrm{~T}, \mathrm{~T}, 2)$ 


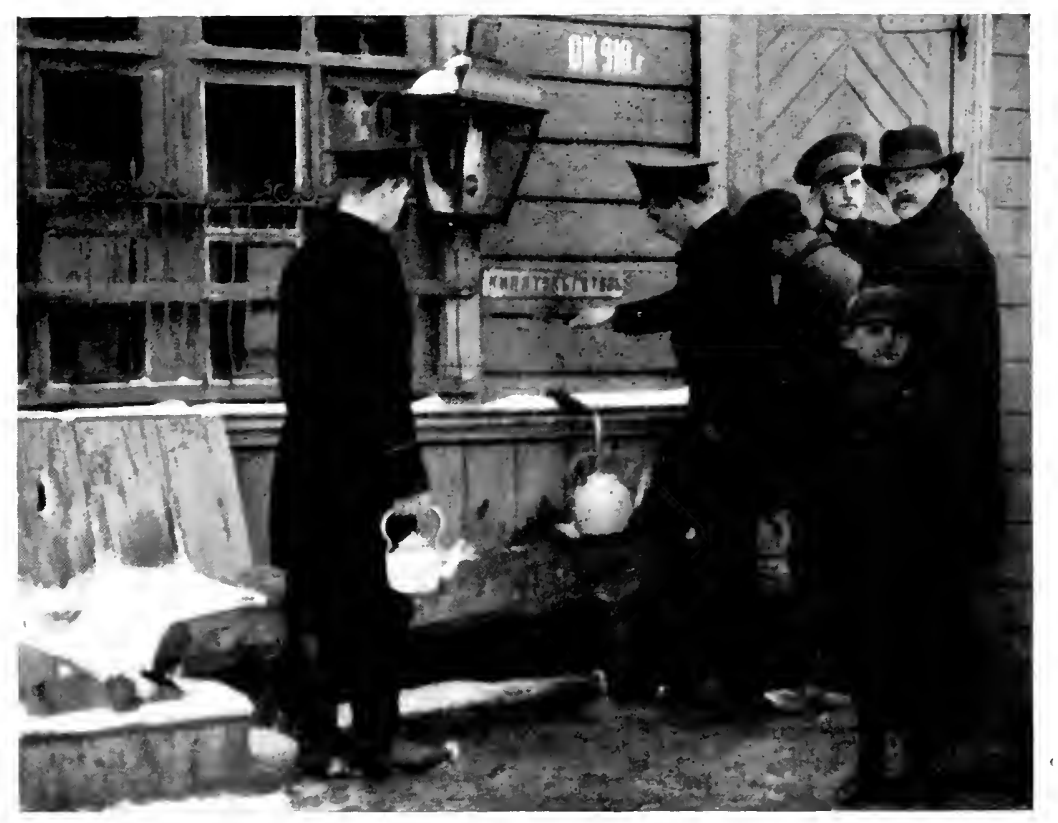

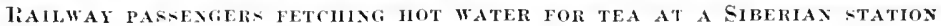
(1)CT. 23)

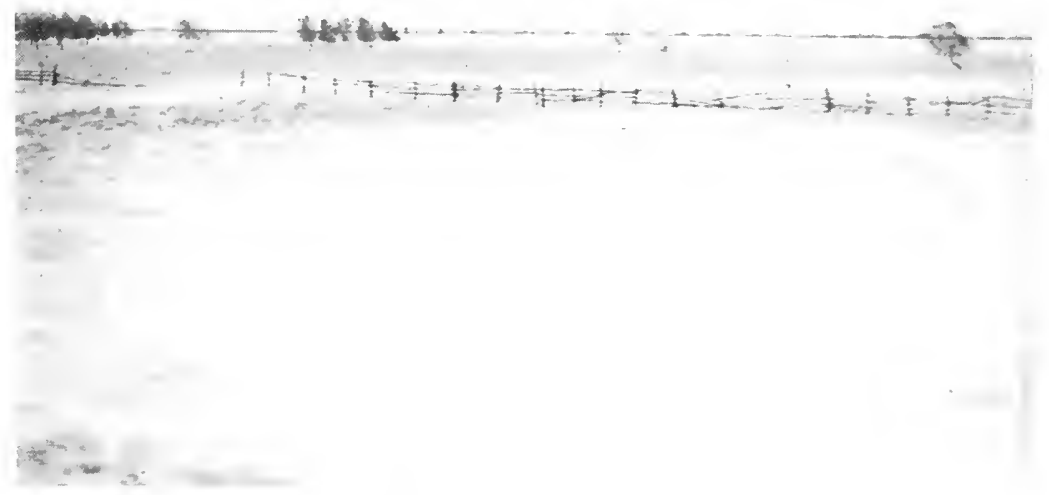

A VIEW OX THE -TEPPES (OCT. 231 


\section{HOMEWARD THROUGH SIBERIA}

Tuesday, October 21. On the following morning we crossed the mighty Yenisei again, whose broad waterway extends southward among the mountains and northward to the boundless plains. At eleven o'clock we arrived at Krasnoyarsk, and were met at the station by Mr. Lied and Mr. Gunnar Christensen, and young Mr. Gadalov. Here also, Vostrotin joined the train and travelled on with us to Petersburg.

The country to the west of Krasnoyarsk is the same rolling plain that we went through to the east of the Yenisei. It is cultivated to some extent, but a far greater part of it is forest. At Krasnoyarsk the wellknown politician and member of the Duma, Rodichev, also got into the train. $\mathrm{He}$ is one of the best speakers in the Duma, and one of the most prominent men in the modern movement for Russian liberty; one of the things that have made him famous is that, as a member of a deputation on the Tsar's accession, he was the first to express the desire of a constitutional form of government. This was looked upon as madness at the time, and he was exiled, as he has been several times since. He had now travelled through Siberia for the first time, and had been as far as Vladivostók and Khabaróvsk, but was disappointed in the country and the people. A desolate, insufficiently populated country, which would be easily conquered, and a people without enterprise or initiative ; these were his impressions. One might drive a plough through the whole country, from the Urál to the Pacific, he thought; but for all that there was mostly uncultivated land and forest to be seen. Otherwise his observations agreed exactly with what has struck me throughout this journey - that the peasants in Siberia ought to go in more for cattle-raising and dairy-farming, which would pay them better, and not so much for corn-growing.

Wednesday, October 22. As we go farther west, the 


\section{THROUGH SIBERIA}

country becomes flatter and flatter, and at Arshinsk we are already beginning to approach the steppes, but it is not entirely flat until we reach the neighbourhood of the Obi. At the point where the railway crosses this river stands the town of Novo-Nikoláyevsk. This is a remarkable town. Fifteen years ago or more, before the railway came, there were a few huts by the river; now there is a city of 85,000 inhabitants.

From here the country is perfectly level for a distance of about 870 miles, as far as Chelyábinsk near the Urál Mountains. It is steppe country that extends to the south and is merged in the Kirghiz Steppes proper; but here it is rather what goes by the name of the "White Birch Steppe." It is an incredibly uniform country, surpassing anything I have hitherto seen. Flat as the sea, but without its waves, prairie-prairie without end; then some low scrub, a few small, whitestemmed birches here and there; now and then a haystack, then occasional ploughed fields, but scarcely a house to be seen from the railway for league after league. In many places the ground is marshy, and stagnant water with stiff grass and reeds may extend for miles on both sides of the line. There is no drainage along the line here with canals and ditches, as on the plain of the Amúr. Other parts are drier, with good, fertile land and black soil, but in places the water and the soil are strongly saline. For long stretches it is striking how little cultivation is to be seen; but Wourtzel assures me that things are quite different a little way from the railway on both sides, where, he tells me, there are many villages.

Thursday, October 23. Farther west the country became somewhat more populated and we saw more cultivation. But here winter had completely set in. The fields were covered with snow, and at Petropavlovsk 432 


\section{HOMEWARD THROUGH SIBERIA}

station it was curious to see the patient, phlegmatic camels standing in a row with their carts and letting the snow turn them white without moving a muscle.

Yes, indeed, this is the monotony of the steppes. What a home for the nomad, who roamed here freely with his cattle and his horses! But now he is ousted by the advancing settler, who makes butter and sends it to England; and the nomad is only to be found in the poorer salt steppes farther south, where the settler has not yet thought it worth his while to establish himself ; but their turn will come, too.

Now and then we see large herds of cows, mostly brown like the Mongolian cattle, with a number of horses and sheep, and mounted herdsmen with their dogs. Occasionally some windmills appear far off on the horizon ; or the cupolas and spires of a white church rear themselves high above the plain, with a group of low timber houses round about. It is as though this towering white church had drawn all its nourishment and vigour from these little houses, thereby stunting them and checking their growth. The farther we go, the deeper is the winter. They are already sledging over the steppes here, and at Kurgán in the afternoon there were only sledges to be seen in the streets. But it is flat, still flat.

Friday, October 24. During the night we arrived at Chelyábinsk, and next morning we were among the eastern foot-hills of the Urál, on our way northward to Yekaterinenburg. It was beautiful, fresh, white wintry weather, with thick forests of big trees, mostly fir and some spruce, weighed down by the snow, and hills, with deep snow on the ground, perfect going for ski. It was just like Christmas, and reminded one extraordinarily of home. Here, then, winter had already begun. 


\section{THROUGH SIBERIA}

We arrived at Yekaterinenburg during the forenoon, and were received at the station by the Mayor and spokesman of the town, the President, Secretary and members of the Geographical Society, and many others, and every kind of hospitality was shown us. I visited the museum and saw geological and mineralogical specimens from this incredibly rich country, which has almost every kind of wealth the rocks can give. We also saw valuable collections of archæology, ethnography and ornithology, and there was much that was interesting. Then we saw all the country can produce in the way of polished stones and jewellery of various kinds. We also saw a little of this handsome hill town. What appeared to me one of its most remarkable buildings was a palace that a rich gold-mine proprietor had built for himself, no doubt because he did not know what to do with his money. But it is so large that after his death no one could live in it, and now the whole palace with all its glories has been turned into a printing office. After a pleasant dinner with Mr. Beer, chief engineer, and his amiable family, we went on to a meeting of the Geographical Society in the evening, where I gave a lecture on the voyage to the Yenisei. Here, again, great interest was shown in the development of this sea-route, which however can scarcely affect this particular town. I was received with great kindness, and was presented with a diploma and a handsome gift in commemoration of my visit to the town and of its industry in precious stones. Our stay ended in our being taken to the handsome opera house, where we heard the first act of Tchaikovsky's Spardam. But the train went at 8.49 P.M., and unfortunately we were obliged to take our leave without hearing any more of this beautiful music.

Saturday, October 25. Now we are through the 434 


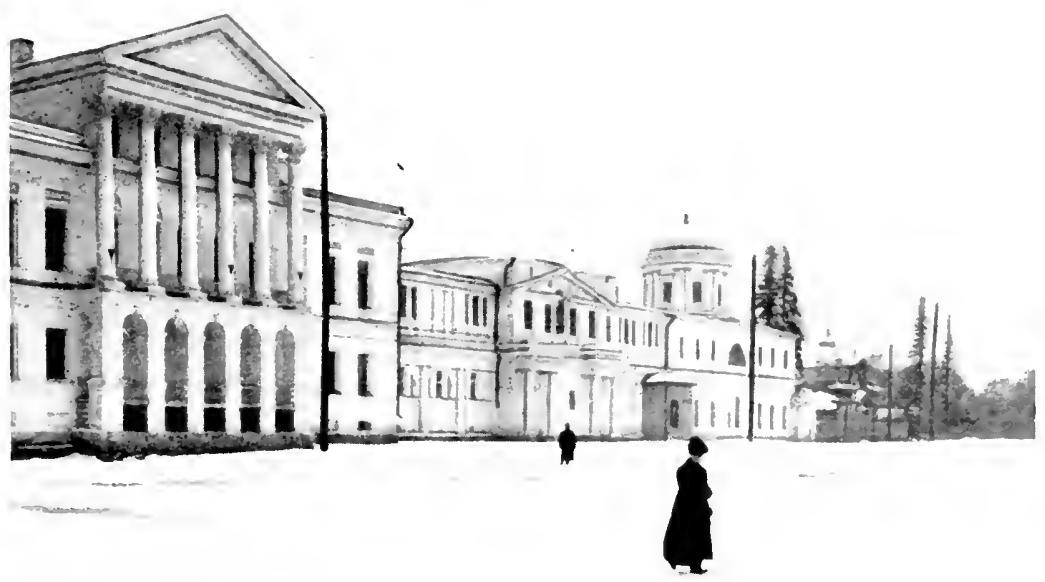

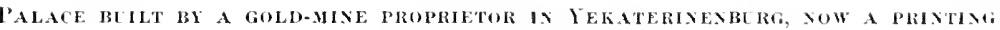
OFFICE (UCT. 24)

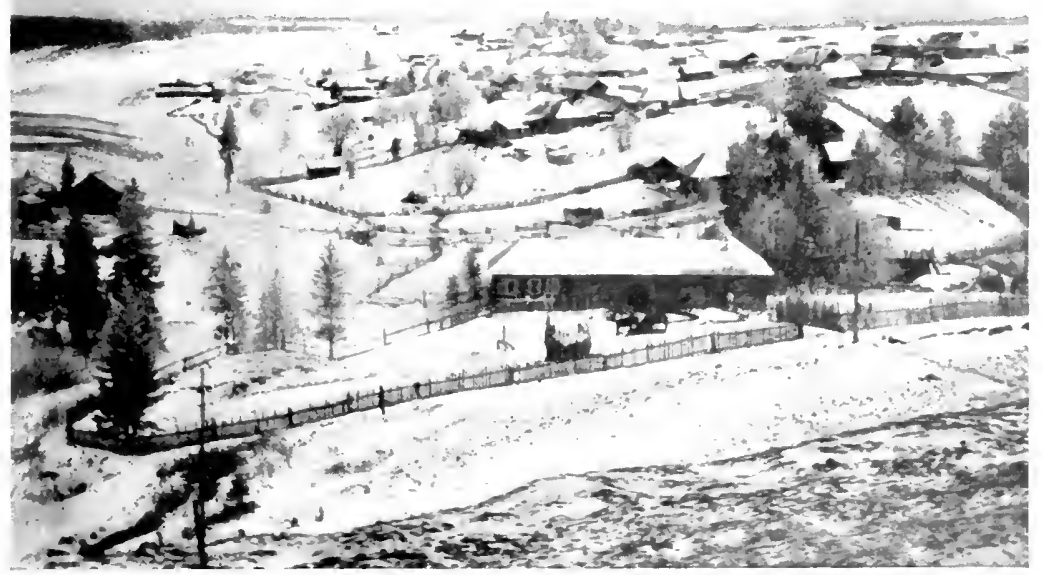

A VILLAGE IN THE GOVERMAEXT OF VIATKA (UCT. 25) 


$$
\text { . }
$$




\section{HOMEWARD THROUGH SIBERIA}

Urál and back in Europe. In the morning we arrived at Perm and crossed the Kama, on which a great deal of ice had formed. The "drift-ice" on the Kama reminded me not a little of the newly formed ice, the so-called pancake ice, up in the Arctic. It has a wintry look. A hilly country with much spruce forest among the fields and fences; it is rather like Norway, only the shape of the sledges is different, with their runners raised high in front. The houses, too, have a turn that is not altogether Norwegian; and then, of course, these haystacks standing unprotected everywhere and not a hay-barn to be seen, though there is timber enough for building. Winter has already begun, but the covering of snow is not so very thick yet, only a few inches, but still enough for sledging.

Towards midnight we came to Viatka, which is a well-known centre of the peasants' home industry in wooden articles. It is extraordinary what they can make out of birch-wood and birch-bark, and at such ridiculously low prices. There was a large selection of these things on a stall at the station. Altogether they are go-ahead, broad-minded people in the government of Viatka, as in that of Perm. There are no great landowners, but for all that they have zemstvos and communal self-government; and it is asserted that these governments are better managed than the more conservative and nationalist neighbouring governments, such as that of Volugda, where the people are said not to be so enterprising, at any rate as agriculturists. It may be remarked that the population of these governments of Viatka and Perm is probably, for the most part, of Finno-Ugrian origin, and that the Slavs came in somewhat later; but now the peasants speak Russian.

Sunday, October 26 . We are now rapidly approaching 


\section{THROUGH SIBERIA}

our destination. Only one more day and we shall be in Petersburg; I shall leave this carriage, in which I have now lived for a month, since I came aboard at Krasnoyarsk on September 29, excepting, of course, the interval when we were travelling through the Ussúri District and the Amúr District. The landscape is still just as wintry, but it has become rather flatter; there is forest, chiefly spruce, interspersed with birch and aspen and other leaf-bearing trees, and there are cultivated fields. And soon we shall see the last of it.

I have a feeling of sadness on parting from these great melancholy forests and this solemn scenery, with its broad, simple lines, free from all petty details. I have come to love it, this boundless land, mighty as the ocean itself, with its infinite plains and its mountainsits frozen Arctic coast-its free and desolate tundraits deep, mysterious taiga, from the Urál to the Pacific -its grass-grown, rolling steppes-its purple, wooded hills_and its little scattered patches of human life. 


\section{APPENDIX}

\section{THE NAVIGATION OF THE KARA SEA}

$\mathbf{B}^{\mathrm{Y}}$

September 10, a week after we had left for the south on the Omul, the loading of the Correct was finished, and on the afternoon of that day she weighed anchor and started on her homeward voyage. On September 12, to the south of Dickson Island, they met with a good deal of floating ice, and this extended on the west towards Vilkitsky Island, but was there for the most part slack. Farther west through the Kara Sea they encountered no ice. For some days they had a strong head-wind, at times increasing to a gale, with heavy sea, so that the ship made little headway. On September 16 the Correct passed through the Kara Strait, and at midnight between September 19 and 20 she arrived at South Honnings-våg, without being obstructed by ice in any part of the voyage.

Not many days after us two Russian ships also sailed eastward through the Kara Sea. Captain Charles J. Spahde in the trawler Sapad encountered ice on August 12 (1913) to the west of Yugor Shar, and entered the Kara Sea towards the same evening through that strait. This was two days after the Correct passed through the Kara Strait. The sea was open, and a course was made north-westward through the Kara Sea. But about seventy sea-miles from the Yugor Strait, Spahde again met with ice on the morning of August 14, and followed its edge for a long way to the north-west; but as the ice did not appear to ofier any passage in that quarter, he turned and went to the south-east, until he came into the proximity of the land on the south side of the Kara Sea. Here, he got through the ice in the direction of Yamal, apparently by the same long, open bay which we saw extending north-eastward in the ice 


\section{APPENDIX}

on the night between August 11 and 12, three days before Spahde.

He then went northward through the ice off the coast of Yamal for the next few days, but farther out to sea than the Correct, and found the ice more open there. On August 18 he had got as far north as latitude $73^{\circ} 56^{\prime} \mathrm{N}$. and about longitude $67^{\circ} \mathrm{E}$., but had heavy and difficult ice to the east of him all the way. He went southward again to look for a passage through the ice. At last, on August 20, he succeeded in getting through and into open sea on the north side of White Island, and then sailed past the latter southward into the Gulf of Obi. The Sapad had sprung a bad leak during her passage through the ice through bumping against the floes.

On August 22, 23, and 24, they were trawling in the Gulf of Obi, but without result, as the sturgeon they were fishing for had already gone up the Obi. On August 26 Spahde was back off the northern extremity of White Island on his way home. Here he encountered ice and had to reduce speed for some hours, until in the evening he was able to go full-speed again between big floes. The next day he went southward off the coast of Yamal through ice to Cape Kharosovai in latitude $71^{\circ} 7^{\prime} \mathrm{N}$., beyond which the sea was free of ice, and on the following day, August 28, Spahde passed through the Yugor Strait going west.

General N. Morosov, in the Government ship Nikolai II, left Archangel in the middle of July and attempted to go through the Yugor Strait or the Kara Strait, but was stopped by impenetrable ice to the west of Vaigach, and cruised in this ice for some days without being able to go forward; and the steamers Dan and Vassian, which were to bring stores for the wireless stations, did the same. Morosov then tried Matochkin Shar, and passed through it without difficulty on August 16. He made a course due east in open sea, until, seventy sea-miles from the strait, he encountered scattered ice. This soon became more closely packed, and after going seventy miles more through the ice, he was stopped. He then tried going round the north of it, and arrived in about latitude $74^{\circ} 45^{\prime} \mathrm{N}$. along the compact edge of the ice. Finding it hopeless to get round to 438 


\section{APPENDIX}

the north, he sailed southward again and tried to force his way through the ice towards White Island; after going between thirty and forty sea-miles through heavy ice, he succeeded in making a passage and reached White Island on August 26. $\mathrm{He}$ stayed there eleven days to erect a sea-mark of concrete, sixty feet high. On September 6 he arrived at Vilkitsky Island, where another sea-mark was set up, and on September 10 he proceeded to Dickson Island, where a mark was erected on the island of Verns. It was not until September 25, that Morosov left there again and sailed to the west in a heavy storm. Therc was scattered ice, but on the following day he met with closer ice to the north-east of Vilkitsky Island. So much snow fell that it filled up the intervals between the floes, and as there was also frost, the position of the vessel became dangerous; on September 27 she was entirely shut in and drifted with the ice; but two days later the ice opened somewhat, and she was able to come out into open sea on the other side. Through entirely ice-free water Morosov then went round the north of White Island and southward along the west coast of Yamal, and on October 1 he reached the Yugor Strait.

These three expeditions through the Kara Sea in 1913 show that in August there was still a great deal of ice in the eastern part of that sea and to the north-west of Yamal. The quantity of ice decreased greatly towards the close of the month, and in the latter part of September neither the Correct nor the Nikolai II encountered ice on the whole voyage through the Kara Sea from White Island to Vaigach.

In order to form an opinion of future prospects of regular navigation in the Kara Sea, a knowledge of previous experiences in its waters is important.

We do not know how early the sea-route from Europe to Siberia became known, or when trading communication was developed by this way. In 1620 navigation by this route was forbidden by the Tsar of Russia, and the little we know of voyages before that time is mainly derived from the few Western Europeans who attempted in the sixteenth century to find the sea-route to China along the coast of Siberia. We also find some 


\section{APPENDIX}

notices in the chronicles of Novgorod, and in reports of the voyevods of Tobólsk, who persistently sought to obtain the prohibition of voyages between the White Sea and the rivers of Siberia.

From these authorities it is sufficiently clear that in the latter half of the sixteenth century there was a well-known trading communication along the coast from the Pechora and the White Sea to the Gulf of Obi. The usual route was doubtless through the Yugor Strait, but perhaps the Kara Strait was also used, when the former was obstructed by ice-and then along the south coast of the Kara Sea to Yamal. As a rule the course was not round the north of this peninsula, but along two rivers which run right across it to the Gulf of Obi.

1556. In 1556 Stephen Burrough was sent out from England to find the Obi, which was known from hearsay. He arrived on August 10 at the Kara Strait and Vaigach. He was prevented by ice from entering the Kara Sea, but from a Russian walrus-hunter he obtained much information which showed that the continuation of the route to the estuary of the Obi was well known to the Russians at that time.

1580. In 1580 Arthur Pet and Charles Jackman left England with two ships to seek the North-East Passage. On August 2 Pet went through the Kara Strait into the Kara Sea. Jackman also reached this sea with his ship, but there was a great deal of ice as they sailed to the east along its south coast. It is possible that they got far enough to sight Yamal, but on August 7 they had to turn back. On August 27 they came out again through the Kara Strait going west.

1581. Various rumours point to a Western European ship, perhaps English, having been wrecked at the mouth of the Obi in 1581, and to her crew having been massacred by the Samoyedes, who thought they had come to rob and oppress them.

1594. In 1594 an expedition of four ships was dispatched from Holland to find the North-East Passage. While Willem 440 Barentsz with two ships sailed northward along the west 


\section{APPENDIX}

coast of Novaya Zemlya and reached its northern extremity, Cornelis Nai, who was the admiral of the fleet, sailed into Yugor Shar on July 25 with the other two ships and on August 1 entered the Kara Sea, where at first there was a good deal of ice. But by August 9 the ice had decreased, and soon they found the Kara Sea almost ice-free, and thought they had now found the sea-route open all the way to China. They reached the west coast of Yamal, and believed they had there passed the mouth of the Obi. They sailed farther north along the west coast and perhaps reached latitude $71_{2}^{1}{ }^{\circ} \mathrm{N}$. As the sea was still open and without a sign of ice, they eould not doubt having discovered the open sea-route to China; they therefore turned back and passed through the Yugor Strait again on August 14.

1595. In the following year, 1595, Cornelis Nai returned, this time as admiral of a fleet of seven ships, and Willem Barentsz accompanied him as chief pilot. On August 19 they found Yugor Shar closely packed with ice. Here they came across some Russian sealers, who told them that from Kholmogori on the White Sea and "from their country some smacks sailed annually through the Sea of Tartary right past the River Obi to another river, the Gillissy, where they carried on a trade in cloth and other stufis ; and that ten small smacks would soon come from Kholmogori to sail to that river, and would winter there, as they usually did." The "Gillissy" is, of course, the Yenisei, and this is, as far as I know, the first mention of it in literature. They also said that "it had been a long and hard winter, and that one year was not like another. Sometimes winter came earlier, sometimes later ; but all the ice would soon disappear, as it did every year, and it would be ten weeks before the real winter set in again." On August 25 the fleet sailed through the Yugor Strait without meeting ice until they had gone eight sea-miles into the Kara Sea. Many attempts were made to go forward along the south eoast, but the iee conditions were very awkward, and they did not go far. Even the indefatigable Barentsz had to give up at last, and on 


\section{APPENDIX}

September 15 the fleet sailed back through the Yugor Strait on its way home.

1596. In 1596 Willem Barentsz attempted to penetrate to the eastward round the north of Novaya Zemlya, but was surrounded by ice at Ijs Haven on the north coast in latitude $76^{\circ} 7^{\prime} \mathrm{N}$. at the end of August. They had to winter there, and abandoned the ship next summer, making for home in their boats. Barentsz died of scurvy on the way.

1601. The sea-trade between Northern Russia and the estuaries of the Obi and Yenisei received a fresh impetus from the foundation, in 1601, of the fortified town of Mangaséya on the lower course of the Tas, a little above the head of the Gulf of Tas, which is a branch of the Gulf of Obi. Voyages between the White Sea and the Obi and Mangaséya were frequently undertaken in boats of light draught along the coast to Mutnaya Bay on the west coast of Yamal, in about latitude $70^{\circ} 20^{\prime} \mathrm{N}$. There they ascended the Mutnaya River (i.e. the muddy river) to the three lakes of Nei-te, which communicate with one another. From there the boats were drawn across the low, narrow neck of land to Lake Yambu-to, whence they followed the Selyonaya (i.e. green) River, also called (in Samoyede) the Sho-yaga, to the Gulf of Obi, and thence through the Gulf of Tas up the River Tas to Mangaséya. There must at times have been a very active trade by this route. On August 10, 1611, some Englishmen met at the mouth of the Pechora no fewer than twenty-six Russian smacks which had been bound for Mangaséya, but had been forced to return that year by ice.

It looks as though the above-mentioned route by the rivers across Yamal was not the only one that was known, but that the way round the north, past White Island, was also well understood, though perhaps it was not so often used. Even if the navigators did not succeed in penetrating every year through the Kara Sea to the Obi and Mangaséya, and even if the voyage took two years, through their having to winter, this trade must have flourished and was certainly very lucrative. The skins 


\section{APPENDIX}

of sables, squirrels, foxes, and other furs were specially valuable, and large quantities of these animals were caught at that time in northern Siberia. We hear that sables from certain places on this route to Mangaséya were specially sought after. Many commodities were also imported through Mangaséya, and of these the English furnished no inconsiderable quantity. The voyevods of Tobólsk, therefore, became louder and louder in their complaints of this northern trade, which, of course, involved a loss to their traders. They wanted to have the route forbidden to Russians, in order, as they said, that they might not draw foreigners after them into Siberia.

1620. In 1620, therefore, the use of this trade-route was forbidden by a ukase of the Tsar Mikhael Fedorovich; and those who transgressed the prohibition were to be flogged to death. Fifty men were posted on Vaigach as a guard. In this way those who wished to carry on trade with Mangaséya were to be forced to take the land-route, in order that they might not escape the customs; but this route was attended by too many difficulties, and the result was that from the year 1620 Mangaséya declined, after having been in its flourishing days an important place, where two thousand traders met in the summer.

After this prohibition of 1620 it seems that the Russians entirely ceased their voyages to the Obi. On the other hand, they certainly continued their sealing in the Kara Sea for a long time, and no doubt they also carried on trade with the Samoyedes of Yamal; but of this there is no record. The Dutchman, Witsen, in his great work (of 1705) only has a casual mention of some voyages 1690-of this kind to Yamal in 1690 and 1691, derived from the 91 mate of a wrecked vessel who had wintered there. After this time Russian sealing appears gradually to have ceased.

It would take us too far to mention all the attempts that have been made in the course of years to sail to the east through the Kara Sea; unsuccessfully, in the case of most of the earlier voyages, but sometimes with better 1694 fortune. Thus, in 1694, the Dutch whaling captain, 


\section{APPENDIX}

Willem de Vlamingh, sailed round the north of Novaya Zemlya to Barentsz's winter harbour, and from there to the south-east to about latitude $74^{\circ}$ N., somewhere to the north of the estuary of the Obi or Yenisei in perfectly open sea.

During the great northern expedition the Russians resumed serious attempts to explore the Kara Sea and the 1734-coast of Siberia eastward in the years 1734-39, and after

39 several years of efiort Maluigin and Skuratov succeeded in making their way past Yamal and White Island into the Gulf of Obi in 1737 .

Among Russians who have more recently performed special service in the exploration of the coasts of the Kara Sea, may be mentioned Savva Fofanov Loshkin, who circumnavigated Novaya Zemlya in 1741-42 (?) ; Rosmuislov, who went through Matochkin Shar (1768-69); Pakhtusov and Tsivolka (1833-35), who sailed along the east coast of Novaya Zemlya; von Baer (1837), and Paul von Krusen-

1860 stern, who, in 1860, went through the Kara Strait and found the Kara Sea entirely free of ice, but had to turn back on September 13 on account of imperfect outfit.

1862 On August 15, 1862, he made his way to the eastward through the Yugor Strait, found much ice, was surrounded, and drifted on to the east until on August 26 he sighted Yamal, and then drifted northward with the ice, until he and his crew abandoned the vessel on September 17, and with the help of the Samoyedes reached Obdorsk overland.

After that time the Norwegian sealers in their small vessels began to extend their voyages to the eastward in search of new hunting-grounds, thereby inaugurating a new epoch in the navigation of the Kara Sea.

1868. In 1868 the sealing skipper, Elling Carlsen, in a sloop from Hammerfest entered the Kara Sea by the Kara Strait and returned by Yugor Shar.

1869. In 1869 Carlsen pushed on to the neighbourhood of White Island, and laid his homeward course to Norway through Matochkin Shar. In the same year the Norwegian sealing skipper, Edvard Johansen, sailed through the Kara Strait on June 29, and crossed the Kara Sea in 


\section{APPENDIX}

perfectly ice-free water to the coast of Yamal, followed this coast northward to White Island, which he reached on August 7, then crossed the Kara Sea again, and went southward along the east coast of Novaya Zemlya to the Kara Strait, and through it back to Norway. In the same summer the English sportsman, Major John Palliser, sailed through Matochkin Shar across the Kara Sea to the neighbourhood of White Island, and back through the Yugor Strait.

In the succeeding years Norwegian sealing skippers sailed through the Kara Sea in all directions.

1870. 1870 was a specially favourable year, and the Kara Sea was found to be practically free of ice as early as the first part of August.

1871. 1871 was also a fairly favourable ice year, especially in the northern part of the Kara Sea. On September 12 sealing skipper Mack reached latitude $75^{\circ} 25^{\prime} \mathrm{N}$. and longitude $82^{\circ} 30^{\prime} \mathrm{E}$. in open water. He thus went farther east than the mouth of the Yenisei.

1872 and 1873 were unfavourable years, with much ice in the Kara Sea.

1874. But in 1874 the conditions were better again, and many Norwegian sealing skippers sailed through the Kara Sea in all directions. In this year, too, the Englishman, Joseph Wiggins, made his way through the Kara Strait and the Kara Sea round the north of White Island to a point north of the Obi estuary, from which he returned, passing through the Kara Strait on August 28.

1875. In 1875 Baron Nordenskiöld sailed in the Norwegian sealing sloop, Pröven (Skipper Isaksen), through the Yugor Strait on August 2, crossed the almost ice-free Kara Sea, and reached Dickson Island to the north of the Yenisei estuary on August 15.

1876. In 1876 the ice conditions were again favourable. Nordenskiöld went with the steamer Ymer and a cargo through Matochkin Shar on August 5, and reached the Yenisei estuary on August 15. Captain Wiggins also took a steamer through the Kara Strait on August 3, and arrived off the estuary of the Yenisei on September 9. 


\section{APPENDIX}

1877. In 1877 the ice conditions were favourable, and one or two steamers reached the mouths of the Yenisei and Obi.

1878. In 1878, when Nordenskiöld set out on his expedition in the Vega, the Kara Sea was almost entirely free of ice at the beginning of August, and several steamers went out and home through the Kara Sea that summer, among them that of Captain Wiggins, who sailed to the Gulf of Obi. Farther north the sea was also unusually free of ice, and the sealing skipper, Edvard Johansen, went round the north of Novaya Zemlya and so far to the east that he sighted land on the Taimyr Peninsula and discovered Lonely Island (Ensomheten).

1879. In 1879 the ice conditions were less favourable for the passage through the straits, and no fewer than six cargo steamers and one sailing ship tried in vain to get through to the Obi that way. One ship, the Neptun, succeeded in entering the Kara Sea by Matochkin Shar on September 3, but she was forced to return by ice. Captain Dallman, in the steamer Louise, on the other hand, managed to get through the Yugor Strait on September 8 or 9 and into the Kara Sea, which he found almost free of ice, and on September 13 he reached Golchíkha on the Yenisei estuary, from whence he returned through the Yugor Strait on October 11. Several Norwegian sealing skippers sailed through the Kara Sea that summer.

1880. Nor were the ice conditions in the Kara Sea particularly favourable in 1880. One or two steamboats had to turn back without entering the Kara Sea, while the steamer Neptun reached the Gulf of Obi, and was back in the Yugor Strait on September 19. Sibiriakov, in the steamer Oscar Dickson, with the schooner Nordland sometimes in tow, crossed the Kara Sea, and reached the neighbourhood of Vilkitsky Island on September 24, where the vessels ran aground and were surrounded by ice. They finally reached Gyda Bay, but were afterwards wrecked in the ice.

1881. 1881 was a more favourable ice year, when two steamers and some lighters made their way to the estuary of the Yenisei.

1882. 1882 was a particularly unfavourable ice year in the Kara 446 


\section{APPENDIX}

Sea. The steamers Louise and Nordenskiöld attempted in vain to get through, and the Dutch expedition in the Varna and the Danish expedition in the Diymphna (Captain Hovgaard) were caught in the ice and drifted in it all the winter.

1883. Nor was 1883 a favourable ice year, and no ships passed through the Kara Sea in that year, though perhaps this is rather to be attributed to other accidents.

1884. Nor does 1884 appear to have been a favourable year. The steamer Nordenskiöld was forced to return, though this, it is true, was owing to damage to her engines; and we do not know that any other ship attempted the voyage.

There is no record of any navigation in the Kara Sca in 1885 or 1886.

1887. 1887 was a favourable ycar. Captain Wiggins found the Kara Sea almost ice-free on August 29, reached the Yenisei estuary and returned.

1888. In 1888 there was much ice in the Kara Sea. As late as September 25 Captain Wiggins saw large masses of ice, but also some open water. He sailed to White Island and returned on October 1 .

1889. In 1889 the Kara Sea was open. Captain Wiggins reached the estuary of the Yenisei on September 4 without difficulty.

1890. 1890 was a favourable year. Three steamers arrived in the Yenisei estuary.

In 1891 and 1892 there was no navigation in the Kara Sea, nor did any sealers enter it.

1893. In 1893 the Fram met with a good deal of ice in the Kara Sea in the first half of August, while Captain Wiggins with six steamers found little ice at the end of the month, and arrived without difficulty in the Yenisei estuary.

1894. 1894 was a favourable year. Wiggins passed through the Kara Sca in open water at the end of August to the Yenisei estuary.

1895. In 1895 Wiggins encountered a good deal of ice in the Kara Sea at the end of August and beginning of September, but, nevertheless, reached the Yenisei estuary. 


\section{APPENDIX}

1896. 1896 was a favourable ice year. Two steamers reached the Yenisei estuary and two left it.

1897. 1897 was a very favourable year. Eleven steamboats sailed to the mouths of the Obi and Yenisei.

1898. 1898 seems also to have been a favourable iee year. Six steamboats passed through the Kara Sea to the estuaries of the Obi and Yenisei. The Russian exploration ship, Pakhtusov, also found little ice in the Kara Sea.

1899. In 1899 there was a lot of ice in the south of the Kara Sea. Four large English steamers could not get through the straits, and after one of them had sunk in the ice, the others returned home; but several Norwegian sealing sloops made successful voyages through the Kara Sea, as did the Russian Pakhtusov.

1900. 1900 was a favourable year. Baron von Toll in the Sarya ("Dawn") met with only small quantities of scattered ice in the Kara Sea in the first half of August. The Pakhtusov also met with little ice, and by the latter half of August most of it seems to have disappeared. Several Norwegian sealing sloops sailed out and home through the Kara Sea, and one of them even went right up to Franz Josef Land.

1901. 1901 was an unusually favourable year. A Norwegian sealer found the Kara Sea free of ice as early as the beginning of August, and the Pakhtusov found it in the same state in the early days of September.

1902. In 1902 there was much ice in the Kara Sea as late as the end of August and beginning of September, when the Pakhtusov sailed some distance to the eastward along the south coast, turning back on September 10. The Samoyedes reported that the Kara Strait had been entirely frozen that winter, and said that this happened very rarely.

1903. In 1903 there was much ice in the straits, and neither the Pakhtusov nor any other ship succeeded in entering the Kara Sea.

1904. 1904 was a very favourable year. The Pakhtusov found the Kara Sea entirely free of ice when she entered it in the latter half of August. 


\section{APPENDIX}

1905. In 1905 twenty-two steamers were dispatched by the Russian Government to the Yenisei estuary, and two German steamers went to the mouth of the Obi. As late as the end of August they found the Yugor Strait closed by ice, but they got through in the early days of September and found the Kara Sea almost entirely ice-free, with the exception of some scattered ice in its south-western part.

1906. In 1906 the ice conditions in the Kara Sea appear to have been favourable, but no accurate information is available.

1907. In 1907 the ice conditions seem to have been fairly favourable in the Kara Sea. The Russian sealer, Sviatoi Foka (the "Holy Seal "), sailed through the Kara Sea in ice-free water at the close of August, and returned after successful walrus-hunting in September. The Russian steamboat, Bakan, passed through the Yugor Strait on August 31 and reached the Yenisei on September 27.

1908. In 1908 the conditions appear to have been favourable; several Russian and Norwegian sloops were engaged in sealing in the Kara Sea that year.

No information is obtainable of the ice conditions in the Kara Sea in 1909 and 1910.

1911. In 1911 there was a lot of ice in the Kara Sea, but the Englishman, Webster, reached the Yenisei estuary in the Nimrod and the ship returned.

1912. In 1912 there was an unusual quantity of ice in the Kara Sea. Several ships which were to bring stores for the wireless station at Mora Salé, in Yamal, tried in vain to get there up to the middle of September. One or two other Russian ships also attempted without success to get through the ice to the eastward, and on September 28 and 29 the vessels returned homeward from Yugor Shar.

It has been mentioned in Chapter I that in this year the Siberian Company dispatched the Norwegian steamer Tulla to the Yenisei. The vessel arrived at the Yugor Strait on August 12, but could not get through on account of ice. The Kara Strait was also closed. On August 27 the Tulla passed through the Yugor Strait ; but there was a great deal of ice, and she could only make a little headway 


\section{APPENDIX}

along the south-west coast. After lying at anchor and waiting for four days, the ship returned to the Yugor Strait on September 4 and went home to Norway.

This survey of navigation to and through the Kara Sea, brief as it is, will doubtless be sufficient to show that the ice conditions in that sea are liable to great variation from one year to another. But, on the other hand, the reports of the various voyages show clearly enough how little the general conditions have changed during the $\mathbf{3 3 3}$ years since the first English expedition penetrated into the Kara Sea in 1580. If we read the description of this voyage, or of the Dutch expeditions of 1594 and 1595, they seem entirely applicable to the most recent expeditions through the Kara Sea, with the same open water in one year and the same difficulties with the ice in the next. But in those days, of course, they had only sails, whereas we now have steam.

Our survey also shows how remarkably rare it is in more recent times for ships to fail in getting through this sea, when serious attempts have been made. In the forty-five years since Norwegian sealers, at the close of the sixties, reopened this sea to navigation, there seem only to have been a few summers when it was impossible to find a passage. In the forty years since 1874, during which steamers have attempted to reach the estuaries of the Obi and Yenisei, we may say that it was only in the four years, 1882, 1902,1903, and 1912, that the ice conditions prevented all ships from reaching their destinations. 1883 was another year in which no ship arrived, but one of those which made the attempt had her propeller broken by the ice, and the other turned back to tow this vessel home to Norway. In 1902 and 1903 only one ship, the Pakhtusov, made the attempt. That it was a difficult ice year is clear enough, but we know nothing of the ice conditions in other parts of the Kara Sea at the time. In 1912 it was only attempted to go forward along the south coast of the Kara Sea ; we do not know what the ice conditions were in the northern parts.

The numerous earlier expeditions thus show with certainty that in the great majority of years it is possible to reach the Siberian rivers through the Kara Sea, and these expeditions do 450 


\section{APPENDIX}

not prove that it would not be possible to do so every year. My belief is that, with all the facilities of our time, it ought only to be impossible in altogether exceptional years-such as rarely occur, if ever-to overcome the difficulties of the ice in the Kara Sea, and to find a way through to the estuaries of the Obi and Yenisei.

But the survey here given shows, nevertheless, that there must be great variations from one year to another in the quantity of ice to be found in the Kara Sea in summer. In some years, 1878 for instance, it seems to have been almost ice-free from its southern part to as far north as Lonely Island and the neighbourhood of Franz Josef Land; while in other years there was much ice both in the northern and southern parts of the sca, which made progress difficult, even if it was not altogether impossible. In 1882, for example, there was much ice both in the south and in the north of the Kara Sea ; and in 1883 it was also full of ice, so far as it was investigated. In 1888 and 1895 much ice was seen there as late as the end of September, and in 1902 and 1903 it was full of ice, at any rate in its southwestern part. But, on the other hand, the Kara Sea was found to be more or less free of ice at the end of August in such years as 1887, 1890, 1894, 1897 and 1898, 1900 especially, 1901, and 1904.

It is therefore incorrect to suppose that an approximately equal quantity of ice is adrift in this sea every summer and autumn, and that we may therefore reckon that, if progress is difficult in the southern part, it must be easy in its northern, and vice versa. No doubt the winds and the drift of the ice which they create have a great deal to do with the direction in which the bulk of the ice is carried, but a still more important factor as regards the chances of navigation in various years is the quantity of the ice itself. For the future navigation of the Kara Sea it will therefore be desirable to find out, if possible, to what these great variations in the quantity of the ice may be due.

Two possibilities may be imagined. They may either be due to variations in the prevailing winds and sea-currents, the effect of which is that, while in one year great masses of ice are driven into this sea from the northward and fill it, in other years the ice masses are driven northward and out of the sea. Or clse we 


\section{APPENDIX}

must suppose that the greater part of the ice which is found in the Kara Sea belongs to that sea and has not come from elsewhere, and thus we have to deal with a variation in the quantity of ice that is formed and melts every year in the sea itself.

The first hypothesis is improbable. The Kara Sea, in the region between Yamal and Novaya Zemlya, is to be considered as so far land-locked and shallow that great quantities of ice cannot be expected to drift into it from the north. The ice that is found there, in any case in the southern part, between Yamal and Novaya Zemlya, gives one the impression of having been formed in this sea itself. It is not the heavy ice that is met with farther north.

We must therefore suppose that there may be great variations from one year to another in the quantities of ice that are formed and melt in this sea itself. That this should be due to variations in the temperature of the sea-water itself, occasioned by changes in the currents from year to year, is improbable. The quantity of water that the currents can bring into this land-locked sea from the west is so small that it can be of little or no consequence. But there is the additional factor that the Kara Sea is covered with a layer of water of lower salinity, which is formed by the admixture of river-water and water derived from the melting of snow and ice, and this water is therefore so much lighter than the subjacent, more saline water, that even the most intense refrigeration cannot cause it to sink down into the latter; the result is that this surface-layer becomes independent of the possible variations of temperature in the subjacent layers which might be due to variations in the quantity of water added to the latter by currents flowing round the north of Novaya Zemlya.*

The quantity of the ice that is formed every year in the Kara Sea must be determined by the refrigeration of the surface of this sea in the course of the winter, and also by the layer of snow covering the ice; for naturally less ice is formed under a thick layer of snow than under a thin one. After a cold winter with little snowfall the quantity of ice in the Kara Sea in the

* The masses of water that may be brought in through the southern straits will be too small to have any appreciable effect in this respect.

452 


\section{APPENDIX}

following year will be much greater than after a mild winter with a heavy snowfall. If the severe winter is then succeeded by a relatively cold and raw spring and summer, little ice will melt, and we shall have a particularly unfavourable ice year in the Kara Sea. If, on the other hand, the mild winter with heavy snowfall is succeeded by a warm spring and summer with much sunshine, the melting of the ice will proceed rapidly, and we may expect a fairly ice-free Kara Sea.

Another thing to be considered is that the formation of ice in winter is to a great extent dependent on the conditions prevailing during the autumn-whether there is much or little ice, whether the surface-waters are cold or warm. If the sea is tolerably free of ice at the close of summer, as it often is, the water in the surface-layers will be relatively warm, and will require time to be cooled down to freezing-point, and moreover the formation of ice will be impeded by the winds, which keep the sea rough; and when new ice has been formed, it will immediately be broken up again and destroyed by the sea, which grinds it to a mash. It may take time for the formation of ice to become strong enough to prevail against wind and sea.

In those years, on the other hand, when, during the autumn there is much ice in the sea, which has lasted through the summer from the previous winter, the water of the surface-layers will be colder, and new ice will quickly be able to form between the drifting floes, which will entirely lay the seas and prevent the wind from obtaining a hold. The formation of ice may then proceed more or less undisturbed from the very beginning of winter. A year with much ice may therefore influence the conditions in the following year ; and if, for instance, two severe winters occur in succession, there is a prospect that the summer which follows them may be one of special difficulty; while, on the other hand, it cannot always be assumed that a mild winter is capable of counteracting the effects of a preceding difficult ice year.

Even at a very early period it appears to have been realized that the severity of the winter had an influence on the quantity of ice in the Kara Sea in the following summer. In 1595 we heard that the Russian sealers told the Dutchmen, who met 


\section{APPENDIX}

them in the Yugor Strait, that one year was not like another; that it had been a long and hard winter, which in their opinion explained the unfavourable nature of the ice conditions that year.

A comparison of the average temperatures of the air in winter and summer in the region bordering on the Kara Sea, with the ice conditions prevailing in that sea, would necessarily afford a means of testing the correctness of the theory here put forward. But unfortunately there is no meteorological station near the Kara Sea where regular observations have been made during a long series of years. The nearest station is Maliye Karmakuli, on the west coast of Novaya Zemlya, but from there we have only a fairly continuous series of observations between the years 1896 and 1910, besides an intermittent record for a few separate winters before that time: 1876-77, 1878-79, 1882-83, and 1891-92. We must therefore have recourse to stations to the south on the mainland, and the nearest of these is Obdorsk, from which we have an excellent series of observations from the autumn of 1882 to 1913. The nearcst station in Russia is at Pustozersk on the Pechora. From there observations are available from New Year 1901 to the spring of 1906, when the station was discontinued; but at the same time regular observations were commenced at Oxino, which lies at a short distance from it.

By the kind courtesy of the director of the Central Physical Observatory in St. Petersburg, and of the subdirector, Mr. E. Stelling, I have been given a transcript of all the mean monthly temperatures reported from these stations.

The mean figures from Obdorsk are calculated from observations taken at 7 A.M., 1 P.M., and 9 P.M., and have been corrected to the true mean for the twenty-four hours. The same is the case with the figures for Karmakuli. On the other hand, the monthly means for Pustozersk and Oxino are calculated direct from the daily observations taken at 7 A.M., 1 P.M., and 9 P.M., without any correction.

From these various monthly means I have then added up the figures given in the following Tables. Table I gives a comparison of the mean temperature for each winter, from November 1 to the end of April, for each station. Table II 454 


\section{APPENDIX}

gives the mean temperatures for the spring and summer months in each year, from May 1 to August 31. Table III gives the mean temperatures of the whole ten months, from November of the preceding year to the end of August, since the temperatures for the whole of this period may be supposed to influence the ice conditions in the Kara Sea as we find them in August and September.

TABLE I. MEAN WINTER TEMPERATURES FROM NOVEMBER 1 TO APRIL 30

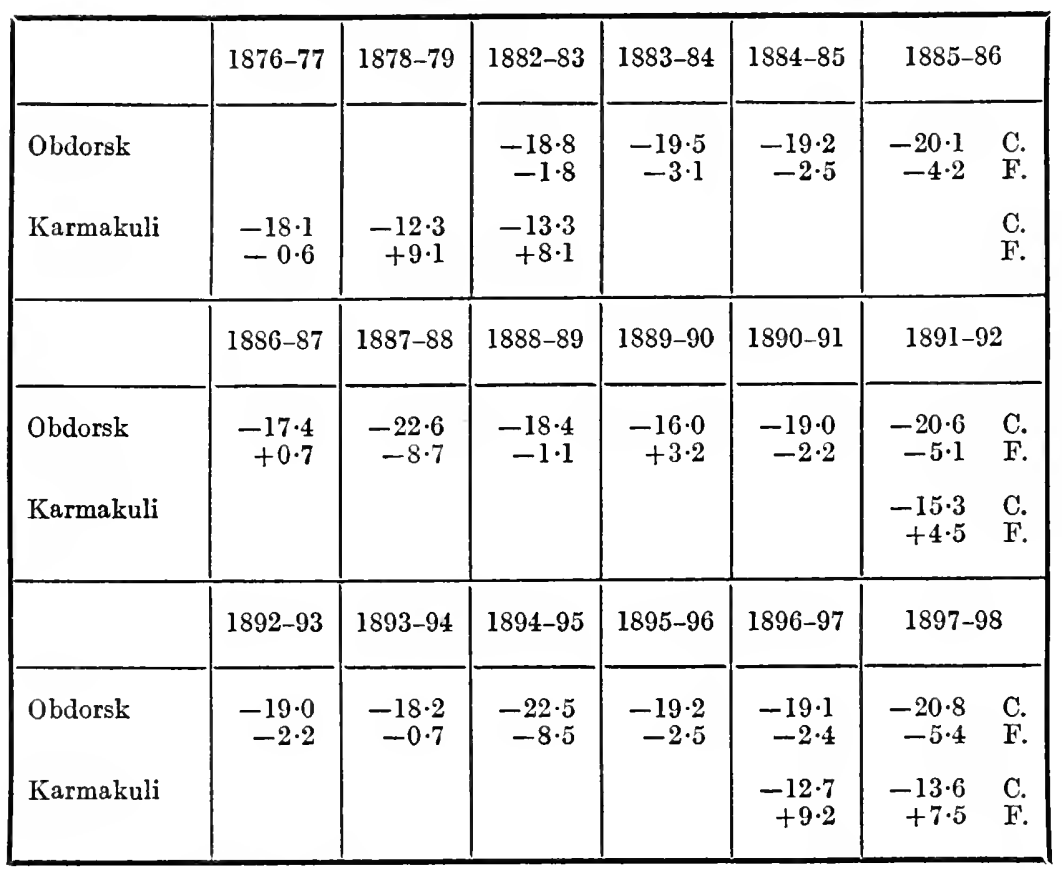

\begin{tabular}{|c|c|c|c|c|c|c|c|c|}
\hline & $1898-99$ & $1899-00$ & $1900-01$ & $1901-02$ & 1902-03 & 1903-04 & $1904-05$ & $1905-06$ \\
\hline Obdorsk . & $\begin{array}{r}-20 \cdot 3 \\
-4.5\end{array}$ & $\begin{array}{r}-16 \cdot 3 \\
+2.7\end{array}$ & $\begin{array}{r}-17.3 \\
+0.9\end{array}$ & $\begin{array}{l}-23 \cdot 9 \\
-11 \cdot 0\end{array}$ & $\begin{array}{r}-19 \cdot 8 \\
-3.6\end{array}$ & $\begin{array}{r}-16.4 \\
+2.5\end{array}$ & $\begin{array}{r}-16.9 \\
+1.6\end{array}$ & $\begin{array}{rl}-19.1 & \mathrm{C} . \\
-2.4 & \mathrm{~F}\end{array}$ \\
\hline Karmakuli & $\begin{array}{r}-16 \cdot 1 \\
+3 \cdot 0\end{array}$ & $\begin{array}{l}-11.8 \\
+10.8\end{array}$ & & $\begin{array}{r}-20 \cdot 2 \\
-4 \cdot 3\end{array}$ & $\begin{array}{r}-16.4 \\
+2.5\end{array}$ & $\begin{array}{l}-10 \cdot 7 \\
+12 \cdot 8\end{array}$ & $\begin{array}{r}-12 \cdot 7 \\
+9 \cdot 2\end{array}$ & $\begin{array}{r}-13.9 \text { C. } \\
+7.0 \text { F. }\end{array}$ \\
\hline Pustozersk & & & $\begin{array}{l}(-12 \cdot 8) \\
(+9 \cdot 0)\end{array}$ & $\begin{array}{r}-19 \cdot 2 \\
-2 \cdot 5\end{array}$ & $\begin{array}{r}-15 \cdot 1 \\
+4.8\end{array}$ & $\begin{array}{l}-10 \cdot 95 \\
+12 \cdot 3\end{array}$ & $\begin{array}{l}-11 \cdot 1 \\
+12 \cdot 0\end{array}$ & $\begin{array}{r}-12.3 \text { C. } \\
+9.1 \text { F. }\end{array}$ \\
\hline
\end{tabular}




\section{APPENDIX}

TABLE I-continued

\begin{tabular}{|c|c|c|c|c|c|c|c|c|}
\hline & $1906-07$ & 1907-08 & 1908-09 & $1909-10$ & $1910-11$ & $1911-12$ & \multicolumn{2}{|c|}{$1912-13$} \\
\hline Obdorsk & $\begin{array}{r}-14.5 \\
+5.9\end{array}$ & $\begin{array}{r}-19 \cdot 3 \\
-2 \cdot 7\end{array}$ & $\begin{array}{r}-20 \cdot 0 \\
-4.0\end{array}$ & $\begin{array}{r}-17 \cdot 1 \\
+1.2\end{array}$ & $\begin{array}{r}-206 \\
-5 \cdot 1\end{array}$ & $\begin{array}{r}(-19 \cdot 3) \\
(-2 \cdot 7)\end{array}$ & $\begin{array}{r}-18 \cdot 6 \\
-1 \cdot 5\end{array}$ & $\begin{array}{l}\text { C. } \\
\text { F. }\end{array}$ \\
\hline Karmakuli & $\begin{array}{r}-8 \cdot 1 \\
+17 \cdot 4\end{array}$ & $\begin{array}{l}-12 \cdot 2 \\
+101\end{array}$ & $\begin{array}{r}-14.7 \\
+5.6\end{array}$ & $\begin{array}{r}-13 \cdot 6 \\
+7 \cdot 5\end{array}$ & & & & $\begin{array}{l}\text { C. } \\
\text { F. }\end{array}$ \\
\hline Oxino & $\begin{array}{l}-10.8 \\
+12.6\end{array}$ & $\begin{array}{r}-14.9 \\
+5.2\end{array}$ & $\begin{array}{r}-14.0 \\
+6.8\end{array}$ & $\begin{array}{l}-10.1 \\
+13.8\end{array}$ & $\begin{array}{r}-16 \cdot 0 \\
+3 \cdot 2\end{array}$ & $\begin{array}{r}-16.6 \\
+2.1\end{array}$ & $\begin{array}{l}-11 \cdot 7 \\
+11 \cdot 0\end{array}$ & $\begin{array}{l}\text { C. } \\
\text { F. }\end{array}$ \\
\hline
\end{tabular}

TABLE II. MEAN TEMPERATURES FOR THE SPRING AND SUMMER MONTHS, MAY 1 To AUGUST 31

\begin{tabular}{|c|c|c|c|c|c|c|c|}
\hline & 1879 & 1883 & 1884 & 1885 & 1886 & \multicolumn{2}{|c|}{1887} \\
\hline Obdorsk & & $\begin{array}{r}5 \cdot 8 \\
42 \cdot 4\end{array}$ & $\begin{array}{r}4 \cdot 3 \\
39 \cdot 7\end{array}$ & $\begin{array}{r}4 \cdot 4 \\
39 \cdot 9\end{array}$ & $\begin{array}{r}5 \cdot 4 \\
41 \cdot 7\end{array}$ & $\begin{array}{r}8 \cdot 8 \\
47 \cdot 8\end{array}$ & $\begin{array}{l}\text { C. } \\
\text { F. }\end{array}$ \\
\hline \multirow[t]{2}{*}{ Karmakuli } & $\begin{array}{c}(1 \cdot 9) \\
(35 \cdot 4)\end{array}$ & $\begin{array}{r}1 \cdot 8 \\
35 \cdot 2\end{array}$ & & & & & $\begin{array}{l}\text { C. } \\
\text { F. }\end{array}$ \\
\hline & 1888 & 1889 & 1890 & 1891 & 1892 & \multicolumn{2}{|c|}{1893} \\
\hline \multirow{2}{*}{$\begin{array}{l}\text { Obdorsk } \\
\text { Karmakuli }\end{array}$} & $\begin{array}{r}7 \cdot 9 \\
46 \cdot 2\end{array}$ & $\begin{array}{r}6 \cdot 5 \\
43 \cdot 7\end{array}$ & $\begin{array}{r}5 \cdot 8 \\
42 \cdot 4\end{array}$ & $\begin{array}{r}4 \cdot 2 \\
39 \cdot 5\end{array}$ & $\begin{array}{r}8 \cdot 6 \\
47 \cdot 5\end{array}$ & $\begin{array}{r}7 \cdot 5 \\
45 \cdot 5\end{array}$ & $\begin{array}{l}\text { C. } \\
\text { F. }\end{array}$ \\
\hline & 1894 & 1895 & 1896 & 1897 & 1898 & & \\
\hline Obdorsk & $\begin{array}{r}8 \cdot 5 \\
47 \cdot 3\end{array}$ & $\begin{array}{r}6 \cdot 2 \\
43 \cdot 1\end{array}$ & $\begin{array}{r}9 \cdot 0 \\
48 \cdot 2\end{array}$ & $\begin{array}{r}9 \cdot 9 \\
49 \cdot 8\end{array}$ & $\begin{array}{r}7 \cdot 8 \\
46 \cdot 0\end{array}$ & & $\begin{array}{l}\text { C. } \\
\text { F. }\end{array}$ \\
\hline Karmakuli & & & & $\begin{array}{r}4 \cdot 1 \\
39 \cdot 4\end{array}$ & $\begin{array}{r}(2 \cdot 8) \\
(37 \cdot 0)\end{array}$ & & $\begin{array}{l}\text { C. } \\
\text { F. }\end{array}$ \\
\hline
\end{tabular}

\begin{tabular}{|c|c|c|c|c|c|c|c|c|c|}
\hline & 1899 & 1900 & 1901 & 1902 & 1903 & 1904 & 1905 & \multicolumn{2}{|c|}{1906} \\
\hline Obdorsk & $\begin{array}{r}5 \cdot 9 \\
42 \cdot 6\end{array}$ & $\begin{array}{r}8 \cdot 1 \\
46 \cdot 6\end{array}$ & $\begin{array}{r}6 \cdot 7 \\
44 \cdot 1\end{array}$ & $\begin{array}{r}6 \cdot 6 \\
43 \cdot 9\end{array}$ & $\begin{array}{r}6 \cdot 6 \\
43 \cdot 9\end{array}$ & $\begin{array}{l}10 \cdot 0 \\
50 \cdot 0\end{array}$ & & $\begin{array}{r}9 \cdot 1 \\
48 \cdot 4\end{array}$ & $\begin{array}{l}\text { C. } \\
\text { F. }\end{array}$ \\
\hline Karmakuli & $\begin{array}{r}(0 \cdot 5) \\
(32 \cdot 9)\end{array}$ & $\begin{array}{r}2 \cdot 2 \\
35 \cdot 9\end{array}$ & & $\begin{array}{r}1 \cdot 6 \\
34 \cdot 9\end{array}$ & $\begin{array}{r}(1 \cdot 5) \\
(34 \cdot 7)\end{array}$ & $\begin{array}{r}3 \cdot 7 \\
38 \cdot 7\end{array}$ & $\begin{array}{r}(2 \cdot 9) \\
(37 \cdot 2)\end{array}$ & $\begin{array}{r}2 \cdot 4 \\
36 \cdot 3\end{array}$ & $\begin{array}{l}\text { C. } \\
\text { F. }\end{array}$ \\
\hline Pustozersk & & & $\begin{array}{r}6 \cdot 4 \\
43 \cdot 5\end{array}$ & $\begin{array}{r}6 \cdot 4 \\
43 \cdot 5\end{array}$ & $\begin{array}{r}6 \cdot 9 \\
44 \cdot 4\end{array}$ & $\begin{array}{r}8.8 \\
47.8\end{array}$ & $\begin{array}{r}8 \cdot 0 \\
46 \cdot 4\end{array}$ & $\begin{array}{r}8 \cdot 2 \\
46 \cdot 7\end{array}$ & $\begin{array}{l}\text { C. } \\
\text { F. }\end{array}$ \\
\hline
\end{tabular}




\section{APPENDIX}

TABLE II-continued

\begin{tabular}{|c|c|c|c|c|c|c|c|c|}
\hline & 1907 & 1908 & 1909 & 1910 & 1911 & 1912 & \multicolumn{2}{|c|}{1913} \\
\hline Obdorsk & $\begin{array}{r}7 \cdot 8 \\
46 \cdot 0\end{array}$ & $\begin{array}{r}8 \cdot 6 \\
47 \cdot 5\end{array}$ & $\begin{array}{r}8 \cdot 2 \\
46 \cdot 7\end{array}$ & $\begin{array}{r}9 \cdot 0 \\
48 \cdot 2\end{array}$ & $\begin{array}{r}8 \cdot 5 \\
47 \cdot 3\end{array}$ & $\begin{array}{r}5 \cdot 8 \\
424\end{array}$ & $\begin{array}{r}8 \cdot 0 \\
46 \cdot 4\end{array}$ & $\begin{array}{l}\text { C. } \\
\text { F. }\end{array}$ \\
\hline Karmakuli & $\begin{array}{r}2 \cdot 9 \\
37 \cdot 2\end{array}$ & $\begin{array}{r}3 \cdot 0 \\
37 \cdot 4\end{array}$ & $\begin{array}{r}2 \cdot 6 \\
36 \cdot 7\end{array}$ & $\begin{array}{r}(2.8) \\
(37 \cdot 0)\end{array}$ & & & & $\begin{array}{l}\text { C. } \\
\text { F. }\end{array}$ \\
\hline Oxino & $\begin{array}{r}8 \cdot 3 \\
46 \cdot 9\end{array}$ & $\begin{array}{r}7 \cdot 4 \\
45 \cdot 3\end{array}$ & $\begin{array}{r}6 \cdot 4 \\
43 \cdot 5\end{array}$ & $\begin{array}{r}7 \cdot 0 \\
44 \cdot 6\end{array}$ & $\begin{array}{r}6 \cdot 6 \\
43 \cdot 9\end{array}$ & $\begin{array}{r}5 \cdot 6 \\
42 \cdot 1\end{array}$ & $\begin{array}{r}7 \cdot 1 \\
44 \cdot 8\end{array}$ & $\begin{array}{l}\text { C. } \\
\text { F. }\end{array}$ \\
\hline
\end{tabular}

TABLE III. MEAN TEMPERATURES FOR THE TEN MONTHS, NOVEMBER 1 To AUGUST 31

\begin{tabular}{|c|c|c|c|c|c|c|c|}
\hline & 1879 & 1883 & 1884 & 1885 & 1886 & \multicolumn{2}{|l|}{1887} \\
\hline $\begin{array}{l}\text { Obdorsk } \\
\text { Karmakuli }\end{array}$ & $\begin{array}{r}-6 \cdot 6 \\
+20 \cdot 1\end{array}$ & $\begin{array}{r}-8 \cdot 9 \\
+16.0\end{array}$ & $\begin{array}{r}-10 \cdot 0 \\
+14 \cdot 0\end{array}$ & $\begin{array}{r}-9 \cdot 7 \\
+14 \cdot 6\end{array}$ & $\begin{array}{r}-9 \cdot 9 \\
+14 \cdot 2\end{array}$ & $\begin{array}{r}-6 \cdot 9 \\
+19 \cdot 2\end{array}$ & $\begin{array}{l}\text { C. } \\
\text { F. } \\
\text { C. } \\
\text { F. }\end{array}$ \\
\hline & 1888 & 1889 & 1890 & 1891 & 1892 & 1893 & \\
\hline $\begin{array}{l}\text { Obdorsk } \\
\text { Karmakuli }\end{array}$ & $\begin{array}{l}-10.4 \\
+133\end{array}$ & $\begin{array}{r}-8.4 \\
+16.9\end{array}$ & $\begin{array}{r}-7 \cdot 2 \\
+19 \cdot 1\end{array}$ & $\begin{array}{r}-9 \cdot 7 \\
+14 \cdot 6\end{array}$ & $\begin{array}{r}-8.9 \\
+16.0\end{array}$ & $\begin{array}{r}-8 \cdot 4 \\
+16 \cdot 9\end{array}$ & $\begin{array}{l}\text { C. } \\
\text { F. }\end{array}$ \\
\hline & 1894 & 1895 & 1896 & 1897 & 1898 & & \\
\hline $\begin{array}{l}\text { Obdorsk } \\
\text { Karmakuli }\end{array}$ & $\begin{array}{r}-7 \cdot 6 \\
+18 \cdot 3\end{array}$ & $\begin{array}{l}-11 \cdot 0 \\
+12 \cdot 2\end{array}$ & $\begin{array}{r}-7 \cdot 9 \\
+17 \cdot 8\end{array}$ & $\begin{array}{r}-7 \cdot 4 \\
+18 \cdot 7 \\
-6 \cdot 0 \\
+21 \cdot 2\end{array}$ & $\begin{array}{r}-9 \cdot 4 \\
+15 \cdot 1 \\
(-7 \cdot 1) \\
(+19 \cdot 2)\end{array}$ & & $\begin{array}{l}\text { C. } \\
\text { F. } \\
\text { C. } \\
\text { F. }\end{array}$ \\
\hline
\end{tabular}

\begin{tabular}{|c|c|c|c|c|c|c|c|c|}
\hline & 1899 & 1900 & 1901 & 1902 & 1903 & 1904 & 1905 & 1906 \\
\hline Obdorsk & $\begin{array}{r}-9 \cdot 8 \\
+14 \cdot 4\end{array}$ & $\begin{array}{r}-6 \cdot 5 \\
+20 \cdot 3\end{array}$ & $\begin{array}{r}-7 \cdot 7 \\
+18 \cdot 2\end{array}$ & $\begin{array}{l}-11 \cdot 7 \\
+11 \cdot 0\end{array}$ & $\begin{array}{r}-9 \cdot 3 \\
+15 \cdot 3\end{array}$ & $\begin{array}{r}-5 \cdot 8 \\
+21 \cdot 6\end{array}$ & & $\begin{array}{r}-7.8 \text { C. } \\
+18.0 \text { F. }\end{array}$ \\
\hline Karmakuli & $\begin{array}{l}(-9 \cdot 5) \\
(+14 \cdot 9)\end{array}$ & $\begin{array}{r}-6.2 \\
+20.9\end{array}$ & & $\begin{array}{l}-11 \cdot 5 \\
+11.3\end{array}$ & $\left(\begin{array}{c}(-9 \cdot 2) \\
(+15 \cdot 5)\end{array}\right.$ & $\begin{array}{r}-4 \cdot 9 \\
+23.2\end{array}$ & $\begin{array}{r}(-6 \cdot 5) \\
(+20 \cdot 3)\end{array}$ & $\begin{array}{rl}-7.4 & \mathrm{C} . \\
+18.7 & \mathrm{~F}\end{array}$ \\
\hline Pustozersk & & & $\left(\begin{array}{l}(-5 \cdot 1) \\
(+22 \cdot 8)\end{array}\right.$ & $\begin{array}{r}-9 \cdot 0 \\
+15 \cdot 8\end{array}$ & $\begin{array}{r}-6 \cdot 3 \\
+20 \cdot 7\end{array}$ & $\begin{array}{r}-3 \cdot 1 \\
+26 \cdot 4\end{array}$ & $\begin{array}{r}-3.5 \\
+25.7\end{array}$ & $\begin{aligned}-4 \cdot 1 & \text { C. } \\
+24 \cdot 6 & \text { F. }\end{aligned}$ \\
\hline
\end{tabular}




\section{APPENDIX}

TABLE III-continued

\begin{tabular}{|l|r|r|r|r|r|r|rr|}
\hline & 1907 & 1908 & 1909 & 1910 & 1911 & 1912 & 1913 & \\
\hline \multirow{2}{*}{ Obdorsk } & $-5 \cdot 6$ & $-8 \cdot 1$ & $-8 \cdot 7$ & $-6 \cdot 7$ & $-8 \cdot 9$ & $-9 \cdot 4$ & $-8 \cdot 0$ & $\mathrm{C}$. \\
& $+21 \cdot 9$ & $+17 \cdot 4$ & $+16 \cdot 4$ & $+20 \cdot 0$ & $+16 \cdot 0$ & $+15 \cdot 1$ & $+17 \cdot 6$ & $\mathrm{~F}$. \\
Karmakuli & $-3 \cdot 8$ & $-6 \cdot 1$ & $-7 \cdot 8$ & $(-7 \cdot 1)$ & & & & $\mathrm{C}$. \\
& $+25 \cdot 2$ & $+21 \cdot 0$ & $+18 \cdot 0$ & $(+19 \cdot 2)$ & & & F. \\
& $-2 \cdot 6$ & $-5 \cdot 4$ & $-5 \cdot 3$ & $-2 \cdot 7$ & $-6 \cdot 4$ & $-7 \cdot 2$ & $-3 \cdot 6$ & $\mathrm{C}$. \\
& $+27 \cdot 3$ & $+22 \cdot 3$ & $+22 \cdot 5$ & $+27 \cdot 2$ & $+20 \cdot 5$ & $+19 \cdot 1$ & $+25 \cdot 5$ & $\mathrm{~F}$. \\
\hline
\end{tabular}

In Figures I and II the means arrived at for the winters and for the ten months are compared in curves for each of the three stations. The years are indicated in a horizontal direction, and the degrees of temperature are shown in the scale on the left. These curves show that in those years for which we have simultaneous observations from the three stations, the fluctuations in the three curves coincide fairly nearly, especially in the curves which represent the means for the whole ten months from November to August. In the curves for the winter temperature there a few minor exceptions in 1897 and 1898, when the changes of temperature at Karmakuli do not entirely coincide with those at Obdorsk, and in 1905, when the temperature at Pustozersk is relatively a little lower than at Obdorsk and Karmakuli. But the great fluctuations in the curves occur simultaneously at all three stations.

As regard the spring and summer months it is difficult to form an opinion, as the observations at Karmakuli are deficient; in the summer of 1909 there were no observations for three months, and in 1898, 1899, 1903, and 1905 there were no observations for August; by introducing a mean temperature for August for the last four years it has been possible to calculate an approximate figure for the mean temperature for the four summer months, and this is inserted in parenthesis in Table II. The figures arrived at show that the fluctuations in the mean temperature for these months, the spring and summer months, coincide approximately at all three stations.

According to this we have the right to assume that the mean values for the temperatures at Obdorsk may give an approximately correct representation of the fluctuations in the mean 458 


\section{APPENDIX}

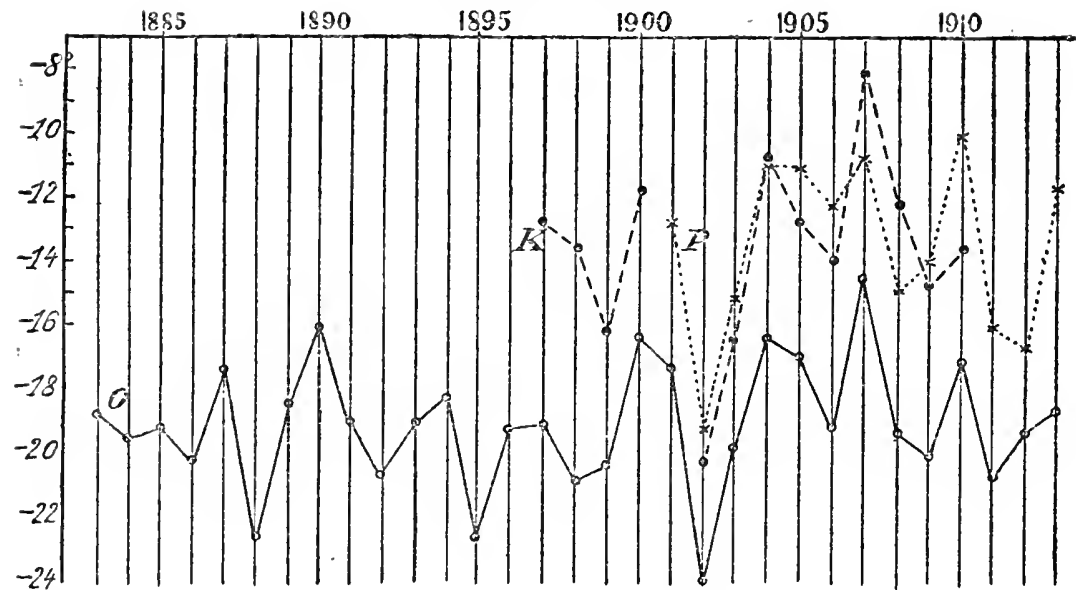

Fra. I. Curves demonstrating the changes in the mean winter temperatures (for the six months from November 1 of the previous year to April 30) at Obdorsk (Curve O), at Maliye Karmakuli (Curve K), and at Pustozersk and Oxino (Curve P). The values of the temperature in degrees Centigrade below zero are given in the vertical scale to the left, the years are given in the horizontal scale above.

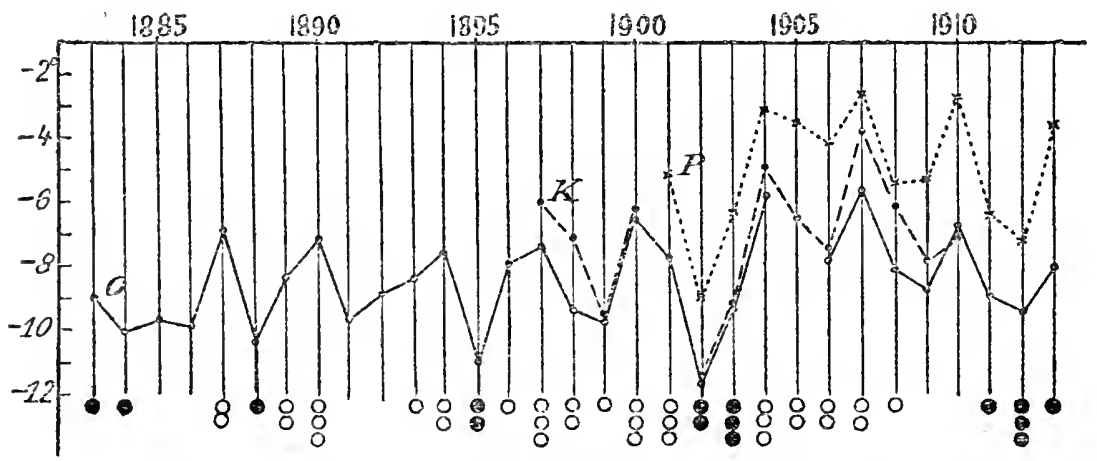

Fig. II. Curves demonstrating the changes in the mean temperature of the ten months from November 1 (of the previous year) to August 31 at Obdorsk (Curve O), at Maliye Karmakuli (Curve K), and at Pustozersk and Oxino (Curve P).

One black disc indicates that it was not a favourable season in the Kara Sea ; ice was met with in August and September. Two black discs indicate that there was very much ice in the Kara Sea in the season (August and September), and three black discs that the sea was full of ice.

One ring indicates that the Kara Sea was fairly open in the season; two rings that it was very open, and three rings that there was practically no ice in this sea in the season (August and September). 


\section{APPENDIX}

temperatures for the corresponding year in the region around the Kara Sea, although, of course, we must not lose sight of the possibility of minor deviations, since Obdorsk lies rather far to the south. If we now compare the curves for the mean temperatures at Obdorsk-especially that for the ten monthswith the impression of the ice conditions which we obtain from the reports of former voyages, we find a remarkable agreement. Below the figure an attempt has been made to indicate the ice conditions as they appear to have been from the survey of voyages in the various years given above. (See Fig. II.) We find that the ice years were grouped about the years in which the curve shows the lowest average temperatures, such as 1888, 1895, 1902 and 1903, 1912 ; or else they occur when there had been a relatively low temperature for several years in succession, as in 1883 and 1884; a particularly unfavourable year was to be expected in 1903, as the year itself was comparatively cold, and it succeeded an unusually cold year, 1902. On the other hand, the open years occurred to a marked extent at the periods when the curve shows the highest temperatures, as in 1887, 1890, 1894, 1896 and 1897, but especially in 1900 and 1901, and in 1904. There seems to have been an exception in 1907, when there was apparently some ice in the Kara Sea, although it was a very warm year. But there cannot have been much ice, in any case at the end of August, as a Norwegian sealer and the Russian sealer Foka both sailed through the Kara Sea at the close of August, and found ice-free water.

Greater agreement than this can hardly be expected, and we seem to be justified in assuming a connexion between the variations in the quantity of ice in the Kara Sea in autumn, and the variations in the mean temperature of the air in these regions during the preceding year. But if this is correct, it must enable us to form a fairly confident opinion of what the ice conditions and the chances of navigation in the Kara Sea will be in the autumn, if we can find out in the spring or early summer what sort of a winter and spring there has been in the region around the Kara Sea, or at Obdorsk, for instance. It is true that the summer temperature, as we have seen, also influences the melting of the ice; but in most years we ought, 460 


\section{APPENDIX}

nevertheless, to be able to form an approximate opinion of what the conditions will be. This may possibly be of great value to this navigation in the future.

But the navigability of waters like those of the Kara Sea is, of course, not merely dependent upon the quantity of ice, but also on its spread and distribution in the sea, and in this respect the direction and force of the winds and the movements of the water are naturally of great importance. Even if in one summer there is no great quantity of ice in the sea, unfavourable winds may, of course, carry the ice down towards the straits, for instance-the Kara Strait and the Yugor Strait-thus rendering their passagc very difficult, during part of the summer in any case; but in such years moderately easy progress is to be expected in other parts of the sea.

The relative depths of the sea also have a bearing on the movements of the water and the distribution of the ice. During the voyage in the Correct, as also on former occasions, I believe my experience to have shown that the ice in the Kara Sea, as in the Arctic Ocean generally, often has a strong tendency to remain over the shallow parts of the sea. The water has less movement there, since the uneven bottom offers resistance, and it is less easy for the wind to move the water and the ice. The winter ice will, therefore usually lie longer where the sea is shallow than over deeper parts.

As will appear from all that has been said above, the difficulties of navigation from Europe to the estuaries of the Yenisei and Obi lie almost exclusively in the ice conditions in the Kara Sea, between Novaya Zemlya and Yamal, and we must be prepared in some years to find the passage of this sea diffieult, occasionally very difficult, while the season during which navigation is possible is always short. If it is desired to go out and home in the shortest possible time, it may be taken as a general rule that ships should not leave Europe very early, and in difficult years they should leave later than in favourable ones. We may, perhaps reckon as an average time for the commencement of navigation in the Kara Sea the latter half of August, and in some years as late a time as the beginning of September. As suggested above, it may be possible to form an opinion some time in advance of the conditions that will prevail 


\section{APPENDIX}

in the various years, as soon as it is known what the winter has been like.

But in order to provide a still surer basis in the future for regular navigation in the Kara Sea, it would be of the greatest importance, in my opinion, to obtain a more complete and systematic knowledge than we now possess of the ice conditions in that sea in the summer and autumn. The point is to obtain an accurate idea of how large a quantity of ice actually exists in these waters during the time in which navigation can take place; how rapidly the ice decreases in the course of the summer and autumn, and how great are the variations in the quantity of ice from year to year. It will also be important to find out how and to what extent the ice is displaced by wind and current. Investigations ought also to be made of the currents and their variations, the temperature and salinity of the sea at various depths and in its various parts, at all periods of the summer and autumn.

A systematic investigation of this kind might most profitably be undertaken by three or four comparatively small sailing cutters with motor power, which might penetrate, as soon as the ice permitted, through the various inlets into the Kara Sea, both in its northern and southern parts, and perhaps also westward from the Yenisei estuary. These boats should cruise in the various parts of this sea till as late as possible in the autumn, and make accurate observations of the distribution of the ice, and so on, at various times.

What we know at present of the ice conditions in the Kara Sea is derived merely from occasional and casual observations on the various voyages that have been made. There can be no doubt that such continued and systematic investigations would result in an understanding of these conditions, based on definite observations, which would be of the greatest importance to the security of future navigation to the great Siberian rivers.

If these motor-cutters are provided with wireless telegraphy, they will at the same time be of immediate service in sending information of the ice conditions from out at sea to the wireless stations, from which again the information can be communicated to Europe or to ships on the way to the Kara Sea. On entering the Kara Sea, these ships will also be able to obtain direct 462 


\section{APPENDIX}

telegraphic information from the cutters lying in the ice in different directions, and this will, of course, be of the greatest importance to navigation.

But for obtaining a survey of the distribution of the ice and giving an immediate report of it, aeroplanes or waterplanes will be far better than even these motor-cutters. The distance from the wireless station at Mora Sale, in Yamal, to the wireless station on Yugor Strait is not more than 120 nautical miles, and the distance from Yamai across to the wireless station on Vaigach is something like 160 nautical milcs. These distances are such as may be easily covered by the aeroplanes of our time, and it is obvious that by flying along these lines-say, from the station at Mora Salé to the station on Yugor Strait or Vaigach, or in the contrary direction-once a week, an airman would enable these stations to give the most reliable information of the distribution of the ice. If it should prove desirable, there would be little trouble in establishing one or two depots of petrol on the northern part of the coast of Yamal, say, about latitude $71^{\circ}$ and another farther north. An aeroplane could then easily fly northward from Mora Salé along the coast of Yamal to these depots, observing the ice conditions on the way. After getting a fresh supply of petrol there, it could then fly straight across the Kara Sea to Vaigach or Yugor Shar, and the return flight could be made in the other direction. In this way it would be possible to be kept accurately informed of the ice conditions in the southern Kara Sea.

If in addition a wireless station were established at Matochkin Shar, with an aeroplane attached to it, it would be possible to obtain information of the ice conditions and prospects of navigation in that part of the sea also.

It is probable that aeroplanes or waterplanes employed in this way will, in future, be an important aid to navigation in such waters as these, especially as the expenses they involve hardly seem to be insuperable. On the plain of Yamal, on the Yugor Strait, and in Vaigach there can be no difficulty in finding sufficient level ground for the ascent and descent of aeroplanes. Nor will there be any trouble in rising or landing with an aeroplane on the large floes that lie off the shores.

As it appears to be agreed on all hands that a successful 


\section{APPENDIX}

development of the sea-route from Europe to the estuaries of the Obi and Yenisei will be of great value to the exploitation of Siberia's immense possibilities, the sacrifices which may be involved in such arrangements for the security of this navigation must be regarded as small in proportion to the advantages to be gained thereby. 


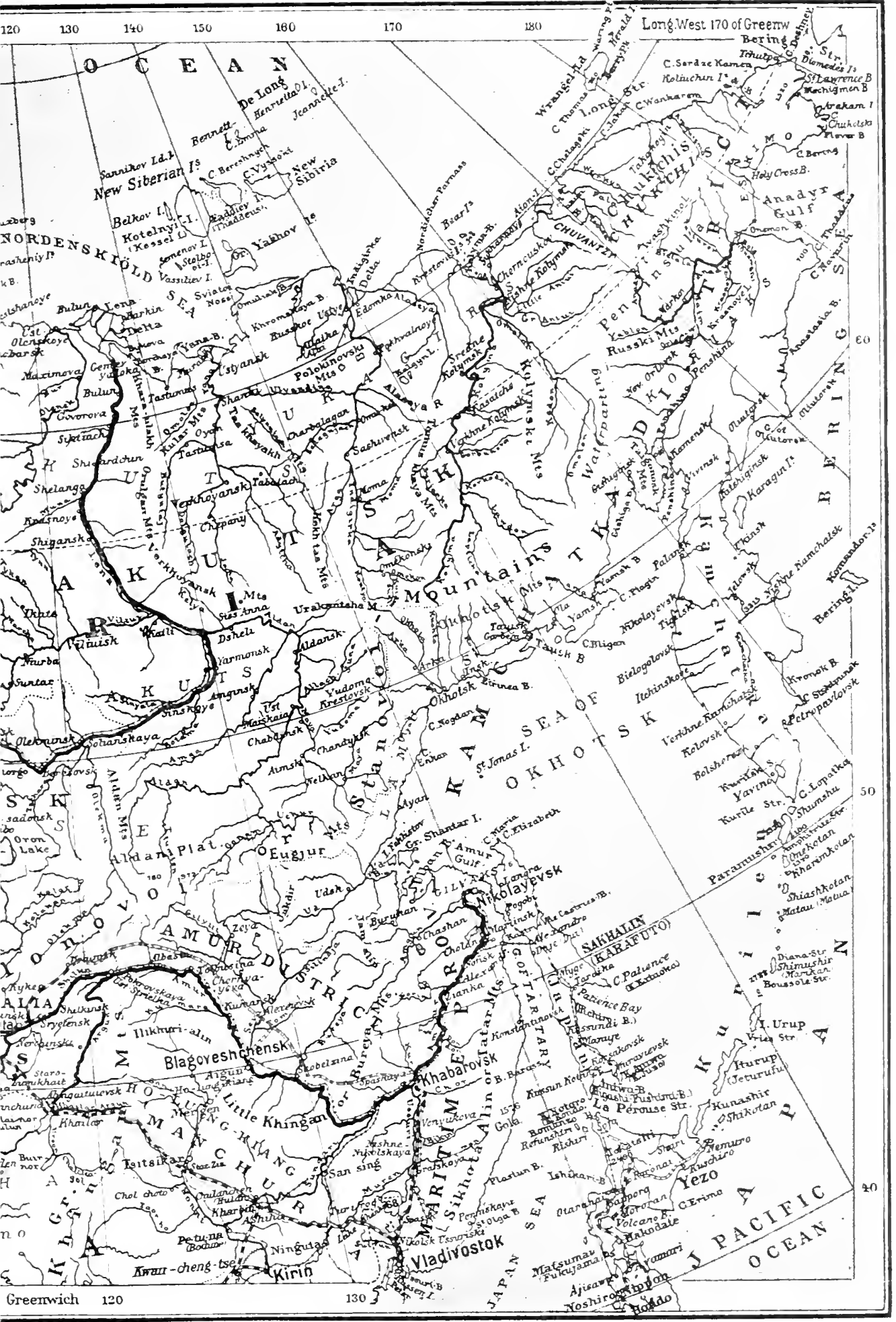

'S ROUTES, OUTWARI AND HOMEIARD. 


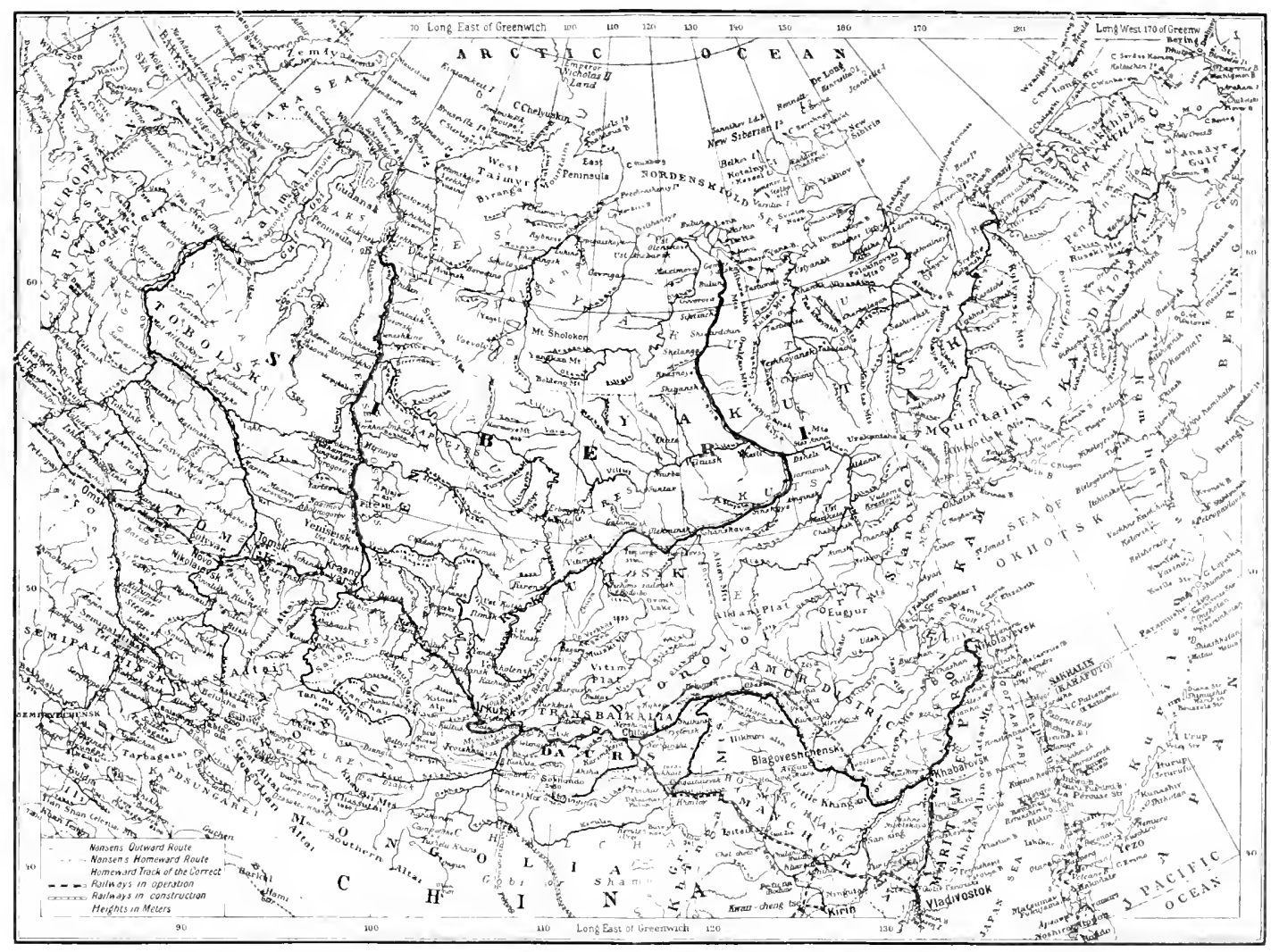

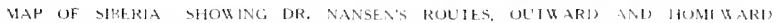




\section{INDEX}

Achinsk, 254

Advent Bay, 8, 9

Aeroplanes, 463-64

Agá River, the, 316

Agriculture, prospects in Siberia, 23940 ; system of, $241-44$; machinery for, 296-97

Department of, reports, 285, 290

Agul River, the, 218

Aigún, Treaty of, 355, 357

Ainos, the, 336

Alaska, 283

Albasin, 354

Aldán River, the, 353-54

Aleúr River, the, 425

Aleuts, the, 335

Alexandrovsk, 176

Alexei, cook of the Omul, 129, 141, 173

Alexéyevsk, 407-9, 41], 413

Altai Mountains, 88-90, 171-72, 287

Amasár River, the, 424, 428

Amasár Station, 424

Amundsen, Roald, 13, 155

Amúr Bay, 332

Bridge, the, 345-46, 383

district, mountains of the, 276 ; gold, 291 ; conditions for settlers, 295-96 ; yield of corn, etc., 300 note; the journey through, 323, 375-89; conquest of, 354-55 ; colonization of, 35760 ; Chinese rising of $1900,371-$ 72 ; description of country, 375-76 ; elimate, 376-77 ; natives, 377-78 ; population, 378 ; hospitality in, 387
Amúr railway line, $316,317,344-45$; prohibition regarding Chinese, 369 , project, $378-81$; labour difficulties, 381-82; length, 382 ; sections, $382-83$; probable terminus, 428

River, the, formation, 315-16 ; journey on, $318,326,334,335$, $338,342,345-46,375$; tributaries, 333, 392, 409, 420 ; Russian influence on, 351, 356 ; discovery, 353 ; fishing, 387 ; channel, 399 ; confluence with the Séya, 404 ; traffic on the, 405

Amurskiy, Count Muraviev, 345, 355

Anábara River, the, 150, 154, 180, 183, 197, 207

Anadyr River, the, 291

Ananyino, 141-43

Angará River, the, 71, 147, 165-66, 176 , 229 ; length, 70-1 ; rapids of the, 304-5, 309-10

Angeleska, 176 and note

Animals, frozen, of Siberia, 118-21

Anuchin, Russian traveller, 171, 207

Archangel, wireless station at, 17;

Samoyedes of, 30 ; route by, 438

Argún River, the, 315,318

Armenia, exiles from, 227

Arseniev, Captain, researches of, 335 , 337-38, 344, 347-48

Arshinsk, 432

Arteushka Station, 421

Arthur, Port, 338, 356, 379

Avam-Samoyedes, 93

BAER, voN, 157, 444

Baikál, ice-breaker, 305 


\section{INDEX}

Baikál Lake, 71, 352 ; forests of the shores, 160, 311-12 ; deseription, 305-6 ; railway line, 3068,312 ; mountains of, $307-9$; the two basins, 309-10; fauna, 310 ; fish, 310-11 , inhabitants of the shores, 311 ; delta of the Selengá, 429-30

Station, 305, 312

Bakan, Russian steamboat, 449

Balkan War, 77

Banks, peasants', 286

Barabá Steppes, 89

Barents Sea, 15

Barentsz, IVillem, voyages of, 440-42

Barim Station, 322

Barkovski, engineer, 402

Bassöe, harbour-master, 146

Bear, the, 201-2 ; superstitions regarding, 226

Beer, Mr., 434

Bégechev, Nikiphor Aléxeyevich, 15455

Bei-Kem River, the, 71

Beli Ostrov. Sce White Island

Belugas, 75, 148

Bennett Island, 154

Bergen railway line, 306 note

Bering Strait, 66, 283

Berlin, 335

Berries, wild, 240

Bikín River, the, 342

Bila people, the, 172

Birá River, the, 390, 392, 393

Station, 390

Black Uryúm River, the, 424-25

Blacks, Australian, 336

Blagovéshehensk, 366, 371-72, 404

Blencathra, the. See Newport

Boats from hollowed trees, 200

Bodö, 174

Bohemia, the "Sokol" movement in, 276

Bokhi domination, the, 336

Bolkhovitinov cited, 368,372

Boxer rebellion of $1900,176,366,371$ 72

Brandt cited, 121

466
Brekovskie Islands, 80-1, 84, 110

Bronze Age, the, 336

Brusílov expedition, 63-6, 144-45

Bulgarians, origin of the, 91

Bunge, Dr. Alexander von, cited, 417 note

Buréya Mountains, 375-76

River, the, $375-76$; bridge across, 401-2

Buréya-Séya Plain, 376-77, 399, 400-9, 417

Buriats, Mongolian, 310, 312

Burrough, Stephen, 440

\section{Campbell, 113}

Canoes, Ostiak, 190 ; Tungus, 347

Carlsen, Elling, 444

Castrén, Alexander, researches, 88, 96 , $100,171,218-19,226$

Catherine, Empress, and Pimen, 134-35

Cattle, method of driving, 267

Cattle-raising, Siberian method, 244

Caucasia, 155-56

Caucasian exiles, 227, 386

Caviar, 107

Cedar, export of, 325 nuts, 170,174

Central Amúr Plain, journey across the, 376, 384-89

Physical Observatory, Petersburg, 454

Chang-kwan-tsai-lín Range, 325-26

Chefu, 329

Chelyábinsk, 432-33

Chelyuskin, Cape, 66

Cherkesses, 181

Chernáya River, the, $\mathbf{4 2 5}$

Chílka. See Shílka

China, Boxer rising, 176, 366, 371-72 ; cattle from, 267-68; revolutionary changes in, 351 ; Russian agreement of 1896,356 ; revolt of 1868 , 358 ; the modern army, 373-74; sea route to, 441

Chinese, investigators of the YeniseiOstiaks, 172 and note; in Transbaikalia, 313 ; types, 320 ; villages, 


\section{INDEX}

Chinese-continued

322 ; agriculturists, $325-26$; cultivation of opium by, 327-28; in Vladivostók, 339-40; Manchu, 354; in Siberia, 360-62, 364-71; the anti-Chinese policy, 381-82 ; labour in the Imperial mines, 425

Chinese Empire, frontier, 354-56

Chir, 107-8, 137

Chirachi holm, 19

Chitá, 314, 315-17, 414, 428

Chitkan River, the, railway accident at, $422-23$

Christensen, Messrs. Ivar A., 12

Mr. Gunnar, 82-4, 113-18, 127, 132,431

Christiania, 6, 240, 271, 335

Christianity in Siberia, 102, 125_26

Chukchis Peninsula, 283 people, 341,348

Churcheni people, 337

Coal-measures, 156

Coal-mines, Siberian, 291

Coastal platform, the, 68

Colonization, sums devoted to, by the Government, 285; position of settlers, 298; by Cossacks, 357-59; by peasants, $359-61$; by exiled convicts, 361-62 ; by Koreans, Chinese, Japanese, etc., 362-71; the Manses, 364-65

Convents, Siberian, 104-6

Convicts, in Turukhansk, 182-83, 189 ; influence on population, 255-56 ; amnesty for, 269 ; colonization by, $361-62$; as railway labourers, $419-$ 20,424

Cooper, Fenimore, 238

Corn, etc, comparative yield, 299-300

Correct, the, voyage to the mouth of the Yenisei, 3, 7, 11-14, 20-24, 61$63,82,84-86,118,127-29,132,145$, $175,257,272,280$; captain of, mentioned. See Samuelsen, Johan

Cossacks, wives of, position, 100 ; in Turukhansk, 182 ; agricultural, 343 ; colonization by, 354, 357-60, 395-96

Crimean War, 355
Crosses, wayside, 269

Crows, signs by, 180

Czechs, the "Sokol" movement by, 276

DAHL, Dr. Knut, 109 and note

Dairy-farming in Siberia, 293, 298-300

Dallman, Captain, 446

Dalniy, port of, 339,356

Damalu people, 336

Dan, steamer, 438

Danes in Siberia, 293

Dashnaktsutyun, 152

Daurs, the, 354,377

"Decembrists," the, 313-15

Deer, Vladivostók, 347-48

Devil's Island, 61, 63

Dickson Harbour, 3, 63, 64, 66, 69

Island, 63, 64, 69, 73, 180, 437, 439,445

Diymphna, the, 447

Djævle-öia. See Devil's Island

Doctors in Siberia, 166, 197-98

Dog-harness, 143

Dogs, frozen extinct animals for, 11920 ; sledge-dogs, 127 ; boat drawn by, 203-4

Dog-sledges, 348

Dolgans, the, 87, 93 ; mud-huts of, 127 ; a woman Dolgan, 161

Dolphins, 75

Donner, MI. Kai, on the Samoyedes, cited, 33 note, 92 note, $93,96-7$; on reindeer culture, 94 note; and the Yenisei-Ostiaks, 171, 207-8, 218

Dorpat, 145

"Draumkrædi," the, lines quoted from, 114

Dreyfus case, 177

Droshkies, 262-63

Dubo people, the, 88-9

Duck, long-tailed, 67

Dudinka, 124, 126, 142, 150-51, 156, $160,177,180,183-84,187,197$, 249

EASTERN Chinese Railway, 316-17, $321-22,344,356,379,428$ 


\section{INDEX}

Education in Siberia, 177

Eidsvold, 2

Elk, 121, 201 ; horns of the, 334, 364 note

Elops, 108

Emigration, Russian, 281-85, 293, 303, 357-62

Ermine, 77

Esaulovka, 395

Eskimo, the, method of eating fish, 36 ; as a hunter, 37 ; his woodsupply, 170 ; sealing, 310 ; origin, 335

Esperanto, a speech in, 257

Esseiskoye Ozero Lake, 186

Exiles of Siberia: Russian political, $74-76,85,151-53,182-83,193$, 205-6 ; criminal, 161 ; raid by political, 183-84; treatment of political, 188-89; Armenian political, 227 ; Caucasian political, 257 ; amnesty for, 269; the "Decembrists," 313-15

Fata Morgana, the, 122

Fedorovich, Tsar Mikhael, ukase of, 443

Finmark, 94, 174; temperatures in 168

Finno-Ugrians, 91, 92 note, 171

Fins, religion of the, 226

Fish, Samoyede manner of eating, 36 ; methods of drying, 74-5, 106, 249

Fisheries, the Yenisei, 107-12, 137 ; at Levinski Pesók, 148; Russian method, 249

Fishing Lapps, 32, 103

Fish-wells, 248

Florence, 334

Fogs, 45-6, 67-8

Foka, German sealer, 449,460

Fonahn, Mr., cited, 364 note

Forest, the Siberian, \&4-5, 160-63, 167-70, 174-75, 210-11, 239-40, $291-92,327$

fires, 167-68, 316, 326-27

Forth Bridge, the, 345

Foxes, 64, 70, 77, 146
Fram, story of the, $34,137,154,256$ 57, 305, 447

Franseska, 176

Franz Josef Land, 15, 44, 448, 451

Frost, effect in winter, 403-4

Fulmars, 14

Furs, bartering for, 118, 180, 202

GaDÁLOv, Peter Ivanovich, reception of the party, 271-72, 274, 278, 431

Game, Siberian, 165-66, 175

Ganukan, 399, 401.

Geese, wild, 113, 114

Gelochi, the, 172

Geographical Society of Krasnoyarsk, 271, 277 ; Irkutsk, 304 ; Khabaróvsk, 344, 349 ; Yekaterinenburg, 434

Geological Society of Krasnoyarsk, 278

Georgian exiles, 152, 257, 386

Germany, North, 200, 238

"Gillissy," the, 441

Gilyaks of the Amúr, 335, 341, 348, 354

Ginseng root, use of, 364 and note

Gjöa, sloop, 13

Glenmour, the, 129

Gnats, 195

Gobi, desert of, $85,318,319,323$

Golaya, Mount, 334

Golchíkha, 76, 83, 107, 108, 115, 129, 133,446 ; frozen mammoth at, $118-$ 19

Gold : the Siberian goldfields, 229-30, 238 ; prospecting for, 232-33 ; methods of extraction, 290-91 ; gold-washings, 328, 407, 420, 424 ; the Imperial mines, 424-25

"Golden Horn (The)," 338-39, 341

Golds of the Ussúri Valley, 335, 341, $348-49,377-78$

Golomyanka, 310

Gondatti, Nikolai Lvovich, policy of, $339-40,369$

Station, 409-11, 414

Granaries, Siberian, 216

Grand Hotel, Christiania, 1

Graphite, 175-76

Graves, Yenisei-Ostiak, 175 


\section{INDEX}

Great Khingán Range, the, 309, 319, $321-23$

Great Russians, 365

Greenland, sledge for, 348

Gremyachinsk Range, 268

Gulf Stream, 15, 61

Gusakovski, Dr., 405, 407

Gwiniad, 107

Gyda Bay, 446

HARAS, the, 172

Hamar, 2

Hamburg, 84

Hammerfest, 176, 444

Han dynasty, 336

Hansen, Dr. Andreas M., 171

Hardanger, 395

Hares, 165-66

Hart's horn, 334, 364 note

Hay, value, 162

Hercules, sloop, 64

Hinlopen Strait, 10

Hiong-nu, 89

Historians, Chinese, 336

Höga berg, 154

Home Rule for Siberia, question of, 288-90

Honnings-våg, 14, 17, 437

Horns, 334, 364 and note

Hovgaard, Captain, 447

Huene, Baron von Hoiningen, work of, 324-28, 437; and the Khunkuses, $329-31$; in Vladivostók, 339 ; the parting with him, 342

Huts, abandoned, 70, 74-6

IBseN in Dudinka, 151

Ice, the first, 20-24; pack-ice, 3440 ; ground ice, 43-44; calved ice, 44 ; slack, 45 ; dirtiness of the, 48 49 ; in the Kara Sea, 437-39, 451$54,460-64$

Ice Age in Siberia, absence of sign of, $410,416-19$

Icebergs, 44-50

Ice-breakers, 305-6

Ice Fjord, 8, 9

Iceland, traders of, 217-18
Ice-pressure, 44-45

Ignatiev, Count, 355-56

Ijs Haven, 442

Ikons, Russian. See Shamáns

Ilou people, the, 336-37

Immigration into Siberia, 285, 293-303

In River and Station, 386

Infant mortality among the Samoyedes, 97

Ingö, 17

Ingodá River, the, 315-16, 428

Irkutsk, 3, 82, 83, 278, 312, 378, 430 ; and the convict raid, 183-84; the journey to, 278-79; goldfields, 291 ; immigration into, 302 ; arrival at, $304-5$

Iron Age, the, 336

Irtish River, the, 92

Isachenko, V., cited, 109 note, 112 note

Isaksen, 445

Isvolsky, M., speech of, quoted, 352

Ivan the Terrible, 353

Ivanitzski, Senator, 370

JACKMax, Charles, royage of, 440

Jæderen, 24

Japan, mountains of, 309

Sea of, 333,341

Japanese in Vladirostók, 339-40, 362 ; in the Amúr and Ussúri districts, 362, 366; Chinese and the, 371

War, lessons from the, 280, 281$86,350-51,356,366,372,379$

Johansen, Captain Hans Christian, 11, $13,16,20,21,26,41,44,54-7$, 58,61

Edward, royages of, $444-46$

Jutland, 24

KABATSKIY Island, 156

Kama, the, 435

Kamassintses, the, 88, 89, 93, 96

Kamchadales, the, 341,348

Kamchatka, 160, 338, 355

Kamen-Samoyedes, 30

Kamenushka River, the, 393

Kan, the, $71,88,218,270$ 


\section{INDEX}

Kanin Nos, 15

Kan-kuen, the, 172 note

Kansk, 243, 279

Kara Sea, journey to mouth of Yenisei, $2-5$; possibilities of annual navigation, 6-7, 277, 292, 43764 ; wireless stations, 7 ; conditions in the, 16 ; ice of the, $20,21,24,44-55,65,451-54$, 460-61; Samoyedes of the, 31 ; expeditions to the, 64, 116 ; trade of the, 139

Strait, 18-20, 54, 437, 440, 44445,461

Karaulnoye, 135-36

Karelian, 91

Karimskaya-Station, 316, 428

Karmakul, Cape, 164

Karmakuli, Maliye, 454-59

Karskiya Vorota, 18

Kasanskoye, 137-39

Kayaks, 190

Kentei-Alín Range, the, 326-27

Kerák Station, 382-83, 409, 420

Khabaróv, Yerofei Pávlovich, 354

Khabaróvsk, 323-24, 376-77, 379, $382-83$; garrison, 333 ; precipita. tion, 335 ; railway to, 339 ; road to, $342-44$; population, 345 ; the Amúr Bridge, 345-46; the exhibition, 346-48; life in, 369-70

Khailár River, the, 318

Khamar-daban, 307

Khánka, Lake, 333, 342, 358

Kharbin, 323-24, 328; khunkuses of, 331 ; bazaars, 339

Kharkov, 74, 77

Kharosovai, Cape, 438

Khátanga Bay, 88, 95, 154

River, the, 150, 154, 183-84, 197, 207

Khekhtsir Range, the, 342-43

Khetinsky Island, 141

Khilbk River, the, 314-15

Khingán River, the, 392

Khodók, 295-96

Khodoki, 293-94

Kholevo, Franz, 386
Kholmogori, 441

Kholmogórovo, 247-48

Khua-Kem River, the, 71

Khulunbuir Plateau, 318-19

Khunkus bands, 328-31

Kibirov, Mr., 181-82

Kidani tribe, the, 337

Kimkán Station, 393

Kirghiz Steppes, 287, 290, 432

Kirghizes, the, 172 and note

Kitmanov, Mime., hospitality of, 251, $253,255,258-60,270$

Kittiwake River, the, 14

Klare, A. A., 402-3

Knop, Baron von, 135

Kolguev, 7

Koltes, the, 218 and note

Korea, frontier of, 333, 356 ; Russian influence in, $350-51$; settlement regarding immigration into Russia, $362-63$

Koreans in Vladirostok, 339 ; in Khabaróvsk, 346 ; in the Amúr and Ussúri districts, 343, 360-71; on the Amúr Railway, 382

Kossogol, Lake, 71, 88

Krasnoyarsk, 3, 7, 71, 76, 85-6, 128, $145,162,166,183-84,206,219,235$, $245,253-54,272,312,431,436$; the ride to, 260-71 ; the Mayor of, 26869 ; Cathedral of the Nativity, 272 ; description, 273-76 ; the Sports Club, 276-77 ; meeting of the Geographical Society, 277-78; departure from, 278-79

Krestova, 141

Krestovskiy Islands, 70

Krusenstern, Paul ron, 444

Ksényevski Mountains, 425 Station, 428

Kuan-yun dominion, 337-38

Kuengá, 382, 425

Kultúk, 306, 311

Kundsha, 137

Kundúr Station, 396

Kunst and Albers, Messrs., 344

Kuréika River, the, 173, 175-77, 240 


\section{INDEX}

Kurgán, 433

Kusor Nos, 18

Irwan-tung, the line to, 339 ; frontier, 352 ; acquisition of, 356

Lamde tribe, 33

Land, distribution to colonists, 292303

Lapps, clothing of the, 29, 98

Fishing, 32, 103 ; Reindeer, 32, 91, 103,123

Lau-yu-ling Range, 327, 332

Lebiashiy Ostrov, 121-22

Lena River, the, $13,127,142-13,186$, $315,353-54,375,420$

Lena, steamer, 13, 141, 144-45

Levinski Pesók, 148, 249

Li Hung Chang, quoted, 367

Liau, house of, 337

Lied, Mr. Jonas, incidents of the journey, 1-3, 5-7, 11, 16, 28, 41, $50-51,65,118-19,132,145,198$, 431

Lister, 24

Little Khingán, journey over the, 376 , 389-99, 417

Russians, 365

Liverovskiy, Alexander Vasilievich, 383

Loans, State, to settlers, 295-96

Lonely Island, 67, 446, $45 \mathrm{l}$

Loons, 210

Lorentzen, Consul-General, 2

Loris.Melikov, Joseph G., account of, $1,5-6$; ineidents of the journey, 8 , $11,16,41,80,85,118,197-99,209$, 235, 247, 312; and the Samoyedes, 26 ; and the exiles, 76-77, 151-52, $188-89,205-6,227$; and the Yuraks, 125 ; countrymen of, 181, 257 ; and the Yenisei-Ostiaks, 202; and the Shaman, 224-25; and tho traders, 236 ; the ride to Krasnoyarsk, 261, $270-71,278$

Loshkin, Savva Fofanov, 444

Louise, steamer, 446-47

Lukoráya Protóka, 139

Lyakhov Islands, 119
Machinery, agricultural, 296-97

Mack, sealing skipper, 445

Mails, system of carrying, 164

Makárov, Admiral, 176

Malinóvka Station, 383

Maliye Karmakuli. See Karmakuli

Maluigin, voyage of, 444

Malygin Strait, 31, 58

Mammoth, frozen, 118-21

Mana River, the, 88

Manchester, 335

Manchuria : first impressions, 318-20 ; temperature, 320 ; the railway, 320-25 ; agricultural districts, 325-26 ; mountains, 326-27 ; Russian element in, 350-52 ; history of Pussian domination, $353-56$; Korean immigration into, 363 ; Russian occupation, $1900,367,372$

Eastern, mountains of, 309

Southern, 356

Manchus, 91, 357, 377 ; settlements of, 365-66

Manegres, 377

Mangaséya, 144 note, 179, 184-85, 44243

Manses, origin of the, 337 ; and the Amúr Cossacks, 353-59; and the Colonists, 364-65

Manure, use in Siberia, 234, 243-44, 300

Maritime Province. See Primorskaya Oblasty

Matochkin Shar, 67, 438, 444-46, 463

Mators, the, 89, 96

Maya River, 354

Mean temperatures, table of, $455-60$

Mergen, 373

Meteorological stations, 45t-59

Middendorff, Siberian authority, cited, $88,89,93,97,100,101,104,120$, 160,236

Mineral wealth of Sibcria, 290-92

Minusinsk, 4, 155, 248

Mir system of agrieulture, 241-43, 296

Mirage in Siberia, 122, 164

Mimaya village, 209 


\section{INDEX}

Miroyédikha Village, 179, 191-92

Mohammedans in Siberia, 181

Monastir, town of, 191

Monastirskiy, 231

Mongolia, mountains of, 70,71 ; camels of, 84-5; corn districts of, 241 ; cattle from, 267 ; frontier, 323

Northern, 4

Plateau of, 318,319

Mongols, 91 ; rise of the, 337

Mora Salé, 25, 64, 449, 463

Mora Yaga River, 25

Moral deer, the, 347-48

Morosov, General N., 438-39

Moscow, 283

Muksun, 107, 108, 109, 148

Muraviev, Gov. See Amurskiy, Count Muraviev

Murén River, the, 327

Murman coast, the, 176

Mútan, plain of the, 325-26

Mutnaya Bay, 442

River, 442

Mysováya Station, 306, 312

NADIM, 30

Nai, Cornelis, 441

Namsos, 195

Nansen Station, 402-3

Naples, 342

Nasímoro, 245-46, 248

Nativity, Cathedral of the, Krasno. yarsk, 272

Naval stations, 338, 355, 432-33

Nehring cited, 120

Nei-te, three lakes of, 442

Neptun, the, 446

Nérchinsk, Treaty of, 354

Nevelskiy, adventure of, 355

Never River, the, 409, 420

New Jersey, scrub pine of, 174

New Siberia, 119

Newport, British warship, 65

Nice, 334

Nicholas, Tsar, 313-14, 351

Nikhólsk. 337, 342

Nikodem, book of, 144 note

472
Nikolai II, Government ship, 438-39

Nikoláyevsk, 335, 338, 355

Nimrod, the, 64, 449

Ninguta, district of, 337

"Nora," 151

Nordenskiöld, Baron, expedition of, $13,41,49,154-55,445-46$

Nordenskiöld, steamer, 13, 447

Nordland, coast of, 2 ; temperatures, 168 ; yield of corn, etc., 299-300

Nordland, schooner, 446

Nordvik Bay, 154

North Cape Current, 15, 86

North-east Passage, search for the, 63

Northern lights, the, 134

Norway : coastal platform, 68 ; fishing population, 111 ; elk of, 121 ; haymaking in, 162 ; temperatures in, 168 ; forests, $169-70,428$; conditions in 1899, 176-77; traders of, 217-18; women of, 226 ; peasants of, 242 ; emigrants from, 283,302 ; population, 297 ; yield of corn, etc., 299-300 ; railway, 306 note; reminiscences of, $390,392,429,435$

Norwegian Central Statistical Bureau, reports, 299-300

Naval Rescrve, 11

Nosónovski Island, 80-2, 83, 108, 113, 122-23, 126

Pesók, 83-4, 87-112

Novaya Zemlya, 7, 17, 44, 64, 66, 67, $441-42,444-46,452,461$

Novo-Nikoláyevsk, 293,432

Nuksha Range, 420

River, 420

Numendal, 429

Nummelin expedition, 114-16

Nyelma, 107-9, 111, 211

Nyelmovoiy Ostrov, 211

Nyérchinsk, 428

OBDORSK district, 27-9, 126, 197, 444 ; Samoyedes of the, 30, 32 ; winter fair, 30-1 ; civilization in, 32 ; jurisdiction of, 124; observations made at, $45 \pm-60$ 


\section{INDEX}

Obi River, the, Samoyedes of, 30-3, 92 and note, 207-8; mouth of the, $59,60,441-42$; forests, 89 - steamboats of the, 147 ; navigation, $432,440,443,445$

Gulf of, $31,48,49,59,438,440$, $442,444,446-48,461$

Obi-Ostiaks, 143

Ofot Line of Norway, 306 note

Oil-wells, Siberian, 291

Okhotsk, sea of, 333-34, 354

Okotetta tribe, the, 33

Oldoi River, the, 420

Oleniy Island, 19

Olkhón, Island of, 311

Omul-fishing, 107-9, 111, 112

Omul, voyage of the, 128-29, 173, 204,

272,280 ; at Yeniseisk, 250-51, 259

Onón River, the, 315-16

Opium, cultivation of, $327-28$

Ordá Yabtung, the, 124

Oroches, the, $335,341,348,377$

Oryol, " Eagle," 129

Oscar Dickson, steamer, 446

Osier scrub, 113, 114, 116

Osinorski Rapids, the, 219, 231-32

Ossetin people, the, 181

Ostiaks, the, 87, 89, 149, 164 ; Ugrian, 33 note; sledge-dogs of the, 137 ; number in the Turukhansk district, 218-19; types, 221 ; boats of the, 226-27. See also Yenisei-Ostiaks

Ostiak-Samoyedes, 30, 87, 90, 93, 95, 96

Ottar cited, 94

Oxino, observations at, 454-59

Pacific, first sight of the, 340-41

Pakhtusov, voyage of, 444

Palktusov, Russian exploration ship, 448, 450

Palavinaya, 163

Palliser, Major John, 444

Pandora II. See Newport

Papuans, 336

Peasants, Mir system of agriculture, 241-43 ; banks for, 286 ; immigrant, $359-61$

Pechora, the, 7, 16, 440, 442
Peik-to-shan volcano, 326

Peking, march of the Allies on, 176, 372 ; Khunkuscs of, 329

Treaty of, $355-56,365$

Pelatka-fishing, 137

Penkovaya Station, 424

Perm, 288, 435

"Pesk," the, 29

Pet, Arthur, 440

Peter the Grcat, 138

Bay, 332, 334, 338

Petersburg, 229, 287-88, 293, 356-57, 436

Pctropavlovsk Naval Station, 338, 355, 432-33

Petrovsk ironworks, 313-14

Pimen, story of, 134-35

Pit River, the, 230

Plankton-fishing, 108

Podkámennaya Tungúska, 71, 229-30

Podrutskiy, Yeogéniy Ulianovich, 382, 429

Pokrovka, 385

Polar Sea, whaling, 13

Popham, voyages to the Yenisei, 65

Population of Siberia, 282

Portsmouth, treaty of, 352

Potapovskoye, 161

Poyarkov, Vasiliy, 353-54

Preobrasheniy Island, 154-55

Preobrashenskoye, Cape, 154

Primorskaya Oblasty, 333-35

Prisons along railway line, 419-20, 424

Progranichnoye Station, 331-32

Prokofeva Bank, 18

Pröven, sailing sloop, 445

Ptarmigan, 113-17

Pustoy, 107

Pustozersk district, 27

Meteorological Station, 454-59

Pyasina, 180

RADLOFF, Dr., cited, 89,172

Railways, Russian, 280-81 ; Siberian, projected, 290, 292 ; the line around Baikál, 306-8 ; importance to cultivation of land, 325-26 ; a Decauville, through Manchuria proposed, 373 


\section{INDEX}

Ramstedt, G. J., investigations, 172-73

Rasdolni, 424

Ratijen, engincer, 397

Red Cross Society, expedition toTurukhansk, 166

Reindeer, 30-2, 67-9 ; wealth from, 94 and note, 99, 201 ; sledges, 348

Island. See Oleniy Island

Lapps, the, 32, 91, 103, 123

Religion, Yurak, 125

Revillon, 151

Revolt, military, of December 14, 1825, 313-14

Rhinoceros, frozen, 119

Ritscher, Captain Alfred, 8-10

Rivers, velocity, effect of variation in, $139-40$; movement to the right, 156-58; method of removing rock from river-beds, 232 ; effects of earth's rotation on banks, $240-41$, 376

Roads, Siberian, width, 267 ; Russia to the Amúr district, 378

Rodichev, M., 431

Romanov Jubilee, amnesty, 269

Rosmuislov, 444

Rostov, 152

Rusánov, 64, 66

Russia: Russians in the Amúr and Ussúri districts, 88, 123, 366-67 ; fishermen, 105, 110, 111, 223, 23334 ; types in the northern Yenisei, 143-44; trade in Yeniseisk, 255; growth of the Russian Empire, 283 ; emigration from, 284-85, 293-304, 331 ; Siberian policy of Russia, 28890 ; position of peasants, 298 ; yield of corn, 299-300 ; villages, 322 ; possession of the Ussúri country, 337-38 ; Manchurian policy of, 35052 ; history of domination in Manchuria, 353 ; frontier, 354-56; the march on Pcking, 372; present position in the East, $373-74$; trade of northern, 442

SABLE, the, 216

\section{4}

Sakhalín, coal of, 291 ; loans to set tlers, 295; mountains of, 309 ; people of, 336

South, restoration of, 352

Sakhandó Station, 314

Sakhanin Island, soundings, 17-8

Salmon-fishing, 107

Samoyedes of Yamal, 6, 29-32, 65, 103 , 443 ; description and habits, 24-33, 348 ; visits of, 26-8, 34-9 ; Samoyedes of the Obi, 31, 33, 92 and note, 207-8 ; manner of eating fish, 36 ; the Samoyede as a hunter, 3738 ; trading by, 75 ; history of the, $88-98$; religion, 102,226 ; honesty, 104-5; a civilized Samoyede, 149 ; superstitions, 160 ; language, 171 ; types, 220-21 ; and the explorers, 440,448

See also Ostiak-Samoyedes, TavgySamoyedes, Urál-Samoyedes, Yenisei-Samoyedes

Samuelsen, Johan, captain of the Correct, 7, 8, 11, 25, 26, 34, 41, 45, $50,54,56,69,74,81,129,132$

Sapad, trawler, 437-38

Sars, Prof. Ossian, 311

Sarya, the, 448

Saw-mills, absence of, 245

Saxlund, MIr., experiments, 170 note

Sayan Mountains, 71, 88, 93, 96, 172, 268

Sbega, station of, 425

Scandinavia, mountains of, 275-76 ; population, 282

Schools of Turukhansk district, 188 ; railway, $383,385-86$

Schrenck cited, 120

Schröder-Stranz expedition, 8-9

Schwanen berg, Captain, 114, 116

Seal-hunting, 37, 38

Seals, ringed, $37,148,310$; bearded, 50

Sedóv expedition, 66

Seest, Boris Vasilievich, 382, 429

Seines, number used, 110

Seld, 107-9, 148, 150, 201, 204, 249

Selengá River, the, 70, 71, 304, 307, 309-13, 429 


\section{INDEX}

Selinkhe Station, 331

Selo Igarskoye, 164

Selo Tolstyi Nos, 134

Selyonaya River, 442

Serebrennikov, Serguéy Pavlovich, 383

Serfdom, 284

Sergyeeva, 241

Severnoe Sianie, story of Nummelin, 114-16

Séya River, the, 353, 375-76, 400, 404, 420 ; Chinese settlements on the, 365-66 ; the bridge at Alexéyevsk, 407-8

Shamáns, 102, 126, 144 note, 223-26

Shao - bo - shan. See Chang - kwantsailín

Sharks, 248

Shchegolióv, mine-owner, 272

Shílkha River, the, 315-16, 378, 425, 427

Shitkov cited, 33

Sho-yaga River, 442

Siberian and Transbaikalian Railway, $3-4,313-17$

Siberian Company, the, 2-4, 449

Siberians, the primitive peoples, 87107 ; peasant types, $143-44$

Sibiriakov, voyage of, 13,446 Island, 60-1

Sidórov, "Northern Russia " cited, 75, $180,216,219$

Sig, 107, 109

Sikhotá-Alín Mountain range, 309, $334-36,342$

Silova, 426

Skaters, Russian, 276

Skidalski, Messrs., 325, 328, 339

Skis, 47, 347-48

Skua, the, 14

Skugarevsky, engineer, 396

Skuratov, voyage of, 444

Slavs, the, 92

Sledge-dogs, 137, 143, 148-49

Sledges, 136-37, 141-43, 341, 348

Small-pox, epidemie of, 166

Smugglers of the Little Khingán, 39798
"Sokol" movement, the, 276

Solotoy Rog, 338-39, 341

"Solveig," 344

Sopochnaya Karga, 74

South-Eastern Chinese Railway, 339

Soya bean, export of, 326

Spahde, Captain, voyage of, 437-38

Spitsbergen, 8, 10, 15, 44, 235

Squirrels, epidemic among, 165 and note- 66,222 and note

Sryétensk, 316, 378, 379

Stanovoi Mountains. See Yáblonovi

Staxrud, Captain, 8

Stelling, Mr. E., 454

Stéppes, the, 89, 287-90, 432

Sternberg, Dr., 335

Stettin, 3

Stolypin, M., and the Mir system, 24243

Stone Age, the, 336

Sturgeon, 107, 108, 111, 232, 310 ; bait for, 137 ; sturgeon soup, 141 ; methods of keeping alive, 218-49

Sui-fun, 332

Sultanovski Selo, 163

Sumarókova, 211-12, 218, 227-29, 239, 249 ; exiles at, 236

Sungarí, the, 325, 326, 336, 376

Suomi, 95

Sushkóvo, 164-65

Sviataya Anna. See Newport

Sviatoi Foka. See Foka

Svyato-Troitskiy Monastir, 178-79, 183-84

Svyerevo, 107

Swans, 162

Syphilis, cases of, 35

Syrianski Pesólk River, 198

Syryenians, the, 27

TAIGÁ, the Siberian, 160-62, 194

Taimyr Peninsula, 88, 95, 104-5, 446

Taldan Station, 414, 418-19

Tanganyika, 308

Taptugári Station, 421

Tarantass, mode of travelling by, 26162

Tartary, Sea of, 441 


\section{INDEX}

Tas, Gulf of, 442

Tas River, the, 144 note, 184, 442

Tashkend, 387, 412

Tatars, the, 89, 91, 93, 96, 172, 181

Tavgy-Samoyedes, 93, 95

Taxes, Siberian, 124-25, 296

Tchaikovsky, Spardam, 434

Tea-drinking in Russia, 187, 213, 264

Telegrams, method of sending, 235, $2 \pm 6,252$

Tents, Samoyede method of moving, 103-4; Yurak, 136

Tikhon, monk, story of, 184-86

Tobbllsk, voyevods of, and northern trade, 440,443

Toll, Baron von, 64, 119-21, 153-54, 448

Tolstoi Nos, 115

Tom River, 172

Tomsk, 206, 254, 285; yield of corn, etc., 301 note

Traders of the Northern Yenisei, 14143 ; of Dudinka, 150-51; evils brought by the, $214-15$; relations with the natires, 216-18; Vostrotin and, 236

Transbaikal Railway, 314-17, 378-79, 382

Transbaikalia: gold-mines of, 291 ; loans to settlers, 295-96 ; description, 312-13 : Cossacks from, 35758 ; Russian population of, 367 ; frontier, $375,409,424-26$

Tregúbov, Vladimir Vladimirovich, 383, 415-16

Treurenberg Bay, 8, 9

Troika, 262

Troitskiy Monastir, 178-79; convict raid at, 183-84; wooded ridge at, 191-92

Tromsö, 2, 3, 7, 10, 13, 141 ; Catholic hospital at, 8 ; the fortune-teller at, 20

Sound, 14

Trondhjem, 2

Trubetskbi, Princess, exile, 314

Tsin, house of, 337

Tsitsikar, 319,373
Tsivolka, 444

Tubins, the, 89,96

Tulla, voyage of the, $3,449-50$

Tulún Station, 430

Tundra, culture of the, 89-90, 94

Tungus, the, 87-93, 166, 186, 220-21, $236,312,335,348,377$; women of the, 127 ; language, 197 ; religion, 226 ; diffusion, 341

Tungúska River, the, 345,376 ; the Lower, 70, 71, 179 ; Middle, 70 ; the Podkámennaya, 71, 229-30 ; rapids of the, 192 ; confluence with the Ussúri, 384 ; tributaries, 386

Tunnelling of the Little Khingán, 392$99,401,420-21$

Turán Mountains, 375

Turco-Tatar language, 171-72

Turkestan, conditions for scttlers, 296 ; immigration into, 302 ; fruit of, 387

Turks, the, 89, 91, 96

Turukhan River, the, 178

Turukhansk, 100, 138, 145, 152, 165$66,179-80,254$; sale of vodka prohibited, 216-17

district, seat of administration, 178 ; trade of, 181-82 ; schools of, 188 ; convicts of the, 18990 ; effect of the gold discovery, 230

Turukhansk steamboat, the transhipment, 82-6; captain of the, 130 , 132

Turukhansky knyas, the, 135

UDA River, the, 313

Ulya River, 354

United States, work in Alaska, 283 ; emigration to, 284

Urál, gold-seekers from the, 229

Mountains, 160, 432-33, 435

Urál-Samoyedes, 30

Urini River, the, 386

Urkan River, 420, 424

Uryúm River, the, 425, 428

Station, 382, 425-26

Valley, 425 


\section{INDEX}

Ussúri country: gold of the, 291 ; conditions for settling in, 29596 ; yield of corn, etc., 300 note ; history, 336-39 ; Russian influence in, 351-56; frontier, 355 ; colonization of, $357-60$

Russian, 327

South, 333, 342

Railway line, 378-79

River, the $327,333-35,342,345$, 376,384

Utrennaya Sarya, 116

VAIGACH, 438-40, 463 ; wireless station at, $13,14,16,18,64$; the guard on, 443

Vaigach, ice-breaker, 66

Valdres, 429

Vardö, 145

Varna, expedition of the, 447

Vasily Mangaseiskiy, saint, 184-85

Vassian, steamer, 64, 438

$V$ ega, the, 13, 446

Verkhne-Imbátskoye, 204-5, 209

Verkhne-Udinsk, 313

Verns, Island of, 439

Viatka, 288, 435

Victoria Nyanza, 308

Queen, 176

Victoria, steamer, 13

Vilkitsky, Admiral, 66, 133

Island, 60, 66, 437, 439, 446

Villages, Chinese, 322

Vitim River, the, 315

Vladivostók, 253, 323-25, 379 ; arrival at, 332 ; garrison, 333 ; latitude, 334 ; precipitation, 335 ; development, 338-39 ; population, $339-40$; coast, $341-42$; distance from Peters. burg, 357 ; a lady's ride to Petersburg from, 414

Vlamingh, Willem de, royage, 443-44

Vodka, 27, 30, 34, 104, 182, 211-17

Voguls, the, 33

Volkonsky, Princess, 314

Volugda, 435

Vorogovo, 183, 187, 227, 233-34

Voronov Nos, 19
Vostrotin, Stephan Vasilievitch, member of the Duma, 1-2, 5; buying a motor-boat, 10-11, 78; incidents of the journey, 11, 41, 85, 133, 138, $141,145,173,187,197,212-13,215$, 257 ; and the Samoyedes, 27, 29, $34,98-9$; walrus-hunting, 50 ; and the Yuraks, 125; and the Dolgans, 127 ; ships of, 129 ; nephews of, 130 ; at Karaulnoye, 135-37 ; and the people of Sushkóvo, 165 ; experiences in Norway, 176-77; political interests, 190 ; and the traders, 212 $13,215,236$; and the YeniseiOstiaks, 222-23 ; and the shamán, 224-25 ; gold-mines of, 229 ; on native methods, 232-33; acquaintances, $234-36$; the first telegram, 246 ; on sturgeon-fishing, 248 ; arrival at Yeniseisk, 250-5l ; the ride to Krasnoyarsk, 261, 263-65, 271 ; photographic work, 272 ; in Krasnoyarsk, 277-78; on the trade route, 279-80 ; at Baikal Station, 312 ; return to Petersburg, 431

WALRUS-HUNTING, 50-1

Webster, voyage of, 449

Whale, superstitions regarding the, 75 , 148

Whaling, 75

Whist, Mr., 2

White birch, 388

"White Birch Steppe," 432

White Island (Beli Ostrov), 22, 55, 57 $59,438-39,442,414-45,447$

Sea, entrance, $15,88,95,440-41$

Tsar, respect for the, 105

Uryúm, the, 425

Wiggins, Joseph, voyages, $445-47$

Wireless stations, 7, 12-13, 16-18, 64, 463

Witsen cited, $\mathbf{4 4 3}$

Wolves, 166

Women, Samoyede, 99-102 ; Tungus, 127

Wood, Siberian, hardness of, 169-70; origin of Arctic drift-wood, 170 


\section{INDEX}

Wourtzel, Mr., invitation to the author, $7,85-6,128,235,253,271,278-81$, 308 ; work of, 316-17, 323-24, 342, $414-15,432$; at Khabarórsk, 34445 ; opinions of, quoted, $385-86$

Wourtzel, Miss, 413

YáblonovaYa Station, 314-15

Yáblonovi Mountain chain, 309, 313$14,353-54,375,429$

Yabtung Alyo, 124-26

Yakovleva Kossá, 78

Yakuts, the, 88, 93, 127, 149, 186

Yakutsk, 13, 353, 354, 375

Yamal, 13, 20, 22, 24-5, 36, 41-4, $437-42,444-45,452,461$; Samoyedes of, 29-32, 65, 103, 443-44; soundings, 57

Yambu-to, Lake, 442

Yanova Islands, 19

Yartsevo, 240

Yaruslav, 184

Yasak, Russian tax, 29, 89, 103

Yefremov Kamen, 69

Yekaterinenburg, 433-34

Yekaterinoslav, 74

"Yellow Question," the, 362-74

Yenisei Bay, 107-8

Yenisei River, the, 2-5, 16, 431, 442 ; route to the estuary, $64,67,69,84$, 139 ; length and basin, 70-1; bed of the, 71-3; sources, 71 ; tributaries, $71,88,179,218$; whales, 75 ; width at Nosónorski Island, 80 ; end of the Correct's journey, 85; native tribes along the, 87 ; forests, 89,160 ; fisheries of the, 107-12, 201 ; depth, 133 ; banks and velocity, 139-41, 158, 191-92, 240-41 ; steamboats and lighters, 145-47; Government flotilla, $145-47$; rocks of the shore, 159-60, 164; traders of the, 180 ; ridges along the, 228 29 ; gold, 229-30; mountain pass above Krasnoyarsk, 273 ; the ferry, 274-75; chances of regular sailings, $349,445-61$; lecture on the, 434
Yenisei-Ostiaks, the, 6, 33, 87, 93, 136, 149,166 ; canoes of the, $136,211-$ 12,220 ; birch-bark tents of the, $170-71,189-90,198-99$; origin of the, 171-72 ; types, 199-200, 22026 ; poverty of the, 201, 214-16, 236 ; language, 202 ; seld-fishing, 204 ; Donner and the, 207-8; boats of the, 211-12, 220 ; distribution of the, 218-19, 258; sense of beauty, 347

Yenisei-Samoyedes, the, 87, 95; a visit to, 98-99 ; fishing trade, 111 ; of Nosónovski Ostrov, 123 ; taxation of, 125

Yeniseisk, 71, 85-7, 114, 128, 133, $135,153,175-76,187$; traders of, 111-12, 180 ; pavements of, 155 ; price of hay in, 162 ; monastery of, 184-86; the journey to, 234-35, 240 ; arrival of the Omul, 250-51

district of, the Mir system in, 243 ; absence of saw-mills, 245 ; description, 253-54 ; trade, 255; inhabitants, 255-56; schools, $257-60$; population, 285 ; goldfields, 290-91; immigration into, 294, 302 ; farming in, 299 300

Yeniseisk, steamboat, 130-31

Yermak, cxile of, 353

Yermak, the, 176

Imer, the, 445

Young, Sir Allen, 65

Yugor Strait, 13, 14, 17-18, 64, 437$41,444-49,454,461$

Yurak, 87, 95, 99, 151, 184; Samoyedes of, 30

Yuraks, language of the, 6 ; trading, 75 ; fishing, 111; a chief and his two wives, 123-24; of Nosonovski Ostrov, 123-27; method of taxation, 124-25; a camp, 137

ZeMstvo, policy of, 288-90

Zöppritz, 157 
PRINTED AT

THE BALLANTYNE PRESS

LONDON 


$$
\text { . }
$$


22024

University of California

SOUTHERN REGIONAL LIBRARY FACILITY

405 Hilgard Avenue, Los Angeles, CA 90024-1388

Return this material to the library from which it was borrowed.

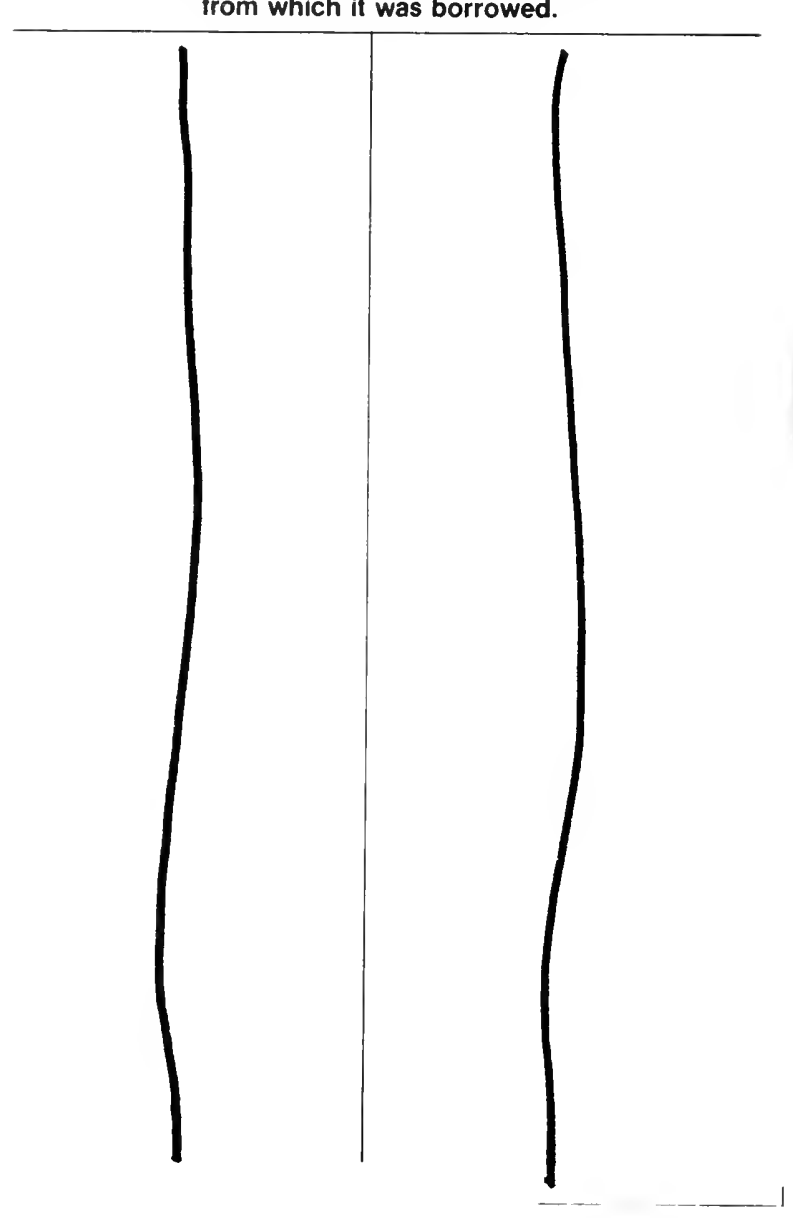




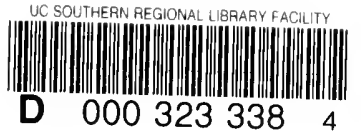


University

Souther

Librar 